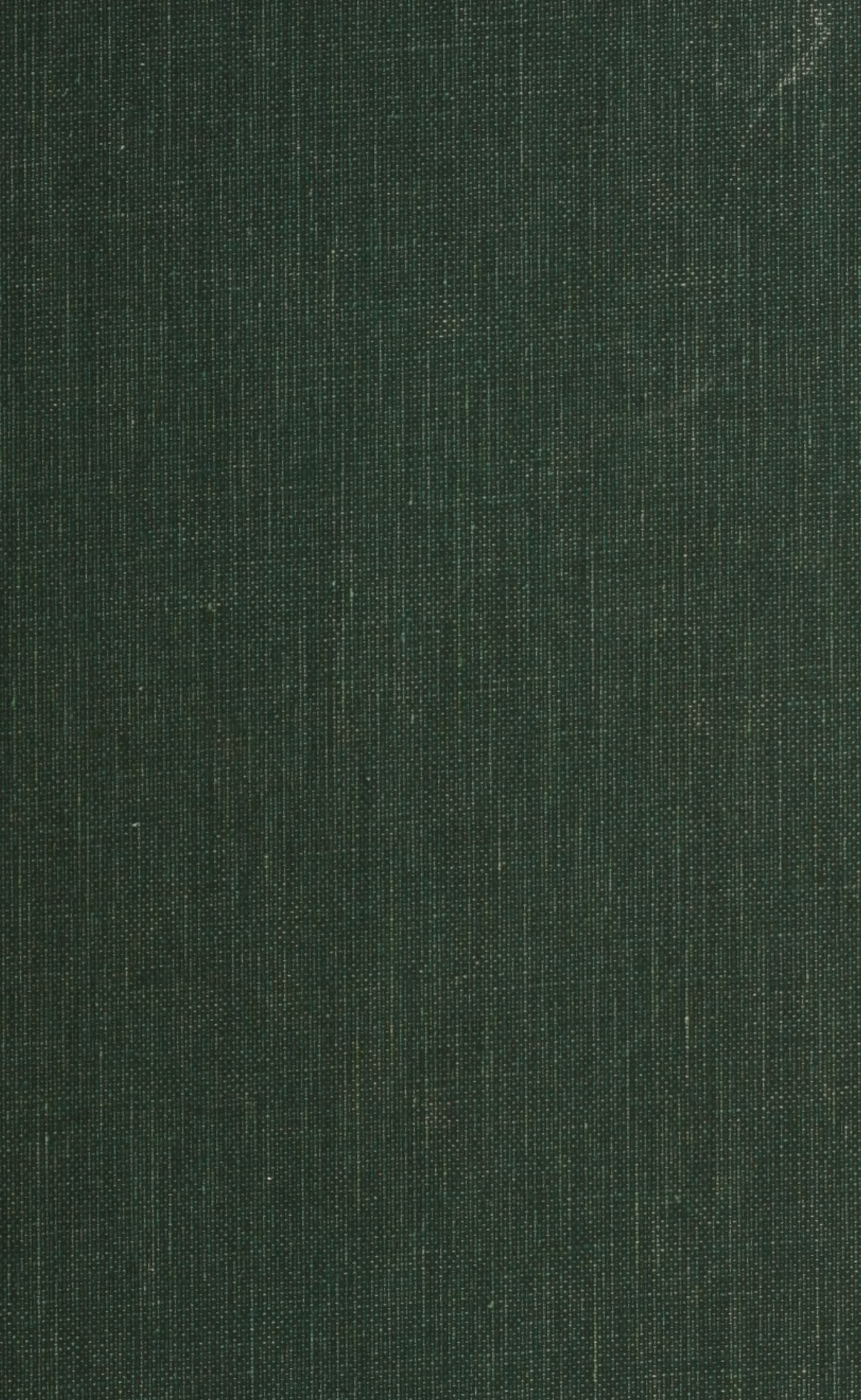




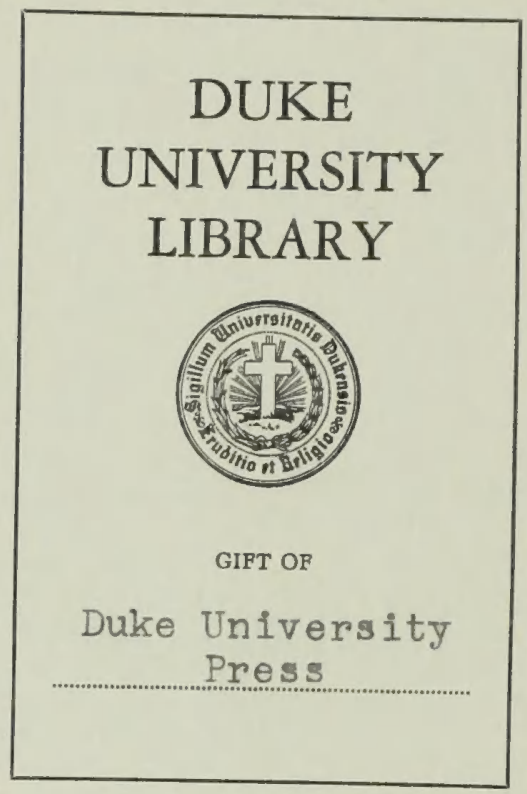



Digitized by the Internet Archive in 2020 with funding from Duke University Libraries 


\section{FLOWERS FOR}

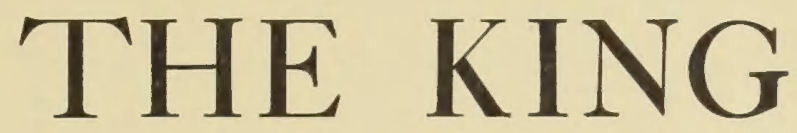

THE EXPEDITION

O F

RUIZ A D P A V O N

A N D T H E

FLORA OF PERU

BY

ARTHUR ROBERT STEELE

DURHAM, NORTH CAROLINA

D UKE UNIVERSITY PRESS

M C M L X I V 
(C) 1964, DUKE UNIVERSITY PRESS

Library of Congress Catalogue Card number $64-11428$ Cambridge University Press, London, N.W. $x$, England PRINTED IN THE UNITED STATES OF AMERICA BY THE SEEMAN PRINTERY, INC., DURHAM, N. C. 


\section{E D I C A T E D \\ TO}

MARY LOUISE STEELE

BERNIECE AVERY SMITH

GEORGE WILLIAM EPPARD SMITH AND TO THE MEMORY OF

W I L L A R T H U R S T E E L E 
This volume has received a subvention from the Duke University Council on Hispanic Research under a grant made by the Ford Foundation for the promotion of international studies. 


\section{PREF A C E}

The lure of a rendezvous with the "Maids of Honor" and Goya's "Naked Maja" draws crowds of sightseers daily into the far-famed Prado Museum of Art. But next door, behind the high iron fence of the Jardín Botánico de Madrid, scarcely anyone comes. Even the gardeners are too often absent for want of money to pay them. The director fondles his maroon and gold guestbook, proudly pointing to the signature of Umberto, onetime king of Italy, but lamenting the lack of Spanish names among the distinguished company.

The dignified gate to the garden, fronting on the noise and gasoline fumes of the busy Paseo del Prado, is the symbol of a vanished age. Dating from I78r, the gate honors the king who gave life to the garden, Charles III, "restorer of the botanic art for the health and delight of his citizens." Through the portal one enters that age now vanished, an age when the botanic garden was new and Spain yearned to become, and spent money freely trying to become, the world leader in plant exploration, an age when botany was a matter of state and ministers were not strangers to the botanical scene.

Hispanophiles, to ward off the buffeting so often their lot in the field of world opinion, have seized upon these words of Alexander von Humboldt, the great German scholar who witnessed first hand this moment of Spanish glory:

No European government has laid out greater sums to advance the knowledge of plants than the Spanish government. Three botanical expeditions, those of Peru, New Granada, and New Spain, ... . have cost the state about two million francs. Besides, botanic gardens have been established at Manila and in the Canary Islands. The commission destined to survey the Güines canal was also charged with examining the vegetable products of the island of Cuba. All this research, made during twenty years in the most fertile regions of the new continent, has not only enriched the domain of science with more than four thousand new species of plants; it has also contributed greatly to spread the taste for natural history among the inhabitants of the country. ${ }^{1}$

I. Translated by the author from Alexander von Humboldt, Essai politique sur 
Dr. Samuel L. Mitchill, professor of natural history at Columbia College in New York, passed on Humboldt's information to the members of the historical society of his state at their annual meeting in I8I3. "I wish it was in my power," he said, "to state the particulars of the great exertions for the improvement of American botany made by the kings of Spain." Dr. Mitchill put the outlay for the expeditions at $\$ 370,000$. $^{2}$

Our story concerns the first of those expeditions lauded by Humboldt, that of Hipólito Ruiz López (1754-1816) and José Antonio Pavón y Jiménez (I754-I840) to the viceroyalty of Peru. ${ }^{3}$ Life became an adventure for these young pharmacists in November, I777, when they set sail from Cádiz in search of seeds and specimens, drawings and details, hoping to provide their king - and all mankind-with the first comprehensively documented study of plant life in the Spanish New World. For more than a decade they explored the deserts, the harsh Andean heights, and the oppressive but rewarding tropical forests of this botanic Eden, accompanied by two illustrators, Joseph Brunete (I746-I787) and Isidro Gálvez (I754-1829), and, for six years, by a French botanist, Joseph Dombey (I742-I794). And when the last members of the group returned to Spain in 1788 , they left others behind to carry on the work, albeit sporadically, for more than a quarter-century.

As Humboldt has already made clear, the viceroyalty of Peru was but one of many Spanish dominions to yield its fruits to eager naturalists. Ruiz and Pavón confined their efforts to Peru and Chile; their replacements strayed no farther than Quito. But meanwhile, from 1783 until thoughts of political independence usurped attention in 1816 , another and larger group studied the flora of New Granada. Observations in New Spain went on from 1786 to 1803 . On a smaller scale, the Royal Company of the Philippines sought out knowledge

le royaume de la Nouvelle-Espagne (Paris, I8II), I, Bk. II, chap. vii, I20. An English translator of 1822 (John Black) converts Humboldt's estimate of two million francs into $£ 83,340$ sterling. The Güines canal, projected in 1796 , was supposed to link Havana and the southern coast and open up the interior to commerce. Construction was actually begun, but lack of funds and jealousies of some slighted landowners brought work to a stop. (Jacobo de la Pezuela, Historia de la isla de Cuba [Madrid, 1868-1878], III, 309-310.)

2. New York Historical Society, Collections, II (1814), 206.

3. The spelling of Pavón's first name, José, has been adopted in this study in accordance with the modern form he used in his later years. At an earlier date he was accustomed to choose more frequently either the spelling Josef or Joseph $(\mathrm{Jph})$. 
of plants in that remote archipelago. In addition, botanists were an important part of a hydrographic expedition that, between I 789 and I 794, touched nearly all of the Spanish possessions. ${ }^{4}$

Regrettably, the results of most of this effort have languished in obscurity to the present day, for war-torn Spain was in no position to reward its scientists with publication. One partial exception stands out. Thanks to support, not of Spain, but of citizens in the wide reaches of the Spanish Empire, the Flora of Peru attained a quarter, though no more than a quarter, of its publication goal. The wages of war indeed help to explain this impuissance, but, at least in the case of Ruiz and Pavón, a score of other vicissitudes must be considered.

This, then, is our task: to relate the story of Ruiz, Pavón, and the Flora of Peru in its grandeur and its farcicality. As a historian, not a scientist, we direct our words to non-scientist readers-or, more to the point, to those who would learn of the cultural and intellectual history of Spain, and especially of Spain in America. We seek to record the human side of the expedition and its frustrating afteryears, with all of the tensions, the hardships, the follies, the heartaches, the triumphs, and the international jealousies.

But one can scarcely leave out a discussion of botany itself, for that science held a place of honor in the eighteenth-century heart. On the assumption that the student of history may bring to his task a limited knowledge of botanical development, an abundance of background material is included. Unless the reader can see the upsurge of interest in botany in Spain as part of a larger whole, he will likely give too much, or perhaps not enough, stress to this phenomenon. For technical analyses of plant discoveries made by the expedition, the reader is directed to those few works of Hipólito Ruiz which have been immortalized in type.

A word about the subtitle to this study. The reader will doubtless become aware of the importance of Joseph Dombey, the French member of the party, and may wonder at the omission of his name

4. The Cuban venture mentioned by Humboldt was led by Baltasar Manuel Boldó, an Aragonese physician, as botanist, assisted by the draftsman José Guio. Their project was undone by the death of Boldo at Havana in 1799. (Miguel Colmeiro, La botánica y los botánicos de la peninsula hispano-lusitana [Madrid, I858], pp. I3, 47, 186-187.) Another expedition cut short by death was that of Pehr Löfling, a Swedish botanist who battled illness in Venezuela for two years (1754-1756) while trying to collect plant specimens for the Spanish crown. For more about the Löfling expedition, see Pp. 30-36, below. 
from the title. A desire for brevity, a concern especially with Spanish affairs, and a realization that Dombey did not share in the expedition during all the years of its life have dictated this omission. No minimizing of his role is intended, though he did not always live up to expectations. Admirers of Chile may also cavil at the frequent omission of its name from the title we use for the masterwork of Ruiz and Pavón. After all, they called it Flora Peruviana et Chilensis. Again, a need for brevity and a recognition of the fact that the men spent far more time in Peru justify the exclusion. Chileans may take their solace in the fact that the botanists seemingly found more delight in a few months in the southern realm than in all the years in Peru.

There were many facets to scientific activity during the Enlightenment in the viceroyalty of Peru. When the present study was conceived, the author, in the first bloom of overestimation, hoped to fuse them all into one grand whole. The Ruiz-Pavón expedition would be only the beginning-a chapter or so. But a synthesis cannot be attempted until one has mastered the details. In this sense the following pages, which long ago burst the bounds of a chapter, are still but first steps to the understanding of a movement that has yet to receive its fair share of attention.

Thanks to the generous financial help of the Henry L. and Grace Doherty Charitable Foundation, the author spent a year in Peru and Chile, gathering material on the range of scientific interest in those parts during the Enlightenment. The fact that comparatively few of the notes then taken have been used in the present study does not negate their importance; it merely postpones their appearance until they can be better understood in relation to the prodigious and varied efforts that the mother country exerted to promote the cause of science.

Others who generously shared of their resources to advance the study toward its end were the persons to whom the work is dedicated, as well as the Publications Committee of the Duke University Graduate School of Arts and Sciences and its acting chairman, Dr. Robert S. Smith, whose grant did much to assure publication, and the Research Foundation of the University of Toledo, which paid for the author's trip to Spain and France in the summer of 1959. Perhaps the author should also acknowledge the help of his bank, which put 
enough trust in his honest face to lend him the cash for a first trip to Spain in the summer of 1958.

Work on this book has done much to restore the author's faith in the kindness, generosity, and unselfishness of so many of his fellow men and women. Especially does this apply to Señorita María de los Ángeles Calatayud, of the Museo Nacional de Ciencias Naturales in Madrid, who so often gave of her time to fill in the gaps in the author's knowledge. Others in Spain who cannot go unnoticed are Dr. Enrique Alvarez López, late director of the Instituto Botánico A. J. Cavanilles de Madrid, whose unexpected death in December, I96I, halted his career as a perceptive analyst of Spanish botanical history; Dr. Eduardo Balguerías Quesada, director of the Jardín Botánico de Madrid; Dr. José de la Peña y Cámara, director of the Archivo General de Indias in Seville; and Dr. Antonio Rodríguez Moñino, the noted Spanish bibliographer, who set the author on the track of a most useful collection of periodical sources. For help and encouragement during his stay in Peru, the author is grateful to Señor Federico Schwab. The assistance of Mr. Thomas O'Grady, general secretary of the Linnean Society of London, and Professor Alberto Chiarugi, director of the Istituto Botanico della Università di Firenze, is acknowledged in the appropriate footnotes. Warm appreciation is especially reserved for Miss Phyllis I. Edwards, librarian, Botanical Section, British Museum (Natural History), who solved a dilemma of the author at the cost of personal effort.

Closer to home, the following members of the staff of the Department of Botany, United States National Museum, were most helpful in verifying plant nomenclature: Drs. John J. Wurdack, associate curator; and Lyman Smith and C. V. Morton, senior botanists. Another helping out in the same vein was Dr. F. R. Fosberg, of the United States Geological Survey. One other botanist, Dr. George H. M. Lawrence, director of the Rachel McMasters Miller Hunt Botanical Library at Carnegie Institute of Technology, deserves notice for "exceptional services rendered," a far too modest description of the help and inspiration he provided the author. Dr. Clement G. Motten, professor of history at Temple University, who read an earlier version of the manuscript, made many valuable suggestions which I hope he will find have been carried out to his taste; Mr. Thomas M. Simkins, Jr., curator of rare books in the Duke 
University Library, and, especially, Dr. Frederic M. Wheelock, professor of classical languages at the University of Toledo, rescued the author from a Latin morass; Dr. Duane D. Smith, chairman of the history department of which the author is a member, demonstrated his interest and encouragement in a very tangible manner; and Mrs. Donna Clarkson transformed much of a bespattered manuscript into an accurate reflection of the author's thoughts. His thanks go out to all of these individuals, together with his assurance that any errors remaining are the sole responsibility of the author.

Of the many persons who have helped to see this study to completion, from its inception as a doctoral dissertation at Duke University, two stand out for their extraordinary patience, advice, and encouragement: Professor John Tate Lanning and my wife, Elizabeth, for whom these small words of gratitude are but scant repayment. My wife's share in making the index was also a major one.

The author has no illusions that his study is complete. The almost uninterrupted discovery of new ideas and developments went on until the final page was done and shows no sign of a let-up. But he takes leave to present his work now in hopes that the major outlines are at least, and at last, coming clear.

Arthur R. Steele

University of Toledo 


\section{CONTEN TS}

chapter

page

I. BACKGROUND TO BOTANY

Handmaiden to Medicine, 3; The Century of Joyfull Newes, 4; Filing Systems and the Linnaean Revolution, 7 ; Flowering of the Gardens, IO; The Scientific Traveler, 12; EarthFlatteners and the Search for Quinine, 16; The Years Beyond, 22; What Is a Botanist?, 25.

II. SPAIN TAKES TO BOTANY: THE

EIGHTEENTH CENTURY

For the Cure of a Great Swoon, 27; Löfing and the "Conversion" of Spain, 30; A Garden and Some Books, 36; The Curiosities in the Cabinet, 39; The Dream of José Celestino Mutis, 44; Why Spanish Enthusiasm? 46.

III. GENESIS OF THE EXPEDITION

Turgot's Design, 50; An Expert of the French Temperament and Four Tyros of the Spanish, 52; The Way to Harmony, 57; Money Matters, 60.

IV. THE KEY TO THE CITY OF KINGS

A Cultural Revolution in the Making, 65; "All that Glitters...," 74 .

V. THE GENTLE YEAR

Orientation in the Ways of Plants and Men, 79; To North, to South, 82 .

VI. THE SCIENTIFIC QUESTS OF JOSEPH DOMBEY

Shopper by Proxy, 88; The Unvirtuous Cinnamon, 89; In Pursuit of Platinum, 92; Nitrate or Not?, 94; By the Waters of Chauchin, 97. 


\section{VIRGIN LANDS OF MOUNTAIN} ANI $M O N T A \tilde{N} A$

Tarma: "Temperate, Luxuriant, Pleasant," 99; Huánuco: Salvation by Quinine, 102; Dombey's Bad News from the Good Advice, II I.

VIII. CHILEAN INTERLUDE

Concepción: Parliament, Plague, and Pine Trees, II7; Mutual Enthusiasm in Santiago, 124; The Mercury Mirage, I 25; A u Revoir, $M$. Dombey, I3I.

IX. FOUR YEARS IN THE PERUVIAN BACKLANDS

An Extension Means "Greater Riches," 135; Pozuzo: Two Months for a Century, I37; The Adding of the Agregados, I I I Holocaust of the Many-Headed Monster, 143; The Burning Question, 148; Trouble Takes No Holidays, 152; Final Trips for Tired Men, 155.

\section{IN'TERNATIONAL RELATIONS AND} THE RACE FOR PUBLICATION

Partition Under Protest, I6I; The Reluctant Pledge, 165; A Long Problem of Division, 169; Dombey in Decline, I73; The Case of the Abducted Herbarium, 176.

XI. THE CONTROVERSIAL BARK

Botany: The Seventh Nymph?, 187; Gardeners Without Glory, 189; The Seven Species of Don Hipólito, 192; Mutis' Quina of Many Colors, 197; The Physicians" "Line of Demarcation," 198; The Invective Supplement, 203; The Wages of Factionalism, 207; Victory Goes Elsewhere, 210.

XII. AMERICA RESCUES THE FLORA

XIII. THE PRODROMUS AND THE POLEMICS

The Winding Road to Grandeur and Magnificence, 225; The Disputatious Mister Anonymous, 233; The Waning of Gómez Ortega, 240. 
XIV. AN UNFULFILLED FLORA FOR THE KING 246 An End to Munificence, 246; Rubio the Undaunted, 249; The Way to Insolvency, 254; For Reasons of State, a Fossilized Flora, 257.

XV. PERUVIAN SEQUEL

For Want of a Chair, 266; The Peripatetic Professor, 272; Frail First Steps at San Fernando, 279.

\section{JOSÉ PAVÓN AND THE DECADES}

OF DECADENCE

The Second Botanist Becomes the First, 285; International Trader in Plants, Friendship, and Cockle Shells, 291; The Liberal Renaissance, 300; Treadmill to Nowhere, 305; A Few Questions of Probity, 309; Swan Song Largo e Sostenuto, 315; The Octogenarian's Atonement, 321 ; A Last Word, 325 .

APPENDIXES

B I B L I O G R A P H Y

IN DEX

\section{ILLUSTRATIONS}

Facing page 232: The title page of the Prodromus

Facing page 254: The title page of the Flora Peruviana

Following page 332: Don Hipólito Ruiz; A. J. Cavanilles; Plaza Mayor de Huánuco; Illustrations from Gómez Ortega's work on the shipment of living plants; Routes of Ruiz, Pavón, and Dombey (maps); Cinchona ovata (plate from the Flora Peruviana); Physalis prostrata (plate from an illustration by Redouté published in L'Héritier's Stirpes novae); Gate of the Jardín Botánico de Madrid 

FLOWERS FOR THE KING 



\section{B A C K G R U N D TO BO TA NY}

\section{HANDMAIDEN TO MEDICINE}

Man turned to plants as sustenance for his body and solace for his ills an eternity ago, but became a botanical scientist only yesterday. True, the Greece of old spawned the "father of botany," Aristotle's disciple Theophrastus. He asked fundamental questions: Why does a plant have this organ, or that? How does this plant differ from that? His answers would not please us today, though his system of classification-trees, shrubs, herbs-had its devotees two thousand years after his time. What he needed most was a mass of data, proven by observation, to substantiate his theories.

The successors of Theophrastus might have supplied that data, but theirs was a different world, without place for rational theorizing or systematic observation. Thus, botany fell into its modest role as handmaiden to medicine. The encyclopedic Natural History of Pliny-facts, errors, and all-compiled in the first century A.D. and circulated widely during medieval times, devoted nearly a fourth of its contents to the medicinal properties of plants. The same century produced the work "more attentively studied word for word and line by line [with one possible exception] than any other book on botany which has yet been written." "This was the "herbal" of Dioscorides, an outline of the pharmaceutical properties of some six hundred species. The descriptions are sc brief that only a portion of the plants can be identified today. ${ }^{2}$ Yet, in the sixteenth century alone, over thirty different editions were published (the original

1. Howard S. Reed, A Short History of the Plant Sciences (Waltham, Mass., 1942), p. 43. The possible exception is Kaspar Bauhin, Pinax theatri botanici

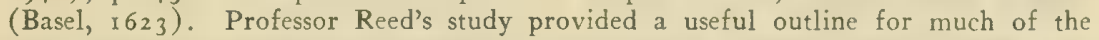
early historical background contained in this chapter. Other general works consulted were Ellison Hawks, Pioneers of Plant Study (New York, r923), and R. J. Harvey-Gibson, Outlines of the History of Botany (London, 1919).

2. Agnes Arber, Herbals: Their Origin and Evolution (2nd ed.; Cambridge, 1938), P. 10. 
Greek, as well as Latin, French, Italian, and Spanish). ${ }^{3}$ This figure reveals the static nature of botanical knowledge until well into the seventeenth century, though most of these editions contained new commentaries.

The invention of printing brought herbals to their zenith of popularity in the sixteenth century. Catalogues of plants had circulated in manuscript, sometimes for hundreds of years; now these surged from the presses and called into being a host of new ones. An expert has compiled a list ("far from being exhaustive") of ninety-nine different herbals and "related botanical works" published between 1472 and I670." By the latter date, however, botany had begun to win comparative independence: plants were no longer classified merely by qualities that made them medicinally useful. On the other hand, advancement in engraving techniques gave the illustrations so much importance that they threatened to convert botany into a picture book science for bibliophiles. But the painter and engraver brought to bear upon the various plants their acute powers of observation and the effect on botanical studies was no doubt beneficial. ${ }^{5}$

\section{THE CENTURY OF JOYFULL NEWES}

The sixteenth century was, as everyone knows, a period of great discovery, not only of lands and peoples and gold, but of strange foodstuffs and cure-alls. Migration of species from America to all parts of the globe, as a result of these discoveries, has been called "the most extensive, the most prominent, the most universal and the

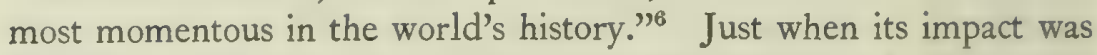
first felt in Europe is still a matter of doubt, ${ }^{7}$ but Gonzalo Fernández

3. This count is based upon published lists of holdings of the British Museum and the French Bibliothèque Nationale. It does not include an indeterminate number of mere reprints. The Spanish translation of 1555 was republished many times, and, with annotations, appeared as late as 1752 . (Colmeiro, La botánica y los botánicos, p. 3.)

4. Arber, Herbals, pp. $271-285$.

5. Ibid., pp. 245-246, 264-265.

6. Berthold Laufer, "The American Plant Migration," The Scientific Monthly, XXVIII (March, 1929), 241.

7. Arthur S. Aiton, "The Impact of the Flora and Fauna of the New World upon the Old World during the Sixteenth Century," Biologia, II (Chronica Botanica, Vol. XII, Nos. 4-6 [1950-195I]), 123. 
de Oviedo has gained the title of "First Naturalist of the New World" for the excellent, though "popular," descriptions he made as early as $1535 .^{\circ}$

None of the other Spanish historians of the sixteenth century equalled Oviedo in botanical detail, but, as might be expected, a wide variety of fact and fancy filtered into the mother country from the lips and pens of conquistadores and settlers. An early "Opinion on the Method of Making Discoveries in the Indies," drawn up by a cosmographer of Charles $\mathrm{V}$, told the explorer to determine

what are the items of sustenance of the land and which ones are generally used, whether fruits or seeds, and all manner of spices, drugs or whatever other scents, and find out the time in which each one of these things is gathered, and learn the time in which one can reproduce the trees, plants, herbs, and fruits that these parts offer, and if the natives use them for medicines, as we do. ${ }^{9}$

The man who would piece together in two published tomes (I 569 I57I) those random fragments of medical import was a Sevillian physician, Nicolás Monardes. His credulity may have diminished the scientific value of his labors, but it did not dim their appeal. The English edition, in fact, bore this enticing title: Joyfull Nerves out of the Nerve Founde Worlde. ${ }^{10}$

In order to distinguish the true from the false, Philip II in 1570 commissioned a study of the "natural, ancient, and political" history of New Spain. For the task he selected the palace physician Francisco Hernández ( I 5 I4-I578) and sent him off to America in the capacity of protomédico, or "medical examiner," the first one in the New World. Hernández, being a doctor, and knowing it would be "such a great enterprise not to have to bring medicine from Spain to the Indies, nor from Alexandria to Spain," put his best efforts into studying plants, questioning more than twenty native physicians, and testing medicaments on the ailing of Mexico City. His work was no

8. Historia general y natural de las Indias (Madrid, 1851-1855), Vol. I, Bks. VIII-XI. In 98 folio-sized pages of the 1851 edition, Oviedo describes 43 fruitbearing trees, 34 "wild" trees, 8 medicinal trees and plants, and Io herbs, growing mostly in Española and Tierra Firme.

9. Germán Latorre, "Instrucción general o parecer sobre el modo de hacer descubrimientos en las Indias," Congreso de Historia y Geografía Hispano-Americanas, Actas y memorias (Madrid, 1914), p. 30r.

I0. A two-volume edition in the "Tudor Translations" series was published in London in 1925. The "newes" sought to disclose "suche present remedie for all deseases, as maie seme altogether incredible: notwithstandyng by practize founde out, to bee true." 
doubt made easier by the traditions of materia medica and botanical gardening that were a part of Aztec culture.

By 1577 Hernández had compiled six folio volumes of text and ten of drawings, which he carefully dispatched to Spain, together with seeds and plants for a new royal garden at Aranjuez. Exhausted by his labors, he gave up the prospect of a similar undertaking in Peru, and had scarcely returned to Spain when he died in I 578.

It appeared for a time that Hernández's name and his papers would both pass into oblivion, perhaps for reasons of personal intrigue or a shift in ministerial fortunes. But Philip II came to the rescue by ordering the protomédico of Naples, Dr. Nardo Antonio Reccho, to distil the essence of Hernández's findings. In doing his duty, however, Reccho not only "fearlessly" excluded "all of the natural history that seemed of no use in medicine," but ended by publishing nothing either.

Fortunately, Friar Francisco Ximénez saw the need to furnish a medical guide for the haciendas and towns of Mexico that had neither physician nor pharmacist, and in I6I5 at Mexico City published the first edition of Hernández's work. He based it, however, upon the incomplete summation by Reccho. The Accademia dei Lincei of Rome put Reccho's data to use again between 1629 and 1651 , thereby providing in three editions an annotated description of $4 \mathrm{I} 2$ plants, and drawings of some 650. But before Hernández's labors could come to full fruition, fire struck El Escorial palace in 167 I and destroyed nearly all of the original manuscript.

Not even a copy of the emasculated work could be spared for Hipólito Ruiz and José Pavón when they embarked for Peru in I777. Meanwhile, however, the official Spanish historian Juan Bautista Muñoz had rescued a hitherto unknown copy of the original manuscript, but without the drawings, "from the cockroaches and termites" of the Jesuit Colegio Máximo in Madrid. From this new source Casimiro Gómez Ortega, chief botanist of the Spanish government, published three volumes in I790. Even this work was unfinished, for it left out the parts on animals and minerals.

As the first expedition of natural history ever sent out by a government, the Hernández venture is a landmark in the annals of botanical science. Although he classified his plants largely according to unscientific Aztec standards, and his descriptions are often too brief or vague, Hernández preserved a body of ethno-botanical lore 
that probably otherwise would have been lost. The story of its publication is likewise significant, suggesting the personal, physical, and financial difficulties of printing such a stock of technical data and so many elaborate drawings. This pattern of failure would be repeated many times over, for the eyes of Spanish authorities were invariably bigger than their stomachs when it came to digesting the vast quantities of botanical knowledge unceasingly offered up by the Indies. ${ }^{11}$

\section{FILING SYSTEMS AND THE LINNAEAN REVOLUTION}

The seventeenth century revealed the first valid attempts, not influenced by Aristotelian thinking, to study plants without concern for their practical uses. Joachim Jung ( I587-1657), adding new insight to existing information, concluded, for instance, that a plant selects beneficial foods not because it has an intelligent soul, but because its roots are devised to accept only certain ingredients, meanwhile rejecting others. The pioneer chemist J. B. van Helmont (I577-I 644) sought to determine the relative importance of soil and water in the growth of a tree. He reached the wrong conclusion, for he stated that the mass of the tree was derived entirely from the water and not at all from the soil, but historically more important, he backed up his reasoning by a carefully tended experiment, five years in the doing. The Italian Marcello Malpighi (I628-1694) and the Englishman Nehemiah Grew (I628-I7II) became the first scien-

II. An edition which promises at last to include all of Hernández's surviving works is now being issued by the Universidad Nacional de México (Obras completas [3 vols. to date; 1959-1960]). Vol. I contains a thorough bio-bibliographical study of Hernández by the editor, Germán Somolinos d'Ardois; Vols. II-III contain Hernández's observations on plants, animals, and minerals; commentaries on his work are promised for subsequent volumes. Other modern editions are Cuatro libros de la naturaleza y virtudes medicinales de las plantas y animales de la Nueva España (first published in Mexico, 1615, by Francisco Ximénez) (Morelia, Mexico, 1888), with a useful introduction by Nicolás León; and Historia de las plantas de Nueva España (3 vols.; Mexico City, I942-1946), the first volume of which contains the text of Gómez Ortega's prologue. Some letters from Hernández to Philip II are reproduced in Colección de documentos inéditos para la historia de España (Madrid, 1842-1895), I, 362-379. Additional correspondence and a study of Hernández's career may be found in José Luis Benítez Miura, "El Dr. Francisco Hernández: 1514-1578 (cartas inéditas)," Anuario de estudios americanos, VII (1950), 367-409. See also Germán Somolinos d’Ardois, "Bibliografía del Dr. Francisco Hernández, humanista del siglo XVI," Inter-American Review of Bibliography, VII (Jan.-March, I 957), I-76. 
tists to use a microscope for detailed study of the tissues, fibers, and vessels of plants. Born in the same year, and presenting their findings concurrently, they exemplify the best in international co-operation.

But whatever their contribution to studies of plant nutrition and anatomy, these precursors were a century and more ahead of their times-too far to establish an unbroken line of succession. More in keeping with immediate needs was an adequate method of plant classification, a "filing system" for the vastly expanded supply of plant samples and descriptions, one that would enable explorers the world around properly to label their finds, one that would endow botany with a truly universal language. Theophrastus' categories of trees, shrubs, and herbs could simply not meet the challenge. From I623 to 1750 botanists espoused no fewer than twenty-five new systems. ${ }^{12}$ England liked John Ray's (1627-I 705), based upon fruit type (conebearing, nut-bearing, pomiferous, etc.), and subdivided according to leaf and flower characters. France and Spain preferred Joseph Pitton de Tournefort (1656-1708), who looked to the flower for his guide; he rejected the idea that root, stalk, or leaf could provide a reliable base. Then in I732 Carl Linnaeus (I707-I778) of Sweden introduced his sexual system, and botanical science came to life, if not yet to maturity.

Linnaeus made stamens, or pollen-bearing organs, and pistils, or seed-bearing organs, the foundation of his system. To account for all plants, he created twenty-four classes, largely on a numerical base: for example, Classes I to X consisted of plants with one to ten stamens. Many of the remaining classes were decided by the form of union: i.e., Class XVI had all stamens united by their filaments; XVII had them all united in two bundles; XVIII in several bundles. A further segregation into orders depended largely upon the status of the pistils. Class XXIV, Cryptogamia, included all of the lower forms, from ferns and mosses downward, for which he could find neither stamens nor pistils.

This system, as its creator well knew, was entirely artificial, ignoring the fact that all characters, not merely the sex organs, must enter into a true and natural arrangement of plants. In the words of a modern authority, it was as though Linnaeus had grouped together

12. Émile Guyénot, Les Sciences de la vie aux XVII et XVIII siècles: l'idée d'évolution (Paris, 1941), pp. 16, 19. 
all four-legged furniture whether tables, chairs, or chests. ${ }^{13}$ Yet the artificiality of Linnaeus' system turned out to be its greatest asset from the standpoint of public acceptance. A student with but little practice could arrange plants and, more importantly, find them again. As a result of the Swede's innovations, botany, "instead of remaining an abstruse study, confined to the schools, ... was converted into an agreeable amusement, to persons of leisure in all ranks and situations."14 Of incalculable aid in spreading the Linnaean gospel was his adoption of "binary" nomenclature, giving every plant a two-word name, the first for genus and the second for species. The idea was not a new one, but until Linnaeus' time it had not been consistently applied. Even he did not expect it to replace the multiple names so often given to plants, but it proved so adaptable that its use has prevailed to the present day, long outlasting acceptance of the sexual system of classification. Listen to the Marquis de Condorcet:

Linnaeus has been reproached for having made botanical nomenclature too easy, and having thus brought on a multitude of mediocre works. That objection seems only to prove the progress botany has made in his hands. Nothing, perhaps, shows better how far a science has advanced than the facility of putting out mediocre books on such a science, and the difficulty of writing ones which contain new things. ${ }^{15}$

English scholars turned as readily to the Swede as did the dilettante. Ray's catalogue of English plants was adapted to the system in I 760 and favorable reception by the London College of Physicians assured predominance for Linnaean doctrines. ${ }^{16}$ Englishmen vied with each other to suggest alterations in his Systema naturae, that they might be mentioned in one of his works. ${ }^{17}$ The leading botanists of Holland and Germany also began to use the Linnaean system. In France, however, he made less headway. He became one of eight foreign associate members of the Académie des Sciences, and Bernard de Jussieu arranged $\mathrm{La}$ Trianon garden at Versailles according to Linnaeus' classification, though with modifications that later grew into the "natural" system of Bernard's nephew, Antoine Laurent

13. George H. M. Lawrence, Taxonomy of Vascular Plants (New York, 1951), p. 32 .

14. Samuel Miller, A Brief Retrospect of the Eighteenth Century (New York, I 803 ), I, I 35 .

15. "Éloge de M. de Linné," in Oewvres (Paris, 1847-1849), II, 343-344.

16. Miller, Brief Retrospect, p. 136 .

17. Knut Hagberg, Carl Linnaeus (London, 1952), p. 159. 
de Jussieu (1748-1836). ${ }^{18}$ But with the imperious Count Buffon (1707-1788), disdainful of all "methods," guiding the destinies of the royal museum of natural history and botanic garden in Paris, there was little chance for Linnaean ideas to take root. Indeed, Tournefort's system held on until Antoine Laurent published his "natural" classification in I 789.

By the end of the century Linnaean adherents had begun to lose the fight, as a score of natural systems arose, encompassing all parts of the plant. When in 1859 Charles Darwin's On the Origin of Species put a halt to the notion that "all species were settled once and for all, created by God in the dawn of time," botanists set off on a new crusade to classify plants in accordance with their "race history." But that is another story.

Some present-day observers, with a hindsight of evolutionary knowledge, claim that Linnaeus set back the attainment of a true natural classification by nearly a hundred years. ${ }^{19}$ But the man must be judged in the light of his times, and probably no one before or since has given such an impetus to botanical study. Even today Linnaeus "will continue to be the hub from which all serious taxonomic research at the lowest (species) level must emanate."20 And while plant scientists search, often in vain, to learn of the origins of plants, and sometimes are unaware even of a plant's nearest relative, Linnaean nomenclature goes on almost unscathed.

\section{FLOWERING OF THE GARDENS}

Even as the formal garden of the Italian Renaissance cast its spell upon the wealthy in other parts of Europe, so Italy gave birth to the first gardens for botanical study in the modern sense of the term. By the middle of the sixteenth century the universities of Padua, Pisa, and Bologna each had one. ${ }^{21}$

18. Hawks, Pioneers of Plant Study, p. 242.

19. Harvey-Gibson, Outlines of the History of Botany, p. 55.

20. Lawrence, Taxonomy of Vascular Plants, p. 18. See ibid., pp. 13-41, and Earl L. Core, Plant Taxonomy (Englewood Cliffs, N. J., 1955), pp. 9-61, for excellent summaries of the history of plant classification.

21. It is hopeless in this brief discussion to give exact dates in all cases, as no two writers agree. The uncertainty is due largely to the informal beginnings and the inability to decide what exactly was a "botanic garden." For the most complete listing of gardens see C. Stuart Gager, "Botanic Gardens of the World: Materials 
In Spain, Andrés Laguna propounded the need for a botanic garden as early as 1555 in an edition of Dioscorides. A royal cédula authorized one at Aranjuez a mere three years later, on what was already the site of an elaborate formal garden. Befitting the times, its special object was to be the display and protection of rare and medicinally useful plants gathered in southern Spain and the Indies. ${ }^{22}$ But official attention soon waned, thereby undoing whatever progress had been made. Philip III, at the instigation of his physician, ordered the establishment of a "Jardín de Yerbas" at Madrid in 1598, but its life was likewise fleeting. In the same decade Simón Tovar drew up a catalogue of medicinal plants and other exotics he was cultivating in Seville. The seventeenth century, however, was sterile, and only in the eighteenth did the Peninsula get a true botanic garden. ${ }^{23}$

Meanwhile other nations entered upon the study. By the end of the sixteenth century, Leyden and Leipzig had botanic gardens, and in 1593 the famous one at Montpellier opened its gates. In an institution of learning so widely renowned for medical training, the latter garden was, strangely enough, designed not merely to teach physicians and to study "simples," but to help solve problems of the farm and economy in general. In contrast, the Jardin du Roi, officially created at Paris in I635, had at first a more limited goal: to facilitate plant study among physicians. Three doctors of the Faculté were named to make plant demonstrations, and the catalogue of I 640 listed 2,360 species. ${ }^{24}$

for a History," Brooklyn Botanic Garden Record, XXVI (No. 3, July, 1937), 1 49-353.

22. Documentation for the existence of this garden seems to depend on the statement of Francisco Franco, in his Libro de las enfermedades contagiosas (Seville, I569), that he saw the cédula. The royal will was that Francisco de Castilla take charge of the transport of a large number of "curious" trees and herbs. "And afterwards, by request of said Don Francisco, another Fisico and I asked many questions of the herbalist about the doctrine of herbs, and found him well versed in them; and he gave a good account of the chapters of Dioscorides: and certainly seemed to me well practiced in the field. His Majesty was quite right in having turned over that charge to him." (Ignacio de Asso, "Discurso sobre los naturalistas españoles," Anales de ciencias naturales, III [1801], I74, note of Antonio Cavanilles.) See also Hipólito Ruiz and José Pavón, Florae Peruvianae, et Chilensis prodromus, sive novorum generum plantarum Peruvianarum, et Chilensium descriptiones, et icones (Madrid, I794), p. iii. (Hereinafter Ruiz and Pavón, Prodromus.)

23. Miguel Colmeiro, "Bosquejo histórico y estadístico del Jardín Botánico de Madrid," Anales de la Sociedad Española de Historia Natural, IV (1875), 243-244. (Hereinafter Colmeiro, "Jardín Botánico.")

24. Maurice Caullery, "Histoire des sciences biologiques" in Histoire de la nation française, ed. Gabriel Hanotaux, XV (Paris, 1924), 72-74. 
The history of botanic gardens in England begins at Oxford in I62I, and by I669 Robert Morrison was "in the habit of giving three demonstrations weekly, at a table in the middle of the newlyestablished Physick Garden.”25 But a century later the avid seeker of professional knowledge at Oxford would not have been so fortunate. In the thirty-six years (1747-1783) that Humphry Sibthorp held the chair he reportedly gave but one lecture in botany and made no other arrangements for instruction. ${ }^{28}$ More important in England was the Chelsea Physic Garden, constructed by the London Society of Apothecaries in 1686, which long flourished with a healthy esprit de corps. ${ }^{27}$ The wondrous Kew Gardens near London assumed the lead a full eighty-six years later under the enthusiastic guidance of Sir Joseph Banks. He envisioned Kew as an "exchange house" for the entire British Empire where plants from all parts of the world could be tested and acclimatized, if possible, to other regions. ${ }^{28}$

Berlin witnessed a start in 1646 and Amsterdam in 1682 , but the big flood came after the mid-eighteenth century: Vienna (1754), Madrid (I755), Lyons and Nancy (1758), Cambridge (I762), Versailles (1765), Frankfurt (I766), Budapest (I77I), Coimbra (I772), Milan (I78I), and of course Kew, among numerous others. Until this time the unquestioned leader was the great institution at Paris, which had left the purely medical in order to embrace, under royal sponsorship, all fields of botanic study.

\section{THE SCIENTIFIC TRAVELER}

To stock these treasure-houses, the seventeenth and eighteenth centuries turned to a relative newcomer, the scientific traveler. One of the great botanical voyagers of the seventeenth century was Georg Eberhard Rumphius (1628-1702). Sent to the small island of Am-

25. Hawks, Pioneers of Plant Study, p. 207.

26. Hector Charles Cameron, Sir Joseph Banks (London, 1952), pp. 2-3.

27. The members had a monthly hunt for plants from April to September in some village around London. At the end of the season a copy of Ray's Synopsis (later William Hudson's Flora Anglica) was given to the one discovering the greatest number of plants. Once a year everyone made a longer excursion "to collect the scarce plants and dine together; on which occasion they are frequently accompanied by other gentlemen, who are fond of the same pursuits." (Richard Pulteney, Historical and Biographical Sketches of the Progress of Botany in England [London, 1790], II, 99-101.)

28. Cameron, Sir Joseph Banks, p. 63. 
boina in the Moluccas in 1653 by the Dutch East India Company, which was especially interested in the local spices, Rumphius described about I,700 forms of the flora of that tiny bit of land. The first European to make botanic collections in China (and whose herbarium arrived home safely) was James Cunningham, a physician sent out to the English factory at Amoy in I698. Tournefort was by no means a stay-at-home classifier, having ranged through Spain and Portugal and then, at the expense of the French king, to Greece, the Black Sea countries, and Asia Minor. His Relation d'un voyage $d u$ Levant was published in I7I7. Michel Adanson (I727-1806) chose the hot, unhealthy, dangerous, and almost unknown Senegal, in West Africa, as his base of operations. In studying the finds he had made for the India Company over a four-year period, he developed a natural system of classification and evolved in a crude form the idea of the mutability of species. The enmity of rivals regrettably delayed acceptance of the work of this explorer, taxonomist, systematist, philosopher, and encyclopedist. Pierre Sonnerat (I745-18 I4) traveled from the islands of Bourbon and Madagascar in the Indian Ocean to India, Ceylon, the Moluccas, and China between I 768 and I 778 and deposited a rich collection with the "cabinet" of the French king.

Pupils of Linnaeus added to the stream of travelers: Olof Torén, Pehr Osbeck, Carl Fredrik Adler, and Christopher Tärnström toured China or the East Indies. Carl Peter Thunberg published a flora of Japan and also spent three years botanizing in South Africa. Andreas Berlin and Adam Afzelius conducted investigations in West Africa. Fredrik Hasselquist and Pehr Forsskal studied the Near East. Andreas Sparrman went to South Africa and later rounded the globe after joining Captain James Cook's second great voyage of I772-I 775. On the first of Cook's expeditions (I768-I77I), Daniel Karl Solander assisted the noted Sir Joseph Banks. Daniel Rolander went to Surinam, and Pehr Kalm brought North America into the Linnaean orbit when he voyaged at the expense of Swedish universities through Pennsylvania, New Jersey, New York, and parts of Canada in I748-r 751 , seeking plants adaptable to the Swedish climate. ${ }^{29}$

The English colonies themselves produced a surprising number 29. See Rob. E. Fries, A Short History of Botany in Sweden (Uppsala, I 950), pp. 28-34. 
of amateur botanists: men like John Bartram ( I699-I 777), a farmer who became a prodigious plant collector for profit, started a private botanic garden in Philadelphia, was sought out by travelers from Europe, and eventually was appointed "King's Botanist in America"; Alexander Garden (ca. I 730-I79I), a South Carolina physician who corresponded with Linnaeus for years, even daring to dispute him in I 77I, and became a fellow of the Royal Society of London; and Cadwalader Colden ( $1688-1776$ ), lieutenant governor of New York, who first showed Linnaeus' works to Dr. Garden, and whose own plant findings were published in Sweden in I743-1744. There was also John Clayton, M.D. (ca. I685-1773), who sent plants to John Frederick Gronovius in Leyden for the Flora Virginica ( 1743). John Mitchell (d. 1768), another Virginia man of medicine, forwarded seeds and plants to Europe in the I740's and had thirty new genera listed in a paper published by the Royal Society. Humphry Marshall (I 722-I8OI), who had been sending many specimens from Pennsylvania to England since 1767 , published the Arbustrum Americanum, arranged according to Linnaean principles, in 1785 -the first strictly American botanical work (written by a native American and printed in the United States).

The new breed of scientific travelers first entered South America in I638, when the Dutch West India Company sent Georg Marcgrave (I6IO-I644) to northern Brazil (then under Dutch control) as "astronomer" and investigator of geography and natural history. Willem Piso, physician to the leader of the expedition, the Count of Nassau-Siegen, assumed charge of botanical studies insofar as they pertained to medicine. Marcgrave's death in I644, when he was about to leave for home, caused great confusion, for he had written his manuscripts largely in cipher: he apparently suspected Piso would appropriate them as his own. The task of decoding the notes was unfortunately handled by a man who knew little of natural history. The Historia naturalis Brasiliae appeared in I 648 under Piso's name, though it is unlikely he had much to do with the editing. A recent student of Marcgrave's work declares that, had the scientist lived to see his labors done, "our knowledge of the natural things of Brazil would have been more advanced in the year 1650 than it was in the year I 800."30

30. E. W. Gudger, "George Marcgrave, the First Student of American Natural History," The Popular Science Monthly, LXXXI (Sept., 1912), $250-274$. 
One of the most eminent naturalist-visitors to the New World was Hans Sloane (1660-I753). He came to Jamaica in 1687 in the usual guise of physician (to the Duke of Albemarle), but was also trained exceptionally well in botany. He stayed only fifteen months, yet gathered some eight hundred new species of plants which he published according to Ray's system in 1696. Sloane's later work on the Antilles (1707-I 725) is a botanical classic because of its exactness of definition, an advantage which renders it useful even today to students of West Indian plant nomenclature and classification. ${ }^{31}$

Jamaica continued under observation as Patrick Browne (ca. I 720 I790) set himself up as a physician there in I746. During nine years he collected over one thousand species, all well defined in his Civil and Natural History of Jamaica (London, I756). Meanwhile, Griffith Hughes, rector of the parish of St. Lucy on Barbados, was working on his natural history of that island, and published it in 1750 . His descriptions are considered sufficiently precise for the identification of many species, but his is the work of a man who followed "the rules of no system of botany." Another physician, the Scotsman William Houston, spent four years (I729-I 733) in Cuba, Veracruz, Campeche, and especially Jamaica, from whence he sent specimens and seeds to Philip Miller, who described them in his Gardeners Dictionary. Mark Catesby (ca. I679-I 749) collected in the Bahamas, as well as in South Carolina, Georgia, and Florida, from 1722 through I726, and his sumptuous illustrations created a stir among dilettantes and scientists alike.

Whereas the British government gave no financial support to the study of plants - even the "King's Botanist" John Bartram received no official encouragement ${ }^{32}$ - the French began to promote the science in I689. In that year, Louis XIV sent Joseph Donat Surian (d. I69I) and Charles Plumier (I646-I704) to Martinique and Haiti, specifically to report on plants. Surian prepared the herbarium and studied the medicinal properties, while Plumier, utilizing his talents for both drawing and botany, made the illustrations and descriptions. Upon returning to France after eighteen months, Surian was suddenly dismissed and shortly died, and Plumier became botaniste $d u$ roi. He made a second voyage to the Antilles in I696-1697, and in I704

31. G. R. de Beer, Sir Hans Sloane and the British Museum (London, 1953), esp. pp. I 100-10I.

32. Ernest Earnest, John and William Bartram, Botanists and Explorers (Philadelphia, 1940), p. 80 . 
was on his way to Peru to study the bark of the tree from which quinine comes, when he died unexpectedly in Cádiz. ${ }^{33}$

An official French "expedition" did reach Peru and Chile in I709, in the person of Father Louis Feuillée, mathematician to the king. His main task was to determine longitudes and chart the coasts of South America, but he also thought it "useful" to know more about the diverse flora and fauna of the countries along his route. Spanish American officialdom was wary at first of the stranger, but in time he was even offered the chair of mathematics in Lima which had been vacated at the death of Juan Ramón Koenig. ${ }^{34}$

Botany was only a sideline to Feuillée: while working on a map of Lima at the request of the viceroy, he stole an hour a day to draw "some plant or animal that an Indian I was paying for the purpose brought me every evening, not having the leisure myself to go and look for them."3.5 The nature of Feuillée's mission prevented his traveling very far inland. Thus his "History of the medicinal plants which are most in use in the realms of South America, Peru, and Chile" is limited in scope (it includes fifty plates), but it provides the first detailed knowledge of vegetation along the Pacific Coast.

Close on Feuillée's heels was another mathematician (and engineer), Amédée François Frézier, who from I7I2 to I7I4 in the same area performed much the same cartographical functions (and, in his own eyes, with greater proficiency). Interspersed with his pungent remarks on the laziness, licentiousness, and extravagance of the local residents are various plant descriptions, but only four plates. $^{36}$

\section{EARTH-FLATTENERS AND THE SEARCH FOR QUININE}

The extent of state-sponsored promotion of science by the French is shown to no better advantage than in the earth-measuring expeditions of I735. Theorists had already concluded the earth was not

33. Nouvelle biographie générale, ed. J. C. F. Hoefer (Paris, I872), XL, 499501. Pulteney, Historical and Biographical Sketches, II, 52.

34. Louis Feuillée, Journal des observations physiques, mathématiques et botaniques (Paris, I 714-I 725), I, 5-6, 492-493.

35. Ibid., I, 438.

36. Relation du voyage de la Mer du Sud aux côtes du Chily et du Pérou (Paris, 1756$)$. 
a perfect sphere-but was it flattened at the poles or slightly elongated? In order to find the answer, the Académie des Sciences sent a group to Lapland and another to the region now called Ecuador. Each measured the length of a degree, and variations in the findings decided the argument in favor of the earth-flatteners. ${ }^{37}$

As the first foreign scientists to penetrate the interior of Spanish America, the Frenchmen on the equatorial expedition could scarcely have failed to quicken Spanish intellectual curiosity. The king of Spain, in fact, had authorized the expedition, at least in part, "to give his own subjects a taste for the ... sciences." 38 He required the Academicians to accept as equals the company of two young Spanish naval officers, Jorge Juan (I7I3-I773) and Antonio de Ulloa (I716I795), and though the Spaniards performed with distinction, there is little doubt they learned far more from their illustrious companions - Charles Marie de la Condamine, Pierre Bouguer, and Louis Godin -than the other way around.

Intercourse between the Frenchmen and intellectuals in the Spanish colonies must have been frequent during the nine-year stay. The ideas of Descartes, Leibnitz, and Newton seem to have been taught in Quito at least as early as the first appearance of the expedition. ${ }^{39}$ The University of San Marcos in Lima gave Bouguer an honorary doctor's degree. La Condamine received the same distinction and, in addition, was sought for the chair of mathematics, but declined. Godin accepted in his stead in 1744, and held the post until r75 I, when he was appointed director of the midshipmen's academy in Cádiz. ${ }^{40}$ La Condamine exchanged geographical and astronomical observations with the aging Peruvian savant Pedro Peralta y

37. Variations in the orbital motion of Vanguard satellite Beta 1958 have led to the recent conclusion that the earth is in fact slightly pear-shaped (or, as some would say, persimmon-shaped). ("Shape of the Earth," Sky and Telescope, XVIII [March, 1959], 249; "Vanguard Measurements Give Pear-Shaped Component of Earth's Figure," Science, CXXIX [Feb. 27, 1959], 565-566.) I, 6 .

38. Antonio de Ulloa, A Voyage to South America (2nd ed.; London, 1760),

39. John Tate Lanning, Academic Culture in the Spanish Colonies (New York, 1940), p. 65 .

40. Luis Antonio Eguiguren, Diccionario histórico cronológico de la Real y Pontificia Universidad de San Marcos y sus colegios (Lima, I940-1951), I, cii. The Abbé de Pauw is responsible for spreading the allegation that "when $\mathrm{Mr}$. Godin was chosen professor of mathematics and astronomy in Peru, he did not find a student capable of understanding his lessons, and his lessons have never been understood in this corner of the world." (Recherches philosophiques sur les Américains [Berlin, 1770], II, 166.) 
Barnuevo (1663-1743). Peralta, scientist, poet, and playwright, ${ }^{\mathbf{1 1}}$ was spoken of by the Frenchman as a "learned and celebrated creole."42 Cosme Bueno (I7II-I798), later to become physician, mathematician, editor of the almanac Conocimiento de los tiempos for forty-two years, author of a geographical description of Peru and articles on the properties of air and water, inoculation, the whims of pregnant women, and "the art of flying" (he did not believe it feasible or even desirable), had come to Lima from Spain five years before the arrival of the earth-measurers. Eusebio Llano Zapata (ca. I7 16-1800), the self-educated "maestro de universitarios," who was familiar with eight languages, wrote eleven works before he was twenty-five, advocated a public library in Lima, and later in life composed a "history" of the mineral and vegetable realms of Peru, was married in the year La Condamine first went to Lima (1737), and of a certainty came to know Godin after the latter assumed the chair of mathematics.

Among its many achievements, the French expedition made notable contributions to botanical knowledge. La Condamine was not a botanist, yet he gave Europe its first notice of the hevea tree from which comes South American rubber. ${ }^{43}$ On a hazardous trip down the Amazon he discovered barbasco, which contains the alkaloid rotenone, an ingredient of insecticides. ${ }^{44}$ Finally, he brought out the first botanical data on the source of the drug which would later be known as quinine. It had first entered Europe a full century before, but scientists still knew little about it, though the situation might have been different if Plumier had lived to carry out his mission of I $704 .^{45}$

41. See Bess Mae Mann, "Pedro Peralta Barnuevo and the Culture of His Epoch," unpublished M.A. thesis, Duke University, 1937.

42. Quoted by Juan María Gutiérrez, "Escritores americanos anteriores al siglo XIX: Doctor Don Pedro de Peralta," Revista del Rio de la Plata, VIII ( 1874 ), 199. 43. Howard and Ralph Wolf, Rubber: $A$ Story of Glory and Greed (New York, 1936), p. 28. Spanish chroniclers long before had mentioned the existence of rubber in Mexico, but their notices failed to catch the interest as La Condamine's did.

44. Victor Wolfgang von Hagen, South America Called Them (New York, 1945), p. 68.

45. Sir Hans Sloane, caught in the midst of enthusiasm for quinine when he sailed for Jamaica in I 687 , hoped to find some specific remedy like the "quinquina." when quinine was isolated as one of two alkaloids present in cinchona bark and was shown to be the more effective of these alkaloids as an anti-malarial agent. In 
Several factors help to explain this lag. First, the trees (for many decades general opinion did not know for sure that the source was a tree) were located in the remote Loja region of the audiencia of Quito. Second, medical men had been under the sway of the ancient idea that fevers (which quinine was supposed to remedy) could be relieved only by expelling corrupt "humors" from the body: the new drug expelled nothing, hence it could not be a valid cure.

Third, quinine was for a half-century the victim of religious dissension. Jesuits had been first to promote its use. When in 1652 the Archduke Leopold of Austria failed to receive a cure and rose up in wrath against the drug, one of his chief supporters in a campaign of spite was the renowned professor of medicine at the University of Louvain, Vopiscus Plempius. Louvain was a center of Jansenism, and the tirade against quinine became lost in the larger Jansenist-Jesuit quarrel over predestination versus free will. Only after an English quack, Robert Talbor, ${ }^{46}$ had attained phenomenal success with a "secret cure" for the ague, had become physician to Charles II, and had sold his secret to Louis XIV of France with the understanding it would not be published until Talbor's death, did an opportunity arise to change the public mind. Talbor died in $168 \mathrm{I}$ and his mysterious remedy was exposed: "quinquina" mixed with a different wine each time to disguise the identity of the drug. After the first complete treatise on its medical properties had been published in I 7 I I by the Italian Francesco Torti, who introduced "malaria" into the language and made it clear that quinine had no value against other types of fever, it was impossible to stem the flood of books in support of the "Peruvian bark."

There were more deterrents, however, to public esteem. There was much mixing of inferior grades with the best, and some downright falsification. Just as important was a long-time confusion in the use of the name quina (or quinaquina, and other variants). Originally it had been applied to a bark yielding the "balsam of Peru" (now known as Myroxylon Peruiferum L.), which had been used to com-

the present work, "quinine" is used interchangeably with quina for purposes of variety and to provide the English-speaking reader with a term he can recognize, in the full realization that the term was not yet in use during the period under
discussion.

46. The name is sometimes given as Tabor. In France the doctor changed it to Talbot. (Jaime Jaramillo-Arango, The Conquest of Malaria [London, 1950], p. 79.) 
bat fevers without particular success. When the quinine-producing bark first appeared in European markets and was advocated as a remedy for malaria (ague), it was given the same name, quina, for indeed there were certain similarities. Eventually the "quinine tree" took over the term, and balsam of Peru went on to other medicinal, and even industrial uses. But the seed of confusion was still there.

Plainly, more information was needed before real reforms could be made. La Condamine had carried out only a cursory study of the plant, which he had seen in Loja in 1737 while on his way to Lima. The Académie des Sciences had published a description in the following year, and Linnaeus had named the tree Cinchona. ${ }^{47}$ La Condamine tried to bring young living trees to France in 1743, but failed when a wave washed them from his canoe at the mouth of the Amazon River. Seeds he had carried to Cayenne did not germinate, ${ }^{48}$ and the world's knowledge still rested on an amateur's incomplete account.

The French scientist, however, promised a more thorough report on quina from Joseph de Jussieu (1704-1779), an associate on the expedition. This physician and member of the famous botanical dynasty had indeed come to America to pursue plant investigation. And he did indeed study cinchona stands, though apparently no earlier than La Condamine. ${ }^{49}$ Collections De Jussieu made in 1739 at Zaruma (Loja) of "a great number of specimens" eventually found their way to Paris, where Alexander von Humboldt compared them with his own samples gathered on the same spot sixty years later. ${ }^{50}$ Condorcet relates that De Jussieu observed different species,

47. In honor of the viceroy of Peru a century before, the Count of Chinchón, whose wife was supposed to have been the first to be healed by quina, though the tale has been exploded many times since. See A. W. Haggis, "Fundamental Errors in the Early History of Cinchona," Bulletin of the History of Medicine, X (1941), 568-587.

48. Charles Marie de la Condamine, Viaje a la América Meridional (2nd ed.; Buenos Aires, 1945), pp. 31-32, 102. For a good summary of the early history of quinine see Jaramillo-Arango, The Conquest of Malaria, or the Spanish version, "Estudio crítico acerca de los hechos básicos de la historia de la quina," Anales de la Sociedad Peruana de Historia de la Medicina, X (Lima, 1949), 31-88. A popular account is M. L. Duran-Reynals, The Fever Bark Tree: The Pageant of Quinine (New York, 1946).

49. A French quinine manufacturer published in 1936 a manuscript, said to be De Jussieu's, which contains a description in Latin, dated 1737 , of a cinchona tree. (Joseph de Jussieu, Description de l'arbre à quinquina: mémoire inédit de Joseph de Jussieu ( ${ }^{7} 737$ ) [Paris: Société du Traitement des Quinquinas, 1936].)

50. Alexander von Humboldt, "Cinchona Forests of South America," in Aylmer Bourke Lambert, An Illustration of the Genus Cinchona (London, 182I), p. 23. 
determined their relative "virtues," uncovered deceptive and wasteful means of collection, and prepared a quantity of quina "extract," which he hoped would be more effective than that manufactured from the bark in France. ${ }^{51}$

The promising prospects envisioned, however, turned as bitter as the "Peruvian bark" itself. A shortage of money that kept De Jussieu from returning to France with La Condamine might have been a blessing to science, for the botanist had an unstilled curiosity to see more of the great continent. But his attention was forcibly diverted to the practice of medicine, not only by his own penury but by the persuasion - and perhaps even intimidation-of a colonial government that needed his help in stemming epidemics. A modern author claims, for instance, that although in 1745 De Jussieu intended to return to France, the authorities in Quito, faced with an outbreak of smallpox, threatened heavy penalties against anyone helping him to depart."

Illness periodically nagged De Jussieu himself, but in 1747 he undertook an expedition southeast of Quito into the so-called land of cinnamon, from whence he sent specimens to France. In the following year he began again to think about going home, and headed for Lima under French orders to give to Godin the scientific instruments once used by the earth-measuring expedition. He patched up his personal quarrel with Godin and the pair decided to leave for Buenos Aires, Brazil, and Europe. De Jussieu's curiosity, however, caused a change of plans. Intrigued by the sights of Upper Peru as the men headed toward the Atlantic, he said goodbye to Godin and plunged into the forested yungas of present-day Bolivia to become the first botanist to study the coca plant in its native habitat. He succeeded, in fact, in sending some living specimens to Paris. This foray eventually led him to Potosi in 1750 where he fell prey to solicitations of the provincial governor to become his official physician. For the next five years De Jussieu found himself not only ministering to patients but, with the facility of a true son of the eighteenth century, becoming a construction engineer of roads and bridges. ${ }^{53}$

From this point on, botany seems to have played a secondary role in his life. Linnaeus wrote of De Jussieu in I753: "Those who

51. "Éloge de M. de Jussieu," Oeuvres, II, 356-360.

52. Alfred Lacroix, Notice historique sur les cinq de Jussieu, membres de l'Académie des Sciences ( $5712-1853$ ) (Paris, 1936), p. 54.

53.Ibid., pp. 52, 54-56. 
have been with him say that he has done almost nothing [of a botanical nature], he has only practiced [medicine]." ${ }^{34}$ One of De Jussieu's former companions, Antonio de Ulloa, offers a possible clue. On the way to Buenos Aires the Frenchman is supposed to have entrusted a trunkful of notebooks and dried plants to a servant who, unaware of the contents, absconded with the lot across the frontier to Brazil, never to be found again. This so shocked De Jussieu, says Ulloa, and the effort needed to recoup the losses seemed so great, that he withdrew into a shell in Lima. ${ }^{55}$ Ulloa's timetable of events does not quite fit the facts, but De Jussieu did indeed go back to Lima in I 755 and remained until I 770, fearful for his life were he to undertake the long voyage around the Horn. He continued to practice medicine despite ill-health, and wrote his brother Bernard of the mortification botany had caused him, saying he had sought consolation in the study of mathematics.

The last decade of his sojourn in America saw a progressive decline in his physical and mental powers, and when he at last reached Paris, by way of Panama, in I771, he scarcely knew his brothers. Though he lived eight more years, the derangement of his mind rendered useless the scientific knowledge that had once been at his fingertips. He had left some manuscripts in Lima, but in time most were lost. In fact, one of Joseph Dombey's tasks as a member of the Ruiz-Pavón expedition was to track down the stray papers, but he had little success. ${ }^{56}$ De Jussieu was a member of the Académie des Sciences for thirty-six years, but never once entered its halls or wrote a mémoire-a coldly clear indication of the misfortunes endured by this tragic figure of science. ${ }^{57}$

\section{THE YEARS BEYOND}

Brief mention need be made of only a few other state-endowed expeditions. Nikolaus Joseph von Jacquin ( I 727-18 I 7), a Hollander settled in Vienna, was sent by Emperor Francis $I$ to the Antilles to

54. Letter to Pehr Lölling, Aug. 20, 1753. Stig Rydén, Pedro Loefling en Venezuela (Madrid, 1957), p. 56.

55. Noticias americanas (Madrid, 1792), pp. 90-91.

56. See pp. 51, 88-89, below.

57. Most of the details of De Jussieu's life have been taken from Lacroix, Notice historique sur les cinq de Jussieu, pp. 52-57, and Condorcet, "Éloge," Oeures, II, 357-369. 
collect plants and animals for the newly established gardens of Schönbrunn and the museum of natural history. In the four years from I755 to I759 he touched numerous islands and even the Spanish territories of Cuba (49 plants) and Venezuela ( 5 plants). Altogether he turned up 435 species, in part new, though a portion of his work is defective in that it omits to mention localities. Jean Baptiste Christophe Aublet ( I 720-I 778), scarcely back from nine years on Ile de France (Mauritius) in the Indian Ocean, where he had been sent by the government to study the flora and establish a botanic garden, set out for French Guiana in I 762. Here, using the Linnaean classification system, he laid the foundations for tropical-forest botany in America, and during two years described four hundred new species. ${ }^{58}$

Spain, beginning to reawaken to the possibilities of, and the necessity for, botanical exploration, entered the field in I754. An expedition was being fitted out to establish the boundary between Portuguese and Spanish territory in northern South America. The Spanish government decided to include a botanical section which would first study plants in the Orinoco region (present-day Venezuela) and then go on to Bogotá, Quito, Lima, Buenos Aires, and Patagonia-a project that stood little prospect of fulfilment on such a gigantic scale. In charge of botany was Pehr Löfling, a student of Linnaeus who had been working in Spain. But Löfling died in 1756 , his helpers were too inexperienced to go on, and the scientific results were disheartening.

Finally, in the great earth-girdling voyages of Louis Antoine de Bougainville and Captain James Cook, as with no round-the-world travelers before their time, science became an end in itself and not an amateur plaything of professional adventurers.

Bougainville intended first to assure French possession of the Falkland Islands off the Argentine coast and then to carry out extensive explorations in the Pacific. He took with him on the journey, which began in I766, the naturalist Philibert Commerson (1727I773). On a three-year voyage they stopped in Rio de Janeiro, Montevideo, Buenos Aires, the Straits of Magellan, and numerous Pacific islands. Commerson left the ship at Île de France, where he

58. The Guianas received further attention from the amateur Edward Bancroft (Dutch Guiana, 1766); from Frédérique Allamand and Daniel Rolander (Dutch Guiana, ca. I 755-1770); and Louis Claude Marie Richard (French Guiana, I 781 ). The latter was sent by the French king to study plants of economic value and investigate the possibilities of introducing them into the Old World. 
spent his remaining years. Though he published nothing, his herbarium was eventually sent to Paris, where subsequent students acknowledged its value. As the first trained botanist to visit Argentine territory, Commerson has warranted some attention at this point, but Bougainville will remain much longer in the memory for the brilliant red or purple flowering vines bearing his name that beautify so many walls in the tropics.

The most famous traveler of the latter half of the eighteenth century was Captain Cook. He made his first round-the-world voyage in $1768-1771$, as part of the international endeavor to observe the transit of Venus in 1769 . Studies of natural history assumed a place of prominence, though not because of generosity on the part of the English government. Rather, they became a reality because Joseph Banks, whose wealth could stand the strain, paid his own way and that of Linnaeus' pupil Daniel Solander and six other associates, in order to make the studies. Unfortunately, their publications on finds in Tahiti, New Zealand, and Botany Bay fell short of expectations, but Banks returned to become probably the most widely known botanist in the world as the head of Kew Gardens and the Royal Society of London.

When Cook projected a second voyage for I772-I775, Banks found himself pushed out of the way. The navy apparently wanted no part of his meddling. But the cause of natural history was upheld, interestingly enough, when Parliament itself offered funds to send the German father-and-son team of Johann R. and Johann G. Forster. They were an argumentative, and even scurrilous, pair, but their subsequent publications were substantial, including, incidentally, studies on the plants of the Straits of Magellan. The son appears to have been the influence that started Humboldt upon his memorable career. ${ }^{59}$

A whole new field of botanical thought opened up in I774, when Joseph Priestley (1733-1804) discovered oxygen and its production by plants. A century before that date, Malpighi and Grew had propounded hazy notions about the intermingling of juices and their

59. Helmut de Terra, Humboldt (New York, 1955), pp. 38-39. Cameron, Sir Joseph Banks, pp. 5, 14-16, 50-51, 55, 73-74, 78. See also Elmer D. Merrill, Botany of Cook's Voyage (Waltham, Mass., 1954). A convenient summary of many of the plant-hunting expeditions discussed above, and of which the present writer made considerable use, is Carlos E. Chardón, Los naturalistas en la América Latina (Ciudad Trujillo, r 949), I, 35-77. 
subsequent fermentation. Stephen Hales (1677-I76I) undertook actual measurement of the sap flow and then studied capillarity and root pressures as factors in raising the sap. Finally, in a study of the leaves he concluded that they gathered part of the plant's nutriment from the air. Hales announced his discoveries in 1727. For the next half-century studies in this vein lagged for want of well-planned experiments and suffered from illogical and misleading conclusions. Priestley abruptly changed the pattern when he observed that plants confined in an atmosphere rich in carbon dioxide ("fixed air") produced within a few days large amounts of oxygen ("dephlogisticated air"). He was not a botanist: his interest was in the effects of plants on air, not the reverse. But his discovery was so fundamental it beckoned plant scientists along new paths. By 1779 Jan Ingenhousz ( I 730-I 799) had found that oxygen formation by plants depended on sunlight, and he theorized on how air, made unfit for breathing by animals, was purified by green plants during daylight hours.

\section{WHAT IS A BOTANIST?}

There is no need to carry the story further, for we have reached the date when Spain was to send the first of its great eighteenthcentury botanical expeditions overseas. In 1776 plant classification was in the grip of the artificial Linnaean system, though several tentative efforts had been made to find a natural classification-one that could locate a plant in its true natural family by taking into account all of its characteristics. Plant morphology and anatomy had seen little advance since the work of Jung, Grew, and Malpighi. Studies of reproduction were still in an elementary state. The way had barely been cleared for advancement in the fields of plant physiology and plant nutrition.

Today, in the twentieth century, "botany" includes plant taxonomy, morphology, cytology, physiology, mycology, ecology, pathology, paleobotany, wood technology, and dozens more of specialties within specialties. Two present-day botanists lament the popular conception of themselves as individuals "who can name plants." As they put it:

One is likely to visualize a more or less eccentric person, with plant press in hand, tramping through woods, meadows, swamps, and 
fields, collecting plants, neatly pressing them, giving them long, "meaningless" Latin names, and then filing the mounted specimens away in a herbarium that smells of napthalene. ${ }^{60}$

However incomplete this notion in our day, it would have struck close to the truth in the eighteenth century.

Miguel Barnades, author of the first botanical textbook to be published in the Spanish language, wrote in 1767 that the knowledge of the internal structure of plants, of their growth, and of their propagation was a branch of physics and chemistry. Concern for the pharmaceutical virtues was a part of materia medica, and study of the uses of plants in agriculture, gardening, and dyeing came under the heading of economy. Only the "historical" part, which was essential to the recognition of plants according to their exterior form, retained par excellence the name of botany, being the fundamental for all the rest. For, according to Barnades, one must know a plant well by its outer configuration before delving into its inner structure or learning to cultivate it or put it to use. ${ }^{61}$

Thus, as we think of the botanists Ruiz and Pavón, it is important to see them in terms of their century. They did not overlook the industrial and especially the medicinal uses of plants, for they had begun their adult lives as pharmacists. Essentially, however, they were plant-hunters, plant-collectors, and plant-classifiers-for they were satisfying the greatest need of eighteenth-century botanical science: to learn the what, the when, and the where. Future generations would take care of the how and the why.

6o. Wilfred W. Robbins and T. Elliot Weier, Botany: An Introduction to Plant Science (New York, 1950), pp. 7-8.

61. Principios de botánica, sacados de los mejores escritores, y puestos en lengua castellana (Madrid, 1767), pp. 43-44. 


\section{SPAIN TAKES TO BOTANY: THE EIGHTEENTH CENTURY}

Linnaeus, in one of his testier moments, thought it "cause for grief that in the more cultivated places of Europe [and he meant here specifically Spain] such botanical barbarism exists in our time." Except for specimens gathered by Tournefort and a few others, "no Spanish flowers are known to us." As if, perhaps, to convert the botanical heathen, he called attention to "those very rarest plants in the most fertile places" that still remained undiscovered. ${ }^{1}$

If this was his plan, he must have been agreeably surprised to find that it worked. When his student Pehr Löfling appeared in the Peninsula, trembling at the prospect of life among savages, "the gloom which this thought had spread over his countenance was soon changed into joy and contentment," for he found several well-versed lovers of botany who opened their homes, libraries, and gardens to him. ${ }^{2}$ Like all over-simplifications, Linnaeus' remarks were almost, but not quite, true.

\section{FOR THE CURE OF A GREAT SWOON}

After Spain had become a leader in botanical studies in the latter half of the eighteenth century, the Spaniard unabashedly admitted his onetime torpidity. "Although Spain has been perhaps the last

I. "Hispanicae Florae nullae nobis innotuerunt, adeoque plantae istae rarissimae, in locis Hispaniae fertilissimis, minus detectae sunt. Dolendus est, quod in locis Europae cultioribus, tanta existat nostro tempore barbaries botanices!" (Bibliotheca botanica [Amsterdam, $175 \mathrm{I}$ ], p. 135.)

2. "An Abstract of the Most Useful and Necessary Articles Mentioned by Peter Loefling," in [Jean Bernard] Bossu, Travels Through that Part of North America Formerly Called Louisiana (London, I771), II, 79. This "Abstract" is a paraphrase translation of the words of Linnaeus in his Iter Hispanicum, but libraries usually catalogue it under Löfing. The quotation above represents the spirit though not the words of Linnaeus. 
among European nations in cultivating methodical botany, nevertheless...," he would say. Or: "We cannot deny that from Philip II [d. I 598] to Philip V [I700] botany underwent a great 'swoon.' "4

To belie a tale of Spanish ignorance in the seventeenth century, one could cite Bernardo de Cienfuegos. In I 627 he started a "History of Plants" which, though unfinished, ran to seven manuscript volumes, over five thousand pages, and hundreds of illustrations in color-almost all a compilation of other people's work. Whoever cared to assemble a larger body of data, the compiler wrote in his prologue, was welcome to the task-he at least had made a start! Despite its five thousand pages, the study was supposedly selective. Writes an admirer: Cienfuegos had no concern for a plant merely because it was unlike another; but if it had a special quality of interest, then no detail was too small to be left unstudied. "This disdain for all newness that does not offer interest," the analyst goes on, and with a degree of reason, "is a characteristic of Spanish science that lasted even into the eighteenth century and inspired Iriarte's famous fable, "The Naturalist and the Newts." "5

In the late years of the seventeenth century the Salvador family of Barcelona did its best to establish a botanical dynasty. Juan Salvador ( I 596-I 68 I), pharmacist and student of plants, had a son (Jaime, I649-I 740) who trained at Montpellier and assisted Tournefort in two of his Spanish excursions (ca. I680). The Frenchman is supposed to have bestowed upon him the title, "Phoenix of his country." Jaime's son (Juan, I683-I726) had similar education and experience, for in 1718 he assisted Antoine and Bernard de Jussieu in their botanical journey through Spain. The door to scientific progress in the

3. Memorial literario, instructivo y curioso de la corte de Madrid, IX (Dec., $1786), 494$.

4. Ibid., XV (Dec., I 788 ), 694 .

5. Celso Arévalo, "Bernardo de Cienfuegos y la botánica de su época," in Asociación Nacional de Historiadores de la Ciencia Española, Estudios sobre la ciencia española del siglo XVII (Madrid, 1935), pp. 323-325, 329. See also Colmeiro, La botánica y los botánicos, pp. 66-67, 157. The fable of Iriarte deals with a naturalist who caught two newts and hastened to make a thorough dissection of one of them. After all of the curious had had their say, he let the other newt loose. Promptly it returned to its crevice and told all its neighbors about the affair. Never had it been so proud! Why should newts suffer the insult of being called disgusting reptiles (sabandijas) when they possessed features so worthy of contemplation?

In Iriarte's opinion, they were still disgusting reptiles. To study them minutely, just as to criticize worthless books in detail (and this is what he was really driving at), is only to do them a favor which their little value does not warrant. (Tomás de Iriarte, Poesias ["Clásicos Castellanos," No. 136] [Madrid, 1953], pp. 75-78.) 
Peninsula had thus been left ajar, but Juan died prematurely, and though his brother (also a botanist) and his descendants preserved the good collection of plants already begun, the Salvadorean influence was unable to burst its regional bounds. ${ }^{6}$

Philip V, the first Bourbon ruler of Spain ( I 700-I 746), worked a change-though little more than a token change-in the official frame of mind. He provided that a teacher of botany be attached to the royal medical society of Seville, and his physicians established several small gardens, including one at the college of surgery in Cádiz and another at Migas Calientes on the outskirts of Madrid. These were by no means true botanic gardens, but their raison d'être was laudable: to help remove pharmacists from the "ignorance and rusticity learned either from the most abject common people or from the advice of their ancestors."

Before passing final judgment on Philip in matters of natural history, one should note a cédula he sent throughout the Empire in I 7 I2, calling upon officials of state and church to watch for unusual examples of animals, minerals, and plants. Each specimen remitted to Spain-from the colonies or from lands more remote, like China, Japan, and the East Indies-must be identified by a statement of its properties and uses, distinguishing between the "certain and doubtful ones." And each remittance should bear the name of the sender, "because my royal intention is that inventories be made of all these things." As a resting place for the curiosities the king envisioned a "library" established near the royal palace, complete with books on "all manner of sciences," and open to the public daily. ${ }^{8}$

A praiseworthy idea, to be sure, but could it yield more than a hobbyist's assortment of curios, uneven in scientific value? The

6. Colmeiro, La botánica y los botánicos, pp. 158-160. Joseph Quer related in I 762 that nowhere in his travels throughout Europe had he seen better informed vendors of herbs than in Barcelona, thanks to indoctrination by the Salvador family. "Even a noted woman, called Hypólita, has become so famous that one may call her maestra of this art, on account of her great experience with her garden of officinal plants that she used to have at the Hospital of San Lorenzo." (Flora española [Madrid, I 762-1764], I, 43-44.)

7. Juan Sempere y Guarinos, Ensayo de una biblioteca española de los mejores escritores del reynado de Carlos III (Madrid, I785-1789), VI, 38-39. Ruiz and Pavón, Prodromus, p. iv. Colmeiro, "Jardín Botánico," p. 245. Quer, Flora española, I, 40-42. The chair in Seville was established by a royal decree of May 13, I 729. The society declined in importance in subsequent years but was resuscitated in 1764 . (Sempere y Guarinos, Ensayo, VI, 38-39, 42.)

8. Colección de documentos históricos, recopilados del Archivo del Arzobispado de Santiago (Santiago de Chile, 1919-I92I), IV, 270-272. 
merits of studying the commonplace are not easy to discern when one is enchanted by the exotic. Robert Hooke (1635-I 703), the famous English experimental physicist, once offered a pertinent warning. The use of such collections, he said, "is not for divertisement, and wonder, and gazing, as 'tis for the most part thought and esteemed, and like pictures for children to admire and be pleased with, but for the most serious and diligent study of the most able and proficient in natural philosophy." And where would the monarch have found adequately trained personnel to scout out these natural products? But if Philip's venture bore no immediate scientific fruit, even so, many specimens remained for later generations to study with more practiced eyes.

\section{LÖFLING AND THE "CONVERSION"}

\section{OF SPAIN}

Ferdinand VI, who ascended the throne in 1746 , proved that Spanish botany, like a Spanish seedling, needed only a healthy shower -in this case a shower of funds from the public treasury-in order to make it grow. Linnaeus, not a disinterested authority, tells the story in this fashion:

Some Englishmen led by Robert More, a fellow of the Royal Society of London, weary of the tales of travelers who voyaged "sound asleep," decided to see for themselves the "marvels of the world." At a dinner party in Spain, Secretary of State Joseph de Carvajal asked them the usual question: What did they think of his country? Their reply was disconcerting, for they repeated Linnaeus' admonition that Spanish plant life was probably as rich as it was unknown. Having verified Linnaeus' words for himself, Carvajal vowed to free his nation of reproach. He immediately petitioned the Swedish botanist to send an expert to Spain: the very invitation Linnaeus was awaiting. ${ }^{10}$

9. De Beer, Sir Hans Sloane, p. 109.

10. Carl Linnaeus, Iter Hispanicum (Stockholm, 1 758), pp. [4-5] of foreword. For a recent Spanish translation of this section see Rydén, Pedro Loefling, pp. 195196. An earlier Spanish translation, much more complete than Bossu's English version mentioned in $\mathrm{n} .2$ of this chapter, but considered faulty by Rydén, is Pehr Löfling, "Observaciones de historia natural hechas en España y en América por Pedro Loefling: traducidas del Sueco, segun la edicion de Carlos Linneo, por D. Ignacio de Asso," Anales de ciencias naturales, III (Madrid, 1801), 278-315; IV 
The man chosen was Pehr Löfling ${ }^{11}$ ( $1729-1756$ ), a favorite pupil whom Linnaeus had brought into his own household as his son's companion. Löfling cast off to bring light to Darkest Spain in May, I75I. Landing at Oporto, Portugal, he luckily encountered Louis Godin, onetime member of the earth-measuring expedition to Quito. Godin was just back from his post as professor of mathematics in Lima and on his way to Madrid before taking over headship of the midshipmen's academy in Cádiz. Not only did Godin ease Löfling across the language barrier, but he introduced the Swede into highest circles from the moment of his arrival at Madrid in October, I 751 .

The newcomer was most agreeably surprised-perhaps openly astonished is more apt-to find a small coterie of botanists already at work. ${ }^{12}$ He mentions five by name:

Joseph Quer (I695-I 764), "first surgeon of the army." He was born in Perpignan of Spanish parents. While traveling with the army, he studied the plants of Spain, North Africa, and Italy, and received botanical instruction in Pisa and Bologna. Later, with the financial backing of noblemen in Madrid, he was able to maintain the best plant collection in Spain in his own botanic garden. His herbarium, in Löfling's opinion, contained "very curious and exquisite things."

Juan Minuart (I693-I768), "first pharmacist of the hospitals." He had begun as one of Jaime Salvador's pupils and had gathered a herbarium while attached to the military as a pharmacist. The Swede found him "a diligent observer" and "the conserver of the true botany in Spain."

Joseph Ortega (d. I76I), "first pharmacist of the army" and founder and perpetual secretary of the Academia de Medicina in Madrid. Löfling was impressed with Ortega's salary of 24,000 reales, three times that of Löfling himself, which made him a "powerful man." Besides, he had his own pharmacy, the best-stocked in the city. Within four years he would be sent to the capitals of Europe to study the workings of academies of science in the hope that one

(1801), 155-191; V (1802), 82-104, 296-340. Rydén presents a revised Spanish translation of Linnaeus' foreword and two letters Löfling wrote to Linnaeus from Venezuela.

II. This spelling of Löfling's name has been adopted here to conform to the practice followed by Löfling himself. See Rydén, Pedro Loefing, p. I 5.

12. Ibid., pp. 200-201. 
relationships with commercial interests of Spain's other rival in that region, the Dutch. ${ }^{21}$ But Spain rightly assumed Löfling's concern to be purely scientific and, in fact, the botanist accepted the Catholic faith seven hours before his death.22

Two young graduate physicians, Benito Pastor and Antonio Condal, were made assistant botanists and began to take lessons from the Swede. They apparently knew nothing of botany, but as Löfling frequently said, "they will make progress." "23 Two other youths, aged sixteen and seventeen, Juan de Dios Castel and Bruno Salvador Carmona, joined the group as illustrators. Löfling expressed delight. "They draw very well," he said. Starting to study natural history at such an early age, they could become very proficient. ${ }^{24}$ The crown jumped Löfling's pay to 10,000 reales, plus a single grant of 20,000 reales vellón for equipment and clothing. The young physicians received a salary half as large as their teacher's.

Although Venezuela was the first destination, plans called for Löfling to travel far beyond the Orinoco. Talk was bandied about of Santa Fe de Bogotá, Quito, Lima, Buenos Aires-perhaps "all the provinces of South America."25 Men familiar only with the confines of Europe seemed always to speak so blithely about "all of South America."

The botanists' principal task was to find plants of possible economic value, as well as the means to exploit them. Löfling was to remit, on each ship sailing for Europe, duplicate sets of all of his observations, drawings, and specimens, "in order that they might not

2x. Rydén, Pedro Loefting, pp. 90-93.

22. Daniel Scheidenburg, chaplain of the Swedish legation in Madrid, to Linnacus, 1756. Ibid., p. 244. In 1782 the viceroy of New Granada, secking the aid of Swedish mining experts to improve production in his jurisdiction, wrote to the Minister of the Indies: "The difference of religion that they profess ought not to serve as an obstacle, it being most likely that in time they will reconcile themselves with our Church, as happened to the Swede Pedro Loefling. ... . And in truth we must not fear that people of purely mechanical learning will develop converts to their religion here." (Viceroy Antonio Caballero y Góngora to José de Gálvez, Santa Fe de Bogotá, Oct. 14, 1782. Ibid., pp. 131-132.) This statement is perhaps of even more interest when we take into account that the viceroy was also archbishop.

23. Löfling, "Observaciones," Anales de ciencias naturales, III, 290; V, 308, 3 Io, 328,337 .

24. Löfling to Linnaeus, Madrid, Oct. 15, 1753. Linnaeus, Iter Hispanicum, p. 90; Löfling, "Observaciones," Anales de ciencias naturales, V, 315-316. See also ibid., III, 290 (note by Antonio Cavanilles).

25. Löfling to Linnaeus, Madrid, Oct. 15, 1753. Rydén, Pedro Loefing, pp. 46-47. 
be so easily lost." The first set would be earmarked for the newly established museum of natural history, ${ }^{26}$ and the others set aside as barter for curiosities from the "cabinets" of France, England, Sweden, and elsewhere. ${ }^{27}$

Linnaeus rejoiced. In his last missive to Löfling before the expedition sailed, he especially praised the minister Carvajal who "must be a great man to understand the importance of what nobody up to now has known how to take advantage of."'28 Later Linnaeus would embellish this point:

Various nations consider it a raison d'état to hide their advantages, especially in distant colonies. But Señor Carvajal was too great a statesman to let himself be deceived by these motives. He knew that the rich resources of nature are inexhaustible and that, using them with the necessary knowledge, one had no need to fear their lack. He saw how the French and English, in many varied ways, had learned to exploit their colonies after having learned to know their territories and products in a better manner. ${ }^{29}$

For all the hopes and preparations, the expedition ended in disappointment. The men sailed from Cádiz on February I 5, I754, and arrived in Cumaná (Venezuela) on April II. Within four months intermittent fevers began to strike down Löfling and, although in the end he brought in about six hundred species of plants, including thirty new genera and 250 species not mentioned before by Linnaeus, ${ }^{30}$ recurrent illness constantly drained his strength.

Work ended abruptly on February 22, I756, when Löfling died at a mission near the junction of the Caroni and Orinoco rivers. The young physician-assistants went their separate ways, but the illustrators brought the drawings to Spain in $176 \mathrm{I}$, in hopes they could be reproduced. For nineteen years Castel and, after his death, Carmona, reportedly worked on the task, but nothing resulted, "no doubt because of the continuous and urgent occupations of the professor of botany who was supposed to direct their work." 31 Some 1,700 folio

26. See pp. 39-43, below.

27. Löfling to Linnaeus, Madrid, Aug. 27, 1753. Linnaeus, Iter Hispanicum, p. 85 ; Löfling, "Observaciones," Anales de ciencias naturales, V, 309.

28. Linnaeus to Löfling, Oct. 2, I 753. Rydén, Pedro Loefling, p. 59.

29. From Linnaeus' prologue to the Iter Hispanicum. My translation is from the revised Spanish version of Rydén in Pedro Loefing, pp. 204-205.

30. Löfling, "Abstract," in Bossu, Travels, II, 85.

3 r. Löfling, "Observaciones," Anales de ciencias naturales, III, 290, 292 note. This note was written by Antonio Cavanilles in $180 \mathrm{I}$, the year in which he became botanical professor, and may have been another disparagement of his predecessor Casimiro Gómez Ortega, for whom he held no love. See pp. $241-2+5$, below. 
in plants inclined him more toward pharmacy. He won permanent title to the chair of botany by oposición in 1772 . Apparently little or no uncertainty clouded the decision, not alone because of Gómez Ortega's family connections, but because the fledgling chair of botany in Madrid had yet to produce a home-trained scientist of stature to compete with him. ${ }^{36}$

The new professor launched his career with a flood of publications. He was already noted for translating the account of Commander John Byron's voyage, containing descriptions of Patagonia and Chile, to which he added notes on natural history. Falling into line with Charles III's desire to replenish the forests of Spain, ${ }^{37}$ he published in 1772 a translation of Henri Louis Duhamel's La Physique des arbres, and translated two more treatises by the same author in $1773-1774$ on the care and reproduction of trees. ${ }^{38}$ He made the first index of plants in the Madrid garden in 1772 and found 650 species, more than one-half Spanish in origin. The total in these early years would later rise to $1,200-1,500,{ }^{39}$ still far behind the leaders in other parts of Europe.

The Tournefortian system must have been hanging on by a thread, for Gómez Ortega brought out a booklet in Latin to explain it in 1773 (Spanish version, I783). But within five years Antonio Palau, holder of the second chair of botany, published a Spanish translation of the theoretical parts of Linnaeus. Its transitional character is best indicated in Palau's statement of purpose: "to explain the philosophy and botanical fundamentals of Linnaeus in order to clarify the Institutiones of Tournefort and make them easily understood." ${ }^{40}$

Yet, Spain would soon be firmly committed to Linnaeus. In I 777 Ruiz and Pavón were ordered to follow the Swedish system, and Gómez Ortega became its strongest defender in Spain. Palau published between I 784 and I 788 the "practical part" (Species plantarum) of Linnaeus in eight volumes, plus a small compendium for field trips, to which Palau added the common names and Spanish localities

36. José Celestino Mutis, who studied under Barnades, would certainly have qualified had he not gone to America long hefore. See pp. 44-46, below.

37. Sempere y Guarinos, Ensayo, IV, 159-16I.

38. Colmeiro, La botánica y los botánicos, p. 9.

39. Colmeiro, "Jardín Botánico," p. 247.

40. Quoted in Jean Sarrailh, L'Espagne éclairée de la seconde moitié du XVIII siècle (Paris, 1954), p. 444. 
of many plants. The victory of Linnaeus was insured when the two professors at the garden in Madrid held strictly to his doctrines in their Curso elemental de botánica, published in 1788 , which had a noticeably popularizing effect. ${ }^{41}$

A wide interest in botany, however, could not easily develop as long as the royal garden occupied such an out-of-the-way site. The French botanist Joseph Dombey, who was to accompany Ruiz and Pavón, remarked the small number of pupils Gómez Ortega had for his thrice-weekly 7 A.M. class, given from the middle of May to about the end of June. ${ }^{42}$ By the time of Dombey's visit, however, construction was already advanced on a new garden on the Prado in central Madrid. The king had ordered purchase of the land on July 25, 1774, and Gómez Ortega was sent to inspect facilities in France, England, Holland, and Italy. With the zeal of the first botanist and of Secretary of State Floridablanca to keep it alive, the new institution began to function in $\mathrm{I} 78 \mathrm{I}$, with a staff of two professors, one first gardener, two assistants, sixteen gardeners, and, in the summertime, six peons. Up to twenty persons in various parts of Spain received commissions as correspondents. ${ }^{43}$

\section{THE CURIOSITIES IN THE CABINET}

Meanwhile, a parallel venture took over the scientific spotlightthe museum, or "cabinet," of natural history. For many years the government had possessed a motley collection of the curiosities of natural history, to a considerable extent the result of cédulas like that of I 7 I 2 urging the citizenry and officials to remit unusual specimens to the court. Antonio de Ulloa, back from the earth-measuring expedition, talked the king into renting a sala in which to display them. Then in 1753 he brought an Irishman, William Bowles, to Madrid to make a study of Spain's natural and industrial resources, and Bowles, among other duties, took charge of the curiosities under

41. Colmeiro, La botánica y los botánicos, p. 172 .

42. Dombey to André Thouin, chief gardener of the royal botanic garden in Paris, Madrid, June 6 and July 7, 1777. E. T. Hamy (ed.), Joseph Dombey, médecin, naturaliste, archéologue, explorateur du Pérou, du Chili et du Brésil $(1778-1785)$ : sa vie, son oeuvre, sa correspondance (Paris, 1905), pp. $20,24$.
(Hereinafter Hamy, Dombey.)

43. "Real Jardin Botánico," Memorial literario, I (April, I 784), 30. Colmeiro, La botánica y los botánicos, p. 167. Colmeiro, "Jardín Botánico," p. 259. 
Ulloa's general direction. Minerals held Bowles's attention, and he wrote an important Introducción a la historia natural y a la geografia física de España (Madrid, I775), but the museum of natural history was a failure. Ulloa was too busy, Bowles was not interested, and the higher echelons of government apparently cared not in the least.

It remained for a transplanted native of Guayaquil, Pedro Francisco Dávila, to put the museum on its feet. Having lived in Paris for some twenty-five years in the manner of a cultured Frenchman, he had amassed a collection of curiosities. But in 1767 sore finances and poor health compelled him to offer them for sale.

Charles III was approached as a possible buyer. The monarch asked the opinion of an Augustinian friar, Enrique Flórez, who had his own museum in the Convento de San Felipe in Madrid. Flórez's analysis gives informative sidelights on the status of interest in natural history. He told the monarch it was hard to analyze a collection merely by consulting the catalogue. ${ }^{44}$ The cost of such objects "is not founded on intrinsic value but on the arbitrary value of taste and curiosity, because I am advised from London that they are offering there more than 23,000 reales for a little shell and they do not want to sell. In Spain they wouldn't give a peso, because this pleasure hasn't been introduced."

As a "hobbyist" himself, Flórez could not abide Spain's continuing ignorance, "seeing the exceeding appreciation that the cultured people of Europe take in this delectable study." He wanted to arouse among Spaniards interest in these "divine marvels" in order to wipe out the "stigma that our nation suffers among those who ought to look at it as first in the world." Others were robbing Spain, and shining because of it. Thank goodness, it looked as though the era of neglect was coming to an end. But, despite his obvious desire to have Charles III buy the collection, Flórez hesitated to make a specific proposal. The actual collection ought to be appraised by "people who know."45

The king at first refused to buy, but four years later, in $177 \mathrm{I}$, was prevailed upon to rescue both Dávila and at least a part of his collec-

44. A descriptive catalogue of the collection occupied three volumes. (Sempere y Guarinos, Ensayo, II, 242.) The French naturalist Adanson is said to have called if "truly the richest cabinet any private party had yet put together." (Quoted by Hinólito Unanue in Mercurio peruano, II [June 2, 1791], 86.)

45. Agustín J. Barreiro, El Museo Nacional de Ciencias Naturales (Madrid, I 944) DD. I-IO. 
tion. To house the newly gained wealth, the monarch set aside the second story of a good-sized building, bought in I774, whose first floor was earmarked for the Academia de Nobles Artes de San Fernando. Dávila became permanent director of this museum of natural history at an annual salary of 60,000 reales and living quarters. ${ }^{46}$ A contemporary, Antonio Ponz, commented on the event with great hopes:

This Cabinet can already be counted among the outstanding ones known to date; and if in the future it continues to be enriched with the zeal displayed in the beginning, it will be considered the best. Those who profess true love for their country would wish that it not remain as a mere curiosity, and that by the capital of the realm taking advantage of the beneficence of the king, it serve, as it ought to serve, for the advancement of the natural sciences, in which we are so backward. ${ }^{47}$

The cabinet began its public life on November 4, I776, and thenceforth opened for five or six hours every Monday and Thursday. A description of the museum seven years later has been preserved for posterity. There were two "magnificent" rooms for minerals (one for mineralogy and one for precious stones) that apparently attracted most attention. Two "spacious" salons held the animals and birds, another hall displayed insects, and yet another, sea life and petrifactions. Antiquities occupied two more rooms, and there was a library of books on natural history. A big room was set aside for "exquisite rare woods" and seeds, in the middle of which, for lack of other space, could be found "an elephant and its skeleton," two pieces "worthy of all admiration, and prepared by the painter and desiccator of this Royal Cabinet, D. Juan Bautista Bru." Above all, the placement of the objects caught the eye: they were "arranged

46. Sempere y Guarinos, Ensayo, II, 244. This source, which has been used by many subsequent writers who mention the museum, is vague as to the exact disposition of Dávila's possessions, but says that during the time the sale was open, he sold nearly 800,000 reales worth, "which still wasn't the value of half." Dávila's debts amounted to only 300,000 reales and, according to Sempere, he used the balance to purchase other curiosities which he brought to Spain. Later authors have jumped to the conclusion that Charles III bought the entire lot. There is likelihood, however, of more than a grain of truth in the remarks of the English traveler Joseph Townsend, who toured Spain in 1786-1787. "I apprehend," he wrote, "that after he [Dávila] had published his much admired catalogue, the best of the specimens were picked and culled, and that the refuse only were carried to the king of Spain." (Joseph Townsend, A Journey through Spain in the Years 1786 and 1787 [3rd ed.; Dublin, I792], I, 18I.)

47. Antonio Ponz, Viaje de España (Madrid, 1947), tomo V, 6th division, pars. $46-47$, p. 487 . 
and disposed on some large and spacious mahogany shelves, handsomely made, with fine glass in front so as not to let in the dust." ${ }^{38}$

To help stock the museum, a new instruction went out to all Spanish realms in 1776 . The painstaking directions, drafted by Dávila, reveal a sincere effort to obtain all conceivable specimens of minerals, animals, birds, insects, reptiles, shellfish, petrifactions, archeological objects, and the many representatives of the vegetable kingdom.

Just to speak of the last category: From all trees were to be sent a piece of the wood with its bark, either of trunk or branch, one-half vara ( 17 inches) in length and six inches in diameter; a smaller branch with its leaves and flowers; the fruit of the tree, either dried, or conserved in a liquor such as sugar-cane aguardiente; the seeds; and the sap, balsam, or oil, whether pure or extracted by incision or pressure. The local name of the tree, together with its history and a list of its properties or uses, was to accompany the shipment.

The crown voiced special interest in the supposed cinnamon tree of the Quijos district in the audiencia of Quito, together with any snails or caterpillars making their homes in the tree, as well as the resulting butterflies. Other desired specimens rating special mention were cinchona, the source of quinine; icho grass from the high mountain plateaus, useful for matting and cordage, as pasturage for llamas, and in the smelting of cinnabar and extraction of quicksilver; Paraguayan tea (yerba maté); obocuru, a plant found in southern Paraguay similar to the watermelon; coca, the dried leaf stimulant chewed by the Andean Indians, together with the lye used in its mastication; the grass known as mataduras; the hualhua of the Indians, used in the healing of wounds; ipecac; jalapa, the plant of New Spain and Guatemala from which indigo was derived; the plant fed upon by the dye-producing cochineal insects; pines of all types, especially those whose nuts were edible; the large alerce tree of southern Chile; all species of cedar; ebony from Peru; cascol resin from Guayaquil; a large number of woods including rosewood, Brazilwood, blond sandalwood, and others (cocobola, colorado, violeta, moradillo, serpentina, paloferro, granadillo, and wood of Campeche); white holly; white balsam; the black balsam of Peru; the balsam of Copaiba; numerous oils and resins such as oil of Mary and of palo, 48. "Real Gabinete de Historia Natural," Memorial literario, I (Feb., 1784), 18-21. 
resin of palo-santo, gum of lemon, sandarach, almond-like benzoin, gum of the storax, and gum lac; "and all plants, roots, fruits, and seeds known to be useful either in medicine, or for dyes, or whatever other thing of advantage to man and beasts, etc."

The inexperienced collectors were told to gather plants both in and out of flower and to place the specimens between the leaves of a book or rag paper, "spreading them out with great caution, without bending the leaves, or destroying their natural shape." In turn, the plants were to be put under a weight, dried in the shade, returned to the book, and identified as to their properties and uses, whether annual or perennial, in what type of soil found, when they bloomed and when they bore fruit or seeds, and whether the leaves were always green. The seeds were to be selected when fully developed, dried in the shade, and put between papers, with the necessary explanation. Fruits were to be dried or, if that were not possible, preserved in liquor. ${ }^{49}$

Soon the Indian mummies, the condor feathers, the skull containing curare poison, the sea lion, the "embalmed monster," not to mention the butterflies, insects, minerals, and dried plants, started to pour into Madrid. We need dwell no further on the subject, though it is hard to resist a mention of the most prolific contributor of all, Don Fernando José López de Cárdenas, priest of Montoro in Córdoba, Spain. He divided plants into three categories: (I) perfectas, such as nuts, apples, and other pomiferous plants, that reproduce themselves by seeds; (2) vilísimas, such as moss, that reproduce "by accident"; and (3) those of perfección media, "born" without seeds "spontaneously," especially in uncultivated lands, but subsequently producing their own seeds "by the persistence of that germinative virtue the Supreme Creator communicated in the beginning of time." He also maintained that snakes were formed from women's hair which had fallen out by the roots into a pool of water. "It is certain and I have investigated it for myself." But he endowed the museum with large numbers of fossils, minerals, and woods, and would no doubt have been less susceptible to folklore had he lived in a section closer to the scientific stream. ${ }^{50}$

49. Printed, undated Instrucción. Archivo Nacional de Santiago (Chile), Capitanía General, Vol. 726, doc. 56, pp. 125-137. The letter of transmittal, signed by José de Gálvez, is dated May го, г 776.

50. Agustín J. Barreiro, La historia natural en España durante el último tercio del siglo XVIII, extracted from the proceedings of the Asociación Española para el 


\section{THE DREAM OF JOSÉ CELESTINO MUTIS}

Outside official circles, individuals could always be found with more than a passing interest in plants. To name a few, Buenaventura Serra completed a fora of the Balearic Islands in 1772 , arranged in alphabetical order; Tomás Manuel Villanova formed and studied a collection of plants in Valencia and wrote several unpublished analyses; Salvador Soliva wrote a dissertation on the senna of Spain which was printed in I 774; Ignacio Jordán de Asso y del Río, already noted for studies in law, collected over one thousand plants during a trip through Aragón and published the first of many botanical compilations, classified according to the Linnaean system, in the following year. $^{51}$

More important to our story, however, is José Celestino Mutis (1732-1808). While acting as an examiner of the protomedicato in Madrid in 1757 , he took up the study of botany and worked for three years under the tutelage of Miguel Barnades. In 1760 , dreaming of a chance to study the fauna and flora of America, he got an appointment as physician to the incoming viceroy of New Granada, Pedro Mesía de la Cerda. Soon after Mutis arrived in the New World in 1760 he began a sporadic correspondence with Linnaeus extending over a period of seventeen years, that would make him known all over Europe through the great man's published works. Mutis found his desire to study plants foiled time and again, however, by the pressing need to serve as physician.

Hoping to break out of the shackles, he wrote two remarkable letters to Charles III in I763-1764. He visualized himself as suc cessor to Löfling and to Jacquin, ${ }^{52}$ the latter having only recentily covered the nearby coast.-. The hinterland was untouched. Give Mutis two assistants and two illustrators and "immortal glory would result" for His Majesty. Plants of great economic value would be

Progreso de las Ciencias [Madrid, 1920?], pp. 37-50. See also Barreiro, El Museo Nacional, for a more complete discussion of acquisitions. In 1785 the king ordered a sumptuous new building to be constructed on the Prado for the museum. But two decades later it was not finished and the Napoleonic invasion turned attention elsewhere. When at last it was completed, the building became the renowned Prado museum of painting and sculpture under the impetus of Queen Isabella II's interest in the fine arts. (El Museo, p. 20.)

51. Colmeiro, La botánica y los botánicos, pp. 74, 166, 169, 170-171.

52. See pp. 22-23, above. 
studied and samples sent to Spain to "excite curiosity." Quina production and distribution would be carried on with greater confidence "when my observations appear in public." Mutis would experiment with cultivation of the wild cinnamon to determine its true classification and do away with "the mistake that some have suffered in holding it to be the legitimate [cinnamon] of Ceylon." Spices of all types could be introduced into the valley of the Marañon-enough to supply all Europe. Mutis would also make observations on medicine, physics, geography, and astronomy. There might be others in Spain eager to undertake the task; he would willingly give way to a more seasoned hand. But here he was, on the scene, accustomed to the climate, and ready with a set of assistants. He had thought of nothing else for four years and enjoyed the backing of the viceroy. Surely the monarch would recognize the enormous advantages to be gained. ${ }^{53}$

Charles III must have felt constrained to win his "immortal glory" elsewhere, for he took no action on Mutis' proposals. In I 764 the naturalist sent to Linnaeus specimens of quina he had received from Loja and from these Linnaeus made the first revisions of La Condamine's incomplete findings. Eight years later Mutis discovered a cinchona tree of a different species near Bogotá, and commerce in quina could at last be opened up via Cartagena and the Caribbean, instead of the far-off Pacific coast. ${ }^{54}$ For four years (I 762-I 766) Mutis gave public lessons in mathematics and Newtonian philosophy, the first ones in the viceroyalty. During another four years (1766I 770 ) and again from 1777 to 1782 he was metallurgist in charge of stepping up production of the mines. In addition, he was appointed, in $177 \mathrm{I}$, professor of medicine and protomédico.

As for the study of natural history, until I 782 Mutis endured the crown's neglect of his efforts, consoled only by the "sweet memory" of his "repeated discoveries approved of and celebrated in Sweden." In that year the Archbishop-Viceroy Antonio Caballero y Góngora found him buried in "profound philosophical lethargy" at the royal mines of Sapo in the jurisdiction of Ibagué. "Instructed patiently" in Mutis' many achievements and spurred by the knowledge that Humboldt was already authorized to visit America, the viceroy on his

53. Representación hecha al Rey, Santa Fe de Bogotá, June 20, 1764. A. Federico Gredilla, Biografía de José Celestino Mutis (Madrid, I9II), pp. 21-31.

54. Humboldt, "Cinchona Forests," p. 26. For the consequences of this discovery, see chap. xi, below. 
own initiative created a provisional "Botanical Expedition of the New Kingdom of Granada": Mutis, one assistant, and one draftsman. Finally, in 1783 , two decades after Mutis had first petitioned the crown, Charles III approved a royal botanical expedition with Mutis as first botanist and astronomer. ${ }^{55}$

\section{WHY SPANISH ENTHUSIASM?}

Though its beginnings were tortuous and slow, Spanish botany entered an era of excited ferment in the last half of the eighteenth century. Observers ever since, viewing the stimulation of botany as only a part of Charles III's comprehensive plan to reform the intellectual and scientific life of the nation, ${ }^{58}$ have tried to explain the large share of attention allotted to the plant sciences.

It is customary to point out the good standing of botany in the spiritual realm. As long as mutability of species was not yet a question, botany did indeed seem a fairly innocuous form of scientific activity, upsetting no sacred credos. In fact, from a more positive standpoint, as Miguel Barnades commented in his text, the beauty of growing things demonstrates to us God's wisdom; their preservation, multiplication, and renewal show us His power; and their usefulness to men reveals His ineffable goodness. ${ }^{57}$ Numerous churchmen were attracted to botany. ${ }^{58}$ This argument implies that clerical opposition to most forms of new learning hindered the development of the scientific spirit in Spain. It suggests a government ready to burst into scientific prominence, all the while held back by a powerful church, and forced to turn to plant study for want of another outlet. There is a grain of truth in this grotesque distortion, but we should beware of making a stir about it.

A more positive explanation is demanded for the official interest in botany, and in part it lies in the economic value of plants. This seems almost too obvious for comment. Yet it becomes especially

55. Mutis to the viceroy, Santa Fe, March 27, 1783. Gredilla, Biografia de Mutis, pp. 165-175.

56. The best single work on the subject is Sarrailh, L'Espagne éclairée.

57. Principios de botánica, pp. 25-26.

58. Among those in America during the eighteenth century were Juan Ignacio Molina, a Jesuit in Chile; Archbishop Baltasar Jaime Martínez de Compañón, of Trujillo (Peru) and Bogotá; and Father Francisco González Laguna of the Agonizante order in Lima. Mutis also became a cleric. 
significant when we consider that attempts to revive Spain economically were an inconsequential part of public policy until the second half of the eighteenth century.

The Count of Campomanes, councilor of His Majesty, in 1774 wrote his celebrated Discurso sobre el fomento de la industria popular, drawn up by order of the king and council, to suggest means of relieving unemployment in Spain. Among the twenty-one "paragraphs" of his work, one explained the necessity for the study of natural history. The nation, he urged, should give prizes to those who could demonstrate the value of plants to manufacturing. ${ }^{59}$ Another proposal urged that so-called economic societies, similar to one already functioning since 1765 in Basque territory, be established in the capital of each province; and within a year (July I7, I 775) the Sociedad Económica de Madrid was licensed by the crown. This event, occurring at the seat of government and with the blessing of the Spanish king, set off a chain reaction. By 1787 , during the very years that the Ruiz-Pavón expedition was carrying out its studies, more than fifty Spanish cities had requested authority to form economic societies: ${ }^{60}$ Zaragoza in I776; Valencia and Seville, I 777 ; Palma and Tudela, I778; Segovia, I780; Oviedo, 178 I.

All were quite similarly organized, and all drew support from influential classes of society. Of the estimated five thousand members in the years to 1808 , most were "enlightened nobles, reformist ecclesiastics, and persons of the middle class imbued with the current philanthropism," as well as "a striking number of public officials." Intellectuals played a lesser part. ${ }^{61}$ In their efforts to stimulate by all means possible the improvement of agriculture, industry, and commerce, the societies demonstrated the passion for "useful knowledge" so characteristic of the Enlightenment. Material prosperity was their main concern; they sought to promote it by condemnation of idleness, by improved technology, and by better vocational education. The Madrid society dotted its memorias with statistics and cautioned its members against the "monstrous paradoxes" and "vain questions" so frequent in Spanish argument. ${ }^{62}$

59. Sempere y Guarinos, Ensayo, II, 80.

6o.Ibid., V, I78. William Coxe, L'Espagne sous les rois de la maison de Bourbon (Paris, 1827 ), VI, I 12.

61. Robert J. Shafer, The Economic Societies in the Spanish World $\left(17^{6} 3-18_{21}\right)$

(Syracuse, N. Y., I 958), pp. 7I, 73.

62. Ibid, p. 66 . 
Botany felt the influence of this pursuit of "useful knowledge." Statutes of the societies usually spoke of the "cultivation of all plants and trees from which some utility can be derived" as a matter of grave concern. ${ }^{63}$ One of the first memoirs published by the Basque society in 1765 dealt with the plants that could grow most favorably on the diversified terrain of the province. The society in Madrid printed a memoir in 1777 on the use of gums and resins in the manufacture of linen. Of less immediately recognizable usefulness was the plan of the Real Sociedad Aragonesa to arrange a "cabinet" according to Linnaean principles. Stimulated by the prospect of a prize of fifty doubloons, it became in 1786 the first group to draw up an outline for a natural history of Spain. ${ }^{64}$

Botany as a science for its own sake was obviously of little concern to these groups. Nor were many of them, especially in the smaller towns, able to survive the handicap of a shortage of talented members. But the societies in the major cities must have exerted some influence in keeping alive for a time in the Peninsula the urge for scientific knowledge. ${ }^{65}$ If this is so, botany benefited indirectly, just as did every other branch of science.

Campomanes performed another service by rescuing Bernardo Ward's Proyecto económico from the forgotten files. Among many other details, this plan, drafted in 1762 and based on an earlier report by José del Campillo y Cosío in 1743 , called for the collection of samples, from all the realms, of trees, fruits, herbs, and grains which "they say by well-founded tradition, and confirm by experiment, have some special virtue for health, pleasure, or other use."

63. See, e.g., Estatutos de la Real Sociedad Patriótica de la M. N. y M.L. Ciudad de Sevilla, y su reynado (Seville, 1778 ), title X, No. 4, p. 28.

64. Sempere y Guarinos, Ensayo, V, 157-158, 194. "Real Sociedad Aragonesa de los Amigos del País," Memorial literario, IX (Oct., 1786), I 59.

65. Sarrailh, L'Espagne éclairée, pp. 284-285. Shafer is not too certain of the durability of their contribution: "It may be that they helped, a bit, to reduce ignorance in Spain, or at least to promote new ideas in a very narrow though important circle. In the Societies some men of position managed to consider a little the rectification of the deficiencies of Spanish economic life. But this group was unrepresentative in that it lacked the generally fine sensitivity to threats to their position of the privileged orders in the Spanish world. They helped create that confusion of the Spanish spirit in contemplation of the new age which has been so apparent in modern times." (Economic Societies in the Spanish World, p. I 17 .)

66. Published in Madrid, 1779, p. 272. By the time of publication this program was already in operation. At least a dozen manuscript copies of José del Campillo y Cosío, "Nuevo sistema de gobierno económico para la América . . " may be 
Certain authors have pursued the illusive, but fascinating, goal of analyzing Spain's affinity for the natural sciences in terms of a "national characteristic." Thus the French scholar, G. Desdevises du Dezert:

These sciences of observation, whose object is always concrete, and which especially call for order, patience, and memory, seem better suited to the national temperament [of the Spanish] than the abstract speculations of mathematics or the lengthy meditations which the experimental sciences demand. ${ }^{67}$

There are those who might not agree; for example, a modern Spaniard, Celso Arévalo: "The ... hostility with which the Linnaean orientation was received in Spain is a proof of the resistance that the Spanish genius offered to the dry taxonomic orientation." In Spain, Arévalo maintains, science always had a "human character."68

But such speculation aside, other reasons exist to help clarify the Spanish interest in botany. Since the earliest days of discovery in America, many writers had mentioned plants-a necessary result of their full-measured curiosity. The collector's urge, sweeping natural history into favor among the upper classes of other European lands, exerted a new kind of persuasion: witness the growth of the "cabinet" in Madrid. Enthusiasm touched off in Europe by the Linnaean revolution had begun to penetrate Spanish thought by I776. And certainly, prodding by the master himself, aimed toward Spain, did not go unheeded. It would seem that Spain, determined to promote the sciences and having such vast unstudied domains, drifted into herborization because, together with metallurgy, it was the most obvious and readily available type of scientific activity upon which to lavish official funds.

So much for underlying causes. They help to explain Spain's interest in botany, but they fail to point out the immediate incentive that would channel her zeal along a definite course. This incentive took the form of a specific request from a foreign nation and is the subject of the chapter to follow. found in the Biblioteca Nacional in Madrid. The work, though begun in 1743 ,
was not published until 1789 .

67. "La Richesse et la civilisation espagnole au XVIII siècle," Revue hispanique, LXXIII (1928), 333.

68. "Bernardo de Cienfuegos," pp. 334, 335. 


\section{GENESIS OF THE EXPEDITION}

\section{TURGOT'S DESIGN}

Increased attention to botany and the precedent of the Löfling expedition made it likely that Spain would some day sponsor another plant-hunting excursion into her American hinterlands. But France, and especially Anne Robert Jacques Turgot, who became Louis XVI's - chief minister and controller general in I774, forced the hand of Charles III by asking to send a botanist to Peru.

Science intrigued Turgot, good encyclopédiste that he was, though his talents lay in the realm of political economy. From a union of these two interests came plans to help save a sagging France by diversifying agriculture, industry, and commerce. Geographical discovery, in the grip of a feverish revival, was awakening for the first time a truly scientific curiosity about the natural history of the lands encountered. Bougainville had come back from his globe-girdling voyage in 1769 , and Captain Cook was just returning from his second great expedition.

Turgot thus had ample reason to envision an itinerant academy, beating its way about the earth, uncovering knowledge of remote localities-and helping to broaden the French economy. ${ }^{1}$ Although these grand plans had to bow to the immediate needs of economic reform, which, by the way, cost Turgot his job at the hands of his enemies in 1776 , he nonetheless arranged two smaller expeditions. The first, to the Indian Ocean, was ill-starred, for the ship went down, and the scientist, Saint-Emond, perished before reaching his goal. ${ }^{2}$ The second, not actually undertaken until Turgot left office, was that of the botanist Joseph Dombey, sent to Peru with Ruiz and Pavón.

Why did Peru become the goal of a French expedition? As officially affirmed by the Marquis de Condorcet, secretary of the

1. [Pierre Samuel Dupont de Nemours], Mémoires sur la vie et les ouvrages de M. Turgot, ministre d'état (Philadelphia, I782), Pt. I, p. I22.

2. Ibid., Pt. II, pp. I88-189. 
Académie des Sciences, who handled the French side of the matter, it was to recoup the losses of luckless Joseph de Jussieu. ${ }^{3}$ One suspects the hand of Joseph's brother Bernard and his nephew Antoine Laurent de Jussieu; the latter could be found at every turn helping to free the Dombey expedition from coils of red tape. ${ }^{4}$ Condorcet also pointed out that herbaria had been pouring into France from India, the South Seas, Madagascar, and the Cape of Good Hope; now Spanish America ought to share its blessings with the world. ${ }^{5}$ Turgot, perennially concerned about finding plants for commercial development on French soil, urged upon Dombey a number of chores which might bring economic benefit to France. One need not suppose other motives behind the selection of Peru, though Dombey at least once was accused of spying on Spanish territory. ${ }^{6}$

Turgot's proposal made a favorable impression in Spain. Condorcet had sent it to Fernando de Magallón, former secretary to the Spanish ambassador in Paris and no stranger to encyclopedist circles. Magallón, in forwarding the request to the Council of the Indies, took pains to point out how the king could embellish his fame as a protector of science simply by granting a passport to this French subject. $^{7}$ Charles III of Spain was in fact the uncle of Louis XVI. However, the new Minister of the Indies, José de Gálvez, who would assume control of the venture, may have brought mixed emotions to the task. He had once been solicitor for the French at Madrid, and his second wife, who died in 1775 , was a native of France. ${ }^{8}$ But according to the gossipy Jean François Bourgoing, a later chargé

3. Reported by [Fernando de Magallón, former secretary to the Spanish ambassador in Paris] to [José de Gálvez, Minister of the Indies], [Madrid], n.d. [before Feb. 23, 1776]. Archivo General de Indias (hereinafter AGI), Audiencia de Lima (hereinafter Lima), legajo 606.

4. Hamy, Dombey, pp. 3, 13, 213,305-307, 314-315,317-318. Enrique Alvarez Lopez ("Dombey y la expedición al Perú y Chile," Anales del Instituto Botánico $A$. J. Cavanilles de Madrid, XIV [1955], 36, 37) rightly points out that Dombey at first thought he was heading for some such destination as Bourbon, Madagascar, or Pondichery (Dombey to Thouin, Fort Levêque, Sept. 26, 1775, Hamy, Dombey, p. 5), but is incorrect in stating that Turgot had fallen from power before Peru was decided upon as a destination. Negotiations began with Spain at least by February, 1776; Turgot was not ousted until May.

5. [Magallón] to [José de Gálvez], [Madrid], n.d. [before Feb. 23, 1776]. AGI, Lima, legajo 606 .

6. Dombey to Thouin, Cádiz, March I, 1785. Hamy, Dombey, p. 120.

7. Copy of letter to [José de Gálvez], n.d. [shortly before Feb. 23, 1776]. AGI, Lima, legajo 606.

8. Herbert Ingram Priestley, José de Gálvez, Visitor-General of New Spain $(x 765-1771)$ (Berkeley, I916), p. 4. 
d'affaires at the Spanish court, "these multiplied communications with the French nation have not prevented [Gálvez] from conceiving for her an aversion, which he but awkwardly disguised under protestations of friendship."

The principal factor in Spain's assent was no doubt the chance it gave to strike a bargain. Dombey could go, the French were advised by late February, I776, but "two Spanish professors" must accompany him, and he must leave in Spain a duplicate of all of his finds. ${ }^{10}$ Spain was only beginning to realize the potentialities of science. If Casimiro Gómez Ortega could locate suitable protégés, what could be better than practical field work in the company of a ten-year veteran like Dombey? Juan and Ulloa had stepped into almost the same situation when they joined La Condamine in 1735 .

The ouster of Turgot in May, I776, held up negotiations for a time, but despite the lukewarm attitude of his successor Jean Etienne Bernard Clugny, the French king at last authorized the money to be spent on August 27, I776. Galvez, with rash optimism, forecast departure by November, I776, but the "two Spanish professors" were not even named until the twenty-fifth of that month, and the party did not in fact sail from Cádiz until an additional year had passed. ${ }^{11}$ The delay in appointing the Spanish personnel and the twelve months taken thereafter in preparations seem ample proof that Spain had had no concrete notion of hunting for plants overseas until the French proposal was placed in her lap.

\section{AN EXPERT OF THE FRENCH TEMPERAMENT AND FOUR TYROS OF THE SPANISH}

In comparison with Joseph Dombey, the Spaniards chosen as botanists could scarcely boast of their experience with plants, ${ }^{12}$ though

9. Modern State of Spain (London, 1808), II, 181-182.

10. [José de Gálvez] to Magallón, El Pardo, Feb. 23, 1776. AGI, Lima, legajo 606.

Ix. Clugny correspondence, Versailles, June-Aug., I776; brevet of Louis XVI, Aug. 27, 1776; Magallón to Condorcet, Madrid, Sept. 16, 1776. Hamy, Dombey, pp. 305-307, 309, and plate XVII. Hipólito Ruiz, Relación histórica del viage, que hizo a los reynos del Perú y Chile el botánico D. Hipólito Ruiz en el año de 1777 hasta él de ${ }_{17} 88$, en cuya época regresó a Madrid, ed. Jaime Jaramillo-Arango (2nd ed.; 2 vols.; Madrid, 1952), I, 403-405. (Hereinafter, Ruiz, Relación.)

12. Salvador Rivas Godoy, "Ruiz y Pavón, discípulos destacados de Gómez Ortega," Anales de la Real Academia de Farmacia, XXI (No. 1, 1955), 28, points 
both had practical knowledge of pharmacy. Hipólito Ruiz had worked in Madrid in the drugstore of his uncle Manuel López, but did not obtain a pharmacist's license until $\mathbf{1} 790$, upon his return from America. ${ }^{13}$ Pavón held a subvention to study botany, chemistry, and pharmacy, and to work at the royal pharmacies of Buen Retiro and San Ildefonso from 1773 to $1777,{ }^{14}$ but would not have had sufficient experience for a license. Nor does it appear that he ever got a license or sought to resume the profession when he returned to Spain. ${ }^{15}$

Hipólito Ruiz López was born on August 8, I754, at Belorado (Burgos), of a landholding family, a distant branch of which would one day become the Counts of Lerena. Sent to Madrid at an early age, he studied logic, experimental physics, chemistry, and pharmacy, while serving in his uncle's shop. An especial interest in botany drew him in 1772 to the garden at Migas Calientes, where he seems to have made a favorable impression upon Professors Gómez Ortega and Palau. Ruiz nearly lost his chance to go to Peru because of objections by his pharmacist uncle, who feared complications of a pulmonary ailment that had shown signs of developing in this twentythree-year-old. ${ }^{16}$

out two errors Ruiz made in the casual identification of Spanish plants upon his return to Spain from Peru, and deduces that Ruiz must not have had much field experience in Spain prior to his departure for America. Pavón, however, possessed a herbarium of plants collected near his native city, which may possibly antedate his participation in the expedition to Peru.

13. For a copy of the license, see Joaquín Olmedilla y Puig, "Episodios biográficos del sabio botánico español Hipólito Ruiz López," El porøenir farmacéutico (Madrid, No. I5, I 885 ). The license, dated February 5, I790, states that Ruiz had practiced the "science of the apothecary under approved masters for more than four years." A committee of three, including Casimiro Gómez Ortega, had questioned him to their satisfaction in "Latinity and the theory and practice of said science [of pharmacy]," and he was now entitled to practice anywhere in His
Majesty's realms.

I4. Pavón to José Antonio Caballero, Minister of Grace and Justice, Madrid, Feb. I 4, 1800 . In Museo Nacional de Ciencias Naturales, Madrid, Ruiz-Pavón papers (hereinafter $\mathrm{MCN}$ ), I 800 . When I last consulted these papers in the summer of 1959 , they were filed, without cataloguing, in temporary folders labeled by year. Citations hereinafter will indicate the year of the folder only when it is different from the year of the document in question. In some cases more than one folder exists for a given year.

I 5. Rivas Godoy, "Ruiz y Pavón, discípulos," Anales de la Real Academia de Farmacia, XXI, 32-33.

16. [Antonio Ruiz], An Historical Eulogium on Don Hippolito Ruiz Lopez (Salisbury, I 831), pp. I-4, 55. Colmeiro, La botánica y los botánicos, p. I 79. Enciclopedia universal ilustrada (Espasa-Calpe), LII (Madrid, I926), 782. Hipó-
lito Ruiz, Respuesta para desengaño del público á la impugnacion. . . contra el Pródromo de la Flora del Peru (Madrid, I796), p. 3. 
One of Ruiz's four sons has left this description, written shortly after the death of his father:

Don Hippolito Ruiz was of the middle stature, more than usually stout, but well proportioned. [In another place, however, the son speaks of Ruiz's "great corpulence."] His complexion was rather dark, his features good, his hair and eyes black, and the latter lively and penetrating [his pharmacist's license, however, describes his hair as "light chestnut" (castaño claro), and speaks of a scar at the right end of his upper lip]; his eyebrows [were] thick, his physiognomy grave, and in his face was painted that serenity, which is inseparable from a man of upright character. His deportment was unaffected, though dignified; his temper frank and generous yet sedate and circumspect. His manners were formal, but open and consistent. He was prudent, laborious, sparing, and very zealous for the glory of the nation. ${ }^{17}$

José Antonio Pavón y Jiménez was born at Casatejada (Cáceres) on April 22, 1754. At age eleven he came to live in Madrid at the home of his uncle José Pavón, who was "second pharmacist" of Charles III. In I 763 he began his studies-logic, physics, ethics, and metaphysics-in the Colegio de Santo Tomás. After three years he turned to mathematics, geography, mineralogy, experimental physics and chemistry, the Italian and French languages, and finally botany and pharmacy when he, like Ruiz, came under the wing of Gómez Ortega. ${ }^{18}$

Ortega ${ }^{19}$ thought it indispensable that two painters go along to make reproductions of the flora. A pleasant disposition and a willingness to take orders were to be as important as artistic ability. The men must "copy nature exactly, without presuming to correct or embellish it, as some draftsmen are accustomed to do by adding coloring and adornment taken right out of their imagination." 20 On February 12, I777, José de Gálvez asked Ignacio de Hermosilla, head of the Real Academia de Nobles Artes de San Fernando, to begin the search. His four best pupils who fulfilled the conditions of "bachelorhood,

17. Historical Eulogium, pp. 53, 54-55. Olmedilla y Puig, "Episodios biográficos," El porvenir farmacéutico (I885).

18. Agustín J. Barreiro, Don José Antonio Pavón y Jiménez, r754-1840, extracted from the proceedings of the Asociación Española para el Progreso de las Ciencias [Madrid, 1933?], p. 6. No portrait or ready-made description of Pavón can be found. We shall have to let Pavón's actions speak on his behalf.

19. Casimiro Gómez Ortega is very often referred to in correspondence of the times as "Ortega," though this was, of course, his mother's maiden name.

20. Partido y condiciones que como base para el viage ... propone... Gómez Ortega, Nov. 25, 1776. Ruiz, Relación, I, 404. 
skill, and a gentle disposition" were told to make drawings of flowers, fruits, and herbs in the presence of witnesses. Professors of art and "other intelligent persons" (including the Minister of the Indies) then judged two of the men as unquestionably the best. ${ }^{21}$ As a result, on March 8, 1777, the king appointed as first draftsman to the expedition Joseph Brunete, a native of Madrid (1746-I787) who had been a student of the top-ranking painter in Spain, the Bohemian Antony Raphael Mengs. Choice for the second position was another resident of Madrid, Isidro Gálvez (I754-I829). ${ }^{22}$ After watching the two artists in action for more than a year, however, Dombey felt that Gálvez was the better. ${ }^{23}$

Brunete, born in I 746, was the oldest Spaniard on the expedition, but the dean of all in both age and experience was the Frenchman Joseph Dombey, born at Mâcon on February 22, I 742. His father was a confectioner and fairly well-to-do, but Dombey, with the full approval of his parent, preferred a career in medicine, in keeping with a family tradition. Orphaned at age fourteen, he came under the care of an aunt, the niece of the Jesuit mathematician and maritime engineer, Paul Hoste, whose many years of sea voyaging may have given the young man his taste for travel. Or was it the influence of the venturesome botanist Philibert Commerson, whom Dombey also claimed as a relative?

Dombey emerged from Montpellier with a doctorate of medicine in 1767 . As his attention turned toward natural history, his life became involved in plant-collecting trips to the Pyrenees, the marshes of Bresse, and along the eastern border of France in the mountains of the Dauphiné. For a time he acted as guide for Jean Jacques Rousseau, who was then becoming interested in botany. A sojourn in Paris in 1772 made him known to scientists at the Jardin du Roi, and Antoine de Jussieu recommended him for the overseas

21. Hermosilla to José de Gálvez, Madrid, March 19, 1777. MCN.

22. Copies of the baptismal certificates of Brunete and Isidro Gálvez may be found in $\mathrm{MCN}$, 1777 . These copies are dated January 5 and 7, 1777, indicating that perhaps the two men were being considered for the job even before the order of February 12, 1777 , was sent to the art academy. See also Dombey to Thouin, Cádiz, April 24, 1785. Hamy, Dombey, p. 162. Mengs (1728-1779) had also been first painter to the elector of Saxony and director of the Vatican school of painting. His most noted work in Spain is contained in several of the ceilings of the royal palace in Madrid. (Encyclopedia Britannica, XV [1949], 248-249. Visitor's Guide to Madrid and Places of Interest in its Vicinity [Madrid, r958], pp. 97-98.)

23. Dombey to Gómez Ortega, Cádiz, March 8, 1785. MCN. 
assignment. Dombey learned of his selection in August, 1775, while herborizing in the Swiss Alps, and from then until leaving for Spain he came under the tutelage of André Thouin, gardener-in-chief in Paris. When finally Dombey headed for Madrid, as he tells us, he traveled all the way on foot, gathering and studying plants as he went. ${ }^{24}$

A contemporary describes Dombey as "of pleasing countenance, gay in spirit, well-proportioned, with a strong constitution."

He applied himself with the same fervor to his studies and to the pleasures of his age, and thought neither of fortune nor reputation. Likeable and generous, he launched himself into society, reckoning neither the loss of time nor the expense; tomorrow for him was a distant future. In winter he seemed occupied only in amusements of the city, but as soon as springtime restored the vegetation to life, he was called to the countryside by the flowers... . If he had the money, he spared none in order to facilitate his excursions; not having any more, he knew how to do without, to go on foot, and to live with the frugality of an anchorite, until he found someone who was willing to lend him some. Then, calculating that he would soon be well enough off to pay up, he never hesitated to offer exorbitant interest, and as he continued to spend without thinking, the time of repayment arrived, he found himself alarmed over his debts and took refuge in ruinous expedients. With his inconsistency he combined an extreme considerateness: for him a word of honor was a sacred obligation. Equally confident and unselfish, he was affable and ready in his dealings, and he combined with that affability a firmness, a courage, and a kind of loftiness suitable to a man who respected himself. ${ }^{25}$

The Spanish government readily acknowledged Dombey's supremacy in botanical experience. But, as Magallón suggested, even though the Frenchman, "because of his skill and botanical knowledge deserves to be chief of the expedition, I do not know if it will be advisable that he be so declared." And he added in explanation, "you know what the French temperament [genio] is."26 Dombey was indeed not very impressed with the status of botany in Spain:

24. Hamy, Dombey, pp. viii-xvi, xviii, I-5, I 57. M. J. Mouton-Fontenille, Éloge de Joseph Dombey, médecin, botaniste du roi (Bourg, [ca. 180o]), p. 19. P[aul] A[ntoine] Cap, Joseph Dombey, naturaliste (Paris, 1858), p. 4. [Jean Emanuel] Gilibert, "Notice sur la vie et les travaux d'Antoine [sic] Dombey," Recueil des actes de la Société de Santé de Lyon (Lyon, 1798), pp. 457-458.

25. J. P. F. Deleuze, "Notice historique sur Joseph Dombey," Annales du Muséum National d'Histoire Naturelle (Paris), IV (1804), 137-138.

26. Aclaración de algunas dudas, March 9, 1777 . Ruiz, Relación, I, 407. 
M. Ortega and Palau, Barnades ${ }^{27}$ and Ortiz (these last are medical doctors) are the only ones who love botany. But the little competition that exists in Madrid, in spite of the good intentions of the king and his ministers, makes me believe that one would have plenty of trouble in introducing a taste for the sciences in Spain. ${ }^{28}$

It is undoubtedly true that the French, and Dombey himself, felt superior to their Hispanic colleagues. The first brevet of Louis XVI sending Dombey to Peru made no mention of Spanish permission for the voyage, a fact that pained the Peninsular authorities. ${ }^{29}$ Dombey spoke of "the two Spanish pupils whom they will give me" and of the "two illustrators of the same nation who will accompany me." And again: "I hope that the advantages my coming to Spain procure for the Spanish gentlemen will procure for me some respect on their part." ${ }^{\text {30 }}$

The numerical predominance of the Spaniards, the fact that the work would be carried on in Hispanic territory, and the increasing indication that Spain was determined to make something big of the affair, left no other logical solution than that a Spaniard be put in charge. Thus, Hipólito Ruiz was chosen "first botanist" because of his "naturally wise nature and his greater proficiency [than Pavón's] in botany." Official orders referred to Dombey as a "botaniconaturalist in the capacity of accompanying member to the Spaniards of the same profession." 32

\section{THE WAY TO HARMONY}

Broadly stated by the Spanish crown, the aim of the expedition was

the methodical examination and identification of the products of nature of my American dominions, not only to promote the progress of

27. Miguel Barnades, son of the deceased botanical professor of the same name, previously mentioned.

28. Dombey to De Jussieu, Cádiz, Oct. 16, 1777. Hamy, Dombey, pp. 236-237.

29. Dombey to Thouin, Madrid, Nov. 11, 1776. Ibid., p. 6.

30. Dombey to Thouin, Madrid, Dec. 5, 1776, and to De Jussieu, Madrid, April 25, 1777. Ibid., pp. 8, 225.

3r. Gómez Ortega to José de Gálvez, Madrid, April 8, I777. Ruiz, Relación, I, 410. Ruiz was also said to have been selected because of his seniority, but in actual fact he was about three months younger than Pavón.

32. Official appointments of Ruiz and Dombey, Aranjuez, April 8, 1777. Ibid., I, 412, 4I. . Dombey wrote De Jussieu that he was to be called a "medico-botanist," while Ruiz and Pavón would bear the title of "professors." (Letter from Madrid, April 25, 1777. Hamy, Dombey, p. 225.) 
the physical sciences, but also to banish doubts and falsifications which exist in medicine, painting, and other important arts, and to foster commerce, and to form herbaria and collections of the products of nature, describing and making drawings of the plants found in these, my fertile dominions, in order to enrich my Museum of Natural History and the Botanical Garden of the Court. ${ }^{33}$

The men were to spend four years in the viceroyalty of Peru. ${ }^{34}$ After a year in the environs of Lima, they would head for the audiencia of Quito-in Dombey's words, the botanist's "promised land."

Harmony must be the rule. The Spaniards were advised to "win [Dombey's] confidence and friendship and take advantage of his knowledge of botany and natural history, as well as of the art and method of placing plants in order and preserving them, and of forming herbaria." In turn, they should advise him of their own discoveries, "making a mystery of nothing, so as to bind him by such frankness to reciprocate equally with what he himself discovers." But the Spaniards should in no way consider themselves dependent upon Dombey, nor allow him to treat them as subalterns. ${ }^{36}$

The best way to solve the problem, Gómez Ortega decided, was for the botanists to do their collecting jointly at first, until the Spaniards were ready to set out on their own. Thereafter Ruiz and Pavón would alternate in accompanying Dombey. In any case, they would meet for consultation every few days, reaching decisions by majority rule-a stipulation that left the power unquestionably in the hands of the Spaniards. ${ }^{37}$

To prevent discord, the discoverer of each plant would list its name in his diary, and whenever the respective finds of each man were made known to the others, all would sign each diary, thus giving evidence as to which botanist had "the first right to be able to publish it." This point is worth noting in view of later events. To assure Spain the full fruit of discoveries in her own dominions, it was further stipulated that Dombey, upon his return to Europe, must present for consideration of the professors of the botanic garden in Madrid two copies of his plants and observations. These would

33. Appointment of Ruiz. Ruiz, Relación, I, 4 r r.

34. Ibid., I, 4I 2. Dombey had once thought the expedition might last seven or eight years. (Dombey to De Jussieu, Paris, Oct. 7, 1776. Hamy, Dombey, p. 214.)

35. Dombey to Thouin, Lima, April I9 and Dec. II, 1778 . Ibid., pp. 37, 49.

36. Instrucción (1776). Ruiz, Relación, I, 393-394.

37. Suplemento que Don Casimiro Gómez-Ortega cree se puede añadir a la instrucción. Ibid., I, 402. 
be compared in the presence of Dombey and his Spanish companions, and one copy of each plant chosen to be kept in Spain. In the event Dombey had found the only example, he would of course be allowed to take it to France, but a description and drawing, together with observations and notes, must be left with the botanical authorities in Spain. ${ }^{38}$

Lest the members of the expedition turn their eyes afield, the Spanish government warned that under no condition could they enter into business dealings with either European or overseas merchants, or traffic in commodities of a scientific nature. In addition, they were forbidden to make maps or sketches of the terrain, towns, ports, or coastline. In short, as the crown specified, their voyage and commission were "puramente literarios." 39

To aid their scientific pursuits, the government supplied Ruiz and Pavón with an armload of books. Several major works of Linnaeus occupied first importance: the Philosophia botanica (Ist ed., I75I) and Genera plantarum (6th ed. rev., I 764) and two sets (3 volumes in 4) of the Systema naturae (r2th ed. rev., I766-I768). For good measure, the Institutiones rei herbariae of Tournefort was added. Bulking largest were the compilations of earlier botanical explorers in America: the Historia naturalis Brasiliae of Piso and Marcgrave, first published in I648; Charles Plumier's Nova plantarum Americanarum genera (I 703), detailing the results of his three trips to the French Antilles; the Journal of Father Feuillée covering his voyage along the Peruvian coast (published I7I4-I725); Löfling's "sumamente rara" letters as gathered by Linnaeus (presumably the Stockholm edition of I758); and Jacquin's Selectarum stirpium Americanarum historia ( 1763 ), that Linnaean-modeled example of another monarch's interest in botany-the report of five years in the Antilles on a mission for the botanic garden of Schönbrunn.

Finally, the entertaining and informative works of Juan and Ulloa were appended as guidebooks for the Spanish neophytes. ${ }^{40}$ No copy of Francisco Hernández's study on Mexican plants could be found for the use of the party, but Gómez Ortega was charged to keep trying and to remit it to Lima if one could be located. ${ }^{41}$ Ortega

38. Instrucción. Ibid., I, 394-395.

39. Ibid., I, 400-40I.

40. These included the Relación histórica del viage a la América meridional, written by Ulloa ( 5 vols., 1748), and the Noticias americanas (1st ed.; 1772).

41. Ruiz, Relación, I, 424-425. 
eventually published a new edition of Hernández in 1790. Dombey carried his own supply of books, but it is not known what these included. ${ }^{42}$

\section{MONEY MATTERS}

The expedition thus far has been considered as a botanical venture, and in great part it was. But Dombey had achieved the status, not uncommon in his times, of a man who might be expected to know at least a little about many things. Thus we shall see him testing mineral waters, proving quicksilver deposits, collecting platinum, analyzing saltpeter, and performing a variety of other tasks that would be left to more specialized hands in our day. In addition, he practiced medicine when the need for doctors arose.

But despite Dombey's all-round talents and his obvious edge in botanical knowledge, it was the Spanish members, every one, from first botanist to last draftsman, who got the better salary. The base pay of each Spaniard was set at I,000 pesos moneda de Indias annually, beginning with the date of sailing. Moreover, the rate was to double whenever they were actually in the field-2,000 pesos per man per year. ${ }^{3}$ "In the field" meant, in practice, "outside of Lima." By I 784 , however, the Spaniards were getting double salary even in the capital in order to "stimulate them," and in recognition of the high cost of living. ${ }^{44}$

The illustrators had support from two sectors in their claim upon a salary equal to that of the botanists. Their master at the academy of

42. Dombey to Thouin, Madrid, June 6, 1777; Dombey to Jacques Necker, controller general, Madrid, Sept. 18, I777. Hamy, Dombey, pp. 21, 235. At
least a portion of these were donated by a wealthy amateur who asked only to be paid with "bits of natural history."

43. On the matter of double salary, the Spanish appointments read: "Durante sus viages en aquel Reyno para los expresados fines gozará el sueldo doble para subvenir a los precisos gastos que con este motivo le occurran." (Nombramientos. Ruiz, Relación, I, 412, 413,415,416.) Incidentally, when they returned to Spain, each was to be paid 500 pesos per year until publication of their findings was completed.

44. Manuel del Campo, paymaster of the Caja Real de Lima, to Jorge Escobedo, visitador general, [Lima], Dec. 16, 1782. MCN, 1783. Also printed in Anales de la Real Academia de Farmacia, XXI (No. 5, 1955), 442-443. Gómez Ortega pointed out, in justifying the double salary while in Lima, that the botanists did deposit the fruits of their labors. (Ortega to José de Gálvez, Madrid, Oct. I 3, 1784. MCN.) 
art, Ignacio de Hermosilla, said they deserved at least the same pay, for, in fact, by leaving Spain, they were sacrificing even more than the botanists. Presumably he felt it was possible to earn more money in Spain as an artist than as a plant scientist. ${ }^{45}$ Magallón also stood up for the draftsmen, pointing out that their expenses were the same and their work "perhaps greater." With equal pay, everyone would be content. The additional sum involved was "in itself only a bagatelle, and much would be gained by spurring [the draftsmen] on at their work." ${ }^{46}$

To the French government, apparently, enthusiasm for one's task was enough. Dombey's initial appointment, based on the recommendation of De Jussieu, called for 3,000 livres (600 pesos) per year-only 30 per cent of the Spaniards' salary when actually in the field! ${ }^{47}$ In justice to the French, it should be said there was no fair standard of comparison. The celebrated Philibert Commerson had been paid only 2,400 livres. But even when José de Gálvez, with years of experience in America, confirmed the inadequacy of Dombey's salary, Turgot's successors held fast in their refusal to grant him a raise. ${ }^{48}$

Dombey was prepared, as he said, to sell his last shirt in order to make the voyage, for he might never have another opportunity, but he was nevertheless ready to fight for more money. His appeal to Antoine de Jussieu brought out the support of members of the Académie des Sciences who, by now, had an unwitting ally in the salary schedule of the Spanish botanists. The Academicians told the controller general, albeit in error, that the Spaniards were each to receive 20,000 livres per year-nearly seven times Dombey's wage. This startling contrast goaded the French into raising Dombey's salary to 6,000 livres ( 1,200 pesos), and there it remained throughout his stay in America, well beneath the pay of his fellows when in the field. ${ }^{49}$

45. Letter to José de Gálvez, Madrid, March 19, 1777. MCN.

46. Aclaración de algunas dudas, March 9, 1777. Ruiz, Relación I, 407.

47. Clugny to De Jussieu, Versailles, July 20, I776, and Taboureau des Réaux, controller general, to Comte de Vergennes, Minister of Foreign Affairs, Paris, Dec. I3, I776. Hamy, Dombey, pp. 306, 313 .

48. Thouin to Dombey, [July, I775]; Marquis d'Ossun, French ambassador to Spain, to Vergennes, El Escorial, Nov. 25, 1776; Dombey to De Jussieu, Madrid, Jan. 2, 1777; Taboureau des Réaux to Vergennes, Paris, Dec. 13, 1776; D'Ossun to Dombey, Madrid, Jan, I, I777. Ibid., pp. 3, 312, $217-218,313$.

49. Dombey to De Jussieu, Madrid, Jan. 2, 1777; observations of Académie, undated (probably Jan., 1777); Taboureau des Réaux to De Jussieu, Paris, Feb. 
Dombey benefited from his raise less in purse than in peace of mind. A heavy spender in his youth, he was no stranger to pursuing creditors. In fact, in September, 1775, he almost missed out on the trip to America by being detained for a time in a debtor's prison at Fort Levêque. Embarking on the voyage brought no respite trom the plague. Rather, he was forced to go heavily in debt to outfit himself for the trip, and, in order to maintain a reputation at home, had to assign all of his raise to his creditors. Surprisingly enough, his correspondence after coming to America often mentions sums he lent to the free-spending Spaniards. ${ }^{50}$

Before the date of departure, Dombey's government did, in truth, promise him an extraordinaire of 600 pesos, which, years later, he discovered was "for one time only," to be paid if the viceroy of Peru thought the situation urgent enough. Apparently, that official was not hard to convince, for he dealt out the full sum on July II, I 778, when the botanists were getting ready to leave Lima on merely their first short-scale maneuver. ${ }^{51}$ Nor was Dombey's plea in 1779 for financial equality with the Spaniards entirely ignored, for the French king authorized another extraordinaire of 2,000 pesos in September, I 780 , to buy items necessary "for the progress of science" (e.g. curiosities for the king's museum) or to pay the costs of sickness or other misfortune. But the urging of neither viceroy nor minister of the

18, 1777. Ibid., pp. 217-219, 314-315. Dombey expressed his appreciation to José de Gálvez for help in securing the raise in a letter of Feb. 20, 1777, from Madrid. MCN. The Marquis d'Ossun told José de Gálvez, however, that there would be no further "increase or gratification for any reason whatsoever." (Aranjuez, April 13, 1777. MCN.) A royal order to Comte de Montmorin, French
ambassador to Spain (Aranjuez, April 9, 1780, MCN) confirms that Dombey did not receive double salary in the field.

50. Dombey to Thouin, Fort Levêque, Sept. 26, 1775, Hamy, Dombey, p. 5: "I think that I will not be able to work today with you. A merchant of this region to whom I owe four hundred livres and who had promised to wait until I could pay him, has not kept his word. I have been arrested this morning at 7 o'clock by a bailiff and put into Fort Levêque." Dombey to Thouin, Madrid, March 31, 1777; De l'Isle, chief clerk of finance, to Taboureau des Réaux, April 27, 1777; Taboureau des Réaux to De Jussieu, Paris, May 28, 1777; Dombey to De Jussieu, Madrid, Aug. 25, 1777. Ibid., pp. 15, 317-318, 231. On December 1, 1781, Ruiz and Pavón owed Dombey 880 pesos. (Dombey to Thouin, Lima, Nov. 24, 1781 . Ibid., p. 83.) For other references to sums advanced by Dombey see ibid., pp. 49, 75.

51. Marquis d'Ossun to José de Gálvez, San Lorenzo, Oct. 16, 1777; certificate of Manuel del Campo and Diego Sáenz de Ayala, Lima, March 18, 1782. MCN. Taboureau des Réaux to De Jussieu, Paris, May 28, I777; Micault d'Harvelay, garde du trésor royal, to Count Aranda, Spanish ambassador to France, Paris, April 29, 1777 ; Dombey to Necker, Madrid, Sept. 18, 1777; Dombey to Thouin, Lima, Dec. 11, I 778, and Cádiz, April I2, 1785. Hamy, Dombey, pp. 31 7, 22-23, 234-235, 44, 154 . 
Indies was enough to lower the bars against a salary increase for the Frenchman. ${ }^{52}$

Needless to say, Dombey never gained his wish that the French government supply him with an assistant, and he had to buy all of his needs, scientific or personal, out of his salary. The Spaniards, on the other hand, had a fund of 3,000 pesos to take care of urgent requirements, and the government provided all necessary books, instruments, and supplies. These comparisons, so favorable to the Spaniards, are good evidence that Spain was beginning in earnest to reap the botanical harvest in her overseas realms. ${ }^{53}$

52. Dombey to Viceroy Manuel de Guirior, Lima, Aug. 15, 1779; Guirior to José de Gálvez, Lima, Aug. 20, 1779; [Gálvez] to Montmorin, San Ildefonso, Sept. 20, 1780; royal order to viceroy of Peru, San Ildefonso, Sept. 20, 1780; certificates of Manuel del Campo and Diego Sáenz de Ayala, Lima, March 18, 1782, and Feb. 27, 1784; Gálvez to Bourgoing, El Pardo, Feb. 20, 1785. MCN. Dombey to Thouin, Lima, Nov. 24, 1781, and to Joly de Fleury, controller general, Rio de Janeiro, Aug. 14, 1784. Hamy, Dombey, pp. 82, 273.

53. D'Ossun to Dombey, El Escorial, Nov. II, I776; Dombey to De Jussieu, Madrid, April 25, 1777. Ibid., pp. 19, 28, 225-226. Ruiz, Relación, I, 405, 422424,4 I 2,415 . 


\section{THE KEY TO THE}

\section{I T Y O F K I N S}

All was right with the world when the botanists saw the shores of Europe fade out of sight on November 4, I777. They were sailing to America on one of the best ships in the Spanish fleet-the sixtycannon El Peruano. Dreaming of new worlds to conquer, Dombey brought along "plenty of seeds and fruit stones to plant in America so as to turn over to these wild Indians with one hand what I take away from them with the other." No serious incident marred the journey of five months and four days between Cádiz and Lima, barring the severe cold, snow, and hail of midsummer at sixty-one degrees south latitude.

The storm-rocked passage around the Horn was mild punishment compared to the likely fate of the party had they followed the original plan to debark at Buenos Aires. Hostilities with Portugal in this region had made an overland crossing to Lima unwise. One can thus well imagine the men's mingled horror and relief at hearing, upon arrival in Lima, how Indians had slaughtered an overland caravan daring to make the trip. Hasty calculation made it plain that, but for the grace of war with Portugal and the guiding hand of the "god of botany," the scientists' heads would have been trophies of the indios bravos. ${ }^{2}$ Here was pointed evidence, if they needed it, to prove they had entered a new and strange land.

I. Dombey to Thouin, Cádiz, Oct. 16, 1777, and to De Jussieu, Madrid, Aug. 25, I777. Hamy, Dombey, pp. 30, 232. Dombey was granted free passage and meals during the voyage by the Spanish government. (Dombey to Thouin, Madrid, Aug. 25, 1777 . Ibid., p. 26.)

2. Dombey to De Jussieu, Madrid, April 25, 1777, and to Thouin, Lima, April 19, 1778 . Ibid., pp. 226, 37 . 


\section{A CULTURAL REVOLUTION IN THE MAKING}

The fifty thousand leisure-loving citizens of the greatest city in South America were basking in the last days of summer when the newcomers arrived in Lima on April 8, I778. Protocol demanded fitting receptions, the love of pomp encouraged such festivities, and, after one hundred and fifty-five days at sea, the scientists relished the opportunity to participate. In those slow-moving times, almost a month went by before the botanists got down to business. ${ }^{3}$

First came a ceremonial welcome by Viceroy Manuel de Guirior, who had once been called, by the savant Mutis, "the most ardent promoter of science." Even the skeptical Dombey was impressed. He wrote that Guirior "speaks French well and has a very pleasant nature, a condition favorable to our undertaking."

Next to pay their respects and satisfy their curiosity were "the most distinguished and learned persons of Lima." "Unfortunately, the records are silent on the composition of the august group that met on this day. But we know, for instance, that while botanizing at Surco, on the outskirts of Lima, the scientists were guests of the oidor Don Pedro Echevers and that, on their first trip away from the capital, they were escorted part of the way by the Marqués de la Real Confianza and the lawyer Manuel Eraso, "with other gentlemen." Prominent hacendados often provided headquarters for field operations. Francisco Rúa, professor of anatomy in the University of San Marcos, presented Dombey with "a little manuscript" describing a rapuntium and other plants-possibly one of the missing papers of Joseph de Jussieu. Dombey enjoyed the cumpany of Colonel Jaros,

3. Ruiz, Relacion, I, 2-3. Ruiz says that botanizing started on May 4, though Dombey indicates that some specimens were collected before that date. However, Holy Week and the delays in getting the botanists' baggage unloaded prevented much scientific activity. Besides, the fact that Lima is dry in the summer put a severe limit on the wildflowers to be found. (Dombey to Thouin, Lima, April I9, and to De Jussieu, April 16, 1778. Hamy, Dombey, pp. 36, 37, 238.)

4. Mutis to Linnaeus, June 6, 1773. Guillermo Hernández de Alba (ed.), Archivo epistolar del sabio naturalista José Celestino Mutis (Bogotá, 1947), I, 26. Guirior, in his capacity as viceroy of New Granada in 1773 , had been entrusted with the care of gift copies of Linnaeus' works. Mutis tells how the viceroy questioned him at length on the work of the Swedish botanist and envisaged certain applications of the science in his own realms.

5. To Thouin, Lima, April 19, I778. Hamy, Dombey, p. 35.

6. Ruiz, Relación, I, 3. 
Don Juan Baptista de Echegaray, and Don Esteban de Urrutia in his excursions around Lima. It is of more than passing interest to note that Urrutia was mentioned in proceedings of the Inquisition in 1773 as one of forty freemasons in Lima. He was described as "one who lives opposite the Gate of the Jews, . . . a merchant."7

Botany had no greater friend in Peru, however, than Father Francisco González Laguna, overseer of the garden of the Agonizantes (El Jardín de la Buena Muerte). When Ruiz and Pavón later dedicated to him the genus Gonzalagunia they described him as "a truly industrious person, learned, and helper of the studious, untiring promoter of the useful arts and sciences, whose aid, advice, favor, and generosity we profited from during our stay in Peru." Besides informing them of the uses for numerous plants, he cared for many living specimens brought from the field by members of the expedition and awaiting shipment to Spain. ${ }^{8}$

Another of the local wise men was certainly Cosme Bueno, for whom Ruiz and Pavón named Cosmibuena. He received the visitors "with the most pleasing grace" and fostered their excursions "with particular zeal and activity." Dombey called Bueno "a man of rare understanding and much learning." A later admirer singled him out as the "first convert of Newton in Peru," whose home was the "Potosi where all the savants who came from Europe met to be supplied with news." 11

To discuss Bueno's manifold activities is to reveal the state of scientific knowledge in Peru at the time the botanical expedition arrived. Although born in Spain, Bueno received nearly all of his scientific education after coming to Lima at age nineteen. The University of San Marcos awarded him the doctorate of medicine in 1750 , at the comparatively advanced age of thirty-nine, and in the same

7.Ibid., I, 58, 36. Hamy, Dombey, pp. 39-40, 36. Ruiz tells that VisitorGeneral José Antonio Areche had collected the ossified blade of a swordfish for his "cabinet." (Relación, I, 13.) For Urrutia, see José Toribio Medina, Historia del Tribunal del Santo Oficio de la Inquisición de Lima (1569-1820) (Santiago de Chile, I887), II, 362-363.

8. Ruiz and Pavón, Prodromus, p. I2. Ruiz, Relación, I, 303, 304, 3I7, 3 I9, 365,366 .

9. Ruiz and Pavón, Prodromus, p. io.

10. Quoted from MS of Dombey's journal, p. 32, by Hamy, Dombey, p. xxvii.

11. [Gabriel Moreno], "Elogio del doctor don Cosme Bueno," Almanaque peruano y guia de forasteros (Lima, 1799), pp. [2, 7] of the elogio. Reprinted in Manuel de Odriozola (ed.), Documentos literarios del Perí (Lima, 1863-1877), III, 5-IO. 
year he took over the third-ranking chair of "method of Galen" in the University. He held this professorship until I757, when he became prima professor of mathematics and cosmography of the realm, posts which he kept until his death in 1798 . The medical society in Madrid honored him in 1768 with an associate membership. ${ }^{12}$

As the elder statesman of science in Peru, Bueno became a walking fountain of knowledge to which the mighty of both church and state turned for enlightenment. Thus in 1768 , after an investigation ordered by the viceroy, Bueno dashed the hopes of one Juan Joseph Carriel de Castro who thought he had solved two eternal puzzleshow to square the circle and how to find longitude at sea-in one simple operation. Said Bueno, to answer the first problem required a geometrician of talents superior to any the world had yet seen, and poor Carriel de Castro had "not even the slightest smattering" of the subject. If Newton, Descartes, Leibnitz, and Bernouilli had sought the answer in vain, how could this Peruvian pretender succeed? Besides, Bueno could find no possible relation between the proposed solution-achieved solely with the aid of a rope and nail to trace circles in the earth - and the question of longitude. He rightly counseled the viceroy not to waste time on such foolishness. ${ }^{13}$

In the same year of 1768 , when the government at Buenos Aires was trying to dislodge the British from the Falkland Islands, a breakdown of communications paralyzed the Spanish forces. Santiago de Cárdenas, a man "of low character, though not of low mental powers" (as Bueno described him), tried to interest the viceroy at Lima in a proposal to fly messages to and from headquarters. Bueno's judicious evaluation of the aims of "Santiago the Flyer," drafted at Viceroy Manuel de Amat's request, is one of his best efforts. Could man fly by attaching wings to his body? After all, he had learned to swim and to balance himself on a wire. Birds had been taught to say Ave Maria and elephants to shoot a cannon. Almost anything seemed possible. What, then, defied man's ingenuity?

Bueno had the answer. Displaying a sound knowledge of the anatomy of birds and fish-and of men-he concluded that man's

12. Ibid., passim.

13. Informe del cathedratico de Matematicas sobre el punto fixo, Feb. 27, 1768. MS No. 25 in a volume of miscellaneous papers of the colonial period, located in the library of the University of San Marcos (Lima). (Hereinafter San Marcos, Miscellaneous Papers.) I am indebted to Sr. Federico Schwab for the use of this volume. 
body was too dense, his muscles too weak, and his means of manipulating a tail rudder non-existent. Bueno described experiments on fish placed in pneumatic machines, demonstrating how air helped them to raise or lower themselves. But above all, he found the possibilities for destruction of humanity so immense if man should master the air, that anyone who achieved "this impossible thing ought to be thrown out of the world before he propagated an art so fatal and so pernicious." 14

In two celebrated opinions Bueno demonstrated an awareness of recent medical developments. The first, drafted in 1760 at the request of the archbishop, sought without success to determine whether the whims of pregnant women were harmful to the fetus. Citing Boerhave and Van Swieten, he mentioned the need for experiment and observation, but found himself unable to comprehend the mysteries of nature sufficiently to explain the strange phenomenon. ${ }^{15}$

Only a few months before the arrival of Ruiz and Pavón, in a second medical treatise Bueno had appraised the virtues of smallpox inoculation. Indicating familiarity with European literature on the subject, including developments in that very year, he concluded that the endorsement of inoculation by so many crowned heads of Europe was "a general and irresistible reply to all objections-experience has already decided this cause."16

Long-standing tradition dictated that the cosmographer of Peru publish a yearly Conocimiento de los tiempos, or "Knowledge of the Seasons." The oldest copy in existence dates from I 72I, though the almanac was reputedly started as early as 1680 . Basically, the Conocimiento was an astronomical ephemeris, with data on the rising and setting of the sun, the phases of the moon, eclipses, and the conjunctions of the planets, "calculated by the tables of Halley and $\mathrm{La}$

14. Bueno was aware of flights in gas-filled balloons, but dismissed them as impractical for accurate navigation because of the vagaries of air currents. ("Diserta. cion sobre el arte de volar," El conocimiento de los tiempos [Lima, 1793]. Reprinted in Odriozola, Documentos literarios, III, 261-277.) Cárdenas was immortalized by Ricardo Palma in the tradición of "Santiago Volador," and his proposal reprinted in Lima in 1937 (Nuebo Sistema de Nabegar por los aires sacado de las obserbaciones de la naturaleza volátil ....).

I 5. "Disertacion sobre los antojos de las mujeres preñadas," in Odriozola, Documentos literarios, III, $279-293$.

16. Parecer que dio el Doctor Don Cosme Bueno sobre la Representacion que hace el Padre Fray Domingo de Soria para poner en práctica la inoculacion de las Viruelas (Lima, 1778 ), esp. pp. $[21,23-24]$. Reprinted in Odriozola, Documentos literarios, IV, 258-273. 
Lande." An indispensable addition for many years was a prediction of the diseases expected during the various seasons, and a suggestion of ways to mitigate them. For the winter of 1777 we learn that "hypochondriacs will suffer much with their sorrows, manias, and apprehensions." In the spring the "sanguineous" should take the precaution to be bled. The countryside will continue to enjoy an "innocent humidity," that "will not refresh the hopes for future harvests." With a few changes in terms and techniques the same appears in the farmer's almanac of today. ${ }^{17}$

Bueno, who published the almanacs for forty-two years (I 757I 798), held no faith in astrology and began a persistent attack against it in his very first issue. His predecessor (from I 750 to I756), Juan Rer, a Jesuit mathematician from Prague, had struck an earlier blow by eliminating from the almanac "pure conjectures of very tenuous probability." Bueno flayed the pseudo-science more vigorously, and in the year the botanical expedition arrived he wrote that "the governors of the realms give birth to the happy years.... They are the true stars, by whose aspects and well-conceived maxims all is governed." 18

Of lasting benefit was Bueno's attempt to write a "Description of Peru," beginning with the issue for 1764. His predecessors had abandoned the task as hopeless, for there were no worthwhile mapsand how could a good one be made when there were no observations of latitude and longitude except along the coast, "and even of these some very doubtful"? Many of the corregidores in the provinces ignored Bueno's questionnaires or complained that no one in their jurisdiction was capable of replying. But the cosmographer did not hesitate to ask and ask again. His perseverence resulted in a series of articles, over a fifteen-year period, treating all of the immense domain that is today Peru, Bolivia, Argentina, Paraguay, Uruguay, and Chile. He concluded the "Description" in the very year that the Spanish botanists arrived in Peru, and they acknowledged his help in setting up their itinerary. ${ }^{19}$

17. For an excellent summary of the contents of these almanacs see Federico Schwab, "Los almanaques peruanos y guías de forasteros b1680?-1874," Boletín bibliográfico (Universidad Nacional Mayor de San Marcos de Lima), XIX (1948), $\mathrm{I}-48$. One of the best collections of these rare booklets may be seen in the Library of Duke University. Brown University possesses a microfilm copy of those in the Medina collection at the Biblioteca Nacional de Santiago.

18. Ibid., p. 20.

I9. Bueno with "much love and zeal protected our excursions in Lima, and 
Bueno must not have had much to do as professor of mathematics, at least in the early stages of his career. In fact, during his first nine years on the job he may not have had any students at all. But in I 766 Viceroy Amat, alarmed that Peru had suffered the "embarazo" of more than a century without a "public exercise" in mathematics, decreed that military and naval cadets, and any other interested persons, receive training in mathematics at the university. ${ }^{20}$ The supply of books and instruments was short,"1 but the first "cursantes de Matemáticas" demonstrated their proficiency to the applause of the viceroy, government officials, and the assembled professors on June II, 1768 , and received their military promotions, thus serving as a "recommendation for the greater application of the entire corps."22

gave us information to make our trips through those countries of the southern part of America." (Hipólito Ruiz and José Pavón, Suplemento a la quinologia ... [Madrid, 1801], p. 85.) Odriozola, Documentos literarios, III, II-260, contains the text of Bueno's descriptions in full. See p. 260 for comments on the difficulties Bueno encountered. A newer compilation, covering only the parts now within Peru, is Geografia del Perú virreinal (siglo XVIII), ed. Daniel Valcárcel (Lima, 1951). A recent analyst claims that Ruiz "inserted long passages from ... [Bueno] in his diaries of the expeditions through Peru and Chile"-a statement that implies a degree of direct copying not evident after one has read both texts in the original Spanish. (D. W. McPheeters, "The Distinguished Peruvian Scholar Cosme Bueno, 1711-1798," The Hispanic American Historical Rewiew, XXXV [Nov., 1955], 484-485, 49r.) But McPheeters also points out (and this seems the more pertinent observation) that Ruiz "added so much new material and reworked it so skillfully that it is really quite original."

20. Printed decree of Viceroy Amat, Feb. 21, 1766. San Marcos, Miscellaneous Papers. This document is copied in part in numerous works, including Vicente G. Quesada, La wida intelectual en la América española durante los siglos XVI, XVII, y XVIII (Buenos Aires, 1917), pp. 218-219. Federico Villareal, "Historia de las matemáticas en el Perú," Gaceta científica, III (Lima, May 31, 1887), 170, says Bueno had no students up to 1766 . However, Gabriel Moreno, who studied medicine under Bueno, was also professor of the "analytical part" of the mathematics course started by Amat (ibid., III [July 31, 1887], 236) and must have received his learning somewhere in Peru. Amat's remarks should not be construed as denying the presence of some able mathematicians in the viceroyalty during that century. Juan Ramón Koenig impressed the visiting Father Feuillée very highly in 1709: "continual application to linear geometry had made him, without contradiction, one of the most knowing geometricians in all the Indies." (Feuillée, Journal, I, 430.) Pedro Peralta's abilities as cosmographer and engineer were lauded by Father Benito Jerónimo Feijóo in his famous Teatro critico, party as the result of Peralta's services to visiting scientists such as Frézier. She chair of mathematics was Louis Godin, erstwhile member of the $\mathrm{La}$ Condamine expedition. It seems almost certain that Bueno himself learned his mathematics in Peru.

21. Ynforme el Sor $\mathrm{D}^{\mathrm{r}}$ Don Domingo de Orrantia, egecutor respectivo a la Casa de Sn. Pablo, que Libros é instrumentos Mathemáticos se hallan en ella, Lima, x 6 de julio de r 768. "Manuscritos inéditos relativos a la Universidad de San Marcos," Boletin bibliográfico, XII (1942), I19.

22. [Manuel Martínez de la Ruda, et al.], Certamen ò conclusiones Matematicas, 
Unfortunately for the development of mathematics, only the cadets forced to attend upon pain of losing their pay kept the course alive. Over fifty students had enrolled but most dropped out. A comment in $177 \mathrm{I}$ had it that "as long as the 'majors' in the other faculties did not participate with equal regularity, the course would not prove itself in a fruitful manner."23 But some students kept at the task, for, in the year Ruiz and Pavón arrived, Lázaro de Ribera, alférez of the viceroy's cavalry guard, presented his mathematical theses in a ceremonial attended by Viceroy Guirior and his wife.

Ribera's presentation is, in a sense, indicative of the colonial worldin-transition which faced the visiting botanists. The young officer, in the usual outrageously laudatory vein, spoke of his professor, Cosme Bueno, as "this great man, this rare genius, whose luster in mathematics, physics, and medicine will make his name respectable among the great names of the Newtons, Descarteses, and Boerhaaves."24 If Ribera was not ready to abandon the antiquated show of servility so characteristic of the Peru of his day, his elogio nevertheless partook of the new, for praise of Bueno was also praise of Newton and the other scientists.

Glimmerings of support for Newton-at least for the less "dangerous" aspects of his work-had appeared in Lima a decade before, but only with the I780's did the "new wave" begin to slap audibly against the creaky pilings of the old regime. ${ }^{25}$ A young professor of

defendidas en esta Real Universidad de S. Marcos, en presencia del Excmo Señor Virrey, Real Audiencia, y demas Tribunales, por..., ayudante de la Compañia de Artilleros, y Brigada del Callao: D. Pedro Ruiz, y D. Diego Machado, Cadetes de la Tropa; baxo la Instruccion, y direccion Del Doct. D. Cosme Bueno ... [Lima, June I I, I 768], p. [18]. A copy may be found in Biblioteca Nacional de Santiago (Chile) (Hereinafter BNS), Sala Americana, 14 (356-15). Sample questions (out of a total of 73): From Cuzco to the seacoast there were 20 relays of Indians to carry fresh fish to the Inca. The second relay exceeded the first, which had 40 Indians, by 16 ; and the third exceeded the second also by 16 , and so forth. How many were there in the last relay and how many Indians were employed in the haul? The room in which Atahualpa was imprisoned had a width and length of 23 varas and a diagonal of 17 . What was its width and what its length?

23. "Manuscritos inéditos relativos a la Universidad de San Marcos," Boletin bibliográfico, XII (1942), I28-129.

24. Certamen o teses Matematicas, demostradas en la Real Universidad de San Marcos... por Don Lazaro de Ribera, [Lima, I778], in BNS, Sala Americana,
im (259-8); Brown University has a microfilm copy. José Toribio Medina, La imprenta en Lima (1584-1824) (Santiago de Chile, I904-I907), III, 87, is authority for the date. Ribera's propositions included the usual run of arithmetic, algebra, and geometry, plus some practical measurement problems in trigonometry, and nine 25. In 1768 , during the first mathematics certamen in the presence of the viceroy, 
law, José Baquíjano y Carrillo, to the astonishment of his listeners, lashed out against servilismo in $178 \mathrm{I}$ at a reception for the new viceroy. His further remarks in defense of the Indian and against tyranny, at the very time when the country was endangered by the fury of the Tupac Amaru revolt, resulted in the ultimate burning of all available copies of the speech and the installation of a new system of censorship. But the censor, Fray Diego Cisneros, of the order of San Gerónimo, sympathized with the contents of many forbidden books and hesitated not at all in seeing that they were read by men of intellect. One of these men was Toribio Rodríguez de Mendoza, who in 1785 became rector of the already progressive Convictorio of San Carlos, where mathematics and some of the innovations of modern physics had been taught since the founding of the school in 1770 . He turned the Convictorio into an institution completely modern in outlook. On yet another front, in 1787 Father Isidoro Celis, of the Agonizantes, though not forgetting his obligations to divine revelation, published a course of philosophy outlining Newton's principles. ${ }^{28}$

Another precursor of the modern era in Peru, Hipólito Unanue (I 755-1833), had come to Lima from the south the year before the

a participant (probably Cosme Bueno) lauded Newton's contributions to mathematics and optics, and Leibnitz's to analytics, while also praising Euclid, Archimedes, and Ptolemy. (Certamen ò conclusiones Matematicas, defendidas ... por Manuel Martínez de la Ruda, p. [vi], in BNS, Sala Americana, 14 [356-15]; Brown University has a microfilm copy.) Earlier still, in 1765, Juan de Soto made a "very light" exposition of the systems of Descartes and Gassendi, and accepted some of Newton's conclusions. (Felipe Barreda y Laos, Vida intelectual del virreinato del Peru [and ed.; Buenos Aires, 1937], p. 301.)

26. For Baquíjano y Carrillo, see José de la Riva Agüero, "Don José Baquíjano y Carrillo," El Ateneo (Lima), VI (1905), pp. 1955-1956, I958-1959, and Medina, La imprenta en Lima, III, I 06-II 5. For Cisneros, consult Barreda y Laos, Vida intelectual, pp. 303-306, and Manuel de Mendiburu, Diccionario histórico-biográfico del Perú (2nd ed.; Lima, 1931-1934), IV, 159-166. The Convictorio of San Carlos was founded by Viceroy Amat to take the place of two colegios belonging to the banished Jesuits. In conformity with the aims of Charles III to rouse the universities out of their "decadent" Scholastic sleep, Amat provided that the students could adopt whatever philosophical system they chose. The students in examinations of 1774,1777 , and 1778 , rejected the Peripatetic principle of "ffirst matter" along with Descartes' "three elements" and the atomic theory of Gassendi, but accepted the Newtonian position on the vacuum and prismatic refraction of light. (Tomás Rivero and 16 others, Carolinum pensum trienni primi . . [Lima, April 1 5, 1774], in BNS, Sala Americana, 14 [356-15]. Theses of José de Noriega and Mariano Tristán, May 16, 1777, in BNS, 14 [259-8]. Manuel Cabello and 8 others, Pro publico totius philosophiae examine . . . [Lima, Aug. 18, 1778], in ibid.) For a detailed analysis of Celis' course, see Mercurio peruano, IX (Oct. 24 and 27 , 1793), 122-123, 125-126, 127-129. See also José Toribio Medina, Biblioteca hispano-americana (1493-1810) (Santiago de Chile, 1898-1907), V, 238-239, and Barreda y Laos, Vida intelectual, pp. 306-307. 
arrival of Ruiz and Pavón. He was to become a moving spirit of the enlightened periodical, the Mercurio peruano (I79I-I 794); founder of the anatomical amphitheater and first professor to hold demonstrations there; founder of the medical college of San Fernando; creator of a vast plan for reform of university studies adopted by I 8 I 5; student of natural history; author of The Climate of Lima, an innovative work which sought to outline a system of medicine adaptable to conditions in Peru; author of enough other treatises in the modern spirit to fill three volumes; and high government official of the new republic of Peru. Ruiz and Pavón created the genus Unanuea (=Stemodia L.) in his honor. In I 778 , at the time the botanists arrived, Unanue's future lay full ahead, just as it did for many other young men whose names would one day become famous in the cultural revolution in Peru. There were signs of impending change, but these were only faint rumblings of what was to follow. ${ }^{27}$

Although the numbers of the intelligentsia were small, Dombey delighted in their company. "The learned people," he wrote, "render me... justice and honor me with their friendship; that is enough for me!"28 He alluded to them again, still unnamed, in this fashion: "Would you believe," he asked a correspondent in France, "that in a circle of pleasant and select men who cultivate the sciences at the end of the earth, would you believe that they extol Madame du Gage [a French amateur botanist of great talent], her letters have been translated, and our Peruvians cannot believe that such a marvel exists in Europe?" 29

As a medical doctor, however, Dombey encountered opposition among fellow members of the profession in Lima." "I have excited jealousy, [and] I cannot steer clear of ambushes of some secret enemies because I do not associate with anyone." But he shrugged

27. For a good summary of the many ramifications of this intellectual upheaval, see William Pratt Dale, "The Cultural Revolution in Peru, 1750-1820," unpublished Ph.D. dissertation, Duke University, I941. Besides González Laguna, Bueno, and Unanue, the only Peruvian honored by Ruiz and Pavon with the dedication of a genus was Gabriel Moreno, a pupil of Bueno, professor of both mathematics and medicine, and successor to Bueno as editor of the yearly almanac. Ruiz and Pavón, Prodromus, p. I50, called him "very well informed in botany."

28. To Thouin, Lima, April 20, I780. Hamy, Dombey, p. 63.

29. To De la Saudraye, a distinguished amateur botanist in Paris, Lima, Sept. I I, 1778 . Ibid., p. 245.

30. A census of 1790 reported 21 doctors and 56 surgeons in Lima. (Mercurio peruano, I [Feb. 3, 1791], following p. 93.) 
them off: "These annoyances trouble me only slightly, because I know that it is the same in all societies." ${ }^{31}$

Of course, Dombey exaggerated in stating that he declined to "associate with anyone." He was referred upon arrival in Lima to Jean de Bordenave, a canon and native of the French-Pyrenees province of Béarn, who had been the constant companion of Joseph de Jussieu during that botanist's last three tragic years in Peru. When it came time for Dombey to return to Europe, Bordenave felt almost completely ignored, so many were those eager to help the French visitor. $^{32}$

\section{"ALL THAT GLITTERS..."}

To visitor and resident alike, the trademark of Lima in the colonial period was its passion for luxury-not so much in the outward aspect of its structures, for devastating earthquakes began to make that seem impractical, but in the trappings of its dress. "The riches and pomp of this city, especially on solemn festivals," reported Antonio de Ulloa, "is astonishing. The altars . . . are covered with massive silver.... The walls are hung with velvet. ... The magnificence of [Lima's] inhabitants and of its public solemnities are proportional, and displayed with a dignity peculiar to minds inflamed with a desire for honour."33 Some women wore jewelry valued at 50,000 pesos, and others had more, "according to the hierarchy of the ladies." ${ }^{34}$

Travelers in any age, while they thrill to the glamor of new surroundings, are likely to turn into first-degree faultfinders. They bring preconceptions and often a feeling of superiority, and condemn without trial the mannerisms and abilities of the local citizenry. Thus, the luxurious dress and the extravagant ways of the women appalled Ruiz: they recklessly discard expensive painted sheepskin shoes and silk stockings after scarcely a wearing; they never bother to wash their hosiery, for laundered stockings "are not good enough

31. To De la Saudraye, Lima, Sept. 1 I, 1778. Hamy, Dombey, p. 246.

32. Bordenave to Antoine de Jussieu, Lima, April 13, 1784, and April 20, $177^{8}$; Dombey to Thouin, Lima, April 19, 1778. Ibid., pp. $337-338,335,35$.

33. Ulloa, Voyage, II, 38,45 .

34. Gregorio de Cangas, "Descripción de la ciudad de Lima," Revista histórica (Lima), XIV (194I), 333. (Written 1761-1776.) 
even for the servants." One woman paid four pesos for a single large blossom, but upon reaching home found it damaged. As she had already announced her intention to display it, she immediately paid out four pesos for another. Yet, on her afternoon drive the carriage had gone but a few yards when the flower fell off, "all broken apart, which was usual." ${ }^{35}$ These complaints of a mere man have a familiar ring in whatever century!

Nevertheless, those writers in search of the "soul of Lima" usually found it, in the eighteenth century, wrapped in the charms of the feminine sex, and Dombey admitted the women were "extremely pretty and not overly clothed." ${ }^{36}$ But he announced he would not be moved:

The sweetness of their language and the art they possess of trapping their prey allow few to resist them, but as their education is very neglected, they cannot truly seduce any but the least fastidious people.

In general their commerce is not made for an honest man. ${ }^{37}$

But on the whole, it was the men who fared worst from the critical barbs of the visitors. Ruiz could not refrain from mentioning the deceitful, cowardly, and superstitious Indian, the thieving Negro, and the arrogant and drunken mulatto-all stereotypes of the period. Interbreeding of these degenerate creatures produced a physical and moral monster whose bad qualities were imitated by the whites unlucky enough to be reared in so evil an environment. Even though the "ineptitude" of the creole was "self evident," he engulfed him-

35. Relación, I, I9-20, 2 I.

36. "peu couvertes." He may possibly have meant poorly clothed or owning very few clothes, but many travelers were moved to comment on the exotic costumes of the women of all classes, whose shawls draped fully over the upper part of their bodies, but whose legs were visible up to the calf. "To Spaniards at their first coming over," confides Ulloa, "it appears extreamly indecent." (Voyage, II, 57.) The Indian satirist Concolorcorvo has his defender of Lima say in reply that, after all, the great ladies of Europe who are models of "honesty" nevertheless uncover their arms to the elbow, and their bosom "up to the point of showing the part that contains our first nourishment." (Concolorcorvo [Calixto Bustamante Carlos Inca], El lazarillo de ciegos caminantes [Gijon, 1778], p. [24] of the "Carrera quarta.")

37. To Thouin, Lima, Dec. I I, I778. Hamy, Dombey, p. 47. In this connection, note also the following, contained in the same letter (p. 46): "The great number of bachelors has brought about libertinism, promoted by the mildness of the climate, which unceasingly renews one's desires. Libertinism has made venereal disease so common that the well-springs of procreation are poisoned by it. It is opportune that the countryside and Europe renew the city, otherwise it would be depopulated. Venereal disease doesn't cause one to feel pain as in Europe; its mildness makes the inhabitants negligent of the need they ought to have to heal themselves, and no one is exempt from it." 
self in "an alternating jumble of vain and exotic thoughts that to any well considered judgment would seem to be madness." 38

One of Ruiz's stories has an especially symbolic twist. He tells of a woman who spent twenty-five pesos a day on flowers, but less than two reales for her children's bread. Her foulness lay not entirely in a misguided allotment of the family funds: she placed huge quantities of the blossoms, coated with amber and sprinkled with perfume, in clothing and furniture to kill the stale odors. The economic situation in Lima resembled the woman with the flowers-the outer trimmings hid a poverty that daily grew more severe. The dazzling display of diamonds was but a front: mules pulling the coaches ate better than countless señoras. Were it not for the soup offered at religious houses, many people would starve. Ruiz concluded his exercise in hyperbole by reporting that the whites wished they had been born slaves, for the latter had no worries about food, clothing, or housing. ${ }^{39}$

Great political and economic changes were indeed taking place in Peru. In 1776 the new viceroyalty of $\mathrm{La}$ Plata began to function from its capital at Buenos Aires, and with it went a huge area formerly under the government in Lima. Two years later the king broke the legal monopoly of the merchants of Lima by opening other ports to commerce. This no doubt helped foster the welfare of both crown and people, but the traders of Lima wailed loudly. Economic conditions had been unstable for years. Agriculture was decaying. The mines were neglected. Large numbers of unemployed roamed the streets for lack of manufactories, or because they refused to lower themselves to learn a trade. The botanist from Spain, with his built-

38. Relacion, I, 17-18. Castigation of the Spaniard born in America was a favorite pastime of the foreign traveler. A visiting German mining expert, Anton $\mathrm{Z}$. Helms, wrote of the creole in La Plata province (1789): "Though born with a genius capable of attaining whatever ennobles humanity; yet, from an education in the highest degree neglected, he becomes lazy, licentious, and indelicate in his conversation; a hypocrite, and infected with a blind and malignant fanaticism; ... through his inordinate love of pleasure he is . . . enslaved by his mulatto and black females, who rule him with a despotic sway." (Travels from Buenos Ayres, by Potosi, to Lima [London, 1807], pp. 15-16.) A census of 1790 showed the secular population in Lima to be divided as follows:

Spaniards (including creoles) 17,215 Quadroons

Indians

Mestizos

3,912

Quintroons

2,383

Negroes

4,631

Zambos (Negro-Mulatto)

219

3,384

Mulattoes

8,960

5,972

(Mercurio peruano, I [Feb. 3, 179I], following p. 93.)
39. Relación, I, 2 I, 24, 25.

Chinos (Negro-Indian)

I, 120

47,796 
in sense of supremacy, laid part of the blame on a mixing of racesthe mestizo's performance on the job was unavoidably inferior. Furthermore, women had no occupation to turn to, now that Spanish lace was replacing a locally made product. The scarcity of foodstuffs and other necessities of life made prices insufferable. "In short," said Ruiz, "the causes of poverty in Lima are infinite, and perhaps only a viceroy with extraordinary zeal could remedy them." 40

With all its faults, Lima remained a city of charm. Colonel of Militia Don Gregorio de Cangas must have felt its spell when he wrote the following, only a few years before Ruiz and Pavón arrived, though he does not agree with the botanists in every detail:

The most notable privileges of the city of Lima, that one can scarcely find in the other hemisphere, are the exceeding kindness to the stranger; the confidence in commerce; the beauty and grace of the ladies; their diminutive feet; the length and abundance of their hair; the benevolent climate; the bakeries; the variety, taste, and fragrance of the fruits; the ostentation of the costly clothing and the extravagant styles of the women; the lofty state of mental faculties; the earthquakes; ... the bronze foundries; the weakness of the buildings from the foundations upward; the multitude of domestics for the ordinary service of a house; the easy gainful placement of the youths; the frankness and sincerity of communication. ${ }^{41}$

Even the botanists qualified their denunciations. Ruiz admitted there were many illustrious families who watched carefully over the training of their children, "in whom one sees models of the most exact politeness, decorum, and virtue transmitted to their noble descendants." ${ }^{2}$ Dombey likewise spoke with pleasure of the generosity of the grands of both Spain and Peru. ${ }^{43}$

When, months later-or years later-the scientists sweltered in their lonely jungle camp, or faced death on some rocky Andean precipice, one is tempted to believe that they now and then longed to enjoy anew the blissful days and the easy life of the City of Kings. Perhaps they might even have been diverted then by a cock fight, a corrida in the Acho bull ring, a performance of the Italian comedy troupe, or a chance in the new lottery-those symbols of indolence or

40. See Guillermo Céspedes, "Lima y Buenos Aires: repercusiones económicas y políticas de la creación del virreinato del Plata," Anuario de estudios americanos, III (Seville, 1946), 667-874. Ruiz, Relación, I, 25-26.

41. "Descripción de Lima," Revista histórica, XIV, 331-332.

42. Relación, I, 18.

43. To Thouin, Concepción, Dec. 24, 1782. Hamy, Dombey, p. 96. 
vice they so readily flayed on the written page. Yes, and perhaps they sighed for a view of the well-turned calf of a Peruvian lady of quality or looked forward to a chat in the new coffee house with one of that "circle of pleasant and select men who cultivate the sciences at the end of the earth." For even at the end of the earth all was not darkness. 


\title{
THE GENTLE YEAR
}

\author{
ORIENTATION IN THE WAYS OF \\ PLANTS AND MEN
}

The startled villagers in the oceanside towns of Bellavista and Miraflores, and the poor folk clinging to the slopes of San Cristóbal hill-indeed, all whose homes lay close beyond the walls of the capital city-had a new topic of conversation early in May of 1778 . Brujos yerbateros-herb-gathering witch doctors, no less--were at work! Even some of the more worldly citizens were bewildered by the sight of the botanists in action: "People are astonished to see us, sent by two great monarchs, carrying plants and crossing the fields on foot; they haven't waited long to despise us! Without carriages, without servants, we are poor people!"”

To the erudite, the visiting scientists were not sorcerers but sexualistas: the first to define and describe the Peruvian flora according to Linnaean principles of sexual classification. As innovators, the botanists had no alternative but to study nearly every one of the thousands of species they were certain to find. Naturally, the crown sought knowledge of plants and trees little-known in Europe and believed to be valuable to medicine, commerce, or the arts. What uses for them had the Indians and "inteligentes" found? In what sort of climate did they flourish? Might they be propagated in Spain itself? What temperatures would keep the specimens alive in the proposed heaters at the royal botanic garden in Madrid? No doubt the men would find many other plants and trees whose value was already known. That was no reason for passing them by; Ruiz and Pavón were the first who could provide genuine botanical information about them. They could neglect only those everyday specimens offering

I. Dombey to Thouin, Lima, Dec. II, I778. Hamy, Dombey, p. 48. Ruiz, Relación, I, 3. Fellow passengers of the botanists on El Peruano, dreaming of fortunes to be made in America, also considered them imbeciles. (Dombey to Thouin, Cádiz, Oct. 16, 1777. Hamy, Dombey, p. 3o.) 
no novelty to the European eye-though not without noting their existence.

The botanists of course had orders to collect species in the form of seeds and dried plant specimens mounted on paper (herbaria), but Ruiz and Pavón must also try to send living plants, bulbs, shoots, and grassy sod back to Spain. These would be propagated in Madrid for the botanists to study more closely upon their return; meanwhile, the staff at the royal garden would try to adapt them to the soil and climate of Spain. Finally, as insurance against loss, the scientists must also propagate in Peru additional plants of the rarest and most valuable species. ${ }^{2}$

"Orientation"-in the principles of plant study and the mannerisms of temperamental men-lasted from May 4 to July 22, r778. It was a time for differences in provenience and personality to reveal themselves, perhaps even more readily than differences in the structure of plants. It was also a time for the somberness of winter to settle firmly over the city. The gentle mist called garúa dampened the streets and byways, and brought a chill to the bones. But in the countryside, with the end of the summer drought, it was time for the annual wildflower spectacle to begin.

Visitors never cease to thrill to the floral displays of the beautiful city of Lima. Irrigation produces the most exciting ones, for true rain is almost unknown. But the garúa creates its own charming scenes, as on San Juan's day (June 24) in the Paseo de Amancaes. Then, as today so in centuries past, the limeños crossed the River Rímac to glory in the panorama of golden flowers coming into bloom on the hillsides east of the city. In a burst of fervor on this festive occasion, Dombey named a plant worn in the hair of the women celebrants Dugagesia verticillata, in honor of Madame la marquise du Gage de Pommereuil, the feminine amateur botanist he so much admired. ${ }^{3}$

But the spirit of Amancaes was dimmed for Dombey by the rigid stand of his Spanish companions. Establishing a precedent probably designed to minimize the value of his publications, the Spaniards re-

2. Instrucción (I776). Ruiz, Relación, I, 395-396, 399.

3. He later discovered it to be, not a new genus, but a species of pepper, and was forced to find a substitute with which to render homage to Madame du Gage. (Dombey to Thouin, Lima, Dec. 11, 1778, and April 20, 1780. Hamy, Dombey, pp. 40,60.) The two principal performers in the display of Amancaes were Narcissus odorus ("Amancaes") and Begonia tuberosa ("Little flower of San Juan"). (Ruiz, Relación, I, 30, 34.) 
fused to give him even one drawing of the plant to send to Madame du Gage. ${ }^{4}$ Dombey's old friend André Thouin, chief gardener at the Jardin du Roi, also had to do without. Dombey wrote him: "You would never imagine the regret I feel in not being able to send you at least the sketches of the plants I dedicate to you." "5

Mutual feelings of distrust and disquiet had begun to develop before the party left Spain. There was, of course, the fear that Dombey would dominate. On the surface, however, Casimiro Gómez Ortega, organizer of the expedition, was a model of cordiality. Concerning Dombey, the Spanish professor once wrote to Thouin: "The more I know him the more I esteem him." ${ }^{6}$ Dombey was made a correspondent of the Academia de Medicina in Madrid. But the Frenchman was convinced, though his grounds are never made clear, that beneath this outward good fellowship lay a feeling of mistrust. "Because the good of my voyage demands it," Dombey wrote Thouin, "I thank him [Gómez Ortega] . . . every day for his good intentions on my behalf." But Dombey was "not able to think well of him, even though he embraces me daily." He described Ortega's actions as "roguish tricks (espiégleries) but explained them only to this degree:

Without that jealousy for which persons following the same career ought to be condemned, $M$. Ortega would be a very estimable man. His diligence and the esteem he enjoys in this country [Spain], and which he deserves for his labors, are sufficient. It would be much more to his glory if he abandoned the Machiavellian tricks that debase great men which he learned at Bologna. ${ }^{7}$

To protect himself, Dombey began to acquire certificates from prominent public officials wherever he went, confirming his good behavior and acknowledging special services which he had performed. ${ }^{8}$

One inkling of Dombey's concern over friction with the Spanish botanists-his "indolent companions," his journal called them ${ }^{9}$-ex-

4. Dombey to Thouin, Cádiz, March 15, 1785. Hamy, Dombey, p. I39.

5. From Lima, Dec. I1, 1778 . Ibid., pp. 43-44.

6. Letter from Madrid [April], 1777. See also letters of Feb. I7 and March 3. I777. Ibid., pp. 327-328.

7. To Thouin, Madrid, March 31 and Aug. 25, I777; to De Jussieu, Madrid, Aug. 25, 1777. Ibid., pp. 13, 26-27, 231.

8. Dombey to Thouin, on board El Peruano, Oct. 28, 1777. Ibid., p. 33. For the text of twenty such documents see ibid., pp. 397-4II. It should be noted, however, that this was a common practice; Pavón also possessed numerous testimonials. (Barreiro, Don José Antonio Pavón, p. 7.)

9. Quoted in Hamy, Dombey, p. xxxii. 
posed itself in his first days in Lima. The French canon Jean de Bordenave had offered lodging to Dombey at the colegio where he presided, an enticing proposal for the newcomer, who claimed always to be short of funds. But Dombey refused, fearing, as he put it, that the botanical work would languish for lack of communication with the other members of the party: he preferred to live in the same house and eat at the same table for the good of the expedition. ${ }^{10}$

Despite his personal feelings, Dombey eagerly sought to preserve good relations with his Spanish superiors. Thus, for Viceroy Manuel de Guirior he named Guirriora rivularis, found outside the walls of Lima. "You know," he wrote Thouin, "that one must protect himself and this is the way to do it." To José de Gálvez, Minister of the Indies, he joined with Ruiz and Pavón in dedicating Galvezia limensis, a plant with leaves like those of the myrtle, bedecked with scarlet flowers. With the genus Casimiria, the French botanist even rewarded Casimiro Gómez Ortega, "whose friendship I have not renounced, in spite of his ill will toward me. [He] has received the tribute his talents deserve; this will be the only vengeance I extract from him."11 Perhaps it was poetic justice that Dombey later learned that Casimiria, one of the spectacular performers at the festival of Amancaes, was in reality a begonia, already classified by Linnaeus. ${ }^{12}$

\section{TO NORTH, TO SOUTH}

With orientation over, the party on July 22, I 778 , cautiously dipped its toes into the stream of plant life outside the metropolis, and found it at first but a trickle. Their initial destination was Arnedo, commonly called Chancay, the closest settlement to the north of at least a modest size. The intervening forty miles of rock and sand, so typical of the Peruvian coastline, scarcely seemed encouraging.

On this first leg of the journey, thieves outdid nature in providing excitement for the travelers. Loaded down as they were with

10. Dombey to Thouin, Lima, April 19, 1778. Ibid., pp. 34-36.

11. Dombey to Thouin, Lima, Dec. I1, 1778. Ibid., pp. 39-40. Dombey's dedication to Guirior is not recorded today in the Index Kewensis, but there is Guirriora punctata named by Ruiz and Pavón. Ruiz and Pavón announced their dedication to José de Gálvez by letter from Lima, July 5, I778. MCN.

12. Dombey to De Jussieu, Lima, April 20, 1779. Hamy, Dombey, pp. 253254. See also ibid., p. xxx. 
three months' pay in advance, the men of the expedition must have seemed ideal victims to a local badman named Uracan. Shortly after dark on July 23 , he and two Negro women rode up to the Tambo de Copacabana, where the botanists were bedding down for the night. The bandit apparently expected little trouble in drawing lodginghouse employees into the plot. In some fashion, however, the botanists were warned in the nick of time, and Uracan, whose Indian name coincidentally resembled the Spanish word for "hurricane," was reduced to a mild zephyr with two pistols leveled at his chest. The women hurried off to warn other accomplices but the majordomo of a local hacienda felled one of their horses with a well-placed shot. They surrendered readily and, with Uracan's help, soon exposed the extensive nature of the conspiracy.

The scientists took posts at the door of the tambo to await the approach of four more unsuspecting bandits. Their patience was rewarded about nine o'clock. When the intruders refused to answer a sentry's query, the guard (Dombey says it was he) opened fire. One of the thieves fell to the ground, mortally wounded, and the others fled into the darkness.

National bias raises its head in the conflicting versions of the aftermath. Dombey was astounded to note that, when the botanists returned to Lima, the authorities undertook no inquiry. He speculated that, if the thieves had killed the scientists, official inaction would have been the same. According to Ruiz, however, the ringleader was banished to Valdivia, Chile, and the Negro women sent back to their masters. But the three thieves who escaped in the melee were never apprehended. ${ }^{13}$

The botanists found respite in the pleasant surroundings of the Arnedo Valley. To the traveler, nearly all of coastal Peru appears a barren waste, and indeed only where the rivers swoop suddenly down from the Andes can agriculture be supported. Arnedo's lifestream was the Pasamayo River. Along its banks were the grain fields, the fruit and vegetable holdings, and the pasture lands of the wealthy hacendados, who spent most of their time in the capital. One obliging landowner, Don Toribio Bravo de Castilla, acted as host to the scientists from July 24 to the end of August, I 778 . Ruiz referred to him as a "gentleman of the most distinguished nobility of Lima" I, 36-37.

13. Dombey to Thouin, Lima, Dec. 11, I778. Ibid., pp. 44-45. Ruiz, Relación, 
and "our well-wisher and addict of botany." He not only accompanied the plant hunters in Chancay, but even in Lima on the hills of Amancaes, where he gathered specimens and dried them himself. ${ }^{14}$

In September the botanists began the next lap of the journeyanother fifty miles to the north - to the sugar-cane fields of Huaura. Despite the seeming sterility of the desert, the winter mists had manufactured a treasure house of plants. Only in this season, and in the "meadows on the desert" called lomas, where September fogs hung low over coastal hillside and plain, could a botanist here earn his keep. Between Chancay and Huaura the party found some forty species. ${ }^{15}$

By October 22, 1778, they were back in Lima, putting their collections in order and preparing for an outing that promised pure pleasure. They would go only twenty miles south, to the summer resorts of the elite at Lurín, and to the Indian ruins of Pachacamac. For months on end winter's gloom had denied the sun even a moment of glory. The mists had yielded their floral harvest, but had wrought a sadness in the hearts of men. Now, it was December and sunshine ruled. Ruiz glowed with delight when he thought of Lurin: of the flowers along the ubiquitous quimchas, or reed garden fences, and of the frondage that made every walk a delight. ${ }^{16}$

Dombey found pleasure in the archeological storehouse of Pachacamac. This cluster of pyramids and temples had been the sacred city of a pre-Inca society, dating back to A.D. 600-900. Its central feature was a huge terraced structure, I 80 by 400 feet at the base, dedicated to the Supreme Creator. After the inhabitants were conquered by the Incas in the fifteenth century, a massive Temple to the Sun was erected, but time and neglect had destroyed the external magnificence of Pachacamac long before Dombey's arrival. In the dry climate, however, the ancient cemetery of pilgrims of high caste still preserved many priceless relics.

An urge to collect these things had, in Lima and Huaura, already eaten into Dombey's heart. In fact, three of the first seven boxes he remitted to Europe were filled with Indian vases and other antiquities.

17. Ruiz, Relación, I, 37, 43, 194, 198.

15. Ibid., I, 40. For a vivid picture of a modern botanist's experience with the lomas, see T. Harper Goodspeed, Plant Hunters in the Andes (New York, 1941), p. 24: "in the midst of this rainless desert, I walked through fields of filmy-leaved flowering plants in water-soaked boots and with clothing wet by the dew from a mantle of delicate vegetation. ..."

16. Relación, I, 50. 
Among the prize objects Dombey earmarked for Louis XVI was a so-called vestidura del Inca, for which the botanist confessed he paid nearly seven hundred pesos-seven months' salary! There is little possibility this costly poncho had ever graced the wardrobe of the Inca himself. Rather, it had apparently been removed from the tomb of a wealthy personage at Pachacamac and, so Dombey claims, preserved by a noble Indian family in Lima for over a century, as "an ancient mark of a power that exists no more." Dombey was not an expert in these matters, but his interest in native relics far surpassed that of the casual tourist of his day. ${ }^{17}$

When the expedition returned to Lima on March 6, I779, after spending a month on the outskirts at the home of an oidor in Surco, it was time to make the first remissions to Europe. The Buen Consejo was due to sail April 3. But meanwhile Dombey had been dispatched to the mountains by the viceroy to analyze certain mineral waters, ${ }^{18}$ so Ruiz and Pavón assumed the duties of packing.

All told, they loaded seventeen cases on the vessel, ten for the account of the Spaniards and seven for Dombey. Of the Spanish contributions, three boxes contained dried plants (approximately 275 different plants of I 80 genera) $;^{19}$ one box contained bulbs, roots, and fruits, and another held the collection of seeds (these two cases represented samples from about i 60 plants). A sixth case was made up of miscellaneous "natural curiosities." men put a smaller box holding 242 drawings "illuminated in their

I7. The items he shipped to Europe included numerous pottery vessels, shaped in the images of animals and men performing every conceivable act-a unique and valuable means for reading the social history of these peoples. There were also ornately carved wooden staffs of command, netting needles, and spindles; gold, silver, and copper instruments and statuettes; stone utensils; and a wooden balance arm, which was one of Dombey's most important finds. See Hamy, Dombey, pp. xxxiv-xxxv, xxxviii, xliii-xlviii, liv-lv; also Dombey to Thouin, Lima, Dec. I I, 1778, and Cádiz, March 1, 1785, and Dombey to D'Angeviller, Lima, Dec. 20, 1778. Ibid., pp. 41-43, I17, 247-248.

18. See pp. 97-98, below.

19. It is difficult to get an exact count from the list furnished the Spanish government by Ruiz (Relación, I, 431-433), but since Dombey sent 284 different plants, the estimate for the Spaniards is no doubt reasonably accurate. Wherever possible, some 6 to 12 specimens of each plant were enclosed, all arranged by class. A description of nearly all plants was also included. (Ibid., I, 434.)

20. More specifically "a sack of amethyst stones-a stone in which others are formed-a packet of coquitos [the fruit of a species of palm, the size of a plum] from Guayaquil-various litile shells-a little basket with 4 hummingbirds-a little puppy formed in a mine by nature-four armadillos-two little huaqueros [pitchers] - a small box with fragments from mines-two bags of round stones which serve as bullets-two marine plants." (Ibid., I, 434.) 
natural colors." The balance of the Spanish remissions comprised living plants divided between two heated containers (estufas) and two boxes open to the air, filled with 94 samples of 24 different species, plus three bulbs and some planted seeds. ${ }^{21}$

Dombey looked hopefully but dubiously at the idea of shipping live plants. The six months' voyage without care of anyone who knew or wanted to know about them, the bad weather in rounding the Horn, the shortage of fresh water-all were obvious indications that only the greatest luck would bring living plants to Europe. But Ruiz and Pavón were merely following instructions, given them long before, to imitate the English in this matter. Thus Ruiz was to give the commandant of embarkation a copy of the proper procedure so the specimens could be shepherded with all due care. ${ }^{22}$

Dombey's own remissions were made up as follows: three boxes containing principally archeological finds; two of botanical objects, including seeds and his herbarium of 284 plants; and two cases of minerals, among which were 38 pounds of platinum and samples of silver and mercury. He also sent a tin of supposed saltpeter to be chemically analyzed in Spain. But, for fear of loss at sea, the Frenchman saved out, when he could, duplicates of plants and minerals. In most cases this was simple, for he had tried to collect a dozen specimens of each plant. ${ }^{23}$

$$
\text { * * * } \quad *
$$

Almost one full year had elapsed since the members of the expedition first set foot in the viceroyalty. They had no doubt learned a lot

2 1. Ibid., I, 6r, 430-442.

22. Instrucción (1776). Ibid., I, 399. Dombey to Thouin, Lima, Dec. I 1, I 778 , and April 20, 1779. Hamy, Dombey, pp. 43, 51. Casimiro Gómez Ortega published a 70-page statement in 1779 on the means of transporting living plants over long distances, which indeed demanded much of the ship captains in whose care the plants would be deposited. (Instruccion sobre el modo mas seguro y económico de transportar plantas vivas por mar y tierra á los paises mas distantes [Madrid, 1779]. AGI, Indiferente General, legajo I544.) See Cameron, Sir Joseph Banks, pp. 65-66, for evidence of the extreme precautions taken by Banks in the transmission of living breadfruit trees from the South Seas in 1787 .

23. Dombey to Thouin, Lima, Dec. I1, 1778, April 20, 1779, and April 20, 1780. Inventaires des Collections de Joseph Dombey. Hamy, Dombey, pp. 49, 50-52, 55-56, 423-425. Ruiz, Relación, I, 439. Among Dombey's remissions was a good supply of quinoa grains, so widely used to make flour in Peru. Dombey was enthusiastic about using quinoa as a substitute for rice in France and pointed out that the temperature in which the quinoa flourished was like that of springtime in Paris. He was also intrigued by the means the Indians had devised for preserving potatoes (chuño) and thought it might help to solve the periodic shortages in France. (Hamy, Dombey, pp. 42, 52, 201-202.) 
about botany and more about each other, but in no wise, by eighteenth-century standards, could they be described as "roughing it." They had hardly left sight of the sea; they had found comparatively few "new" plants, they had seen none of the true wonderlands of Peru. Once they had talked of moving to Quito. That idea must now be shelved for a time, for hidden in Peru beyond Andean peaks was an untouched tropical forest begging for attention. Mountain cloudbursts began always to abate in April. It was time for adventure; there was no cause for delay. But before following the botanists into the Andes, some words on the varied pursuits of Joseph Dombey may help counteract a judgment that science had fallen complete victim to the temptations of life during one year in the "white man's Peru." 


\section{THE SCIENTIFIC QUESTS}

\section{OF JOSEPH DOMBEY}

\section{SHOPPER BY PROXY}

French stay-at-home scientists and experimenters thought of Joseph Dombey as a most useful man. His eighteenth-century outlook encompassed all of nature. Though by profession a physician and botanist, he felt no qualms when called upon, for instance, to make a chemical analysis. But more important than his inferred allaround capabilities was the mere fact that he could spend four years in South America. Europe was so far away, the hazards of travel so many, and the governmental restrictions so burdensome, that few scientifically-minded foreigners ever had such an opportunity. It is no wonder, then, that Dombey came to Peru armed with a "shopping list" of things to do and see and buy for his friends in science who could share his experience only vicariously.

At the head of his list, of course, was a reminder to hunt for manuscripts left by Joseph de Jussieu. Dombey had scarcely arrived in Lima when he had news to report. A certain Martin Delgard had been custodian of some of De Jussieu's books and papers, and at his death they fell to the care of his daughter. Meantime, a French surgeon named Jacques Lagrange had come to Lima with letters of recommendation to Delgard, and, learning of his death, lodged with the daughter, all the while using the books. In Dombey's version of the story, when the jealous husband of Mlle Delgard took exception to the presence of the stranger, Lagrange departed for Europe, taking the books and papers with him. But in actual fact, Lagrange had been denounced to the Inquisition in November, I773, for saying that he was a freemason. The Holy Office sought to send him to prison, but the viceroy intervened to dispatch him to Spain because of crimes he had committed, unrelated to the Faith. After confinement for a 
time at Cádiz he was set free, and took a post as physician to some comic actors en route to Peru, when he was again apprehended by the Inquisition. Dombey was under the impression that Lagrange had died at sea off the Chilean coast, and that his vessel had been forced to return to Peru. Thus the French botanist still held hopesalbeit faint-of finding some of the materials. ${ }^{1}$ Over two years later he located "three little manuscripts," but, he added ruefully, "If I had arrived earlier in Lima, I would have been able to collect plenty of rough drafts of his works."'

As a guide to further pursuits, Dombey had asked the aging natural historian and specialist in antiquities, Jean François Séguier, to draw up a series of suggestions. The elder statesman of science urged him to study the nature and composition of the mountains, and find out all he could about the production of gold, silver, and quicksilver, not to mention iron, tin, lead, and copper. Why, asked Séguier, were those regions of America so abundant in precious metals? What surface appearances might give a clue to similar deposits elsewhere? Was it true that mines existed where the earth gave off a peculiar odor-perhaps an indication of the degree of richness of the ores? Could there possibly be any diamonds in Peru like those found in Brazil? Was there petrified wood to reveal secrets of the early geologic history of the region? Séguier advised Dombey on how to preserve animals and insects, and urged him to study the relationship of the contemporary Indians to the ancient inhabitants of the country. Finally, as a numismatist, he asked Dombey to find samples of preColumbian money in metal or shell. ${ }^{3}$

\section{THE UNVIRTUOUS CINNAMON}

Dombey entered on one project even before leaving Spain: a study of the so-called American cinnamon. The Spaniards for over

I. Dombey to A. de Jussieu, Lima, April 20, I778. Hamy, Dombey, pp. 241242. Medina, Historia . . de la Inquisición de Lima, II, 362-363, 367.

2. To A. de Jussieu, Lima, Nov. 2, 1781. Hamy, Dombey, p. 262.

3. Instructions que Séguier envoie à Dombey ..... Ibid., pp. 318-323. Dombey also received instructions and advice from Marc Antoine Louis de La Tourette, voyager and councilor of the mint; Jean Louis Rast de Maupas, agronomist; Albert de Haller, Swiss naturalist; Honoré Léonard Jean Baptiste Bertin, minister and patron of the sciences; the Abbé Jean Rozier, agronomist and collaborator of $\mathrm{La}$ Tourette; Joseph Jérome le François de Lalande, the celebrated astronomer, and several others. (Dombey to Thouin, Madrid, Aug. 25, 1777. Ibid., p. 27.) 
two centuries had clung to the hope that the trees found by Gonzalo Pizarro in 1540 in the audiencia of Quito would relieve them of dependence for this valuable spice on the onetime Portuguese, and now Dutch, colony of Ceylon. Just how valuable it was may be seen in this estimate, made in 1780 for the Real Sociedad Económica de Madrid: In Spain itself, a half-pound of cinnamon for every one of the million batches of chocolate ground during the year amounted to 500,000 pounds; other uses, in medicine or as seasoning, took IOO,OOO; in Spanish America annual consumption possibly reached another 600,000 pounds. Excepting some poor grade bark from the Philippines, the Dutch got a peso for every pound consumed. ${ }^{4}$

From the very first, the Spanish noted a significant difference between the trees of the two hemispheres: "The vertue, sweet smell, and taste, is in the fruite [of the tree of Quito], which is contrarie to the Sinamon, that is brought from the Orientall Indias, for onely in the rinde of the Tree is that which hath the sweet savour and pleasaunt smell." Early reports had it that the taste of the two varieties was equal, though that of the American product perhaps not so long-lasting, ${ }^{6}$ but further experience demonstrated that the cinnamon of Quito had a bitterness that limited its usability.

The idea of forsaking the development of cinnamon groves nevertheless died hard. Pedro de Maldonado, the enlightened governor of Esmeraldas province in the audiencia of Quito, who had worked closely with $\mathrm{La}$ Condamine and the earth-measuring expedition, discussed the matter with Bernard de Jussieu in Paris in 1746. Maldonado died in 1748 and his plan for cultivation lapsed, but shortly before the Ruiz-Pavón venture came into being, the president of Quito reopened the problem by sending samples to Spain for examination by Gómez Ortega and the king's apothecaries. The chief botanist seemed optimistic, for he appended to the list of instructions for the expedition to Peru a provision that they study both trees and terrain "in order that they might meditate on all those means that could be had to sweeten [the cinnamon], and if possible to make it as good as that of Ceylon." "7

4. Francisco Dionisio Fernández Molinillo to "Señores de la Clase de Agricultura" of the Real Sociedad Económica de Madrid, Madrid, Jan. 25, 1780, fols. [9-1o]. Biblioteca Real Palacio (Madrid), signatura 2512, Papeles Varios, Vol. V, document 24.

5. Monardes, Joyfull Neques, II, 4.

6. Oviedo, Historia general, lib. IX, cap. XXXI.

7. Dombey to Thouin, Madrid, Feb. 24, 1777. Gálvez to the members of the 
Even as the botanists were sailing to America the Real Sociedad Económica de Madrid began to investigate new samples from Quito. Two merchants, who claimed forty years' experience in the cinnamon trade, found the specimens of almost no use, and worth not even onefifth peso a pound. ${ }^{8}$ This approach, however, did not answer the question of where to lay the blame. Gómez Ortega felt that any "inteligente" could see he was dealing with the true cinnamon. The taste was fundamentally the same; the odor was the same; the essential oil had the same properties. The trouble, then, was twofold: ( I) poor shipping conditions, whereby the bark became too moist and took too long to reach Spain; and (2) poor conditions of production, in which the trees, growing wild in dense forests, had no chance to get needed sunshine and air. ${ }^{9}$ As a result of Ortega's judgment, the society undertook to suggest means of encouraging cultivation and perhaps of planting groves in areas more easily accessible to Spain. ${ }^{10}$

Dombey's eagerness to study the problem arose at an early date, when Bernard de Jussieu told him of Maldonado's plans for cultivating the trees. While waiting for the expedition to start, Dombey gathered all the data he could find in France and Spain. Then, as soon as he arrived in South America, he solicited cuttings from Quito and Bogotá.

The French botanist, however, met the same blank wall as all of his predecessors. His samples proved to be Laurus indica of Linnaeus and not Cinnamomum zeylandicum of the Dutch. ${ }^{11}$ Dombey sent a number of cuttings to José de Gálvez in Spain, telling him that some profit might possibly be derived from the calyxes. But the Spanish government, he cautioned, should not expect that cultivation of the tree would ever lead to a commerce in cinnamon such as the Dutch enjoyed. The tree was of a different species. Further to convince the minister, Dombey asked his friend Thouin to send Gálvez some leaves of the Dutch variety out of his herbarium. "It is useful and

expedition, El Pardo, Feb. 15, 1777. Hamy, Dombey, pp. 9-10. Suplemento que Don Casimiro Gómez-Ortega cree se puede añadir a la instrucción. Ruiz, Relación, I, 402 .

8. Joseph Melchor de Urquijo (and a second person named Heros) to Joseph de Guevara Vasconcelos of the Real Sociedad Económica de Madrid, Madrid, March 31, 1778. Biblioteca Real Palacio, signatura 2512, Papeles Varios, Vol. V, document 24.

9. Gómez Ortega to Guevara Vasconcelos, Madrid, March 21, 1778. Ibid.

I o. Fernández Molinillo to "Clase de Agricultura," Madrid, Jan. 25, I780. Ibid.

11. Nicolás Monardes had commented in 1571 that the tree had a leaf "like to Laurell." (Joyfull Newes, II, 3.) 
of interest," he wrote, "to do away with all doubt on a thing of such importance so that the Spanish government knows what it has, when some private parties would like to undertake a business that would be costly and useless to the state."12

\section{IN PURSUIT OF PLATINUM}

Another item on Dombey's list was the reminder to collect platinum. This metal may have been known to the ancients (though probably not as a separate body), for it occurs in many alluvial beds mixed with grains of gold. Its high melting point, however, would have made it difficult to work and it seems to have been neglected entirely until the eighteenth century. In fact, the first certain published reference to it occurs in Antonio de Ulloa's Voyage to South America, which appeared originally in $\mathbf{1} 748 .^{13}$ Ulloa tells how gold mines had been abandoned "on account of the platina [presumably a derogatory diminutive of plata, or silver]; a substance of such resistance, that, when struck on an anvil of steel, it is not easy to be separated; nor is it calcinable; so that the metal, inclosed within this obdurate body, could not be extracted without infinite labour and charge."14

Shortly after mid-century, European chemists-Englishmen, Swedes, Germans, Frenchmen, and the Irish mineralogist in Spain, William Bowles-began to experiment and to publish papers on the new metal. In 1758 it was at last partially melted by French scientists with the aid of a powerful burning glass. Then in 1772 it proved to be soluble in nitric acid when alloyed with a large quantity of silver, and from that time on experiments multiplied rapidly. ${ }^{15}$

12. Letters from Madrid, Feb. 24, 1777, and Lima, April 20, 1780. Hamy, Dombey, pp. 10-11, 58-59. It will be recalled that José Celestino Mutis proposed in 1764 to do away with "the mistake that some have suffered" in believing the cinnamon of Quito to be the same as that of Ceylon. See p. 45 , above.

13. James Lewis Howe, Bibliography of Metals of the Platinum Group (Washington, D. C., I 897), p. I1. T. Kirke Rose, The Precious Metals, Comprising Gold, Silver, and Platinum (London, 1909), p. 254. Julius Caesar Scaliger or della Scala in his Exotericarum exercitationum liber quintus decimus (Paris, 1557) refers to an unknown mineral from "Honduras" which could not be melted "by fire or by any of the Spanish arts." See Donald McDonald, A History of Platinum from the Earliest Times to the Eighteen-Eighties (London, 1960), p. 3.

14. Voyage, I, 471 .

I 5. McDonald, History of Platinum, pp. 23-57. Rose, Precious Metals, p. 255. 
The world of science was dependent upon Spanish co-operation, for until I 824 the only readily available source of platinum was South America, principally alluvial deposits in the province of Choco, in what is now Colombia. ${ }^{16}$ Gómez Ortega fortunately recognized the value of experimentation and got permission to send quantities to a number of foreign metallurgists. He thus took satisfaction in the announcement by the Comte de Milly to the Académie des Sciences on June 23, I 779, of the Count's new method of making the metal ductile. Milly displayed pridefully a platinum snuff box rimmed with gold, and a small painting, done with colors originating in the "saline-metallic" parts of platinum, whose aliveness, even after exposure to the summer sun, gave it "the air of a Rembrandt."17 It was Ortega's pleasure to point out his own share as a promoter of the new development, in presenting the snuff box to Minister of the Indies Gálvez. ${ }^{18}$

Dombey benefited from this era of good will by receiving permission, while still in Spain, to send twenty pounds of platinum to France. By April, I 779, however, he had accumulated thirty-eight pounds and began to feel uneasy when he sent it on the Buen Consejo with his first shipment of plants. For sixteen pounds he had traded four pairs of linen sheets from Holland and twelve shirts, which he considered an excellent bargain. On another occasion he speaks of having to secure it sub rosa and the cost ran accordingly high. ${ }^{19}$

Dombey's difficulties were the product of an inner conflict in Spanish policy. Jewelers had discovered that they could alloy plati-

16. Platinum was found in the Ural Mountains in 1819 and within a few years Russia became the top producer in the world. See McDonald, History of Platinum, pp. I 56-I 57 .

17. Memoria que en 23 de Junio de 1779 recitó en la Real Academia de las Ciencias de París el Conde de Milly: sobre los experimentos é investigaciones que habia practicado con la platina, que le remitió desde Madrid D. ${ }^{\mathrm{n}}$ Casimiro Ortega. Biblioteca Real Palacio, signatura 2860, Miscelánea de Ayala, XLVII, 277.

18. Madrid, Nov. 24, 1780. Ruiz, Relación, I, 443. See also p. 446, wherein Gálvez presented the box to His Majesty. Ortega also, having learned earlier from Count Buffon of the beautiful jewelry to be made from platinum, sent a quantity to be fashioned into balls, sword hilts, snuff boxes, and other items, including a gift for Madame Thouin. (Gómez Ortega to Thouin, Madrid, April 2, 1778. Hamy, Dombey, p. 330.)

19. Dombey to Thouin, Madrid, Aug. 25, I777, and Lima, Dec. I1, 1778, and to De la Saudraye, Lima, Sept. 11, 1778. Hamy, Dombey, pp. 28, 45-46, 246. The 38 pounds was divided thus: I I to the Académie des Sciences, i I to the cabinet of the king, I I to Turgot, and 5 to the French metallurgist Balthasar Georges Sage. (Dombey to Thouin, Lima, April 20, I779. Ibid., p. 51.) See also Dombey to Thouin, Cádiz, April 27, 1785. Ibid., p. 165. The French were considering platinum for the manufacture of telescopes and offcial weights and measures, because of its lack of susceptibility to changes in temperature. (Ibid., pp. xli, xlii.) 
num to a degree with gold without reducing the specific gravity of the latter or altering its appearance, and that heavy alloys of platinum with silver and copper could be gilded. The end product could then be fraudulently palmed off as gold. Thus, while with one hand encouraging scientific experiments, the government sought with the other to prohibit the shipment of platinum to Europe in order to protect the buyers of gold objects. As of 1778 all was supposed to be delivered to the royal mints in New Granada, and for a time, at least, it was the policy of the mints to throw the platinum thus collected into the river. Yet, since the government did not pay for this platinum, quantities filtered into private hands in Spain despite the prohibition, and with an increased demand in Europe, smuggling began to flourish. ${ }^{20}$

It indeed took special action to get Dombey's platinum to Paris, for by now the Spaniards were beginning to expand their own experiments. François Chavaneau, a French professor of chemistry, had been brought into service of the royal seminary at Vergara, and would soon receive a quantity of platinum to work with. Ortega later reported that by 1786 Chavaneau was making platinum malleable "to a degree of perfection very superior to that of all who had preceded him."21

\section{NITRATE OR NOT?}

Yet another task to preoccupy Dombey was the inspection of possible saltpeter deposits along the Peruvian coast. As an ingredient of gunpowder, saltpeter was indispensable. Large surface deposits of the "ordinary" type (potassium nitrate) were located in India, Burma, Siam, and Ceylon. Spain also produced a good supply, but other countries of Europe had to depend, aside from heavy imports from India, on domestic production of the so-called wall saltpeter (calcium nitrate). This latter substance, formed by the contact of decaying nitrogenous matter with alkalis, air, and moisture, was found in certain soft stone quarries and on the walls and floors of old buildings,

20. McDonald, History of Platinum, pp. 14, 18-19, 61. See also Dombey to Thouin, Lima, Dec. I I, I 778. Hamy, Dombey, pp. 45-46.

21. Informe de D. Casimiro Ortega sobre la importancia del uso de la Platina. Biblioteca Real Palacio, signatura 2873, Miscelánea de Ayala, LV, 3-4. See Anales de la Real Academia de Farmacia (Madrid), XXIII (No. 3, 1957), 298-301, for a résumé of 57 documents on platinum-working in Spain, 1755-1789, taken from AGI, Audiencia de Santa Fe, legajo 835, dated March 18, 1789. 
stables, barns, latrines, and cellars that had been built from earth or limestone containing nitrous material.

In France, until the time of Turgot, this nitrate had been collected by a corps of saltpeter gatherers, who roamed the countryside, picking over the rubble of demolished buildings. They also had the right to dig out the substance not only from stables and barns, but even from the cellars and houses of citizens. In each town they could demand billeting and free wood and were a much-despised lot.

Not only was the practice odious, but production continually declined, and Turgot resolved to do something about it. He had the example of other European countries, notably Sweden and Prussia, whose chemists had been experimenting with means to produce saltpeter artificially. The French government offered a prize of 4,000 livres to the one who could best unlock nature's secret of saltpeter manufacture. Dombey left for Peru soon after, and the timeliness of the problem was naturally impressed upon him. ${ }^{22}$

He made a cursory study of possible saltpeter deposits along the Peruvian coast, and predicted that a respectable volume of commerce might be developed. He sent samples to Turgot, to the metallurgist Balthasar Georges Sage, to Buffon, and to Count d'Angeviller, the director general of "buildings, gardens, royal manufactures, and academies." He also wrote a mémoire that was later inserted in printed studies on the problem. ${ }^{23}$ Dombey admitted he was hurrying to publish his findings even though they were mere conjectures, because of the wide interest in the subject at that time, and "because in the business I'm in, one doesn't live very long."24

Ruiz also thought chances were good for nitrate production around Lima. The supply was impregnated with sea salt, which seemed to discourage its use, but according to Ruiz the salt could be separated out with little expense if the local residents were instructed in the simple methods required. ${ }^{25}$

22. Material for the above discussion has been taken from Mémoires de mathématique et de physique, présentés à l'A cadémie Royale des Sciences, XI (Paris, 1786), I-13, 98-102, 421-477. A brief summary of the saltpeter-gunpowder situation is contained in [Dupont de Nemours], Mémoires : . . de Turgot, Pt. II, pp. 75-88, and Douglas Dakin, Turgot and the Ancien Régime in France (London, 1939), pp. 164-166. See also John Talbot Dillon, Travels Through Spain (2nd ed,; London, 1782 ), pp. 40-41.

23. Dombey to Thouin, Lima, Dec. I I, 1778. Hamy, Dombey, p. 42. The mémoire was published in Observations sur la physique, XV (1780), 212-2I4.

24. To D'Angeviller, Lima, Dec. 20, 1778. Hamy, Dombey, pp. 248-2.49.

25. Relación, I, 7. Ruiz also spoke of potassium nitrate in the vicinity of 
Gómez Ortega, who inspected samples sent to Spain, was disappointed with the prospects. He assured Gálvez that Dombey's finds were not the salitre he was looking for, but another type of salt, abundant in various parts of Spain under the name of sal de compas -a low-cost, bitter salt used as a purgative and in the process of etching. The Spanish scientist told how, from one pound of the substance, he had extracted eight ounces of crystallized salt, which he forwarded to Gálvez as proof. He observed that the salt did not crystallize in long needles as was the case with purified nitre, nor did it have the same sharp taste. It did not ignite with a loud noise when placed on coals. Instead, when the crystals swelled in the fire and discharged their moisture, they were immediately extinguished. A fine ingredient of gunpowder these would make! But Ortega charitably continued:

The mistake made by Dombey and his companions in their judgment of this mineral is not strange, since their voyage is not directed toward chemical ends, in which they aren't as well versed as in botany, and because they judged what they found in the rough state, by its external appearance. Thus it will be advisable to revoke the order given to the viceroy of Lima to remit samples of this Supposed Salitre from the coasts of the Southern Sea.

Revealing his sensitivity to the criticism of Spanish scientific attitudes, Gómez Ortega concluded:

If your excellency [Gálvez] would approve, I will let Dombey and even his correspondents of the Royal Academy of Sciences in Paris know, confidentially and opportunely, of their mistake, in order that those savants will not perhaps come to think that we here adopt blindly and without examination, everything that is written to the ministry on these matters from faraway lands. ${ }^{26}$

In view of the enormous development of the nitrate industry in Chile during the nineteenth century, one is tempted to speculate on the relative merits of the opinions of Dombey and Gomez Ortega. An explorer who followed many years later states that Dombey provided the first news of nitrate deposits in Tarapaca. ${ }^{27}$ That section, once in southern Peru and now in northern Chile, was indeed the first great center of the nitrate boom, but there is no indication that Dombey was speaking of an area so far to the south.

Huánuco and of Sayán (east of Huaura, not far from the coast). See ibid., I, I 35,198 .

26. To Gálvez, Madrid, Nov. 24, 1780 . Ibid., I, 443-444.

27. Antonio Raimondi, El Perú (Lima, 1874-1913), I, I3. 
Subsequently, the periodical Minerva peruana of June I 5, I 809, carried under the heading "Important Discovery" the news that in Tarapaca "they have discovered about thirty leagues of cubic nitre, sodium nitrate, which is formed in the hills under the surface of the earth, so petrified that it is necessary to get it out with bar and powder, in such a quantity that it can provide not only the Americas but Europe as well." Isolating the nitrate from the soda, however, had baffled the entrepreneurs for ten years. Then Thaddeus Haenke, who had come to South America as a naturalist with the Malaspina hydrographic expedition of I789-I794 and stayed on to live in what is now Bolivia, informed them of the theory and practice of separation, and the newspaper looked forward to a new era. It was not until I830, however, that the first shipment from Tarapacá headed for Europe.

There was some gunpowder manufactured in Peru during the late colonial period, as it is mentioned in documents of $1784-1786$ and subsequent years. The Gazeta de Lima of December 4, I8I I, reported the shipment to Spain of many quintales of potassium nitrate "and a great quantity of gunpowder made with that ingredient at the factory in Lima." The later industry in Tarapacá was founded on the deposits of sodium nitrate, which turned out to be easier to work than the potassium nitrate. ${ }^{28}$ Thus, while it is possible that Dombey and Ruiz were dealing with legitimate sources for gunpowder manufacture, it seems safe to say that they did not know of the vast fields that years later would revolutionize world nitrate production.

\section{BY THE WATERS OF CHAUCHIN}

Whatever Gómez Ortega may have thought of Dombey's abilities in extra-botanic endeavor, the viceroys did not hesitate to call upon the Frenchman to perform special assignments. Very likely there was no one else better qualified, nor more readily available. But it also seems logical to believe that Dombey's reputation as a "foreign scientist" influenced the choice in this part of the world which had yet to realize its own scientific potential.

28. Roberto Hernández C[ornejo], El salitre (Valparaíso, Chile, 1930), pp. 8 , 12, 14,28 . 
Just as the trip to the south of Lima was coming to a close early in 1779 , the viceroy sent word that he would like Dombey to make an analysis of the mineral waters at Chauchín, near the source of the Huaura River. On March II the Frenchman headed north, accompanying the wife of an oidor, who was going to take the thermal baths for which the spot was noted. ${ }^{29}$ From that time until September, I 779, Dombey reveled in the opportunity to make discoveries on his own.

Nibbling at select botanical morsels in between his studies of the waters, Dombey was alternately exultant and depressed by life in the Andes. "If the fear of disquieting those who are awaiting the results of my work did not disturb my spirit," he said, "I would be the happiest of men to live in these beautiful mountains." He had described five new genera in seven days, but there were drawbacks. Only the alcalde spoke a language he could understand, bread was unknown, and the natives hesitated to sell provisions to Dombey. "In spite of the natural law which does not permit one to get things by force," he explained, "I am obliged to kill hens and make off with anything I need, which I pay for afterwards." He wished for his horse, his usual cuisine, his bed, and two or three slaves to lighten his work so that he could have time to write. ${ }^{30}$

His burden was made easier, despite his complaints, by the addition of an Indian helper - a man whom he began to teach in the ways of botany. The experiment was quite successful, at least in speeding up the drying of plants, and within two years Dombey acquired yet another assistant. Both continued in his service for the remainder of his time in America. ${ }^{31}$

There is a new suggestion of French-Spanish animosity in reports on the excursion to Chauchín. Ruiz wrote in his Relación that Dombey neither concluded his work of analyzing the waters, nor gave an account of what they contained. Dombey, on the other hand, claimed he turned in a report to the viceroy. ${ }^{32}$ But whether or not the men appreciated each other's abilities or points of view, they still had many months of joint labor ahead. They had come to Peru to hunt plants and not to pick quarrels.

29. Viceroy Guirior to Dombey, Lima, Feb. 16, 1779. Hamy, Dombey, p. 53. Ruiz, Relación, I, 61.

30. To De Jussieu, Lima, April 20, I779. Hamy, Dombey, p. 253.

31. Ibid., pp. 53, 6I, 65, 73, 76, 79-80, 83, 262, 263.

32. Ruiz, Relación, I, 45. Dombey to Thouin, Lima, April 20, 1780. Hamy, Dombey, p. 56 . 


\title{
VIRGIN LANDS OF MOUNTAIN
}

\section{A ND MONTA $\widetilde{N} A$}

\author{
TARMA: "TEMPERATE, LUXURIANT, \\ PLEASANT"
}

At the "Gate of Marvels" in the late morning of May 12, I 779, two Spanish plant hunters and two painters, trailed by a string of pack mules, said farewell to Lima and set out for the first time into botanists' virgin land. They would enter the mountains many more times, but what later experience can equal the first? What torments and frights are not greatest when one never before has seen their like? The scientists lost their voices in the roar of the cascading Río Rimac; climbed stairways that were no more than piles of loose stone ready to tumble the incautious to the bottom of a gorge; saw one of their mules drown in an icy stream; swung perilously upon a rawhide rope bridge one cold midnight by the light of icho grass flares; and gasped for breath in the three-mile-high atmosphere at the summit.

A bigger obstacle even than inanimate nature was humanity itself. All but one of the drivers deserted on the upward climb, absconding with three of the animals, and the Spanish scientists had to turn into muleteers. They at last induced another Indian driver to help them, but even he soon vanished, likewise seizing a mule-cargo and all. At last, on May 20, I779, they rode into La Oroya, I 20 miles from Lima-a short span by the standards of today, a short lifetime to men who had learned firsthand the hazards of travel in the Andes. The next, and last, day's journey was easier, and in the afternoon of May 2 I they saw for the first time their new home-Tarma, pleasant Tarma. ${ }^{1}$

The botanists did surprisingly well on the upward trail in adding to their collection of plants, despite energy lost in trying to conquer 1. Relación, I, 62-74. 
the old Inca highway, and the near-absolute sterility of many stretches. But the province of Tarma opened their eyes to the real possibilities. Climatic zones ranged from hot through temperate to cold, each with distinctive vegetation. "Almost all the plants were new to us," Ruiz wrote happily, "and precioso for enriching Botany and Materia Medica to the benefaction of humanity."2

His Relación is fortified with pages of listings: plants and trees to mend fractures and heal wounds; to ease childbirth; to quench thirst; to fashion hatchet handles; to guard against melancholy; to make shampoos; to remove cataracts; to restore the appetite. There were laxatives, dyes, and remedies for asthma. One plant, so the natives believed, made women fecund. A tree-like shrub, Datura sanguimea or red floripondio, supposedly drove the person insane who dared nap beneath its branches. Buddleja incana purged the "viscous humors," deadened the aching tooth when applied in a poultice, and yielded an excellent hardwood for building purposes. Various species of Tillandsia were an anti-nervine when used in hot baths. The Indians made bedspreads from them that kept insects away. They pounded them into a paste to apply against hemorrhoids; they sheltered unripened fruit with them; they wrapped pottery in them when going on a journey; and they asked them to sooth an aching back. There was the "make drunk-make drunk" fruit (Arbutus multiflora, called by the natives machamacha), and the "pepper-pepper" (Ceratostema grandiflorum). And there were many more, though useful perhaps only for adding a touch of beauty to the hair or altar. ${ }^{3}$

The botanists set up headquarters in the town of Tarma, agreeable to live in for its moderate climate, invigorating for its 10,000foot elevation. The guidebook of today calls it "a quiet retreat favored by those desiring a few days of rest."4 Ruiz spoke of the area as "temperate, luxuriant, and pleasant." The nearby hills he found "dressed most of the year with plants, which at the time of the rains burst into flower and beautify all that narrow valley with the variety of their colors." The four thousand residents included a

2. Ibid., I, 74 .

3. Ibid., I, 93-104.

4. Earl Parker Hanson (ed.), The New World Guides to the Latin American Republics (3rd ed.; New York, 1950), II, 66, of the section on Peru.

5. Relación, I, 9r. 
garrison to protect against unfriendly Chunchos of the lowland jungle lying fifty miles to the east.

Sorties into the neighboring countryside took most of the time during the eight months in Tarma. On one occasion (July 27-30) Ruiz and the draftsman Gálvez went sixty miles south into the province of Jauja, to the Franciscan convent of Ocopa. Here was headquarters for missionaries to the uncivilized jungle natives, and the friars had a good library and one of the handsomest edifices in the whole of Peru. The two visitors were warmly welcomed, but found few plants different from those in Tarma. The padres told them it would be easier and safer to penetrate the tropical forest from Tarma and no less productive of botanical specimens, so Ruiz decided there was no need to stay longer at Ocopa. ${ }^{6}$

The Spanish botanists delayed a major invasion of the jungle until Dombey had joined the party toward the end of September, r779. Thereupon Pavón and Brunete headed for Palca while Ruiz, Dombey, and Gálvez set out for Huasahuasi, the last outpost on the fringe of Chuncho country. From there, accompanied by soldiers of the frontier garrison, the botanists made their first excursion into the montaña, or tropical forest, and found more than forty entirely new species almost for the asking. Ruiz abandons the matter-of-fact style so characteristic of his Relación to rhapsodize on a wonderland where it seemed as though "nature had destined those lands for orchids since the creation of the world." The ground was

covered with a multitude of plants, whose perpetual fragrance and aroma delight and refresh the senses in such a way that it is as if the land invited one never to leave. Of all the plants, the most abundant are those of the orchid family, whose bulbs, laid out over the face of the ground, cover the most dry and rocky terrain like a stone pavement, and the varied colors of their strange and precious flowers give a special tint to that unusual pavement of nature. ${ }^{7}$

Pavón took two chests of dried plants to Lima on October 25 and was back at Tarma within a month, but the beginning of the summer torrents in the jungle cut short anyone's ambitions to spend more time there. Ruiz and Dombey even had to postpone investigation of the quinine trees they thought they had seen. ${ }^{8}$ On December 5 they returned to Tarma for some last-minute botanizing, and Dombey as

6. Ibid., I, 105-109.

7. Ibid., I, Iо1, I I 4 .

8. Ibid., I, I I5-I I 6 . 
a physician became immersed in efforts to put down a minor epidemic. ${ }^{\circ}$ By January 24, I 780 , everyone was back in Lima.

Dombey during these months began to complain of the stresses wrenching away his good health:

The heat of the torrid zone, the sudden passage from hot to cold, the suffocating air which one breathes in the very high places, have made a considerable change in my constitution. That great vigor I enjoyed in Europe is not the same here. ${ }^{10}$

His disposition suffered as well. He was a stranger in the land, subject to all the anxieties of the role, though he tried to ease his way by providing occasional medical service:

People are above all people; those of Spain [here he means all Spanish dominions] believe themselves to be the best Christians. The actions of Frenchmen, children of frivolity and of playfulness, have lost our nation its reputation in Spain, which obliges me to be a much better Christian in Lima than in Paris. Nevertheless, in the minds of the people I am nothing but a heretic. If the Inquisition had any power over an envoy of a king I would not live an instant in Spain. I visit my sick patients gratis, I furnish money and medicine to the poor along with my medical advice; but in spite of that I am no more virtuous in the eyes of the people. ${ }^{11}$

\section{HUÁNUCO: SALVATION BY QUININE}

The scientists had not yet arrived at the half-way point of their scheduled four-year stay in America, nor had the crown forgotten the audiencia of Quito to be their ultimate goal. Gómez Ortega notified the men that orders were pending to send them by water to Guayaquil. From that point they would botanize overland to the city of Quito, and then undertake a study of quinine and cinnamon trees. Later they would proceed by land to Bogotá, and thence down the Magdalena River, finally embarking from Cartagena on the return journey to Europe. ${ }^{12}$

9. An official certificate of the governor of Tarma confirms that Dombey "demonstrated capacity, charity, and medical talents" in the help he gave "liberally," "unselfishly," and with "recognized prudence" to the afficted. (Pueblo de Castro, Jan. 3, 1780. Hamy, Dombey, p. 397.)

1 o. To De Jussieu, Lima, April 20, 1780. Ibid., p. 257.

11. To Thouin, Lima, April 20, 1780 . Ibid., p. 63.

12. Dombey to Thouin and to De Jussieu, Lima, April 20, 1780. Ibid., pp. $6 \mathrm{I}-62,256$. 
While the men waited for orders, there was plenty to do in Lima. For one thing, a termite, Termes fatidicum, which Linnaeus had found consuming Löfling's plant specimens, was enjoying a similar feast on the herbarium that Pavón had left a few months before in Lima. It was necessary to transfer the plants to new papers, to label them properly, and arrange everything by class before boxing for shipment. The crown had resolved, however, that nothing be sent to Spain while war still raged with England. Against the day when the seas would be free, the botanists deposited their prizes in the royal armory. ${ }^{13}$

However enticing the prospects in Quito, the botanists knew better than anyone in far-off Spain that they had barely been introduced to Peru. They were not even sure they had seen a quina tree, though collection of the bark had recently begun in the Peruvian forests. Summer torrents had driven them from the montaña, but the weather was due to improve by April or May. Meanwhile they waited out the storms and future commands in sunny, summery Lima.

Such was the paradox of Peru. When rain assaulted jungle and mountain, Lima and the coast glittered in sunshine; when the mists of winter closed tight around the capital, the sierra and montaña lay content with mere wisps of moisture. True, one speaks of the "dry" season in the tropical forest only in comparative terms, for precipitation is year-round, but at least the burdens of travel and exploration are eased and the drying of plants more feasible. On the other hand, each plant has its own time to bloom and a "complete" collection is but a figure of speech unless the seeker can spend a full year at each site. The members of the expedition had thus far compromised with practicality.

In the absence of official orders to the contrary, the scientists once again set out for the mountains, near the end of April, I780. At Tarma the Spaniards paused briefly to perfect some descriptions they had left incomplete during the previous stay, before moving on to Huánuco, their next base of operations. ${ }^{14}$ This city, which then boasted

13. Dombey to Thouin, Lima, April 20, 1780. Ibid., p. 56. Ruiz, Relación, I, 119-120. During this period Ruiz and Pavón are said to have offered in the halls of the University of San Marcos a "manifestación y lección objetiva" of the data thus far gathered. A present-day historian of the Peruvian university comments: "One can be sure that they were the first 'free' lessons on the sciences given in America, as only in 1788 were courses of botany opened in Mexico." (Eguiguren, Diccionario histórico cronológico, I, civ.)

I4. The Spaniards followed the previously used route. Dombey, whose mule- 
six thousand souls, lies on a forested eastern slope of the Andes overlooking the jungle. Nearby, the waters of the Huallaga River make their way toward the Marañon and the Amazon. The members of the expedition, having traveled I 50 miles north from Tarma and 300 all told from Lima, were ready to resume active labors by May 2I, I 780 .

Ruiz was unable to hide his disappointment over the immediate surroundings. The men had already held their noses in the windswept smelter town of Pasco, where the residents burned manure in their dismal dwellings to keep warm. Ruiz tells with a shudder how the stench stayed in the clothes and on the bodies of the unfortunate people of Pasco. Huánuco discouraged him for other reasons. He found it a caricature of its former self. Once it had been, as Dombey said, "the nec plus ultra of the Spanish Conquest in the interior": The City of León of Huánuco of the Cavaliers. Though its location seemed excellent, the area had declined in importance with the suppression of the feudal encomiendas, and many settlers had gone back to Lima.

The Indians, who composed a large share of the populace, especially appalled Ruiz. His feelings were aroused less by pity than disgust. He admitted the severity of the ruling classes as a partial cause of the degradation, but he directed his tirade mostly against the hapless natives themselves. All the old saws from the days of the Conquest about the lazy, slow, idolatrous, unambitious, dishonorable, undignified, malicious Indian were dragged out and reiterated. Ruiz added some more of his own: They crave the latest fads; they exaggerate everything; they have nothing and yet more than enough; they treat their wives like slaves and their mistresses like ladies; no gift pleases them because they see in it a hidden intention, "and perhaps they are not deceived." When they beg they put on airs; they speak ill of everything; they make religious devotion a procurer for their drunken revels. When they seem to be praying, they are only gossiping; they eat very poorly; they generally sleep clothed; and, scorning life, they die without fear. ${ }^{15}$

Ruiz offered many suggestions for the resuscitation of Huánuco:

teers were from the province of Canta, farther to the north, set out on his own for Huánuco.

15. Dombey to Thouin, Huánuco, May 20, I780. Hamy, Dombey, p. 65. Ruiz, Relación, I, 124-125, 141, 146-147. Ruiz must have thought these charges a bit strong, for he marked this section to be omitted in the final copy of his text. 
raise its spiritual level by installing a strict bishopric; make it headquarters of an intendancy; ${ }^{16}$ move the real caja from odoriferous Pasco to Huánuco. Then the miners would have to come to Huánuco to smelt their silver "and after having had for several days the benefit of a mild climate and one unquestionably much more healthful than that of Pasco, they would return to their mines taking back fruits, seeds, coca, and other staples indispensable to their workers, and in Huánuco they would leave much money, which that fertile province lacks today." The visiting Spaniard also advocated increased cultivation and collection of cacao, coffee, indigo, medicinal roots, balsams and similar oils, vanilla, and dozens of other tropical products. ${ }^{17}$

Another possible source of prosperity stood a good chance to outstrip the rest. This was quina, the quinine-producing bark, which had been discovered in Huánuco and Panatahuas provinces by $\mathrm{Ma}$ nuel Alcarraz, probably not long before $17760^{18}$ First tests seemed to indicate the bark would rival in quality the famous product of Loja. The Marqués de Premio Real, a dealer of the drug in Lima, no doubt stirred by the report of finds in New Granada during I772I774 by Mutis and others, put life into the budding industry in Huánuco. He brought peons from Loja to teach the natives how to gather the bark, and by 1778 the first results of his efforts were beginning to appear on the market in Lima. The collection procedure, however, was a muddled one and destructive to the forests-a complaint as easily made about every other quina-producing area. By I779, the year before Ruiz and Pavón appeared in Huánuco, annual production of raw cascarilla from there reached two or three thousand arrobas-fifty thousand to seventy-five thousand pounds. The trade

16. This suggestion was obviously not put forth by Ruiz at the time of his first visit to Huánuco, as the intendancy system of administration was not introduced into Peru until 1784 .

17. Relación, I, 145-146.

18. Hipólito Ruiz and José Pavón, Flora Peruviana, et Chilensis, sive descriptiones, et icones plantarum Peruvianarum, et Chilensium, secundum systema Linnaeanum digestae, cum characteribus plurium generum evulgatorum reformatis ([Madrid], 1798-1802), II, ii. (Hereinafter Ruiz and Pavón, Flora Peruviana.) Ruiz reported in an earlier publication that the first finds were made by Francisco Renquifo in the vicinity of Cuchero (Panatahuas) in 1776. (Quinologia, o tratado del árbol de la quina ó cascarilla, con su descripcion y la de otras especies de quinos nuevamente descubiertas en el Perù [Madrid, 1792], p. 8. See also Ruiz, Relación, I, $135-136$. 
increased in succeeding years and by $I 788$ it was estimated that forty thousand arrobas had been sent to Lima. ${ }^{18}$

The botanists pushed into quinine country early in July, I780, setting up camp at Cuchero, about fifty miles northeast of Huánuco. They found a tangled mass of trees and creeping plants of every size and description- "without the least clearing for pasture or cultivation." The little church and eleven huts, which had once housed the population of this tiny village before the missionary moved it to a better location, now served as living quarters and warehouses for the quina collectors. All foodstuffs had to be carried in from Huánuco or other places, a fact the botanists sadly pondered as they forced down their daily ration of insect-ridden salted meat, toasted yuca, and maize. ${ }^{20}$

They came to see quinine trees and they found them-Cinchona purpurea or purple quina, C. nitida or "true Peruvian quina," and C. magnifolia (flor de azahar or citrus blossom), which Ruiz later described as identical with Mutis' red quina and "very weak in its virtues." But they also found trouble, and one night of panic turned a planned three months of study into a hasty three weeks of undone observations.

It happened on the evening of August I, I780. A peon flashed the word that the camp was surrounded by more than three thousand Chunchos, ${ }^{22}$ whom he had seen just before sunset perched in the trees and stalking the brush. The Europeans decided to flee, taking their manuscripts with them, convinced in their fright that the church,

19. Ruiz, Relación, I, 135-136. Ruiz, Quinologia, pp. 8, 13. The name cascarilla, meaning thin and fine bark, was applied to distinguish the quinine from the previously collected thicker, coarser bark of the "balsam of Peru." (JaramilloArango, "Estudio crítico," Anales ... Historia de la Medicina, X, 62.)

20. Ruiz, Relación, I, 152-156, 160. See also Hamy, Dombey, p. 73.

21. Relación, I, 153, 164. Current nomenclature of the various species of Cinchona is omitted from the present work because of the unfinished state of taxonomic study of this genus. According to a letter to the author from the acknowledged expert on Cinchona, Dr. F. R. Fosberg (Washington, D. C., April 1, 1963), not only are decisions still to be made as to whether certain species are identical, varietally distinct only, or really distinct species, but "involved, also, is the matter of whether Cinchona is really one genus, as treated by Ruiz and Pavón and other earlier authors, or whether it should be broken up into 5 or more modern genera, as done by some." Because Dr. Fosberg's commitments prevent him from carrying out further studies at the present time, it has been thought advisable to refrain from identifying the species of Cinchona beyond the names given by Ruiz and Pavón or their contemporaries.

22. Ruiz, Relacion, I, 160. Dombey states the number was supposed to have been two hundred. (Hamy, Dombey, p. 74.) 
the most likely fortification, would offer no defense against the flaming arrows of their attackers.

Stumbling off into the night through a dense fog, falling into holes, guided by a boy who knew neither left nor right well enough to call out the course, Dombey and Pavón spent four hours traveling little more than a half-league to the settlement of Casapillo. They arrived covered with mud. The two draftsmen had started behind them but almost immediately lost the way, and together with Ruiz decided to stick it out in Cuchero for the night.

There were thirty persons in Cuchero. One was sent to Casape to bring reinforcements and within an hour fifteen men arrived, armed with knives and two sabers. In all, the group mustered three firearms: one with a bad flint and minus a ramrod, and two cannon, one of which could hardly be operated. But they fired the pieces nevertheless, on the well-known theory that the Indians were afraid of firearms. The rest of the weapons collected for the occasion included six sabers, four swords, and various machetes or other knives. The night was spent awaiting the attack, while the three Europeans guarded the road out of the settlement to prevent the workers from fleeing.

As morning drew near, the Spaniards discovered they had almost been victims of a ruse, intended by the peon to disorganize them so that their supplies could be pilfered. The botanist and his draftsmen were left looking at each other, as Ruiz said, like Don Quixote and Sancho Panza after the adventure of the fulling mill.

Meanwhile, in Casapillo, Dombey and Pavón had reported the supposed raid, and this settlement went through the same sort of preparations for trouble. Next morning it was learned, of course, that all was well, but rumors are hard to put down and word spread to Lima that the Indians were up in arms. A special agent was sent to lay plans for defense only to find the incident to be a figment of one peon's fancy. ${ }^{23}$

Ruiz gently chided Dombey and Pavón for being swayed by the irresponsible mutterings of a single workman. He might, in truth, have felt some justification in parading his own intrepidity, for while the other botanists withdrew immediately to Huánuco, Ruiz and the two draftsmen remained in Chinchao, a coca settlement ten leagues

23. Dombey to Thouin, Huánuco, Sept. 20, 1780. Hamy, Dombey, pp. 74-75. Ruiz, Relación, I, 161-163. 
southwest of Cuchero, for another month. Although the episode now sounds farcical, it becomes less so in the light of subsequent events. A mere three months later, in the province of Huamalies to the west of Huánuco, the botanists saw a party of two hundred armed mestizos, led by the corregidor, on their way to punish the residents of an Indian town who had attempted to kill the royal tax collector. ${ }^{24}$ And only four months after the event in Cuchero, the whole viceroyalty was turned upside down by the revolt of Tupac Amaru, a descendant of the Inca, who unleashed a mob of fifty thousand Indians against the whites in the province of Cuzco. He was captured and met a savage death on May I8, I78I, but the uprising, spreading southward, did not finally die out in the vicinity of La Paz (present-day Bolivia) until 1783 .

The time spent at Cuchero was not an absolute loss, for it first introduced the Spanish botanists to the process for making an "extract" of quinine. ${ }^{25}$ A paper read to the royal society of medicine in Paris had pointed out the superior virtues of an extract manufactured in America from fresh cuttings, over one concocted in the pharmacies of Europe after the bark had lost some of its strength. Joseph de Jussieu, it was noted, had made such an extract which was preserved for over forty years without appreciable loss of effectiveness. The conclusion reached was that "if success is had in making an extract equal to... [De Jussieu's], it would cure illnesses with more certainty where the use of quina is indicated, and would also be of more general utility." Ruiz was proud to state that he and Pavón, from these beginnings, had made an extract on various occasions during their stay in Peru. The Peruvians had followed their example with such success, Ruiz acknowledged a dozen years later, that more than forty thousand pounds of extract had been shipped to Europe and,

24. Ruiz, Relación, I, I 77-178.

25. The procedure was more or less as follows: The desired quantity of freshly cut and finely fragmented bark was placed in four parts of water for forty hours, then cooked over a low flame until half the liquor had been consumed. The remaining liquid was then poured into an earthen jar. To the bark was added one-half the original amount of water, and the mixture boiled over a moderate flame until half the liquor was gone. Once the bark had been filtered out of this second brew, the two liquids were mixed, and the sediment allowed to accumulate for twenty hours. Following this, the clear liquid was poured off and cooked until it attained the consistency of honey. Placed in another and smaller vessel, the new mixture was subjected to a very low flame, all the while being stirred to prevent burning, until a caramel-like result was obtained. This was then put in jars, tin containers, or boxes made from the quinine trees themselves. When the liquid had cooled, the vessels were carefully sealed to keep out the humidity. (Ruiz, Quinologia, pp. 42-43.) 
as word of its efficacy and lower price spread about, the business stood to increase even more. ${ }^{26}$

Vegetation in the vicinity of Chinchao, where Ruiz and the artists now set up camp, .was very similar to that of Cuchero, except that coca leaves substituted for quinine bark as the foundation of the economy. The loneliness of the two sites was much the same. Even as Cuchero with its eleven abandoned huts, Chinchao was so small the visiting priests had to celebrate, in an uninterrupted three-to-fourday stretch, all of the religious holidays of the year. It was the only time of year when Mass was held. ${ }^{27}$

Most newcomers to the Andes observe with interest and frequently with positive revulsion the enslavement of the Indians to coca. The natives will not work-and are convinced that they cannotwithout chewing constantly upon the leaves. Although only with time had Ruiz overcome an outlander's belief in the useless nature of the plant, the moral aspects of dependence upon a habit-forming drug did not seem to disturb him:

For a long time I lived with the conviction that coca was, just as tobacco, an overgrown weed designed for the pleasure of the Indians; but experience has made me change that unfounded opinion, demonstrating with positive facts the admirable effects of those leaves which look so insipid, inert, and odorless. Besides, when taken in a liquid mixture, coca is a well-proven medicinal remedy, since it cures dysenteric excretions, attacks diarrhea, and promotes menstruation in those who have given birth to children. Administered in powdered form with sugar, it corrects acidity and strengthens the teeth. ${ }^{28}$

A reunion of all members of the expedition took place in Huánuco at the beginning of October, I 780, but it did not last very long. Ruiz and Gálvez, egged on by reports of rare specimens in the province of Huamalies, headed west on October 25. They found, however, that the elevated sites of Chavinillo, Chupán, Obas, and Cahuac were too cold for much vegetation, and heavy rains added final proof that life was more beautiful in Huánuco. Ruiz regaled his comrades with tales of the glowworms he had seen at Chavinillo: for a full two weeks he had needed no light to read by other than that provided by two of the insects kept in a paper cone. "There is no doubt," he mused, "that if these insects could be kept alive and propagated in

26. Ibid., pp. 46-48.

27. Ruiz, Relación, I, I68, I 73.

28. Ibid., I, I 7 1. 
glass bottles, they would give off an admirable light to use inside the house and save the expense of artificial light."29

Meanwhile, in Huánuco, Dombey's curiosity had been so agitated by a piece of natural rubber he obtained from a local Indian, that he made a special trip to Lima in October, 1780 , to acquire extra funds for penetrating well into the Amazon region. But when he got back to Huánuco in January, I 781, with 2,400 borrowed pesos, he found the military situation perilous as a result of the Tupac Amaru uprising. The fighting was days away to the south, but no mountain town could rest easily for fear of local disturbances. Dombey offered the corregidor of Huánuco one thousand pesos of the funds he had just borrowed in Lima, plus ten cargas (about 64 bushels) of wheat and the same of beans, in order to help feed the local detachment of soldiers. The city council declined his gift with appreciation, whereupon he set aside the food for the benefit of the patients in local hospitals and the "newly converted poor folk in the villages." Details of the offer went through channels to Minister José de Gálvez in Spain. ${ }^{30}$

With the threat of raids and the certainty of rains hanging over their heads, the party stayed close to Huánuco from early November, I 780, until March 22, I78r, except for Dombey's fund-raising visit to Lima. Though Huánuco did not escape a surfeit of cloudbursts, the sun came out almost daily and the ground dried very quickly. The tableau of flowers was unending and yet ever-changing, and for the first time the botanists spent nearly the full winter in the highlands.

They were properly impressed with the floral display in Huánuco, but not a little distressed with one plant that practically covered the plazas and streets. This was Datura Stramonium L. or chamico, known in English as thorn apple. The Indians used its seeds to induce infatuation, and trouble began when one lad of ten years hid some seeds in bread and got another boy to eat the concoction. The victim became helplessly tipsified. His parents called on Dombey to administer a remedy, but nothing worked. At one time the boy had been "lively, sharp, mischievous, and happy," but, according to Ruiz, he "never regained those qualities." The corregidor ordered the

29. Ibid., I, $177-178,184$.

30. Dombey to Thouin, Lima, Nov. 2, $178 \mathrm{r}$, and certificates of secular and clerical officials in Huánuco. Hamy, Dombey, pp. 80, 399-407. 
plants pulled up and burned, but Ruiz noted when he came back to Huanuco that they were flourishing as strongly as ever. The plant often does sow itself, and besides, the natives used the leaves and seeds, beaten to a pulp, as a remedy for piles, and some took an infusion of leaves to halt "ardor of the urine and excoriations resulting from hot purgations." A mixture of the pulp and vinegar, applied to spine or kidney, was considered a good relief for gout and hernia. ${ }^{31}$ The people, it would seem, did not want to get rid of the plant.

\section{DOMBEY'S BAD NEWS FROM THE GOOD ADVICE}

In the meantime a new cause for anxiety arose: the British had captured the Buen Consejo (the Good Advice), which was carrying the first plant remissions to Spain. Thus, to make up for the supposed losses, the Spanish botanists and painters headed north from Lima once more. From July 5 to September 9 they combed the land about Chancay and Huaura, and this time also went eastward from Huaura to the edge of the mountains at Sayán. Near the last place, Ruiz encountered a compatriot, Joaquín Galdeano, who had just been named oidor of Mexico, and who rode around with the botanists in order to observe the techniques of gathering plants. Sayán offered little novelty, but the men were by now able to turn toward Lima with their mission of replacement accomplished. ${ }^{32}$

Dombey felt no need to go north with the Spaniards, as he had saved out some specimens from the first shipment to Europe for this very eventuality. Instead he planned, at the request of the French astronomer and authority on navigation, Joseph Lalande, to measure the variation between low and high tides at the port of Callao. But the Spanish crown designated naval officers to make the observations,

31. Ruiz, Relación, I, 128, 148.

32. Dombey to Thouin, Lima, Oct. 20, 1780. Hamy, Dombey, p. 77. Ruiz, Relación, I, 193, 194-203. One of the plants Ruiz found in Sayán, Mimosa latisiliqua (Lysiloma latisiliqua, [L.] Benth.) was said to make anyone bald who washed his head in a solution of the leaves. With reason the botanist doubted that many people had tried to demonstrate the truth of this statement "since nobody wanted to be bald, at least on the head." But if the plant would do away with whiskers it would be worth a gold peso, "especially in that country." (Ibid., I,
202.) 
an arrangement that annoyed Dombey. He refused to be an underling, and when one of the officers died the project fell through. ${ }^{33}$

If sparks flew over a minor occurrence, what temptations to explode churned within Dombey when he heard the latest news from the Buen Consejo? The goods were safe, it was true. But the British had offered the cargo for sale in Lisbon, and when the French consul tried to rescue Dombey's boxes he found that Spain had tied up the lot. ${ }^{34}$

José de Gálvez ordered that Dombey's remissions be restored to French hands except-and this was what hurt-except for the valued "vestidura del Inca." That garment would become a precious exhibit, the first of its kind, in the museum of natural history in Madrid. Gómez Ortega on his own initiative may also have taken some choice Indian pottery for the Spanish museum. Of course, modern laws against exporting archeological relics aim to do exactly what Gómez Ortega and Gálvez were doing-to preserve for the home government all of the prizes within its realms. ${ }^{35}$

On top of the indignities Dombey felt he had already suffered, Gómez Ortega heaped criticism of the Frenchman's botanizing tech-

33. Dombey to Thouin, Cádiz, March 1, 1785. Hamy, Dombey, p. 123. Oficio al virrey, Nov. 24, 1779; Viceroy Jáuregui to Gálvez, Sept. 20, 1780. Ruiz, Relación, I, 429, 442. See also ibid., I, I 94.

34. Dombey to Thouin, Cádiz, March I, 1785. Hamy, Dombey, p. I17. On the capture of the vessel, see various letters in Archivo General de Simancas (Spain), Sección de Estado, legajo 7323 antiguo, Nov. 26, 1779, through Feb. 22, 1780.

35. Dombey to Thouin, Cádiz, March 1, 1785. Hamy, Dombey, p. i17. The poncho may very well be the beautiful specimen now encased in glass at the Museo de América in Madrid. An inventory taken at the time of transfer from the Museo de Ciencias Naturales to the Museo de América describes it as "Trage de Yuca (Pachayoc. Lengua quichua.) Hallado con los huesos, en un enterramiento de mas de quinientos años de antiguedad, en las ruinas del templo de Pachacamá (Perú). Ejemplar notabilísimo. Largo 0.9 I ancho 0.79." I am indebted to Sra. María Luisa Vázquez de Parga, secretary of the museum, for this information. Marcos Jiménez de la Espada describes the garment as follows: "It is truly beautiful, not for the sumptuousness and magnificence of its appearance and the richness of its material, but for the exquisiteness of its texture, the freshness and luster of its colors, the artistic combination of its ornamentation, in short, for all that truly constitutes the superior quality most appropriate and characteristic of this class of artifact.

"To such excellence is joined its state of preservation, so perfect, that at the time of uniting it with other American jewels in the Cabinet of Natural History at the end of the past century [eighteenth], and during the years it was hidden there as if in a second huaca or tomb, there was no other of its type in Europe so perfect and entire." Jiménez de la Espada adds, however, that the inventory is wrong in calling it a "trage," for it is only part of one, and to attribute the garment to an Inca ruler is stretching a point. ("El cumpi-uncu hallado en Pachacamác," El Centenario, I [Madrid, 1892 ], 450-451, 467.) See also Hamy, Dombey, p. cvi, for an illustration of the garment. 
niques. The Spanish scientist reported to Gálvez that Dombey had violated his agreement by not remitting to Spain as complete an herbarium as the one he had destined for France. Dombey, however, as a safety measure, had deliberately held out some specimens. But Gómez Ortega also complained that many of Dombey's plants were not accompanied by written descriptions. He conceded that the defects might have been caused by haste in packing, but he asked Gálvez to warn France that more care should be exercised in the future. Dombey, however, already knew his descriptions were incomplete, for he had not yet thoroughly examined all of the plants.

Gómez Ortega was happy with the shipment by his own men. He planned to have the drawings bound into three volumes for presentation to the king. The herbaria he would preserve in the care of Bruno Salvador Carmona, the onetime draftsman of the Löfling expedition, until the botanists returned from Peru. A portion of the seeds went to the royal botanic garden and the rest were set aside for gardens of friends. Incidentally, the living plants had not survived the interrupted journey.

Gálvez wrote the viceroy of Peru to see that henceforth Dombey send a sample of every species to Spain. When word was passed to the Frenchman, he demanded in turn that Ruiz and Pavón give him copies of their drawings. The viceroy, so Dombey relates, snapped back that the Spaniards owed nothing to France. Dombey answered, "What do I owe Spain? Does the king of Spain pay my salary?" But since the Frenchman was obligated by the original instructions to share his finds with Spain, the incident was closed without further trouble. ${ }^{36}$

Dombey, however, never ceased to be wary of his Spanish companions. He recalled in one letter to Paris the difficulties encountered by the members of the La Condamine expedition. Especially vivid in his mind was the assassination of the French physician Jean Seniergues by a mob at the bull ring in Cuenca (Ecuador) in $1739 .^{37}$ Dombey

36. Gómez Ortega to Gálvez, Madrid, Nov. 24, I780. Ruiz, Relación, I, 444445. Dombey to Thouin, Lima, April 20, 1779, and Cádiz, March I, 1785 ; Gálvez to Gómez Ortega, El Pardo, Jan. 30, I781. Hamy, Dombey, pp. 5 I, 118 , 416. Here is Dombey's version of how the incident ended: "The viceroy, who understood clearly that I was right and who, besides, was a very affable gentleman, calmed me and said: 'I will have a copy made for you of the Minister's letter that I will sign and that I will have signed by the secretary of the government. I advise you to respond politely:' And in fact I answered this gentleman with an apologetic and polite letter." (Ibid., p. 118. .)

37. See La Condamine, Viaje, pp. 108-147. 
saw no way to keep out of trouble but to refuse nearly all participation in social affairs. His friend in Peru, Jean de Bordenave, blamed Dombey's failure to unbend on the "incivilities" he was forced to suffer at the hands of his fellow botanists. Their "bizarre humor," said Bordenave, was “incompatible with Dombey's conduct and good nature." 38

Dombey describes, with feeling, the complexities of life among sensitive artistes of an intimate expedition:

The diversity of opinion on the march or at work brings about misunderstandings which, even if they don't break out into the open, embitter the heart. All men have the same passions; he who knows how to repress them is the virtuous man. Not to hate a companion who receives a privilege, a recompense that one does not himself receive but thinks he deserves, is such a good quality that the man who would not hate another in this instance, would deserve the greatest honors. . . . I do not speak of recognition accorded a general whom I do not know, to a citizen in different circumstances from my own (it is rare that one is jealous of that preference), but I speak of the jealousy engendered among persons who follow the same career. In this case, a commendation, some preference accorded to the one who has superior talents, will suffice to make him detested by his companions on the voyage who will seek occasions to embarrass him, and heap all sorts of indignities upon him. That is why, my dear friend, harmony is so rare among brothers; they live together, and there are few parents discreet enough to hide the preference they accord to the most likeable personality. Virtue, good actions, daughters of virtue, are enough to make enemies of those with whom one must spend a part of his life. It is quite usual to see expeditions fail for such very reasons. ${ }^{39}$

On the Spanish side it is harder, in the absence of personal letters, to test the attitude toward Dombey, though even in his Relación Ruiz occasionally deprecates Dombey's abilities. Pavón has remained largely a silent partner in the records of the expedition, but there is evidence that Dombey and Pavón got along quite well-that they came to refer to each other as "my friend" with more than mere politeness. ${ }^{40}$ As for Dombey's associations among the Spanish colonials, there is only the word of a scarcely unbiased observer, Jean de Bordenave: "Nearly all those who know him praise his talent, his disinter-

38. Dombey to Thouin, Lima, Nov. 24, 178I; Bordenave to De Jussieu, Lima, April I3, I784. Hamy, Dombey, pp. 87, 337.

39. To Thouin, Lima, Nov. 24, I781. Ibid., pp. 86-87.

40. Dombey to Thouin, Lyon, Dec. 13, 1787, and Jan. 3, 1788. Ibid., pp. $209,210$. 
estedness, his prudence, and his untiring zeal for the service of the king and the advancement of natural history." His kindly manner had won him many friends, who were so ready to help him, lamented Bordenave, that Dombey seemed always to prefer aid from those others, "who assuredly do not hold as much love for him as I."41

Whatever their feelings toward one another, none was ready to abandon the expedition. On the contrary, they fell prey to propagandists for the southern kingdom of Chile, who have never ceased to speak of the benign climate and bountiful vegetation of their native soil. Thus, on December 2I, I78I, when the Spanish vessel Nuestra Señora de Belén sailed from Callao, bound for Talcahuano to load wines and grain, among its passengers were three botanists and two draftsmen about to begin another phase of their New World adventure.

Original instructions had called for a four-year stay in America. At the time of departure for Chile, the botanists had completed three years, eight months, and ten days of that period. Sixteen and one-half of these months had been spent in Lima, three months in nearby Lurín-Surco, five months in Chancay-Huaura, eight and one-half months at Tarma, and over eleven months in the vicinity of Huánuco. Why, with the time so nearly used up, did they not simply head for Spain? Certainly one answer lay in the hazards of travel on the Atlantic as long as there was war with England. The visitador general, who had assumed control of such matters in Peru, thus extended their time until November 30, $1782 .{ }^{42}$

As recently as October, 1780 , the members had expected the proximate arrival of orders sending them northward to Quito. The man bearing the instructions, Miguel María de Gálvez, was supposed at that time to have already reached Buenos Aires, but the records show no further reference to him. Probably the "state of the country"-the danger of Indian rebellion throughout the Andes-helped add a note of caution. Then, by 1782 , the viceroy of New Granada had instituted a provisional expedition under the headship of José Celestino Mutis, with undoubted jurisdiction over some of the territory in Quito originally considered in the preserve of Ruiz and Pavón. In whatever case, Ruiz and Pavón, to judge from their reactions at

41. To De Jussieu, Lima, April 13, I784. Ibid., p. 337.

42. Ruiz et al. to visitador general, Concepción, Nov. I1, 1782; Jorge Escobedo, visitador general, to José de Gálvez, Lima, Jan. 30, 1783, No. $38 . \mathrm{MCN},{ }_{7} 8_{3}$. 
a later date, had no desire to return to Spain. Dombey complained more and more of ill-health, but even he was unable to resist the predicted delights of Chile. ${ }^{43}$ The thought of new fields to conquer no doubt spurred all of them on, and the southern kingdom did not disappoint.

43. Dombey to Thouin, Lima, April 20, Huánuco, Sept. 20, and Lima, Oct. 20, 1780, and Nov. 24, 1781; to De Jussieu, Lima, Nov. 2, 1781. Hamy, Dombey, pp. $61,75,77,83,260$. 


\section{CHILEAN IN T ERL U DE}

\section{CONCEPCIÓN: PARLIAMENT, PLAGUE,} AND PINE TREES

Superlatives rose easily to the tongue of Hipólito Ruiz as he observed the amenable climate, the abundant vegetation, and the affable inhabitants of central Chile. He was in an "earthly paradise"_-"one of the most desirable and enviable countries on the face of the globe." Everyone was "kindly and generous to the needy and the stranger."

Colonel Ambrosio Higgins (1720-1801) set the pattern for hospitality. No sooner had the scientists arrived at the port of Talcahuano on January 30,1782 , than he offered them his quarters in nearby Concepción. As maestro de campo and acting governor of the province, he had an unenviable task of holding the warlike Araucanian Indians in check. ${ }^{2}$ The visitors soon had a chance to see how he did it, for he invited them to attend one of his unique parleys with the militant tribesmen.

Only José Pavón rejected the opportunity. He declined a trip to the convocation, according to the critical Ruiz, to avoid crossing the Bío-Bío River. ${ }^{3}$ Presumably Ruiz attributed his partner's hesitation not to the physical characteristics of the stream, which could be crossed on a raft in a half-hour during that "dry" season, but to the fact that it marked the northern limit for the Araucanians, who were not finally subdued for another century.

With hopes for a successful "parliament" on everyone's mind, plant life got little more than a glance during this educational tour

I. Relación, I, 207, 229, 270, 280 .

2. Higgins later became captain general of Chile and eventually viceroy of Peru. $\mathrm{He}$ adopted an "O" " as a prefix to his name in 1788 when he first commenced to petition the crown for permission to use the title of his "ancestor," the Baron of Ballenary, "Juan Duff O'Higgins." He was granted the title in 1795. (Ricardo Donoso, El Marqués de Osorno Don Ambrosio Higgins [Santiago de Chile, 1941], pp. 277-279.) His natural son Bernardo O'Higgins would later help to liberate Chile from the Spanish rule that Ambrosio had fought so hard to defend.

3. Relación, I, 209. 
to the south. But not a warlike ripple disturbed the powwow, held at Fort Arauco. Higgins withstood the tedium of ceremonial, which the botanists found "long and annoying," toasted the chief with wine, and sat back to allow the rank and file to celebrate by racing through the plaza on horseback or drinking themselves into a stupor. As a reminder that England was a serious enemy, he directed the tribes to keep a continuous lookout along the coast and notify the Spaniards if more than two vessels came into view. Higgins also made it plain to the assemblage that he would not tolerate internal strife; he would send in troops to quell "disorders, machinations, and bad conduct of the seditious ones."

Although everything went smoothly, no one believed the big problems had been solved. Ruiz commented that no successful means had been contrived to lure the natives from a "wild and barbarous life." Attempts to move them into towns had led only to rebellion in I766. Ruiz had the usual newcomer's answer: apply more force.

These Indians are all declared enemies of the Europeans, or rather of the rules and customs of the latter; thus it will be very hard to subject them to life in towns as long as they continue to be treated with kindness and tolerance, as commanded by the Spanish sovereigns. If the Chileans were ordered or allowed to subdue the Indians with the use of arms, in a short while this would compel them to live in towns, so as to free [the Chileans] from the forays and frequent robberies that take place at their haciendas, and at the same time halt some killings. ${ }^{4}$

The captain general of Chile, however, had more faith in Higgins' technique-of using force only in cases of serious dereliction. He wrote the crown a month later that the maestro de campo had "even to an extent attracted [the Indians] to subordination and obedience to the king."

The Araucanian interlude lasted less than a week, and early in March, I 782, the botanists set up headquarters in the city of Concepción for a stay of more than twelve months. New Concepción was a frontier settlement of crude dwellings built a mere seventeen years before, when residents of the old city on the coast gave up the fight against tidal waves and earthquakes. Of the town's ten thousand inhabitants, more than half spent most of their time on the surrounding haciendas. Whatever the shortcomings of the city, the sky was

4. Ibid., I, 215-218, 22 I, 223,224 .

5. Donoso, El Marqués de Osorno, p. II6. 
beautiful and the climate ideal- "more benign than in Spain." Central Chile has often been compared to central California; indeed many striking similarities exist in weather and vegetation. Although Concepción is rightly considered a part of the central zone, it offers a taste of the forest lands that dominate the "Switzerland" of southern Chile. Thus "trees and shrubs of valuable and exquisite wood" assumed prime importance in the new investigations.

One of the principal attractions was certainly the so-called Chilean pine (Araucaria araucana), now popularly known as the "monkey puzzle" tree, from the strange configuration of its branches, which would thwart the climbing ability of even a monkey. Only the year before, it had stirred attention when lightning at Concepción destroyed the mainmast of the warship San Pedro de Alcántara. To locate a replacement, Higgins sent his commandant of troops at Santa Juana, Luis de Benavente, with the ship's master carpenter, into Indian country of the cordillera. Within thirty leagues of Santa Juana they found over seventy suitable specimens of the Chilean pine, 30 to 36 varas ( 85 to 100 feet) tall and 27 inches in diameter. They also reported seeing between Angol and the coast about three hundred pines, 50 to 80 feet high, serviceable as topmasts, mizzenmasts, and yardarms, and numberless others in some way useful for ships of the royal armada. Higgins promised that on his next trip to the frontier he would persuade the Indians to permit collection of the pines.

The Ministry of the Indies avidly read details of the excursion, and immediately demanded full information. President Ambrosio de Benavides of Chile responded that results were "admirable"-though experience would have to confirm the pine's durability. ${ }^{7}$ When Ruiz and Pavón arrived the trees were already being cut for marine usage.

While the ministry waited for time and experience to tell their story, botanists began to debate the true nomenclature of the tree. Ruiz, Pavón, and Dombey were naturally agog to study it. Pavón entered the forest first with a naval officer and brought out branches

6. Ruiz, Relacion, I, 250-252. Ruiz and Pavón wrote Ortega that seeds from Chile ought to flourish better in Spain than those from Peru, because of the similarity in climate. (Gómez Ortega to José de Gálvez, Madrid, Oct. 21, I783. MCN.)

7. Higgins to President Benavides, Concepción, March I6, I78I; Benavides to José de Gálvez, Santiago, April 3, 178I, No. 53; royal order to Benavides, San Ildefonso, July 31, 178I; Benavides to Gálvez, Santiago, May I, I782. MCN, 1781. The president also sent data to the ministry on Jan. 3 and Dec. 3, 1782 . See AGI, Audiencia de Chile (hereinafter Chile), legajo I92, Nos. 53, 86, 93 , I 24. 
laden with flowers and cones. In doing so, incidentally, he was "exposing his life" in the land of the "infidel Indians," thus belying the taunts of his fellow botanists. Later Ruiz found more pines near the coast at Talcahuano. He claims that a study of both stands convinced all three botanists they had found a new species of the genus Pimus of Linnaeus - "the most valuable yet discovered." Juan Ignacio Molina, the Chilean Jesuit who wrote the natural history of his native land while exiled in faraway Italy, also called it a Pinus. ${ }^{10}$ But French experts were shortly to conclude that the tree was of an entirely new genus: Dombeya, according to the Chevalier de Lamarck (I744I 829); Araucaria, according to Antoine de Jussieu. The leader-to-be of botany in Spain, Antonio José Cavanilles, an outspoken enemy of Ruiz, stood up for Araucaria and, much to the disgust of Ruiz, so did Pavón after he returned to Spain. Some very unscholarly words were bandied about in later years over this issue.

For posterity the tree became Araucaria, suitably in honor of the Indians in whose terrain it was found. A Dombeyan biographer, following his subject's own lead, attempts to credit Dombey with suggesting the use of the pine on royal vessels. Ruiz rightly declares that cutting was already under way before they arrived, but even he counts the pine as one of the botanists' major "discoveries."

Ruiz sent some kernels to Spain but it was left to Higgins to attempt the shipment of living trees. In response to a royal order of March 25, I 783, he selected Luis de Benavente as chaperone to fortytwo tubs, containing fifty-nine of the young trees. They were to be embarked on the same San Pedro de Alcántara that had first made use of the pine in $\mathrm{I} 78 \mathrm{I}$. But as was so often the case, the captain protested the intrusion vigorously. He was finally forced to take on twenty of the smallest tubs and six little boxes of cones, nuts, and resin, but only under severe pressure would he agree to take Bena-

8. Ruiz, Relación, I, 241-242. Pavón to Joseph Antonio Caballero, Minister of Grace and Justice, Madrid, Feb. 14, 1800. MCN.

9. Relación, I, 246-247.

10. Saggio sulla storia naturale del Chili (Bologna, 1782), Pp. 182-184, discusses the "Pinus Araucana" ("called by the Spaniards pino de la tierra, and more like the Pezzo, or the Fir, than the Pine, although in a way quite different from all three").

1. Deleuze, "Notice historique," Annales du Muséum National d'Histoire Naturelle, IV, 152. Ruiz to Gálvez, Lima, April 10, 1784. Ruiz, Relación, I, 457. Dombey to Thouin, Cádiz, May 14, I785. Hamy, Dombey, pp. 172-173. Dombey remarks that a mast for which the crown spent 30,000 pesos in Lima was duplicated in Chile for one-tenth the cost. (Ibid.) 
vente. The ill-starred San Pedro, however, never reached its destination.

Ruiz took with him on his own return to Spain one living "Pinus Chilensis," but it is not known whether the tree survived the trip. In I 804, the botanists were still trying to get seeds of the pine from Chile to propagate in Spain, but in that very year Dombey's biographer reported that experience was showing the wood to be too soft. ${ }^{12}$

Further to confirm the admiration of the Spanish botanists for the trees of Chile, they chose three to honor themselves and their old teacher, Gómez Ortega:

Ruizia fragrans (or Boldo) [now known as Peumus fragrans (R. \& P.) Pers.; Ruizia today is a shrub named by Cavanilles]: This little tree grows eighteen to twenty-four feet high, is very luxuriant [and] stays green all the time .... the density of its branches and leaves, which continually emit an exceedingly pleasant fragrance, something like cinnamon, provides a delightful shade . . .: the natives make much use of the pulverized leaves to tone up the stomach and relieve pains; with the juice [of the leaves], drawn out by means of plain water, they cure earaches; to cure running sores and colds in the head they apply them parboiled, crushed, and sprinkled with wine. Hot baths of the leaves are used as excellent anti-rheumatics and antidropsicals. The ripe fruits, though small, are sweet and appetizing; when still too young they are treated with the same solution as olives, and when well pickled are even more exquisite than the latter. From the pits of the ripened fruits they make some rosary beads, because, besides being strong they are naturally hew $\mathrm{n}$, as if they had purposely been carved: those people also use the leaves for condiments and pickled dressing in place of the common laurel. Its wood and branches have various uses in buildings and when [the wood] burns it gives off a very pleasant fragrance that is never annoying. Finally, barrels made of the wood improve the quality of wines stored in them

12. Gómez Ortega to Gálvez, Madrid, Oct. 21, I783; Higgins to Gálvez, Concepción, March 28, 1785, and correspondence between Captain Manuel Eguía of the San Pedro and Higgins, Talcahuano, March 8, I3, and 15, I785; Gálvez to President of Chile, San Lorenzo, Oct. I3, I785; Ruiz and Pavón to Caballero, Madrid, Feb. 8, I 804 . MCN. "Lista de las plantas vivas." Ruiz, Relación, I, 475. Deleuze, "Notice historique," Annales du Muséum National d'Histoire Naturelle, IV, i 53 note. Here is a comment by an English traveler in the nineteenth century: "The Araucaria imbricata, with the exception of one or two trees near the coast that have probably been planted, is only found in the interior of the Indian country, south of the Bio-bio. Its wood is said to be very resinous and close-grained, but brittle. Whether it be from this circumstance, or the difficulty of transporting it from the interior, I am not aware, but the timber of the Araucaria is never exported." ([Alexander Cruckshanks], "Account of an Excursion from Lima to Pasco, Edinburgh, Nov. 25th, 1830, to Dr. Hooker from Alexander Cruckshanks," Botanical Miscellany, II [London, 1831], 17I.) 
for some time. It is certainly a little tree worthy of being propagated and cultivated in gardens for its leafiness, beautiful verdure, and delightful fragrance, and because one can use an infusion of its leaves daily in place of tea. [The last use is still a common one in Chilean homes as an alternate after-dinner beverage to coffee.]

Pavonia sempervirens (Laurel of Chile) [now known as Laurelia sempervirens (R.\& P.) Tul.; Pavonia today is a shrub named by Cavanilles]: this tree is tall, leafy, and beautiful: green all year: its wood is white, soft, with wavy threads in its center and fragrant like the sassafras. From the trunk they make beams, planks, and joists for buildings and other uses in carpentry. The leaves are used in Chile in place of the common laurel for pickled dressing and other seasoning. One can make excellent medical applications because of the fragrance and virtue as a corroborant: hot baths [in a solution of the leaves] strengthen the nerves and may also be given in cases of spasms, paralysis, and convulsions. An infusion of the leaves, if drunk in abundant amount, alleviates rheumatic pains.

Gomortega nitida (or Keule) [=G. Keule (Mol.) I.M. Johnst.]: this is the tallest, leafiest, and most beautiful tree, except the Chilean pine, which grows in this realm, standing out from the other trees, when viewed at a great distance, because of the verdure and beautiful luster of its leaves. Exquisite wood, of dark red color, which takes a high polish, is obtained from the trunk. Its leaves have an acidastringent taste; they stick to the teeth when chewed because of the high resin content; rubbed between the fingers they give off an odor like that of rosemary or spirits of turpentine, from which we can infer efficacious corroborant and comforting virtues: they burn easily even when green. The beautiful fruits are the size of little hen's eggs, shiny and yellow in color, that entice one to eat them; but when eaten in excess they cause headaches; their pulp, though not very juicy, is sufficiently sweet and pleasant; the pit is as hard as a rock; the shell is very thick and encloses two or three little almonds. This tree is always green and in flower or fruit all year, and it regularly flowers anew when the fruits are ripe or nearly so. ${ }^{13}$

Dombey would have us remember him as the savior of Concepcion from a rampaging epidemic. He states incredibly - nay, impossiblythat the plague wiped out 21,400 people in that community and 14,000 in Santiago. Renouncing association with his friends, who feared for their safety from contagion, Dombey dedicated himself "especially to the poor" -with "astonishing success." He reports that his medical achievements ended fear among the populace and induced generosity among the rich; within two months the epidemic had been stamped out. The bishop of Concepción, so Dombey's story goes,

13. Ruiz, Relación, I, 238-239, 234-235. 
tried hard to keep the skilled French medical man in his diocese. He offered an annual income of 2,000 pesos and sought to marry Dombey off to a rich young maiden. Dombey confesses that the offer was more enticing to heart than to purse. But overcome by a sense of duty, he spurned the proposition, satisfying himself with a certificate from the bishop acknowledging his services. ${ }^{14}$

Considering the indicated enormity of the "pest," it is surprising that Ruiz does not mention it in his Relación, nor does Ambrosio Higgins in his official certification of Dombey's services. The bishop of Concepción alludes to the Frenchman's contribution in these words:

Among his particularly good qualities, we have noted his great love for his neighbor. We are informed that, being destined to treat the sick for the want of a doctor, without the least self-interest he helped the miserable people who needed his assistance gratuitously, not only by purchasing medicaments, but with his knowledge, which uncovered the nature of the illnesses in the homes, for all of which he deserved the greatest recompense..$^{15}$

Epidemics indeed hit the colonies severely and often. A modern tabulation of the numerous plagues in Chile mentions none, however, for the period in which the botanists visited that realm (1782-I 783). Closest in time was an outbreak of malsito,${ }^{16}$ which attacked Santiago and Concepción in I779-1780. Between October, 1779, and January $2 \mathrm{I}$, I780, for instance, 3,978 women were treated at the orphanage, in lieu of better hospital facilities, and this was no doubt only a portion of the afflicted. ${ }^{17}$

It seems safe to say that, even if Dombey overestimated the mortality during his stay and magnified his own contribution, at least he did not hesitate to put his medical knowledge into use. When he left Concepción, he claimed "the sweet satisfaction of being paid for my trouble by the tears of the poor who overwhelmed me with affection."18

14. Dombey to Thouin, Santiago, Aug. 20, I783, and Cádiz, March 1, 1785. Certificate of Bishop Francisco Joseph de Marán, Concepción, March 26, 1783. Hamy, Dombey, pp. 98-99, I I9-120, 407-408.

15. Ibid., p. 408 .

16. "This epidemic is not well identified. Some attribute it to contagion brought to Talcahuano by the squadron of Admiral Vaccaro, others to an atmospheric decomposition caused by a big downpour followed by a drought, and, inasmuch as it took on the appearance of grippe there are some who hold it to be a form of yellow fever imported from Peru, and others, typhus fever." (Pedro Lautaro Ferrer, Historia general de la medicina en Chile [Talca, Chile, (1904)], p. 259.) 17. Ibid.

18. Dombey to Thouin, Cádiz, March 1, 1785. Hamy, Dombey, p. 120. 


\section{MUTUAL ENTHUSIASM IN SANTIAGO}

As March, I783, came to a close, the men began the 275-mile overland trek northward to the capital city, Santiago. The visitador general had already granted them another stay of twelve months, to November 30, I783, for war was still on and he felt the men should in no case leave their work undone. Besides, the small sum involved in their salaries would hardly hurt the royal treasury, for the crown was obligated to support the men to a degree even after their return to Spain. ${ }^{18}$

Ruiz tells how, at Talca, "persons of the greatest distinction" came out to meet him and the artists, who traveled so often separately from Pavón and Dombey. The corregidor of Colchagua treated Ruiz "with the most kindly affection." This was but a prelude to the round of festivities awaiting them in Santiago, where the first contingent arrived on Holy Tuesday, April I 5. When all were assembled, the president of the audiencia, Ambrosio de Benavides, the bishop, and the regent of the audiencia, Tomás Álvarez Azevedo, opened their houses and their tables to the scientists. All the nobility of the city, in imitation of these three illustrious leaders, sent gifts or offered the use of their homes. ${ }^{20}$

Apparently some of the enthusiasm generated in Chile passed down the scale, to judge from an incident related by Ruiz. While botanizing near the capital the scientists were joined by a "skillful pharmacist," Don Fulgencio Rodenas, who wanted to learn the technique of collecting plants. Dismounting from his horse to snare a new specimen, he failed to secure the reins. When a mare whinnied in the distance, the poor pharmacist's mount started off at a run. A

Dombey says that, in all, he spent 4,000 pesos to succor the poor in Peru and Chile. (To Thouin, Lima, Feb. 8, 1784 . Ibid., p. I02.)

19. The Spanish botanists asked the visitador general in Peru for a one-year extension on November II, 1782. (MCN.) The oficiales reales of the royal treasury were dubious of its legitimacy, but the fiscal of the royal audiencia in Lima advised the visitador Jorge Escobedo to grant it on the above-mentioned grounds. The latter complied on January 58,1783 . (Escobedo to oficiales reales, Lima, Dec. Io, 1782; Manuel del Campo to Escobedo, Lima, Dec. 16, 1782; opinion of Moreno [fiscal], Lima, Jan. 14, 1783; Escobedo to José de Gálvez, Lima, Jan. 30, ${ }_{78} 3$, No. 38. MCN, I783.) Escobedo notified the members of the expedition from Lima, Jan. I 8, I783. (Ruiz, Relación, I, 447-448.)

20. Ibid., I, $27 x-273$. 
search for the beast proved useless, but the would-be botanist managed to hire a nag that, besides being covered with harness-sores and thin "as a flute," was "without equal for slowness." Don Fulgencio, with his plant pouch no more than a dirty parchment that had once served as the lining of a book, and with a half-dozen sheets of crumpled paper, rode along like a "martyr of botany," bearing patiently "the pounding of that semi-skeleton hack." His hands full of plants, time after time the pouch fell in the dirt; once the neophyte was himself tumbled to the ground. But Ruiz admiringly reported that apparently nothing daunted this White Knight, for he went out with them again and again, until new orders sent the scientists back to Peru. ${ }^{21}$

The tertulias, or "chit-chat parties," and the popular country diversions of the people intrigued Ruiz, and Santiago, too, impressed him:

The majority [of its inhabitants] are Spaniards or Creoles, of good height, graceful figure, [and] good education, formal in their dealings and contracts, and gentlemen in descent and behavior. The members of the fair sex, besides [possessing] natural beauty, enhanced by natural cleanliness, are pleasant and obliging, singularly generous, and endowed with humanity besides. They are so dedicated to music that one can hardly find a señorita who does not know how to play one or more instruments with sufficient accuracy and skill, and they sing along with them, either just in fun or as taught by masters, forming in the evening brilliant orchestras and decent diversions. ${ }^{22}$

Very few Indians appeared among the 34,000 residents of the corregimiento-a fact no doubt influencing his favorable opinion of the place.

\section{THE MERCURY MIRAGE}

Dombey spent far less time in the capital than his companions, for once again he received a special assignment. This time he was asked by the regent of the royal audiencia, Tomás Álvarez Azevedo, to examine the quicksilver mines in northern Chile, not far from La Serena. For over a century their history had been one of futility and neglect. Impresarios of silver mines in the north of Chile were 
forced to import their mercury from Peru and Spain, and make a painful journey of nearly three hundred leagues to pick it up in Santiago, across sandy wastes and tortuous mountain trails. Now even this stock was endangered, for the great Huancavelica mercury mines in Peru were declining, diggings at Almadén in Spain could not supply all of America, and frequent wars left shipments to the whims of fortune. The obvious remedy was to awaken the Chilean quicksilver mines from their years of somnolence; otherwise the kingdom of Chile faced "ultimate perdition." 23

Dombey spent three months at the diggings, returning at the end of August, 1783, with a load of ore and optimistic hopes for some forty sites. The climate was moderate, the pasture land abundant, the many trees apt for smelting the ore. Tests he made in Coquimbo and "an imperfect assay" at Santiago in the presence of Álvarez Azevedo further promoted his expectations. ${ }^{24}$

The regent thanked Dombey for his punctuality, his zeal, and his love for the crown. No doubt his official gratitude was the more profuse because Dombey paid all the expenses. These the Frenchman calculated at 3,000 pesos, or two-and-a-half times his annual salary. ${ }^{25}$ And, strangely enough, the Ministry of the Indies could find no record that Dombey ever drew a single penny of the salary due him in Chile. ${ }^{26}$ Although Dombey renounced none of his salary for the stay in Peru, he stresses over and over that he would never accept money from Spain for such additional expenses. ${ }^{27}$

Dombey's part in the quest for quicksilver was done, and his biographers have found cause to pin another medal on his chest. But to properly appraise his work one ought to pursue the issue a short way into the future. Despite the regent's enthusiasm and his promise

23. Summary expediente (no title) beginning "Santiago de Chile, 4 de octubre de 1783 ," pars. 1, 3, 5. AGI, Chile, legajo 387 . See also the printed leaflet, Descubrimiento y progresos de las minas de azogue del Reyno de Chile, in the same legajo. Dombey reported in $178_{3}$ that out of 2,000 mines in the territory of Andacollo, all of them rich, only twenty were being worked for want of quicksilver or qualified laborers. (Summary expediente, par. 24.)

24. Summary expediente, pars. II-I3, I9-2I. AGI, Chile, legajo 387. Dombey's report is itself in the same legajo. See also Dombey to Thouin, Cádiz, March I, 1785. Hamy, Dombey, p. I 21.

25. Summary expediente, par. 11. AGI, Chile, legajo 387.

26. Certificate of Manuel del Campo and Diego Sáenz de Ayala, Lima, Feb. 27, I 784 ; Escobedo to Gálvez, Lima, April 13, 1784, No. 247. MCN. France was not asked to reimburse Spain for any salary accrued during the time in Chile.

27. See esp. Dombey to Thouin, Cádiz, March 1, and April 8, 24, and 27, 1785 . Hamy, Dombey, pp. I19, I21, 122, 148, 150, 159, 165, I66. 
that the Minister of the Indies would learn of Dombey's services to the Spanish Empire, ${ }^{28}$ Álvarez Azevedo was unwilling to risk a fullscale plunge without further assays. He thus asked for studies to be made in both Almadén and Lima, and for a specialist to come from Huancavelica.

Tests at Almadén were a failure. The task next passed to the skilled hands of Joseph and Fausto de Elhuyar at the Seminario de Vergara, but their assays were too inconclusive to prove anything either. Meanwhile, the visitador general Escobedo had set his experts from Huancavelica, including the well-known Josef Coquet, to the job of testing Dombey's samples in Lima. They likewise labored in vain; a new mine discovered at Huarochiri in Peru offered much better prospects than the one in Chile. Escobedo thus thought it useless to send his man to the southern kingdom.

However, a person with some knowledge of mining at Huancavelica, having learned of the frenzy in Chile, had already made his way there. He was Miguel de Ormachea, erstwhile majordomo from the town of Cañete. He recommended that no decision be reached until furnaces had been built at the mine site; Dombey's samples in themselves proved nothing. Álvarez Azevedo was still being pressed by the crown to take action, and thus decided to accept Ormachea's proposal. The regent designated Josef Antonio de Roxas, a resident of Santiago, as his official representative and overseer of the project. ${ }^{29}$ The men left the capital on February 25, I785, to begin their task.

Roxas concluded that the first of two mines Dombey had recommended (Majas de Cabrito) could not be worked because it was filled with rubble. After this sad blow, "which couldn't have been greater," Roxas went to the mine of La Jarilla, where he found only poor-quality ore. Even had the ore been of value, the mine was unworkable. "Thus we were left in one day completely disenchanted by the fatal state of these mines." Further investigation revealed a small vein of rich ore, and the men began the arduous task of clearing water from the mine. But "imagine our confusion," wrote Roxas: nothing conformed to Dombey's optimistic descriptions.

If Don Joseph Dombey had entered the mines, even with very little knowledge of them, he would have seen that the stones he 28. Álvarez Azevedo to Dombey, Santiago, Sept. 4, I783. Ibid., p. 415.

29. Summary expediente. AGI, Chile, legajo 387 , pars. I r, 12, 26, 30, 34, 39, $5^{8-60}, 62$. 
carried out, despite being reasonably good, only proved that there had been ore there, and that they were what had been left attached to the roof or arch of those sites by those who worked them, so as not to endanger the mine by thinning it out too much. He would have seen, wherever water allowed him to reconnoitre, that where the work of the former miners stopped there was no similar ore, nor even any of much less value. He would have informed himself positively, as I have done, that those workings had not been left in operation, which is the same as saying they are exhausted. ${ }^{30}$

But the matter was so urgent Roxas refused to forsake it. At great pains provisions were hauled in. Gangs of men cut their way into the cliffs of La Jarilla. They built furnaces. They expectantly carted out box after box of ore only to have their hopes cut down. Roxas fell ill and said Ormachea was unskilled; couldn't they halt their labors? No, said the regent, for they had found a good vein.

Hopes soared again when the men examined a mine at Punitaqui. New furnaces were built. Ore samples sent to Spain showed a 28 per cent yield; Almadén produced only 24 ! At last the regent's faith would be justified! New overseers arrived, new mines turned up. But somehow the years rolled on. By I 789 Punitaqui alone had cost the crown 25,000 pesos and in fact produced little to show for it. In I 790 came the "ultimate disenchantment." The mines were exhausted; they had been worked with a "lack of inteligencia." It would be far better to forget the sorrowful tale and bring in quicksilver by sea to Coquimbo. ${ }^{31}$

Hipólito Ruiz, apparently unaware of the outcome, needed no proof to be disenchanted. He convinced himself that Dombey had been sent on the mission only because he, Ruiz, was ill. Dombey, he

30. Roxas to Álvarez Azevedo, April 28, 1785. AGI, Chile, legajo 39r, fols. $[1,3-5,7 \mathrm{~V}, 8]$.

31. Summary expediente, pars. $67-72,76,77,80,100,10 \mathrm{r}$, and fols. [58v.-59v., 61-62, 65-65v.]. AGI, Chile, legajo 387. A printed circular of undetermined origin contained in the same legajo states that when Álvarez Azevedo left Chile to become a member of the Council of the Indies "a certain political reason" caused the mines to be abandoned. In 1795-1796 two German mineralogists, Conrad and Christian Heuland, came to Chile under the auspices of the Spanish government to collect minerals for the royal cabinet of natural history and to write a "Physical Geography" of America. They confirmed fully the low state of quicksilver production and the poor prospects for success of the mines at La Jarilla, Majas de Cabrito, and Punitaqui. In 1796 the government opened Punitaqui to private operation, having found that it produced little more than a ton per year. La Jarilla and Majas de Cabrito were evidently worthless. (Agustín Barreiro, El viaje científico de Conrado y Cristián Heuland a Chile y Perú, organizado por el gobierno español en 1795 [Madrid, 1929], pp. 97-98, 105-106.) 
said, lacked the indispensable knowledge of chemistry. Why had the regent given this task to him when there were in Santiago "practical miners" and "many good professors of pharmacy"? 32 The pharmacist Ruiz was obviously jealous. He had even refused the regent's request that one of their draftsmen accompany Dombey to the mines to draw up the desired plans. ${ }^{33}$ Thus another brick was added to the wall of bitterness rising between the two men. Dombey, however, exempted Pavón from thoughts of envy. ${ }^{34}$

There were times when the Frenchman was forced to admire the skill of Ruiz in keeping the expedition in motion. Once, while in Chile, Dombey expressed doubt that any other person could have "fulfilled such an important commission so worthily"-for the men had paid attention to their work, and, in general, had maintained good health. ${ }^{35}$ At bottom, however, Dombey felt he was doing a better job than the Spaniards. Though poorer financially, he flattered himself that he possessed a better collection of specimens. ${ }^{36}$

An incident along the road from Concepción to Santiago-if we may accept Dombey's version-would have been enough to undo any charity he still held out toward some of his companions. He was traveling in the company of Pavón, five days' journey behind the others. When the pair arrived in Talca, so the Frenchman claims, he found himself suspected as a spy who had "maintained a criminal correspondence with the English." He attributed the rumor to the "baseness" of Ruiz and the draftsmen, and states that only repeated affirmations of his loyalty, in the presence of Pavón, saved him from further embarrassment. But, says Dombey, "instead of complaining about such a procedure, I hid it; I never spoke to them about it." Probably the whole incident was a sample of the "bizarre humor" of the Spanish botanists that so annoyed Bordenave. ${ }^{38}$

Once Dombey had gone back to Europe, he carried on occasional polite exchanges with Ruiz, but they fail to hide the anxieties and the strife of these prior years. In a letter from Cádiz on March I3, I 785, in response to Ruiz's expressed good wishes, Dombey pleaded

32. Relación, I, $263,273$.

33. Ibid., I, 273. Alvarez Azevedo to Dombey, Santiago, May 20, I783. Hamy, Dombey, p. 4I3. Summary expediente, par. 10. AGI, Chile, legajo 387.

34. To Thouin, Cádiz, March I, 1785. Hamy, Dombey, p. I 20.

35. To Thouin, Concepción, Dec. 24, 1782. Ibid., p. 94.

36. To Thouin, Santiago, Aug. 20, 1783 . Ibid., p. 99.

37. To Thouin, Cádiz, March I, 1785. Ibid., p. 120.

38. See p. I1 4, above. 
that he be pardoned by the Spaniards for his "faults" and his "quick temper" which was not "rancorous." He had never had the "least desire" to anger Ruiz. Ruiz replied from Huánuco on November I2, I 785 , that he need not pardon an offense, since he had never received one from his dear friend, M. Dombey; rather, Ruiz would take all the blame for past altercations between them. ${ }^{39}$

More difficult to fathom than the Dombey-Ruiz relationship is the Frenchman's financial maneuvering. His official salary was 6,000 livres ( $I, 200$ pesos) a year. Yet he says that he usually spent in South America about 100,000 livres a year. Platinum, gemstones, and archeological curiosities came high. Two servants he had hired in America cost him annually more than he himself received from his government. He even claims spending double his yearly salary merely for the packing cases in which to ship his final remissions to Europe. ${ }^{40}$

Dombey luckily found a number of willing creditors, for he boasted that during two years he could procure ten to twenty thousand pesos (50,000-100,000 livres) "à la minute." His friend Bordenave, for example, had lent him 60,000 livres. Esteban de Urrutia, the supposed freemason, was another obliging creditor. Strangely enough, Dombey claims to have left Peru and Chile free of debt to any person in those realms. He says he refused at all times to take money for doctoring the sick. Regulations forbade him to engage in commerce. Did he do so under cover? Did he really pay his debts? Or is his acquaintance Deleuze correct in surmising that Dombey was a first-class gambler ${ }^{41}$ This is a guessing game that anyone may play.

39. Hamy, Dombey, pp. 28 I-284.

40. Dombey to Thouin, Concepción, Dec. 24, 1782, [Cádiz, Feb.-March, 1785], and Cádiz, April 27,1785; Dombey to De Jussieu, Lima, Nov. 2, 1781, and Cádiz, Feb. 24, 1785. Ibid., pp. 95, 132, 165, 260-261, 277. Mouton-Fontenille describes Dombey's packing procedures as follows: "The cases were double [i.e., each enclosed in another]. When they were mailed, he cut out long and broad strips of oxhide, immersed them in water, and when they were well soaked he stretched them forcibly around the outside cases and fastened them. When the hide had dried out, he gave it another good tug and pressed the cases with great force." Deleuze states that the cases were covered with entire skins, but Mouton-Fontenille says this is not what Dombey told him. (Mouton-Fontenille, Eloge de Joseph Dombey, pp. 25-26.)

41. Dombey to De Jussieu, Cádiz, Feb. 24, 1785. Hamy, Dombey, p. 278. See also Dombey to De Jussieu, Cádiz, May 31, 1785, and to Thouin, Feb. 24, 1785, in ibid., pp. 291-292, 115 . Deleuze ("Notice historique," pp. 145-146) speaks of the women of Lima as passionately fond of gambling. Dombey gave himself over to their amusement in a "noble and disinterested, but attentive manner," and, of all things, won. How singular, comments Deleuze, that "a taste so often ruinous, and 


\section{AU REVOIR, M. DOMBEY}

Despite Dombey's remarks about the general good health of the scientists, he was nearing the end of his usefulness to the expedition. He complained of deafness and dimming eyesight. Scurvy had sapped his strength. His gums were bleeding and he could eat very little. ${ }^{42}$ From reading his increasingly pessimistic letters one almost expects a re-enactment of the sad tale of Joseph de Jussieu. It is thus no surprise to find Dombey turning his thoughts toward home. When the party left Valparaíso for Lima on October I 5, I783, aboard the Señora de las Mercedes, Dombey had done his last botanizing in the Spanish domain. ${ }^{43}$

He had importuned José de Gálvez, the Count d'Angeviller, and the French controller general for his return to Europe long before the expedition had even reached Santiago de Chile. Only the need for peace with England had blocked his way, and now that problem was solved. Nevertheless, Dombey faced a new barrier when the party reached Lima on November 3, I 783: namely Jorge Escobedo, the visitador general. This illustrious gentleman, who had been sent to Peru to establish the intendancy system of administration, straighten out urgent financial problems, and restore order after the rebellion of Tupac Amaru, was a potent force to contend with.

Dombey needed Escobedo's approval to clear his collection of minerals for shipment to France. Momentarily, his record of good relations with Spanish officialdom tottered precariously. We cannot know for certain what happened during the meeting of these two hypersensitive men, but Dombey insists the official insulted him. In reply-and once again there is only Dombey's side of the story to recount-the Frenchman assured Escobedo, in a manner "not lacking in respect," that he was an envoy of the French government whose status was "a good bit more to be respected" than Escobedo's. The

almost always opposite to that for study," had provided the means for Dombey's purchases of specimens of natural history! Álvarez López ("Dombey y la expedición al Perú y Chile," Anales del Instituto Botánico A. J. Cavanilles, XIV, 63-64, 67) rightly asks whether this is a sufficient explanation for Dombey's extramural income. 42. Dombey to Thouin, Concepción, May 26 and Dec. 24, 1782, and Santiago, Aug. 20, 1783; Dombey to Mme du Gage, Santiago, Aug. 20, 1783. Hamy,

Dombey, pp. 89, 96, 98, 268 .

43. Ruiz, Relación, I, 282. 
visitador is said to have replied, “And suppose I don't allow you to go home? What revenge would you take then?" To which Dombey retorted, "I would already have pierced your heart, but since it is up to the king of France, who will be told everything, to order you punished, I can rest easy." This firmness reputedly had its effect, and on the following day Escobedo was more indulgent. ${ }^{44}$

The idea that Dombey intimidated Escobedo is hard to accept. Only two months before, Viceroy Jáuregui had sent Escobedo a royal order of December 25, I 782, permitting Dombey to ship his boxes to Europe, platinum included..$^{45}$ Dombey attributed the supposed attitude of the visitador to the prodding of Gómez Ortega, and indeed the latter was under the impression that Dombey had agreed to stay in America for one more year. ${ }^{46}$ In fact, on October 22, I 783 , after the French government had already asked for his return to Europe, Dombey was named a corresponding member of the new botanic garden in Madrid, with all the "prerogatives and exemptions enjoyed by professors of medicine, surgery, and pharmacy." His duty was to report in detail from time to time on the Peruvian plants worthy of cultivation in Madrid. The puzzle of why Dombey was chosen for this commission is only exceeded by the question of why Ruiz and Pavón were not. ${ }^{47}$ It is true, however, that the Spaniards genuinely feared that Dombey, once in Europe, would get his "Flora Peruviana et Chilensis" into print first. ${ }^{48}$ Even so, the Frenchman did receive permission to return home and to take a wide variety of specimens valued at nearly five thousand pesos. ${ }^{49}$ But four days

44. Dombey to Thouin, Concepción, Dec. 24, I782, and Cádiz, March 1, 1785.

Hamy, Dombey, pp. 95, 122.
45. Jáuregui to José de Gálvez, Lima, Sept. 16, 1783. AGI, Indiferente General, legajo 1550.

46. Dombey to Thouin, Cádiz, March 1, 1785. Hamy, Dombey, p. 122. Also, Gómez Ortega to Gálvez, Madrid, Sept. i 8 , 1784 . MCN.

47. Josef Pérez Cavallero, intendant of the botanic garden, to Dombey, Madrid, Oct. 22, I783; Comte de Montmorin, French ambassador to Spain, to Gálvez, San Ildefonso, Aug. 26, 1783 . MCN.

48. Dombey spoke of a desire to publish in letters to Thouin, Concepción, Dec. 24, 1782, and Cádiz, April 8, I 785. Hamy, Dombey, pp. 96, 149. See chap. X, below, for a detailed treatment of this problem.

49. Dombey to De Jussieu, Santiago, Aug. 20, I783. Hamy, Dombey, p. 266. Dombey had to pay the usual "fifth" to the crown. (Ibid., p. 426.) He was able to remit such items as 160 pounds of platinum; a "superb piece of corneous black silver weighing 7 to 8 pounds" from Copiapó, Chile; "several beautiful stones ... that expose, when one breaks the stone, tree-like crystallizations of silver and copper mixed to form a magnificent sight"; "superb pieces from the gold mine of Petorca [Chile] of which one alone weighs 100 pounds"; about 25,000 francs of silver from 
before Dombey was to sail, Ruiz warned Minister José de Gálvez in the most vigorous terms:

The eagerness that I have recognized in M. Dombey to magnify his work even at the cost of my labor, and to hurry up and print it under his name, has obliged me to double my vigilance to enlarge and perfect my own, without neglecting a detailed index. I am convinced that with an opportunity to publish, our monarch will in no wise wish to award France the glory of printing first, all the more since our nation has so few [works] of its kind, and has spent and is spending so much for this cause. Ours, in comparison with M. Dombey's, is much superior, not only because the drawings go with it, but because his is less orderly; and although he has inserted in his descriptions many of mine, I have achieved, as far as I'm concerned, better "incubation."

This explanation and the effort that he has revealed to finish and correct his from mine, makes me fear also that by some pretext he will manage to get hold of my work there [in Spain]. Thus it doesn't seem vain to me to warn Your Excellency to take care and not entrust it to a printer who is not loyal. ${ }^{50}$

Dombey embarked for Cádiz on April I4, I784, aboard El Peruano-the same vessel, with the same captain, that had carried the scientists to the New World more than six years before. He again received free passage, a "magnanimous" offer saving him i 5,000 livres, at which he never ceased to marvel. ${ }^{51}$ All seventy-three cases of his collection went with him: minerals, 2 I boxes; dried plants, I 8; tree fragments, 4; seeds and bark, 3; cones from the Chilean pine, I; archeological relics, I2; petrified bones, I; birds, I; fish, I; green sand (atacamite) from northern Chile, 2 ; and miscellaneous specimens such as shells, rubber, earth suitable for dyes, and a collection of curiosities from Tahiti. ${ }^{52}$ Despite this mass of materials, Dombey regretted his inability to satisfy all of his desires: "I would need Mr. Banks's fortune and his knowledge to put my voyage to profit; then I would need a vessel in which to ship all my collection and I would be in charge." 53

Huantajaya, and many samples of gold, silver, copper, and mercury from Coquimbo, Santiago, Concagua, Potosí, Tarma, Huamalíes, Cajamarca, and other provinces. (Dombey to Thouin, Rio de Janeiro, Aug. 14, 1784. Raison des effets contenus dans les 2 I caisses...., Feb. 4, 178I. Raison des objets d'histoire naturelle et des curiosités contenues dans les 73 caissons .... Ibid., pp. 108, 425-427, 427-428.)

50. Letter of April xo, 1784 . Relación, I, 458.

51. Dombey to Vergennes, Rio de Janeiro, Aug. I4, I784. Hamy, Dombey, p. 274. Dombey to Gálvez, Rio de Janeiro, Aug. 14, I 784 , and Cádiz, Feb. 24 , I 785.
MCN.

52. Hamy, Dombey, pp. 425-428.

53. To Thouin, Rio de Janeiro, Aug. 14, 1784. Ibid., p. I09. 
For a sick man, Dombey had chosen the wrong time and the wrong route to go home. Passage around the Horn was severe. Death seemed imminent. Dombey thought he might lose his mind; but instead, he lost only his hair. He tells how thirty-two of the passengers and crew, victims of scurvy, were buried at sea and seventy-two went to the infirmary. Dombey had to fight off dysentery. The ship's steering mechanism broke and no one wanted to brave the cold water to fix it. So, says the Frenchman, he offered a reward that induced a dozen men to spend five minutes each in the water. Finally the ship hobbled into Rio de Janeiro.

While El Peruano underwent repairs, Dombey spent three months in the Brazilian city. The generosity of the viceroy and the politeness of the people made the visit more pleasant than expected. There was a "tone of elegance that one doesn't find in any of the colonies" Dombey had previously visited - a result of the English influence, he explained. Heavy rains prevented much serious botanizing, but the Frenchman had a field day anyway, trying to decide how to allot his limited funds for the purchase of curiosities. He acquired an aquamarine "the size of a pigeon's egg," a small sapphire, two tiny topaz stones in two colors, a collection of wood, and "two superb pieces of transparent rock crystal that contain another crystallization inside which seems to resemble sewing needles." For the last item he paid six ounces of gold, having been told the crystals were originally intended for the king of Portugal. Dombey was also thrilled to acquire a piece of "gomme élastique" for the Académie des Sciences, "so as to contribute a bit toward a trip in the air." How convenient it would be for botanists, he mused, if the aerial balloon were perfected. ${ }^{54}$

El Peruano was again ready for the high seas in November, 1784 . Finally, on February 22, 1785, it rode into the Bay of Cádiz, ${ }^{55}$ where a new saga of frustration was about to begin.

54. To Thouin, Rio de Janeiro, July $I_{3}$ and Aug. 14, I784, and Cádiz, March I, 1785 . Ibid., pp. 102-106, 127 .

55.Ibid., p. I 14. 


\section{FOUR YEARS IN THE}

\section{PERUVIAN BACKLANDS}

\section{AN EXTENSION MEANS "GREATER RICHES"}

If the Spanish botanists hoped to exhaust the bottomless barrel of floral goodies in the montaña of the Marañón, they could not think of returning to Spain. The Tupac Amaru rebellion was crushed, the mock raid at Cuchero a cause for amusement. No longer need they go to Quito, for the Mutis expedition had taken charge there. The increased experience of Ruiz and Pavón promised "greater riches without the least doubt" - and more knowledge of quinine in particular-if only they could re-enter the Peruvian forest. All they needed was permission to go.

The men began pleading with Escobedo long before the end of their stay in Chile, but he hesitated. "You recognize and I confess," he wrote them on July 2I, I783, "that the immense scope ... of your profession is boundless." He need have had no fear, however, of granting an extension, for the crown did not object. A royal order of September IO, I 783 , told the botanists to "continue for the time they need to study what they have not yet examined in that South America." There was even talk of sending them to the viceroyalty of La Plata. The order mentioned no deadline, but the visitador must "exhort" the men and "see that they take advantage of the time." "2

1. Ruiz, Relación, I, 451. The botanists were ordered in late $178_{3}$ to let Mutis know of their discoveries and observations. At that time there was apparently still some thought of sending Ruiz and Pavón to Quito, provided Mutis agreed, but obviously nothing came of the matter. (Gómez Ortega to José de Gálvez, Madrid, Oct. 21, I 783 ; royal order to Escobedo, San Lorenzo, Nov 21, I783. MCN.)

2. Escobedo to the expedition, Lima, July 21, 1783. MCN. This document shows that the botanists asked Escobedo for an extension on March 25, 1783, while still at Concepción. They wrote also to José de Gálvez from Concepción on March $2_{3}$, and repeated their request from Santiago on September 12, 1783 . Ruiz, Relación, 
But with communication limited to the speed of sail, though the crown had given its blessing, no one in Peru knew of it. When the expedition returned from Chile in November, 1783, there was of course no word. By mid-February, 1784 , the scientists were disconsolate. They needed money and sold all of the supplies they had optimistically bought for another excursion. When, finally, news of the extension arrived on February $2 \mathrm{I}$, they had to buy everything anew. The visitador-usually a reluctant spender of government funds-sympathetically gave them 2,000 pesos for "equipment, peons, and packing," but balked at their request for a pay increase. As an alternative, he allowed them their old "double salary" even while they stayed in Lima-a privilege usually reserved for work in the field. This would "stimulate them to labor with application and enthusiasm," though he assured the king they would not receive the additional pay without "antecedent merit." It must be said that the monarch confirmed Escobedo's actions in every case. ${ }^{3}$

Before undertaking new exploits, the men had to prepare the specimens from five years of collecting for the voyage to Spain. By May 4, I 784, the visitador could report that the preciosidades were on their way, aboard the San Pedro de Alcántara. José de Gálvez replied to this word that His Majesty was "very satisfied with the application and constancy with which these professors have gone about fulfilling their commission" and was awaiting the arrival of the specimens "with anxiety."

I, 446-447, 451. The royal order of Sept. 10, 1783, from San Ildefonso, is in MCN and in Archivo Histórico de Hacienda (Lima), libro 900, fol. 19. It should be noted that this order was in reality only a confirmation of Escobedo's extension of the botanists' stay until November 30,1783 . But because of its indefinite terminology it left the way open for further extensions. See also marginal comment of Sept. 4, 1783 , to letter of March 23, 1783, from the expedition in Concepción to Gálvez; crown to the expedition, San Ildefonso, Sept. 10, 1783. Ruiz, Relación, I, 447, 450.

3. Ruiz, Relación, I, 283, 285. Archivo Histórico de Hacienda (Lima), libro 900, fols. 19, 28. Escobedo to José de Gálvez, Lima, April 13, 1784, Nos. 240 and 241, and May 10, I 784, No. 264; Gálvez to Escobedo, San Lorenzo, Nov. I8, 1784 , and El Pardo, Jan. 31, 1785. MCN. Ruiz and Pavón had also received a 3,000 peso grant in Chile to cover extraordinary expenses. See letter No. 24 I cited above. Escobedo did not have to feel hesitant, for the crown on November 21, 1783 , from San Lorenzo, had authorized him to regulate any increase in the botanists' expense account in order to "inflame their zeal for the best advancement of their profession." (MCN.) See also Carlos A. Romero, "Algunos documentos sobre la misión geodésica francesa de 1736," Revista histórica (Lima), X (1936), i 16, for other documents on the pay of Ruiz and Pavón.

4. To Escobedo, San Lorenzo, Nov. 18, 1784. Archivo Histórico de Hacienda (Lima), libro 900, fol. 24. 
The shipment totaled fifty-five cases, containing dried plants, seeds, and wood; bits of gold, silver, and copper; preserved animals, birds, and fish; shells, stones, and earth; and utensils and clothing of the Indians. Plant drawings totaled I, $\mathrm{OI} 3$, of which more than eight hundred were new. The rest had been re-executed when it was thought in I 780 that Spain would never see the cargo of the Buen Consejo again. Ruiz decided, because the danger of loss was still high, to turn the two folio tomes of plant descriptions over to the visitador Escobedo for personal transmittal to Spain whenever that worthy should finish his task in Peru.

Ruiz could not renounce sending living specimens to Spain. The botanists prepared six stoves containing thirty-one tubs of trees and shrubs, and entrusted them to one José Jacobeli, who, being "intelligent and overcareful," was supposed to watch them during the voyage. For this service they paid him fifty pesos. At least as much depended, however, upon the weather, the supply of water, and the interest of the captain, as on the intelligence and overcarefulness of Jacobeli. Seventeen little Chilean pines and a selection of pine cones formed a choice part of the collection. There were four species of bananas, three avocado trees, various cedars, four guavas, three plums "that they call the friar's," the guaiacum, five "little cherries of Lima," two cocoa trees and one of coffee, two of quinaquina, three soapworts, three aromatic myrrh trees, two of ginger, four cassias (senna), the Chilean peumo, two lucumos, two walnut trees, the mammee, the calaguala root, and other specialties. ${ }^{5}$ A small box of seeds, a container of bulbs, and a package of quinine extract rounded out the shipment.

\section{POZUZO: TWO MONTHS FOR A CENTURY}

When the party again took the high road toward Huánuco on May I2, I784, the weight of responsibility hung heavily to make this "the greatest year yet." During the journey, however, illness held Ruiz to almost a crawl. But a month's rest in Huánuco during June must have restored his energy, for on July 8 he left the city,

5. The taro, tutumo, planta hedionda, suche, palillo, pacae, achote, tumbo, rosa de la china, manta de Otaheti, lancha jaravisco, huighan, and árbol de las cuentas. (Ruiz, Relación, I, 283, 457-460.) 
ahead of all his companions, to guide a pack train of twenty-one animals to the new jungle site of Pozuzo.

The clangor of church bells, the smile of a lonely missionary, and the interested stares of the fourteen "poor and miserable" residents greeted Ruiz as he entered Pozuzo on July 19, 1784. He was now forty-five leagues east-southeast of Huánuco, on the far side of the eastern cordillera of the Andes, where his companions joined him within three days.

Fortunately, a fascinating display of plant life offset their disgust at this "unhappy pueblo." Ruiz found the natives "loathsome," "ugly," and "passionately fond of chicha [a fermented beverage] and Venus." Because no local foodstuff pleased their European taste, the scientists had sent in fifty sheep for a meat supply. But jungle growth left no room for pasture and the starving animals became "as transparent as parchment or lanterns." On the other hand, the variety of trees, shrubs, and plants was so great, a relay of botanists "could hardly examine them in a hundred years."

The scientists substituted two months of hard work for the impossibility of a century's labor, and by September 27 , when they went back to Huánuco, Ruiz had tallied 400 descriptions, 3 I 4 dried specimens, 300 drawings, and 250 corrections of descriptions made previously elsewhere. Though the impenetrability of some parts of the jungle and "the fear of jaguars, bears, wild boars, tapirs, and other animals" limited their explorations, the stay at Pozuzo must have seemed more like a century than two months:

Many days we went on foot four to eight leagues through the forest, returning most times to the pueblo at night, cut to pieces by the thorns and branches, choked, thirsty, and worn out, but loaded down with beautiful plants. Not a few times we escaped death from the frequent and sudden falling of old trees [and] the landslides of rocks and earth that followed, especially after a rain, and other times from the destruction wrought by the felling of big trees that our peons cut for us to examine. So as to work here we left Pozuzo almost naked, our legs and arms broken out into pimples that attacked us after our daily botanizing. Our fingernails weren't enough to scratch with, so we brought out some instrument with which we slaughtered ourselves, unable to find any other remedy to guard against this humor than several days' rest, and the refreshment given by lemonade. ${ }^{7}$

6.Ibid., 1, $285^{-290,292,305 . ~}$

7.Ibid., I, 290-29I. 
Try as they might, suffer as they might, the botanists unavoidably missed the flowering of many exotic species. So it was with the star reed or bejuco de la estrella (Aristolochia fragrantissima Ruiz). After discovering it in Pozuzo, Ruiz tried for two years without success to find it in flower or in fruit. He had heard of its esteem among the Indians as a cure for dysentery, inflammatory malignant fevers, rheumatic pains, colds, insect and reptile bites, and "weariness of the body." and its "exquisite camphorous, balsamic and bitter flavor" excited in Ruiz "the most lively wish" to acquaint himself with the plant.

To test its properties, Ruiz sent stalks and roots to his friend "the celebrated Dr. Cosme Bueno" in Lima. Bueno returned not only "repeated thanks" but an "intimation" that the new plant was a more efficient and certain remedy than the so-called Virginia snake root. That possibility intrigued Ruiz, who was naturally eager to attach economic value-and competitive value-to any of his discoveries. Later, after analyzing for himself a batch of the English product, Ruiz even warned that its use was potentially dangerous: in a fourpound shipment he found twelve ounces of earth, six ounces of unknown roots, and six ounces of black and rotten roots! The bejuco of Peru, on the other hand, was subject to no such adulteration. The stalks and roots were so large the bark could easily be separated from the useless woody part or from other plants, which was unfeasible in the case of the snake root.

Shortly before leaving for Spain, Ruiz noted that chewing on the bejuco produced an "abundant and viscous saliva," which he thought might be helpful in combating a toothache. When experimentation on frequent sufferers had confirmed his view, Ruiz turned over a quantity to González Laguna. "So many persons daily flocked to the cell of this friar," Ruiz happily announced, "that in a short time the packet of Star-reed was consumed," and the father was asking for more. When Ruiz left for Spain, a second supply was likewise gone, "a proof," says the botanist, "of its virtues as an adontalgic."

8. Hipólito Ruiz, "Memoir on the Virtues and Uses of the Plant Called in Peru the Star-Reed (Bejuco de la Estrella)," in Lambert, Illustration of the Genus Cinchona, p. 15 ז. "Memoria sobre las virtudes y usos de la planta llamada en América Bejuco de la Estrella," (summarized in Variedades de ciencias, literatura y artes [Madrid], III [1805], 62.) Even the missionaries confirmed, said Ruiz, that drinking a brew of the bark brought on copious sweating for three days, and the patient was back at work on the fourth, "without the least contrary result." (Relación, I, 304.) 
Finally-perhaps best of all!-Ruiz found that keeping a piece of bark in the mouth prevented, through "its pungency and fragrance," the "perception of the bad smell and putrid miasmata peculiar to the breath and perspiration of some persons."

Father González Laguna, by planting some of the roots in his garden in Lima, demonstrated that the plant bloomed in January and February, a season when rains made the montaña almost inaccessible. But if the flower of the star reed had been a virtual will-o'-thewisp to the frustrated jungle searcher, other plants almost shouted for notice during their brief moment of glory. Thus, on the morning of September 17, I 784, when the botanists peered from their hut, they gazed in wonder at the snow-draped hillside across the river from Pozuzo. The phenomenon turned out to be shrubs of Bignonia alba (= Macfadyena bracteosa [DC.] Benth. \& Hook.), their leaves entirely fallen away, flaunting a garment of huge blossoms. Two days later hardly a flower remained, and in their stead grew tender fruits. ${ }^{10}$

In May, I785, Escobedo remitted to Spain, aboard El Dragón, sixty-six living plants of twenty-nine species, but, true to the luckless tradition, none of them survived the journey. ${ }^{11}$ Even so, the two months at Pozuzo had been among the most productive of the entire expedition. But in the next eight months, from October 7, I784, to June IO, I 785 , the men scarcely ventured beyond the city of Huánuco. Several reasons help to explain this immobility: summer rains in the jungle, the burden of preparing the latest acquisitions for shipment, and a new illness that struck Ruiz down for over a month.

$$
* * *
$$

Official documents reveal little of the botanists' personal lives. But now and again a chance discovery ever so slightly lifts the

9. Ruiz, "Memoir on ... the Star-Reed," pp. 151-153. "Memoria sobre... Bejuco de la Estrella," pp. 60-62. Ruiz, Relación, I, 303-304.

10. Ruiz, Relación, I, 299-300. This tree is one of the few in that area to shed its leaves. Ruiz also located Smilax China L., a root known to the Japanese and Chinese, and used by the Indians to settle the nerves and counteract poisons. Gómez Ortega recommended to Gálvez that the viceroys promote its remission zealously, for the root was unanimously endorsed by the physicians of Europe. Ortega planted some of Ruiz's seeds in Spain. (Ruiz to José de Gálvez, Huánuco, Nov. ix, 1784 ; Gómez Ortega to Gálvez, Madrid, June 27, 1785. MCN.)

II. Ruiz to José de Gálvez, Huánuco, April ix and May I1, 1785; Escobedo to Gálvez, Lima, May 5, I785; Josef Jordán y Acosta, passenger on El Dragón, to interim president of the Casa de Contratación of Cádiz, Oct. 27, 1785; statement of Miguel Soler, warehouse guard of the Consulado at Cádiz, Nov. 25, 1785. MCN. 
curtain on that hidden half of the story. Thus, tucked amidst the pages of a manuscript volume of the botanical descriptions of Ruiz and Pavón is a plaintive letter, dated at Huánuco on what appears to be January 2I, I809. It is signed "Mercedes Pabon" and addressed to "Sr Don José Pabon ... My most esteemed father and my Señor." Though much of the letter is illegible it is obviously from a daughter who "knows, other than God, no father but you." She prays unceasingly for her parent's good health, but laments, "It is possible that you have so much forgotten me that, despite four letters [from me], you do not deign to write .... We are suffering the greatest needs there are in the world." Mercedes, conceived during one of those long sojourns in Huánuco, would now have been an adult. Did this missive encounter the same neglect as the others? Our romantic nature will have to be content with visions of the botanist slipping the letter between the sheets of an old manuscript volume, where it lay untouched for a century and a half until found by the present author. ${ }^{12}$

\section{THE ADDING OF THE AGREGADOS}

The botanists faced two new problems during this present long interval in Huánuco. First, they learned that all of the living plants aboard the San Pedro de Alcántara had been lost in a storm off the Chilean coast, though at least the other 53 cases were safe. ${ }^{13}$ This meant a search for replacements, except for such now inaccessible gems as the Chilean pine. Second, the botanists faced the most time-consuming task of all-to teach two novices the principles of botanizing and sketching of plants literally "from the ground up."

Though Gómez Ortega had felt that this year of study in Peru "would bear more fruit" for Ruiz and Pavón "than all the previous ones," the men should then return straightway to Spain "without

12. Found among "Manuscritos Botanicos de Descripciones Originales hechas en el Peru desde el año de 1778 por $\mathrm{D}^{\mathrm{n}}$ Jose Pavon y $\mathrm{D}^{\mathrm{n}}$ Hipolito Ruiz" in the Jardín Botánico de Madrid. The disconnected nature of the correspondence may have been partially the result of the Napoleonic invasion of Spain.

13. Statement of Gaspar de Amenavar, Talcahuano, Aug. 18, I784; Viceroy Teodoro de Croix to José de Gálvez, Lima, Oct. 5, 1784, No. 84, and Gálvez's marginal note of April 14, 1785 ; Ruiz to Gálvez, Huánuco, Nov. I I, I784. MCN. The crown ordered Ruiz in the future to divide his remissions among several ships so as to lessen the risk of loss. (Gálvez to visitador general, Aranjuez, April 8, and to viceroy, April I 5, 1785 . MCN.) 
persisting in new journeys by land." Ortega advocated that the expedition take along on its next foray into the jungle "one or two youths," who would learn how to do the work and continue it when the botanists had gone back to Spain. Besides adding to the number of specimens, these new men could answer the questions of Ruiz and Pavón as they readied their notes in Spain for publication. ${ }^{14}$

The crown approved on March 7, 1784, and the visitador found the two replacements-the agregados, as they would be called-among the ranks of the Soria regiment stationed at Lima. Juan José Tafalla (I755?-I8II) and Francisco Pulgar were true neophytes in the art of botany. But they bore the recommendation of Father González Laguna as the best available for the task, and Tafalla, about a year younger than Ruiz and Pavón, had indeed been a pharmacist of sorts in Navarre, and Pulgar a painter in Toledo. Their annual salary was fixed at 600 pesos corrientes each. ${ }^{15}$

It upset Ruiz that only one botanist was added. Two were necessary, he said. If a choice must be made, there was less need for a draftsman than a botanist. There was no use, he explained, for a skilled artist to draw a plant without a skilled botanist to advise him. If something should happen to Tafalla, the expedition would collapse. ${ }^{16}$

14. Gómez Ortega to Gálvez, Madrid, March 1, 1784. Ruiz, Relación, I, 453454. Dombey, in one of his many diatribes against Gómez Ortega, claimed that
the latter had kept Ruiz and Pavón in Peru only in order to enhance his own reputation: "Ortega will have the honor to present to the king of Spain the work of these unfortunate men, will receive the reward which is their due, and they will die victims of the bad faith of their master." (To Thouin, Cádiz, March 1, 1785. Hamy, Dombey, p. 126.) While it will later become clear that Dombey had reason to be suspicious of Ortega (see p. 167), in this instance the Frenchman was overworking his imagination.

15. Oficio por el cual se prorroga la misión, El Pardo, March 7, 1784. Ruiz, Relación, I, 455-456. Escobedo to José de Gálvez, Lima, Jan. 5, I785, No. 390. MCN. The visitador notified Ruiz and Pavón about the replacements on October 29, 1784; they received the letter on December 14, 1784. Copy of Ruiz et al. to Escobedo, Huánuco, Jan. x, I785. MCN, 1787. The crown approved the appointment of the agregados at Aranjuez on June 16, 1785. See Ruiz, Relación, I, 464466,470 . Tafalla's birth date is calculated from a deposition he made on December 10, I 785 , to the effect that he was thirty years of age. See "Causa Criminal seguida por los Profesores Botanicos de S.M. contra Don Matias Trauco," AGI, Lima, legajo 677, No. $36 \mathrm{D}$, printed in Anales de la Real Academia de Farmacia, XXI (No. $3,1955), 265$.

16. A present-day student of art puts a somewhat different emphasis upon the skill of a plant painter: "Only those who have attempted to draw flowers can appreciate what restless models these can sometimes be-how quickly petals open and stems curve. Further, the colour of many flowers is so dazzling that at the best it can only be approximated in paint. Moreover, the botanical artist finds 
More serious still was Tafalla's lack of experience. He knew no Latin, for example. Even a "semi-philosopher" (medio filósofo), thought Ruiz, could not learn the necessary science in so short a time as that left to him in Peru, and Ruiz did not want to take the blame for Tafalla's mistakes.

But he was unable to wheedle more manpower from the visitador, and gladly admitted by April, I785, that the agregados were doing fine. He even began to urge that their annual salary be increased to I,, 000 pesos. But Escobedo, having given the senior botanists another I,ooo-peso grant-in-aid, was reluctant to dip further into the treasury until the new men had really proved themselves. Instead, he settled on a 200-peso grant-in-aid for each one, so that they might prepare for their first trip into the dense montaña. ${ }^{17}$

\section{HOLOCAUST OF THE MANY-HEADED MONSTER}

With the coming of June it was time for baptism of the agregados -for submersion deep in the tropical forests northeast of Huánuco. The botanists had once fled in panic from the region during a falsely reported Indian raid, and they now searched carefully for a new home. By mid-month they had settled at the hacienda of Macora, whose administrator agreed to furnish some foodstuffs and to enlighten the men on the vegetation in his domain.

But things did not go smoothly. The senior artists, fed up with frontier life, began to complain of illness. Ruiz, his legs a mass of blotches, grunted with scorn. The draftsmen did not look sick to him. They had in fact escaped real torment "by not going out into the field as we [botanists] do, nor sharing in the continuous fatigue, falls, blows, heat, thirst, hunger, inclemencies of weather, and the

himself at once and always in a dilemma: is he the servant of Science, or of Art? There can, I think, be no doubt that he must learn to serve both masters. The greatest flower painters have been those who have found beauty in truth; who have understood plants scientifically, but who have yet seen and described them with the eye and hand of the artist." (Wilfrid Blunt, The Art of Botanical Illustration [London, 1950], p. 3.)

17. Ruiz and Pavón to Escobedo, Lima, Jan, I, 1785 , and Huánuco, April I I, 1785 ; Escobedo to the botanists, Lima, Feb. 20, 1785; Escobedo to José de Gálvez, Lima, May 5, I785. Gálvez to Escobedo, San Lorenzo, Oct. I I, I 785 , approved the visitador's actions. $\mathrm{MCN}, 1787,1785$. 
havoc we suffer on account of the ruggedness and roughness of those brambly jungles."18

Now the illustrators began to hurry their work. They called for "two, three, and even four" plants a day. Contrary to orders, they insisted on sketching the branch or whole plant first, before undertaking a detailed drawing of the parts of the fructification. As a result, because of the short life of some of the fruits, there was no time to present these vital parts properly. "Although they were reprimanded for the small degree of accuracy in their work," Ruiz recalls, "they answered that they did not know how to do it better."

Then one day in early August Ruiz suddenly understood these tactics. To his surprise and consternation, a group of mule tenders arrived to take the artists back to Huánuco. The "mutineers" justified their departure on the grounds that too little work was left to be done. To Ruiz, with visions of new plants running on to infinity, this was sheer nonsense, but all he could do was stomp off in anger. The next morning, August 6, I 785, when the draftsmen started back to Huánuco, Ruiz was already at work in the woods, his eyes, if not his thoughts, far removed from the ill-humored scene of departure. ${ }^{19}$

A calm settled over the hacienda. ${ }^{20}$ Pavón tried to relax, his skin burning and his muscles weakened by mal de Mayco, caused, it was said, when he forgetfully lay in the shadow of a Rhus decandria. ${ }^{21}$ Tafalla bent over his plants in the workroom, and three peons puttered about the house. Outside the sun began to beat upon the thatched roofs of the little settlement, though a breeze stirred through the trees. The administrator of the hacienda, Matías Trabuco, ${ }^{22}$ gathered up two Indians and began his day's duties.

It was August, and time for a new phase of the endless battle against the jungle. Every year, before planting of coca or corn could begin, the undergrowth that constantly assailed the fields had to be cleared away. First an aisle was hacked through the trees and brush,

I 8. Relación, I, 309-3 II.

I9. Ibid., I, 312 .

20. The following details are synthesized, unless otherwise indicated, from the testimony contained in "Causa Criminal," Anales de la Real Academia de Farmacia, XXI (No. 3, 1955), 26r-285, and (No. 4, 1955), 357-384.

21. Ruiz to Gómez Ortega, Huánuco, Sept. II, 1785. MCN, I785 y I 786. Rhus is a genus of sumac, some of whose species have poisonous properties, including the well-known poison ivy and poison oak.

22. The correct appellation of this individual is as confusing as are all other aspects of the case. He is referred to as Trauco perhaps more often than as Trabuco, and both names are sometimes used even in the same document. 
and the dead trunks and branches left to dry out. At Macora that was already done. Now the gap must be cleared by burning. Trabuco set fire to the brush and, satisfying himself that everything was under control, went inside to enjoy some refreshment.

Suddenly Captain Agustín Ruiz, maestro de campo of the hacienda, who lived with Trabuco, appeared at the door of his quarters and let out a shout. The fire had jumped to the roof of the botanists' house and was licking at the straw. The occupants leaped into action; even the disabled Pavón found new strength. He hurried outside with part of his plant collection and dashed in again to aid the others in a helter-skelter rush to save their belongings. There was no time to think of priorities. Take this trunk! Take that mattress! Watch out for the roof! As Pavón hastened out for the third time, a campaign tent erected inside the house as protection against the rain collapsed in flames, scorching his leg. One of the botanists' three parrots managed to escape with its feathers singed. Seconds later the roof fell in. Nothing more would be saved from that holocaust.

When Hipólito Ruiz rounded the hillside at five o'clock and saw the "absolute volcano" spread out before him, he scrambled madly in its direction. "I don't know why I didn't lose my mind," he later wrote.

With no consolation in my heart, I recklessly entered the fire where I knew my papers to be, but all was in vain. Circumstances forced me to get out, for the fire was still alive. Going half-crazy, I wanted to kill myself. But finally, overcome by rushing around and shouting, I fell on the ground at midnight exhausted. ${ }^{23}$

Ruiz tells pathetically how he rescued fragments of the drawings of Tournefort which had fused with the pewter from his battered inkwell.

The men spent a cold and fitful night in the garden, while thunder rumbled and the tropical heavens unloosed a torrent. In the morning Ruiz again rummaged through the ruins, but all he could save was his silver chamber pot, now melted beyond use, and five plates, one saucer, one pitcher, and his spurs. Gone were twenty boxes of specimens collected in the past two months; diaries compiled for more than three years; three folio volumes of botanical descriptions, covering a period of four years and including six hundred corrected descriptions of previous finds; books by Linnaeus, Tourne-

23. To Gómez Ortega, Huánuco, Sept. I I, I785. MCN. 
fort, Murray, Plumier, Löfling, and Jacquin; botanical presses, paper, a half-dozen saddles and other riding equipment, guns and sabers, a two-month supply of food; and nearly all the clothing the men had brought from Huánuco. Twenty-two mule loads gone up in smoke! ${ }^{24}$

They had not traveled lightly. Witness the clothing Ruiz had brought to this distant outpost: five suits, including one of silk; three pairs of velvet breeches and seven more plain white ones; two dressing gowns; sixteen pairs of stockings, including four of wool and two of silk; fourteen shirts; two new black hats; two silk hair nets; twelve pairs of shoes; a fine cotton cloak and two others of leather; six sleeping caps; six ties; four handkerchiefs; and some cloth leggings. In addition he carried three pairs of sheets, four hand towels, eight napkins, four tablecloths; a chintz bedspread, two pillows, four pillow cases, a sleeping bag; a china washbowl and mirror; a bottle case with glass flasks, liquor, and a demijohn of wine; a musket and ammunition (Pavón had two pistols); cooking utensils; twenty-eight reams of paper; baling wire; a box of tools; two campaign tents; and books by "some authors to occupy some spare time."

The saddened victims put their salvaged belongings between strips of canvas and in three hampers, and departed on foot. Commandeering a mule here and a saddle there-and not forgetting to gather an occasional plant which they placed between sheets of half-scorched paper-the botanists finally straggled into Huánuco on August I2, I 785.

But the drama of Macora was far from played out. Still unaccounted for was the strange behavior of the draftsmen. They had left Macora on the very morning of the fire and could not have been far from the scene. Ruiz, in fact, states in an early draft of his Relacion that the painters were urged by a neighboring hacendado to return and aid their companions, but they refused to be "moved by compassion." In subsequent drafts, however, all reference to the illustrators is deleted from Ruiz's description of the fire. ${ }^{26}$

24. The fire also destroyed a nearby garden in which rare specimens were being grown. Pavón and his companions saved a total of eight loads. (Ruiz to Escobedo, Huánuco, Sept. I I, I 785. Anales de la Real Academia de Farmacia, XXI, 266-267.)

25. Of their foodstuffs the men lost twelve large cheeses, eighteen boxes of sweets, four sacks of hardtack, two baskets of fresh bread, a block of salt and a loaf of sugar, rice, chickpeas, raisins, oil, vinegar, spices, a sack of vetch, three demijohns of wine and aguardiente, two sacks of potatoes, twenty-five pounds of lard, and a supply of jerked meat. (Ibid., XXI, 270-27r.)

26. Relación, I, xlii, 31 I-314. See also the first published edition of the Relación, 
Two months later the visitador Escobedo was moved to lay down the law. The expedition had become "a monster of many heads and no subordination." He surmised that if the artists had stayed at Macora, they would at least have been able to save some belongings. In the future, all members of the party must submit to the commands of Ruiz. The draftsmen, however, were still defiant. They answered, according to the version given by Ruiz, that they recognized only the king or his minister as their chief. A new order told the botanists to recoup the loss of the living plants swept overboard from the San Pedro de Alcántara, but it omitted specific mention of the draftsmen. Collecting living trees, they said, was a task for botanists alone. Ergo, they were no longer a part of the expedition; they would prepare to leave for Lima and thence Spain.

This preposterous assumption, if actually put forth, hardly warrants consideration. ${ }^{27}$ At any rate, the crown held no such view, for on June 4,1785 , it extended indefinitely the life of the expedition. His Majesty now desired that all members continue

for the time they need, not only to improve and perfect their discoveries and useful observations, but also to leave with the two individuals ... such instructions and knowledge of the objects of natural history and places where they are found, that they may afterwards furnish the news and drawings that are asked for to illustrate the works of said botanists when they have gone back to Spain, and continue the remissions for the Botanic Garden. ${ }^{28}$

For reasons to be discussed in the following chapter, it is possible to assume that this new royal order was prompted by knowledge that Dombey was no longer a threat to publication, and thus there was little need for the botanists to hurry to Spain.

edited by Agustín Jesús Barreiro, based on an earlier draft. (Relación del viaje hecho a los reynos del Perú y Chile por los botánicos y dibuxantes enviados para aquella expedición, extractado de los diarios por el orden que llevó en estos su autor, [Madrid, 1931] , p. 284.) Nothing is said anywhere about the part played in these proceedings by the new artist, Pulgar. It is certain, however, that he did not remain at Macora with the botanists.

27. This incident is reported in the Barreiro edition of Ruiz's Relación, pp. 289290 , but is omitted from the revised version.

28. The order was received in Lima on Nov. 25, 1785. (Archivo Histórico de Hacienda [Lima], libro 900 , fol. 4I.) 


\section{THE BURNING QUESTION}

Ruiz was by now preoccupied with another problem whose solution should have been simple. How could he account to the crown for the loss at Macora of manuscripts, specimens, and four to five thousand pesos of government property? ${ }^{29}$ In a letter to the visitador Escobedo on September II, I 785, he unloaded the blame on Trabuco. The administrator of the hacienda, for all his experience (variously reported as five and fifteen years), had ignited the fire while the sun blazed and the wind blew to a degree seldom seen in those parts. $\mathrm{He}$ did not protect the roofs with wet sacking nor station peons at each hut with moist hides. Moreover, he omitted to tell the botanists he was going to burn so they could move their belongings to safety. Ruiz asked that the intendant of the region take testimony to absolve the botanists of liability, and that Trabuco be forced to pay for his crime of "little reflection and much temerity." 30

This demand for vengeance was a mistake. A much better idea was the simple request, made five days later by Ruiz and Pavón, that the intendant give them a certificate of release from liability. Although the botanists would still have Trabuco and other witnesses called to testify, and they did not intend to relieve him of blame, nothing was said in the new petition about criminality or punishment. ${ }^{31}$ The milder approach may have reflected Pavón's “docile, placid, and affable disposition," for the first letter had been the work of the "irascible" Ruiz alone. ${ }^{32}$

In any event, from the two divergent petitions stemmed a lingering doubt as to whether the case was civil or criminal, or even a legal case at all, and the judicial papers shuttled between Lima and the montaña for two and one-half years. It would have been easy for the intendant to clear the botanists, but the visitador became stirred up over Trabuco's alleged criminality, and would not rest until the latter had been brought to justice.

29. Ruiz alone had to spend 2,404 pesos fuertes to replenish his supplies. (Ruiz, Relación, I, 314.)

30. Causa Criminal, Anales de la Real Academia de Farmacia, XXI, 266-267.

31. Petition from Huánuco, Sept. 16, 1785, in ibid., XXI, 261-262.

32. Trabuco's defender at law attached these labels to the personalities of the two botanists. (Statement of José Antonio Onís in ibid., XXI, 371.) 
That proved a more difficult task than expected. Trabuco disappeared for the first time on the night of the fire-alarmed, so he says, because Pavón had chased him with murder in mind, and Ruiz with musket in hand. The senior botanist ridiculed the notion. Why would anyone even try to track his quarry in the dense forest after dark? Maybe he had said he would like to kill Trabuco-but was not that understandable? Ruiz's choler must have subsided, for he later met Trabuco in Huánuco without bringing up the touchy subject. By the time the legal mill had begun to grind, Trabuco was gone again. ${ }^{33}$

He had been sent by the intendant to Huallanca on a mission concerning the collection of money. Shortly thereafter he took his family to this new location and was soon engaged in milling metal for a living, far from the annoyance of Huánuco. Meanwhile, the intendant had turned over investigation of the fire to his asesor, and the asesor had referred it to his subdelegado, and on this lower level nothing was done to seek out Trabuco. The subdelegado of Huánuco listlessly heard testimony of some witnesses who, except for Juan Tafalla and the botanists' cook, were reluctant to blame the administrator for the blaze. But the legal advisor (fiscal) of the visitador even so insisted that Trabuco be taken into custody and hauled back to Huánuco for trial. ${ }^{34}$

When this word reached Trabuco, he set out for Huánuco posthaste. Upon arrival, April 8, 1786, he was immediately thrust into jail. For two weeks the sixty-nine-year-old unfortunate sat exposed to the elements in a structure that had "no more roof than the sky" while the populace prepared for Holy Week, celebrated Holy Week, and recovered from the lengthy festivities. When at last the authorities paid attention, he refuted every statement of Ruiz and Pavón. He had warned them three days in advance of the fire; there was no wind all morning; he had set the blaze early, before the sun was hot, and five hours had elapsed from that moment until the roof

33. "Reposicion de Don Matias Trauco," [1786]; "Escrito" of Ruiz and Pavón, Huánuco, Oct. 26, 1786. Ibid., XXI, 277, 284-285.

34. "Reposicion de Don Matias Trauco," [1786]; auto of the asesor Bartolomé de Bedoya, Huánuco, Nov. 2, 1785; "Certificazion," Huánuco, Oct. 26, I 785 ; testimony of Agustín Ruiz and Ildefonso Mallorga, Huánuco, Sept. 30, I 785 ; "Proveido" of the subdelegado Cristóbal de Zavala, Huánuco, Dec. 10, I 785 ; testimony of Juan Tafalla and Basilio Buitrón, Dec. 10, 1785 ; Ruiz and Pavón to Escobedo, Huánuco, Nov. I2, 1785 ; opinion of the fiscal Moreno, Lima, Jan. 4, 1786. Ibid., XXI, 262-266, 268 . 
was ignited; Pavón and even the departing draftsmen knew the fire had been lit and all agreed there was no cause for alarm; Trabuco had lost his own belongings in the fire, so he could not have set it maliciously. (No one, however, had accused him of deliberate malice.) Three more months of moist confinement passed before Trabuco was discharged from jail under bond on July 24, I786. His son Pedro, a local priest, and a legal practitioner named José Antonio Onís, skilled in juridical obfuscation, took up Trabuco's defense..$^{35}$

It is futile to try making sense of the subsequent legal tug-of-war, carried on through sworn depositions for nearly two years. The fire was set at seven and eleven o'clock. Hipólito Ruiz left for the forest to botanize at five-thirty and nine o'clock. The roof caught fire at ten, eleven, and one o'clock. The draftsmen left at ten and one o'clock. There was no wind and it was very windy. The trees and brush had been cut before the botanists arrived at Macora and thus were ready to burn, and they had been cut after the botanists arrived and should not have been burned for another month. Two witnesses who had once testified on behalf of the botanists, including the maestro de campo Agustín Ruiz, switched their stories to support Trabuço. Yet Onís claimed that his client was a poor little man fighting giants who intimidated his witnesses and used the judges and official scribes as their own lawyers. ${ }^{36}$

The botanists' case sagged when Pavón admitted he had seen the fire and had asked Trabuco if the houses were in danger. Tafalla said he and Pavón had asked Trabuco "the same day or a few days earlier" if there was a risk. The administrator, they alleged, had denied the possibility. Even so, these revelations shattered the botanists' contention that if they had known of the fire they would have removed their belongings to safety. As Onís pointed out in defense of Trabuco, "everyone is obligated to guard his own [property]." In fact, Onís even offered the far-fetched observation that, since neighboring hacendados had told Ruiz of possible dangers from burning, the botanist should have warned Trabuco ${ }^{37}$

The defense scored again with the disclosure that Trabuco, as

35. "Diligencia" at Huallanca, March 29, 1786; statement of Trabuco [Trauco], Huánuco, April 21, 1786; decree of subdelegado Zavala, [1786]; statement of Pedro Trauco, [1786]; "Escrito" of Onís, [1786]. Ibid., XXI, 275-279, 285.

36. Ibid., XXI, 278-285, 357-375.

37. Statement of Ruiz and Pavón, Huánuco, Oct. 26, 1786; of Tafalla, Dec. ro, 1785; of Onís, [1787]. Ibid., XXI, 283,265, 374 . 
official tobacco monopolist in the area, had lost his entire stock in the fire without having to reimburse the crown for destruction of government property. Nor had the owner of the hacienda, Dona Nicolasa Llanos, made any claims upon Trabuco for damage to her estate. As for safety measures, Trabuco could not have stationed a vast crew of peons to ward off sparks, for there were but a few men available for work.

He concluded with the arrogant demand that, since the botanists had offered no proof and were obvious calumniators of his poor client, the penalty they sought to enforce upon Trabuco should in justice fall upon their own shoulders. At least they should pay the costs of the legal action! ${ }^{38}$ Fortunately for the reputation of colonial justice, the regional fiscal at Tarma, when pressed for an opinion, refused to be disconcerted by the wily Onís. Even if details of the fire were in doubt, Trabuco must have been guilty of some kind of omission-else why did the blaze get out of control? ${ }^{39}$

This sensible conclusion, however, was lost in a subsequent wave of legal mumbo jumbo. The intendant, who apparently had little acquaintance with the case despite his responsibility to decide its outcome, could no longer lean on the visitador Escobedo, for the latter was returning to Spain. It was of no avail to drop the case into the hands of Viceroy Teodoro de Croix-though the intendant tried-for Croix knew even less about it than he. Finally, on March 6, I 788, the intendant turned to his asesor Bartolomé de Bedoya for an opinion. Bedoya, who had directed the legal proceedings at the inception of the case before turning them over to the subdelegado, and whose mother-in-law reputedly owned the burned-out hacienda, hesitated not a minute in deciding against the botanists. He absolved Trabuco of criminal intent and responsibility for the loss of government property, and followed Onís in recommending that the botanists pay all costs. ${ }^{40}$

By now Ruiz and Pavón were in Lima making ready to leave for Spain. Once again a fiscal-this time the viceroy's own adviserraised a cry against the surrealistic decision. How was it possible that

38. Statement of Onis, $[\mathrm{I} 787]$, in ibid., XXI, 369, 370, 373, 375. Statement of Pedro Trauco, [1786], in ibid., XXI, 280.

39. Opinion of Oct. 20,1787 , at Tarma. Ibid., XXI, 376.

40. Intendant of Tarma to viceroy, Tarma, Jan. I 8, 1788; opinion of fiscal, Lima, Jan. 31, I788; viceroy to intendant, Lima, Feb. I1, 1788; decree of intendant, Tarma, March 6, 1788; sentence, Tarma, March 10, 1788. Ibid., XXI, 380-381. Ruiz, Relación, I, 3 I 4. 
men who had lost nearly everything in a fire that was not of their doing be made to assume the blame, when the individual whose omissions were obvious was allowed to go scot-free? The local authorities at Huánuco, he said, had been much too indulgent with Trabuco. More capable hands than those of a mere subdelegado would have insisted on better proof. ${ }^{41}$

Alas, by the time the fiscal had rendered his opinion, only five days remained before the botanists were to sail. They begged a certificate from the viceroy annulling the sentence, and put their final fate in the hands of the authorities in Spain. ${ }^{42}$ At this point the records become silent. It seems likely, however, that nothing was done to enforce the decision, given the damaging comments of the fiscal and the position of the viceroy. If nothing concrete resulted from thirty months of legal maneuvering, perhaps at least we have learned something of colonial justice in action. It is fortunate that the fiscal is able to restore our faith in fair play.

\section{TROUBLE TAKES NO HOLIDAYS}

In order to trace the after-effects of the Macora fire it was necessary to bypass more than two years of botanical adventuring. Since "misfortunes come not as single spies," we can scarcely assume that no further troubles plagued the scientists in those two years.

A month after the fire, Ruiz wrote to Spain that in all that time he had not known rest. This may have been partly because he was so busy duplicating I 60 descriptions from old drafts, drawings, and dried plants that had luckily been stored in Huánuco. But, more to the point, he was alluding to the cumulative effects of five attacks of fever. ${ }^{43}$ In mid-October the strain began to show, and for five months he worked less than half-time. Four bleedings and a dosage of lemonade, followed by a diet of fruits, vegetables, and fresh fish, eventually

4. Opinions of fiscal Viderique, Lima, March 27 and 29, 1788. Causa Criminal, Anales de la Real Academia de Farmacia, XXI, 382-383.

42. Decree of viceroy, Lima, March 29, 1788 . Ibid., XXI, 383-384. Croix to Antonio Porlier, Minister of Grace and Justice for the Indies, Lima, Aug. 5, 1788. José Toribio Medina, Biblioteca hispano-chilena ( $15^{2} 3^{-18} 87$ ) (Santiago de Chile, 1897-1899), III, 268-269. Memorias de los vireyes que han gobernado el Peri (Lima, 1859), V, 292 (memoria of Croix). Ruiz, Relación, I, $314,367$.

43. To Gómez Ortega, Huánuco, Sept. I1, I 785 . MCN, I785 y I786. Ruiz reported his companions' health as good; they were "more content" than he. 
seemed to restore his health, but by then he had petitioned to go home. $^{44}$

Ruiz now faced another dilemma. On June 7, 1786, he learned that the Minister of the Indies planned to dismiss the agregados as soon as the regular members of the expedition returned to Spain. ${ }^{45}$ This marked a strange about-face. Was the change of heart founded on the belief that Ruiz considered the tyros inept? ${ }^{46}$ Or, more serious$1 \mathrm{y}$, was the treasury less eager now to spend money on botanical research? ${ }^{47}$

In answer to the first supposition, Ruiz reminded Escobedo that on repeated occasions he had commented favorably on the "application, inclination, good conduct, and advancement of said agregados." As for the financial barrier, Gómez Ortega in Spain proposed to reduce it in size with a new solution. There no doubt exists, he said, or ought to exist at the university in Lima, a "chair of simples, or materia medica." And probably it is presided over by some physician who "hardly knows the herbs except their names given in prescriptions and books." Why not let the botanist-agregado and draftsman take over the job with an obligation to teach theoretical and practical botany as well as continue botanical explorations on behalf of Ruiz and Pavón? The visitador Escobedo and the renowned Cosme Bueno could no doubt unearth the necessary funds. ${ }^{49}$

To the monarch's credit, on March 18, 1787, he ordered Ruiz and Pavón to return to Spain and the agregados to remain in their stead. He favored Ortega's idea as an ultimate answer, but showed no inclination to stop the pay of Tafalla and Pulgar. ${ }^{50}$ By the beginning of 1787 , in fact, he had raised their salary to one thousand pesos each. ${ }^{51}$

Meanwhile, the jinx ship San Pedro de Alcántara had been beating its way to Spain with a cargo of gold, silver, copper, cocoa, quina

44. Relación, I, 318. Ruiz to José de Gálvez, Huánuco, Dec. 12, 1785. MCN. 45. Relación, I, 319.

46. This was the interpretation placed upon Ruiz's words by Escobedo, who learned of them through a royal order dated Oct. 29, 1785. See ibid., I, 468.

47. Gómez Ortega to the Marqués de Sonora (José de Gálvez), Madrid, Feb. 28, $1787 . \mathrm{MCN}$.

48. Letter of July 9, 1786, from Huánuco. Relación, I, 469. See also ibid., I, $319,467-472$.

49. Gómez Ortega to Marqués de Sonora, Madrid, Feb. 28, 1787 . MCN.

50. Royal order to S.or Superintendente Subdelegado de $\mathbf{R}^{1}$ Hacienda de Lima (Escobedo), El Pardo, March 18, 1787. MCN.

51. Ruiz, Relación, I, 471-472. 
-and fifty-three cases of "natural products" collected by Ruiz and Pavón. The vessel had begun to leak while still at Callao and hasty repairs were only partially successful. The ship's new master, Manuel de Eguia, although perturbed that two to three inches of water seeped into the hull each day, feared being taken for a coward if he did not sail. By the time the San Pedro arrived at Talcahuano, Chile, thirty-one containers of living plants had been swept overboard, and now the talk said eighteen to twenty inches of water a day was pouring into the hold. Captain Eguía tried to hide the reality from his officers, but when a storm off the Falkland Islands dumped in that much water in an hour, the master could not avoid stopping for repairs at Rio de Janeiro. In the Brazilian capital he replaced the deceased and deserters with Portuguese and English mariners and sailed on November 4, I 785, although against the best advice of the captain of the port.

At last on February 2, I786, at 3:30 in the afternoon, the weary crew saw the European coast. Having decided they were off the Berlingas Islands, the captain outlined the ship's course and retired to his cabin for the night. Suddenly at IO:30 P.M. the jutting coastline of Peniche, Portugal, loomed up in the face of the sailor on watch. An order to luff was too late to keep the vessel from scraping the rocks, but the danger might have abated had not some misguided soul commanded a change of course. In the confusion the San Pedro slammed against the coastline again, the ship's bottom gave way, and those not lucky enough to be in the roundhouse went to their doom. ${ }^{52}$

Thirty-nine men, women, and children died that night; twentynine were saved. ${ }^{53}$ The sea greedily consumed 1,706,106 pesos of minted gold and 5,669,996 pesos of minted silver, as well as sizable quantities in bulk of these and other metals. ${ }^{54}$ And down too went all the plants Ruiz and Pavón had collected for five years.

Many more months would pass before the botanists heard the disheartening news. And, even then, hope lingered that divers might stumble upon the cases of plants. But eighteen months of salvage

52. Decision of the Council of the Indies, June $2 \mathrm{I}, \mathrm{I} 788$, in expediente on the causes of the shipwreck of the San Pedro de Alcántara. AGI, Indiferente General, legajo 2762 .

53. Año de 1786. Extracto del Expediente sobre el Naufragio del Navio de

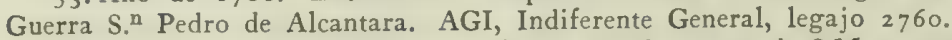

54. Noticia de los caudales... y frutos que de cuenta de S.M. y particulares se registraron en Lima y Talcahuano en el Navio S. ${ }^{n}$ Pedro de Alcantara. AGI, Indiferente General, legajo 2763 . 
operations at a cost of 310,000 pesos were not dedicated to the pursuit of scientific knowledge. The divers, working in four fathoms at low tide, turned back 92 per cent of the gold and 84 per cent of the silver to its rightful owners, ${ }^{55}$ but they passed by all of the "frutos." It would have been little solace for Ruiz and Pavón to know that Captain Eguía was "perpetually" deprived of his calling in 1788 . (As a matter of fact, four years later he was absolved of all blame and restored to duty. $)^{56}$

\section{FINAL TRIPS FOR TIRED MEN}

On May 10, I786, Ruiz sent the agregados to Lima with fifty-six tubs of living trees and shrubs. At the same time he urgently asked for money again to make a new entrance into the forest, and when Tafalla and Pulgar returned from the capital on July 9 they brought the necessary financial blessings. ${ }^{57}$

The new goal was Muña, twenty-four leagues east of Huánuco. The botanists arrived on August 7, 1786, and, finding their allotted quarters too small, set out to build their own. On August I 5 the draftsmen, who had once refused to stay in these dark forests, arrived at Muña and a new search for plants began.

With only forty inhabitants, Muña was probably no more enticing to the artists than the other frontier settlements, but Ruiz found more than usual to praise. He witnessed with pleasure the regulated life of this small village of quina collectors. Under the constant eye of a missionary from Ocopa, the natives were not as subject to the usual drunkenness. They gathered at the church both morning and night, and on feast days the alcalde posted himself at the door to check on the laggards. The congregation arranged itself according to age, with the eldest in the rear "in order to observe the irreverence of the younger ones and punish it," a procedure which seemed quite effective to the Spaniard. None were rich, but none lacked food or clothing-an idyllic society in the best eighteenth-century terms! ${ }^{58}$

The botanists made Muña their headquarters until September 24,

55. Ibid.

56. Council of the Indies resolutions of June 21, 1788, and March 22, 1792. AGI, Indiferente General, legajos 2762 and 2763 .

57. Ruiz, Relación, I, 319.

58. Ibid., I, 332, 334-335. 
I 786, when the seasonal rains drove them back to Huánuco. Among the plants uncovered during this time were two more species of cinchona, C. ovata (or "female-widgeon colored"-named "for the outer coloring of its spongy and thin bark"), and C. lanceolata, or "boob yellow"-so called for its deceptive similarity to the finest cinchona and "for the interior color of its extremely bitter bark, that in my opinion is as worthy of esteem in medicine as the quina oficinal." 158

There was much to do in Huánuco, if the men were to recoup the losses of the San Pedro de Alcantara, but Ruiz again found the draftsmen resting on their easels. As the senior botanist tells it, the painters, faced with the alternative of believing the shipment had been saved or of doing their work over again, chose the optimistic view. They refused to lend a hand in re-duplicating until positive of the shipwreck losses. However, the rupture between botanists and painters may have been healed somewhat when Brunete left for Lima on private business in November, I 786.

In truth, none of the party could have been very idle, to judge by the sizable shipment Pavón and the new artist Pulgar escorted to Lima in January, I787. They took seventy-three boxes of dried plants and "other natural products," and eighteen containers of living plants, including forty stands of what they considered to be Cinchona officinalis. The remittance also included 586 drawings, a fact that somewhat modifies the report of painter obstructionism. All items were loaded on board the ships El Brillante, El Pilar, and La Fe and, miracle of miracles, made the journey safely to Spain. ${ }^{60}$

During the absence of three of his company, Ruiz found a new target for verbal fustigation. He was Antonio José Cavanilles, a rising star in the Spanish botanical firmament, who would soon become more than a match for the ofttimes fretful Ruiz. Cavanilles was working on a thorough study of the Monadelphia class of plants and announced to the world a whole series of new genera, based on his observations in the botanic gardens of Paris. Three of the genera

59. Ibid., I, 336, 340. See p. 196, below.

60. Ibid., I, 341, 472 . Ruiz to Sonora, Huánuco, Jan, I1, 1787. MCN. The living plants that actually reached Spain comprised eight stoves with 32 tubs, and two boxes. They arrived in Cádiz in August, 1787, and Ruiz heard the good news in February, 1788. MCN, I 787 , contains numerous and somewhat contradictory documents with regard to this shipment. See also note of Ruiz and Pavón, Lima, Feb. 20, 1788, in Anales de la Real Academia de Farmacia, XXI (No. 5, 1955), 448. 
he named Ruizia, Pavonia, and Dombeya, and, thinking the botanists in Peru would be honored, sent drawings and descriptions to them. ${ }^{61}$ Probably because of a personal interest in the names, and because similar plant life abounded in the vicinity of Huánuco, Ruiz undertook a closer analysis of the newly proposed genera. He could find no "solid fundamentals" to separate them from other genera already known, and hastened to call attention to Cavanilles' mistakes. ${ }^{62}$ Thus began a rivalry that for years bespattered the Spanish botanical scene with epithets scholarly and unscholarly. ${ }^{63}$ Nor did Ruiz's arguments alter the fact that Ruizia, Pavonia, and Dombeya today are those genera selected by Cavanilles, not the trees picked out by the botanists in Chile to dedicate to themselves.

Pavón and Pulgar had just returned from Lima on May i6, i 787 , with supplies for another campaign in the montaña, when news arrived that the draftsman Brunete was in Pasco, seriously ill. On the way back from Lima in that very month, he had fallen from his mule. Suffering from exposure he finally arrived in Pasco, but before word could reach his companions Brunete drew his last breath. ${ }^{64}$

The winter months of June through September were, of course, best for penetrating the jungle. Settlement of Brunete's affairs probably complicated the schedule this time, but on August 3,1787, the party left for Pillao, twelve leagues northeast of Huánuco and one of the many "last outposts" of Spanish civilization. Boasting but fifty-five residents, "all Indians and poor," the village was a typically sparse settlement in a potentially rich region. "The fields around Pillao are suitable for sowing all kinds of grain," Ruiz commented, "but the small number of inhabitants keeps them untilled and the people content themselves with planting those few seeds and roots that they need for their sustenance." ${ }^{\prime 65}$

61. Cavanilles to Mutis, Paris, May I, 1786. Gredilla, Biografia de Mutis, Pp. 288-290.

62. Relación, I, 3 I8, 341.

63. See chap. xiii, below.

64. Ruiz, Relación, I, 342-343. Brunete died on May 14, 1787. (Ruiz to Sonora, Huánuco, June 10, 1787. MCN.) With Brunete's death and the consequent stoppage of his pay, the visitador Escobedo felt fewer qualms about having authorized a larger salary for Tafalla and Pulgar. (Ruiz, Relación, I, 467.) Brunete's sister Faustina received a pension variously reported as 9 reales a day, and 300 pesos annually. See MCN, 1788, and Ruiz and Pavón to Caballero, Madrid, Jan. 19, 1801. MCN.

65. Relación, I, 346-347. On the way to Pillao the botanists were queried by the owner of four date palms as to why they would not bear. He learned the facts of life when they told him that he had no masculine plants. (Ibid., I, 345.) 
If Pillao was a place that "might have been," the next stop, Chacahuassi, was a forbidding zone that "never could be." Here, in a remote settlement three days' travel from Pillao and populated by no more than four workers in quina, life was indeed hard-and wet. "That narrow and exceeding deep dungeon, where the sun hardly enters but a few hours at midday, ... that oppressed and sad place, in which nothing could oblige us to subsist a single day more but the desire to comply with our commission"- these were not words of affection. The mud-covered party sloshed into the village on September 28, I787, and the three following days of deluge and earth slides were not calculated to improve their disposition. Even the orchestra of birds, crickets, and toads inspired nothing but distaste in Ruiz's mind. The "out-of-tune canticles," and the perpetual noise of the rivers, made shouting the only means of conversation,

all of which had us so worn out and our heads so stupefied that at times we seemed crazy and at times insensate deaf-mutes. [We were] overcome by the greatest sadness, by the affliction of not being able to run to more peaceful places, nor to better talkfests, and even reading annoyed us instead of amusing and diverting us. ${ }^{66}$

As depressing as their surroundings was the heart-rending condition of the natives:

Only interest in the precious and universal specific quina could induce man to live, as those peons live, among those dark wildernesses so many days, which at times with those frequent downpours and overcast skies seem like the blackest of nights, ... going about almost naked, living on toasted maize and coca when the dried meat, vetch, or frijoles are used up, drenched continuously in the dense forests and walking along perpetual precipices and slopes so dangerous, that just remembering them terrifies one.

Held constantly in debt by the entrepreneurs of the quina trade, the Indians could never escape the morass. Ruiz discovered that the natives, having been paid in advance, perennially owed one or two hundred arrobas of the bark, whose intrinsic worth was "much more than all their ranchos, fields, and livestock." Worse yet, the majority died without spiritual assistance. Their burial, which ought to have cost five pesos, could scarcely be bought for fifty. Church celebrations -only a means for the Indians to get drunk-were often postponed by order of the priests so their parishioners could gather the quina they needed to pay their debts. The Indians, in their desperation to 66. Ibid., I, 348-35I. 
collect more bark in less time, destroyed valuable stands by rash and unscientific means. For the same reason they neglected their fields, making foodstuffs perennially scarce. ${ }^{67}$

Amid all this gloom, it is no wonder that the members of the expedition grew tired of their jobs. Ten years older and twenty years wiser than when they left the Spanish mainland, they had adventured enough for a lifetime. With what mingled feelings of weariness and relief they must have received, on October I2, I787, the order to return to Spain! Within two weeks they were back in Huánuco, and, after spending three months to put their discoveries in order, they left the mountains for the last time. Finally, on February IO, I 788, they reached Lima, steppingstone to the promised land. ${ }^{68}$

Viceroy Teodoro de Croix, seeking a founding father for the newly authorized botanic garden in Lima, and feeling Tafalla was not yet ripe for the job, sought to induce either Ruiz or Pavón to remain. Ruiz assured Croix that Tafalla was entirely adequate for the professorship. Besides, Ruiz and Pavón were being called to the Court by the monarch to publish their Flora. They could hardly refuse to obey the orders of their king! And, comments Ruiz, "His Excellency, desisting in his proposal, showed himself very pleased at my mode of thinking." 69 No mere viceroy could keep the botanists from going home now.

They devoted their last days in Lima to preserving the plants picked up on the way to the capital, observing and describing the specimens cultivated by González Laguna in the garden of Buena Muerte, and packing everything for the voyage. On March 31, I788, the scientists set out for Callao, where they stowed their boxes on two vessels: fifteen on El Dragón and fourteen on El Jasón. There were, besides, 589 drawings, and Ruiz's especial pride, 24 tubs of living plants. The latter comprised 45 different species, including four new genera, and, counting duplicates, totaled 102 individual plants. ${ }^{70}$ Ruiz took with him on El Dragón the full number of plant descriptions-close to three thousand-that had been prepared during

67. Ibid., I, 352-354. Ruiz elaborated at length on the bad economics of quininegathering. See pp. 194-195, below.

68. Ibid., I, 354, 360-362, 363-364.

69. Ibid., I, 365 .

70. Of the 102 plants, 71 survived the journey to Spain. 
their stay. ${ }^{71}$ For safety's sake, duplicates of some of the descriptions were put on board the companion vessel, El Jasón, and the remainder of the duplicates and all triplicates were turned over to Tafalla, to be sent in various later mailings. ${ }^{72}$ Then, at three o'clock on the afternoon of April r, I788, Hipólito Ruiz, José Pavón, and the illustrator Isidro Gálvez, aboard The Dragon, slipped out into the Pacific. They would never again see Peru.

71. Including the two folio volumes originally entrusted to Escobedo for delivery to Spain. The visitador himself had left Peru only one month before the botanists. Ruiz had originally estimated the number of descriptions at 2,400 (Ruiz and Pavón, Prodromus, p. xviii), but later revised it to 3,000 (Ruiz and Pavón, Flora Peruviana, I, i).

72. Participa don Hipólito Ruiz al Secretario de Estado . . . Sept. 13, 1788. Ruiz, Relación, I, 472-473. Lista de las plantas vivas traídas a la España ..., Sept. I 3, I 788. Ibid., I, 475-476. See also ibid., I, 365-367. A detailed list of remittances may be found in MCN, 1788 . 


\section{N T ER NATIONALR E L A T IONS}

\section{A ND THE RACE FOR \\ P U B L I C A T I O N}

\section{PARTITION UNDER PROTEST}

Dombey arrived in Cádiz aboard El Peruano on his forty-third birthday, February 22, 1785 , exhausted beyond his years. The French government, in fact, would not have been surprised to find him dead. ${ }^{1}$ The ocean had threatened him often with "a death more frightening than a criminal's," "2 but the agonies of a sea voyage would soon be dimmed in his memory by the ordeal of inaction and defeat he faced at the Spanish port.

He banked heavily on flattery and certificates of good behavior to win favor from the Spanish authorities. "The Court of Spain is very generous," he hopefully declared. To Minister José de Gálvez he wrote, "Your Excellency's virtues are already so well known throughout the universe, I cannot add a thing to the eulogies already published by the most eloquent pens." And did not Gálvez know of the many medical services Dombey had rendered free of charge? of the scientific commissions he had undertaken at his own expense? of the offers made to keep him in South America? He could hardly hope to win out-and-out exemption from the customs nuisance, but perhaps the inspectors would open only a few cases at random! ${ }^{3}$

Months earlier, French officials had begun to look for means to avoid a tussle with those stern functionaries "charged with the duty

I. "L'effet chez moi a été tal que je suis comme hébété." (Dombey to Thouin, and to De Jussieu, Cádiz, Feb. 24, I785. Hamy, Dombey, pp. I I 4, 275-276.) Note added to a statement by Gómez Ortega, Madrid, Sept. 18, 1784, contained in "I 786. Extractos sĩe el asunto de la remision de 73 cax. . . . q. hizo . . . Dombey." MCN, 1785 y 1786.

2. Dombey to Thouin, Cádiz, Feb. 24, 1785 . Hamy, Dombey, p. I 44.

3. Dombey to Thouin, and to De Jussieu, Cádiz, Feb. 24, 1785. Ibid., pp. I 14I $15,277-278$. Dombey to Gálvez, same date. MCN. 
of enforcing the Laws of the Indies." A long delay at Cádiz, they told the Spanish government, might destroy Dombey's plants. To prove their good intent, the French would gladly open the cases in Paris in the presence of a Spanish representative. As for the platinum in Dombey's luggage, Spain need not fear that France would ignore the necessary fees for importing this precious substance. ${ }^{4}$

But international problems are not so easily resolved. Gálvez thought the French request "as exorbitant as it is unique." Gómez Ortega had been on edge for months with a fear that Dombey would publish ahead of the Spaniards. Of course, Ortega might solve that problem, as the Minister of the Indies suggested, by starting publication of the Spanish findings as soon as the papers and herbaria arrived from Peru. But the minister's main concern, immediately made clear to the French, was the requirement, specified from the very beginning, that Dombey must give to Spain a collection equal to that destined for France. Behind the scenes, Gálvez on August I8, I 784, questioned Ortega on the possibility of detaining Dombey's boxes until Ruiz and Pavón had returned, or at least until the minister could be sure that Spain had its equal share of the spoils. ${ }^{6}$

Dombey had anticipated this stand and was ready with a counterattack. All three botanists, he reasoned, had collected specimens of identical plants. In addition, before leaving Peru, Dombey had turned over to Ruiz and Pavón two duplicates of every plant specimen in his collection, as well as a description of each. Then, "to avoid all argument between Spain and France," the viceroy of Peru and the visitador had thought it best to ship the specimens belonging to the Spanish on the San Pedro de Alcantara and those of the French on El Peruano. Dombey had obtained receipts from Ruiz and Pavón, which he forwarded to José de Gálvez immediately upon arrival in Spain. ${ }^{7}$ On what grounds, pray tell, could the Spanish government now allege that Dombey owed it something?

4. Montmorin, French ambassador, to Gálvez, San Ildefonso, Aug. 26, 1783 ; Vergennes, French foreign minister, to Floridablanca, Spanish Minister of State, Versailles, Aug. 17, 1784 . MCN.

5. Marginal note on Floridablanca to Gálvez, Aug. 29, 1784. MCN.

6. Gómez Ortega to Gálvez, Madrid, Oct. 21, 1783, and Oct. 13 and Nov. 30, 1784 ; Gálvez to Gómez Ortega, San Ildefonso, Aug. 18, and San Lorenzo, Nov. 18, 1784. MCN. See also Floridablanca to Vergennes, San Ildefonso, Sept. 13, 1784. Hamy, Dombey, p. 344 .

7. Dombey to Thouin, Concepción, Dec. 24, 1782, [Cádiz, Feb.-March, 1785 ]; Cádiz, April 24, 1785 . Ibid., pp. 94, 134, 135, 136, I 59. 
Two factors complicated the issue. The Spanish authorities found it hard to accept the Frenchman's claim that he had already given Ruiz and Pavón their share. Dombey's collection of seventy-three boxes was twenty more than that of his colleagues, and Ruiz had said nothing about getting plants from Dombey. ${ }^{\circ}$ Besides, the original instructions had called for Dombey to present his specimens to the Spanish crown upon his return to Europe. In truth, Dombey's receipts, though probably valid, were too vague to be convincing. One, signed by Ruiz on October 13, I781, merely stated that he had received from Dombey "two copies of each plant of those he had discovered in the first excursion to the province of Chancay, and in the vicinity of [Lima], which were remitted to Spain on the warship Buen Consejo; besides these I have received and boxed up others of those he has found in the province of Tarma and the edge of the montaña." The other receipt, dated April I 8, I 783, covered "fifteen little packages... of the plants gathered and dried in the bishopric of Concepción de Chile."10

More upsetting was the still uncertain fate of the San Pedro de Alcántara, carrying the remittances of Ruiz and Pavón. Rumors were flying that the vessel had run into heavy seas off the coast of Chile, suffering big losses. If Dombey had followed orders and waited to divide his collection in Spain, said Ortega in exasperation, there would have been less concern over this possible loss at sea. But since Dombey no doubt possessed many samples of each plant, it seemed to Gómez Ortega merely a matter of courtesy to aid Spain in this potential emergency. ${ }^{11}$

Dombey, though, assumed the position that he could not relinquish a single specimen without the approval of his French superiors. If Ruiz and Pavón had denied him drawings because they were Spanish property, how could he legally do more than he had already done to assist the Spanish government? He would present Ortega with some specimens to soften the blow whenever the French ministry gave its permission. ${ }^{12}$ Dombey was hardly prepared, however, for the decision made by his government in mid-March, I785, that he

8. Gálvez to Gómez Ortega, San IIdefonso, Aug. 18, 1784; Gómez Ortega to Gálvez, Madrid, Sept. 18, 1784, and March 23, 1785. MCN.

9. Instrucción (1776). Ruiz, Relación, I, 394.

10. Copies of the receipts are in MCN, 1785.

I1. Gómez Ortega to Gálvez, Madrid, March 23, 1785. MCN.

12. Dombey to Thouin, [Cádiz, Feb.-March, 1785], and to Ruiz, Cádiz, March 13, 1785. Hamy, Dombey, pp. 132, $280-281$. 
must divide all of his finds with Spain. A few days of reflection convinced him that he ought gracefully to accept the inevitable, but he could not suppress for long his fits of discouragement, anger, and resignation. ${ }^{13}$ Even his elation upon learning in Cádiz that he had been named a correspondent of the Académie des Sciences of Paris ${ }^{14}$ could not override a burgeoning sense of doom.

The matter of publication was of less moment than other problems to Dombey. He honestly conceded the inability of France to publish a good flora because Spain had all of the drawings. "It is not important to me where the work is published," he assured Ortega. The Frenchman had only in mind for the present that his old master Thouin help him compare his descriptions of plants with others already published. He would also like to see similar specimens in the major gardens of Europe, though that would not be easy. After he had corrected his manuscript he would send it to Spain to be printed..$^{15}$

At bottom, Dombey's troubles were again financial. When he arrived in Cádiz, he was, as he put it, "nude." Living in Spain was costly, and soon he was inexplicably 12,400 livres in debt. Private persons had in the past undoubtedly sponsored the purchase of many of his curiosities, ${ }^{16}$ but in Cádiz he found it hard to interest new creditors. Even those who had once been willing to help were cool when they learned he must split his collection. ${ }^{17}$ During his wait for action, Spain denied him access to the boxes. He could almost feel the humidity ravaging his specimens. ${ }^{18}$ But there were other moments

13. D'Angeviller to Dombey, Versailles, March 17, I785; Dombey to Thouin, Cádiz, April 8, I785. Ibid., pp. 420, 146. The French, in fact, as soon as they heard of the storm losses and even before being approached by Spain, had offered to share Dombey's collection. (Vergennes to Jean François Bourgoing, French chargé d'affaires in Spain, Versailles, March 18, 1785 ; D'Angeviller to Vergennes, Versailles, March 16, 1785. Ibid., p. 346.)

14. The appointment, dated August 20, 1783 , was made to encourage him "to continue the exchange of letters in which he is engaged with $\mathbf{M}$. de Jussieu on matters of mathematics and physics." (Ibid., pp. 130-131.)

15. Dombey to Gómez Ortega, Cádiz, March 8 and 10, 1785. MCN.

16. In a letter to Vergennes of February 25, 1785 , from Cádiz (Hamy, Dombey, p. 275), he spoke of the 73 boxes which had been accumulated "aux frais de S[a] $M$ [ajesté] $T$ [rès] $C$ [hrétienne] et par les avances de différents particuliers qui ont voulus prendre intérêst à mon sort."

17. Dombey to Thouin, Cádiz, March 15, and April 6 and 8, 1785; Dombey to De Jussieu, Cádiz, May 31, 1785. Ibid., pp. I37, I 38, I43-144, 146, I51-152, 292.

I 8. Dombey to Thouin, [Cádiz, Feb.-March, 1785]. Ibid., pp. 133, I 36, 14014I. The letters to Thouin strongly affirm Dombey's worry over losses by humidity. But in a missive to Ruiz from Cádiz (March 13,1785 , in ibid., p. 282) he said 
when he did not care if he ever saw the cases again. As he wrote Ortega, "I have firmly resolved to go to the poorhouse to die and perhaps never will go to Paris."19

Part of the procrastination must be charged to Spanish indecision on when and how to publish the findings of the expedition. On March 15, I785, the Minister of the Indies sent Ortega two manuscript volumes of plant descriptions remitted six years earlier by Ruiz. Were they ready for publication? Ortega could not decide. Ruiz had pursued his task seemingly "with vigilance and excessive application" - even Dombey testified to that. But the descriptions ought to be judged in the presence of the dried plants and drawings whose arrival was shortly expected-with good luck-on the San Pedro de Alcántara. Supposing Ortega should make corrections? The botanists in Peru might then have legitimate grounds for complaint. And how would they take to the almost certain mistakes? And what about Pavón's discoveries? Thus far every manuscript had borne Ruiz's name alone. Would Dombey keep his word to send his manuscript to Spain for publication? His correspondence in the past, thought Ortega, had not always rung true. If there were no other way to prevent foreigners from snatching the glory from Spain, then publish we must, and print corrections in a supplement. At any rate, perhaps Ortega could begin to engrave the drawings sent in I779, omitting for the present the names of the plants. ${ }^{20}$ What a dilemma!

\section{THE RELUCTANT PLEDGE}

Spain chose an easy way out: the government would require Dombey's promise not to publish until Ruiz and Pavón had returned to Spain. ${ }^{21}$ Officials in Cádiz attached a further restriction: Dombey could not even leave the city until he had taken the pledge. ${ }^{22}$ These ultimatums shocked Dombey. He refused to sign the promise until

he could "live content" that the fault was not his, but that of the place and the delay. "I have complied with my obligation. The blame can't fall on me."

19. Letter of March 10, 1785 , from Cádiz. MCN.

20. Gómez Ortega to Gálvez, Madrid, March 23, 1785 . MCN.

2.1. Marginal note, dated March 3 I, 1785 , to letter of Gómez Ortega to Gálvez, March 23, 1785 . MCN. The order was transmitted to Cádiz on April 8, 1785. (Gálvez to Presidente Interino de la Contratación de Cádiz. MCN.)

22. Bartolomé de Ortega, Presidente Interino de la Contratación de Cádiz, to Gálvez, Cádiz, April 15, 1785. MCN. 
the French government gave its permission, although waiting meant weeks more of delay, dickering, and expense. ${ }^{23}$

To Dombey, the mastermind behind the plot must certainly be Gómez Ortega. Even before this episode Dombey had written: "The hate I have worked up toward Ortega is so great, if he weren't as big as he is, I would try to get my revenge!" Now he could see it all clearly. However severe the storm encountered by the San Pedro de Alcantara, the plant descriptions and drawings would certainly not have been thrown overboard. They would shortly be arriving in Spain, and while Ruiz and Pavón were kept in Peru, "Ortega would publish, there's the nub of the matter."”4 José de Gálvez was a "great minister," but, occupied in other affairs, was being duped by Gómez Ortega. ${ }^{25}$ The latter not only had opened Dombey's correspondence -or so the Frenchman charged-but kept word of his accomplishments from reaching the minister. "I have always been insulted and they will end by assassinating me," he wrote. Again speaking of Gómez Ortega: "What astonishes me is that while [the French] monarch busies himself eagerly over the progress of the sciences, a vile man takes my work away from him." 27

Dombey's friends in France joined in the tirade. Antoine de Jussieu argued, and with considerable justification, that "the freedom of the sciences cannot be a party to such a demand which tends only to dishonor ... the country from which such a bizarre ruling emanates." In a letter to the French foreign minister he laid the blame on "some intriguing subalterns, basely jealous of a merit which is not their own."28 André Thouin was more specific: one lone individual had brought about all of Dombey's misfortunes. The wicked man's name was Ortega and he was envious of everyone but his wife! Thouin snorted at the thought of these "professors" (Ruiz and Pavón) that Dombey was supposed to wait for. What professors? These pupils who had barely mastered the rudiments of science?

23. Dombey to Vergennes, Cádiz, April 15 and 25, 1785, and to Thouin, Cádiz, April 24 and 27,1785 . Hamy, Dombey, pp. 156, 286, $158,164,169$.

24. Dombey to Thouin, Cádiz, March i 8 and April 27, 1785. Ibid., pp. 141, $168-169$.

25. Dombey to Vergennes, Cádiz, May ro, 1785 . Ibid., p. I 71.

26. Dombey to Thouin, Cádiz, March 1, May 14, and June 8, 1785, and to Vergennes, Cádiz, May 10, 1785. Ibid., pp. I 16-117, 175, 179, 171 .

27. Dombey to Thouin, Cádiz, May 14, April 24, March 18, April 5, and June

8, 1785 . Ibid., pp. $177,160,141,143,184$.

28. To Vergennes, [June 11,1785 ]. Ibid., p. 363. 
They had been selected more as observers than to contribute to botanical discovery. "Their little skill" was so evident to the Spanish minister that whenever "interesting observations" were called for, Dombey was always chosen to make them. ${ }^{29}$

In fairness to Ruiz and Pavón-and Dombey— it must be pointed out, however, that Dombey had written to Ruiz on March I3, I 785, of how greatly he felt "my separation from a companion of your talent." He offered to gather a collection of new botanical books for Ruiz, in return for a sample of each new plant Ruiz had found. The recent work of Carl Peter Thunberg (Flora Iaponica, Leipzig, I784) was "very good," but Ruiz's would be "more extensive" and "more esteemed." Ruiz answered that Dombey did not need to make the collection of books in order to keep the Spaniard's affection. He would save out the plant specimens even so. ${ }^{30}$

Nowhere in the instructions agreed to at the start of the expedition does any requirement appear that Dombey delay publication of his owon findings. It will be recalled that, to prevent argument over primacy of discovery, all three botanists were to sign the record of each new plant so as to determine who had "the first right to be able to publish it." ${ }^{31}$ But, of course, when the voyage was planned, it had been generally assumed that the men would return together to Europe. Gómez Ortega was not completely convinced of the need for hasty publication, but would undertake it if necessary. He appears to have felt that Dombey had virtually agreed not to publish, by his admission that he lacked the drawings. The solemn promise invoked by higher-ups was only confirmation of the obvious. There is no doubt, however, that Ortega was suspicious. Before the decision was finally made to divide the collection in Cádiz, Ortega had suggested to the ministry that Dombey be brought to Madrid and housed under his roof, so the Spanish could keep an eye on him. ${ }^{32}$

29. To Vergennes, Paris, June Io, to D'Angeviller, June 15, and to Louis Guillaume LeMonnier, professor of botany, June 15, 1785. Ibid., pp. 370-372, 373-375.

30. Ibid., pp. 280,283 .

3. See pp. 58-59, above.

32. To Gálvez, Madrid, March 23, 1785. MCN. Ortega wrote Thouin on April 4, 1785: "I am awaiting impatiently the arrival in Madrid of our dear friend Mr. Dombey, whom I have invited to stay with me. I have encouraged him as far as I am able and will not fail to show him all the good offices of friendship that are his due." (Hamy, Dombey, p. 332.) Dombey would have been happy to come to Madrid. (Marginal note, dated April 2, 1785 , to letter of Gómez Ortega to Gálvez, March 23, I785. MCN.) 
Scientifically speaking, Spain was not justified in prohibiting publication by Dombey; practically speaking, she could perhaps not stop him entirely anyway; on the other hand, the absence of drawings would keep him from doing a creditable job. But inasmuch as the plants were products of the Spanish dominions and Spain had a reputation for backwardness to surmount, her position was certainly understandable. In any event, on June 4, I785, Minister of Foreign Affairs the Comte de Vergennes ordered Dombey to sign the Spanish demand, provided he be allowed to render a written account of the voyage to the French king and the Académie des Sciences at Paris. ${ }^{33}$

Spain was, in a sense, already too late to invoke an absolute ban on publication in France. At least ten species of plants whose seeds had been sent by Dombey from America were now flourishing at the royal botanic garden in Paris. A wealthy member of the French Académie des Sciences and a fanatical enthusiast in matters botanic, Charles Louis L'Héritier de Brutelle (I746-I 800), had been permitted by the French authorities to secure drawings and to have engravings made of the plants. By the time Dombey arrived in Spain the first plates were coming off the press as part of a publication dealing with "plants newly discovered." 34 To prevent further damage to Spanish dignity, the French government now advised Dombey to halt publication of his plants by L'Héritier, and Dombey immediately transmitted the order to that individual. ${ }^{35}$

France, in bowing before Spanish demands, may have been guided by the assurance of José de Gálvez that Ruiz and Pavón would re-

33. Hamy, Dombey, p. 349. Dombey did not actually sign the promise until June 28. It was given to the president of the Casa de Contratación in Cádiz and went as follows: "In order to conform to the desire of His Catholic Majesty, which was communicated to me by the president of the Contratación of Cádiz the sixteenth of April last and in consequence of the orders of the court of France, I the undersigned promise not to publish my work done in South America until the arrival in Europe of the Spanish professors who at the present time are in Peru, reserving to myself, however, the right to render an account to the king and to the Royal Academy of Sciences of Paris." (Ibid., p. 297.)

34. Dombey received in the mail from L'Héritier, reproductions of Spilanthes albus of Lima, Aristotelia Macqui of Chile, and Siegesbeckia flosculosa. These formed part of the first two fascicles of L'Héritier's Stirpes novae, aut minus cognitae, quas descriptionibus et iconibus ( 6 fascicles in 2 vols.; Paris, 1784-1785) (publication did not actually begin until 1785 and continued until 1789 , despite the dates appearing on the title pages; material for two additional fascicles was never published). See Dombey to Thouin, Cádiz, April I 2 and 24,1785 , to Duc de la Vauguyon, French ambassador, and to L'Héritier, June 7, 1785. Hamy, Dombey, pp. 153, 158, 293, 294-295.

35. La Vauguyon to Dombey, Aranjuez, May 31, 1785; Dombey to La Vauguyon and to L'Héritier, Cádiz, June 7, 1785. Ibid., pp. 181, 293-294, 294-295. 
turn to Europe early in $1786^{36}$ - a prediction that missed fire by more than two and one-half years. It is not fair to state that the French ministers showed no interest in Dombey's fate, but they indeed surrendered with little urging. (In Spanish eyes, of course, the French government was merely recognizing its legal obligations.) Dombey now had only one other means for partially frustrating the Spanish design. Upon the advice of Jean Baptiste Poirel, secretary of the French consulate at Cádiz, he had turned over his diary and miscellaneous manuscripts in April to the master of the French frigate La Bellone, for delivery to the Ministry of Foreign Affairs in Paris, and by midsummer the papers were safely in the hands of Vergennes. ${ }^{37}$

\section{A LONG PROBLEM OF DIVISION}

The long-awaited partition of Dombey's boxes began on June 13, I785, nearly four months after his arrival in Cádiz, and well over two months after the Spanish crown had decided to send a representative to the port to make the division. ${ }^{38}$ Spanish dawdling did little to lift the burden of Dombey's ill-health, though it should be noted that Spain began the division two weeks before Dombey finally relinquished his rights to publish.

The man selected to make the partition was Juan de Cuéllar, later known for botanical exploration in the Philippines. Ortega described him as a "most attentive and proficient student of botany, ... distinguished among all his fellows for his knowledge of chemistry, Scholastic philosophy (because in his time no other was taught in our halls), and the use of the French language, as well as for his good manners and obvious talent." He was also a licensed professor of pharmacy, who had given up the practice because of "the calamity of the times." 39

36. La Vauguyon to Vergennes, Aranjuez, June 13, 1785. Ibid., pp. 349-350.

37. Dombey to Thouin, Cádiz, April 24, and to Vergennes, April 25, 1785 ; Thouin to Dombey, Paris, July 15, 1785. Ibid., pp. 158, 286, 378.

38. Juan de Cuéllar, the Spanish representative at the partition, to José de Gálvez, Cádiz, June 21, I785. MCN. The king had resolved on March 31, 1785, to send a pupil of Gómez Ortega's to handle the task. Marginal note on Gómez Ortega to Gálvez, March 23, 1785 . MCN.

39. Gómez Ortega to Gálvez, Madrid, May I3, 1785. MCN. Cuéllar received 3,000 reales each way for travel expenses, and 2,792 reales for subsistence during his 72 days in Cádiz. (MCN, May 18 and 21, and Aug. 19, 1785.) 
Instructions drafted by Ortega called for Cuéllar to check every box, "sheet by sheet, and object by object," separating out one-half of the pieces for Spain. In cases where Dombey had paid for zoological or mineral specimens, he would be compensated at a fair rate for the Spanish share, which would, however, be taken from him only when the royal cabinet of natural history did not already have the item. Cuéllar must also take (or make) a copy of Dombey's diary, observations, descriptions, notes, and any other papers dealing with scientific aspects of the expedition. ${ }^{40}$

The painstaking task went on "daily from eight to twelve in the morning and from four till dark in the afternoon," from June I 3 to August 5, 1785-an average of only one and one-half boxes a day. Even so, Dombey's desperation helped hasten the proceedings. The Spanish delegate could not transcribe the descriptions fast enough? Let him have Dombey's copy and be done with it! Dombey would keep a note only of those items he could not easily remember. ${ }^{41} \mathrm{He}$ wanted nothing more than to be rid of Spain. In one of his moments of greatest dejection, he offered to circle the globe in order to get out of Cádiz. At another, he said he would gladly leave Spain now just as, nine years before, he had entered it-on foot. ${ }^{42}$

Cuéllar likewise had his share of frustration, tolerating Dombey's "impulses and animation." ${ }^{3} \mathrm{He}$ was especially irked that Dombey had rushed the diary and other papers to France. Although the Frenchman insisted that they contained nothing not already in Cuéllar's possession, the Spaniards were incredulous. Ortega even favored withholding Dombey's entire share, but the excitement eventually subsided. ${ }^{44}$

Ill-feeling reached a new peak, however, when Spanish officials in Madrid, including Ortega, demanded the partition of five cases Dombey had brought from Brazil. Cuéllar himself was dubious, for Dombey stood firmly opposed, and neither could tolerate the prospect of two months more of haggling. No justification for this step indeed

40. Ynstruccion, sobre el modo con que ... Cuellar deberá proceder. (Attached to letter of Gómez Ortega to Gálvez, May 13, 1785 . MCN.)

41. Dombey to Thouin, Cádiz, July 19, 1785. Hamy, Dombey, p. 196. Cuéllar to Gálvez, Cádiz, June 2 I and Aug. 5, $1785 . \mathrm{MCN}$.

42. To Thouin, Cádiz, March 18 and April 5, I785. Hamy, Dombey, pp. 140, 143.

43. Bartolomé de Ortega to Gálvez, Cádiz, Aug. 19, 1785. MCN.

44. Cuéllar to Gálvez, Cádiz, June 21, 1785; Gómez Ortega to Gálvez, Madrid, Aug. I0, 1785 . MCN. 
existed. The French botanist had already allowed customs officials to inspect three of the boxes, and, he said, they had thrust their hammer into a collection of insects. Dombey grudgingly let Cuéllar look into the other two cases, but refused to allow him to make a list of their contents. ${ }^{45}$

French officialdom now came alive. Among the curiosities was a piece of some unnamed metal, decorated with "the prettiest and rarest birds of South America and especially of Brazil," that Dombey had intended as a gift for the queen of France. When word reached the director of museums, D'Angeviller, he trembled at the thought of losing that prize:

I am quite angry to see myself deprived of the possibility of presenting to her this curious and perhaps unique piece. Permit me to beg of you [he was writing to Vergennes] to write M. the Duke of La Vauguyon to insure that these five cases, absolutely personal to $M$. Dombey and which have not been in the least gathered in lands of Spanish domination, are given back to him in their entirety and without partition... The honest manner in which the French Minister has conducted himself toward the Spanish Minister in this affair demands on the latter's part more gracious condescension. ${ }^{46}$

D'Angeviller need not have troubled himself, for Spain on August 2 I, I 785 , renounced all claim to the five boxes, conceding they belonged to Dombey alone. ${ }^{47}$

Unfortunately for Spain, the most impressive of Dombey's treasures in the eyes of Cuéllar was an "elastic stone"-part of the Brazilian collection. But even without a sample of this rubber, Spain had acquired thirty-seven boxes of plants, seeds, bark, herbs, woods, resin, shells, animals, birds, fish, reptiles, insects, bezoar stones, Indian clothing, tools, ornaments, poisoned arrows, and dozens of huaqueros or decorated jugs, as well as samples of gold, silver, copper, and quicksilver ore. On top of this, Spain took a share of the 160 pounds

45. Royal order to Presidente Interino de la Contratación de Cádiz, San Ildefonso, July 30, I785; Cuéllar to Gálvez, Cádiz, Aug. 5 and 9, 1785 ; Gómez Ortega to Gálvez, Madrid, Aug. 10, 1785; Bartolomé de Ortega to Gálvez, Cádiz, Aug. 9, 1785. MCN. Dombey to Thouin, Cádiz, March 15, 1785. Hamy, Dombey, p. 138. 46. Dombey to D'Angeviller, Cádiz, Aug. 9, I785; D’Angeviller to Vergennes, Versailles, Aug. 28, 1785. Ibid., pp. 299-300, 352. Dombey had earlier spoken of a "tree" upon whose branches were thirteen "pretty" stuffed birds, which he had brought from Brazil for the queen. (To Thouin, Cádiz, March I, 1785. Ibid., p. 124.)

47. La Vauguyon to Gálvez, San Ildefonso, Aug. 19, 1785 ; marginal note of Aug. 2 I to letter of Gómez Ortega to Gálvez, Aug. 19, 1785 . MCN. 
of platinum being brought to Europe for chemical experimentation. ${ }^{48}$

Two biased opinions come to the same conclusion as to the merits of the Spanish share. Ruiz was unimpressed. "They turned over to us upon our arrival in Madrid," he said, "only some skeletons (esqueletos) of plants with very few notes and an occasional description." 49 And the Chevalier Bourgoing, the French chargé d'affaires, later wrote that "the commissioners [sic] nominated by the Spanish government were not as intelligent as [Dombey]." Thus, "the portion which fell to the share of France, proved to be the more valuable." $" 50$

For the entire Spanish lot, whatever its value, Dombey received not a penny, though not because of Spanish parsimony. When Cuéllar asked Dombey to quote a price on Spain's share of the minerals, ${ }^{51}$ Vergennes notified Madrid that "the objects gathered by Dombey do not belong to him," but to the French crown. Consequently, the question of a monetary value did not concern Dombey. The king of France deemed himself "only too happy to be able to do on this occasion whatever is agreeable to the [Spanish] king, his uncle." ${ }^{2}$ It is no wonder that Dombey sourly remarked that the grands of both nations were in league against him. ${ }^{53}$ Dombey had returned from America with the firm intention of selling many of his mineral specimens, and had been talking about the display he

48. Cuéllar to Gálvez, Cádiz, June 2 I, and Madrid, Sept. 3, 1785; Gómez Ortega to Gálvez, Madrid, Aug. 28, 1785 . MCN. For a detailed list of the first 24 boxes see "Noticia individual de lo que contienen los caxos conducidos del Peru por el Botanico Frances Mr Dombey que se remiten para el $\mathbf{R}^{1}$. Gabinete de Historia natural," MCN, 1786. Hamy, Dombey, pp. 427-428, gives an abbreviated list of the contents of all 73 cases and on pp. $429-430$ a list of some of the archeological specimens brought to France.

49. Relación, I, I.

50. Modern State of Spain, I, 257.

51. Dombey to D'Angeviller, Cádiz, June 21, 1785. Hamy, Dombey, p. 296. Cuéllar to Gálvez, Cádiz, June 21, I 785. MCN. Dombey had no idea about what to charge. His friend Thouin offered this solution: put a price on each item in terms of its intrinsic worth, its rarity, the trouble it had cost to obtain it, and its utility, then adjust the figures so that the total cost of the objects equalled the sum of Dombey's expenses. (Thouin to Dombey, Paris, July 15, 1785. Hamy, Dombey, p. 376.$)$

52. Vergennes to La Vauguyon, Versailles, July 1, I785. Ibid., p. 351. See also Gómez Ortega to Gálvez, Madrid, Aug. 28, 1785. MCN.

53. "les Grands ont des égards les uns pour les autres." (Dombey to Thouin, Cádiz, July 4, I785. Hamy, Dombey, p. I89.) Vergennes, according to Dombey, apparently believed that the botanist's expenses had been no greater than the sum already paid him out of the treasury. (Dombey to De Jussieu, Cádiz, May 3 1 , 1785. Ibid., p. 290.) 
would arrange in Paris. While word circulated, the naturalist would see that the controller general received a memorandum

in which it will say that $M$. Dombey, recently arrived from Peru, has, besides a considerable collection of plants and curiosities, a rich collection of minerals; that it would be interesting to see the collection placed in the Cabinet of the king, and that it would be $a$ propos to name commissioners of the Academy to fix the price. ${ }^{54}$

One more story of woe turns up in the account of a contemporary biographer, who claims to have heard it from Dombey's lips. During the latter's stay in Cádiz, an attempt was made to poison him (and perhaps, another attempt to do away with him by the sword). Then, one night on Dombey's doorstep a man was murdered, "whom they took to be our naturalist." Dombey, "seized with horror, escaped secretly and, protected by the French consul, had his boxes embarked, and landed at Le Havre." ${ }^{\text {} 5}$ The Dombeyan polemicists are so inclined to romanticize their subject that the story is repeated here without further comment solely to please those lovers of mystery who find unraveling Dombey's financial maneuvers too tame an avocation.

When Dombey arrived in Paris on October 1 3, 1785, his long suffering was at last rewarded. The French king not only satisfied him with 60,000 livres to pay his expenses in gathering the collection, but promised to continue his 6,000-livre salary until he had finished cataloguing and describing the objects. Further salary adjustments would be made after completing that task..$^{56}$ Yet, on January I, I 786, the hapless botanist found it necessary to beg the treasury to comply fully with its promise, so he could meet the demands of his creditors. ${ }^{57}$ His career as an explorer in South America thus ended in debt, even as it had begun.

\section{DOMBEY IN DECLINE}

Upon his return to France, Dombey seemingly renounced concern for the fate of his collections. Even so, the French government was 54. Dombey to Thouin, Cádiz, March 1, 1785. Ibid., pp. 131-132. See also ibid., pp. 98,144 .

55. Mouton-Fontenille, Éloge de Joseph Dombey, p. 35. See also Gilibert, "Notice sur la vie," p. 461, and Cap, Joseph Dombey, p. 12.

56. Controller general to Dombey, Versailles, Oct. 3 I, I 785 ; Dombey to Vergennes, Paris, Oct. 14 and Nov. 2, 1785. Hamy, Dombey, pp. 422, 300-301.

57. To Charles Alexandre de Calonne, Minister of Finance, Paris, Jan, I, 1786. Ibid., pp. 301-302. 
still paying his pension in 1788 , though at the beginning of that year Dombey had to fight a reduction of one-third threatened by new policies of economic reform at that perilous period of French history. ${ }^{58}$

The remaining years of his life require little notice here, except to mention his indirect part in rivalry over who would publish his discoveries." He tried to settle down to "a little house and garden." He moved to Gex, to Lyon, to Tullins, back to Lyon-but none was a haven for his unsettled mind. He refused to accept a vacancy in the Académie des Sciences opened by the death of Jean Etienne Guettard ( I 7 I 5-1786). He is said to have refused an offer of I00,000 livres from Catherine the Great for duplicates remaining in his personal collection of plants, preferring to give them to his French colleagues. Finally, he reputedly turned down "without hesitation" a "very considerable" offer of José de Gálvez to "make amends in some manner for the sacrifices they had demanded of him in Spain." ${ }^{\prime 60}$ Dombey did try to interest himself in experiments on saltpeter. The product he had uncovered along the Peruvian coast owed its origin, he thought, to a reaction between sea salt and "some other substances," and he briefly considered setting up his own laboratory for investigation of the matter. ${ }^{61}$

Dombey took a melancholy pride in the fact that his former associates in America still wrote him from time to time. The regent of Chile sent word that a man had been found to take on the mining operations at Coquimbo and was optimistic of the results. ${ }^{62}$ Pavón sent a sample of "a tree the Indians near the Marañón call yamich, and in the general language of Peru cauchu," which he thought to be "la veritable gomme élastique du Pérou." ${ }^{63}$

But Dombey's interest in these things was fast dissolving. "Amigo," he wrote to Ruiz, "don't take any trouble to send me either plants or descriptions." His collection had gone to the kings of Spain

58. Dombey to Thouin, Lyon, Jan. 3, 1788; Thouin to Dombey, Paris, Dec. 27, 1787. Ibid., pp. 210,381 .

59. See pp. $176-183$, below.

60. Deleuze, "Notice historique," p. 161. Deleuze cites the authority of Dr. Michel, a physician in Tullins, who claimed to have read the letter from Gálvez. For further verification of Dombey's loss of interest in botany see Gilibert, "Notice sur la vie," pp. $462-463$.

61. Dombey to Thouin, Gex, April 2, 1786. Hamy, Dombey, p. 198.

62. Dombey to Thouin, Tullins, June 29, 1786. Ibid., p. 202. We know, however, from pp. 127-128, above, that the mines proved to be almost worthless.

63. Dombey to Thouin, Lyon, Dec. ${ }_{15},{ }_{1786}$. Ibid., pp. 205-206. 
and France. His personal curios had been given away. And now he had burned his papers! "In this way, naked as when I came into this world, I have no fear of losing anything but the friendship of yourself and my companions; may God keep you many years." ${ }^{64}$ When months later, further samples of seeds and roots arrived, Dombey turned them over to Thouin. ${ }^{65}$ He warned the latter, however, not to let anyone know of these donations. "Although they [Ruiz and Pavón] may be sacrificed, as I have been, yet their luck will turn out even worse if it is known that they have passed on to me some drawings and plants." ${ }^{66}$

One thought could never be rubbed from the mind of Dombey: his dislike for the top Spanish officials. This hatred had at last come to include José de Gálvez himself. While writing to Ruiz he would say, "You know that no Court rewards one like that of Spain. Thus, have no fear. . . Gálvez, protector of the Sciences and the Sages, will know how to reward your labors and all your troubles as you deserve." But Dombey confided to Thouin that "the poor unfortunates don't know that the minister of the Indies fears their presence in Madrid, and for that reason will never give in to their demand to come home." Dit Dombey's crowning comment-and one which, even in its braggadocio, had a grain of truth-was this, written to Thouin on June 29, I786:

M. de Gálvez knows that the countries which he governs are in a state of weakness so great, that he fears to expose them to the ridicule of foreigners. That weakness in reality is so great, that, if I were fifteen years younger, I would seek to avenge myself on $M$. de Gálvez by going back to Peru or Chile to bring about that revolution. I would not even seek out a single person in Europe to help me. ${ }^{68}$

It was Dombey's knowledge of this weakness, and, especially of the Tupac Amaru uprising in Peru, which had, so the Frenchman claimed, obliged Gálvez to keep his eye on him. ${ }^{69}$

64. Letter from Lyon, Oct. 9, 1786. Ibid., p. 304. The question of what papers Dombey burned is unresolved. His principal manuscripts had been turned over to Vergennes early in Dombey's stay at Cádiz. Probably he had reference to numerous studies he had once planned to write up-such as a report to Lalande on temperature readings and barometric pressure in Lima over a twenty-year period, and a medical study on the mal del valle. See ibid., pp. $43,129,162$.

65. Letters from Lyon, Jan. 15 and Dec. 13,1787 , and Jan. 3, 1788. Ibid., pp. 207-208, 209, 210-2II.

66. Letter from Lyon, Dec. 15, 1785. Ibid., p. 206.

67. Dombey to Ruiz, Lyon, Oct. 9, 1786 and to Thouin, Lyon, Dec. 1 5, 1786. Ibid., pp. 303, 205.

68. Ibid., p. $20 \mathrm{I}$.

69. Dombey to Thouin, Lyon, Jan. 3, 1788. Ibid., p. 2 r2. Alessandro Malaspina, 


\section{THE CASE OF THE ABDUCTED}

\section{HERBARIUM}

While Dombey fretted in retirement, the melodrama of publication was far from played out. The spotlight now turned upon the same Charles Louis L'Héritier who had published the controversial plates. Comfortably wealthy and passionately fond of botany, he lavished time and money on the study of plants. He could not rest as long as some new species was flowering in a Parisian garden and begging to be described. Young botanists made incessant rounds of the gardens at his expense in order to advise him when rarities were in bloom, and skilled artists made drawings of the plants at his bidding. Pierre Joseph Redouté ( I 759-1 840), "the most popular flower painter in the whole history of botanical art," got his start under L'Héritier's direction. ${ }^{70}$

L'Héritier, convinced he could do no wrong, cared not a fig for José de Gálvez or signed agreements. He unquestionably knew of the French promise not to publish, for Dombey had notified him by letter of June 7, 1785, and later, in March, 1786, L'Héritier asked Dombey for a copy of the pledge. ${ }^{71}$ But L'Héritier had the support of the renowned Count Buffon, director of the royal museum and custodian of the Dombey collection. The Journal général de France of January I4, I786, in fact, published the news that L'Héritier was "charged with the description of M. Dombey's herbarium."72 On February 25 Buffon turned over the entire plant collection to him with the understanding that L'Héritier would draft a catalogue, have drawings made of "the most interesting" species, put the descriptions

an Italian in the service of Spain who commanded for her yet another scientific voyage (1789-1794) to South America, was taken prisoner by the Spanish government on November 24, 1795, as a "traitor," for just such beliefs and remarks as those expressed by Dombey. For a complete account of this incident, see Pedro de Novo y Colson (ed.), La vuelta al mundo por las corbetas Descubierta y Atrevida al mando del Capitán de Navio D. Alejandro Malaspina desde ${ }_{1789}$ á ${ }_{1794}$ (Madrid, I 885 ).

70. Blunt, Art of Botanical Illustration, p. I 73 .

71. Dombey to L'Héritier, Cádiz, June 7, 1785, and to Thouin, Lyon, Sept. I 2, 1786. Hamy, Dombey, pp. 294-295, 203.

72. M. Maudit, a doctor of medicine, was to handle the description of the insects; scholars to put the other materials in order had not yet been named. (Journal général de France [No. 6, Jan. 14, 1786], pp. 22-23.) 
in order, and "publish first the genera and then the species without delay." "3

Gloating over his acquisition, L'Héritier had the effrontery to write Ruiz and Pavón, on March 9, I786, a most amazing letter. $\mathrm{He}$ told them that Dombey, because of ill-health, had transferred the task of publishing to him. "I will be only the editor," he said, "which flatters me infinitely." Supposing there were a thousand new plants, the work of publishing would take perhaps ten years. "If you deign to keep us posted on your future discoveries during the course of the enterprise, the flora will be that much more complete." ${ }^{\text {t4 }}$

Had the Spanish botanists in Peru received the letter, ${ }^{75}$ they would have hooted in derision at the next remark: "I will see to it that the public is not unaware of how you have had a part in the work." And he added, "M. Dombey brought back hardly any fruits from Peru and that often puts us at a disadvantage for descriptions and figures. If you could supply them it would oblige us infinitely. As for Chile, we seem to be well supplied with fruits." For compensation, L'Héritier sent Ruiz and Pavón the first two fascicles of the Stirpes novae which included some of the drawings of Dombey's plants. He also asked the Spaniards to choose which plants they would like to have named in their honor.

In the following month L'Héritier sent the third fascicle of his Stirpes novae to the botanists in Peru, together with a new idea for promoting the publication of Dombey's flora. When a "certain number" of engravings had been made, a subscription would be opened. Inasmuch as probably the biggest market for the work would be in Peru and Chile, L'Héritier wanted to send Ruiz a prospectus to spread around. ${ }^{76}$

While Ruiz and Pavón were being properly mystified by this last communication, Spanish wrath over l'affaire L'Héritier reached fever heat. The Ministry of the Indies could stand French irresponsibility no longer, and resolved to expose it in the Gazeta de

73. Séance [of the directors of the museum of natural history] du 24 messidor de l'an 5 (July 12, 1797). Hamy, Dombey, p. 389.

74. Letter from Paris. Ibid., pp. $382-383$.

75. They apparently did not get this letter until twelve years later. (Ruiz to L'Héritier, Madrid, Nov. 5, 1798. Ibid., pp. 383-384.)

76. Letters from Paris, March 9 and April 28, 1786. Ibid., pp. 382-383. L'Héritier apparently had no qualms about flaunting his publications in the face of Spanish officialdom, to judge from the further evidence of this letter, dated at Paris, May 19, 1786, from the mining expert Fausto de Elhuyar to his brother Juan José, who was in Colombia: "I have sent ... to the Secretariat of the Indies a roll of the 
Madrid. Thus on July II, I786, an article appeared repeating in detail the story that had been published six months earlier in the Journal général de France. Appended was a long footnote reciting all the complaints the Spaniards could think of, and placing much of the blame on Dombey. "A manifest violation of the contract" and a "usurpation of the glory" due the Spaniards, expostulated the Gazeta. Besides, the project demonstrated a lack of respect toward "the public of all nations" who would be buying a work "incomplete in its descriptions and imperfect in its drawings." 78

The next step-an official protest to Foreign Minister Vergennes - produced a dismayed reply. He was properly shocked to learn of the malfeasance of the French scholars. Certainly Dombey could not be to blame for the plates already published, for they had been done before he returned from America. But what was this about L'Héritier holding possession of the herbarium and manuscripts? Steps must be taken to return the entire lot to Buffon, and Spain must be assured that France would never violate her agreement. ${ }^{79}$

Spanish officialdom was as skeptical as ever. Gómez Ortega deduced, with some justification, that Dombey was not an utter bystander to the affair. Certainly he knew even before turning over the herbarium to Buffon that L'Héritier was going to work on it the Journal général admitted as much. But in Dombey's defense, it must be said that the Journal did not specifically mention "publication." 80 To Ortega, however, Dombey's nefarious actions during the whole expedition made his defense "unjust and useless."

drawings and descriptions published by L'Héritier, of the plants that Dombey had. ... In this connection L'Héritier asks me to tell you that he is very anxious to enter into correspondence and friendship with D. Celestino Mutis, and he hopes that you will try to satisfy him." (Gredilla, Biografia de Mutis, p. 162.)

77. See "Extractos sĩe el asunto de la remision de 73 cax. $^{\text {s }}$ de Hist. ${ }^{\text {a }}$ nat . . .," $M C N, 1785$ y 1786 . The suggestion to insert a notice in the Gazeta was made at least by June 5, I786. The original article in the Journal général consisted of a glowing description of Dombey's finds which were then on display in his house pending removal to the museum of natural history. A sidelight on eighteenth-century attitudes may be gleaned from the Journal's comment on Dombey's archeological specimens: they were more intended "to excite the curiosity of the vulgar" than of value for the "advancement of natural history and the arts." (Journal général de France, Jan. 14, 1786, p. 22.)

78. Issue of July II, I 786, No. 55, pp. 453-454. Hamy, Dombey, pp. 354-355.

79. Correspondence of La Vauguyon, Vergennes, and Calonne, July 20-Sept. 15, 1786. Ibid., pp. $353-356$.

80. The text merely said: “Note. C'est M. 1'Héritier qui s'est chargé de la description de l'Herbier de M. Dombey." (Journal général de France, Jan. 14, I 786, pp. 22-23.)

$8 \mathrm{I}$. Two of these "atrocities" seem to have been Dombey's failure to send com- 
But even Ortega admitted that part of the Spanish effort to place the blame on Dombey had been a mere dodge to avoid outright accusations against French higher-ups. Now, however, Spain must demand that the Journal général explain why L'Héritier's work was being suspended; that Dombey be required to send to Spain a copy of his manuscripts, and that the museum in Paris regain the herbaria and descriptions. ${ }^{82}$

France was already acting on this last demand. Thus, one day in September, I786, André Thouin knocked at L'Héritier's door. Would the good sir kindly give back the Dombeyan plants and papers? L'Héritier replied with "beaucoup de sang froid" that he would release them whenever the receipt was returned that he had given for them to Buffon. ${ }^{83}$

Thouin set out to find the receipt. L'Héritier in the meantime hastily packed up the plants with the aid of his wife and the painter Redouté, stole off to Calais, and took immediate passage for England. To prospective callers, including Thouin, he was "on vacation at his Estate in Picardie." When British customs inspectors at Dover raised questions about the herbarium, he told them he was bringing it in at the invitation of Sir Joseph Banks. That illustrious botanist and director of Kew Gardens was out of town, but the secretary of the Royal Society, Sir Charles Blagden (I 748-1820), and Banks's librarian at Dean Street, Soho, Jonas Dryander (1748-1810), received and entertained the unexpected visitor, for L'Héritier's was a well-known name in the world of botany.

But the guest forgot his manners. He set out to verify Dombey's classifications by comparing them with specimens in Banks's herbarium, and with the descriptions of Linnaeus. In so doing, he damaged some British specimens. When Banks learned of this "enormity," he sent a scorching letter to be handed to the Frenchman-so severe a reproof that Blagden and Dryander feared to deliver it and asked Banks to send a gentler remonstrance.

Dryander wrote Banks, on October 3, i 786 :

plete descriptions on the Buen Consejo in 1779 , and his remittance to France of the diary of his voyage before Spain could make a copy. (Gazeta de Madrid, July II, 1786.)

82. Gómez Ortega to [Marqués de Sonora], Madrid, Oct. 25, I786. MCN. Another Spaniard who pilloried Dombey was Francisco Cerdá, first chief clerk of the Secretariat of Grace and Justice for the Indies. (Letter to Pedro de Aparici, Oct. 2, [1786]. MCN.)

83. Thouin to Dombey, Paris, Dec. 27, 1787. Hamy, Dombey, p. 379. 
Dr. Blagden thinks M. L'héritier, from what he has conversed with him, a strange fellow and I have in my two visits with him to Kew seen several instances of his having in a pretty high degree the French impudence or want of consideration in asking for what one may not like to grant. ...

On 'Thursdays I cannot well prevent L'héritier being here in my absence but on the other days of the week he shall not want my presence to keep him from abusing the liberty of the herbarium. The room upstairs I have locked and shall keep him clear of that.

The Englishmen feared most that if they withheld privileges from L'Héritier "he would not fail to make great noise at Paris about his supposed ill-treatment." ${ }^{\text {\&4 }}$ They obviously did not know that he was a fugitive from Paris.

Banks, however, was not so reticent. On November I3, I 786, he confided the story to the secretary of the Spanish minister to England. According to the secretary, Banks regretted he could not halt publication, for English law allowed complete freedom of expression. But he concluded that "Dombey was scandalously lacking in good faith and every principle of integrity." The secretary then read him the celebrated article in the Gazeta de Madrid, and Banks was once more "scandalized at the shamelessness of the Frenchman." He was "convinced that the Flora of Peru will be an excellent work and would rejoice with all his heart to see its antagonists heartily ridiculed." ${ }^{85}$ One cannot fail to mention, however, a letter Banks wrote several months later to an English friend. He regretted that L'Héritier had "cut me off from any attempts of obtaining specimens of Dombey's by saying that he was pledged to the Minister to return them in exactly the state in which he took them away from France, which, says he, I must for my honor's sake do."

By now Spain was convinced that the entire French government shared the guilt of this "horrendous felony." Either the ministry was indifferent to such a serious matter or was acting with deliberate malice in order to publish ahead of Ruiz and Pavón. Certainly it was not credible that L'Héritier, "of his own caprice ... would brave the indignation" of the ministry. ${ }^{87}$ How little Spain knew of this strange individual!

8. Nouvelle biographie (Hoefer), XXXI, 71. Cameron, Sir Joseph Banks, pp. $122-124$, based on copies of letters in the Dawson Turner collection, V, 59, 87.

85. Juan Virio to Gómez Ortega, London, Nov. I 4, I786. MCN, 1785 y 1786.

86. To Sir James Edward Smith, May, 1787. Linnean Society, Smith Correspondence, I, 8I, quoted in Cameron, Sir Joseph Banks, p. 124 note.

87. See "Extractos sĩe el asunto de la remision de 73 cax."." MCN, 1785 y 
L'Héritier, who stayed in England fifteen months "to the amazement of everyone," ${ }^{88}$ certainly did all he could to keep his movements quiet. First he hired the English artist, James Sowerby ( 1 757-1 822), to make copies of the new genera. But only a select few persons in England ever saw Dombey's specimens, and apparently many months elapsed before André Thouin learned what his quarry was doing across the Channel. L'Héritier brought the artist Redouté to London in April, I 787 ("make your preparations without saying anything to anyone"), while other labor on engravings continued in the French capital. "We must work vigorously," L'Héritier established as his motto, "otherwise we will never see the end of this job." 89

Dombey suspected what was going on and envisaged himself once more the innocent victim of Spanish wrath, but when L'Héritier returned to Paris in December, I787, Dombey awoke from his nightmare into the dawn of a bright new day. Once again hope glimmered that his findings would see print. José de Gálvez had died on June I 7 of that year. Vergennes, too, was gone. Passage of time had erased the question from the memory of other French officials. "No one speaks of it any more," Thouin wrote to Dombey. But he warned of the need for secrecy until the actual publication date, for Ruiz and Pavón had not yet left Peru, the promise to Spain remained in force, and "the fat Ortega" still had ears to hear. ${ }^{90}$

Indeed, the memory of the victimized Spaniards was long-lived. It will be recalled that L'Héritier had sent Ruiz and Pavón copies of his first three fascicles of the Stirpes novae in $1786 .{ }^{91}$ In the following year the botanists in Peru, who had been briefed on the whole affair, decided not to send L'Héritier the drawings of a genus they had promised to dedicate to him. Rather, they would place everything in the hands of the Minister of the Indies. Perhaps in that manner they could expose L'Héritier's game. ${ }^{92}$

And in truth, L'Héritier could not stand being snubbed any

1786. Count Floridablanca, the Spanish Minister of State, was given the whole story on December 19, 1786.

88. Banks to Smith, May, 1787 . Quoted in Cameron, Sir Joseph Banks, p. I24.

89. Thouin to Dombey, Paris, Dec. 27, 1787 ; L'Héritier to Redouté, London, Oct. 26, 1786, and April 3, 1787. Hamy, Dombey, pp. 379-380, 386-387.

90. Dombey to Thouin, Lyon, Oct. 16,1786 , and Jan. 3, 1788; Thouin to Dombey, Paris, Dec. 27, 1787. Ibid., pp. 204, $211,380-38 \mathrm{I}$.

91. See p. 177, above. Apparently only the third fascicle arrived in Peru.

92. Ruiz to Marqués de Sonora, Feb. 9, I787. MCN. Ruiz found L'Héritier's drawings of three Peruvian plants to be "well colored" but with "defective" generic descriptions. 
longer. He wrote to the new Minister of the Indies, Antonio Valdés, on May 12, I788, to find out what had happened to the drawings of the plant named in his honor. Gómez Ortega assumed the task of advising the minister. L'Héritier's "daring or innocence" was astonishing. He was either ignorant of, or chose to ignore, the dissatisfaction his conduct had caused in Spain. And now a fourth fascicle had appeared with more of Dombey's plants! By all means, L'Héritier should be answered coldly. Tell him the drawings had not come yet (Ortega did not know if they had); that Ruiz and Pavón would soon be home and would "immediately" publish their discoveries. Spain, said Ortega, owed nothing to L'Héritier; rather, he should be rebuked. ${ }^{93}$

In the end Spain emerged the victor. Although Thouin complimented L'Héritier on his "unique zeal, to be expatriated so long and to have made such important pecuniary sacrifices," and Dombey was "charmed" to hear of his accomplishments, ${ }^{94}$ in actual fact the results belied the promise. By I 789 the fifth fascicle of his Stirpes novae was off the press (and from that year until I 792 he published the Sertum Anglicum), but even then he had published only twenty-two plates from Dombey's remittances. Because of the importance Antonio José Cavanilles assumes later in the present study, there is some interest in noting his reaction to the Stirpes novae:

The duty of an author is to perfect and extend the limits of the science he pursues, and to render to every author the justice he deserves. Reason and honesty demand of him, and science obliges him never to swerve from the principal end, which is perfection. Selflove which begets the mania of appearing to be a creator must be suppressed in public, and philosophy alone must guide the pen of a writer impassioned by the sciences. ... Imagine my surprise then to see the appearance of M. L'Héritier's fifth fascicle, where this double duty of an author is forgotten! He describes anew plants that I have published, he gathers up the results of my observations, and he puts out huge plates often useless and defective, but without indicating the source from which he has taken a part of the ideas he presents. Certainly botanists will not regard as new the plants of this fascicle, despite the antedating [dated 1785, but published 1789] and the changing of names. The first fault, supposing it to be voluntary, is very serious, as it robs previous authors of the merit of having worked,

93. L'Héritier to Valdés, Paris, May I2, I788; Gómez Ortega to Valdés, June 2, 1788; Ministry of the Indies to L'Héritier, Aranjuez, June 7, 1788. MCN.

94. Dombey to Thouin, Lyon, Jan. 3, 1788 ; Thouin to Dombey, Paris, Dec. 27, 1787. Hamy, Dombey, pp. $211,380-38 \mathrm{I}$. 
and the second is a new source of difficulty in botany. That science, made difficult already by the great number of plants, will be made even more so by the changing of names, and if $M$. L'Héritier has done it to keep the title of his work Stirpes novae, I believe the good of science and justice demands a little sacrifice from him.

M. L'Héritier will perhaps say that he has seen the plants as well as I, that he had had them drawn and engraved even before 1785 , and that he needs to consult only works of great merit. But can the public know or give an opinion on the merit of a work that remains locked up in the portfolio of its author? Is it not right that the one who shows himself first, keep his rank of seniority, because he offers himself first to criticism and because he furnishes others with a means to perfect their ideas? ${ }^{95}$

Though L'Héritier seemed to be busy, not a sign appeared of the full-scale study of Dombey's herbarium. In England, L'Héritier had become a super-bibliophile-perhaps bibliomaniac is a better term. Adulation of Sir Joseph Banks's marvelous library and herbarium had aroused in the Frenchman a desire to equal it. Banks had written in May, I 787 , that L'Héritier "has left off working at Dombey's Herbarium some time and now runs most diligently from garden to garden, buying plants in profusion and books without end." said that he had tried to acquire every work dealing with botany, in whatever language, and had begun to esteem books in terms of their rarity, "even to giving this merit to some of his own." "97 Not only did he apparently neglect Dombey's herbarium, but the cost of books ate deeply into his patrimony. When the Revolution broke out in I 789, he became a battalion commander in the national guard, and then in turn an official in the Ministry of Justice and a judge in the civil tribunal of Paris. The botanical study fell victim to physical strife, occupational demands, and shortage of money, and nothing was heard of it for nearly ten years.

95. "Observations de M. L'Abbé Cavanilles de l'Académie des Sciences d' Upsal, sur le cinquième fascicule de M. L'Héritier," Observations sur la physique, sur l'histoire naturelle et sur les arts, XXXIV (March, 1789), 183-184. L'Héritier did not mention Cavanilles' dissertation, according to a statement in the Journal de Paris, No. 63, because it "didn't seem to him worthy of being [cited]." (Ibid., p.
1 1 I.)

96. Cameron, Sir Joseph Banks, p. 124.

97. Georges Cuvier, "Éloge historique de l'Héritier lu le 5 avril I801," Recueil des éloges historiques lus dans les séances publiques de l'Institut de France (nouvelle édition; Paris, 186I), I, 66-67. L'Héritier had some of his own dissertations printed in only five copies and distributed each to a different person, so that no one would have a complete collection. (Ibid.) 
Meanwhile, Ruiz and Pavón had long since (1788) returned to Spain. It was the appearance in France of the Prodromus, or introductory volume, of their Flora, that touched off the pursuit of L'Héritier again. At French request, copies had come into the hands of the archives, the national library, the library of the Corps Législatif, and the Institut National, successor to the Académie des Sciences. ${ }^{98}$ The officials of the museum of natural history next became convinced that the museum ought also to have a copy. They asked L'Héritier, who was at the time a bureau chief in the Ministry of Justice, to obtain it-which served to remind the museum staff that L'Héritier was still holding Dombey's herbarium.

The assembly of the museum on July 19, 1797, drafted a resolution demanding to know how long L'Héritier intended to keep the plants. At that very moment, Citizen René Louiche Desfontaines, the professor of botany, was engaged in making a single large and methodical collection out of all the miscellaneous herbaria in the museum. Dombey's was indispensable; yet for eleven years the public had been deprived of its use without receiving the compensation of a published work. Now that Ruiz and Pavón had begun to publish, and Father Juan Ignacio Molina had written a work on the plants of Chile, botanists and amateurs were eager to compare these printed descriptions with specimens of the plants themselves. If L'Héritier still planned to publish, the museum might let him have the herbarium, a part at a time, but first he must return it intact.

Three months later, no answer having arrived, the museum on October 15, 1797, drafted another request. Would M. L'Héritier please pay attention? Still no answer. In December, 1797, the administrators of the museum lost their patience. L'Héritier must indicate the exact day they could claim the Dombey collection. This flushed the pursued out of the bushes. He told the officials, in "une manière cathégorique": Release of the specimens will not take place "until after the publication of the work that I have promised to the scholarly world and for which I have made so many sacrifices; otherwise it will be the day of my death." In case that were not clear, he

98. See correspondence of Feb. 19 and 26, and April 19 and 22, 1797, between the French ambassador and the Spanish Ministry of Grace and Justice of the Indies. MCN. In $180 \mathrm{I}$, however, it would seem that the Institut had no copy at all. Spain at that time filled in the sets of both the Institut and the botanic garden of Paris. (Correspondence between Pedro Cevallos and Joseph Antonio Caballero, Jan. 2 I, April 2 and 7, 1801. MCN.) 
added: "I declare to you, in spite of the jealousy, in spite of the tricks already played and those to come, Dombey's collection will still be published, and it will be published by me alone, or I will die in the attempt." The recent return of peace guaranteed that he would "put the last hand to the monument that I must erect to the memory of Dombey." $" 99$

The administrators of the museum waited patiently for four months after this outburst, and then decided to carry their case to the top. The Minister of the Interior advised them to determine the exact status of L'Héritier's work. If it was almost finished, they should wait a reasonable interval; but if the delay were to be prolonged, the restitution of the herbarium and manuscripts must take place at once. L'Héritier, however, had too much persistence and the directors of the museum were too patient. Twenty more months went by with no change in the situation. ${ }^{100}$ Then fate stepped in: L'Héritier was assassinated at sword's point outside his doorstep on April I6, r800. Neither the perpetrators of the deed nor the reasons for it were ever found out. ${ }^{101}$ Once more the museum staff began its plaint. They asked the heirs to set a date for transfer of the herbarium, and at last, on January 24, I801, the transaction was completed. Everything was in good condition. And thus was justice done!

After collapse of government attempts to purchase L'Héritier's books and papers, Augustin de Candolle, noted Swiss botanist of the epoch, acquired a large parcel-perhaps all -of the manuscripts and drawings which today are preserved at the Conservatoire de Botanique in Geneva. Only a half-dozen drawings of Dombey's plants have been found, and of I,200 sheets of botanical analyses among L'Héritier's papers, only 3i were apparently drafted from samples brought back by Dombey. ${ }^{102}$ If these represent the whole of the collection, there is reason to guess that L'Héritier did not publish Dombey's work because, despite his reassuring remarks, he had in truth exerted very little effort on it.

99. Muséum to L'Héritier, 26 messidor an 5 (July 14, 1797), 24 vendémiaire an 6 (Oct. I5, 1797), I I frimaire an 6 (Dec. I, 1797); L'Héritier to Muséum, 2 I frimaire an 6 (Dec. II, I797). Hamy, Dombey, pp. 389-392. Dombey had died over three years earlier.

I oo. Ibid., p. 393.

Iог. Nouvelle biographie (Hoefer), XXXI, 72.

102. Hamy, Dombey, pp, xcvii-xcviii. 
Joseph Dombey would never know-at least on this earth-of these last years of contention his work had inspired. He had become a health officer at a military hospital during the siege of Lyon, but he desperately wished to escape from the Revolution and the fighting. In 1793 he sought and received a commission to travel to the United States to present a standard of the new metric weights and measures. At the same time he was to buy grain for France and supply answers to a series of questions about science, commerce, and geography in the new nation-an expeditionist in spite of himself.

But a storm forced his vessel to put in at the island of Guadeloupe in the Antilles on February I3, I794, and once more Dombey found himself immersed in the Revolution. The town of Pointe-à-Pitre, where he landed, was in the hands of the revolutionary faction, while the governor of the island, who was a supporter of the old regime, held Basse-Terre. Just as Dombey was ready to sail for Philadelphia, he was abducted by the governor's forces and clapped in jail. The partisans of Pointe-à-Pitre secured his release; and when hotheads sought revenge on the perpetrators of the plot, Dombey, in trying to calm the situation, fell into the water. He was dragged out unconscious, but recovered his senses and the turmoil subsided.

After a bout with fever, the result of his ducking, he embarked again for the United States. But two corsairs halted the ship and carried off Dombey, who was disguised as a Spanish sailor, to prison on the British island of Montserrat in the West Indies, where he died within a few days, sometime in the spring of $\mathrm{I} 794 .{ }^{103}$ His mishap-ridden life is commemorated in Dombeya, a genus named by Cavanilles, comprising some one hundred species of ornamental evergreen trees and shrubs, native to tropical Africa and the Mascarene Islands, regions this well-traveled traveler never saw.

103. Deleuze, "Notice historique," pp, 161-164. 


\section{THE CONTROVERSIAL BARK}

\section{BOTANY: THE SEVENTH NYMPH?}

Seven "prettily dressed nymphs" rode through the streets of Madrid on a summer's day in 1784 to help celebrate the return of peace and the "happy birth of the two most serene princes, Charles and Philip." The spectacle of the sprites on a festooned float symbolized scientifically awakened Spain, for each represented an art or science vying for attention in the capital. One held a glass tumbler, for she was the art of Medicire. Miss Physics carried a barometer; Miss Mathematics, a ruler and compass. A young señorita with brush and canvas obviously portrayed Painting; another denoting Sculpture, clutched carved head and chisel. A sixth, holding a column, announced to viewers that she was Architecture. ${ }^{1}$ What did the seventh nymph represent? Was it Botany? We shall probably never know, because the reporter who left this word-picture forgot to say.

If such a pageant had been repeated in 1788 , the year in which Ruiz and Pavón returned to Spain, Botany would surely not have been ignored, for much had happened during their last years overseas. New botanic gardens graced the scene in Madrid, Cádiz, Cartagena, and Pamplona; others were projected for Zaragoza and Barcelona." The first course of instruction under the new "Plan of Studies" at the garden in Madrid drew 153 registrants in 1784, and four annual prizes were established to stimulate outstanding students. ${ }^{3}$ Professors Ortega and Palau published their elementary course of botany in 1788 ; Ortega completed the Flora española in I 784; Palau translated the Species plantarum of Linnaeus between I 784 and I 788 .

I. "Descripción de las fiestas públicas," Memorial literario, II (July, 1784), 69.

2. Memorial literario, IX (Dec., 1786), 496; XVII (Aug., I789), 591. The last-named gardens, however, were not officially authorized until 1796 and 1798 , respectively. (Sarrailh, L'Espagne éclairée, p. 449.)

3. Memorial literario, I (April, 1784), 34; XV (Sept., 1788), 69. 
Priestley's up-to-the-minute theories concerning the effects of air on plants were discussed in the Correo de Madrid during $1787 .^{4}$

Classes in botanical theory now met for two hours every afternoon from April through July. For the remaining five months of the school year, the professors devoted one hour each day to "practical" demonstrations. The course attracted not only practitioners of medicine, surgery, and pharmacy, but numerous lay enthusiasts, and when the demonstrations began, "various inquisitive and distinguished persons of both sexes" joined the throng who had come to watch the show. ${ }^{5}$

Once each year, beginning in 1785 , Professor Gómez Ortega presented his best pupils in a public demonstration, and a time of glory it was. So that the "numerous and brilliant assemblage" might find the occasion "more varied and pleasant," the hall was "adorned and lighted with the greatest exquisiteness." Guests included such figures as Count Floridablanca, Minister José de Gálvez and his successor Antonio Porlier, the Dukes of Hijar and Villahermosa, the Countess Benavente with her daughter, and an array of diplomats and government officials.

The students expounded botanical definitions, traced the development of classification (rigorously defending Linnaeus), exhibited their herbaria, described flora, explained the process of nutrition, pointed out the functions of sex in plants, and railed against the "false ideas of mistaken generation and the transmutation of ... one species into another." A panel of experts and fellow students kept the prize pupils on their mettle by offering contradictory arguments.

During the intermissions an "entertaining and elegant orchestra" filled the hall with "cheery and joyful harmony." Then, after applause for the final actuante had died away, the flowers adorning hall and platform were distributed to the audience. On the following day, Gómez Ortega escorted his pupils to thank the Minister of State for sponsoring the affair. ${ }^{6}$

4. Correo de Madrid (ó de los ciegos), II (Oct., 1787), 475-476, 485-486, 493$495,500-50 r$.

5. "Real Jardín Botánico," Memorial literario, I (April, 1784), 32-33, 34; III (Sept., 1784 ), 8-9.

6. "Noticia de los exercicios públicos de Botánica... en los días 28 y $3 \mathrm{I}$ de este mes....," Memorial literario, VI (Dec., 1785), 485-486, 490-491; "Botánica. Relación de los exercicios públicos.... en los días 6 y 9 de este Mes ....," ibid., IX (Dec., 1786), 499-502; "Exercicios publicos de Botanica que se tuvieron el dia 16 de Julio de este año ...., "ibid., XV (Sept., I 788), 70-75. See also "Real Jardín Botánico," ibid., XI (July, 1787), 306. 
In the words of a chauvinist contemporary, what other nation was doing so much to arouse enthusiasm for botany? Spain was

not content to be a servile imitator of foreign schools, where there is no example of such a protracted course in which flowering plants are distributed generously among the large audience of the curious and the enthusiast, as well as the student.

Rather, Spain "encouraged its students to glory" by means of public examinations and prizes.

This noble incentive, and this zealous application, arouse the hope, with the most weighty foundation, that whereas good botanists are rare in foreign nations, they will be numerous within a few years in our Spain, whose vast dominions, abounding in countless plants, offer a plentiful harvest and fruit for their diligent investigations. ${ }^{7}$

\section{GARDENERS WITHOUT GLORY}

The pioneer harvesters-Hipólito Ruiz, José Pavón, and Isidro Gálvez-who thankfully watched The Dragon drop anchor at Cádiz on September I2, I788, could testify to the plenty. But as men who had spent eleven years of "heavy labor and dangers without number" in "deserted and trackless places," they spoke less glibly about the glory. They had put up with

heat, fatigue, hunger, thirst, nakedness, want, storms, earthquakes, plagues of mosquitoes and other insects, continuous danger of being devoured by jaguars, bears, and other wild beasts, traps of thieves and disloyal Indians, treason of slaves, falls from precipices and the branches of towering trees, fording of rivers and torrents, the fire at Macora, the shipwreck of the San Pedro de Alcántara, the separation from Dombey, the death of the artist Brunete, [and] the most touching of all, the loss of manuscripts. ${ }^{8}$

They deserved a rest, but it was time to say, with Orlando,

... these trees shall be my books

And [of] their barks my thoughts I'll character.... .

Considering the fervor of the fight with France over rights to publication, the returning botanists should indeed have sought to record their findings without delay. But the old devil Dombey was no longer a contender, and the French Revolution soon removed the

7. Memorial literario, IX (Dec., 1786), 494-495.

8. Ruiz and Pavón, Prodromus, p. xv.

9. As You Like It, III, ii, 5-6. 
threat of L'Héritier's schemes. Thus, if the Spanish botanists had ever entertained a notion of joint publication with France, they now renounced it. The modern reader who seeks to learn how the Flora Peruviana came to be, must prepare for a lengthy journey into time.

Administrative problems had first to be solved. Having left the Indies, the men fell under the jurisdiction of the Ministry of State, and logically enough, were attached to the royal botanic garden as "Demonstrators and Professorial Substitutes." This title was purely nominal, intended only to foster liaison with the garden and thus ease publication problems. But the Ministry of the Indies, having always had charge of the expedition, seemed reluctant to give it up just at the moment of publication. They convinced State that Indies was better qualified for this endeavor where "foreigners think us to be ignorant." Thus dealings between the scientists and the garden had to pass through two ministries. The men found the intendant of the garden "rudely and snappishly" hostile to their borrowing of books and were mortified to find themselves listed in the official guide of government employees merely as "Gardeners." Meanwhile, until they found a permanent site for their office in I792, they became virtually unwanted waifs, trying to work in a garden library that was not only "highly unhealthful" and "deserving of demolition," but, horror of horrors, "usually closed."10

The Spanish government kept its word as to the scientists' salary, although one would never get that view from reading the remarks of Ruiz's son. In I 776 it was plainly promised that all participants were to get half-salary upon completion of the expedition. Inasmuch as their annual pay in America, while not in the field, was $I, 000$ pesos moneda de Indias, or 20,000 reales vellón, it was perfectly in order for the king to decree an annual salary of 10,000 reales to begin when they arrived in Spain on September 12, I788. The point is stressed to offset the claim of Ruiz's son that the Spanish government cheated the botanists out of one-half of their salary. The naturalists may have pressured the crown now and then for a raise, but never on grounds of being defrauded of their legal due. In fact, because of

10. A condition, by the way, which seems to modify the picture of Spanish botanical progress in the period. Gómez Ortega to Antonio Porlier, Minister of Grace and Justice for the Indies, Madrid, Nov. 8, 1788. MCN, 1790. [Porlier] to Count Floridablanca, Minister of State, Palacio, Jan. 3, 1789; Ruiz and Pavón to Pedro Acuña, of the Council of State, Madrid, Jan. I4, 1793; Ruiz and Pavón to Mariano Galensoga, intendant of the botanic garden, Madrid, July 26, 1792. MCN. 
the difference in value between money of America and of Spain, the Io,000-real rate was actually greater than one-half their base pay in the Indies. The ministry thought it a bonus for good work, and a stimulus to expeditions still in being in other parts of the Spanish Empire. ${ }^{11}$

Despite a few inconveniences, the men undoubtedly were delighted to be home at whatever their salary. The botanists had undergone a rugged experience, and the draftsmen had seemingly hated the jungle. Isidro Gálvez had overused his license to artistic temperament by refusing, in company with his fellow painters, to stay on the job in the tropical forest-or at least he was verbally chastised by the Spanish authorities for doing so after Ruiz had complained. The returned trio of explorers had an obligation to publish their findings as soon as possible and were being paid by the Spanish government in the expectation that they would do so. Yet, what were Pavón and Gálvez up to, one year, five months, and nine days after they had landed in Cádiz from a decade of "heavy labor and dangers without number" in "deserted and trackless places"?

At that moment the Spanish crown was seeking a "botanistchemist" to enter the jungles of the province of Quito to establish a government monopoly, and improve the quality, yield, and processing methods of the quina trade. On February 2 I, I 790, José Pavón asked for the job; two days earlier Isidro Gálvez had petitioned for the post as assistant. The botanist had recently married and was expecting his first offspring; he must think of its future, and no doubt the prospective quadrupling of his salary was a prime allurement. The fact that he might not see his family for years was presumably of no moment to him; one never hears again of his wife in the documentation, though his son has a place of modest importance. But the ministry denied the requests of both Pavón and Gálvez. They would be needed soon for work on the Flora of Peru; besides, Pavón did not know enough about chemistry. ${ }^{12}$

Did impecuniosity drive Pavón and Gálvez to seek the New

11. [A. Ruiz], Historical Eulogium, p. 43. Gómez Ortega to Porlier, Madrid, Nov. 8, 1788. MCN, 1790. [Porlier] to Floridablanca, Palacio, Jan. 3, 1789; royal order to Antonio Valdés, Minister of the Indies, Aranjuez, May 25, 1789. MCN.

12. AGI, Indiferente General, legajo 1555. The government turned down Pavón and Gálvez on March 2, 1790, and appointed Vicente Rodríguez Olmedo to the post of botanist in Quito on March II, 1790. He was on the same job at least as late as 1807 . (AGI, Indiferente General, legajo 1557 .) 
World again? Or were they grasping at straws to escape domination by the outspoken Ruiz? Did Pavón regret the anonymity of his job as second botanist? Did he and Gálvez miss the outdoor life more than they had thought? Was the recalcitrance of Gálvez in the field a result of annoyance at the jungle or at Ruiz? Did the pair feel no obligation to finish the Flora of Peru, or did they foresee its failure for want of funds? If it were to be published, did they think that Ruiz would reap the glory-thus, why not let him do the work? There is reason to presume at least the partial validity of any one or all of these guesses. The historian who aspires to re-create the past of anything so complex as a human being must ever remind himself that his evidence is seldom firmer than the yellowed pages he consults in musty archives, and is as fragile as the flakes of dried brown ink left, by the quill pens of a past century, to adhere to his perspiring fingers.

\section{THE SEVEN SPECIES OF DON HIPÓLITO}

The lack of money was the biggest obstacle to publication of the Flora. This handicap was surmounted by a gigantic overseas fundraising drive during I 79I-I 794. Meanwhile, the first work published ( I792) was not a part of the Flora Peruviana at all, but Quinología, a study by Ruiz of cinchona. No doubt the importance of quina to the crown helped push this small volume (ro3 pages) to the fore, ${ }^{13}$ but even it might not have seen print if Ruiz had not donated from his own pocket and arranged for other money to publish it. ${ }^{14} \mathrm{He}$ apologized that his limited funds prevented the inclusion of drawings, but he promised to put them in the Flora. ${ }^{15}$

No monger in patent medicines ever made wider claims for a tonic than Ruiz utters in support of the miracle remedy, quina. The bark

13. The work was dedicated, under date of August 15, I791, to Count Floridablanca, who, "experimenting more than once in the alleviation of [his] precious health through the efficacious beneficence of this Spanish specific," had "contributed by this means to increase more and more its esteem among men." The count knew "much better than I could succeed in doing," added Ruiz, "how to explain the importance to the state, and even to all human kind, of establishing knowledge of the various species of quina, and of jts virtues, its uses, and its commerce." (Pp. i-ii.) 14. Ruiz to Zenon Alonso, an official in the Secretariat of Grace and Justice for the Indies, Madrid, April I $7,179^{8} . \mathrm{MCN}$.

15. Quinologia, p. xi. 
can be ground up and infused or boiled, and then administered as a liquid. If reduced to powdered form or an extract, it can be given in pills, in preserves, in diluted wine, or in water. For recent wounds or external sores it can be applied in a plaster. The drug's effects are "recognized" by experience to be "febrifuge, antiputrid, stomachic, digestive, suppurative, absorbent, [and] anti-spasmodic," and it makes a "comforting and strengthening tonic."

It thus cuts simple or complex intermittent fevers, malignant putrefactions, nervous malignancies, exanthemas and putrid effects of smallpox, continuous fevers that have regular periods of increase, periodic toothache, [and] spread of gangrene.... Administered internally or externally it restores the relaxation of the stomach, reestablishes the digestion, comforts the nerves, and facilitates suppuration in malignant fevers. By increasing the tone and vigor of the fibers, it is an excellent remedy for accidents originating in severe surgical operations. It cures verminous effects, bicho or mal del valle, a type of dysentery known in Peru, ... and fevers from measles when complicated with decay. It fortifies the weakness of the intestines, prevents miscarriages, and is useful against excessive collapse of the lungs. It produces marvelous effects in epidemics, and in the falling away of strength, in periodic headaches, in sweating accompanying a slow fever, and finally, it is an antidote and marvelous specific against all periodic infirmities, except inflammatory types such as gout and rheumatism .... ${ }^{16}$

Ruiz was especially encouraged by the extract of quina developed by him in Peru. He relates how a plaster application had stopped the pain of an elderly lady in Lima who had been unable to sew "because of laxness of an artery that indicated aneurism." As a result, she was able to continue sewing "without the least bother." Before the botanists had left Huánuco for the first time, they had sent a sample of the extract to Cosme Bueno, who succeeded in halting gangrene in one patient. Padre González Laguna, the botanist at the Colegio de Buena Muerte, was another experimenter. With the "same zeal that he had shown up till then in this realm [of botany] and many others to which his singular knowledge and incomparable love for the nation and humanity were extended," the good father used the extract to cure a Negress who was dying of "a badly treated pleuritic pain."17

16. Ibid., pp. 39-40. Apparently Francesco Torti's demonstration in 1711 that quina was valuable only in combating malaria had been forgotten by the end of the century. See Duran-Reynals, Fever Bark Tree, p. 140.

17. Quinologia, p. 5 I. 
Nevertheless, all was not going well. The heavily worked stands in Loja already showed signs of exhaustion. Many trees had been hacked off almost to the base, and collectors often spent fifteen to twenty days in the wilderness, without finding a single usable specimen. To prevent further depletion, Ruiz suggested that, whenever a good stand of quina turned up, the area be cleared of all other vegetation and an hacienda established to produce the bark. Inasmuch as most of the land belonged to the king, he could require it to be cleared as a condition of sale, forbid the buyer to otherwise dispose of the land, and obligate him to plant more cinchona trees.

Ruiz conceded this plan would be costly, but improvement in quantity and quality of the drug would more than make up the difference. The coca haciendas had benefited in this way, though admittedly they were to be found in less difficult areas. With quina farms in production, regular procedures could be set up for drying, the bark protected from sudden downpours, and warehouses built to store the dried bark until favorable weather allowed shipment. But, alas! most men did not see it that way. They wanted to reap immediate benefits, not wait for the fruit of a long-range policy. ${ }^{18}$

In any event, Ruiz insisted upon at least minimum regulation by the government to halt abuses in packing and distribution. Peons sold the bark by weight and had no desire to dry it out fully. Drivers who brought it in from the forest neglected to report when a shower had drenched their cargo, nor did their masters seem to mind or make any attempt to dry out the bark. Shipments were not packed correctly. And, finally, to compound the evil, merchants often stored the bark in damp places. ${ }^{10}$

Ruiz, as a scientist, also saw the need for training in botany to combat inefficiency and error in quina analysis. Few cascarilla ${ }^{20}$ merchants, he alleged, knew how to differentiate species (or "qualities," as they called them), and none did it methodically or without mistakes. One day they would despise a batch as badly colored, or too thick or too thin; the next day it would be exquisite-especially if in a different box! Physicians were just as confused; one approved what others scorned, and the popularity of a species rose and fell with the years. For some doctors, one kind of cascarilla worked wonders; used

18. Ibid., pp. 14-18.

19. Ibid., pp. 24-25.

20. In Peru, the term "cascarilla" was frequently substituted for quina. The term is broader than implied by the present-day genus Cascarilla. 
by other physicians, it made the patient worse. Part of the blame must go back to the bark collectors. Experience told them how to distinguish fine from inferior quality, but they could not often recognize whether they were dealing with different species, or with mere varieties arising from an accident of terrain. Unwillingness of physicians to accept a bark might thus easily result from collectors intermixing species-either because they did not know any better, or because they thought it unimportant. The remedy was "to possess radically the fundamentals of botanical science." 21

Ruiz sought to lay the foundation for better botanical knowledge by announcing that he had observed, collected, described, and had drawings made of seven species of Cinchona: ${ }^{22}$

I. Cinchona officinalis (later called by Ruiz C. nitida), a "fine cascarilla," thought to be identical with the prized product of Loja. The trees, which reached a height of forty feet, favored high hills where it was sufficiently cold at night, but sunny and mild during the day. They had been found in the provinces of Jauja, Huánuco, Panatahuas, Huamalíes, Cajamarca, Moyobamba, and Chachapoyas in Peru, and the "Ecuadorean" provinces of Loja, Jaen, and Cuenca -in other words, distribution was widespread.

2. Cinchona temis (later called by Ruiz $C$. hirsuta), the "thin cascarilla" produced by a small tree, not over fifteen feet tall. Although medical opinion favored the species, economics dictated the virtual abandonment of production, for, because of the thinness of the

21. Ruiz, Quinología, pp. 19-20, 29-30. Great waste also resulted, Ruiz charged, from the belief that the only bark of value was that covered by a type of lichen. Admittedly, this usually meant a better grade, but was not a sufficient indication. Frequently the bark was separated into seven "qualities" depending on color, whereas, according to Ruiz, the color was due solely to the lichens and might vary even on the same tree. (Ibid., pp. 27, 31.)

22. See n. 21, p. 106, above, regarding the omission of present-day names for species of Cinchona. The botanical characteristics of each species as described by Ruiz are also omitted. As to quality of the bark, Ruiz set up the following standards: internal color (the more inflamed, but not opaque, red, the better); thickness of the stalk (between an inch and a half and the thickness of an ordinary writing quill); fleshiness of the bark (not over a linea [one-twelfth of an inch]); consistency (the more solid and strong, the better); weight (the heavier, the better); breaking quality (must be even, i.e., provided the fleshiness is normal, there should be little or no splintering of the ends); gummy resinous sap (the more abundant, the better); odor (the more active and pleasing, the better); taste (the more bitter, the better, but not to the point of creating nausea; should have enough acid to "excite and move" the muscles and the palate without "repugnance," but its astringency should not be so harsh as to pucker the mouth too much); and surface (the rougher and more "cracked," the better). (Ibid., pp. 32-36.) 
bark, a peon could gather no more than a half-arroba a day, as against four or five arrobas of other species. This type had been found on the tops of cold and rainy hills where there was also plenty of sunshine and wind, in the vicinity of Pillao and Acomayo in the province of Panatahuas.

3. Cinchona glabra (later called by Ruiz C. lanceolata), "boob yellow cascarilla," so called because of its similarity to officinal except for a difference of internal color and the absence of a desired covering of lichens. While deceptive in its own appearance, it was considered an almost infallible guide to officinal. Whenever a collector came across $C$. glabra on a hillside, he could expect to find the better grade higher up on the same hill. Ruiz felt that it might be even more effective than the others, but, at this time, it was being admitted into commerce only when mixed with the two previously mentioned species.

4. Cinchona purpurea (purple-leaf boob cascarilla), a species of lesser value to medicine. It was supposedly forbidden in commerce, though collectors often deceived the dealers by mixing it with the three types listed above. The trees, which attained a height of twenty feet, had been discovered on the slopes of low hills, where it was cool at night and very sunny during the day, in the forests of Pati, Cuchero, Muña, and Iscutunam of the province of Panatahuas.

5. Cinchona lutescens (later called by Ruiz C. magnifolia), the flor de azahar or "citrus blossom," giant of all the species-often over one hundred feet tall. Commercial channels accepted the bark only in the form of an extract. The tree's favorite spot was low ground near arroyos, where it was sunny during the day and mild at night; it had been located near Cuchero, Chinchao, Chacahuassi, and Pozuzo.

6. Cinchona pallescens (later called by Ruiz C. ovata), commonly called "cascarilla with bark the color of a female widgeon" (pata de gallareta). A poor stepsister of the other species, its bark was not admitted into commerce, and the extract was not so pure or transparent as that of the azahar, though it was more bitter. This tree of medium height liked best the deep shadows of other taller and leafier trees in the royal forests of Pozuzo and Panao.

7. Cinchona fusca (asmonich), a tall tree growing in deep, hot, and stuffy arroyos of Pozuzo and Muna, where the nights remained warm. No medicinal use had been found for its bark. ${ }^{23}$

23.Ibid., pp. 56-78. Ruiz, Relación, I, 153, 164, 340, 355-356. Ruiz and 
Ruiz felt certain that these seven species did not exhaust the possibilities. In fact, he mentioned three more: "cascarilla with leaves like an olive tree," calisaya, and colorada. The second, which Ruiz likened to "boob yellow," was an extremely bitter variety stirring up interest in Peru after its recent discovery at Monzón. At that very moment Tafalla was forming an expedition in order to get more information about it.

The colorada, found in the audiencia of Quito during I 785-I 786, provides a good example of the strange economics of the quina trade. The collectors who first brought it to Guayaquil had little confidence in its virtues and sold it for a song, and the merchants who passed it from there to Lima were equally dubious. But by the time some boxes reached Cádiz, no doubters happened to be present, and English merchants paid the good price of sixty reales vellón a pound. When this news reached the dealers in Guayaquil and Lima, they hurried to get more colorada; now it was rivalling the best of Loja, even in the eyes of some Spanish medical practitioners. ${ }^{24}$

Ruiz foresaw the extension of quina production into new areas; perhaps into Spain itself-Galicia, Catalonia, the Basque provinces, maybe even Andalusia. ${ }^{25}$ But he especially awaited the findings of José Celestino Mutis in Santa Fe de Bogotá: "What enlightenment we can promise ourselves from the publication of the Quinologia of such a wise medical doctor and botanist!"26

\section{MUTIS' QUINA OF MANY COLORS}

Ruiz's enthusiasm for the work of Mutis had been the result of a short treatise in manuscript that had come to hand just before he published his own "Quinology."27 As befitted a physician, the author,

Pavón, Flora Peruviana, Vols. II, III. It will be noted that the best grades of cascarilla were obtained from trees located near hilltops in areas where the temperature dropped appreciably at night. Species which favored hot, low, or poorly ventilated places did not fare as well commercially.

24. Ruiz, Quinologia, pp. 85-9x.

25. Ibid., p. 21 .

26. Ibid., p. ix.

27. Published at Cádiz in the same year (1792) under the title Instruccion formada por un facultativo existente por muchos años en el Perú, relativa de las especies $y$ virtudes de la quina. The Instrucción was dated at Mariquita (New Granada), Oct. 4, 1790, and signed "J.C.M." (José Celestino Mutis). The reference to Peru in the title, no doubt added by someone in Spain, is an example of 
Mutis, stressed the medicinal effects of each of his four types of quina, which he called orange, red, yellow, and white. God had provided these four species in proportion to the medical need for each, and it was up to mankind to fathom His will. Otherwise "it will only be by a happy coincidence of unknown origin" that man is healed.

He asserted that the orange cascarilla, which he labeled Cinchona lancifolia, was the true quina of Loja and the only species directly febrifuge-the single true specific against intermittent (i.e., malarial) fevers. All other species achieved this end only indirectly. More generally speaking, orange quina "exercised dominion over the nerves." Unluckily, it was exceedingly rare-not more than one tree for every thousand of the other three types. Red quina, or Cinchona oblongifolia, the most profuse species, was master of the muscular system and could halt gangrene most effectively. In cases of inflammation, however, its use was positively harmful. Yellow quina, or Cinchona cordifolia, was a cathartic that worked best "on the mass of the humors." It was the type to use in cases of remittent and continuous fevers. The fourth species, white quina (Cinchona ovalifolia), had been rejected in commerce; yet, of all the varieties it worked best on the bowels, and was very good in many cases of inflammatory fevers. ${ }^{28}$

\section{THE PHYSICIANS" “LINE OF DEMARCATION"}

Neither the hopeful predictions of Ruiz nor the report of Mutis gives any intimation of a battle seething already for fifteen years in

the confusion reigning in Europe about the geography of the Indies. Linnaeus usually spoke of Mutis as living in New Spain. In actual fact, he never set foot in either of these realms.

28. Ibid., pp. 8-17. This information was published as the "Arcano de la quina" in the Papel periódico de la ciudad de Santa Fé de Bogotá (1793-1794) and summarized frequently in subsequent years. See "Observaciones, y Conocimientos de la Quina, debidos al Doctor D. Celestino Mutis, Comisionado por S.M. para este y otros importantes asuntos," Mercurio peruano, XII (1795), 2 I I-214; "Extracto de una memoria del Dr. D. Joseph Celestino Mutis, célebre médico y botánico de Santa Fé de Bogotá," Semanario de agricultura y artes dirigido á los párrocos, IV (Aug. 16 and 23, 1798), IOI-110, II9-123; "De las diferentes especies de quina y sus virtudes medicinales," Gazeta de Guatemala, VI (Sept. 7 and 13, 1802), 216-218, $221-225$. Ruiz summarizes Mutis' findings in Quinologia, pp. viii-ix. A convenient outline of the properties attributed to each species is to be found in Gredilla, Biografia de Mutis, p. 124. 
New Granada over the priority and significance of quina discoveries. Mutis, whose duties as physician, mathematician, mineralogical expert, and cleric left little time to botanize during his first twenty years in America, nevertheless often looked for cinchona. He claims to have found it in 1772 and again in 1773 , and in the latter year sent samples to Linnaeus, which, however, never reached that savant.

In I774, a Panamanian Creole, Don Sebastián José López Ruiz, with considerable learning in the arts, physics, and jurisprudence at the University of San Marcos in Lima, but admittedly little knowledge of botany, also found the tree near Bogotá. López made a great to-do about the importance of his discovery, especially portraying it as an easily accessible replacement for the declining stands of Loja. At his suggestion, samples of two varieties were turned over to Mutis for analysis. But when the latter insisted upon his own priority of discovery, López in 1778 hied himself to Spain, trying to gain recognition as the finder. He was so successful in reaching the ear of Gómez Ortega that he obtained a salary of 2,000 pesos a year to take charge of all quina-gathering in New Granada. ${ }^{29}$

For over four years, López was tsar of cinchona in New Granada while Mutis languished at the mines. But the tables were turned with the advent of Archbishop-Viceroy Antonio Caballero y Góngora and the creation of a botanical expedition under Mutis' direction in $1782 .^{30}$ The viceroy and the regent visitor-general convinced authorities in Spain that López's claims to primacy of discovery were false, whereupon Minister of the Indies Gálvez took away his job and forbade him to come to Spain "to bother the royal attention."

29. Ibid., pp. 106-1 13. Juan Antonio Susto, Sebastián José López Ruix, médico y naturalista ( $1741-1832$ ) (Panamá, 1950), pp. 10-14. "Relación de los Méritos y Servicios de don Sebastian Josef Lopez Ruiz," Madrid, Nov. 19, I 794. AGI, Audiencia de Quito, legajo 227, printed in Anales de la Real Academia de Farmacia, XXIII (No. 3, 1957), 302-304. Gómez Ortega wrote Thouin in April, 1777, from Madrid: "They have just discovered in the realm of Santa $\mathrm{Fe}$ a great abundance of the tree that furnishes the true quinquina in Peru [i.e., in Loja]. The king has sent me four large cases of that bark with samples of the flowers and fruits. We have examined them with Mr. Dombey; we have assured ourselves of the genus Cinchona; we also tend toward the opinion that it is the true medicinal species. His Majesty, excited by my entreaties, has deigned to order that they send us the trees en nature." (Hamy, Dombey, p. 329.)

30. See pp. 45-46, above.

3x. Gredilla, Biografia de Mutis, pp. II 3-1 14. Susto, López Ruiz, p. 16. See also Anales de la Real Academia de Farmacia, XVI (No. 2, 1950), 139-143, for documents from AGI, Audiencia de Santa Fe, legajo 757, dealing with the LópezMutis controversy. 
But the triumph of Mutis was incomplete, for he had been competing not only with López, whom he later called an "ignorant charlatan,"32 but with powerful commercial and governmental interests, representing the quinine trade of Loja, who had no desire to lose their business to an upstart in New Granada. Though a crown monopoly in quina had obvious advantages, rivalry between the areas prevented a satisfactory agreement. In the eyes of the viceroy of New Granada, his realm ought logically to supply Europe and all northern points while Loja sent its bark to Peru, the Philippines, and Asia. Needless to say the prospect of losing all European markets did not sit well with the president of the audiencia of Quito. ${ }^{33}$ As the forests of Huánuco began also to provide competition, traders from Loja moved in to take over these stands. Then, through connections with old-line commercial houses in Spain, they quite successfully edged the bark of New Granada out of the Spanish market. ${ }^{34}$

Indeed, prejudice against New Granadine quina reached very serious proportions. Despite the fact that a junta of experts had, in 1785 , found the bark "identical in species and effects with the select quina of the province of Quito,"35 the king's lord chamberlain (sumiller de corps), supervisor of royal pharmacies, countered that it was "of no value for use in medicine." More tests resulted in a compromise view by Protomédico José Salvarega that the quina of Bogotá was probably suitable for medical use, but could not yet be ranked with that of "Peru" (presumably meaning Loja). The lord chamberlain, the Marquis of Valdecazana, remained unmoved, and on February 25, 1789 , the crown suspended until further notice shipments of quina from Bogotá. ${ }^{36}$

Supplies from there began piling up on the docks in Cádiz. But because so many men were employed in collecting and distributing

32. To Francisco Martínez de Sobral, physician of Charles IV, Mariquita, Dec. 19, 1789 . Gredilla, Biografia de Mutis, p. 99.

33. Ernesto Restrepo Tirado, "Apuntes sobre la quina," Boletin de historia $y$ antigüedades, XXX (Bogotá, Sept.-Oct., 1943), 912-916.

34. Humboldt, "Cinchona Forests," pp. 32-33.

35. Real orden of March 2, 1785 , to viceroy of Santa Fe, in Sebastián Josef López Ruiz, Defensa y demostracion del verdadero descubridor de las quinas del Reyno de Santa Fé ... (Madrid, 1802), p. 24. It was this junta, or one similar to it, of which Restrepo Tirado speaks, in telling that twenty-two practitioners (including the protomédico, physicians of the king's chamber and family, and the chief pharmacist) supported the quality of the bark from New Granada. ("Apuntes sobre la quina," p. 9 I 7.)

36. "Apuntes sobre la quina." 
the bark, the king hesitated to reject it completely, and ordered further tests. Doubts once raised, however, were hard to erase. In the words of Alexander von Humboldt, "Physicians, like the Popes, drew lines of demarcation on the map," insisting that north of a certain point in the northern hemisphere no effective quina could be found.

The effect of mercantile cunning went so far [said Humboldt] that, at the royal command, a quantity of the best orange-coloured cinchona bark from New Granada, which Mutis had caused to be peeled at the expense of the king, was burned, as a decidedly inefficacious remedy, at a time when all Spanish field-hospitals were in the greatest need of it. ${ }^{37}$

Through the years, however, a market for New Granadine quina had been growing in the countries of northern Europe and in the United States, owing to the relative closeness of Cartagena de Indias. Thus English traders hastened to buy secretly a part of the condemned cinchona and sold it at a good price in London. ${ }^{38}$ In recognition of the standing of the bark of Santa $\mathrm{Fe}$ among foreign nations, even the irascible lord chamberlain finally agreed that it could be sold at export. ${ }^{39}$ But on September 7, r790, the king resolved that no further shipments be made at royal expense, because of the bark's proven "bad quality and scanty virtue." Instead, the trade was opened entirely to private commerce to make of it what it could..$^{40}$ Ten years later, however, the monarch found Spain so pressed for the bark he decided to give Bogotá another chance, and dispatched a Frenchman of repute, Louis Rieux, to conduct experiments there.

Malediction reached a new peak as the nineteenth century began. Sebastián López had gotten to Spain to sue Mutis in 1792 and, though he lost his case, he preserved his volubility. Ruiz and Pavón had published drawings and descriptions of nine species of cinchona in I799, in the second volume of the Flora Peruviana. Now, in I800, Francisco Antonio Zea, a botanist trained by Mutis, fired a volley in the Anales de historia natural. ${ }^{41}$ His reasons for writing were many:

37. Humboldt, "Cinchona Forests," pp. 32-33. Restrepo Tirado, "Apuntes sobre la quina," p. 921 .

38. Humboldt, "Cinchona Forests," p. 34.

39. Restrepo Tirado, "Apuntes sobre la quina," pp. 922-923.

40. Mutis to Viceroy Pedro Mendinueta, Santa Fe, Oct. 16, 1801. Gredilla, Biografia de Mutis, p. 134 .

41. II, 196-235, published in Madrid. Zea cited endorsements by foreign experts such as Bergius, Pringle, Murray, Asti, Carminati, and Clarke, as well as experiments by the academicians of Paris and London, in support of his claims for the 
to lay down again the Mutisian principles of quinine medication; to demonstrate by imposing testimonials the little foundation for Spanish prejudice against the bark of New Granada; to reassert the claims of Mutis to priority of discovery in New Granada and wipe out once and for all the bothersome rantings of Sebastián López; and to prove the similarity of New Granadine and Peruvian barks by eliminating the distinctions set up by Ruiz and Pavón.

López in reply invoked again the arguments plaguing Mutis for years. If the latter had come to New Granada already trained as a botanist; if he had frequently passed through country in which cinchona grew; if he had in I 762 first seen samples of the quina of Loja -why did he not discover cinchona in New Granada until I772, eleven years after his arrival? It was growing in profusion all around him. If, in 1772 , he had actually found quina, why did he doubt its efficacy as a drug when he examined the samples turned in by López in 1776 ? Why had he not experimented himself? The very doubts of Mutis, so López alleged, had helped bring on the low repute of New Granadine bark. When Mutis did begin to supervise the gathering of quina, his inefficiency brought further odium to the product through the bad quality of his shipments to Spain. Now Mutis had begun to speak knowingly of the medicinal values of each species. But where did he obtain such data? He was absent for years attending to his mining operations. When in Bogotá, he spent most of his time hearing the confessions of nuns. When did he find opportunity to try out the different species on patients? ${ }^{42}$

Alexander von Humboldt, who should know whereof he speaks, points out that

if we consider the diversity of plants which engage the attention of the botanist in these countries; if we reflect that in the tropics the height of the trunks withdraws from our eyes both leaves and blossoms; we shall be the less surprised that Mutis discovered Cinchona only in 1772 , when he found it in blossom. ${ }^{43}$

Yet when Zea suggested that López was unqualified to have made the discoveries he claimed, the latter, who admitted he was untrained

efficacy of the product of Santa Fe. (Pp. 234-235.) Dr. Clarke, a physician of Philadelphia, had written a tract recommending the white quina of Santa $\mathrm{Fe}$ as an effective remedy for yellow fever. ("Aviso importante" from the Diario de Madrid of Sept. 13, 1800. Gredilla, Biografia de Mutis, pp. 87, 90.)

42. Defensa y demostracion (1802), pp. 10-14, 20.

43. "Cinchona Forests," p. 26. 
in botany, replied that it was enough to have seen dried specimens in Lima during his youth. With their shape and form fixed in his mind, he discovered cinchona near Bogotá the first time he passed through the area. Who else could not do the same? If Zea had gone to Spain possessing no botanical knowledge and had seen a peach or orange or myrtle tree, would he not have recognized it from having seen its like in America? ${ }^{44}$

López excoriated Mutis for being unsure of the bark's effectiveness after only brief acquaintanceship with it, yet he also taunted him for proclaiming the medicinal virtues of quina after Mutis had known of the bark's existence in New Granada for nearly twenty years. In López's sight, apparently, experience was not enough basis for a change of heart. Humboldt did science a service when he wrote López in 1802 that the influence of a discovery was more important than the name of the discoverer. "Most remote posterity will remember those who, carried forward by a patriotic zeal, sacrifice their own interests for the good of their fellow citizens." ${ }^{35}$

\section{THE INVECTIVE SUPPLEMENT}

Zea's second antagonist, Hipólito Ruiz, was a come-lately to the argument. In the Quinologia of 1792 Ruiz had been pleasantly anticipating the "enlightenment" promised by the labors of Mutis. But by 1800 he no longer believed in the invincibility of that "wise medical doctor and botanist." He was certain the quinas of New Granada were inferior. Thus when Zea sought to prove defective Ruiz's classifications of cinchona, the explorer of Peru exploded, joined by his companion Pavón.

As a vehicle for their invective, Ruiz and Pavón published at their own expense a "Supplement to the Quinology." ${ }_{48}$ Ostensibly, it was designed to inform the public of new species of cinchona discovered in Peru by Juan Tafalla. Indeed, it announced five such species. ${ }^{47}$ The authors also presented a drawing and description of

44. Defensa y demostracion, pp. 18-19.

45. Letter of Feb. 4, 1802 , from Quito. Gredilla, Biografía de Mutis, p. I 32.

46. Suplemento a la quinología... (1801). The original Quinologia was written by Ruiz alone. See Suplemento, p. 91 .

47. These were $C$. micrantha and $C$. dichotoma, both of fine quality for medical use; C. negrilla, an excellent "median quality" quina preferable to the orange of New Granada; $C$. acutifolia, very inferior for medical use; and C. laccifera, useful 
the orange quina of New Granada, based on dried specimens brought to Spain by the argumentative Sebastián López. It was published "in order that one may see the notable differences between this quina and the other species of our Flora peruana," and in order, they might have added, to banish the notion that the product of Bogota was just as good as the Peruvian. In a sense, publication of these data was also a slap at Mutis for being so dilatory in making his botanical findings known; he still had disclosed only medicinal data on the species. ${ }^{48}$

More than a repository of new botanical knowledge on cinchona, the supplement was a fire-belching commentary on the inadequacies of Zea and Mutis. It seared Zea for having suggested the intolerable proposition that almost all of the species of Ruiz and Pavón could be reduced to mere varieties of the orange, red, or yellow quinas of Mutis. ${ }^{49}$ If this view gained acceptance, it would have meant equating the quinas of New Granada with those of Peru. The policy of discrimination that had hitherto favored the dealers in Peruvian cinchona would collapse.

Ruiz and Pavón did not deny Zea's allegations completely, but played a cautious game. Yes, their fifth best species, $C$. magnifolia, was the same as the red of New Granada-but it was inferior in any case, fit only for extract. Yes, their $C$. ovata (number 6) was probably the yellow of Mutis-but was even poorer in quality than number 5. Yes, the discovery by Tafalla of a "quina that looks like calisaya" might possibly prove to be the same as the orange-but it would still rate no higher than fourth on their list. In other words, the best Mutis had found, orange, was only of median quality; the red and yellow were inferior; the white, of which no trees had been located in Peru, was worst of all. Cinchona trees in New Granada grew at lower altitudes than the top-quality stands of Loja or Peru-

for dyes but only first among the inferior quinas for medical purposes. (Ibid., pp. 1-10, 1 3.)

48.1bid., pp. i, I4, I1 1.

49. Zea divided the first six of Ruiz's species as follows: Orange

Red

Yellow
1. C. nitida
3. C. glabra
5. C. magnifolia
2. C. hirsuta
4. C. purpurea
6. C. ovata

He sought to relate species no. 7 (C. fusca) to the subsequent $C$. rosea of Ruiz and thence to the orange of Mutis. The new species, $C$. micrantha, he decided, was a variety of yellow. C. dichotoma he considered not cinchona at all. (Zea, "Memoria sobre la quina," pp. 227-230. See also Ruiz and Pavón, Suplemento a la quinologia, pp. $20,45,46,52,54,6 \mathrm{r}, 72,74,87,88$.) 
a sure indication of the inferiority of the former! Moreover, repeated tests and the opinions of practical-minded bark peelers sent from Loja into Peru offered convincing proof of the excellence of the best Peruvian stands. ${ }^{50}$

The principal complaint of Ruiz and Pavón against Zea was his insufficiency of botanical knowledge. He had admittedly been attached to Mutis for only two years, without previous botanical instruction, and had left his company six years ago. How then could he set himself up as an authority to make "delicate" observations of plant synonymity? The "most consummate botanists make mistakes at every step" without the living specimens before their eyes. Yet Zea was trying to present comparisons after having seen no more than the dried plant specimens in Madrid. ${ }^{51}$

Even Zea's study of the dried plants was open to question. Ruiz and Pavón accused him of entering their office (i.e., the "Botanical Office of Peru" in Madrid) and "surreptitiously" handling the specimens in order to take his notes. Aided only by the janitor, instead of Ruiz or Pavón, who would have been happy to assist him, Zea had mistaken some species for others and missed seeing the complete collection. But of course, the botanists jeered, if Zea had behaved in an upright manner, he would not have had material for his fallacious analysis. $^{52}$

The consistent disparagement of Zea's abilities by Ruiz and Pavón -who insisted he had "made a mistake in almost everything pertaining to botany"53 - discounted Zea's own statement that he had "worked a great deal at the side of Sr. Mutis ... in distinguishing the species and varieties of the genus Cinchona, and its barks in diverse states." Continued Zea:

I have handled his manuscripts and spent an entire year traveling through the immense jungles of the Magdalena to inspect the stands of quina oficinal, large or small. Having become familiar with them, and distinguishing their most trifling varieties, more by the advice of Sr. Mutis than by my own knowledge, I do not find it strange that, upon studying carefully the herbarium of the Flora of Peru I have recognized the identity of its dried skeletons or branches with the plants of Santa $\mathrm{Fe}$, and the mistakes that these professors have suffered 101.

50. Ruiz and Pavón, Suplemento a la quinologia, pp. 18, 45, 53, 60-61, 73, 93 ,

5 1. Ibid., pp. vii, $25,66,7$ 1.

52. Ibid., p. 70 .

53. Ibid. 
in making species out of botanical varieties and even from purely accidental ones. ${ }^{54}$

Whether or not the critical reader is convinced of Zea's professional qualifications, he might find it easy to chide Ruiz and Pavón for their own description and drawing of the orange quina of Santa Fe-presented in this same frenzied supplement and admittedly taken entirely from dried specimens which the botanists had never seen in a living state.

Just as Ruiz and Pavón viewed the cinchona of New Granada as subordinate in quality to the Peruvian, so they now tried to show that Mutis' achievements were of smaller moment than their own. Linnaeus' son had once called Mutis the "greatest botanist in America," but what did this mean? At that time long ago there had been none other in the New World-superior or inferior-with whom to compare him.

Mutis was promise without performance. He received a big salary, had a marvelous library, and was employing, at the moment, eighteen artists, who had made four thousand drawings. Yet he never allowed anyone to see his own work and he had never sent specimens to Spain, despite being commissioned an official botanist for seventeen years and living in New Granada for forty. Rumors told of his excellent collection of specimens, but many a catastrophe could occur before the collection reached Europe-Ruiz and Pavón could speak with experience there. Nor could Mutis' specimens be considered reliable, for, because of his age and infirmities, he had not gone into the field for years, but had sent peons or students instead. ${ }^{55}$

In the same breath, Ruiz and Pavón rushed to defend Sebastián López, the persistent adversary of Mutis. López, they said, was much more knowledgeable in botany than even he himself had claimed. He might not be a "more or less superior" plant scientist, but the Peruvian explorers had seen him in Madrid attending lessons at the royal botanic garden and studying chemistry daily for more than three years-which ought to place him above Zea in experience! If López had had the advantages of equipment and assistance available to Mutis, he would have "made progress in botany" in America. ${ }^{56}$

54. "Memoria sobre la quina," p. 226.

55. Suplemento a la quinologia, pp. 21, 23, 25, 31, 77, I10, II I.

56. lbid., p. 34. Ruiz may not have known that in $180 \mathrm{r}$ Zea was in Paris to take instruction in chemistry. (Mutis to Humboldt, Santa Fe, Oct. 21, 1801. Gredilla, Biografía de Mutis, p. 283.) 
Ruiz and Pavón brushed aside Mutis' single publication, the Arcano de la quina. Why would a man like Mutis, "who is and passes as a botanist," fail to tell the public how to recognize the species before dealing with their medicinal virtues? He must have feared the public would discover that his quinas were different from the "superior Peruvian" species! Mutis had also erred in using the names of colors to distinguish his species: the yellow and orange varieties were very similar, the orange did not look the color of an orange at any stage of maturity, and the interior of the white quina was reddish. ${ }^{57}$

Ruiz and his companion claimed to find many "surprising propositions" in the little treatise on quinine, but one may conclude that probably the most annoying was the complete omission by Mutis of any mention of Ruiz's Quinología. Ruiz had published his treatise in I792; Mutis' Arcano began to appear in the following year. Ruiz claimed that the publication of his own Quinologia had goaded Mutis to action. This allegation, however, ignores the fact that the basis for the Arcano was already in manuscript and had been seen by Ruiz before he published his Quinologia. Ruiz also makes the patently ridiculous suggestion that Mutis mentioned seven species (though discussing only four in detail) because Ruiz had also listed seven and the New Granadan did not want to be outclassed. ${ }^{58}$

It seems impossible that Ruiz and Pavón intended these charges to be taken seriously. The pair stood on firm ground when comparing their record of plant remittances and publications with the silence of Mutis, but the derisive and childish nature of many of their other remarks detracts seriously from their scientific stature.

\section{THE WAGES OF FACTIONALISM}

In the eyes of Mutis, the "public writings of the authors and abetters of the Flora of Peru" were evidence of a "sworn pledge" to eliminate the quinas of Santa Fe from consideration by ministry or nation. These men, with the powerful advantage of being at Court, would "leave no stone unturned to bury if they could the memory of

57. Suplemento a la quinologia, pp. 30, 35, 36.

58. Ibid., pp. viii, 28-30, 33, 90. Ruiz, Quinologia, p. viii. Humboldt said that the supplement of Ruiz and Pavón was "written with a bitterness which ought always to remain foreign to the calm course of scientific inquiries." ("Cinchona Forests," p. 34.) 
the quinas of Santa Fe."50 Humboldt, who always expressed respect for Mutis, speaks of "complaisant botanists . . . boldly exalting varieties to species" so as to establish differences between Peruvian and New Granadine cinchonas-to the advantage of the Peruvian, of course. ${ }^{60}$

Actually, Ruiz and Pavón needed no nefarious inducements to defend their findings. The nomenclature and classification of cinchona were still in a "fluid" state, and considerable room existed for error or difference of opinion. "Indeed," says Humboldt, "I hardly know any one tree varying more in the shape of its leaves than Cinchona."

Whoever determines single specimens of dried collections, and has no opportunity to examine or observe them in their native forests, will ... be led to discover different species by leaves which are of one and the same branch.... It would deceive the bark-peelers (cascarilleros) themselves, if they did not know the tree by the glands, left so long unobserved by botanists. ${ }^{61}$

Today some botanists recognize the existence of about I 50 varieties of Cinchona, comprising 38 species. Others feel that the taxonomy of Cinchona is still so indefinite that it may possibly be not one genus, but perhaps five or more genera. ${ }^{62}$ It is no wonder that in the infancy of botanical study of this highly valuable tree there was so much confusion. Sincere men were trying to equate their best specimens with those of Loja without ever having been to Loja for on-thespot comparisons. Nor had Mutis ever seen any part of Peru, nor Ruiz and Pavón the viceroyalty of New Granada.

The status of the revered quina of Loja was itself problematical. A part of its reputation seems based on priority of discovery rather than on inherent excellence of the bark. From the time of La Condamine's find in 1737 until the end of the century, at least three different species bore the figurative trademark "quina de Loja"-a fact

59. To Viceroy Mendinueta, Santa Fe, Oct. 16, 1801. Gredilla, Biografía de Mutis, p. 136.

6o. "Cinchona Forests," p. 32.

$6 \mathrm{I}$. Humboldt points out that cinchona trees vary in the shape and smoothness of their leaves, depending upon the altitude, the severity or mildness of the climate, the degree of moisture in the soil, and whether the trees are standing singly or are closely surrounded by other plants. (Ibid., pp. 36-37.)

62. Encyclopedia Britannica (1960), V, 708. Jaramillo-Arango, "Estudio crítico," p. 85. F. R. Fosberg to the author, Washington, D.C., April 1, I963. See n. 2 I, p. 106, above. 
which Ruiz and Pavón admitted. ${ }^{63}$ The evidence is clear that, at the beginning of the nineteenth century, no one was in a position to stand up as the final arbiter in the game of cinchona identification.

Under the circumstances it is regrettable that the spirit of factionalism hampered logical and efficient development of cinchona stands everywhere. ${ }^{64}$ Ruiz had always been a favorite of Gómez Ortega. The latter had been impressed with Sebastián López from the earliest appearance of that eccentric individual in Spain, and Ruiz and Pavón always treated López with respect. Mutis had never fared well in his relations with Ortega, and Zea thus met a cold reception from the Ortega-López-Ruiz axis. But the new power in Spanish botany, Antonio José Cavanilles, who in 180 I ousted Gómez Ortega as head of the royal botanic garden, was a bitter opponent of Ruiz. He had been on intimate terms with Mutis by correspondence since 1786 , and in 1803 Zea became Cavanilles' assistant in Madrid, and took over the headship after the latter's death in 1804 .

Of all his supporters, however, Mutis looked most hopefully to the illustrious Humboldt to rescue New Granadine quina from the obscurity into which his enemies had thrust it:

In effect, all Europe recognizes in the savant Humboldt a competent judge, whose vote for impartiality and intelligence will cut the learned controversies out by the roots, and end by removing our quinas from the unjust opprobrium in which the botanists of Peru and their henchmen have tried to keep them submerged, with notorious prejudice to humanity, our commerce, and no little insult to the truth. It thus seems impossible that they still resist, as the brightest of daylight, the testimony of two intelligent botanists [Humboldt and his companion Aimé Bonpland], who have observed our quinas in their native soil with the most serious and prolonged study, comparing them afterwards with those of the southern provinces. The identity of species is decisively assured by the uniformity of the climate, soil, and vegetation. Thus, to have resorted to the imaginary reasons of an impertinent and annoying geographical erudition with which they [Ruiz and Pavón] have sought to confuse the public in a miserable

63. Ruiz and Pavón, Suplemento a la quinología, pp. 69-70. Humboldt, "Cinchona Forests," p. 32. See John Eliot Howard, Illustrations of the Nueva Quinologia of Pavón (London, 1862), p. vii: "It certainly appears that this preference [for cinchona of Loja] depends upon the casual fact of our acquaintance with the species having commenced in that region, rather than upon any real superiority."

64. Though Haggis ("Fundamental Errors," Bulletin of the History of Medicine, $X, 420$ ) may have a valid point when he states that "the contest between these distinguished Spanish antagonists was by no means detrimental to the advance of knowledge concerning Cinchona. It stimulated the zeal for botanical investigation and led to an era of pioneer work...." 
apologetic tract, in order to put in doubt the equal efficacy of their medicinal virtues, has only served to rouse the laughter of the learned, who, like Humboldt, have graduated out of medical charlatanry. For, who now does not know that all that tasteless reasoning falls flat when one merely resorts to the simplest proof of experience? In effect, here as in every place where our quinas have been administered they provide the same favorable effects as the celebrated ones of Peru, without the necessity of demanding the renowned [quina] of Loja by some habitual prejudice. And if its efficacy is still questioned in some places doubtless this arises from the absolute ignorance in which the judgment of species and their respective virtues is kept buried. ${ }^{65}$

\section{VICTORY GOES ELSEWHERE}

The final victory belonged to neither. Mutis, Ruiz, and Pavón wrote further studies on cinchona, but none was ever published in the form intended by its author. ${ }^{68}$ The wars of independence upset the system of collection and trade, and new developments in the chemistry of bark analysis, made public in I 820 , caused emphasis to shift to another area-the country we now call Bolivia.

The Bolivian product was calisaya (eventually published as Cinchona Calisaya Wedd.), until the mid-nineteenth century a botanical question mark. ${ }^{67}$ Ruiz, from discoveries in Peru, had thought it pre-

65. Letter to [viceroy?], Santa Fe, May 22, 1803. Gredilla, Biografia de Mutis, pp. 138 - I 39 .

66. Mutis, "Historia de los árboles de la quina" was readied for posthumous publication by his nephew in 1809 , but no more than a few excerpts were ever actually published (Paris, 1872). (Gredilla, Biografia de Mutis, pp. 125-127.) Ruiz and Pavón were authors of the following manuscripts on quina: "Compendio histórico-médico-comercial de las quinas" (86 pp.); "Reparos y reflexiones sobre la Memoria de la quina francesa ... por Mr. Leroy," I808 (15 pp.); "Experimentos químicos sobre las quinas hechos en Madrid año de 1811 por el S. or Vidot y tratados con Hipólito Ruiz" ( 8 pp.); "Causas por que las calenturas intermitentes no cortandose en los primeros accesos pasan a malignas y contagiosas"; "Estampas de quinas" (6 pp.); and "Razón de las siete especies de quina o cascarillas que se hallan en las montañas de las Panatahuas provincia vezina a la de Huánuco" (7 pp.). (List taken from the catalogue of the library of the British Museum [Natural History], where all of these manuscripts are preserved today.) Pavón began by 1820 (and nearly finished) a "Nueva quinología," describing forty-one species. This study was also in the nature of a complaint against Ruiz for publishing the first Quinologia alone. (Colmeiro, La botánica y los botánicos, p. 48.) The English botanist John Eliot Howard bought the manuscript and 54 specimens of bark that had once been Pavón's in 1858 and four years later published his Illustrations of the Nueva Quinologia of Pavon. The Spaniard's drawings had disappeared, and the artist W. Fitch was sent to Madrid to make colored drawings from the original specimens.

67. A listing of varieties drawn up no earlier than 1806 by the "Chief physician of the Spanish army" states of calisaya that "the species to which this bark belongs 
sented excellent possibilities as a febrifuge, though the Peruvian stands apparently never developed commercial importance. The Mercurio peruano of 1793 carried a lengthy article by its inveterate correspondent in La Paz, Pedro Nolasco Crespo, on the virtues of "Collisalla." In I 796 the crown, recognizing the value to medicine of this new variety ("kalisaya"), urged Viceroy Ambrosio O'Higgins to regulate its collection. ${ }^{68}$ Then in $\mathrm{I} 820$ French chemists isolated two alkaloids, cinchonine and quinine (they named the latter) from the bark and showed them, and especially the quinine, to be the antimalarial agents. They published details of a method for determining chemically the amount of quinine in the different barks, and calisaya emerged the victor. During the fighting for independence in Peru and Bolivia, bark collectors stripped the areas they could easily reach, causing the emergent Bolivian republic to impose severe restrictions on the gathering and export of calisaya.

But in the end the South Americans fought a losing battle against their own carelessness and inefficiency and against European nations eager to benefit mankind and their own treasuries. The story of efforts by foreign governments to sneak out seeds and plants for cultivation in more easily accessible areas, and the ultimate success of the Dutch in Java, provide an exciting chapter in the history of nineteenth-century exploration and commerce. ${ }^{69}$ But though Peruvian and New Granadine quinas did not win the battle, no one could say that Mutis or Ruiz or Pavón had not tried.

is unknown in Spain." The compiler goes on: "M. Zea, who finds the Quinquina of Santa $\mathrm{Fe}$ everywhere, pretends that it is no other than a mixture of the orangecoloured and yellow of Mutis. . . . It is really extraordinary that, while the enthusiasts of Mutis regard the orange-coloured Quinquina of Santa $\mathrm{Fe}$ as extremely rare, they meet with it in a great number of common barks." The physician then concludes with this understatement: "May not this contrariety be the result of a little ill humour among some of the members of the two expeditions?" (Laubert, "Memoir on the Different Species of Quinquina," in Lambert, Illustration of the Genus Cinchona, p. 7o.)

68. O'Higgins knew nothing about the bark and called upon members of the commercial body (consulado) to advise him. All those who responded to his request merely recited the leading points of Crespo's article in the Mercurio. (Archivo del Ministerio de Relaciones Exteriores [Lima], libro 2-13, fols. 41-92.) For the discussion by Crespo, see "Carta apologética de la quina, o cascarilla, escrita a la Sociedad por el Dr. D. Pedro Nolasco Crespo," Mercurio peruano, VIII (July 4 and 7,1793 ), 148-152, 156-166.

69. See Appendix A. 


\section{A MERICA RESCUES THE FLORA}

Ruiz and Pavón brought back from Peru and Chile three thousand plant descriptions and more than two thousand drawings ${ }^{1}-$ enough for a dozen folio volumes. Moreover, the deluge had not yet subsided, for other botanists were at work in New Granada, New Spain, and the Philippines. Publication of the whole loomed a gigantean task, physically and financially; having counted his pennies and found them wanting, the king looked across the seas for deliverance.

On September 17, I79I, Charles IV reminded the colonists in America that he was "heir to the heroic virtues and love of the arts and sciences of his august father" and was lending all possible aid to continue the expeditions, but present circumstances demanded special remedies.

As the work is so vast, and the expenses required for its execution in typography, engraving, and coloring are so great, the Royal Treasury cannot support them, on account of the immense expenditures made in the previous reign and in this one to keep up the honor of the Spanish Arms and its own possessions, and to preserve the vassals of those Dominions in peace against the enemies of the Crown.

The projected compilation was "properly a treasure of the natural marvels of that part of the globe, unknown for three centuries and now so envied." Publication would be "principally in honor of its inhabitants." How better could the monarch underwrite the vast publication of the Flora Americana than to tap the wealth of his subjects overseas?

I. Flora Peruviana, I, i. An inventory years later revealed 2,980 different dried plants in the Ruiz-Pavón herbarium, and 2,2,64 illustrations. (Colmeiro, "Jardín Botánico," pp. 326, 327.)

2. Royal order, San Lorenzo, Sept. 17, 1791. Printed copy in the archives of the Ministerio de Relaciones Exteriores (Lima), libro 1-16, fols. 17-18, and in MCN, 1792. Also reprinted nearly in full in Ruiz and Pavón, Prodromus, pp. xv-xviii. 
He thus told the viceroys, archbishops, bishops, deans ecclesiastical and secular, cabildos, and universities that he would be pleased to receive "whatever aid they might contribute, voluntarily and without the slightest hardship, for the execution of the stated work." Each realm received numerous copies of the request so that it could be read by "bodies, communities, town councils, and private persons" whose "love of letters," the nation, and the king might prompt them to help out in this "glorious enterprise." They could donate at once, or by instalments, for the work was "very vast" and would demand a long time to complete. Meanwhile, it would be published piece by piece. $^{3}$

To learn of the American response, there is no better guide than the experience of Chile. ${ }^{4}$ President Ambrosio Higgins acknowledged receipt of the royal order on March 9, 1792, and on March 27 ordered it circulated to prospective contributors. Within a month the replies began to trickle in, usually with a gift and nearly always an apology for the donor's frugality.

The bishop of Santiago, Blas Sobrino y Minayo, was first (on April 28), with a substantial five hundred pesos, to be paid "for one time." If there had not been so big an increase in the ranks of the poor, he explained, his contribution would have been larger. The same day, the Marqués de Monte Pío delivered his offering-a gold jewel box-which he put at the disposition of the crown for "this or other purposes." (Over two years later, as the Chilean collection was at last being readied for shipment to Spain, the Marqués paid 69 pesos, $3-3 / 4$ reales to recoup the box.)

During May, I792, the range of contributions widened. All the way from Concepción, Joseph de Urrutia y Mendiburu, one of the leading citizens who had been especially approached, wrote that he was turning over fifty pesos to the governor of his province. Although, as he said, he was not born in the Americas, he owed to them his fortune and wanted to contribute to their "enlightenment and good name." If circumstances had been better, he would have given "a proof relevant to this truth." The bishop of Concepción also replied early in May, begging to be excused from an immediate donation "because it is necessary to publicize this matter throughout the entire

3.Ibid. Also see order of the Marqués de Bajamar, Sept. 17, 179r. Archivo Nacional de Santiago, Capitanía General, Vol. 675, "Expediente Flora Americana,"

4. Details are contained in ibid., fols. 6-59. 
jurisdiction, persuading and disposing everyone toward this proposition." His goal was a contribution from each and every "subject." Meanwhile, the cabildo of the cathedral in Santiago was considering what it should give. The members were blanketed in gloom. Income from tithes was on the decline; expenses were growing. The body had "always been able to show its love for the royal service in different donations, even for the last war with the Indians of the frontier." But now, "exceedingly mortified," it could give only two hundred pesos for the Flora.

The Conde de la Conquista had no excuses with his offer of one hundred pesos. But, presumably to remove any doubt that this was enough, he added that, when the botanists were in Chile, he gave them "various metals with other curiosities." Besides, he had in 1784 turned over four boxes of medicinal herbs for remission to Spain in accord with the sovereign's wishes. Only two other individuals responded to the president's circular: the Marqués de Villapalma, whose "infortunios" kept him from giving more than one hundred pesos "for now," and the Marqués de Casa Real, who could contribute no more than one hundred himself because of the "increased number of the poor in which this City abounds."

Failure of more answers to arrive prompted Higgins to send a reminder on July 4, I 792. This move brought a flood of replies from both higher-ups and not-so-high. The contador general Juan Ruiz de Balmaceda offered one hundred pesos- "ten per cent of my salary which is the same as I contributed in the last collection ... to relieve the poverty of the royal treasury." The treasurer Francisco Antonio de Abaría announced that he would soon contribute twenty-five pesos, and the director of the tobacco monopoly, Marcos Alonso Gamero, gave one hundred pesos. ${ }^{6}$ This second demand of the president also brought word from two of the wealthy individuals who had hitherto remained silent, Francisco Antonio Ruiz de Tagle and Manuel Francisco Ruiz Tagle. Their apparent remissness had been due, as they wrote from their hacienda in Calera, to the belief that they would soon be in Santiago. But fulfilment of a contract to provide annually

5. It cannot be determined how far down into the ranks the solicitation extended. The final summation listed "El Yltmo. S. or Obispo de esta Diocesis Don Francisco José de Marán, con su Cabildo y Clero."”

6. In the final summary of contributions sent to Spain, no mention was made of any donations from Ruiz de Balmaceda or Abaria. It is thus possible that they did not comply with their promise to pay. 
eight thousand fanegas of lime had kept them too busy, so now they were sending one hundred pesos-apparently a standard sum for the wealthy to give.

Two administrative bodies reacted in contrasting fashion. The superintendency of the real hacienda noted that it was not listed by the crown among the suggested contributors, ${ }^{7}$ but the three top officials were nevertheless pledging a total of 150 pesos. The audiencia also mentioned its omission from the list, but, unlike the hacienda, seemed to take refuge in the fact. Those of the tribunal who were not weighed down with obligations, expenses, "repeated costly transport," and the "indigence" of their families, would let Higgins know later what they could give. If they did not, the statement continued, it would be "because of the undeniable result, in spite of their pain, of not looking upon themselves as wealthy." For the record, it may be stated that none of the five individuals who signed this reply was ever listed among the contributors. ${ }^{8}$

When Higgins' second circular of July 4 reached Valparaíso, it jarred the political and military governor, Luis de Mata, into action. Thinking a formal public campaign unneeded, he convoked a meeting of the "most affluent persons" at his residence on July I 5. He tried to stimulate them by his own donation of twenty pesos, but could collect only thirty-three pesos and two reales additional from the twenty-one individuals who came. Most of these donations were in the one-peso class, though one man signed up for but two reales (onequarter of a peso). The governor forwarded the total sum to Higgins with a deep regret that the fruit of his diligence had been so small.

By August 14, I792, the cuerpo de comercio had completed its canvass of members. A total of 724 pesos had been realized, out of which twenty pesos was deducted for the collector's expenses. Sixtysix individuals had given anywhere from one peso to one hundred

7. This is true, though the supplementary order of the Spanish ministry suggested a much wider scope for donations.

8. The strange omission from the final accounting of an actual payment by the hacienda is as puzzling as is the case of the contador general and treasurer mentioned in n. 6. The individuals Bernardo de Alisbaguirre, superintendent, and Josef Antonio Alcalde and Domingo Salamanca, contador and treasurer, are not to be confused with the other prospective donors holding the same titles. The fact that the only announced contributions which did not find their way into the final accounting were all from fiscal department sources is either coincidental or suspicious, depending upon one's mood at the moment. 
pesos. $^{9}$ The most popular donation was four pesos, but there were numerous gifts of ten and twelve pesos and some even larger. The most unusual feature of this group's response was a list of members who did not offer to contribute at all. Eliminating those who had given in some other capacity, there remained forty-one names. The juez de comercio left it to Higgins to decide what to do about these, but the latter had no comment to make.

Three months after the president's second notice had gone out, a reply was finally drafted by the provincial governor at Concepción, Francisco de la Mata Linares, on September 3, I792. "Thinking that this matter was not urgent," he had been waiting for returns from his far-flung territory before sending an answer. The second circular of July 4 had apparently taken him by surprise, but even now he confessed that five sections (partidos) had still not been heard from, and the ecclesiastical contributions would perhaps not be ready until after the new year had begun. By action of the city of Concepción on June 23, I792, however, it had been decided to order a set of the Flora, "to take advantage of, and to communicate to the public in this province, the usefulness that must result from the publication of said work." By this act they hoped to spread in the province "the learning that His Majesty so generously furnished to all the Spanish nation."

Higgins was visiting in Concepción when that province made its final tally - a very respectable $\mathrm{I}, 554$ pesos, 5-1/2 reales. The summary, turned over to Higgins on January 28, I 793, showed that the governor, town council, and citizenry of Concepción had contributed 297 pesos; the bishop, ecclesiastical cabildo, and clergy, 373 pesos; various units of the military (infantry, dragoons, artillery, and nine garrisons), 263 pesos, $2-1 / 2$ reales; and the six partidos of the province, 62 I pesos, 3 reales. $^{10}$

The surprising productivity of the collection in the outlying partidos of Concepción must have given Higgins an idea, for on the next day, January 29, I793, he ordered a solicitation in each of the comparable subdivisions of the province of Santiago. Luckily for the Flora, it was also decided to seek a donation from four prominent individuals; as a result, one of them, Don Francisco Subercaseaux, of Nantoco (Copiapó), gave the grand sum of five hundred pesos. An-

9. There were two gifts of one hundred pesos, one by Juan Manuel Cruz and the other by Pedro Fernández Balmaceda.

10. Apparently the 50 peso contribution of Joseph de Urrutia y Mendiburu, mentioned above, is included in these figures. 
other, Don José Sepúlveda, of Petorca, sent in fifty pesos. But reports of the subdelegados from their partidos were very disappointing: they could assemble no more than IO4 pesos, 4 reales.

The Subercaseaux income was founded on silver and it must have served him well, ${ }^{11}$ but in general, the mining partidos produced little more than sympathy for the Flora, and some not even that. From Rancagua, on May 28, I 793, twenty-one individuals donated 84 pesos, 4 reales. Ten of them gave less than one peso each, and the maximum for any one person was twelve pesos. The partido of La Serena remitted twenty pesos on September 26.

The remainder of the subdivisions had nothing to offer. Only the villa of San Francisco de la Selva (partido of Copiapó) offered hope. Though the mines were decayed and the soil parched by a chronic lack of rain, a cabildo of all the citizenry on August 7, I 793, proclaimed its eagerness to serve the king. The people decided to postpone action for a fortnight, at which time anyone who could give would do so. Not two weeks, but two months, went by. Then, on November 8, a new meeting was called to report on the donations. In addition to the cabildo members, only the vicar of the villa, Don Benancio Sierra, appeared. So scant were his revenues that he could give nothing. The town councilors could do no better than join in the hope that, if things improved, they would donate with pleasure to some other campaign.

Besides the above, there were but two more donations: fifteen pesos from Don Ignacio Yrigaray, captain commandant of the cavalry regiment of La Princesa, on October I 5, I 792, and two hundred pesos from the Royal University of San Felipe, delivered on January I8, 1793. More than a year after the last sum had come in from the hinterlands, Higgins sent the money on its way to Spain. By his calculations it added up to 4,450 pesos, $7-1 / 4$ reales. Deducting miscellaneous expenses, the final sum turned over to the Spanish crown was 4, 160 pesos. ${ }^{12}$

To summarize, nearly every one of the persons and organizations had complied with the president's request-though among the most obvious non-contributors were the members of the audiencia and President Higgins himself. Likewise, the secular cabildo of Santiago

Ix. Though he was unable to make the donation until August 16, 1793, because his funds were tied up in a big mineral shipment.

12. The remission was dated Oct. I3, 1794, and acknowledged with thanks by the king on April 8, I795. 
made no offering, though the city was well covered in the contributions of the cuerpo de comercio, university, cathedral, and several leading citizens. In evaluating the individual donations, it can be noted that one hundred pesos was equal, for example, to Dombey's official salary for one month. No doubt the small gifts of a few reales or a peso were mostly intended to relieve the donor of any further pressure, rather than as a demonstration of enthusiasm for the Flora. Perhaps most surprising was the excellent showing of the frontier province of Concepción. The contrast with the economically depressed districts of the north is pronounced. It must be remembered, however, that Ruiz and Pavón spent much time at Concepción, but did not go very far north. Another area where they had not botanized, the island of Chiloé, was noticeably unresponsive to the fund appeal.

All in all the drive in Chile succeeded. Times were hard. Urgent demands were frequent to contribute for the welfare of the mother country. ${ }^{13}$ Bearing these facts in mind, one must consider the gift of 4,160 pesos a real tribute to the desires of this remote realm to foster the advancement of science. Here is a recapitulation of the Chilean effort:

\section{Pesos Reales}

Santiago

Cuerpo de comercio

Bishop and cathedral cabildo

University of San Felipe

Outlying partidos (Rancagua; La Serena)

Private citizens

Concepción

$$
\text { Total Santiago }
$$

Governor, council, and citizenry

Ecclesiastical

Military

Partidos

Total Concepción

Valparaiso (Governor and citizenry)

Grand Total

Less: Expenses

Net sent to Spain

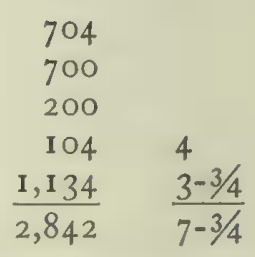

\begin{tabular}{|c|c|}
\hline $\begin{array}{l}297 \\
373 \\
263 \\
621\end{array}$ & $\begin{array}{l}2-1 / 2 \\
3\end{array}$ \\
\hline $\begin{array}{r}1,554 \\
53 \\
\end{array}$ & $\begin{array}{l}5^{-1 / 2} \\
2\end{array}$ \\
\hline $\begin{array}{r}4,450 \\
290\end{array}$ & $\begin{array}{l}7-I / 4 \\
7-I / 4\end{array}$ \\
\hline 4,160 & \\
\hline
\end{tabular}

13. In fact, the very donations for the Flora were sent to Spain in company with "la remesa de caudales de donativo p. ${ }^{a}$ la guerra." 
The king's appeal in Peru yielded more than four times as much, for Peru was wealthier and more populous than Chile, and its plant life the center of attraction in the proposed Flora of Ruiz and Pavón. For example, the cabildo of Lima donated 3,000 pesos from municipal funds, and then provided a table where citizens might contribute daily "according to their possibilities" at any time from 7 A.M. until IO P.M. Inspired by the example of the council members themselves, the townsmen gave a total of 2,067 pesos, $4-\frac{1}{2}$ reales. In sum, the campaign in Lima alone during July and August, I 792, produced the following results: ${ }^{14}$

Consulado (commercial body)

Pesos Reales

Cabildo of Lima (from city funds)

6,000

University of San Marcos

Townspeople of Lima

3,000

3,000

2,067

$4-1 / 2$

Gabriel de Avilés, inspector general of all military troops in the viceroyalty

100

José Manuel de Tagle Ysoaga, commissar of war and navy, for himself and his uncle, José de Tagle y Bracho, senior oidor of the audiencia

I 00

200

Archbishop of Lima

Viceroy Francisco Gil de Taboada y Lemos

Total from Lima

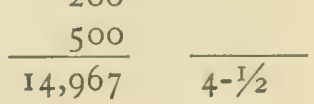

Two outlying intendancies and one bishopric added to this total during I 792 and I793. From Huamanga, fifty-one contributors sent in the respectable sum of 1,787 pesos. Over one-half of this came from ecclesiastical sources. In fact, the most generous contribution of all, 200 pesos, was from the parish priest of Oyolo. One other curate, besides the bishop, gave Ioo pesos, thus rivaling the largest lay donor, the Marqueś de Feria. Many priests gave 25 or 50 pesos. Most of the balance came from government officials who offered similar amounts, though a smattering of about a dozen businessmen gave 6 to 12 pesos each.

14. Archivo Nacional del Perú, Sección Consulado, números 1 I 3 and 17 II. Viceroy Gil to the Marqués de Bajamar, Minister of Grace and Justice, Lima, Aug. 5, I 792; cabildo of Lima to the king, May 7, 1794. MCN. Viceroy Gil to Pedro de Acuña, March 26, 1793. Anales de la Real Academia de Farmacia, XXI (No. 2, 1955), 188-189. Lista de las Personas que han concurrido al Donatibo. MCN, 1794. For expressions of thanks to various bodies from the crown, see Mercurio peruano, XI (May 4, 1794), 12; Archivo Municipal de Lima, libro 30, fol. 338, and libro 29, fols. 25I-25IV.; archives of the Ministerio de Relaciones Exteriores (Lima), libro I-1 6 , fol. 158 . 
The intendancy of Arequipa also furnished over fifty contributors, nearly all secular, but since the usual donation ranged from 2 to 12 pesos, the sum collected was only 648 pesos. The governor intendant himself, it must be said, was responsible for 100 pesos. Finally the bishopric of Cuenca, in present-day Ecuador, sent 425 pesos, including 400 from Bishop José Carrión y Marfil. ${ }^{15}$

One other bishopric, Cuzco, raised I,I 38 pesos among "various subjects," but was too slow in responding for the Flora to benefit. The money was ready to ship in July, I 795, along with nearly I I,000 pesos in donations "to help support the excessive expenses of a just war, in which [Spain] is working to affirm its religion and preserve its churches." Bishop Bartolomé de Heras, in fact, was perfectly willing to toss the Flora donations into the war chest, but the project was itself victimized by the war. The $\mathrm{I}, \mathrm{I} 38$ pesos did not arrive in Spain until I 803 , by which time the Flora fund was in a state of confusion. ${ }^{16}$

Thus, in summary, the Peruvian contribution was as follows:

Lima
Huamanga
Arequipa
Cuenca (bishopric)
Unidentified (probably mostly
Cuzco (bishopric; sent in 1803 )
$\quad$ Grand Total
*See footnote 15.

Pesos Reales

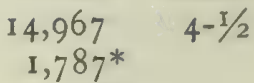

648 *

425

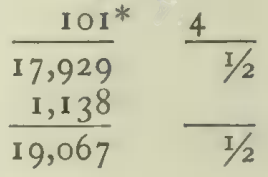

Although the total was much greater than that from Chile, well over half came from the treasuries of three large corporations-the university, the cabildo, and the consulado.

15. Lista de las Personas que han concurrido al Donatibo. MCN, 1794. Archivo Nacional del Perú, Sección Consulado, números II 3 and 1711 . Viceroy Gil to Eugenio de Llaguno, Minister of Grace and Justice, Lima, Dec. 8, 1794. MCN. The viceroy remitted 17,353 pesos, I-1/2 reales aboard the vessel Aurora on March 16, 1793, and 612 pesos, 7 reales on the Liebre, November 29, 1794. There are slight discrepancies among various sources of information on the donations from Arequipa and Huamanga, partly caused, no doubt, by deductions for shipping expenses. For example, although the viceroy remitted 6 I $2_{2}$ pesos, 7 reales on the Liebre, the figure calculated upon arrival in Spain was only 576 pesos, 7 reales. (See "Cuenta de Gastos" signed by Juan Lucas de Saldias at Cádiz, Sept. 4, I 795. MCN.) On the other hand, the sum of ror pesos, 4 reales from unidentified sources (probably Huamanga) must be added to fit the final calculations arrived at in Spain.

16. Barth. ${ }^{\text {me }}$ Obpo del Cuzco to Eugenio de Llaguno, July 10, 1795 (two letters 
While Peru and Chile were the only realms directly concerned with the work of Ruiz and Pavón, the king, of course, wanted funds to underwrite the publication of all of the American floras. Thus no part of the Empire escaped his plea. It would be tedious, and in fact impossible, to recite the minutest details of this campaign, but some aspects demand attention.

Thus, in Mexico City, the cabildo, in embarrassing financial straits, suggested an ingenious solution-a sort of "time-payment plan." Martín Sessé, director of the botanical expedition in Mexico, had been troubled to find an engraver to begin work on his flora. True, at the Real Academia de San Carlos several students were already learning the process, but as usual their expenses were outrunning their means. The viceroy could find no funds to sponsor their training, so the cabildo, in lieu of a direct gift to the crown for the Flora, came to the rescue. By June, I793, three young men had begun their studies as pensioners of the town council at four reales each per day. ${ }^{17}$

The mining tribunal could give nothing, and hoped His Majesty would not censure them for it, but two individuals saved the day for the capital city. They were the archbishop, who donated 2,000 pesos, and Felipe de Zúñiga y Ontiveros, the official surveyor of Mexico City, who gave I,000 pesos. The latter's generosity is accounted for by his gratitude that the king had conceded to him "for two lives" the privilege of printing the Guia de Forasteros, or "Guide for Strangers," a directory of Mexican officialdom. ${ }^{18}$

As frequently happened, the outlying districts took the suggestion to contribute more seriously than did the capital. Thus, over half of the donation from New Spain originated in the provinces. On May 24, I792, Don Rafael de la Luz, the zealous governor of the military presidio of Nuestra Señora del Carmen, on the Gulf of Campeche, called together all of the men he thought able to contribute for "such an important and admirable work." Then, heading the list of donors, he volunteered I 50 pesos from his own pocket. In turn, twenty-nine more individuals filed past with their two, or five, or ten pesos. From

of the same date and a "Razon individual de las cantidades"). AGI, Audiencia del Cuzco, legajo 66. Felipe Román to José Antonio Caballero, Minister of Grace and Justice, Cádiz, June 3, 1803 . MCN, 1804.

17. Testim ${ }^{\circ}$ del Expediente formado, sobre $q^{e}$ se contribuya con alguna cantidad $\mathrm{p}^{\mathbf{a}}$ fom $^{\text {to }}$ de las expediciones Botanicas. Also, Viceroy Conde de Revillagigedo to Pedro de Acuña, Mexico City, June 30, 1793. MCN, I793.

18. Statement of the Tribunal de la Minería, Mexico City, June 2, 1792; Diego de Gardoqui to Llaguno, Aranjuez, April 7, 1794. MCN. 
"el común" came fifty pesos, and the neighboring pueblo of San Joaquín de la Palisada gave 25 pesos, 4 tomines.

The governor sent this grand total of 459 pesos, 4 tomines to the Ministry of the Indies with the "greatest consternation." How could these loyal subjects display their love for the sovereign with such a pittance? But, alas, their right to trade freely with Campeche for goods from Europe had been cut off, and now they lacked "even the most necessary things for human life, as well as the spirit that encouraged them to continue their laborious tasks." Dependent upon agriculture for a living, the people of Carmen needed unrestricted trade with Campeche, Chiapas, and "even all the realm of Guatemala if possible." With access only to the port of Veracruz, as at present, they could not get enough boats to call, and the goods that did enter were priced out of reach. The Ministry of the Indies sent the complaint to the Ministry of the Treasury. ${ }^{19}$

These contributions and the remainder from New Spain can be summarized very briefly: ${ }^{20}$

Archbishop of Mexico

Felipe de Zúñiga, Surveyor

Presidio of Carmen

City Council of Guanajuato (unable to give in I 792, but complied two years later)

Cabildo of the cathedral of

Oaxaca and its priests

Bishop of Oaxaca

Ayuntamiento of San Luis Potosí

Cabildo of Querétaro

Cabildo of Olaya

Bishop of Nuevo León

Cabildo of Aguascalientes

Cabildo of Compostela

Total from New Spain

Pesos

\section{Tomines}

2,000

I, 000

459

4

1,000

606

200

200

300

300

200

100

$\frac{12}{6,377}$
4

2

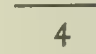

Here, in conclusion, are the results of the collection in the other realms, received in Spain by 1796 :

19. Rafael de la Luz to Marqués de Bajamar, May 24 and July 1, 1792; Bajamar to Luz, San Lorenzo, Oct. 26, 1792. MCN.

20. Revillagigedo to Bajamar, Mexico City, Aug. 30, 1792; Gardoqui to Llaguno, Aranjuez, April 7, and San Ildefonso, Sept. II, I794. See also ayuntamiento of Guanajuato to Bajamar, April 25, I792. MCN. 
New Granada

Santa Fe de Bogotá

Panama and Santa Marta

Unidentified source, remitted in

Pesos Reales

I795 from Cartagena (viceroy

lost the list of contributors)

Plus a bar of gold from Antioquia weigh-

$\begin{array}{ll}\mathrm{I}, 97 \mathrm{I} & \mathrm{I}-\mathrm{I} / \mathrm{2} \\ \mathrm{I}, \mathrm{I} 3^{8} & 3\end{array}$

$\frac{200}{3,309} \quad-\frac{}{4-1 / 2}$ ing 463 castellanos, 4 tomines, whose value in pesos was not known in the Ministry of the Indies at the time of receipt. I estimated the value at $I, 100$ pesos, based upon the example of the Marqués de Monte Pío in Chile

Estimated total New Granada

Venezuela

Cuba

Havana (20 donors)

Puerto Príncipe (52 donors)

Total Cuba

$$
\begin{aligned}
& \frac{1,100}{4,409} \text { est }^{-1 / 2} \\
& \text { I } 8 \text { I } 4
\end{aligned}
$$

$$
\begin{array}{r}
2,560 \\
\frac{333}{2,893} \quad-2 \\
\hline 2
\end{array}
$$

Viceroyalty of La Plata

Puno

Córdoba

Paraguay

Moxos

Cochabamba

Total La Plata

Philippine Islands

From archbishopric; (there may have been an additional fifty pesos from the bishop of Cebu)

Estimated total, other realms

$\frac{586}{10,933} \quad \frac{6}{4^{-1} / 2}$

Besides these sums, there were various amounts, like the $\mathrm{I}, \mathrm{r} 38$ pesos from Cuzco mentioned above, that did not reach Spain until well into the succeeding century. It is unlikely that these ever were made available for the Flora:

Guatemala

$$
\text { Pesos Reales }
$$

A total of 792 pesos had been collected by I793; this included 300 pesos from 
ayuntamiento funds and 492 pesos from 107 donors; largest single donation 25 pesos, from 3 persons. The sum does not seem to have been sent to Spain at that time and is presumably included in the 948 pesos which reached Spain in 1809

Thus, America and the Philippines provided, through voluntary donations, a total of about 4I,900 pesos for the "love of letters." Upon arrival in Spain, and after deducting various transportation expenses, the sums were converted into Spanish reales at 20 reales to the peso. Documentation is available to verify over seventy per cent of the calculations into reales, and we have estimated the rest. The grand total reached 801,969 reales, of which about 47,800 reales probably did not arrive in Spain until 1803 or later. ${ }^{21}$ Ruiz and Pavón had a large vote of confidence from America. They must now begin to deserve it.

21. See Appendix B for more detailed information on the conversion into Spanish reales. Sources for the data on donations from realms outside Peru, Chile, and New Spain are (all from MCN): New Granada: Viceroy José de Espeleta to Llaguno, Santa Fe, Dec. 19, 1794, and Oct. 19, 1796, and allied papers; Gardoqui to Llaguno, Aranjuez, April 17, 1796. Venezuela: undated ministry note in $\mathrm{MCN},{ }_{1}^{1} 79^{2}$, concerning the president of the audiencia of Caracas. Cuba: Luis de Casas to Acuña, Havana, Dec. 15, 1792; receipt signed by Josef Mallen y Castro, Cádiz, March I 5, I 793; Manuel González Guirral to Acuña, Cádiz, March 19, 1793. La Plata: Viceroy Nicolás de Arredondo to Acuña, May 23, 1793; Minister of Grace and Justice to juez de arribadas de Indias, Madrid, Jan. 8, I794; Arredondo to Llaguno, Sept. 18, I794; González Guirral to Llaguno, Cádiz, Dec. 16, 1794; receipt of Manuel de la Piedra, Cádiz, Jan. 22, 1795. Philippines: Archbishop Juan Antonio de Orbego y Gallego to Bajamar, Manila, July 2, 1794 , and allied papers; Bajamar to Llaguno, Madrid, Sept. 23, 1794; Grace and Justice to bishop of Cebu, Aranjuez, April 13, I795: Guatemala: Joseph Domas y Valle to Llaguno, Guatemala, Aug. 20, 1794; Rafael Orozco to Benito Hermida, Cádiz, Aug. 19, 1809 (in MCN, 1808); ministry note to juez de arribadas, Seville, Sept. 22, 1809; see also note in MCN, 1810, from Real Ysla de León, Feb. 18, 1810. La Paz: audiencia of Buenos Aires to Caballero [1804]; Manuel Machon to Caballero, La Coruña, July I1, I804. See also a summary sheet covering all areas in MCN, 1794. Ruiz and Pavón stated in 1813 that contributions from America had totaled one million reales, but they were notably ill-informed on financial affairs (except as to their own salaries). (Decree of Regency government, Cádiz, Oct. 8, 1813 , to Secretaria de Estado y del Despacho de Hacienda. AGI, Indiferente General, legajo 55 .) 


\section{THE PRODROMUS AND}

\section{THE POLEMICS}

\section{THE WINDING ROAD TO GRANDEUR AND MAGNIFICENCE}

The Flora Peruviana must breathe "grandeur and magnificence" worthy of His Majesty-so came word in March, I792, from the very monarch under whose auspices and protection it would be published. The best artists, the most competent engravers, the printer of highest repute, all must turn attention to the task. Quality workmanship, not the lowest bid, would govern the choice of artisans. Of course, no funds had yet arrived from the colonies, but the directors of the project could borrow in the meantime from the confiscated Jesuit properties known as Temporalidades de Indias. ${ }^{1}$

Not until October, I79I, three years after their return to Spain had the botanists begun to meet informally twice a week at the house of Gómez Ortega to make specific plans for publication. ${ }^{2}$ Their greatest source of frustration was still the lack of a place to work. The men barraged the ministry with petitions. How nice it would be to have "a house or part of one" for all to live in! They could then work together without interruption. Often, they found that the plant descriptions did not match the drawings. How essential it was to be able to consult drawings, herbaria, and books at whatever hour! Improper care and a lack of ventilation threatened their herbaria with destruction. Please couldn't the men at least have a room in which to keep such things, where they could go at scheduled hours? ${ }^{3}$

1. [Marqués de Bajamar] to Ruiz, Aranjuez, March 4, r792. MCN.

2. Ortega, Ruiz, Pavón, and Gálvez to Bajamar, Madrid, March 18, 1792; Ruiz to Bajamar, Madrid, Feb. I7, 1792. MCN.

3. Francisco Cerdá, ministerial representative on the botanical junta, to [Bajamar?], Madrid, July 27, 1792; Ortega, Ruiz, Pavón, and Gálvez to Bajamar, Madrid, March 18, 1792 ; Pavón and Gálvez to Antonio Porlier, Madrid, May 24, I792. MCN. 
Faced with a housing shortage, the government assumed an attitude of apathetic sympathy. But there was nothing apathetic about the crown's anxiety to see the Flora rolling off the press." The ministry not only insisted that Gómez Ortega and his fellow professor Antonio Palau sit in on the planning juntas, ${ }^{5}$ but assigned a representative from the Secretariat of Grace and Justice for the Indies to preside. When the court was in Madrid he would be Francisco Cerdá, first chief clerk of the ministry. ${ }^{6}$ The move luckily played into the hands of the botanists and before long they had a place to work.

Cerdá too was house-hunting and had his eyes on a spacious residence on the Calle de Don Pedro, number I, at the intersection of the large square known as the Puerta de Moros. Pondering the yearly rental of I0,000 reales (equal to Ruiz's annual salary), Cerdá offered to turn over three large rooms on the first floor, and two smaller ones on the second, to the botanists. When greater needs arose-that is, those of other expeditions ready to publish-he would consider providing more space. In addition, the botanists could use his library even when he was out of town. True, they could not live at the house, but a separate door would provide for their office complete independence. The catch? The government would pay the rent on the entire house. ${ }^{7}$

Cerdá had friends in strategic places and the king accepted his presumptuous offer. The Ministry of Grace and Justice was directed to pay I0,000 reales on loan, in the end to be covered by Flora funds. ${ }^{8}$ Though payments of rent began on August I, I792, the botanists did not start to open their cases until the following January. In the meantime, housing priorities being as they were, they wouldn't mind government help in looking for living quarters close to their office! ${ }^{8}$

4. [Bajamar] to Ruiz y socios, Aranjuez, April I, I 792. MCN.

5. Bajamar to Count Aranda, Secretary of State, Aranjuez, March 6, 1792. MCN. Palau was either ill or out of town much of the time and served very little as overseer of publication. (Ortega to Bajamar, Aranjuez, April 4, I792. MCN.) He attended meetings on October 28, 1792, and January 7, 1793, but apparently none thereafter. (Junta minutes for those meetings. MCN.)

6. Cerdá to [Bajamar?], Madrid, July 27, 1792, in expediente "Año de 1792.

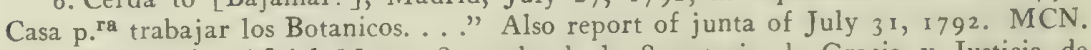
Antonio Porcel, "Oficial Mayor Segundo de la Secretaria de Gracia y Justicia de Indias" and "Secretario de la Superintendencia de Temporalidades de Indias," was to preside when the court was outside Madrid. (Ibid.)

7. Acuña to Porcel, Palacio, Dec. 13, 1792; Cerdá to [Bajamar], July 27 and Aug. 10, 1792 . MCN.

8. Expediente, "Casa p.ra trabajar...," royal order of Aug. I, I 792. MCN.

9. Acuña to Porcel, Palacio, Dec. 13, 1792; juntas of Jan. 7 and Feb. 2, 1793. MCN. 
While the pleas worked their way through bureaucratic toils, plans went ahead for the initial volume. It would be a prodrome, a "running before," to introduce new genera, I 36 in all, and, as it turned out, to correct the errors of previous botanists in the case of thirteen other genera. Subsequent tomes would undertake the systematic coverage of all plants found in Peru and Chile, classified according to Linnaean characteristics.

The botanists also began their search for artisans capable of grandiosity and magnificence. On January 22, I792, an engraver from the royal academy of art, one Francisco de Paula Martí, turned in the first plate as a trial run, asking 400 reales for it. More than one year later the junta in charge of publication agreed to pay him. Meanwhile, another craftsman named José Rubio executed six plates in differing techniques, priced at I 50 to 375 reales each. The botanists rejected the cheaper ones, but accepted Rubio's proposal to charge 250 to 300 reales for future plates for the Prodromus and 350 to 400 reales for the regular Flora plates. On July 31, I 792, he was hired, and Martí is not heard from again. Nine months later Rubio was still uncertain when he would be paid for his plates. ${ }^{10}$ By July 3I, I 792, the junta had also selected the printer: Cerdá's brother-inlaw, Gabriel de Sancha. But by the following spring Sancha and the botanists were wrangling because the paper had not arrived-had not even been ordered-from the factory in Catalonia. ${ }^{11}$

The hurry-up exhortations of king and ministry seemingly made little impression, for another year and a half went by, until September, I794, before the Ministry of Grace and Justice was able to announce that "volume I [meaning the Prodromus] has been completed, and is already bound, for presentation to their Majesties and

Io. Martís work may be seen in plate XIV of Vol. I of the Flora Peruviana. Martí to [Bajamar], Madrid, Jan. 22, 1792; juntas of Jan. 7 and Feb. 2, 1793 ; Ruiz to Bajamar, Madrid, Feb. I 7 and 22, 1792 ; statement of Rubio, Madrid, Feb. r7, 1792; junta of July 31, I792; Ruiz to Acuña, Madrid, April 24, 1793. MCN. In actual practice, the junta at first preferred to evaluate each plate separately, though presumably within the approximate limits proposed by Rubio. On March i 4 , 1793, however, the men agreed to consider setting fixed prices in advance, with each plate to be paid for upon completion. (Ruiz to Bajamar, Madrid, Feb. 17, 1792 ; juntas of July 31, 1792, and March 14, 1793. MCN.) The approved prices for the Prodromus plates, incidentally, were invariably higher than the limit of 300 reales, usually running in the neighborhood of 360 to 420 reales, though at least one cost 600 reales.

II. Junta of July 31, I792; Sancha to Cerdá, [1793]; Ruiz to Acuña, Madrid, April 24, 1793; Sancha to Acuña, Madrid, April 26, 1793; Sancha to Cerdá, Madrid, April 26 and 27, 1793. MCN. 
Royal family and to be put on sale."12 Anyone who has nurtured an idea from conception to colophon learns to expect the unexpected. A day to write a page and two weeks to check a footnote-is this pattern unique? But in the case of the Flora, an inspection under the rug reveals tell-tale gobbets of dust that lead us to suspect we have entered a disordered household. Although the supervisory junta did not meet once a week, as the members had agreed to do, the committee minutes indicate a suprisingly consistent progression toward the goal of publication. From whence, then, the delays?

First, the men did not commence a painstaking comparison of herbaria, drawings, and descriptions until January, I793, when their boxes were moved into Cerdá's house. For the next two months they proceeded to arrange the plants according to Linnaean class. By April 25, they started to try to make sense of the imprecise labels on Dombey's herbarium. In mid-June they could at last turn over the first few descriptions to the printer. While the botanists, including Gómez Ortega, puzzled over the problem of establishing new genera, they were able to set Rubio to work, and by October 18 he had engraved thirty-three plates. These now had to be passed to another artisan, José Rico, for insertion of letters and numbers. ${ }^{13}$

It took four months to draft the prologue (22 printed pages),

12. Note by Eugenio Llaguno concerning a letter of the Duke of Alcudia to Llaguno of Sept. 18, 1794. MCN.

13. The men during this period kept a sketchy diary of their labors, which now rests in the archives of the botanic garden in Madrid. Its contents have been ably summarized in Enrique Álvarez López, "Algunos aspectos de la obra de Ruiz y Pavón," Anales del Instituto Botánico A. J. Cavanilles de Madrid, XII (1953), 26-32.

The duties assigned to the draftsman Isidro Gálvez included making corrections suggested by the junta; checking over all drawings to see if anything had been left out; copying 36 drawings that the deceased Brunete had made too large; adding parts of the fructification at the foot or side of each drawing so as to show them more clearly, a duty the draftsmen had shirked during the expedition; indicating what parts of the foliage could be omitted in the engravings so as to avoid confusion and save time and money (the excess was the result, said Gómez Ortega, of "the taste or caprice they call picturesque"); adding flowers and fruits to some illustrations which had originally been made at the wrong season, making use of the herbaria to do so ("they can be easily copied, for the artist don Ysidro Gálvez has the advantage of having observed the living plants in their native soil"); adding other fructifications not seen by the expedition but found and illustrated by the agregados; copying Dombey's herbaria for new drawings of Chilean plants that had been lost on the San Pedro de Alcántara; drawing from examples in the herbaria other plants not previously done for lack of time, especially the remainder of three hundred species of ferns ("by their nature they lend themselves easily to this operation"). (Razon de los Trabajos que tiene que hacer el Dibuxante, undated but attached to Gómez Ortega to Bajamar, Madrid, June 19, 1792. MCN.) 
from November, I793, through March, I794, and the translation from Latin into Spanish was not completed until the middle of May. Printer's proofs were ready by the end of that month, and there was little cause to expect a further wait for the blessed publication day. ${ }^{14}$

So far, then, the chief criticism to be leveled at the botanists was their tardiness in starting the project, and this was explainable in part by the government's failure to locate a good place for them to work. It must be admitted that members of the junta botched the job of ordering paper for Sancha the printer. The latter finally wrote in exasperation to Pedro de Acuna, the Minister of Grace and Justice, on April 26, I793, that he had been impatiently awaiting the junta's call for nearly a year. Now many of the Catalonian paper mills were in ruins and transportation crippled because of war. He promised a supply of paper within two months if only they would give him the signal. "I take the liberty of directing this answer to Your Excellency," Sancha concluded, "because I fear Ortega and Ruiz have not made Your Excellency aware in all good faith of what $I$ have told them three times."15 Internal tensions undoubtedly threatened the junta at this point, for Francisco Cerdá, co-overseer of the Flora enterprise, but also Sancha's brother-in-law, had put the printer up to the letter. ${ }^{16}$ Even so, paper was available by at least October, I 793, before the plates had been completed and before the prologue had been written.

There is more cause for censure in finding the junta on July 24 , I 793, deciding that for the draftsman to spend only two and one-half hours a day at his board in the Botanical House was not enough to keep up with the engravers. Henceforth Gálvez must take drawings home to work on after hours. The botanists at the same time admonished themselves to carry home descriptions and printer's proofs. One gets the impression that the brief daily stint at Cerdá's house had been common practice for all hands. ${ }^{17}$

Ruiz inherited his uncle's pharmacy, so his outside time may well have been spoken for. The inattention of Pavón and Gálvez is less easily explained. Gómez Ortega tells us they had been insubordinate to Ruiz not only on the expedition, but after their return to Spain.

I 4. Álvarez López, "Algunos aspectos," Anales del Instituto Botánico A.J. Cavanilles, XII, 29-32.

15. To Acuña, Madrid, April 26, I 793. MCN.

16. Sancha to Cerdá, Madrid, April 26, 1793. MCN.

17. Junta of July 24, 1793. MCN. 
Ortega voiced to the ministry the familiar complaint against Gálvez: he refused to recognize "any director other than Your Excellency." Pavón spent no more than two hours at a time on the job, and left it at will, "with much delay to the project." Neither Pavón nor Gálvez displayed "the least zeal." What's more, they laid Ortega's partiality to Ruiz to his relationship by marriage with the latter. But, Ortega points out, weren't the two derelict scientists related to one another in the same way? And besides, he gave the hand of his niece Dona Remigia Gómez Martín to Ruiz because he had been manifestly the only member of the expedition to carry out his duty, the only one to send the manuscripts "that in duplicate and separately the Instruction [of I 776] had required of both botanists."

Ortega's outburst was not unprovoked. On May 24, I792, well before moving into the Botanical House, Pavón and Gálvez had intimated that Ortega and Ruiz were secretly influencing the ministry to issue certain orders, and then hiding the full text of the resultant commands. From this complaint apparently stemmed the decision to put Cerdá in charge of the junta, which, it must be acknowledged, was done with the blessing of Ortega himself. ${ }^{19}$

The focal point of the draftsman's ire seems to have been the appointment, upon Ortega's recommendation, of José Rubio to engrave all of the plates for the Prodromus. On the surface, Ortega's suggestion is logical. As he pointed out, the number of plates would be small (the finished work had 37), speed was urgent, and uniformity essential. In this introductory volume it was less important to achieve beauty than accuracy in the parts of the fructification, for they were the only parts to be presented at this time. Let the regular volumes of the Flora bring out the beauty of the entire plant! As if to reassure the ministry, however, about the grandeur and magnificence of the Prodromus, Ortega predicted that Rubio's plates, based upon "repeated proofs," would equal the best foreign ones of their type. ${ }^{20}$

Rubio, a one-time student at the Real Academia de Nobles Artes de San Fernando and a few months younger than Ruiz and Pavón, had first demonstrated familiarity with plant illustration in 1780 by

18. To Bajamar, Madrid, June I9, 1792. MCN.

19. Pavón and Gálvez to Porlier, Madrid, May 24, 1792. MCN.

20. Gómez Ortega to Bajamar, Aranjuez, April 4, 1792; [Bajamar] to Gómez Ortega, Aranjuez, April 7, 1792. MCN. Rubio's official date of appointment was July 3 I, 1792. See junta minutes of that date. MCN. 
winning a contest for the best paintings of tree branches and flowers adaptable to fabric design. A few months later he placed second in a competition to paint fruit baskets ornamented with flowers, birds, and butterflies. When he heard of the impending return of Ruiz and Pavón from America in 1788 he offered himself as engraver and illuminator of their plates. The academy of fine arts, judging only the pictorial aspects of some prints already engraved and illuminated by Rubio, advised the ministry of his artistic competence. ${ }^{21}$

Rubio's appointment shocked the painter Isidro Gálvez. Having seen a sample engraving, he pronounced it "very distant from the magnificence" called for by the king. Even without previous knowledge of techniques, anyone could tell, said Gálvez, that it was far below the standard set by L'Héritier. Although he received the ministry's order with "blind submission," Gálvez could not refrain from foreseeing Spain as the laughing stock of the botanical world. As the only member of the junta with artistic competence, he feared the blame would ultimately fall upon himself, and asked the ministry to exonerate him from responsibility for Rubio's engravings.

But Gálvez's interest went deeper. As he made plain to the ministry, he was an engraver, too. Although while in America he had put his tools aside, he was now polishing his technique and happened to have a sample for the minister to see. "If my modest abilities merit the acceptance of Your Excellency," he wrote, "I offer to employ them toward the direction of this part of the work, sure that the zeal that animates me in the service of His Majesty, the desire to conform to the high ideals of Your Excellency, and my own interest as a member of the Expedition, will not allow me to omit any diligence or watchfulness that can contribute to the greater perfection of the enterprise." 22

This "ambition for glory" incensed Ortega. Gálvez must have been influenced, Ortega surmised, by "other true engravers who had offered to help him secretly." If the artist would tend to the business for which he was already hired, he would have enough to do. ${ }^{23}$ In any event, Rubio got the appointment, though it hardly welded the Flora staff into a smooth-running team.

21. Certified statement by Ysidoro Basarte, secretary of the Real Academia de Nobles Artes de San Fernando, Madrid, Jan. 25, 1798. MCN.

22. To [Bajamar], Aranjuez, May 18, I 792. MCN.

23. To Bajamar, Madrid, June 19, I 792. MCN. 
When the plates for the Prodromus were completed and it became obvious that a larger staff was necessary to handle the vast number of illustrations for the regular volumes, the Gálvez-Rubio issue popped up again. Just as Gálvez had tried to intrude upon Rubio's province, so now Rubio reminded the staff of his training as an artist. The junta on November 18, I793, decided to recommend that both Rubio and Gálvez be employed as artists, each to be responsible for keeping four different engravers busy. ${ }^{24}$ On December I, Rubio was officially added to the payroll at 6,000 reales a year (Gálvez received I0,000) to be paid from expedition funds. ${ }^{25}$ The junta was asking for more dissension, and got it.

Meanwhile, internal tensions of an even more serious nature began to endanger release of the Prodromus to the public. Although it was ready for distribution in September, I794, and a few copies found their way shortly into outside hands, Ruiz wrote in November, I 795, that "the publication of the Prodromus of the Flora Peruviana was not yet completed." His distress was enhanced by knowledge that a second edition of the work was already being prepared in Rome by Gaspar Xuárez, a native of Tucumán (in present-day Argentina) and cultivator of exotic plants.

Early in 1795 a copy of the first edition had arrived in Rome under unknown circumstances. It was announced in the Efemeridi letterarie di Roma of February 7 and, according to Xuárez, created a stir of interest so great that he, as a native American, was approached to issue a new edition in Italy. The move was prompted by three factors: (I) the difficulty of obtaining Spanish-made merchandise in Italy because of wartime interruptions; (2) fear that the Spanish edition would be too expensive; and (3) knowledge that difficulties within the Spanish court (possibly those centering around Manuel Godoy, the Duke of Alcudia) were holding up release of the Madrid edition. Xuárez hesitated to comply with his friends' desires, but by the fall of I 795, "a certain peculiar concern" within Spain had been resolved, and he felt able to proceed. He found two backers to share his expense and, in a conspectus of September II, I795, announced his intentions to print.

24. Aside from perfecting previous drawings, the men had the responsibility for drawing anew, from dried specimens, those plants lost on the San Pedro de Alcántara.

25. Junta of Nov. 18, 1793; royal resolution, Nov. 25, 1793; junta of March 8, 1794. MCN. Copy of a royal order signed by the Duke of Alcudia, Nov. 25. 1793 , in an expediente concerning Rubio. MCN, 1798. 


\title{
FLORAE PERUVIANAE, ET CHILENSIS PRODROMUS,
}

SIVE NOVORUM GENERUM PLANTARUM

\author{
PERUVIANARUM, ET CHILENSIUM
}

DESCRIPTIONES, ET ICONES.

\section{DESCRIPCIONES Y LÁMINAS}

DE LOS NUEVOS GENEROS DE PLANTAS

DE LA FLORA DEL PERU Y CHILE

\footnotetext{
POR DON HIPOLITO RUIZ Y DON JOSEPH PAVON, BOTÁNICOS DE LA EXPEDICION DEL PERÚ, $Y$ DB LA REAL ACADENIA MEDICA DE MADRID.
}

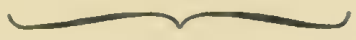

DE ÓRDEN DEL REY. MADRID: EN LA IMPRENTA DE SANCHA M D X X I V. 

Xuárez acted with complete circumspection. He secured Ruiz's permission and created in actuality a more valuable work, for it included numerous corrections of the first edition and presented arguments raging by then in Madrid over some of the classifications made by Ruiz and Pavón. Xuárez took no sides in this quarrel, and sought merely to do for the Flora Peruviana what Nardo Antonio Reccho had once done for the sixteenth-century Mexican flora of Francisco Hernández - to save it from the extinction that seemed so often to doom Spanish botanical efforts.

The Xuárez edition did not reach print until 1797, a year after the Prodromus had been released from purgatory in Madrid. We cannot uncover all of the facets of these two paralytic years, but if the Prodromus itself was immobile, the same can hardly be said of Ruiz. He became embroiled in fierce contention with the newcomer Antonio José Cavanilles ( $1745-1804$ ), not only proving botany a piquant topic in Enlightened Spain, but helping us to guess at some of the factors that nearly capsized the Flora of Peru. With the Prodromus itself a part of the battle, it seems worthwhile to expend some effort in unraveling the story. ${ }^{26}$

\section{THE DISPUTATIOUS MISTER ANONYMOUS}

Here, in this paragraph from the Prodromus, is botanical competition in action:

More than once we have been disturbed by the fear of finding some of the genera that we present as new, already divulged ... by other writers (which is not strange, ... especially considering the present war that has interrupted the trade of books and other things). But one must note, that even putting aside our having been the first to observe and describe them in their native habitat, we have verified that most of those that we found published upon our return to Spain,

26. Ruiz wrote of his fears on November 23, 1795, in a letter from Madrid to Antonio Porcel, enclosing a copy of Xuárez's conspectus. Both are in MCN. The printer Sancha's records show that 567 copies of the Prodromus were released to the Minister of Grace and Justice on June 13, 1796, though the Prince of Parma had been sent a copy on June 19, 1795, and the German ambassador one on September 3 of the same year. (Statement in MCN, 1796, and "Razon de los Prodromos y tomos de la Flora Peruana, que se han dada," Madrid, Sept. I7, I799, MCN.) Xuárez tells of his work on the Prodromus in a foreword to his second edition (Rome, 1797), pp. i-viii. Political conditions of the time are treated very ably in Richard Herr, The Eighteenth Century Revolution in Spain (Princeton, 1958). 
were copied from imperfect descriptions, besides lacking illustrations, or had been made from plants springing from seeds propagated in the gardens of Europe and thus degenerate, or from mere dried specimens. ${ }^{27}$

Therein lay the chicf claim of Ruiz and Pavón to respect in the botanical world; they had seen the plants growing in their native habitat. ${ }^{2-9}$ The Prodromus was a means by which they could establish primacy of discovery and wipe out the alleged gaucheries of others (especially Antonio Cavanilles) who seemed to be treading on their toes. The fury generated between these botanists and their bête noire Cavanilles, went back, in fact, to a time even before the expedition had returned from Peru.

Cavanilles was a well-educated, quick-witted, sharp-tongued Spanish curate, and onetime tutor in Paris of the children of the Duque del Infantado. When in 1777 he first assumed charge of educating this Spanish nobleman's progeny, he had no particular enthusiasm for plants. But when, in I78I, at age thirty-six, he was exposed through his wards to the delights of botany, he entered upon its study with unflagging intensity.

Stimulated by association with men like Antoine de Jussieu and André Thouin at the Jardin du Roi in Paris, Cavanilles undertook a complete study of Monadelphia - that is, plants of the sixteenth class of Linnaeus. After completing the first "dissertation" in 1785 , he sought out more information from Mutis and the team of Ruiz and Pavón. By I 790 he had finished his labors in ten dissertations, covering 70 genera, including 19 new ones, and 643 plants; he had drawn all 296 plates with his own hand "without having had any master other than nature."29

Cavanilles unblushingly recites a list of his admirers: the French Académie des Sciences, newspapers in Paris, Pisa, Zurich, and Göttingen, and "distinguished botanists like Thunberg, De Jussieu, Lamarck, Willdenow, Usteri, and others." Antoine de Jussieu

27. Pp. xviii-xix.

28. The Prodromus did contain, however, drawings of ten genera copied from dried specimens, because the original figures had been lost in the wreck of the San Pedro de Alcántara.

29. Colección de papeles sobre controversias botánicas de D. Antonio Joseph Cavanilles (Madrid, 1796), p. 8. Eduardo Reyes Prosper (ed.), Dos noticias históricas del inmortal botánico y sacerdote hispano-valentino don Antonio José Cavanilles (Madrid, 1917), pp. 26, 197-199. Colmeiro, La botánica y los botánicos, p. 39. Cavanilles to Mutis, Paris, May 1, 1786, in Gredilla, Biografía de Mutis, pp. $288-$ 289 . 
adopted Cavanilles' genera in his Genera plantarum (I789). Jean Baptiste Lamarck reproduced some of Cavanilles' drawings in his Encyclopédie méthodique: Botanique (8 vols., I783-1803). And, Cavanilles recalls, the Spanish professor Gómez Ortega wrote him several times in $\mathrm{I} 785$ and $\mathrm{I} 786$, calling him an "informed, impartial, judicious, and well disposed person." Said Ortega, "Your plates have come out wonderfully and certainly guarantee the glory and satisfaction that result from enriching art, and vindicating the reputation of Spain." 30

The warmth of this reception by Gómez Ortega began to cool in I787. Having just received the third dissertation on Monadelphia, he wrote on March 22 of the appreciation it had won in Madrid, to which he added his own plaudits. "But," continued Ortega, "I wish that you had observed all [the genera] in living plants." ${ }^{\prime 31}$ Cavanilles came to Madrid later that year to take temporary possession of an abbey, and within a short time, according to his account, Ortega's amiability had vanished completely. ${ }^{32}$

Also, much to Cavanilles' chagrin, when he returned to Paris in I 788 he found the widespread adulation for his work undermined by the dissenting opinion of an anonymous author, identified only as a "Resident [vecino] of Lima." "33 This individual informed the world that Ruiz and Pavón had just received a letter from Cavanilles ${ }^{34}$ enclosing a brief summary of his newly discovered genera, ${ }^{35}$ including two named in honor of the botanists in Peru, who, the Vecino reported, found themselves troubled by numerous aspects of Cavanilles' work.

How, they marveled, had Cavanilles been able to discover so many genera among Monadelphia? ${ }^{36}$ In all of "new and delightful" Peru and Chile the expedition had found only a single species of one genus. They "couldn't get over" the slight foundation Cavanilles

30. Coleccion de papeles, pp. 20-21, 32-33, $191,163,4-5$. The letters from Gómez Ortega quoted by Cavanilles were dated Dec. 26, 1785, and Feb. 26, 1786.

31. Quoted in Cavanilles, Colección de papeles, p. 5 note.

32. Ibid., pp. 4-5.

33. "Carta de un vecino de Lima á los autores del Memorial Literario, acerca de las disertaciones Botanicas de D. Antonio Joseph Cabanilles," Memorial literario, $\mathrm{XV}$ (Sept., 1788), 167-169. The letter was dated Nov. I I, 1787 .

34. Dated April 2, 1787 . (Cavanilles, Colección de papeles, pp. I8-19.)

35. Printed in the Journal de physique, Feb., 1787. (Ibid., pp. I9-20.)

36. The genera specifically referred to were Anoda, Palaua, Laguna, Dombeya, Assonia, Ruizia, Pavonia, Cienfuegosia, and Senra. All still hold today except Laguna (=Hibiscus L.) and Assonia (=Dombeya Cav.) 
(though always a "hard-working and praiseworthy enthusiast") must have had for making new genera out of mere species. ${ }^{37}$

Cavanilles must have forgotten the "incontrovertible doctrines" of Linnaeus, mused the Vecino. Else, why would he have failed to note that Linnaeus distinguished the various genera of Monadelphia by the calyx? In closing, the Vecino revealed that the botanists of Peru would not reply to Cavanilles' letter, nor render final judgment on the other new genera, nor go through with their intention to dedicate a new genus to Cavanilles, until they had returned to Spain. ${ }^{38}$ Inasmuch as the Vecino's letter was not published until the very month in which Ruiz and Pavón landed in Spain, Cavanilles had presumably little time to wait.

Who was the author of this critique? One might at first glance suspect either Ruiz or Pavón. But Cavanilles noted in perplexity that Pavón had written him from Huánuco on the same date as the Vecino-November II, I787. Thus, how could the botanists have claimed to be deferring their reply until after returning to Europe? Nor was Pavón's letter critical: he had thanked Cavanilles and praised his botanical labors.

If this missive were cause for wonderment, what must Cavanilles have thought when he received a note from Ruiz dated December 28,1788 (three months after publication of the anonymous carta) excusing his failure to answer earlier, for lack of time? Ruiz sent Cavanilles, so the latter reports, "due thanks for the new genus with which you have deigned to distinguish my name." No one could value the honor more highly. "Permit me," Ruiz is said to have continued, "to tell you my sorrow-that you haven't dedicated this genus to a person of greater merit than I. . . A Among my botanical discoveries I have 128 new genera ... to which, for the greater luster of my work I plan to give the names of learned botanists and protectors, such as Señor Don Antonio José Cavanilles." 39

Señor Don Antonio José Cavanilles by that time had already drafted a public reply to the anonymous "scented-water scholar." 40

37. He had separated three species of Sida into three new genera. Ruizia was Malva; Pavonia and Cienfuegosia were Hibiscus, his detractor claimed. (Memorial literario, $\mathrm{XV}, \mathrm{1} 67-168$.

38. Ibid., pp. $168-169$.

39. Cavanilles, Colección de papeles, pp. 18-19, 2 I, I I 1-1 I 2.

40. "Carta de D. Antonio Cavanilles en respuesta á la que se insertó en la segunda parte del Memorial Literario del mes de Septiembre de 1788, donde se hace crítica de sus Disertaciones botánicas por uno que se títula vecino de Lima," dated Nov. 28, 1788, from Paris. Reprinted in ibid., pp. 19-30. 
Why should anyone be so enamored of Linnaeus that he refused to disown any of the Swede's opinions? Such compliance and enthusiasm were laudable in a tyro but kept the world from learning new truths. Linnaeus had erred like any human being. In his efforts to preserve the "beauty and truth, largely ideal, of his system" he had lost the very consistency he hoped to achieve.

Luckily, wrote Cavanilles, not everyone "suffered from the same infirmity" as the Vecino. No, Mister Anonymous, Cavanilles had not overlooked Linnaeus' doctrine that genera of Monadelphia should be distinguished by their calyxes. "I published it before and I affirm it again, that his doctrine is false, and from it spring many of the contradictions in his work on this matter." 41 The Académie des Sciences had sustained Cavanilles' position and 'from an Anonymous Limeño up to an Academy of Sciences I believe there is some distance."

Why should the botanists of Peru be so surprised to learn, Cavanilles continued, that he had found new genera? As if one couldn't discover plants elsewhere than in Peru and Chile! All one needed was botanical knowledge, which could be obtained, he said, by consulting wise men and good books. The plants to be studied could be gathered by travelers, who might be either learned or ignorant so long as the specimens were well-preserved and had their flower and fruit.

These disdainful thrusts from Paris evoked a quick response. In April and May of I 789 a second anonymous letter, much longer than the first, appeared in the Memorial literario of Madrid. ${ }^{42}$ Its announced purpose was

to forestall the reproach of our enthusiasts of botany who, bedazzled by the specious circumstances of your [Cavanilles'] writing from Paris, by the recommendation of the savants who have approved and promoted the publication of your dissertations, and, above, all, by the

41. E.g., Linnaeus separated Althaea and Alcea "against the natural order of these plants," because the number of divisions of the external calyx differed. (Both are Althaea Tourn. today.) Yet he separated Sida from Napaea (as is still the case), though they had similar calyxes and fructification, etc. (Ibid., pp. 22-23.) See Enrique Álvarez López, "Cavanilles: ensayo biográfico-critico," Anales del Jardin Botánico de Madrid, VI (1 945), 40-46, for an excellent discussion on the relationship of Cavanilles to Linnaean doctrines. This article is typical of the very thorough analyses the late Álvarez López made of many aspects of eighteenth-century botany.

42. "Respuesta á la carta que D. Antonio Cavanilles ha publicado en contextacion á la de un vecino de Lima, sobre la falta de fundamentos para haber establecido varios géneros de Plantas en sus disertaciones Botánicas," Memorial literario, XVI (April, 1789), 580-596; XVII (May, 1789), 41-64. 
magisterial tone of your letter, might attribute reasonableness to it, to the detriment of justice and their own progress.

Let not Spanish youth, "which with so much design has undertaken the study of the natural sciences," isolate itself from the most solid and fundamental principles in a matter of so much importance as the establishment of genera! ${ }^{43}$

Cavanilles, who had returned to Spain in 1789 , held his tongue publicly until he managed to obtain "prematurely" a copy of the Prodromus of Ruiz and Pavón in I 795. He was not mollified by the fact that they had dedicated Cavanillesia to the "noted philosopher and botanist, who has contributed with his untiring assiduity and by various excursions and excellent works to the enlightenment of botany in general, and has been almost alone in clearing up the Monadelphia class." What caught Cavanilles' eye was rather that they had appropriated the names he had already given to new genera-Ruizia, Pavonia, Palaua, Molina, and Dombeya-for discoveries of their own. They were "persuaded," he noticed, for example, "that Ruizias of Señor Cavanilles are rather species of the genus Malva, than any other one ...;" and they held surely that "Pavonias of Señor Cavanilles must indubitably be restored to the genus Urena . . . ."44

Cavanilles lost no time in replying. His long silence had been due, he later recalled, not only to a dislike for wasting time, but because he wanted to "preserve the honor of the voluntary aggressor," who had "written with an artifice foreign to the candor and simplicity appropriate for a litterateur and lover of science." But at last, Cavanilles said, his patience was exhausted. He must make sure that the authors, either named or nameless, did not harm his reputation with impunity. ${ }^{45} \mathrm{He}$ chose for a vehicle the preface to the third volume of his Icones, ${ }^{46}$ which appeared in 1795 . Herein he not only defended his own genera, but ripped into genus after genus presented as new by Ruiz and Pavón in their Prodromus. ${ }^{47}$

43. Ibid., XVI, $580-581$.

44. Ruiz and Pavón, Prodromus, pp. 87, 97, 100, 127, 135. Yet, two years before, in the Quinologia, Ruiz had spoken in deprecation of botanists who work "in the shade and comfort of a Cabinet"-a barb almost certainly intended for Cavanilles. (P. x.) Cavanilles, at least, was convinced that Ruiz singled him out "as with a finger." (Colección de papeles, p. 8.) Molina Ruiz \& Pav. = Baccharis L.; Molina Cav. = Hiptage Gaertn. All others remain as Cavanilles named them.

45. Ibid., pp. 93-94.

46. Icones et descriptiones plantarum (6 vols.; Madrid, 1791-1801), a study of 712 plants, including 59 new genera, either exotics discovered in foreign lands by Spaniards, or plants indigenous to Spain.

47. "Lectori Benevolo," dated Jan. 10, 1795, reprinted in Cavanilles, Colección 
Battle lines were drawn. Hipólito Ruiz, delayed in his work on the Flora, in the following year published a Ioo-page volume for the sole purpose of flogging Cavanilles and defending his own genera. ${ }^{48}$ Scarcely stopping for breath, Cavanilles published a work running to no less than 274 pages in which he presented the full text of all the polemics, beginning with the first anonymous letter. He footnoted the entire compilation with a running commentary of pungent remarks intended to ridicule beyond redemption Ruiz and/or the anónimos. ${ }^{49}$

The number of printed pages of mutual castigation never again reached this peak of $\mathrm{I} 796$, but the intensity of their remarks showed no signs of diminishing. In the Suplemento a la quinologia of 1801, Ruiz and Pavón devoted a ten-page footnote to the correction of Cavanilles' errors (none of which had anything to do with the subject of the book, quinine). In the previous year Ruiz had written a letter to Antoine de Jussieu detailing some of these mistakes, and he now published that missive in the Suplemento. ${ }^{50}$

Cavanilles took space to answer in his own periodical, the Anales de ciencias naturales: though supplements, appendices, and notes "multiplied like mushrooms, whose short life and nature is well known," he would continue on his own path. ${ }^{51}$ The mushrooms continued their propagating ways, for most of the preface of Volume III of the Peruvian Flora, appearing in 1802 , was devoted to the hoary argument. Cavanilles wrote to Mutis that the "author" (and here he did not necessarily mean Ruiz or Pavón), ${ }^{52}$ whom he compared to a "trampled-on viper or a mad dog," had "burst the dikes of his mordacity." 53 Ruiz and Pavón had announced in I $80 \mathrm{I}$ the proximate appearance of a new work, "Animadversiones botanicae in D. Cava-

de papeles, pp. 96-108. Cavanilles found fault with twenty-two of the genera presented in the Prodromus.

48. Hipólito Ruiz, Respuesta para desengaño del público à la impugnacion que ha divulgado prematuramente el Presbitero don Josef Antonio Cavanilles, contra el Pródromo de la Flora del Perí, é insinuacion de algunos de los reparos que ofrecen sus Obras Botánicas (Madrid, 1796).

49. Colección de papeles sobre controversias botánicas ( 1796 ).

50. Pp. 85-86, 12r-154. The letter, in Latin, to De Jussieu is dated Jan., 1800.

5I. "Suplemento al género Buena," Anales de ciencias naturales, IV (I80I), $116,114$.

52. See pp. 24I-242, 244, below, for Cavanilles' implication of Gómez Ortega in the writing of the Flora.

53. Ruiz and Pavón, Flora Perwviana, III, ii-viii. Cavanilles to Mutis, Madrid, Jan. 22, 1803 . 
nilli opera," nilles' death in I804 there was no longer need to keep up the tirade.

\section{THE WANING OF GÓMEZ ORTEGA}

This "Battle of the Books" had many other facets. Ruiz clashed with Pavón over two separate matters, and this roused $\mathrm{C}_{\text {avanilles to }}$ the defense of Pavon. The first involved the old question about identification of the Chilean pine (Araucaria araucana). ${ }^{55}$ The junior member of the partnership, Ruiz alleged, had removed a copy of the description of the pine from their joint office in Madrid, in order to compose a dissertation and thereby gain admittance to the academy of medicine as an académico supermumerario. When the study finally appeared, lo and behold, Pavón had forsaken Ruiz to side with Cavanilles and De Jussieu in calling the Chilean pine Araucaria, instead of a species of Pinus. While Ruiz fumed that Pavón had abandoned the position he publicly held in the Prodromus, Cavanilles jumped in to laud Pavón as "the first discoverer of the pine among the botanists of the expedition." Was it a crime that Pavón had changed his mind? With delight Cavanilles recalled that Pavón had stated, in a public meeting of the academy, "that if the Prodromus were done over again it would come out with fewer imperfections."

The second incident involved another description taken from their joint files by Pavón-this time without the knowledge of Ruiz. The plant in question had tentatively been pronounced a new genus, Cosmibuena, and was so identified in the Prodromus. After the work had been set in type, the two botanists decided the plant was not Cosmibuena - not a new discovery, that is-but Hirtella, found earlier by Jacquin. Ruiz and Pavón made a note to publish the correction in the next volume of their Flora. Meanwhile Pavón told Cavanilles about the change, and when the latter's blistering attack on the Prodromus appeared in 1795 it laid the error bare. Pavón confessed to

54. Suplemento a la quinología, p. 120.

55. See pp. I 19-120, above.

56. Ruiz, Respuesta para desengaño, pp. 17-19, 25. Cavanilles, Colección de papeles, pp. 139, 186. Cavanilles wrote: "I was one of the censors of the dissertation of Pavón and I saw in it the fundamentals with which he demonstrated his assertions. To say that he had no more proof than a change of name, as his companion affirms, is to speak untruthfully and criticize the merit of the dissertation unjustly." (Ibid., p. 141.) 
Ruiz he had shown the data to Cavanilles, and Ruiz squirmed in embarrassment. Cavanilles, however, scoffed at the idea that he had needed anyone to tell him about the mistake. And if Pavón had revealed the information, was that a "pernicious error against science"? ${ }^{57}$

But Cavanilles reserved his choicest invective for Casimiro Gómez Ortega. At stake was a seat of command on the highest rung of the Spanish botanical hierarchy. Although Cavanilles' version, contained in his published writings and snatches of his correspondence, is naturally one-sided, it provides some enlightening suggestions about the true nature of the controversy, for which all the talk about mistaken genera was mere window dressing.

The amicable relations between these two men had begun to deteriorate in 1787 when Cavanilles came back to Spain for a temporary sojourn, modestly proud of the compliments bestowed upon the first sections of his study of Monadelphia. Rumors started to fly, according to Cavanilles, that he would take over Gómez Ortega's post as head of the botanic garden in Madrid. ${ }^{58}$

The existence of this new menace induced Ortega, so Cavanilles claims, to participate in writing the anonymous letters. ${ }^{59}$ However, Cavanilles made no public charges against Ortega until I795, eight years after the date of the first anónimo. Though common opinion had credited Ortega with authorship from the first, Cavanilles had refused for years to believe the canard. ${ }^{80}$ Even now he charged Ortega with authorship of only the second letter. ${ }^{61}$ Inasmuch as Cavanilles also said that Ortega and Ruiz were the only "gladiators" in this "literary combat," 62 we must infer that he thought Ruiz had been the Vecino de Lima-the initial anónimo-an identification that had seemed unlikely when Cavanilles first read the letter. At no time, however, did Cavanilles specifically charge Ruiz with responsibility. To complicate matters, Ruiz asserted in 1796 that he had been the author of both anonymous letters. ${ }^{63}$ 192 .

57. Ruiz, Respuesta para desengaño, p. 52. Cavanilles, Colección de papeles, p.

58. Cavanilles to Mutis, Madrid, April 28, 1795. Gredilla, Biografia de Mutis, p. 292 .

59. Ibid.

60. Cavanilles, Colección de papeles, p. 96, originally printed in the preface to his Icones, Vol. III ( 1795 ).

61. Colección de papeles, pp. 87-89, 92, 1 I I-1 I2.

62. Ibid., p. 95.

63. Respuesta para desengaño, p. 7. 
Cavanilles did not need all these years to discover that Ortega was displeased with his presence in Madrid. The new botanist settled permanently in the Spanish capital in 1789, and shortly thereafter received an order to examine the plants of the royal garden and publish details on them-"without doubt," says Cavanilles, "because in the eighteen years that [Ortega] had been the professor there, he hadn't done it." Ortega is said to have fought the order, but the government continued to support $\mathrm{C}_{\text {avanilles }}{ }^{64}$ and the six volumes of the Icones were the result.

In trying to discredit his rival, Ortega hid, so Cavanilles claims, behind the ample shoulders of his nephew Hipólito Ruiz, even to the point of dictating the preface to the Prodromus and causing Ruiz to adopt the errors of his uncle and the "mania for belittling" Cavanilles' works. ${ }^{65}$

Ruiz admitted that Ortega had helped him and Pavón, but "it was at our request and on order from above." However reasonable it was to expect a teacher of botany to advise his former student who was at the same time his nephew, Cavanilles could only splutter that Ortega "certainly did not know a single plant of the new ones that came from Peru. He had never seen them alive." ${ }^{\prime 66}$ But did Ortega's assistance require such knowledge? It is notable that Cavanilles never links José Pavón with these irregularities. In fact, he claims that Ruiz and Ortega were trying to "dispirit" Pavón, that "industrious, enlightened, modest, and well-behaved man," by forcing him to subscribe to whatever had been printed in the Prodromus. ${ }^{67}$

Cavanilles further charged Ortega with attempting to corner exclusive control over published findings of all of the botanical expeditions to America. According to Cavanilles,

at every opportunity [Ortega] went to the secretariats, making curtsies even to the very porters, and spoke to officials of the privies pretending to promote science so as to unite under his hand all the works of those commissioned by the king, with the hope that, without hardship, some personal income would result from it. ${ }^{68}$

64. Cavanilles to Mutis, Madrid, April 28, 1795. Gredilla, Biografía de Mutis, p. 292. Cavanilles, Colección de papeles, p. 6.

65. Ibid., pp. 8-9, 6, 96-97. Cavanilles to Mutis, Madrid, April 28, 1795. Gredilla, Biografia de Mutis, p. 293.

66. Ruiz, Respuesta para desengaño, pp. 9-10. Cavanilles, Colección de papeles, p. 122.

67. To Mutis, Madrid, April 28, 1795. Gredilla, Biografia de Mutis, p. 296.

68. Ibid., pp. 292-293. Cavanilles warned Mutis in 1794 to beware of Ortega's tentacles. (Ibid., p. 291 . See also pp. 293, 294.) 
It is indeed true that negotiations took place in 1794 to transfer jurisdiction of the Flora office to the Ministry of State, as part of an apparently logical plan to unite all botanical enterprises, whether in Spain or America, under one head-Casimiro Gómez Ortega. The Minister of Grace and Justice for the Indies, Eugenio de Llaguno, at first glance seems to have had no objections. But he must have reconsidered, for he is later reported as refusing to give up the plums on the ground that the expeditions had been born and risen to success in the Indies ministry, which was luckily staffed with able persons. ${ }^{69}$

Another source hints at strife over control of the botanical office. The Eulogium on the life of Ruiz, attributed to his son Antonio, is footnoted with this mysterious allusion:

Many of those who ought to have given [the expedition] their protection, consulted rather the suggestions of their ambition and greediness, than their duty. The commendable labours of Ruiz and his companions excited envy, and were a plea for swelling the hoards of others, under the colour of assisting in the edition of the Flora; a vain pretext, since, instead of co-operating in it, these persons precluded all extraneous intervention by a Royal Decree. Besides this, original works cannot be published correctly, except by the Botanists who collected the materials, and observed the plants flourishing in their native soil. So far, indeed, were they from co-operating in the publication of the Flora, that they exerted all possible endeavours to hinder it, by interposing various obstacles, which were considerably augmented by the discord malignantly stirred up between Ruiz and the Abate Cavanilles. Without doubt, this was because the author of the intrigue did not think himself strong enough to measure his arms with those of the Priest [Cavanilles], who prematurely published his opinions against the doctrine of Ruiz, relative to the legitimacy of the generic character of some American plants. ... Finally, the Spanish Botanists were divided into two parties, which greatly retarded the interest of the science, and occasioned the waste of much time on questions of little moment; because a considerable progress would have been made in this matter, had these two rival leaders united their arms to give it new clearness and lustre. ${ }^{70}$

Although no name is mentioned, the finger points at Gómez Ortega. We have had no hint of trouble between Ruiz and his uncle. Yet, as a modern Spanish scholar, Enrique Álvarez López, points out, the Eulogium never once speaks of Gómez Ortega by name,

69. Duke of Alcudia, Minister of State, to Llaguno, San Ildefonso, Sept. I 8, I794; Llaguno to Alcudia, San Ildefonso, Sept. 2x, 1794; Alcudia to Llaguno, San Lorenzo, Oct. 18, 1794; Cerdá to Caballero, Madrid, May io, 1799. MCN.

70. Historical Eulogium, pp. 43-45. 
though the text is well dotted with references to other individuals. Of course, Ruiz may not have borne the same grudge as his son, but it is notable that Gómez Ortega's name does not appear in junta minutes or office diary notes after the summer of 1794. Alvarez López suggests, without much conviction, that Ortega may have sought to steal glory from Ruiz by trying to publish some of the Peruvian plants on his own account. ${ }^{71}$ Or, by chance, was a rift the result of Ortega's bid for lordship over all of the expeditions? The attempt to bring the Botanical Office of Peru under, the wing of the Ministry of State in September, I794, coincides with a halt in all work on the Flora for at least nine months, and junta sessions were, in fact, not resumed until August, I797. On the other hand, when the junta was in its infancy, and before Cerdá had been assigned as its presiding officer, Ortega had fervently expressed the hope that he would be relieved of directorship, because "as a reward for my zeal and anxiety, I get nothing but vexatious grief." "2 There is some slight evidence that Ortega and Ruiz were still allies in 1796, and the three-year hiatus in junta sessions on succeeding tomes of the Flora is attributable partly to financial troubles and the idiosyncracies of reluctant draftsmen. ${ }^{73}$ Yet the fact remains that, when the junta resumed its work in 1797 , the Minister of Grace and Justice omitted Ortega's name in his instructions on procedure. ${ }^{74}$

The old tsar's hold on the pulse of Spanish botanical life was broken for sure on June I7, I80I, when Cavanilles replaced him as director of the Jardín Botánico and professor of botany. The government retired Ortega on full salary to the little garden at his home, where he spent his time in bitter recollections. ${ }^{75}$ Yet, according to Cavanilles, he could not refrain from meddling in the Flora Peruviana. The new professor charges him with authorship of the preface to Volume III (I802), a performance in which he "neither reformed his awkwardness, nor curbed the evidences of his ignorance, nor was disheartened by the public demonstrations the government had made in separating him from teaching." "i6

71. "Algunos aspectos," Anales del Instituto Botánico A.J. Cavanilles, XII, 36-38.

72. To Bajamar, Madrid, June 19, 1792. MCN.

73. See chap. xiv.

74. Llaguno to Zenon Alonso, new head of the botanical junta, San Ildefonso, Aug. 4, 1797. MCN.

75. Cavanilles to Mutis, Madrid, March 2 and June 19, 1802. Gredilla, Biografía de Mutis, pp. 299-300. Colmeiro, "Jardín Botánico," p. 27 I.

76. To Mutis, Madrid, Jan. 22, 1803. Gredilla, Biografia de Mutis, p. 30 r. 
Cavanilles made substantial improvements at the royal botanic garden. Ortega, in the last years of his tenure as chief, admitted that the garden was becoming impoverished through lack of proper care. Cavanilles, of course, found it "pobre pobrísima" - at the very nadir of usefulness. He increased the size of the herbarium, which, in his time (to I 804), came to total I 2,000 plants; raised (from 3,000 to 7,500 ) the number of species cultivated; improved the admittedly deficient stoves and greenhouse; and reorganized the plants in the garden according to a new version of the sexual system with fifteen instead of twenty-four classes. Although Cavanilles died in 1804 and Gómez Ortega not until 1818, the garden maintained a Cavanillesian tone, thanks to the enthusiasm generated among his students, who at one time numbered two hundred. ${ }^{77}$

Time has largely borne out the validity of the new genera announced by Cavanilles. In fairness to Gómez Ortega, it must be said that attempts were made long after his term as chief botanist had run out to put the various botanical offices under the wing of the "first professor." Royal orders in I80I, I8I4, and I8I5, aiming at a consolidation, brought together only those of New Spain and New Granada, whose directors were deceased. The Botanical Office of Peru, on the other hand, maintained its independence until I $83 \mathrm{I}^{78}$

77. Cavanilles to Mutis, Madrid, March 2 and June 19, 1802. Ibid., pp. 299, 300. Colmeiro, "Jardín Botánico," pp. 27 1-275.

78. Colmeiro, La botánica y los botánicos, p. 39. Barreiro, "Epílogo," in Ruiz, Relacion, I, 493, 507-508. 


\section{A N U NFULFILLED FLORA}

\section{FOR THE K I N G}

\section{AN END TO MUNIFICENCE}

For the Prodromus the goal had been "grandeur and magnificence"; for the rest of the tomes the aim was a more realistic "esteem without munificence." Ruiz and Pavón could fill a dozen volumes with more than one hundred plates apiece, in contrast to the modest thirty-seven plates of the Prodromus. Thousands of additional drawings and descriptions were accumulating in New Spain and New Granada. If sales of the Flora Peruviana were brisk, the money donated in America would be replenished for use by the other expeditions. But, as Ruiz clearly foresaw, "these vast and costly Works ... are in truth only for the Great and Powerful, and for Schools, Gardens, and Libraries." Scarcely two or three botanists in Spain could afford to buy them. ${ }^{1}$

Six hundred copies of the Prodromus were printed on "regular" paper, to be sold at I 20 reales apiece. Another one hundred copies, priced at I 30 (later I 40 ) reales, were printed on "fino." Yet, over a forty-year period, sales amounted to only 65 copies, all but four on regular paper. ${ }^{2}$ Records confirm another 7 I (about equally divided between regular and fino) issued gratis, which should have left 564 in stock. ${ }^{3}$ In actual fact, another hundred or so disappeared, for

1. To Cerdá, Madrid, May i 7, 1794. MCN. The cost of a single volume was over one-third of Ruiz's monthly salary.

2. "El Prodromo ha vendido siempre en Papel a ciento veinte r.s." (Summary of information by José Pavón, Madrid, Sept. 16, 1818. MCN.) Note of June 13, 1796, "Si se vendiesen los de Papel fino, a $130 \mathrm{r}^{\text {s }}$ el esemplar." (MCN.) In actual fact, the only copies of fino actually sold went for I 40 reales. (Copia de la Cuenta presentada a la Junta de Proteccion por $D^{\text {n }}$ Yndalecio Sancha, Madrid, Nov. I 2, 1834. MCN.) See also Razon de los Prodromos y tomos de la Flora Peruviana, Gabriel de Sancha, Madrid, Sept. I7, 1799. MCN.

3. Gift copies were distributed as follows: king and various ministers, 20; Ruiz and Pavón (for personal use and exchange), I 2; Isidro Gálvez, 2; Tafalla, 2; 
Pavón admitted possessing only 450 copies in 1829 , and an inventory of I83 I disclosed an unexplained shortage of "three packages." Even so, nearly two-thirds of the copies had assuredly found no takers in all those years.

The botanists had envisioned at least a modest sale for the Prodromus in America. They had talked of sending fifty copies to be sold in Lima, twenty-five in Mexico City, and six each in Bogotá and Buenos Aires, in addition to providing gift copies for heavy contributors to the fund. ${ }^{5}$ America, however, did not get even a look at the Prodromus until I799, three years after final publication, when one copy on "regular" paper was sent to Lima for the use of Juan Tafalla. To Viceroy O'Higgins, Ruiz explained the niggardliness as due to a fear that the enemy English might intercept Spanish shipping; the copies destined for contributors to the publication fund must wait. ${ }^{6}$ Finally, in 1803 , twelve sets of Flora volumes were dispatched to Lima for distribution to these donors. ${ }^{7}$ There is no record of copies sent to America for public sale, nor of copies provided for contributors outside Peru.

Although in 1794 the future had yet to disclose its dismal pattern, prodigality was already out of style. Engraving and printing the Prodromus had cost at least 29,000 reales. ${ }^{8}$ Another I0,000 went

contributors in Peru, 12; French institutions, 6; Spanish libraries, 2; German ambassador, I; University of Padua, I; Prince of Parma, I; Martin Sessé of the Mexican expedition, 2; proof sheets, 2; "to bind with illuminated plates" (for unspecified recipients), 8. (Razon de los Prodromos y tomos de la Flora Peruviana, Gabriel de Sancha, Madrid, Sept. 17, 1799; correspondence of Pedro Cevallos and José Antonio Caballero, Jan, 21, March 27 and 29, April 2 and 7, 1801, and Jan, 16 and Feb. 28, 1802 ; Est ${ }^{\circ}$ de Lugo, of the Biblioteca Pública de Reales Estudios, to Caballero, Madrid, Jan. 31, 1801 ; Ruiz and Pavón to Alonso, Madrid, Feb. 8, I803; note to Cayetano Soler, Aranjuez, Feb. 16, 1803; Perignon, French ambassador, to Llaguno, Aranjuez, Feb. 19 and April 19, 1797, and Spanish replies of Feb. 26, and April 22, 1797; Copia de la Cuenta presentada ... por $\mathrm{D}^{\mathrm{n}}$ Yndalecio Sancha, Madrid, Nov. 1 2, 1834 . MCN.)

4. Pavón to Ministro de Hacienda de Indias, Nov. 18, 1829. MCN, 1830. Inventario general de todos los Enseres de la oficina Botanica, July 4, 1831. MCN. MCN.

5. Undated ( 1794 ) memorandum, "Prodromo de la flora Peruana. Regalos."

6. Federico Schwab, "Una carta inédita del botánico español Hipólito Ruiz," Boletin bibliográfico, XVII (June, 1947), 129.

7. Ruiz and Pavón to Zenon Alonso, Madrid, Feb. 8, 1803; [Alonso?] to Minister of Hacienda Miguel Cayetano Soler, Aranjuez, Feb. 16, I803. MCN.

8. Sancha to Porcel, n.d. MCN, 1794. Cuenta del importe del grabado de la letra..., Madrid, Oct. 26, 1793. MCN. For each copy given away subsequently, Sancha charged the expedition for binding in paper, 8 reales; in cardboard, 24 reales; in wood boards, 40 reales; and in morocco, 150 reales. The price ultimately asked by Rubio for the plates varied from 6 to 10 doblones ( 1 doblon $=60$ reales), 
every year for rent on Cerdá's house, ${ }^{9}$ and there were, naturally, other expenses for supplies and equipment. A porter brought back from Huánuco, one Pedro Santa María, was officially added to the payroll in April, I 793, at six reales a day. ${ }^{10}$ Ruiz, Pavón, and Gálvez each received a salary of 10,000 reales a year, though not from money collected in America. And all the while the nation was embroiled in the expense and cares of war to help suppress the Revolution in France. In order to retard the outflow of funds, the ministry suggested, for the remaining tomes, the use of smaller type and omission of the Spanish text. Publish only the "most notable, most choice, most useful, and most unknown" plants, omitting any already announced by other botanists, unless the previous drawings were "damaged and disfigured." Then the work could be held to four to six folio volumes. If these sold well, the botanists could add appendices. Above all, they should finish the job without delay, so as not to "cool the ardor of the workers and promoters." 11

At least the ministry agreed with Ruiz that the pages should remain unchanged in size. Otherwise the artists would need to spend years to reduce the dimensions of the drawings and some of the copper already polished would be lost. Ruiz and Pavón agreed to exclude from the drawings all of the unneeded branches and most of the leaves, flowers, and fruits, so as to put three or four designs on one plate. The magnificence would suffer, but the work would still be "nice, and worthy of a sovereign." Ruiz spoke of needing five years to finish the task. ${ }^{12}$

with most hovering close to the lower figure. Data are not available for all plates. (Junta minutes for March 14, April 20, May 28, July 24, Aug. 16, 1793. MCN.) It will be noted that these rates are higher than the maximum of 300 reales settled upon at one time for the Prodromus plates. Sancha told Cerda on February 18, 1794, that he could get copper at the excellent price of $10-1 / 4$ reales per pound, in $40-$ to 60 -pound sheets, each sheet making about 14 finished plates. We do not know if he made this purchase. A less favorable quotation was I I-3/4 reales per pound. (MCN.)

9. For confirmation that the rent was paid out of funds collected in America, see the note attached to a copy of a letter from the Duke of Alcudia to Llaguno, San Ildefonso, Sept. 1 8, $1794 . \mathrm{MCN}$.

10. Junta minutes of March 14, 1793, and attached note by Acuña, Aranjuez, April 3, 1793. MCN.

I I. Letter written to Porcel by Cerda, at the instigation of Llaguno, Aranjuez, June 2, 1794. Incorporated in minutes of the junta of June 17, 1794. MCN.

12. Ruiz to Cerdá, Madrid, May 17, $1794 . \mathrm{MCN}$. 


\section{RUBIO THE UNDAUNTED}

During the summer of I 794, however, as we have already seen, the project hit a snag. Perhaps Ortega and the botanists began to quarrel at this time. The office diary is interrupted suddenly on August 20, I 794, not to be resumed until the following April 22. In the meantime, the botanists continued copying and correlating descriptions, but the draftsmen were idle an entire year. On April 23, I795, all again took up their tasks, but this by no means guaranteed proximate publication. ${ }^{13}$ In fact, the botanists had to "solicit orders incessantly" for over two more years before the king gave consent to print. At last on August 4, I797, a new overseer from the ministry staff, Sr. don Zenon Alonso, was appointed to revive the junta, and talk of printing and engraving once more filled the air. ${ }^{14}$

Ruiz links the renewed interest of the crown with praise given the Prodromus by the French Directory early in $1797 .{ }^{15}$ The botanists also acknowledged the support of the new Minister of Grace and Justice for the Indies, Gaspar Melchor de Jovellanos, and in gratitude dedicated to him the genus Jovellana. ${ }^{16}$ One can scarcely overrate the importance of Jovellanos to the cause. Long active in the Sociedad Económica de Madrid, and advocate of reforms in agriculture and education, he had suffered a decline in political fortune after the death of Charles III. Banished to Asturias for defending Count Cabarrús, an enlightened naturalized Frenchman, he wrote in exile "the greatest single production of the [Economic] Societies of Spain,"

13. Álvarez López, "Algunos aspectos," Anales del Instituto Botánico A.J. Cavanilles, XII, 39.

14. Llaguno to Alonso, San Ildefonso, Aug. 4, 1797; Ruiz, Pavón, and Gálvez to Jovellanos, Madrid, Aug. 2, $1798 . \mathrm{MCN}$.

15. To L'Héritier, Madrid, Nov. 5, 1798. Hamy, Dombey, p. 384. The French ambassador Perignon on February 19, 1797, from Aranjuez, asked Llaguno for a copy of the work that, "without being well known in France, has, however, acquired a reputation." The Spanish government on February 26 supplied two copies, one for the archivist of the republic and the other for the use of the ambassador. The ambassador sent his copy to the Institut National. This body resolved to place the copy in the library of the Corps Législatif "where they are busy gathering together the rarest and choicest works," and the ambassador on April r 9 petitioned Spain to supply the Institut as well as the Bibliothèque Nationale with copies. Spain complied within three days. (MCN.) Another copy was sent to the Institut, and one to the Jardin des Plantes in Paris, in 1801 , at the request of De Jussieu. (Cevallos to Caballero, Palacio, Jan. 21, 180r. MCN.)

16. Alonso, the new overseer, was honored with Alonsoa. (Ruiz and Pavon, Flora Peruviana, I, i.) Both still hold today. 
a treatise on agrarian law, which was denounced to the Inquisition because of its views on mortmain. Nevertheless, he gained the support of the Council of Castile in 1797 and, as minister for the Indies, was in favor with the Court for about a year. This was the most promising year, too, in the life of the Flora Peruviana. Jovellanos was exiled again in 1798 , and in I80I was sent under arrest to Mallorca, where he stayed until the government fell in 1808 after the invasion of Napoleon's troops. ${ }^{17}$

Volume I was at last published about midway through I 798. The botanists laid the blame for delay on "various events and vicissitudes in human affairs which ... unexpectedly happened." ones we have already seen-the war, the apparent split with Gómez Ortega, the struggle between parsimony and grandeur, and the ministerial indifference, or even hostility, until the appearance of Jovellanos-comprise only half the story, for one of the heaviest millstones of all was the temperamental artist José Rubio.

The botanists endured for two years his inaccuracy and "notable slowness" as an artist, his many absences, and his meddling in their affairs. The junta overseers, Cerdá and Porcel, warned him to no avail. ${ }^{19}$ In 1796 Ruiz's patience snapped when Rubio one day exclaimed that "from here on you and Ortega will find out who Rubio is!" Then, says Ruiz, the agitated draftsman "rattled off a multitude of highly unjust insults, threats, and insinuations against a person who wasn't there [presumably Ortega] and who in truth is not deserving of Rubio's calumnies, nor the least word against his honor." When Ruiz questioned Rubio's skill, the latter informed him that the plant scientist Louis Née ${ }^{20}$ approved of Rubio's work, and “he was a better botanist than I [Ruiz]."

Putting aside the odious comparison made by a person inexpert in the field, one can't hide from the sagacity of Your Illustriousness

1 7. Shafer, Economic Societies, pp. 10, 13, 56-59, 85, 98-99.

18. Flora Peruviana, I, i. It is not possible to ascertain the exact date of publication. Porcel wrote Jovellanos from Aranjuez, April 24, I798 (MCN), concerning Volume I, "que va á imprimirse luego." A marginal note of July 21, 1798, to a letter from Ruiz and Pavón to Jovellanos written on July I 8 (MCN), stated that the first volume "acaba de salir a luz." The botanists say elsewhere that they got the order to print in August, 1797 , and completed the task in less than nine months. (To Jovellanos, Madrid, Aug. 2, I 798 . MCN.)

19. Ruiz, Pavón, and Gálvez to Jovellanos, Madrid, March 3, 1798. MCN. See also Álvarez López, "Algunos aspectos," Anales del Instituto Botánico A.J. Cavanilles, XII, 43.

20. Naturalist on the Malaspina hydrographic expedition of 1789-1794. 
[Ruiz was writing to Cerdá] the effrontery and manner of uttering such a proposition...., nor the nonsense of it in imputing to the honored don Luis the approval of drawings of objects he has not seen.

Ruiz portrayed himself as a model of decency and patience, a good fellow to his companions. "We all work together, one sings, another talks, and the third raises questions." And, indeed, "mental labor" like theirs could not be carried on unless "free from noise [!] and with a tranquil spirit." Rubio's complaints-about the inadequacy of their working quarters, and the slimness of his salary, to name only two-were more noise than Ruiz's ears could bear. Either the ministry must find a solution or the senior botanist would resign "with the recompense His Majesty deigns to give me, if I deserve any for my meager services." 21

Matters dragged on until August 4, I797, when the new supervisor Zenon Alonso assumed chairmanship of the junta. Should any member of the staff refuse co-operation, Alonso was to notify the king and the offender's salary would immediately come to a halt. ${ }^{22}$ But eight months later Alonso reported no more progress toward peace than had his predecessors.

As work started on the engravings for Volume I, a new crisis arose. Rubio had done the Prodromus plates, and presumed he would again be chosen to help, but the botanists balked. Rubio was also crushed when authority to revise the plates made from his drawings was given to Gálvez. The latter, he charged, made alterations on Rubio's drawings “against the rules of the Art, and his own [better] judgment, with the aim of spoiling them." ${ }^{23}$ Zenon Alonso persuaded Ruiz and Pavón to let Rubio do a trial plate, but, reported Alonso in April, I798, "this experiment came out so badly, that although he [Rubio] was finally permitted to finish it at home, it was necessary to correct it and doctor it up extensively so that it could pass with the others."

Alonso had agreed with the botanists that Rubio was contentious and lazy, but still held hopes for his usefulness as an artist. Having examined some of his drawings with the help of "one or another person of known intelligence," the overseer could not find so many defects as the botanists claimed. ${ }^{24}$ But Ruiz and Pavón had by now

2 1. To Cerdá, Madrid, Oct. II, $1796 . \mathrm{MCN}$.

22. Llaguno to Alonso, San Ildefonso, Aug. 4, 1797. MCN.

23. Statements of Rubio, Madrid, Jan. 8 and Feb. 28, r798. MCN.

24. Statement, Madrid, April 23, 1798. MCN. 
advanced a sensible solution: to replace Rubio with one or two new draftsmen paid on a piecework basis. ${ }^{25}$ Later experience indeed confirmed the logic of their position. In all of Rubio's sixty-five months on the Flora staff, he made only 54 drawings. ${ }^{26}$ At a salary of 500 reales a month he received 32,500 reales, an average of close to 600 reales per drawing. The botanists ultimately found a satisfactory artist who charged only 60 reales a drawing, a saving of 90 per cent. ${ }^{27}$

Alonso now reluctantly agreed that Rubio ought to be fired, but a spirit of compassion resides in the Spanish heart. The artist would not be dismissed until he could find a new job. Rubio had eyes on a post at the royal porcelain factory and Alonso acknowledged that he could doubtless serve better there, "because the tasks of that establishment do not demand such exactitude and subordination as the drawing of scientific objects."28

The king confirmed Alonso's judgment on May I3, I798, pending a final decision on Rubio's new place of employment. By this time the artist had decided, upon advice of physicians, that he must leave Madrid for a change of air. $^{29}$ A royal resolution of June io approved Rubio's petition, but according to Ruiz and Pavón, the errant Rubio had been to the office only two days in the previous two months, anyway, and then did "no more than draw some lines with a pencil." He was always feigning illness and yet "we found him later in the streets, theatres, and parks." ${ }^{\prime 30}$

Rubio came back to Madrid armed with a new plan to earn money. Four years earlier he had suggested a method of engraving favored by the English, that promised to cut in half the cost of the Flora plates: using a wheel rather than an engraver's chisel. He had at that time engraved two sample plates and had run off four hundred prints, but the junta had decided against his plan. Now he would

25. Ruiz, Pavón, and Gálvez to Jovellanos, Madrid, March 3, 1798. MCN.

26. This figure is taken from a statement by the botanists of March 3, $179^{8}$ (ibid.). It appears unlikely that Rubio completed any more drawings after this time, although his salary continued for fourteen more months. He was put on the payroll as of December 1, 1793. The three volumes published during the lifetime of Ruiz and Pavón contained 24 drawings attributed exclusively to Rubio; 21 in which he was co-artist; and 12 in which he did only minute sections.

27. Ruiz and Pavón to Caballero, Madrid, Jan. 19, 1801. MCN.

28. Statement, Madrid, April 23, 1798 . MCN.

29. Royal order to Alonso from Aranjuez, transmitted to Ruiz and Pavón, May 18, 1798. Statement of Rubio, Madrid, May I3, and of Doctors Lorente and Peña, Madrid, May ro and II, 1798. MCN.

30. Ruiz and Pavón to Alonso, Madrid, May 22, 1798. MCN. 
like to be paid 765 reales for them. ${ }^{31}$ The petition seemed reasonable to Alonso, but his superior and former part-time overseer of the Flora, Antonio Porcel, sputtered that Rubio was "using the Ministry for a plaything or diversion to occupy his spare time." Porcel refused to pass Rubio's "rascally proposition" on to higher authorities without telling them of the way in which the artist had been chosen in the first place and the injustice of paying him any salary at all. ${ }^{32}$

When the botanists finally managed to publish Volume I of the Flora in I 798, the unabashed Rubio was prompted to suggest another scheme. In return for the sum of 2,544 duros (50,880 reales), equivalent to the amount paid out for engraving of this first volume of 106 plates, Rubio promised to produce "another or others ... with greater expertness." Without additional charge he would color forty copies of the plates, thus saving the botanists an estimated 500 reales a copy, or 20,000 reales for the entire run of a single volume. ${ }^{33}$

Ruiz and Pavón were as unmoved as ever. They already had an illuminator of "good conduct and noted ability," experienced at miniatures, Antonio Delgado by name. Although they hated to bother the ministry again they were forced to report that Rubio was "boldly proclaiming that our work is very poor, that he is perfecting it, and that if his propositions had been adopted the king would have saved a half million reales." 34 At long last, the prayers of Ruiz and Pavón were answered. As of May, I799, Rubio drew his last pay from the botanical office and went to work at the same salary in the royal porcelain factory. ${ }^{35}$

31. Abstract of a statement by Rubio, Madrid, Sept. 18, 1798. MCN. The bill was as follows: 2 experimental plates, 480 reales; 400 prints, 160 reales; composition of 5 other plates for the Flora, 125 reales.

32. Alonso to Porcel and return, Oct. I I, I 798. MCN. Porcel's allusion to the conditions under which Rubio was hired cannot be clarified further, except that a statement by Ruiz's son leads to a surmise that perhaps Rubio's hiring was related to the split between Gómez Ortega and the botanists. He tells how Ruiz's assailants tried to remove the draftsman Isidro Gálvez and substitute "an ill instructed bungler." The danger that the plates of the Flora would turn out to be the "first essays of foundling boys," was removed when "the Government was appraised of the malignity of the scheme, and regarded it with a contempt worthy of its baseness." (Historical Eulogium, p. 45.)

33. Madrid, Oct. 11, 1798. MCN. Rubio is unquestionably thinking of a duro of 20 reales, for his calculations conform exactly to the average cost per plate of 480 reales announced by Ruiz. (To Cerdá, Madrid, May 17, 1794. MCN.)

34. To Alonso, Madrid, Oct. I I, I798, and to Caballero, Jan. I 9, I801. MCN. Delgado illuminated twelve sets of each of the first two volumes. (Ibid.)

35. Cayetano Soler to Caballero, Aranjuez, and attached notes of May 8 and 22, I 799. MCN. 
How to climax so ridiculous a story? On September 12, I80I, Rubio wrote the Minister of Grace and Justice that his new employer did not have a statement of his "merits and services" on behalf of the Flora, so necessary to his advancement. Zenon Alonso, to whom the letter was given for reply, was ever the gentleman. He answered simply that Rubio had been recommended by the Academia Real de Nobles Artes; that he had made the engravings for the Prodromus, whose completion had brought him the job as draftsman; and that he had continued in this task "with intelligence and zeal until in May, I 799, His Majesty deigned to transfer him to the post he now has in the Royal Porcelain Factory." ${ }^{36}$ Let us not deign to imagine the letter Ruiz and Pavón would have written in the same circumstance.

\section{THE WAY TO INSOLVENCY}

Buffeted by "incidents," unexpected or otherwise, the first volume of the Flora, which emerged in I798, contained a systematic coverage of 277 species found in Peru and Chile of the first four classes of Linnaeus. The botanists named four new genera, Jovellana, Alonsoa, Anthodon, and Ohigginsia (=Hoffmannia Sw.), the last in honor of their old friend from Chile who was now viceroy of Peru. A total of 106 plates, made up of 219 figures, added to the worth of the volume.

Near the end of the same year, the first volume of another of their compilations, the Systema vegetabilium Florae Peruvianae et Chilensis, made its appearance. Published without plates, it sought an audience unable to afford the expensive illustrated folio tomes but needing a complete compendium of plant descriptions. The Systema tabulated 620 species of the first four classes as well as three new genera, including Monnina, dedicated to José Moñino, the Count of Floridablanca. Some corrections were made on descriptions that had first appeared in the Prodromus, based on data received from Tafalla in Peru, and from other botanists. ${ }^{37}$

36. Rubio to Caballero, Madrid, Sept. 12, I801; Alonso to Caballero, Madrid, Oct. 1, 1801. MCN.

37. Barreiro, "Epílogo," in Ruiz, Relación, I, 493. Ruiz to L'Héritier, Madrid, Nov. 5, 1798. Hamy, Dombey, p. 385. The bill for printing and binding the Systema was dated Dec. 15, 1798. (MCN, I794.) 


\section{FLORA PERUVIANA, ET CHILENSIS,}

SIVE DESCRIPTIONES, ET ICONES

PLANTARUM PERUVIANARUM, ET CHILENSIUM,

SECUNDUM SYSTEMA LINNAEANUM DIGESTAE,

CUM CHARACTERIBUS PLURIUM GENERUM

EVULGATORUM REFORMATIS.

AUCTORIBUS

HIPPOLYTO RUIZ, ET JOSEPHO PAVON, REG. ACAD. MEDIC. MATRIT. SOCIIS.

TOM US I.

SUPERIORUM PERMISSU.

TYPIS GABRIELIS DE SANCHA.

ANNOM.DCC. XCVII. 

And before this whirlwind had wasted away, the botanists had published Volume II of the Flora in the summer of I799. It contained I I 6 plates of 203 figures, covering 25 I more species, belonging to the fifth class of Linnaeus, including ten species of Cinchona. Two new genera were created, one of which (Leonia) honored Francisco León, "promoter of the publication." "38

Sales of the new Flora volumes ran far behind the number of gift copies, and neither figure made much of a dent in the inventory. Sancha had orders to print 300 copies of Volume I on regular paper, to sell at 260 reales, and I 50 copies on fino, priced at 280 reales. But by 1834 , a generation later, he had sold only 2 I "regular" copies and 7 fino. Gratis distribution, along lines similar to that of the Prodromus, took only 69 copies. Volume II, selling at the higher price of 300 to 308 reales ( 320 to 330 for fino), did slightly better: 2 I regular and 12 fino sold; 82 given out. But after deducting five poorly printed ones, there still remained untouched in 1834 the forbidding total of 256 regular and 74 fino copies of Volume II ${ }^{39}$ Even the "poor-man's edition," the Systema vegetabilium, priced at only I 7 reales, had a hard time finding buyers. Sancha sold I 3 and turned over 65 for distribution to the House of Domingo Alonso. Another 79 went into the usual complimentary channels. But this left, out of an original printing of 500 copies, the forlorn total of 343 copies still in Sancha's warehouse. ${ }^{40}$

Meanwhile, the funds collected in America were disappearing at a frightening rate. It cost over 90,000 reales to issue Volume I of the Flora, and the total bill for Volume II came to I I I,265 reales. ${ }^{41}$ The

38. Hamy, Dombey, pp. 384-385. Barreiro, "Epílogo," in Ruiz, Relación, I, 496. A letter from Grace and Justice to Soler, Aranjuez, April 30, I799 (MCN), reported that Volume II was about to be finished for presentation to His Majesty in July. On September 17, 1799 , the printer Sancha reported he had all copies on hand except some already distributed gratis $(\mathrm{MCN})$. Eight sets were sent to various ministers on September 19, 1799. (Estado de los enseres..., 1834. MCN.)

39. Razon de los Prodromos y tomos de la Flora Peruviana, Gabriel de Sancha, Madrid, Sept. I7, I799; Copia de la Cuenta presentada ... por $\mathrm{D}^{\mathrm{n}}$ Yndalecio Sancha, Madrid, Nov. I2, 1834. MCN. Sancha's unsold inventory included only a limited number of sets with illustrations (Vol. I, 44 sets; Vol. II, 34 sets). The remainder of the prints were held by the botanists and doled out to Sancha periodically or at the time of binding.

40. Razon de los Prodromos y tomos de la Flora Peruviana, Gabriel de Sancha, Madrid, Sept. 17, 1799; Copia de la Cuenta presentada ... por D $D^{\mathbf{n}}$ Yndalecio Sancha, Madrid, Nov. 12, 1834. MCN. Ruiz and Pavón complained that Sancha was supposed to charge 20 reales according to an announcement in the Gazeta de Madrid. (To Alonso, n.d. MCN, i 800 .)

4\%. An approximate cost for Volume I may be calculated by adding to Sancha's 
Systema vegetabilium, with no illustrations, cost 5,956 reales. ${ }^{42}$ In addition, it will be recalled that Rubio's antics had drained the funds at the rate of 6,000 reales a year since December I, I 793, and Cerdá had enjoyed the use of a mansion at an annual expense to the botanical office of I0,000 reales, from August I, I792. As we know, Rubio's bubble burst in 1799. Cerdá's free ride at government expense came to an end in the same year. But no sooner said than the government raised the annual salaries of Ruiz, Pavón, and Gálvez 2,000 reales each. This advance, their first since returning to Spain, followed presentation to His Majesty of an illuminated copy of Volume I of the Flora in February, $1799 .^{43}$

For some time the botanists had been hoping to move their office. Cerdá's residence, they said in May, I798, was too far from their homes and the shops of engravers and printer, and their two-room office was "narrow and badly lighted." Ten shelves, three desks, and three large tables, the last always filled with prints, competed for Lebensraum. True, they had a third little room, but it was windowless and crammed with boxes. ${ }^{44}$

As the issue of working space arose, the ministry at last raised its eyebrows over Cerdá's ingenious scheme to rent a house at the expense of the Flora. Cerdá huffed and puffed at the thought of a blemish upon his honor. There breathed within his chest no motive but disinterest. Not he, but the ever-generous king, had authorized

printing estimate of 38,436 reales (Madrid, July 21, 1797), about 50,880 reales for the engraving of 106 plates (Ruiz to Cerdá, Madrid, May 17, 1794, had put the average cost per plate at 8 doblones or 480 reales). This gives a total of 89,3 I 6 reales. Figuring another way, we note that Sancha calculated his selling price for regular copies of Volume II by dividing the total cost of production by the number of copies (regular and fino), and then adding close to one-quarter of this average price as a markup. (E.g., total cost, 111,265 reales for 450 copies of Volume II; average per copy, 247 reales; markup added, 6I reales; selling price, 308 reales for regular copies. [Undated memorandum from Sancha in MCN, 1797.] In other instances, however, Sancha speaks of a selling price of 300 reales. The difference may be due to binding costs, which were 8 reales rústica.) Working backward from a selling price of 260 reales in the case of Volume I, we find a markup of about 52 reales and a cost per copy of 208 reales. Multiplying 208 by 450 copies, we arrive at an estimated total cost of production of 93,600 reales. All sources MCN.

42. Cuenta de la impresion y encuadernacion, Madrid, Dec. I5, 1798. MCN, 1794 .

43. Ruiz, Pavón, and Gálvez to Jovellanos, Madrid, August 2, I798; notes of the ministry, Feb. 6 and 10, 1799. MCN, 1798. León to Alonso, Feb. 14, 1799 (MCN, 1799), states definitely that the pay increase was to come from expedition funds and begin as of January I, 1799.

44. Alonso to Jovellanos, Madrid, May 8, I798; Ruiz and Pavón to Caballero, Madrid, May 26, I799. MCN. 
the Flora to pay the rent. The botanists had their choice of quarters - "comfortable, roomy, and very safe"-and unlimited access to Cerdás library, well-stocked with works on natural history. "Would that the botanists had wanted to make use of my books. ... They would no doubt have found something to enrich their work, and make it more interesting!" But alas, sighed Cerdá, "I always noted in them a certain disagreeableness, which is beside the point to figure out, and an excessive desire for independence." ${ }^{45}$

Though Cerdá appealed to the crown, apparently in the end he was forced to assume the burden of the entire rent as of February I 5 , I799. ${ }^{46}$ His case was hurt by rumors that he had kept the papers dealing with the original arrangement in his private possession, thus withholding from the eyes of the king some of the essential facts. ${ }^{47}$ The botanists meanwhile kept up the search for a new place to work and, at last, as the year I 800 drew to a close, they found their home: an unoccupied room on the second floor of house number 4 , located in the battlements of the very palace itself. Alonso thought the room's location, size, and lighting so salutary he dismissed as "indifferent" any concern over the cost, and early in I8OI the staff moved in. ${ }^{48}$

\section{FOR REASONS OF STATE, A FOSSILIZED FLORA}

A cavalier indifference to expense ill-befitted the times. Harassed ministers, in fact, had already devised a scheme of much greater moment to the Flora than the nuisance of moving. Stated simply, the government needed money and the Flora had some. Here is how the issue was put to Gaspar de Jovellanos, Minister of Grace and Justice, on April I0, I798:

45. León to Alonso, April 26, r798; royal order to Gobernador del Consejo de Indias (Marqués de Bajamar), and [Caballero] to Cerdá, Aranjuez, Feb. 15, I799; Cerdá to Bajamar, Madrid, March 28, 1799 . MCN.

46. Ibid. Bajamar to Caballero, Madrid, March 30, I799. Letter to Cerdá, Aranjuez, June 8, I 799. MCN.

47. León to Alonso, April 26, 1798. MCN. Note of May 26, 1799, appended to a letter of Cerdá's dated Aug. I0, I 792. MCN, 1792.

48. Ruiz and Pavón to Caballero, Madrid, Dec. 2, 1800 , and note of Alonso of the same date. MCN. Álvarez López, "Algunos aspectos," Anales del Instituto Botánico A.J. Cavanilles, XII, 55. 
In consideration of the necessity and desirability of consolidating the credit of the State, and to provide by all means possible to curb the stockjobbing of Royal Bonds, which is causing the most regrettable backwardness in the progress of national industry, and makes all operations of the Royal Treasury extremely costly and difficult, I [Francisco de Saavedra, Minister of the Treasury] hope that Your Excellency will be pleased to find out if in your Ministry of Grace and Justice for Spain and the Indies there are some funds that can be used temporarily to take care of such worthy objects. And in such case, Your Excellency may provide that they be transferred to the Department of Public Debts [Caja de Amortización], either by means of deposit, always at the orders of Your Excellency, or in the form and under the conditions that you deem opportune, with the understanding that they will be inviolably fulfilled. ${ }^{49}$

The Flora funds at the moment amounted to 483,279 reales, and, as the official Antonio Porcel pointed out to his superior Jovellanos, they were not drawing a penny of interest. ${ }^{50}$ Deducting 33,279 reales for current expenses, it seemed reasonable to turn over to the Caja the remaining sum of 450,000 reales at interest of 3 per cent, on condition that the account be open when necessary to withdraw money for the Flora. Saavedra was notified of this decision on April 25, $I 798$, and, with a speed hardly congenial to the dignified pace of Spanish life in the eighteenth century, the money passed into the hands of the Caja within three days. ${ }^{51}$

When, a few months later, the Flora superintendents tested the safety of their money they found it good. On December 9, I 798, they asked for 50,000 reales, especially to pay the engravers, and within two weeks had the sum in their hands. ${ }^{52}$ As Volume II rolled on toward completion in 1799 , the botanists asked again, but now the

49. At Aranjuez, April 10, 1798 . MCN.

50. Aranjuez, April 24, I798. MCN. It is not possible to account for all expenditures to this date. Starting with an estimated 754,168 reales sent from America up to that time, we can assuredly deduct for the Prodromus, 29,000 reales; rent for 6 years, 60,000 reales; Rubio's salary for $4-\frac{1}{3}$ years, 25,500 reales; the porter's wage for 5 years of about 10,000 reales; and perhaps 40,000 reales already paid out on Volume I. This totals 164,500 reales, but leaves 106,389 reales unaccounted for. Part of this no doubt went for books and supplies, and perhaps more for illuminating some copies -of the plates. Much of the balance may have gone to the engravers, though they seem to have been taken care of by subsequent payments from the fund.

51. Porcel to Jovellanos, Aranjuez, April 24, 1798; [Jovellanos] to Saavedra, Aranjuez, April 25, 1798; Saavedra to Jovellanos, Aranjuez, April 27 and May 3, 1798. MCN.

52. Jovellanos to Saavedra, Dec. 9, 1798; Grace and Justice to Cayetano Soler, Palacio, Dec. $17,179^{8}$. MCN. 
response was slower. They needed two demands to get 50,000 reales on May 27, and a request in November for the same amount went unheeded for months. On June I 5, I 800, they secured the tiny sum of 1,952 reales to pay the freight on five boxes sent from Tafalla in Peru. Finally, as the men put the last touches on Volume III in I 802 , and the work went ahead on the plates for Volume IV, the Caja at last conceded another 100,000 reales. At no time could the Flora collect interest on the loan, and, in fact, the government suppressed all interest on such funds effective November 27, I799. By August II, I802, only 199,048 reales of Flora money remained in the Caja. ${ }^{53}$

Thus, as the reservoir dwindled, so did co-operation of the Caja. The king laid the blame for the three-year lag between Volumes II and III on the obstructionism of that body. True, when in July, I 802 , he made the need known for 100,000 reales to keep foreign scientists from beating the botanists into print, the Caja conformed. But just to be sure, when the botanists presented the king with an illuminated copy of the third volume in 1803 , the monarch promised to see "that the conclusion of this interesting work not be retarded any longer" because of difficulty in withdrawing money from the Caja. He then demonstrated his faith in the botanists and Gálvez by granting all three another raise of 2,000 reales. ${ }^{54}$

Several persons in Spain would happily have held the king to his pledge. One was the printer Sancha. As work on Volume III began,

53. Statement of funds paid out by the Caja de Amortizacion, attached to correspondence of 1798 referred to in the previous footnote. MCN. "Sobre deposito de fondos de la Flora," in MCN, 1807; Víctor Soret to Miguel de Lardizábal, Madrid, Oct. 28, 1814. MCN. There is an obvious error of 1,000 reales in the calculation of the last sum on hand, but it is preserved here because the government continued henceforth to use the erroneous figure.

54. Ruiz, Pavón, and Gálvez to Caballero, Madrid, March 21, I803. MCN. See also summary of letter from Ruiz, Pavón and Gálvez, same date, appended to a petition from these men of Aug. 2, 1798. MCN, 1798. Royal order to Cayetano Soler, April 3, 1803, and draft of a note to Ruiz and Pavón of the same date; Ministry of Grace and Justice to Cayetano Soler, Palacio, July 13, 1802. MCN. There is some confusion in the documents as to whether the botanists were receiving I 0,000 or 12,000 reales prior to the last raise; we have chosen to accept the latter figure as correct. If the Flora progressed at a sluggard's pace, part of the blame must be laid to an old failing: not devoting enough hours to its completion. Ruiz complained in 1803 of "anxieties and risks to his health" from dividing his attention between the Flora and his pharmacy at the corner of Calle de Encomienda and Mesón de Paredes. (Two declarations by Ruiz on stamped paper, dated 1803. MCN.) Gálvez was apparently the only draftsman working during these years. (Álvarez López, "Algunos aspectos," Anales del Instituto Botánico A. J. Cavanilles, XII, 55.) 
the Flora staff hesitated to discommode itself by asking the Caja for money for every little bill that came due. They prevailed upon Sancha to bear these miscellaneous expenses temporarily, but the little ones grew into big ones. Soon the Flora was in debt to Sancha for over 60,000 reales. In time his sales, especially of illuminated copies (at 3,220 reales per set), whittled the debt to 28,406 reales, but by then it was the year i 834 . The Flora had paid Sancha not a maravedi in thirty-five years. ${ }^{55}$

Fifteen engravers felt just as deluded, having done 64 plates for Volume $V$ since 1803 , without a sign of reward. ${ }^{58}$ The directors of the Flora made repeated attempts to free another 100,000 reales from the treasury department, but were as often rebuffed. ${ }^{57}$ Yet, according to the figures of a new set of ministers who tried in 1814 to untangle the wreckage from the Napoleonic invasion, the Flora staff had somehow managed to spend another 121 , or 9 reales since 1802 . If this sum is correct, at least half must have gone for the salary increases awarded to Ruiz, Pavón, and Gálvez in 1799 and 1803, which were apparently paid until near the end of 1807 . Supplies and rent no doubt took some of the remainder, and in 1814 another I4,29I reales was freed, probably for salaries. To complicate matters, many years later, in 1830 , still another set of functionaries tried its hand at the accounts and arrived, almost assuredly by mistake, at the old familiar balance on hand of 199,048 reales, as though nothing

55. Sancha had paid the illuminator, Antonio Delgado, $2 x, 680$ reales; had supplied the botanists with various botanical works valued at 3,206 reales; was owed 23,693 reales for printing Volume III; had bound numerous gift copies of the Flora at a cost of 6,359 reales; and had taken care of a hodgepodge of other expenditures totaling 8,174 reales. From this sum of 63,112 reales can be deducted 34,706 reales for sales, leaving a net debt owed to Sancha (to his son Yndalecio, that is) on November 12, 1834 , of 28,406 reales. (Copia de la Cuenta. MCN.) See also Hipólito de Peiroso, of the staff of the contador general, to Secretario de Estado y del Despacho de Hacienda de Yndias, Madrid, Oct. 21, 1829, and Yndalecio Sancha to same, Madrid, Nov. I2, $1829 . \mathrm{MCN}$.

56. Faustino Martínez de la Torre, Manuel Albuerne, and Pedro Nolasco Gascó, three of the "professors of engraving," stated on March 12, 1814, that they had been owed money "more than eleven years" for work done on the Flora. (MCN.) The demands of all fifteen artisans, totaling 31,960 reales, may be found in "Lista general de los Grabadores," accompanying a letter of Ruiz and Pavón to Miguel de Lardizábal, Madrid, Aug. I2, I8I4.-MCN, I8I3. Apparently five additional plates for Volume $\mathrm{V}$ had been done and paid for, presumably before 1803. (Anuncio de las obras publicadas. MCN, I 809 .)

57. "Sobre deposito de fondos de la Flora en la Caja de Amortizacion," in MCN, 1807 , but probably written in 1809 . Another notation, Madrid, February 28 , 1809 , in the same folder, shows that Lorenzo González, portero of the Secretariat of Grace and Justice, "no se ha podido cobrar nada del Cajero Bedoya hasta esta fha aunque ha hido repetidas veces dho Portero." 
had happened since I802. Only one thing is certain: the treasury's neglect of the printer and engravers, presumably because it was tempted by other uses for the money. ${ }^{58}$

But amidst whatever difficulties, Volume III did appear in the summer of 1802 , making known 223 descriptions of species in Classes $\mathrm{V}$ through VII of Linnaeus, illustrated by 176 figures on 104 plates. The men reported on seven new genera: Bonapartea (=Tillandsia Linn.), Lapageria (for the former's Josephine); Luzuriaga (named for a Spanish botanist, chemist, and physician); Guzmania (for a pharmacist and naturalist); Cosmibuena (not the erroneous genus of the Prodromus, but a new one, in honor of the Peruvian savant); Isidrogalvia (=Tofieldia Huds.) in recognition of the draftsman on the expedition; and one other genus, Conanthera. The sales pattern was much the same as before: I9 "regular" and 4 fino sold, at prices identical to those of Volume II; 85 copies distributed free. Deducting Io "false" copies, the inventory in 1834 still stood at 248 regular and 84 fino. ${ }^{59}$

Even with full co-operation of the treasury, the well would run dry in a volume or two. Yet the botanists went on planning a bigger Flora than ever. Witnessing the flow of new material from Tafalla in America, they decided even to have a Suplemento, to comprise four volumes (later projected to five). ${ }^{60}$

Volume IV of the Flora was ready for the printer in 1804 . It contained descriptions of 164 species of Classes VII-IX, and presented three new genera. Corrections were made of some descriptions in the Prodromus and even some of Linnaeus and other botanists. Four new species of quina were reported. And, as though the work

58. Soret to Lardizábal, Madrid, Oct. 28, 1814; Junta de Protección del Museo de Ciencias to Primer Secr ${ }^{0}$ de Estado y del Despacho, Madrid, July 17, 1830. MCN. The botanists stated on September 20, 1809, that they had not been paid for "nearly two years." (Letter from Madrid to Manuel José de Azanza. MCN.) Pavón confirms that the raise had not been paid for twenty-three months as of October I, I 809. (Letter to Azanza, Madrid, Dec. 6, I809. MCN.) Ruiz's son puts the blame on the historian's perennial whipping boy, Manuel Godoy, the king's notorious minister, who, he says, had "thought proper" to give to "another destination" the money originally set aside for the Flora. (Historical Eulogium, pp. 42-43.)

59. Copia de la Cuenta, Madrid, Nov. 12, 1834. MCN. The printing order was the same as for the first two volumes: 300 regular and 150 fino. A letter of July 13, 1802, from Grace and Justice to Cayetano Soler (MCN), reported that Volume III "está impreso." Copies are known to have been distributed to the Biblioteca Real on August I 2, I802. (Estado de los enseres. MCN, 1834.)

6o. Ruiz and Pavón, Flora Peruviana, III, i-ii. Barreiro, "Epílogo," in Ruiz, Relación, I, 497-498, 506. 
were defective without a tirade against Cavanilles, the preface contained an attack upon those botanists who, "impelled by the itching desire to innovate and thus capture the applause of the public," continued to tamper with the Linnaean system of classification. ${ }^{61}$ But Cavanilles and the Flora Peruviana expired together, for the former was dead on May 4, I804, and Volume IV never reached the printer's hands. One can scarcely imagine Sancha's undertaking the task with a bill pending for Volume III. Nevertheless, the IOO plates had been done-and paid for-and a century and a half later the volume appeared in a small facsimile edition. ${ }^{62}$

Work went ahead on Volume V, and in July, I807, it was "being concluded" but not "fulfilled," for reasons now apparent. The botanists promised that another volume of the Systema vegetabilium would appear, though not until Volume IV of the Flora was ready for distribution. ${ }^{\text {B3 }}$

But Charles IV abdicated on March I 8, I808, the French army entered Madrid four days later, and hopes for further publication collapsed. After all, said the captive ministry in 1809 , this "sacrifice of national glory"-this suspension of publication-was inevitable. The botanists must now limit their efforts to "perfecting the works already finished so as to publish them when the state of things permits." At least, however, they were reassured that their salaries would be restored to the budget, and the government promised to look into means for settling the arrears. ${ }^{64}$

We know little of the botanists' experiences during the French occupation, but at least the Madrid city council in 1813 declared them "worthy of rehabilitation among other persons who remained

6r. Ibid., I, 499-502. Álvarez López, "Algunos aspectos," Anales del Instituto Botánico A. J. Cavanilles, XII, 57-58. Lista y Razon de los Tomos que se hallan impresos y prontos para imprimir .... hoy dia 3 I de Julio de 1807 . MCN.

62. Vol. IV was published in instalments in the Anales del Instituto Botánico A.J. Cavanilles, and, upon completion, bound in one volume and republished at Madrid in 1957. In fact, Sancha did perform several services for the botanists after 1805 , including one minor printing job ( 78 reales in 1807 ), and the binding of five sets of the Flora (total cost, 584 reales) between 1808 and 1818 . (Copia de la Cuenta, Madrid, Nov. 12, 1834. MCN).

63. Lista y Razon de los Tomos que se hallan impresos y prontos para imprimir ... hoy dia 31 de Julio de 1807 . MCN. Anuncio de las obras publicadas. MCN, 1809. Ruiz and Pavón to Lardizábal, Madrid, Aug. 12, 1814; Lista general de los Grabadores. MCN, 1813 . The last source lists 15 engravers, due a total of 30,240 reales for 64 plates, plus 1,720 reales owed for the polishing of 86 plates. Vol. V is in the process of being published in instalments in the Anales del Instituto Botánico A. J. Cavanilles (XVI [1958], 353-462; XVII [1959], 377-495).

64. Ministry of the Indies to Ruiz, Palacio, Oct. 25, 1809. MCN. 
serving in their jobs during enemy domination." ${ }^{65}$ According to Ruiz's son, the senior botanist declined the post of "supernumerary examiner of the Council of Health," offered him by the occupation government on May 2, I809. As a result, Joseph Napoleon is said to have written Ruiz this friendly letter, dated April I 2, I810:

The consideration in which the present Ministry hold the learned men, whose works have acquired reputation throughout Europe, has been shewn towards you in the notice inclosed, in order that it may serve as a new stimulus to your application. Accordingly, the Supreme Council of Health, animated by the same spirit as the Ministry, have availed themselves of the inclosed notice, to propose to me another professor for the place of Examiner, which you have not been able to accept, principally because your whole time is devoted to the completion of the Flora of Peru, in which you are pledged both towards Europe and towards posterity.

Lest Ruiz escape completely, Joseph added that the botanist should be "kept in view, that he may be rewarded hereafter with the highest honour of the faculty." In time Ruiz did join a commission to form a new pharmacopoeia. ${ }^{63}$

Despite the slim prospects of being paid for their labors, at least four engravers turned in work during 1809 and I8IO, all destined for the phantom Volume V. In I 8 I i the botanical office moved out of the palace battlements, soon to be destroyed by the French, into the cell and quarters of the Franciscan Commissar General for the Indies. ${ }^{67}$ But was any real work done on the Flora during those trying years? It seems highly unlikely. In the first place, the men must have gone without salary for many months, despite the assurances in 1809 that their jobs would be restored to the budget. In fact, the government in April, I8I4, was still haggling over the date from which the botanists' salaries were to recommence, one whole year after the ministers had begun to take a renewed interest in the Flora $^{68}$

65. Manuel Álvarez Guerra to Secretario interino del Despacho de la Gobernación de Ultramar, San Fernando, Dec. 11, 1813. MCN. The Regency government, however, pointed out that in accordance with the decree of the Cortes of September 21, 1812, Ruiz, Pavón, and other "maestros" were not included in the laws suspending many men from their jobs, and thus did not have to be "rehabilitated." (Ibid.)

66. Historical Eulogium, pp. 50-52.

67. Álvarez López, "Algunos aspectos," Anales del Instituto Botánico $A . J$. Cavanilles, XII, 54, 56. Lardizábal to Secretario de Estado y del Despacho, Palacio, June 16, 1814. AGI, Indiferente General, legajo 551, fol. 64 .

68. Ruiz and Pavón confirmed in 1813 that the intruding government had suspended their salaries and that they had suffered the incumbent misery "solely 
Of all their wartime experiences, the botanists made the most of their loyalty to Spain and the preservation intact of their floral collections. After the French had been ousted, and the naturalists were pleading to be restored to the government payroll, they of course pointed up "the greatest miseries" they had borne in those years. But they could also remind the ministry that, unlike those "bad Spaniards" José Mociño, co-chief of the botanical expedition to New Spain, and Francisco Zea, Cavanilles' successor at the Jardín Botánico in Madrid, they had not connived to carry off to France any of their materials. ${ }^{69}$ By a strange turn of fate, however, Pavón at that very moment was embarking upon his own private, and ethically questionable, venture into international plant peddling. More of that two chapters hence.

The little world of Ruiz and Pavón in I8I3-18 I4 was a microcosm of the shattered and confused Spanish pattern of existence. They had no home for the Flora but the barren cell of a Franciscan friary. For a time they had no salary. Fifteen engravers and a printer, who had lost his health and "faced ruin," clamored for money a decade overdue. And the government found only 63,738 reales left in the Flora account. Yet a ministry letter set forth the same tired phrases as before: continuation of the Flora "deserves the approbation of the scholars of Europe and does honor to the State." True and commendable, but unrealistic.

with the object of saving the manuscripts and precious articles that are the fruit of their voyages." (Summary expediente in MCN, 8 3, statement from Madrid, Sept. 7, I8 I 3.) Álvarez Guerra to Secretario interino del Despacho de Hacienda, Palacio, March I 8, 1814. MCN. Their salaries were ultimately restored as of December 16, I 81 3. (Álvarez Guerra to Despacho de Hacienda, Palacio, April 13, 1814. MCN.)

69. Lardizábal to secretariats of Estado and Gobernación, and to Ruiz and Pavón, Palacio, June 16,1814 . AGI, Indiferente General, legajo 55r, fols. 64-65v. During the French occupation, Mociño served as director of the museum of natural history, for which collaboration he had to suffer temporary imprisonment in a chain gang when the Spanish first drove the invaders from Madrid. During the second French retreat, Mociño straggled out of Spain, carrying his manuscripts and illustrations for the Mexican flora in a cart. Later, a French general took possession of the cart and Mociño lost custody of the plant descriptions. He settled at Montpellier, almost blind and living as a beggar, but still in possession of 1,400 drawings. The great Swiss botanist Augustin de Candolle, who had uncovered a pile of Mociño's manuscripts in the Tuileries, planned to publish the Mexican flora, and took over Mociño's drawings, but was handicapped by what he considered to be inaccuracies in them. When Mociño was able to go back to Spain in 1820 and asked that his illustrations be returned, De Candolle had 1,200 of them copied in ten days by about 120 persons in Geneva. Mociño had scarcely reached Barcelona when he died. (Harold W. Rickett, The Royal Botanical Expedition to New Spain [Chronica Botanica, Vol. XI, No. I ] [Waltham, Mass., 1947], pp. 76-78.)

70. Soret to Lardizábal, Madrid, Oct. 28, 1814. MCN. 
How now these flowers for the king? Alas, they were faded and done for. Faded with the years of neglect and done for as the funds ran dry. In 18 i 6 the Flora breathed its last-though no one at the time would admit it-for in that year at age 62 Hipólito Ruiz died. ${ }^{71}$

71. Ruiz had received an appointment by the tribunal of the Protomedicato as an inspector of drugstores in Madrid, on July 21, 1814. ([A. Ruiz], Historical Eulogium, pp. 52-53.) 


\title{
PER U I A N SEQUEL
}

\author{
FOR WANT OF A CHAIR
}

Twenty-eight years had passed since Ruiz and Pavón sailed home from Peru. A gregados had come and gone, sharing the pleasures of discovery that had once spurred on their mentors, as well as the pains of discomfort, disappointment, and discord. Plant study still clung to life in those distant parts, but not with the vigor an active chair of botany and a botanic garden might have infused.

When the expedition left Lima in 1788 , plans for a professorship had already been laid, stimulated, no doubt, by the proximate opening of a garden in Mexico City. New Spain was fortunate in this respect. By the time its botanical expedition was created in 1786 , the science was flourishing in the mother country, and there was experience in both Peru and New Granada to draw upon. In authorizing the Mexican expedition, the crown called specifically for a garden, and Gómez Ortega chose one of his best pupils, Vicente Cervantes, to teach the classes in botany. On May I, I788, while fireworks blazed and an orchestra "discoursed harmoniously" in the sala de claustros of the University of Mexico, the study of plant science formally began. ${ }^{1}$ After three years in temporary surroundings, the garden found a permanent home alongside the viceroy's palace, where Cervantes cultivated I,400 species and taught courses for thirty years.

I. Rickett, Royal Botanical Expedition to New Spain, pp. 5-7. Here is a description of the event, freely translated and condensed from the Gazeta de México, III (May 6, 1788), 75 (supl.) by Rickett: "Three trees, of the kind known in Mexico as papaya, imitating nature in leaves, flowers, and fruits, represented sex in plants; the sexes being separate in this species. Two female trees bore flowers and fruits of various sizes; a male tree stood between them and emitted from its flowers sparks of fire towards the females, perfectly representing the transfer of pollen through the air. At the foot of the male tree were various devices alluding to the growth of a garden, which illuminated the square with ingenious and brilliant lights of many colors; and others no less entertaining. As the three trees faded from sight, in place of the male appeared an inscription in letters of fire which read AMOR URIT PLANTAS; a quotation from the ingenious work of Linnaeus entitled Sponsalia plantarum." 
Plans for a larger garden on the Hill of Chapultepec failed to work out, but Cervantes for a time made botany almost indispensable to a well-rounded education in Mexico. ${ }^{2}$

The crown decreed the foundation of a chair in Lima on March I 8, I787, five days before Cervantes was summoned to Mexico City. In order, said the king, for knowledge of botany and natural history to take root (so long as the royal purse bore none of the burden!), there should be established at the university "a chair of simples or materia medica." The job befitted the botánico agregado; let the visitador general find the ways and means. ${ }^{3}$

But the visitador went home in the following year, and nothing came of the chair. In I789, Tafalla complained. Gómez Ortega, still the master of Spanish botanical destinies, took up the cry, but suggested Father González Laguna for the post; the agregados needed to drink a bit longer from the padre's fountain of "recognized worth, intelligence, and skill." Ortega's anxiety was whetted by news that the rector of the Convictorio of San Carlos, supported by an offer from two citizens of Lima, Pedro de la Presa and Jaime Palmer, burned with "intense desire" to set up a garden in which to instruct his students "and others who might wish to apply themselves." Alas, the ministry prodded the viceroy for two more years, but not a sign of a plan appeared. ${ }^{5}$

By then Tafalla had won the "entire satisfaction" of Ruiz and Pavón, ${ }^{6}$ though his record seems uneven. At the end of February, I 789 , he sent two boxes to Spain, including two new genera, twenty other plants, and the usual collection of starfish, shells, sea-urchins, "petrified bones of marine animals," bezoar stones, minerals, and Indian artifacts. ${ }^{7}$ A month later, four more boxes followed, containing 64 drawings, a package of descriptions, a feathered quilt and caparison

2. Ibid., pp. 7-1 8, 55-70.

3. Royal order to the visitador general Escobedo, E1 Pardo, March 18, 1787. MCN. Archivo Histórico de Hacienda (Lima), libro 1060, fol. 80.

4. Gómez Ortega to Porlier, Madrid, Aug. 4, 1789. MCN.

5. Draft of a letter to the viceroy of Peru, Madrid, Jan. 4, 1790. MCN. Summary of correspondence of $179 \mathrm{I}$ attached to letter No. 943 from Escobedo, dated June 20, $1788 . M C N$, 1787 . Juan F. C. Herrera, however, says that Viceroy Gil in 1791 commissioned Tafalla and Father González Laguna to start a garden on land next to the Hospital of San Andrés, but a lack of funds spelled doom for the project. ("Juan Tafalla, ilustre botánico español," Revista de ciencias, XXXIX [Lima, Dec., 1937], 54-55.)

6. Ruiz, Pavón, and Gálvez to Bajamar, Madrid, Nov. i8, I791. MCN.

7. Viceroy Croix to Porlier, Lima, Feb. 28, 1789. AGI, Lima, legajo 798, No. 69, in Anales de la Real Academia de Farmacia, XX (No. 6, 1954), 589-590. 
(tapa anca), eleven mineral specimens, three dried plants, twelve vegetables, and a host of bean (poroto) seeds in dry form and planted in two little pots. ${ }^{8}$ On August 30, Pulgar remitted seven more drawings, ${ }^{\theta}$ but there the machinery broke down.

At the root of the evil was money, though as usual not enough of it. To enter the montaña and win repute the agregados needed more pay; to get more pay in the montaña they had need of more repute. In mid-October they suspended work and begged a salary increase, but the ministry, content to pay one thousand pesos apiece, flatly ignored the request. Result: no trek to the montaña. ${ }^{10}$

Nor was the year 1790 productive of much, for Tafalla began it with four months in bed. Shipment in May of five pots of plants hardly warranted his new hopes for a raise. ${ }^{11}$ The plants, by the way, were entrusted to the care of the outgoing viceroy Teodoro de Croix. He put them in the hands of his most trusted servant, and even protected them in his own quarters while rounding the Horn, but none survived. Even so, the servant watered them all the way to the Azores, when, finally convinced it was useless, he threw them into the sea. ${ }^{12}$

Tafalla arose to escort the naturalists of the Malaspina hydrographic expedition to Huánuco in July, I 790, but again the results were slight, for time was available only to collect a few plants, birds,

8. Croix to Porlier, Lima, March 30, 1789, in ibid. (Nos. 2 and 6, 1954), 192193, 590. Both shipments were received in Spain. (González Guirral to Porlier, Cádiz, Sept. 11, 1789. AGI, Lima, legajo 798.) One new drawing had been sent earlier (June 16, 1788). (Viceroy to ministry, No. 33, Lima, June 16, 1788. AGI, Lima, legajo 677, in Anales de la Real Academia de Farmacia, XX [No. 2, 1954], 190.) At this point the agregados urgently requested books and supplies to replace those lost in the Macora fire. The ministry willingly paid out 1,045 reales for books and 925 reales for supplies, though it was more than a year before they reached Tafalla's hands. (Gómez Ortega to Porlier, Madrid, Aug. 4, 1789, and marginal notes of Aug. 24 and Sept. 26, 1789; Cuenta y Razon de los gastos, Nov. 3, 1789; Libros que han venido ... para los Botanicos Agregados, Aug. I4, 1790; receipt of Tafalla and Pulgar, Lima, Sept. 20, 1790. MCN.) The delay was caused by the fact that six of the works (Tournefort, Plumier, and four by Linnaeus) had to be purchased in Paris.

9. Viceroy to the ministry, Lima, Aug. 30, 1789. AGI, Lima, legajo 686, in Anales de la Real Academia de Farmacia, XX, 193.

10. Tafalla and Pulgar to the ministry, Lima, Oct. 15, $1789 . \mathrm{MCN}$.

11. Tafalla and Pulgar to the ministry, Lima, May 15, 1790 . AGI, Indiferente General, legajo 1545 .

12. Manuel de Gorbea y Vadillo, Mre de Plata de la Fragta Princesa, to Presidente de la Real Casa de Contratación, Cádiz, Sept. 21, 1790. AGI, Indiferente General, legajo 1545 . 
and minerals. ${ }^{13}$ But hope is cheap, and when Tafalla remitted five drawings and a few seeds on November 20, I790, he again nudged the ministry for a raise. ${ }^{14}$ Although the request brought no immediate response, the agregados must not have stayed home, for in May and June, I79I, they sent four boxes of seeds, fruits, and roots, and eighteen drawings to Spain. These may have stemmed from a six months' stay on the coast near Ica, two hundred miles south of Lima. It was hardly a collection to match those of old times, but the men stood firm on the need for more money before going again to the mountains. ${ }^{15}$

They now had a friend in the new viceroy, Francisco Gil y Lemos. Though he demurred at doubling their salary in keeping with their hopes, he at least aroused in the ministry a concern for their fate. ${ }^{16}$ Ruiz, Pavón, and Gálvez pitched in to help, though anxious to limit the agregados to but two more years in the jungle. One could be spent, as planned, at Monzón and Chicoplaya, where the earlier botanists had been barred for want of a road. Another year they could search the frontiers of Tarma, Huánuco, Huamalíes, and Panatahuas. For these excursions, an annual grant-in-aid of 800 pesos each, plus a one-time concession of $\mathrm{I}, 000$ pesos for shipping expenses, seemed ample to the men in Spain. After these terms in the montaña, this expense should come to an end, and the agregados settle down in Lima to "their respective obligations."

Ideally they pictured Tafalla in the local chair of botany, and Pulgar on the staff of a projected academy of painting in Lima. ${ }^{17}$ Ortega now concurred, and proposed a limit of one thousand pesos on the salary of Tafalla, though Vicente Cervantes, "an exceptional man," had a five-year appointment in Mexico City at fifteen hundred. With a local endowment of 800 to 900 pesos, such as Cosme Bueno had for his chair, the general treasury would owe little to Tafalla. In return for the trifling sum, the agregado could not only train

13. Tafalla and Pulgar to the ministry, Lima, Aug. 30, 1790. AGI, Indiferente General, legajo 1545 .

14. To [Porlier], Lima, Nov. 20, 1790. AGI, Indiferente General, legajo 1545. Tafalla sent seeds to Spain upon at least eight occasions in $1789-1790$.

15. Ibid. Tafalla and Pulgar to the ministry, Lima, June 20, 1791, and list of items sent on the Concordia. AGI, Indiferente General, legajo 1545. Herrera, "Juan Tafalla," Revista de ciencias, XXXIX, 49.

16. Summary of letter No. 62 from viceroy to ministry, Lima, April 52 1791. MCN, I787. Original published in Anales de la Real Academia de Farmacia, XX, 6oI, from AGI, Lima, legajo 698.

17. To Bajamar, Madrid, Nov. 18, 1791. MCN. 
substitutes and a successor, but botanize around Lima and send plants to Madrid during school vacations. As for the artist, one thousand pesos was too much for drawing a few plants. Pending foundation of the painting school, Pulgar, while still on salary, ought to train a replacement at his own expense. Presumably his successor would prove less burdensome to the treasury. ${ }^{18}$

Ruiz and Pavón were content that Tafalla be made a professor. Gómez Ortega was reconciled. The king had ordered it so. But no word came from the viceroy, though apparently he was satisfied with Tafalla's performance. Why? Ortega accused the protomédico of Lima, Juan Joseph de Aguirre, of jealousy at not having been consulted. "The way to cut this harm, and other more serious ones, out by the roots," Ortega suggested, "is to reform that protomedicato in imitation of what has been done in Madrid, and what is pending with the one in Mexico."19 All the while drumming away at the viceroy to explain the delay, the ministry gave him carte blanche to decide on the proper subvention for the agregados' trips to the mountains. ${ }^{20}$

But while the talk went round and round, Tafalla and Pulgar were already in Huánuco, settling down for two years in the montaña - presumably helped by a grant-in-aid, but hoping out loud for a raise in pay. ${ }^{21}$ On March 26, I793, they revealed their results in a shipment to Spain: seven boxes, containing dried plants, cascarilla, birds, monkeys, and 165 drawings and descriptions, all of which arrived safely. Their windmill of activity kept right on churning, for in July, I793, they asked for supplies to start another excursion. ${ }^{22}$ When treasury bureaucrats tried to hold up their grants until previous accounts could be checked, forthwith even the king came to their

18. To Cerdá, Madrid, Nov. 18, 1791. MCN.

19. Ibid.
20. Summary of communication to viceroy, sent Dec. 2, 1791. MCN, 1787 .

21. They left Lima on June 20, 1791 . ('Tafalla and Pulgar to ministry, Lima, June 20, 1791. AGI, Indiferente General, legajo i545.) Having returned from the tropical forest on October 17, 179I, the agregados wrote of their expectations to stay at Huánuco until May, 1792, at which time they would head into the jungle again. (Letter to ministry, Huánuco, Nov. 20, 1791. AGI, Indiferente General, legajo 1546.)

22. Viceroy to Pedro Acuña, Lima, March 26, 1793. Anales de la Real Academia de Farmacia, XXI, 185-188. For a list of the items received in Spain, March 7 , 1794, see AGI, Indiferente General, legajo 1546. Correspondence of Tafalla and Pulgar with viceroy and real hacienda, July 10, 18, and 22, 1793. Archivo Nacional del Perú, Real Hacienda, legajo [34]. (The legajo number placed in brackets is the one written on the bundle by me. No index to any of the legajos in this section of the Archivo Nacional exists, nor did they have any other identifying symbol at the time I examined them in 1952.) 
rescue. So that they might "use the time making their journeys and departures opportunely," he ordered the immediate disbursement of their moneys. ${ }^{23}$ In 1795 they were sending seeds to Spain from Huánuco and "objects of natural history" from Tarma. ${ }^{24}$ Retirement to academe's quiet groves seemed still a distant dream.

Yet, Father González Laguna, who had enlightened the readers of the Mercurio peruano in I794, for no fewer than thirty-four pages and four issues, on the "Necessity for Scientific Natural History," in another article made a good case for a garden:

These parts have not lacked inquisitive patriots for thirty years, who have worked to adorn our fecund country with whatever they have been able to acquire for their gardens from the vegetable kingdom. The deceased Señor Don Pedro de Echevertz, former oidor of this royal audiencia, Don Jaime Palmer, and recently, D. Pedro de la Presa Carrillo y Albornoz, have brought from Europe at heavy expense whatever of value they found. Would that the lack of good gardeners and the necessity of trusting in careless and perverse people hadn't made their efforts almost useless! I took over this enterprise with anticipation, not confining myself narrowly to garden plants, but to all those that could serve medicine, sustenance, industry, and the pleasure of our countrymen, wherever I have been able to acquire them. The entreaties have been without number, but of all [ the plants] some have disavowed their accustomed soil, others were given into ungrateful hands, others perished for want of an extensive public garden in which to put them, as ordered by the king. Only a small proportion have remained that I cultivate, or see that they are distributed to some interested parties in the Hospital of San Andrés, or which have succeeded in making themselves common. Before this time we knew only those [plants] of our own country, and very few from Spain. Now we have them from very remote parts of Asia, New Spain, and Europe. The noted botanist of His Majesty and author of the Flora Peruana D. Hipólito Ruiz, as if in trade for those he took from this realm, has remitted many that would have enriched this capital if all had lived. ${ }^{25}$

23. Ruiz to Llaguno, Madrid, April I 9, I794; royal order to viceroy, Aranjuez, April 25, 1794. MCN. The order is also in Archivo Histórico de Hacienda (Lima), libro 900, fols. $263-264$.

24. Viceroy Gil to Llaguno, Lima, Sept. 8, I795. AGI, Indiferente General, legajo 1656. See also Archivo Histórico de Hacienda (Lima), libro ro6o, fol. $58 \mathrm{v}$.

25. "Memoria de las plantas extrañas que se cultivan en Lima introducidas en los últimos 30 años hasta él de I 794," Mercurio peruano, XI (July ro, 1794), 165-166. See also "Necesidad de la historia natural científica," ibid., X (Jan. I2, 16, I $9,23,1794), 25-58$. 


\section{THE PERIPATETIC PROFESSOR}

Remarkably, on August 29, I795, the goal loomed out of the winter's mist. Two men-Tafalla and José Manuel Dávalos, a mulatto physician trained at Montpellier-met on that date in a formal oposicion to decide which would assume the chair. Dávalos pointed up Tafalla's dedication to a brilliant career at arms rather than to botany-an appraisal by then almost ten years too late, for Tafalla indeed had the edge in botanical experience. Besides, Dávalos was a mulatto and Tafalla a Spaniard. On the other hand, the physician was no doubt more formally trained, the chair was devoted - principally to materia medica, and the protomédico must have opposed Tafalla. If, as is said, Dávalos agreed to dictate the course without charge, this most certainly decided the issue. A decree of January 26, I 796, named him interim professor and he took possession four days later. ${ }^{26}$

Precisely how did Tafalla fit into the new intellectual climate of Lima in the early I790's? That is hard to say. These were the glorious years of the Mercurio peruano, and of its "editorial staff," the Royal Society of Those Who Love the Country (Real Sociedad de Amantes del Pais). The Mercurio, published from I790 to I794, was a nonpolitical journal, largely creole in view, devoted primarily to the new science and philosophy, and to improving the economy of Peru. ${ }^{27}$ At the end of May, I79I, it announced for forthcoming issues a detailed survey of Peruvian natural history by Tafalla, ${ }^{28}$ but the study never appeared. A modern student of Peruvian botany suggests that Tafalla may have had to suffer in silence just as Dombey, to avoid competition with the slowly developing Flora Peruviana of Ruiz and Pavón. ${ }^{29}$ There is no evidence to support this view. Yet, in 18 I 5 the library of the medical college was said to contain a manuscript detailing five thousand descriptions of Peruvian plants, seven

26. Herrera, "Juan Tafalla," Revista de ciencias, XXXIX, 56. Rubén Vargas Ugarte, Manuscritos peruanos en las bibliotecas de América ("Biblioteca peruana" series, IV [Buenos Aires, 1945]), 259. Eguiguren, Diccionario histórico cronológico, III, 758, 763-766. Juan B. Lastres, Historia de la medicina peruana (Lima, I95 I), II, $265-267,269-270$.

27. See Shafer, Economic Societies, pp. 157-168, and Dale, "The Cultural Revolution in Peru."

28. Mercurio peruano, II (May 29, 1791), 69; (June 2, 1791), 83.

29. Herrera, "Juan Tafalla," Revista de ciencias, XXXIX, 57-58. 
hundred drawings, over fifty samples of cascarilla, and an excellent herbarium. How much of this, if any, was owing to Juan Tafalla? ${ }^{30}$

Nearly every article on plants that did see print in the Mercurio, including a concise introduction to the study of botany, came from the pen of the editor-in-chief, Hipólito Unanue. This young scholar's profuse writings also included a memorable study on coca (1794), substantiated, incidentally, by a description of the plant made by Tafalla and an illustration from the pen of Pulgar. Unanue's noted work on the climate of Lima ( I 806) is, in the parts concerning plants, a pioneer effort in the science of relating living organisms to their environment. Unanue made remissions of plants to Ruiz in Spain and was recognized in the latter's study on "china peruana."

Unanue spoke well of Tafalla, as a man who "applied himself." A recent historian, on the other hand, is inclined-without much proof-to stress Tafalla's mediocrity. ${ }^{32}$ Whatever his true capacity, he swept Dávalos aside in less than two years, with the arrival of the botanists' friend Ambrosio O'Higgins as viceroy of Peru. At the very time the Flora was coming to life again in Spain, Tafalla, by an order of June 7,1797 , took over the chair in Peru. ${ }^{33}$ One suspects that more than coincidence is involved.

Nevertheless, academic instruction in botany took no sudden upswing, for the agregados were off again to the montana-just once more, so they said. But no sooner said than undone. Who could resist the new siren calling them to Guayaquil? Shipments of timber up to seventy feet long, for building a new type of gunboat, were arriving from the northern port. "Instructed persons" with a yen for data clamored for an expedition to the source.

Ruiz and Pavón, frustrated so often in their own desires to go to Guayaquil, were delighted at the prospect. They urged it upon the minister "before [Tafalla] becomes settled down in his professorship." True, the viceroy of New Granada had jurisdiction, and José Celestino Mutis was botanical kingpin in those realms, but it was easier for Tafalla to reach Guayaquil by sea, than for Mutis, far inland to the northeast. ${ }^{34}$ Zenon Alonso, the ministry's representative

30. Mendiburu, Diccionario histórico-biográfico del Perí, I, 72. Herrera, "Juan Tafalla," Revista de ciencias, XXXIX, 57-58.

3r. Barreiro, "Epílogo," in Ruiz, Relación, I, 515. Unanue also wrote a dissertation on tobacco ( 1792 ).

32. Lastres, Historia de la medicina peruana, II, 269-270.

33. Ibid., p. 269. Herrera, "Juan Tafalla," Revista de ciencias, XXXIX, 56. 34. To Jovellanos, Madrid, April 19, 1798. MCN. 
in the botanical junta, chimed in. The trip promised "great gains for Science and the state, with very little expense." The crown ought not to worry about "the shortage of means occasioned by the war, since in America they aren't experiencing this obstacle." The king agreed, and his orders confirming the trip went out to the viceroys of Peru and New Granada on May 26, $1798 .^{35}$

By now Tafalla had a new pair of partners; after stormy sessions in the accustomed tradition, Pulgar had thrown over his job. His illness gets much of the blame: stomach trouble from bad jungle food, and intermittent spells of malaria. Though Pulgar's ailments had halted their work "for extended periods" and "on many occasions," Tafalla could not let him go without finding a replacement.

But no sooner had the artist in 1796 begun to train his successor, José Rivera of Huánuco, than he declared his independence. First, he married in Huánuco without Tafalla's knowledge. Then, though granted at last his raise to 2,000 pesos, he agreed to go into the montaña only after Tafalla had traveled to Lima for a viceregal order. When at last they arrived at Pozuzo, it was too late in the season, and before the mules could start for another site at Muña, Pulgar had rebelled anew. Without warning, he set out for Huánuco, and from there on August 9, I796, left for Lima. His object, said Tafalla, was to commit the forbidden sin of "engaging in commerce." And, less forgiveable, without finishing his drawings!

The viceroy stormed. To the jailhouse with Pulgar! The artist protested his innocence. He was a sick man; his replacement was competent; could he not now retire? O'Higgins summoned Dr. Aguirre, the protomédico general, to conduct an examination. In the end Aguirre and his consultant, Bachiller Feliciano Moreno, merely accepted the draftsman's word that he had been ill for seven or eight years, a condition they found easy to believe. As for Rivera's talents, the word was good. González Laguna admired his work, and Tafalla, back in Lima by October, I 796, was cheered by his conduct. Viceroy O'Higgins, now the Marqués de Osorno, gave his blessing, and on October 3I Rivera was hired at 600 pesos a year. All Pulgar need do was finish his own duplicates and teach the neophyte how to color the drawings.

35. Zenon Alonso's marginal note, April 20, I798, to the above cited letter of Ruiz and Pavón; royal orders to Francisco de Saavedra of the Treasury, and to the viceroys, Aranjuez, May 26, 1798 . MCN. 
But hardly had the dust settled than Pulgar headed for wife and home in Huánuco, where he again came down with malaria. Despite a medical certificate, and Pulgar's claim that his trip was designed to pack up expedition equipment, the viceroy was furious. Away with his "captious statement"! The "true objectives that motivated him ... are not absent from the knowledge of this government [Superioridad]." The intendant Bartolomé Bedoya, at one time the hapless teniente asesor who had sweated through the Macora incendiary trial, was ordered to get the errant Pulgar back to Lima "without excuse."

Bedoya tugged and hauled; Pulgar protested ill-health and worse weather; and the city council of Huánuco complicated matters by electing Pulgar alcalde ordinario. Finally, in early March, I797, the artist appeared in Lima, still disclaiming his guilt. Though he had done no wrong to leave the capital in the first place, he now braved rains, neglected civic duties, and risked loss of his labors in the torrential streams in order to return; was not that enough? Tafalla, with no doubt mingled frustration and relief, agreed that it was, and on March I6, I797, the viceroy officially terminated Pulgar's appointment.

But Spanish colonial stories never end so neatly. There must first be a battle over compensation. On the grounds of illness occurring in the line of duty, Pulgar now claimed his salary since the beginning of the dispute. The treasury in Lima, however, would pay him only to October 31, I 796, when Rivera was hired. Pulgar's long-run objective was another appointment from the king or a pension at half his salary. Ruiz and Pavón came to his aid, in recognition of the "more than three hundred" drawings he had made for the Flora, and on September I, I799, the crown reached its decision. Indigence of the state forbade a pension, but perhaps there might be a subdelega. ción open somewhere in Peru. Two years later, and five years aftet his pay as a draftsman had stopped, Pulgar on December 6, I 80I, be came subdelegado, or administrator, of the local district of Huaylas in the intendancy of Tarma. ${ }^{36}$

So it was that on May I I, I799, Tafalla headed for Guayaquil

36. The story of Pulgar's retirement is treated in extenso in a series of papers in MCN, 1798, beginning with letter No. 68 from the viceroy of Peru to the Minister of Grace and Justice, Lima, Oct. 23, 1798. Notes accompanying this letter reproduce the pertinent documents dating from Aug. I0, 1796, through Aug. 7, 1799. See also, in MCN, 1799, Ruiz and Pavón to Zenon Alonso, Madrid, May 7, 1799; and royal orders of Sept. I, 1799, and Dec. 6, 1801. 
with a new artist in tow by the name of José Rivera. But there was a third party, too: Juan Agustín Manzanilla. He had joined in I 793 as a volunteer botanist "with the view of instructing himself in the practice of this profession and forming an auxiliary career in botany." Serving for three years in the forests without a penny of salary, succored only by handouts from Tafalla, he advanced in botanical knowledge but suffered "a highly notable arrears with respect to his fortune, and the decency of his Person." A sympathetic viceroy got him a grant of one peso a day for the jungle trip of 1797 , and there matters stood as the expedition to Guayaquil began. ${ }^{37}$

Although the trip had its inception in a quest for data on timber, Ruiz and Pavón, of course, widely enlarged its scope. Without their help, in fact, the men would have been pariahs. The party left Lima without the usual subvention, perhaps because a sudden embarkation caught them unawares. Manzanilla and Rivera soon exhausted their pittances, and had to live off Tafalla's kindness. ${ }^{38}$ Their mentors in Spain, meanwhile, excited to see Tafalla become the first botanist to compare the quinas of Loja and Peru in their native habitat, worked willingly to relieve the strain. Even before the trio sailed, Ruiz and Pavón urged a reward for Tafalla to compensate for his aid to the novices, and his gifts to the Indians for plant information. They pointed out that he had helped the tyros because his "age and continuous labors with not a few sick spells and enfeeblement" made it inadvisable to go alone, and necessary that there be a skilled replacement if anything should happen to him. ${ }^{39}$ In January, 1800 , they pleaded again on the trio's behalf for bigger salaries and grants. "It would be a pity," they grieved, "to be in a country flourishing with precious plants, and fail for want of means to discover them." ${ }^{\prime 0}$

Fortunately, officialdom was neither hardhearted nor stone-deaf. In 1800 , the viceroy of Peru doubled Manzanilla's wage to 730 pesos a year, retroactive to the date of sailing. By this time Rivera had reached a level of I,200 pesos. ${ }^{41}$ The budget was stretched again to pay an identical salary to a new artist, Xavier Cortés, who joined the

37. Archivo Histórico de Hacienda (Lima), libro 1164, fols. 312v., 76v. Ruiz and Pavón to Jovellanos, Madrid, April 19, I798; Manzanilla to the crown, Quito, Dec. 20, 1803 . MCN.

38. Ruiz and Pavón to Caballero, Madrid, Jan. 4, I800. MCN.

39. To Alonso, Madrid, May 7, 1799. MCN.

40. To Caballero, Madrid, Jan. 4, $1800 . \mathrm{MCN}$.

41. Ynforme de los Mŕos R. de las Cax. ${ }^{8}$ de Guayaq. ${ }^{1}$ April 26, 1803 ; Tafalla to president of audiencia of Quito, Quito, Aug. 27, 1803. MCN. 
party in I 800 . Little is known about him, but it must have been evident early in the trip that one draftsman would be hard-pressed to keep up with two botanists. ${ }^{42}$

Tafalla fell and injured his chest in September, I802. Alarm struck Ruiz and Pavón to hear that doctors had twice drawn blood, for the party had yet to reach Loja. All eyes ought now to turn to Cinchona, to help polish the Ruiz-Pavón work on the bark "that all Europe wants to see finished." The ministry must urge the president of Quito to give "all aid" to the men. ${ }^{43}$

"All aid" can be an ambiguous term, as the expedition had already learned. To impecunious botanists it meant more money, but to colonial magistrates it more often connoted innocuous "moral support." So much was this so in this case, that Ruiz and Pavón, apprised of the straits of the party, wondered whether orders to the executives of New Granada and Quito had ever reached these gentlemen. ${ }^{44}$

The officials were less in the dark than cautious, as Manzanilla learned in 1803 . He wrote the president of Quito to say he was penniless, enclosing a statement from the treasury of Guayaquil about the high cost of living there. The presidente, Barón de Carondelet, tried to evade the issue by suggesting Manzanilla petition the viceroy of Peru. But the botanist, now four years outside Peruvian jurisdiction, knew he would get nowhere with that approach. Arriving at Quito in August, he importuned Carondelet again, now stressing the indignity of his third-rate status. Was not he "the second one of the expedition not only in work, but also in honor and merit?" Did it seem logical that the draftsmen, who occupied "the third place," and were employed in "matter-of-fact labor," should get more money than he? Fifteen hundred pesos a year, however, might restore his dignity. ${ }^{45}$

Noticeable discouragement over his low salary and months of illhealth brought a slackening in Manzanilla's energies. But when

42. Cortés' appointment was dated Jan. 7, 1800. Archivo Histórico de Hacienda (Lima), libro I 164 , fol. 3 I 2 .

43. To Caballero, Madrid, April 16, 1803. MCN. The botanists in Spain wanted the expedition to "examine, describe, draw, and collect all the species of quinas known empirically in Loja, Cuenca, Jaen de Bracamoros and other provinces of the Presidency of Quito."

44. To Caballero, Madrid, Aug. 18, 1802 . MCN.

45. Manzanilla to president of Quito, Quito, March 23, I803; Ynforme de los Mros R. ${ }^{8}$ de las Cax. ${ }^{8}$ de Guayaq. ${ }^{1}$, April 26, 1803 ; decree of President Carondelet, Quito, May 22, 1803; Manzanilla to the president, Quito, Aug. 26, I803. MCN. 
Tafalla recommended his pay be raised to the level of that of the draftsmen, the presidente unloaded the responsibility upon the viceroy of New Granada. To the latter, "all aid" meant alleviation of temporary and accidental needs, by no means the right to raise salaries. ${ }^{46}$ Manzanilla's last resort was a plea to the king on December 20, 1803 . However, when Ruiz and Pavón, who knew little of Manzanilla, refused to exceed Tafalla's suggestion, the crown could approve no increase at all until given a chance to study his work. ${ }^{47}$ At this point the documents stop. Whether he got his raise we cannot say. Yet, like a faithful dog, he was still on the job for years to come. How did one deliver himself from the arms of the expedition, unless on account of the most fearful misdeeds?

True to the hopes of Ruiz and Pavón, the expedition turned into a search party for quina in I804 and I 805. By the end of that time they had found a reputed thirty-eight new species of Cinchona, to add to the twelve already known to Ruiz and Pavón. Whenever these should arrive in Madrid, the Spanish botanists promised completion of their Quinologia. ${ }^{48}$ But it seems likely that many specimens were not sent until the party had left Guayaquil for Peru early in 1809 , and these had the ill-fortune to lie for four years in the Archives of the Indies in Seville, awaiting the departure of the French. ${ }^{49}$

Spain's world collapsed in I 808, but, paradoxically, in Peru it was a landmark year for the study of plant science. The new Medical

46. Tafalla to president, Quito, Aug. 27, 1803 ; Viceroy Antonio Amar to Presidente Subdelegado de Real Hacienda de Quito, Santa Fe de Bogotá, Nov. 5, 1803. $\mathrm{MCN}$.

47. Petition of Manzanilla to the crown, Quito, Dec. 20, 1803; Ruiz and Pavón to the ministry, Madrid, May 5, I804; king to president of Quito, Aranjuez, May 18, 1804 . MCN.

48. Gazeta de Madrid (No. 67, Aug. 15, 1806), 700-701. A copy may be found in AGI, Indiferente General, legajo 1556.

49. The shipment, comprising 23 boxes of "natural products," arrived at Cádiz on September 16, 1809. (Statement of Manuel Mangas, master of the vessel San Félix de Cantalicio, on that date, at Cádiz. $\mathrm{MCN}$, 1808.) Sent for safekeeping to the Sevillian archives, the boxes were opened by the French when their forces took the city, and the invading general removed some samples, but on the whole the shipment was undisturbed. (Summary expediente of Ministerio de Gobernación, beginning with a communication from Secretario de Estado y del Despacho de Gracia y Justicia, Cádiz, July 13, I813. MCN. Also, Ruiz and Pavón to Ministro Interino de Ultramar, undated, in MCN, 18 13. AGI, Indiferente General, legajo 551, contains further information on this topic, fols. 37-38, 4IV.-42.) Manzanilla remitted 71 descriptions from Guayaquil in the fall of 1808 , and a few weeks later was in northern Peru, at Piura. (Ruiz de Castilla to Minister of Grace and Justice, Quito, Nov. 6 and 21,1808 . MCN.) 
College of San Fernando opened in Lima, and at last the chair of botany had a chance of survival. But professor-elect Tafalla began instead, at the request of Pavón, to prepare for a sojourn of six month in Chile, "in order to remit seeds and drawings of the pines and some Chilean plants that are necessary for continuance of the [Flora Peruviana], as well as to enrich the Botanic Garden of Madrid with some American plants." During his absence, Tafalla left the chair at San Fernando in the hands of Manzanilla. There is cause to wonder, in fact, whether Tafalla ever spent time on the podium, for in I 8 I I the old campaigner ended his earthly career after nearly a quarter-century in the field. ${ }^{50}$

\section{FRAIL FIRST STEPS AT SAN FERNANDO}

Manzanilla by now was scarcely a recruit. Pointing to eighteen years of practical experience, he logically thought of himself as Tafalla's successor, not only at San Fernando, but as director of the expedition. In those topsy-turvy times, however, with revolutions popping all around, the Superior Government in Peru doubted the need for an expedition at all. But apparently Hipólito Unanue, now the protomédico, made its advantages known, and Manzanilla, Rivera, and Cortés were kept on their jobs, pending approval from Spain.

That there were any more big trips seems rather unlikely, though Manzanilla in I8 I 5 made at least one remission, of 19 drawings and 69 descriptions. ${ }^{51}$ Rivera, his eyesight failing, meanwhile in I8 I I had petitioned for a new job similar to that of his predecessor Pulgar. Rivera's salary had apparently been reduced to 600 pesos at the end of the Guayaquil venture, and he made the usual protestations of indigence. We do not know the immediate outcome, but by 18 I 5 he was dead. ${ }^{52}$ Manzanilla and Cortés, however, were kept on at the

50. Archivo Histórico de Hacienda (Lima), libro Ir64, fols. $129,283 \mathrm{v}$, 284; libro 1170 , fols. $89-89$ v.

5r. Eguiguren, Diccionario histórico cronológico, I, 667-669. Marqués de la Concordia, viceroy of Peru, to Secretario de Estado y del Despacho Universal de Indias, Lima, April 17, 1815. AGI, Lima, legajo 749, in Anales de la Real Academia de Farmacia, XXIII (No. I, 1957), 90.

52. Petition from Lima, Dec. 7,1811 , forwarded to Spain by the viceroy on Jan. 17, 1812. Printed in Anales de la Real Academia de Farmacia, XXIII, 82-84, from AGI, Lima, legajo 243 , No. 218. Rivera's death was announced in a letter 
medical college, for both are known to have received a salary in $1816 .^{53}$ When, five years later, the college swore to support the declaration of independence from Spain, Cortés was one of the signers. ${ }^{54}$

The new course of botanical instruction probably played only a minor part in the curriculum. José Gregorio Paredes, in his theses for the licentiate in medicine in I815, stated that "natural history, - botany, and chemistry were rarely cultivated so much by a physician that he could be accused of excess." " At least one medical student, however, took the study seriously. José Gordillo in I 8 I I presented a disputation entitled "Synopsis of the Chemistry of Plants." His was no part of a certamen (literary contest) whose ephemeral life ended along with the game; "it is," he said, "the life and death of plants and the admirable products resulting from either state that will be transmitted to posterity."

The most thorough view we have is regrettably subjective. It comes through the eyes of Juan de Dios Ynciarte, who had studied botany at the new medical college in Lima, and was now, in 1818, seeking a job as professor of the subject. Not content, he said, with the knowledge acquired in Lima, he had obtained a certificate of proficiency from the royal museum in Madrid, and had picked up a "beautiful herbarium of dried Plants in order to provide the best instruction for the Inhabitants of that New World." He had likewise collected seeds of the best medicinal plants of Europe to sow in Lima.

to Pavón from Cortés on Feb. 9, 18 I 5 . (Pavón to Juan Lozano de Torres, Minister of Grace and Justice for the Indies, Madrid, Sept. 16, 1818. Published in ibid, XXIII, 92, from AGI, Lima, legajo 1018.)

53. Vicente Rodríguez Casado and Guillermo Lohmann Villena (eds.), Joaquin de la Pezuela, virrey del Perú, 1816-1821: memoria de gobierno (Seville, 1947), pp. 20, $34-35$. The director of the college certified in 1815 that both men (identified as "botanist and draftsman, respectively, of His Majesty") had continued to instruct the medical students in botany. (Luis A. Eguiguren, El Archivo Nacional del Peri, dependencia del Ministerio de Justicia: breve inventario de expedientes [Lima, 1949], I, 170.) Regarding Cortés' position, however, José Pavón was under the impression in 1818 that the artist had been added to the "University of Lima provisionally, but without the endowment that he ought to enjoy based upon his acquired merits." (Pavón to ministry, Madrid, Sept. 16, 18 18. MCN.)

54. Lastres, Historia de la medicina peruana, III, 122.

55. José Gregorio Paredes, Theses quas pro gradu licentiatus in Medicina obtinendo apud regalem Sancti Marci Universitatem (Lima, 1815). In BNS, Sala Americana, 14 (259-10).

56. José Gordillo, Chemiae vegetabilium synopsis quam pro gradu baccalaureatus obtinendo (Lima, [1811]), pp. [i-ii]. In BNS, Sala Americana, 14 (259-10). 
His news of Peruvian botany was bleak. Not a single student had studied plant science at San Fernando for three years. Tafalla was of course dead, and the "second professor" (presumably Manzanilla) had lost his mind [perdido el juicio]. There was as yet no botanic garden in Lima, and, oh! Your Majesty, "if your great soul (always ready to help your unhappy vassals) would stop for a moment to contemplate the state of Medicine and Pharmacy in those vast Provinces, truly the benign heart of Your Majesty would be stricken with horror."

Ynciarte, despite the "extreme indigence of his unhappy widowed mother" with five younger sons to support, had spent 30,000 reales and "risked his life" to cross the seas from Peru to be "useful to the state and nation." Now, having prepared himself in Spain, he wanted the professorship of botany in Peru. José Pavón, by this time the sole head of the Flora, scoffed at these pretensions. Ynciarte had presented no proof of study under the professor at Lima, and one year of lessons in Madrid was not enough to exempt him from standing a competitive oposición for the chair. Pavón, of course, knew of Tafalla's demise, but had no recent word on Manzanilla. As far as he was aware, from a letter of Xavier Cortés, perhaps dating as far back as August I, I 8 I6, Manzanilla was still living, though ill.

The irrepressible Ynciarte bounced back with another petition, now asking the title of "Botanist" without pay. Though this, too, was refused, he found it hard to stay silent. Could he please have the royal museum of natural science give him the works of Cavanilles and Palau to put at the disposition of the College of San Fernando in Lima? And, at the same time, would not the king reconsider giving Ynciarte "only the title of Botanist" without costing the treasury a cent? The note appended by the ministry to the bottom of his correspondence is brief and final. "According to an opinion given by the Director of the Flora Peruana, this office hunter doesn't have the aptitude to dedicate himself (as he aspires) to the teaching of Botany. August 8 [1818]. Denied." "57

57. The pertinent correspondence is all in MCN, 1818 . It is composed of three undated petitions by Ynciarte to the crown, a letter of May 23, [1818], from Pavón to Lozano de Torres, Minister of Grace and Justice for the Indies, and various ministerial notes, one dated June 1, 1818. Ynciarte was first notified of Pavón's opinion on June 29. Pavón's statements as to the latest word on Manzanilla are conflicting. On May 23, 1818, he said he had heard from Cortés during the preceding year. But on September 16,1818 , he stated he had not had news since August I, 18 I6. (MCN.) 
Another aspirant, José Alonso de Quintanilla, had no greater success despite a long string of qualifications and the blessings of José Pavón. Quintanilla, a "professor of medicine" and corresponding member of the royal botanic garden and museum of natural sciences, had studied four years of botany, three years of the subject as applied to medicine, and two of agriculture, in addition to holding a temporary post as professor of experimental physics at the colegio of San Isidro in Madrid. ${ }^{58}$

But these men appeared two years too soon. By 1818 the brush fires of independence had begun to spread nearly everywhere but in Peru, while at home the restored monarchy, intent on crushing the menace of liberalism, had assumed a Draconian temper and paid little heed to botany. By I 820 , however, there was a different tale to be told. On New Year's Day a coalition of reformers and the officers of an expeditionary army about to sail for America staged an immediately successful revolt, restored the liberal Constitution of I8I2, and forced the king to give it his allegiance. Within a few months the new climate had begun even to revive the wilted leaves of the Flora Peruviana. In the midst of a war for the very preservation of Spain's hold on America, when her colonies were one by one leaving the bosom of their aged mother, the government sought to revitalize a sleeping Flora as though nothing had happened.

In October and November, I 820, plans were announced for a completely new expedition. Rafael Gravier del Valle would go to Lima as professor of botany, assisted by Domingo Escandón, to continue work on the Flora, and "to clarify and perfect some discoveries made years ago by other professors ... of this important science." The government granted generous sums (not so easily collected, however) for books, supplies, and incidental expenses, and the pair sailed almost immediately on a warship bound for the Caribbean. ${ }^{59}$

In January, I $82 \mathrm{I}$, they arrived in Puerto Rico, and were sent on their way toward Portobelo in Panama by an over-generous intendant

58. Petition to the king, Madrid, Aug. 23, 1818; Pavón to Lozano de Torres, Madrid, Sept. 16, 1818. Anales de la Real Academia de Farmacia, XXIII (No. I, 1957), 92, from AGI, Lima, legajo 1018 .

59. Porcel to Secretario del Despacho de Hacienda, Palacio, Oct. 8, Nov. 3 and 6, I 820 . MCN. There was a slight delay at Cádiz because treasury officials there did not have proper authorization to pay Gravier 20,000 reales. Antonio Porcel, secretary for overseas affairs, wrote the treasury on November 6 that unless this matter were immediately taken care of "serious damage to the national service" would result. To retard the expedition would produce the "gravest evils." 
who later got into trouble for having advanced them money. ${ }^{60}$ But General José de San Martín was already encamped on the coast of Peru recruiting regiments for independence. In July, I 82 I, the viceroy had to abandon Lima and only scattered outposts remained in control of the Spanish army. The colony was dead, long live the Republic! The Royal Botanical Expedition was dead, never to live again.

What impact did the agregados have upon the study of botany in Peru? Obviously not as much as at one time had been hoped. Perhaps part of the trouble lay in the fact that the men were without an identity of their own; they were an extension across the seas of the eyes and ears of Ruiz and Pavón. Their discoveries bore the legend, not of "Tafalla" or "Manzanilla," but "Ruiz et Pavón." Some might argue, of course, that Tafalla languished in an obscurity no greater than that to which Ruiz relegated his other associates.

Certainly a major weakness was the failure of the garden and the professorship of botany to emerge from a shadowy state. Instruction in the science could have attained but little status by the time of independence. Given a choice between classroom and countryside, the agregados preferred the latter. Ruiz and Pavón would theoretically have the men settle down in Lima, but let an exciting new trip arise and the itch to prospect for plants returned, even if they now must satisfy it only through their protégés.

There is no accurate way to measure the achievement of the agregados except to say that Ruiz and Pavón often spoke of the men with evident satisfaction. Nor did their monitor and energizer, Father González Laguna, seem to lack confidence in his charges. It is when we remember the afflictions of the decade Ruiz and Pavón spent in America, and recall that Tafalla walked jungle trails for nearly a quarter-century, that the full magnitude of his achievement stands out. Even Manzanilla went into the field for almost twenty years.

The great Alexander von Humboldt, who visited Lima in 1802 , described the scientific ambiance of the capital in these words:

The study of mathematics, chemistry, mineralogy, and botany, is more general at Mexico, Santa Fe [Bogotá], and Lima [than at Havana]. We everywhere observe a great intellectual activity, and among the

6o. Luis de Santiago, intendant of Puerto Rico, to Secretario del Despacho de Hacienda, Jan. 27, 1821; José de Tejada, contador general, to same, Madrid, Sept. 27, 1821; royal order to intendant, Oct. ז0, 1821. MCN. 
youth a wonderful facility of seizing the principles of science. It is said that this facility is still more remarkable among the inhabitants of Quito and Lima than at Mexico and Santa Fe. The former appear to possess more versatility of mind and a more lively imagination, while the Mexicans and the natives of Santa $\mathrm{Fe}$ have the reputation of greater perseverance in the studies to which they have once addicted themselves. ${ }^{61}$

Of course, much of the stimulus to plant study came through other hands than those of the expedition. Padre González Laguna's interest, and his Garden of Buena Muerte, antedated even Ruiz and

- Pavón. Two physicians of Lima stand out among their associates: the venerable Cosme Bueno and the indefatigable Hipólito Unanue. Bueno's concern for plants had a largely medical orientation, but Unanue, as we know, embraced all branches of the science. That Ruiz and Pavón should name for him the genus Unamuea (=Stemodia L.) was not a meaningless gesture. The Malaspina hydrographic expedition, which caused a stir in Lima in I 790, and again (upon its return from the Orient) in I 794 , included two naturalists, Thaddeus Haenke and Louis Née. Haenke, in fact, settled down to live in what is now Bolivia. Humboldt and his colleague, the naturalist Aimé Bonpland, added a touch of glamor in their visit of 1802 .

But for a day-in, day-out spur to keep the science alive, there was no greater contribution than that of Ruiz, Pavón, and their successors. Their study "on location" continued for at least forty years. The strong response to the appeal for funds to publish the Flora is proof that the leaders of the colony viewed the project with interest and pride. And, in I $8 \mathrm{I}$, when Tafalla died and the prospects for continuance dimmed, the parsimonious treasury agreed to keep the expedition in being after Unanue had pointed out its value. The men who contributed to the fund for the Flora, or who voted to keep the expedition alive were not professional botanists. But they had learned enough to know that the study was important. In the midst of demands for money for a thousand pressing needs, that is an outcome of no mean proportion.

61. Political Essay on the Kingdom of New Spain, I, Bk. II, chap. vii, 2 I I. 


\section{JOSÉ PAVÓN AND THE}

\section{DECADES OF DECA DENGE}

\section{THE SECOND BOTANIST BECOMES \\ THE FIRST}

We now approach the last lap of the race. It is no heart-pounding finale; no tumultuous, clamoring mob cheers the runners on to victory, for the small crowd that had come to watch has almost all gone home. The participants are nearly as rigid as statues, restrained by the invisible hand of neglect, or frozen in the face of insuperable obstacles. A few officials remain, slashing sporadically with scourging whips at the wooden competitors. The runners shift now and then from side to side as their gaze catches sight of greener fields. But nothing happens, nothing, at least, that will advance the Flora one leaf beyond that point in time when Hipólito Ruiz said his last goodbyes.

The government talked of giving Ruiz's heirs a yearly pension of 8,000 reales, and perhaps even began to pay it. ${ }^{1}$ Now, after thirtynine years, the leader's mantle fell for the first time on the aging shoulders of José Pavón. Besides the artist Isidro Gálvez, only one other man could be seen in the office. He was the portero Manuel Pérez-custodian, bookkeeper, and man-of-all-work-who had joined the staff in 1815 at eight reales a day in payment for "faithfulness, aptitude, and intelligence in the handling of herbaria."2

The Flora would miss Ruiz's bounding energy and his flowing pen. He was often caustic, but spare in bombast and unending in his zeal to preach the gospel of botany. He did no fawning and spared

1. Memorandum of the Junta de Protección del Museo de Ciencias, Madrid, Aug. 2, I8I6. MCN. A record of action on this proposal has not been located.

2. Royal order to Directors of the Flora Peruviana, Palacio, June 6, I8Is. Archives of the Jardín Botánico de Madrid, Reales ordenes pertenecientes a la Flora Peruana y Chilense, No. 3. 
no feelings, for he spoke directly to the issue, a man to be admired, but not always liked. Many of his papers are gone, but the files at hand testify to his vigor. ${ }^{3}$ Even among his publications, the Flora, the studies on quina, and the hot words traded with Zea and Cavanilles far from exhaust what he had to say. Several other memorias found their way into print. One dealt with the "star reed," discussed in a previous chapter. Another, in 1796, analyzed briefly the properties of the Sargasso alga, a tested anti-scorbutic. There was one in I799 on ratana (Krameria triandra Ruiz \& Pav.), in which both he and Pavón wrote of an extract designed to halt hemorrhages; its virtues had been demonstrated, they said, "with success beyond peradventure," on several Peruvians, including the daughter of Cosme Bueno. In 1805 , as the Flora began to die on the vine, three more studies appeared: a memoria on the yallhoy root (Monnina poly- stachya Ruiz \& Pav.), a cure for dysentery; one on the calaguala root (Polypodium angustifolium Swartz) written to combat bad reports published in Italy; and a third on canchalagua (=Erythraea Chilensis [Willd.] Pers.), a root used to "assuage, purify and thin out the - blood." Yet another, on the putrampui root (Smilax Purampui Ruiz, now synonymous under $S$. febrifuga Kunth.) or "china peruana," was eventually published in $1821 .^{4}$

The number of Ruiz's manuscripts which failed to reach print is extensive. Most are technical in character, though several deviated from the usual pattern, such as a "Formulary for making scientific voyages"; a supplement to the Philosophia botanica of Linnaeus, drafted by Ruiz in conjunction with his old professor Antonio Palau; a supplement to a dictionary and grammar of the Quechua language spoken by the Indians of Peru; and a study on the "Wars of Chile," parts of which are said to have been burned in that colony, "in consequence of the strict orders of the court, to hinder their introduction into Europe."

Even most of the volumes of shared authorship attest to Ruiz's predominance. The same may be said of the jointly signed letters

3. Rafael Roldan Guerrero, address upon the second centennial of the birth of Ruiz and Pavón, Madrid, Oct. 25, 1954, published in Anales de la Real Academia de Farmacia, XXI (No. 1, 1955), 31. The Museo de Ciencias Naturales in Madrid contains the best collection of Ruiz's letters, though none of these is purely personal.

4. These works are summarized in Barreiro's "Epilogo," in Ruiz, Relación, I, 514-517. See also Variedades de ciencias, literatura y artes, III (1805), 190-191, 315-320, and Lambert, Illustration of the Genus Cinchona, pp. 98-176.

5. [A. Ruiz], Historical Eulogium, p. 48. 
resting in archives today: nearly all are composed in the straightforward style and the unadorned hand of the "first botanist," who presumably felt it his duty (and right) to be first. Pavón's individual contributions are small. Two arose from controversies with his colleague: a dissertation on four miscellaneous genera, including the Araucaria, which Ruiz held to be a Pinus; and the "New Quinology" already mentioned. ${ }^{6}$ A third manuscript dealt with species of laurel, and, finally, Pavón drafted an index of popular and botanical names for all plants listed in the Flora Peruviana, with notations as to their uses.

What kind of a man was José Pavón, who must now, at age sixtytwo, venture upon his own? Dombey was more readily drawn to Pavón as a friend, though perhaps not so eager to honor his botanical knowledge. Cavanilles, as if in reaction to his tirades against Ruiz, called Pavón an "industrious, enlightened, and modest man of excellent conduct." But in the eyes of Gómez Ortega, the junior botanist appeared insubordinate and unzealous, if not consummately lazy. Indeed, Pavón would have forsaken the staff in a trice to take a new job at Loja, and had more than one tiff with Ruiz.

Banished to the shadow of Ruiz during most of his active life, Pavón felt compelled to descend to absurd extremes to ingratiate himself with his superiors. Here is a sample, written from Huánuco in May, I786, on the occasion of a shipment of plants to Minister José de Gálvez:

I am dedicating myself with the greatest eagerness, care, and observation to getting these plants sealed up in boxes, so that, once they have arrived in Lima without damage, their embarcation and care in the long voyage to His Majesty will be successful, and the poor Peruvian Botanist will have the honor and merit of showing to Your Excellency the fruit of his labor, giving Your Excellency patent proof of his good and sublime desires in sacrificing his life in carrying out the commission which His Majesty, by the favor of Your Excellency, has deigned to confer upon me.

Your Excellency is the remunerator of men dedicated to the Arts and Sciences, you protect them, and exalt them to the highest degree; I, as one of your pupils, and creature of Your Excellency, hope you will shelter me under your cloak and benevolence, condescending to keep in mind my small virtues acquired in this Realm in the performance of my obligation and the accuracy that I long to achieve.

6. See p. 2 10, n. 66, above.

7. May 20, $1786 . \mathrm{MCN}$. 
Students of Spanish history often read such obsequious prose. The archives in Spain are heavy with the ponderous verbosity of men seeking favors and honor. But in contrast to the terse, though courteous, letters of Hipólito Ruiz, this bowing and scraping comes as a shock. Ruiz's son and eulogist pridefully recalls that his father hesitated to gather the customary testimonials from colonial officials. ${ }^{8}$ Pavón, on the other hand, made himself known with a varied collection of certificates. ${ }^{9}$

From these documents Pavón does emerge as more than a passive liege man to his lord and master Ruiz. Higgins, for instance, commented favorably on the solo efforts of Pavón to bring out Chilean pines from the land of the "pagan Indians." The intendant of Tarma lauded him for directing construction of a public promenade in Huánuco. The cabildo of that city added its praise for Pavón as "the first discoverer" to make known the chemical process for producing extract of cascarilla, and for "discovering" how to exploit yerba maté (Ilex Paraguariensis A. St Hil.) in their vicinity. Bartolomé Bedoya, teniente asesor at the time in the same intendancy, was perhaps most fervent of all. He called attention to Pavón's work in the collection and dissection of animals, birds, and insects. Pavón, he said, with regard for neither health nor expense, had sought all kinds of curiosities, like "strange relics of the ancient Incas, . . . . without any object but to make some exquisite discoveries known." Pavón's "careful and difficult dissertations" demonstrated to Bedoya his "voluminous talent, superior ability, and excessive learning in botany," as well as in experimental physics and chemistry. Finally, the asesor delighted in Pavón's beautiful and well-annotated collection of minerals, the result of "extreme solicitude and expenditure."

A dozen years after leaving America, Pavón drafted a statement

8. Historical Eulogium, pp. 38-40. The governor of Tarma apparently reported favorably of Ruiz on his own initiative. The Eulogium also cites recommendations from the corregidor of Chancay, the cabildo and corregidor of Huanuco, the "bishop of Chile," and Ambrosio Higgins. Ruiz, unlike Pavón, neither presented to Viceroy Croix any documents, nor asked any of him. (Croix to Antonio Valdés, Minister of the Indies, Lima, March 31, 1788. AGI, Lima, legajo 679, No. 91, in Anales de la Real Academia de Farmacia, XXI [1955], 449-450.)

9. To Caballero, Minister of Grace and Justice, Madrid, Feb. 14, 1800. MCN. 10. The certificates, in AGI, Lima, legajo 679, No. 91, are all copied in Anales de la Real Academia de Farmacia, XXI, (No. 5, 1955), 451-460. See esp. those by Higgins, Aug. 30,1783; capitulo of the informe of the intendant of Tarma, Oct. 17,1786 ; Bedoya's certificate, Aug. 18, 1787; and that of the cabildo of Huánuco, Jan. 12, 1788. See also Pavón to Caballero, Madrid, Feb. I4, 1800. $\mathrm{MCN}$. 
of "merits and services" of the type so popular with seekers of governmental favor, which reveals a new side to his character. In an effort to augment his income, he not only recites his achievements, but offers to His Majesty, for presentation to the royal museum of natural history, its first herbarium, of I,500 European plants, and "an abundant collection of seeds, all scientifically classified, which can serve as a base for erecting an admirable monument." Naturally the collection will need a curator and Pavón hopes to be chosen. While waiting for the first vacancy to occur in a permanent (and paying) job, he will serve, he says, without charge, as vice-director of the museum. ${ }^{11}$

The Minister of the Indies could see no harm, but José Clavijo Fajardo, a man of letters and vice-director of the museum, soon ended Pavón's pretensions:

I must say that the offer of the 1,500 European plants in return for said employment, besides carrying with it the bad appearance of offering them as the price of a job, is illusory. It is more than probable that in all of them there aren't twenty not already known and published. The other achievements the exponent alleges, such as the Flora Peruana y Chilense, and the products remitted to this Royal Cabinet of Natural History, he did in common with Ruiz, since both made the trip and the remissions at the expense of the King. Finally, by conceding such future positions, Your Excellency ties his hands against giving them in case of a vacancy to persons who can present greater and more positive merits and superior knowledge. ${ }^{12}$

Needless to say, Pavón did not get the job.

To evaluate Pavón's capabilities and character, we need more than these slender foundations. Yet, recent diligent searches have failed to uncover a file of his letters that is known to have once existed in Spain. We do not even know what he looked like, and in 1954 the citizens of his hometown of Casatejada in Cáceres had to honor the two-hundredth anniversary of his birth with no more than a marble plaque. (A new bust of Ruiz was placed in the plaza of Belorado to celebrate his bicentennial birthday. $)^{13}$

But as one follows the career of Pavón after the death of Ruiz,

x. To Caballero, Madrid, Feb. I4, 1800. MCN.

12. Marginal note to Pavón's petition, and Clavijo Fajardo to Mariano Luis de Urquijo, Minister of State, Madrid, March 8, 1800. MCN.

13. Anales de la Real Academia de Farmacia, XXI (No. 1, I955), 7, 31 . Barreiro consulted some family documents for his brief study on "Don José Antonio Pavón y Jiménez," read to a session in 1932 of the Asociación Española para el Progreso de las Ciencias, but these were meager in content. 
his figure becomes less nebulous. The hurdles he faced were high. The latest estimate showed that to treat all twenty-four Linnaean classes of plants would require eleven volumes and five supplementary tomes. Yet Volume IV lay sleeping for want of money to publish it, and the debts on Volume III had not even been cleared. Work on Volume $\mathrm{V}$ was partially done. ${ }^{14}$ Though the revolution in America was at a low ebb, the irresistible tide of Independence would soon batter the walls of the old regime. And though in 1816 Peru was still loyal to Spain, Pavón lost touch with the agregados after that year.

The botanical office in Spain made a pretense of activity, for the men managed to spend some 4,000 reales a year, a good three-fourths for rent, out of a new allowance of 500 ducats $(5,500$ reales) pro-

14. Here is a brief summary of the planned contents of the tomes:

Volume IV. Species described, 164 (Classes VII-IX of Linnaeus). New genera, 3. Number of plates, 100. Total figures, 142. Plates colored by hand, 37. Corrections made of some descriptions in the Prodromus and even some of Linnaeus and other botanists. New species of quina reported by Tafalla, 4. (A note on all species of quina discovered thus far, was published in the Gazeta de Madrid of Sept. 8, 1807.) Ruiz and Pavón devoted a portion of the preface to a renewed attack on those botanists who, "impelled by the itching desire to innovate and thus capture the applause of the public," continued to tamper with the Linnaean system of classification. Cavanilles was dead, but the battle went on.

Volume V. Species described, 180 (Classes X-XVI). Several new genera, including one dedicated to Antonio Pineda, deceased naturalist of the Malaspina expedition. Number of plates, 114. By this time the descriptions were beginning to include numerous plants from the vicinity of Quito, an area to which Tafalla was devoting much attention. For the first time (except for the bilingual Spanish-Latin Prodromus), some observations were made in Spanish, a procedure "more proper for diffusing our majestic and fluid language throughout foreign countries."

Volume VI. Number of pages, 99, almost all bearing new genera or species. Plates, I53, all but 8 illuminated.

Volume VII. Pages, 131 (mostly Classes XVI-XVIII). Plates, 10I, all but 2 illuminated.

Volume VIII. Species, yo (Class XX). Plates, 105 (in color).

Volume IX. Descriptions, 55 (Class XXI), some lacking the name of genus and/or species. Plates, 117 (all but $I$ in color).

Volume $X$. Descriptions, 80 (Classes XXII-XXIII). Drawings illuminated, 115 (some without titles).

Volume XI. Species, about 9o, plus some new genera (Classes XXIII-XXIV), Plates, 121.

The five volumes comprising the supplement were to be arranged as follows:

Volume I. Descriptions of genera and species, I,000 (Classes I-IV).

Volume II. Descriptions, 206 (Class V). Plates, 152, all but 4 illuminated.

Volume III. Descriptions, roo (Classes VI-X). Plates, 99.

Volume IV. Descriptions, 103 (Clásses X-XIV). Plates, I I 8.

Volume $V$. Descriptions, 3. New genera, 1. Plates, 9o (Classes XII-XIV). (Summarized from information in Barreiro, "Epílogo," reprinted in Ruiz, Relación, I, 499-506.) 
vided for them by the king. ${ }^{15}$ They seemed always to run up a bill for writing paper and eight pints of ink a year, and they bought a good stock of wire to tie up herbaria bundles. It took four or five new brooms a year to keep the office clean, and one-third ton of coal for heat. Every now and then they rented three large tapers and bought a stock of wicks and oil "for the six nights of illumination when Her Majesty, Our Lady the Queen, came to Madrid." In I 8 I 8 , they prettied up their balconies with twenty-one yards of linen. In the same year they moved the engravings from the printer's office to their own, and replaced the deteriorating sheets covering the used copper plates. They "coordinated" the copies of the Prodromus, which presumably means they had them tied up in bundles, and they paid a carpenter to build some boxes. ${ }^{16}$ The months and years went by in "busy-work," and where, oh where, was the Flora?

\section{INTERNATIONAL TRADER IN PLANTS, FRIENDSHIP, AND COCKLE SHELLS}

In truth, Pavón was busy, but apparently not on the Flora. He began his new life on May 28, I8I4, when a letter arrived from Aylmer Bourke Lambert (I76I-I842), a British botanist and collector of considerable means and talent, asking to buy herbarium duplicates, insects, and the like. Though Ruiz still lived and was presumably head of the botanical office, Pavón, short of cash, must have been seeking to sell property of the expedition, for he replied to "Ayemar Bourle Lambert" on August I 2 that he was indeed in the process of separating out I,500 American plants, and hoped the Englishman would let him know which ones, or how many, he wanted. Happy with his new correspondent, Pavón sent three copies of his manuscript, the "Laurographia," including one for the "sublime" Linnean Society of London. In return, Pavón hoped for a Latin

15. Pavón to Ministro de la Península, Madrid, June 7, 1820 . MCN.

16. Cuenta y razon de los gastos..., 1816 and 1817 , in $M C N, 1817$; cuenta for 1818 in MCN, 1818 . "Coordination" of the Prodromus at least marked a step forward, for in 1817 not a single copy of the tome could even be located. (Pavón to Aylmer Bourke Lambert, Madrid, May I, 1817.) Pavón's correspondence with the renowned British botanist and collector is contained in a bound manuscript volume entitled "Letters. A. B. Lambert, Esq.," in the library of the Royal Botanic Gardens at Kew. Hereinafter cited as "Letters to Lambert." The letter cited above is No. 128 in this collection. 
edition of the "immortal" Horace, the expense to be charged against the cost of the plants. For future reference the Spaniard, with little modesty, gave his address as "Don José Antonio Pavón, Author of the Flora Peruana [remember that Ruiz was still living], Botanist of His Catholic Majesty, and Member of many Scientific Academies. I 5 Juanelo Street, second floor, Madrid."17

Nearly a whole year passed before the men got down to details. Even then Pavón cautioned Lambert against impatience to receive the specimens, for he wanted to put the collection in the state of perfection due a distinguished "president" (that is, vice-president) of the Linnean Society of London. The "immutable character of a good Spaniard" forbade Pavón to do otherwise. ${ }^{18}$ The good Spaniard was flattered by the attention he was getting, and would have been even more so to read a letter written by Lambert to Alexander MacLeay, secretary of the Linnean Society: "Is [Pavón] not the author of one of the most celebrated works that ever appeared \& which contains such a number of the most interesting \& useful plants ever given?"11 Pavón was already dreaming of a call to join the august English society, and shortly began to ask about requirements for admittance. He paved the way by announcing his imminent move to bring Lambert into the circle of the Academia de Ciencias in Madrid. ${ }^{20}$

Lambert seemed favorably inclined toward Pavón's desires for membership, for he hastily remarked in a letter to MacLeay that the Flora Peruviana was superior to "what three parts of our present List have done." But his correspondence with MacLeay indicates the existence of a current of counter-opinion. Lambert wrote on September I4, I81 5, "If $\mathrm{Mr} \mathrm{P}$ is not so good a philos. Botanist as some are his situation perhaps ought to be considered \& if I am wrong I hope those who might judge will excuse it." A month later, after MacLeay had questioned Lambert's appraisal, the latter replied:

You seem quite to misunderstand my meaning about Don Pavon. My mentioning him was merely a compliment to his abilities \& did not expect a reply as I had not the least thoughts of proposing him [;] if I had I should have examined our List before I mentioned it. What I

17. "Letters to Lambert," No. 97 (and its duplicate, No. 103), Aug 12, 1814. 18. Ibid., No. r 04 , Madrid, July $3 \mathrm{I}_{2}$ I8 15 .

19. Boyton House, Sept. 14, [1815]. Archives of the Linnean Society of London. I am indebted to Mr. Thomas O'Grady, General Secretary of the Linnean Society, for a microfilm copy of the Lambert-MacLeay correspondence relating to Pavón. 20. "Letters to Lambert," Nos. I04 and 107, Madrid, July 3 I and Aug. 9, I 8 I 5. 
afterward said was a defence of a hasty sentence. I thank you for your information. I am glad we so well agree. Humboldt I really did propose to the President two years ago \& said all I could on the subject. He was the only one I ever presumed to mention or perhaps ever could [;] relating "to being excused" there might be those who might be more able to judge from having examined more minutely the Dons works [and] might excuse my having payed him so hasty a compliment. ${ }^{21}$

MacLeay, who was rapidly building "probably the finest private collection of insects then in existence," had ordered a group from Pavón, and, as the months went by, was severely irked by delays in shipping. Lambert also began to fidget. He wrote MacLeay on October I6, I 815, that "the affairs in Spain I am sadly afraid will turn out a losing game." Pavón again hastened to explain: the tardiness was caused by the "many tasks" of his employment and by "domestic affairs." At last, in July, 1816, Lambert received the first four boxes, for himself and MacLeay. They contained an herbarium of 1,200 American plants, as well as seeds, fruits, and the insects, and a miscellaneous collection of monographs, mostly from the pen of Ruiz, which Lambert would shortly publish in translation. The sum paid to Pavón was 10,253 reales, the equal of his annual salary not many years before. Lambert must have felt the wait worthwhile, for he wrote MacLeay that many of the specimens were "magnificent." $\mathrm{He}$ had "had the good fortune to raise several Peruvian plants from seed 30 years old!" "22 By this time Pavón had induced the Academia de Ciencias in Madrid to make Lambert a corresponding member, and a spirit of good will prevailed. Pavón, however, could not yet decipher the Englishman's name: he had solved the "Bourke," but still clung to the "Ayemar."

21. Sept. 14 and Oct. 16, I815. Archives of the Linnean Society.

22. Dictionary of National Biography, XII (London, 1921-1922), 649. Lambert to MacLeay, undated and June 9, 1815; July 21 and Nov. 11, 1816. Archives of the Linnean Society. "Letters to Lambert," Nos. xo8, I13, and I I6, Madrid, March 30, May 22, and June 5, 1816; Cuenta y razon de los articulos que remito al Señor A. B. Lambert, April 3, 1816 . The books, valued at 222 reales, included the small publications by Ruiz and Pavón, but none of the Flora tomes nor the Prodromus. The insect collection comprised $\mathrm{IO}_{4}$ species from South America, including butterflies, for 1,000 reales, and 300 species from Portugal and Madrid, 800 reales. Pavón had also suggested selling 386 prints of plants from the Flora Peruviana for 1,000 reales, but Lambert did not want to take them.

23. "Letters to Lambert," Nos. II I and 113, Madrid, May I and 22, I816. Lambert's diploma became lost in the mails, thereby placing him in "an awkward situation" in not being able to return his thanks to Pavón, who could not understand the apparent discourtesy of the Englishman. Lambert finally tracked the diploma 
During the remainder of I 8 I 6 Pavón continued work on a second shipment for Lambert, whenever "my great occupation with my Flora Peruana" permitted such diversion. He had earlier apologized to Lambert for delays in publication of the Flora, Spain being, he said, "not so rich as England." Pavón's "conscientiousness and refinement" did not allow him to moderate his "exceeding liveliness and activity" even though he might wish to do so. But lest Lambert think him driven purely by hopes for monetary gain, he hastened to state that, most of all, he wanted to please his English friend. "My heart," he explained, "takes a greater interest in having and earning a friend, and winning him over, than in signs of wealth."24

International currents of botanical shop talk no longer swirled through Pavón's poor land. He fired question after question at Lambert. What do you think of Bonpland's Nova plantarum? ( $\mathrm{He}$ is "my intimate friend," but "he has forgotten me.") Is Humboldt in Paris? Have he and Bonpland published more on equinoctial plants? Did the late L'Héritier ever publish the seventh fascicle of his Stirpes novae? Is Willdenow dead? Does Roemer live in Switzerland? Is De Candolle in Montpellier? Does Hedwig still live? Despite his words about friendship, Pavón might almost be suspected of seeking new markets to conquer. The Spaniard is also revealed in the letters as an avid collector of botanical works, and through the years sought to buy many in partial payment for his plants. Certainly, there was no other way in which he could hope to obtain them, for he had even to implore Lambert not to send duplicates and triplicates of his letters, as Pavón could not afford the postage charged in those days against the recipient. He eventually billed Lambert for the postal fees. ${ }^{25}$

So active had the correspondence become between Pavón and "Is Myster A. B. Lambert," that they began, at Pavón's suggestion, to write in French to save the time and expense of translating from English or Spanish. Lambert presented to Pavón his monograph on Pinus, and sent another on Cinchona to be read at the Academia de down in the office of the foreign ministry. (Lambert to MacLeay, Boyton House, July 21 and Aug. 13, 1816 . Archives of the Linnean Society.)

24. "Letters to Lambert," Nos. I13, 116, and 117, Madrid, May 22, and June 5 and 15,1816 .

25.Ibid., Nos. 104, 107, 108, 116, 117, 119, 148, 149, 151, 155, Madrid, July 3 I and Aug. 9, 1815 , March 30, June 5 and 15, and Sept. 25, 1816, Feb. 15, April 19 , and June 24,1819 , and Sept $23,1824$. 
Ciencias in Madrid. He also began to consider having a set of the Flora Peruviana illuminated. ${ }^{26}$ By October, I 816, Pavón had finally straightened out "Aylmer's" name.

In February, I 8 I 7, Pavón announced that a second shipment was nearly ready: I,500 American plants for 6,000 reales; 53 samples of quina bark for 2,000 reales; and 34 "little trunks" of cinchona wood for I,O00 reales. Pavón also listed a collection of I,355 sea shells, for which he asked 6,000 reales. ${ }^{27}$ Herein, unbeknownst to Pavón, lay hidden the nucleus of a discord that would one day begin to tear asunder the amicable friendship of buyer and seller.

For the time being, however, all was serene, for the boxes containing the shells were shunted aside in transit, and did not arrive in England until the following autumn. Pavón meanwhile dove into preparation for a third, a fourth, and even a fifth shipment for the insatiable English collector. To Lambert's annoyance, Pavón intermixed his Spanish and American plants for the sake of convenience, and sometimes sent too many copies, but at least the Spaniard could say he was "working incessantly" on Lambert's behalf. ${ }^{28}$

During I 8I7 Pavón also offered to sell Lambert 24 ounces of platinum at 120 reales an ounce, and a bit of the "greenish oxide of copper," discovered in Peru by Joseph Dombey, at 40 reales a pound. He said he had already sold some at a higher price to naturalists in France, but we do not know whether Lambert was enticed by the offer. ${ }^{29}$

As I 8 I 7 wore on into autumn, Pavón prodded Lambert again about membership in the Linnean Society. If his English customer had been the only one to please, Pavón would have had smooth sailing. Lambert wrote MacLeay on October I, I 817, that "my Spanish Cargoes turn out far beyond my expectations, \& I never could have supposed it would fall to my lot to be in possession of such a Collection." On January 20, I8I8, Lambert, in company with eleven

26. Ibid., Nos. 112, I18, I19, I 21 , and I 22, Madrid, May 4, Aug. 1o, Sept. 25, Oct. 30, and Dec. 11, 1816. Pavón selected a plant to be named Lambertia, but it is not recorded in the Index Kequensis today.

27. "Letters to Lambert," Cuenta razonada de la segunda coleccion . . ., Feb. $17,18 \mathrm{I} 7$.

28. There were apparently 3,000 Spanish plants, including duplicates, in the shipments, and perhaps even 4,500 American specimens, including duplicates and some plants from the Sessé-Mociño collection of New Spain. (Ibid., Nos. 124-139, Feb. I, 1817, through Feb. 12, 1818. See esp. Nos. 128 and 129, May 1 and 12, 1817$.

29. Ibid., Nos, 126 and 127, Madrid, March 17 and 23, 1817. 
others, officially recommended Pavón "as highly worthy of the honour of being elected a Foreign Member to fill one of the vacancies now declared." But MacLeay, who had not overcome his distaste for Pavón, refused to fall into line. Lambert sent Pavón three letters, written to the former by MacLeay, whose contents may only be guessed at. They pricked Pavón's sensitive hide. "What motive, what reason, is there?" he asked. He offered to make a statement regarding his moral conduct. "This thing is very delicate for me," he added. He would now be "very astonished" at admission into the membership circle, though he had always been "a passionate disciple of the immortal savant Linnaeus." 30

In the wake of this blow came another, concerning the shipment of shells. Pavón had thought the Englishman wanted them, and when word arrived in March, I8 17 , that Lambert did not, the shells were already packed among other items and Pavón was afraid to reopen the box for fear of damaging the contents. He thus suggested that Lambert hold the shells until he could decide their worth: the asking price of 6,000 reales or some lesser amount. "I am a disinterested man," wrote Pavón. "I want to preserve your sincere friendship, and I prefer it to money."31

Pavón did not hear about the shells again until he sent a reminder to Lambert in May, I818. He would better have remained silent. Lambert wanted no part of the shells and, as a favor to Pavón, had asked his business agent, William Matthiessen, to have them assessed and to find a buyer. Imagine Pavón's mortification to receive the following from Matthiessen, dated at London on July 2I, I8I8:

Mr. Lambert sent the box with the shells to me to see if I could get rid of them, but upon examination I found the filthiest trash [porqueria] imaginable. Far from being able to get 6,000 reales, there isn't even anyone who wants to take them for nothing. I have the box in my study creating a nuisance, and if I send it back to $\mathrm{Mr}$. Lambert it will cause more expense. I don't understand how you, as a man of intelligence and learning, can send such a thing and not only lose all his work, but besides run up a big expense in bringing it here, which Mr. Lambert has paid, not to mention the postage on the letters, which has gone up.

30. Archives of the Linnean Society, and "Letters to Lambert," Nos. 138 and 139, Madrid, Feb. 2 and $12,1818$.

31. Ibid., Nos. I 16 and 125 , Madrid, June 5, 1816, and March 6, 1817. 
To add further insult, Matthiessen appended this note: "Shells and snails like those in your box can be found here in abundance at the seashore, and the children are used to gathering them to play with." ${ }^{\prime 32}$

Pavón was naturally furious. He fired a letter to Lambert in Spanish, no longer content with a foreign tongue in the face of "the lowest and grossest contempt" Matthiessen had heaped upon him. What sort of a naturalist would show such scorn for the creatures of Mother Nature? In the eyes of one who loves science, nothing in nature is loathful. Even human excrement is valuable in farming and it is the filthiest of all. Matthiessen's conchologist ought to have known that one cannot find most of these species in England. " $\mathrm{Mr}$. Examiner of my poor contemptible shells and snails has looked at them with eyes filled with cataracts, since he hasn't distinguished between those that are maritime and those from fresh water."

What could be done? Not much. Pavón asked Lambert to remove the box from Matthiessen's sight. "But don't," he begged, "order it thrown in the sea, or in the garbage, or give it to children to play with." Instead, give the wood to some poor fellow or house of charity for the sake of warmth and, if possible, trade off Pavón's "miserable shells" for a shilling or a penny to succor the needy. "This is my mode of thinking, prudently, like a philosopher. If you don't do it, then throw [the contents] into those places where they make débris from demolished buildings." Pavón ended his letter on a grievous note. "I assure you, my friend, that I wasn't expecting such a trick, and this example will serve as a guide for my instruction in the future, after nearly two years spent on this affair."33

Unfortunately, Pavón's next letter, of August 27, I818, is missing from the files, but he was still simmering on September 3 . Though his style was "not Attic like a Cicero or a Demosthenes," he promised to speak for the last time and with the "greatest conciseness." We learn little that is new, except that Lambert apparently had had a buyer on the string, a certain "Mrs. Milady who loved conchology," before the affair blew up. Perhaps it was Milady who had been guilty of lèse-coquille.

32. Ibid., No. 142, Copia de la carta del Señor $\mathrm{d}^{\mathrm{n}}$ Guillermo Matthiessen, London, July 21,1818 .

33. Ibid., No. 142, Madrid, Aug. 13, 1818 . Pavón's reference to human excrement is interpolated from the context of his remarks. The word itself is partially missing in the manuscript, but the sentiment is unquestionably in keeping with his feelings at the moment. 
Pavón's principal reason for writing again was to shore up his fading reputation. He was acquainted, he said, with the systematic methods of modern conchologists and entomologists, for he owned and had studied their works. And if he conceded pre-eminence in learning to shell experts in England, he nonetheless thought himself not "a greenhorn, nor a stranger to theoretical and practical knowledge," for he had traveled in America for eleven years, "observing with eyes well posted by [knowledge of] elemental principles." Besides, the Spanish museum of sciences, whose collections he had studied, in his opinion was second to none in Europe in the number and rarity of its shells. With seeming finality he announced, "I have finished my exposition."

But he was not really done, for he must now assert his qualifications and convictions as a botanist.

I don't hold myself to be in the first rank in botanical knowledge, but as for the philosophical part I give way to nobody, for I have studied and continue studying in the Golden Book, the Philosophia Botanica of the immortal Linnaeus. . . . I don't know a perfect general botanist; I'm not one either, Linnaeus wasn't one, neither is Mr. Desjussieu nor Lamarck, but Linnaeus has been up to now the greatest botanical philosopher. M. L'Héritier, my old friend, has been for me one of those who has treated with the greatest precision the descriptive part of botany-philosophically and with the greatest logic and systematic Linnaean method. ${ }^{34}$

New natural means of plant classification held no place in the heart of this old-school veteran.

Botany lost one of the old-school standbys in that year of 1818 when Casimiro Gómez Ortega died from an accident at seventyseven. Despite their previous strife, Pavón paid his respects to his onetime tutor, that "scholar of the Natural Sciences, great humanist, and Spanish Cicero," in a letter to Lambert. Curiously, Ruiz's death two years before had gone unremarked in Pavón's correspondence with the Englishman. The attention paid to Ortega may have been due to the fact that he had been a corresponding member of English scientific societies, including the Linnean. ${ }^{35}$

Lambert and Pavón tried to pick up the pieces of their shattered friendship, and, symbolically, again wrote in French. The Englishman offered to return the shells, but Pavón rejected the thought.

34. Ibid., No. 144, Madrid, Sept. 3, 1818.

35. Ibid. 
Let Lambert give away to amateur collectors any he did not want. There was no use in sending them to Madrid, for "no one will buy them; there are no amateurs [here] in that branch of natural history." 36

Pavón became increasingly alive to each nuance in their dealings. Late in 1818, when Lambert grew impatient at shipping delays, Pavón rushed to explain that he had been ill. Without fail, he would work all of January to get the specimens ready. "You must not doubt it, on my word of honor.... I still preserve the vivacity and fire of my youth, and consequently my heart knows as yet neither apathy nor inactivity." 37 When Lambert announced in a letter of March 30, I8I9, his satisfaction with the new specimens, Pavón turned handsprings. "You do me a great honor to keep me in your affection all of your life.... We will be two allies and faithful friends bound together and joined like Ivy to Elm."38

Amidst all of this good feeling, Pavón's son, just turned eighteen, began to dream of a job in England. With fatherly pride, Pavón told Lambert, "He is a fine boy," educated in mathematics, drawing, geography, Latin and French grammar, and he can speak French. "He is a hard-working youngster, very honest, and not dissolute." But the voyage to England was never more than a dream.

The Spanish naturalist had a fright in 1819 when Lambert failed to answer his letters for months. One indication of Pavón's unrest was his lapse again into Spanish. He was immensely relieved at the end of the year to learn that, though illness had silenced his English friend, recovery was on the way. Pavón's oversensitivity was never more evident than in his letter to Lambert upon this occasion. He could hardly wait for Lambert to rise from a sick bed, make a hasty examination of the shipments Pavón had recently sent, and, "with the natural and characteristic frankness of the English temperament," let the Spaniard know whether or not he was pleased. ${ }^{40}$ Apparently Lambert was.

In truth, except for the flare-up over the shells, and the flurry over membership in the Linnean Society, their correspondence in these years was friendly. By the end of 18 I 9 Pavón was even hoping

36. Ibid., No. I45, Madrid, Oct. 7, I8 18.

37. Ibid., No. 147 , Madrid, Dec. $21,1818$.

38. Ibid., No. I49, Madrid, April 19, 1819.

39. Ibid., No. I5 1, Madrid, June 24, I 819.

40. Ibid., No. 152, Madrid, Dec. 13, 1819. 
again to be invited into the society, and in May, 1820, he finally bridged that chasm by being elected a foreign member. Ultimately Pavón remitted to Lambert an entire set of the drawings for the unpublished Volumes IV and V of the Flora. ${ }^{41}$

\section{THE LIBERAL RENAISSANCE}

A heart-rending note from the printer Gabriel de Sancha, whose firm and family faced "inevitable Catastrophe" for want of payment, served to refresh the memory of Pavón and the government that the Flora was still unfinished. As I 8 I 9 drew to a close the crown proposed a pitiable means to pay the bill, now seventeen years overdue. Sancha was asked to accept in lieu of his money, one hundred copies of the Prodromus, the only volume of the series in government hands. Needless to say, he refused, though three years later his son agreed to take fifteen copies, if they were not considered as partial payment. ${ }^{22}$

In I 820, however, as Liberal winds cleared the air after the Riego revolt, the Flora had a chance to take on a new glow. Supervision of the project came into the hands of the "Junta for the Protection of the Museum of Natural Sciences." In the laudable hope of removing the Flora from the stagnancy of dead center, the junta on July 30, I 820, asked Pavón for a complete report. He answered nearly two months later, to their surprise, that he had "always tried never to flinch in his duties." The poor man, his guilty conscience showing, was expecting a third degree, and took refuge in saying that he had never received a command to submit to the junta. That body replied in amazement that Pavón could speak directly to the ministry if he chose, but wouldn't he please be quick about providing the necessary data? After all, they wanted no more at this stage than to learn the past history of the Flora. ${ }^{43}$

4r. Ibid., Nos. 151 and 152, Madrid, June 24 and Dec. 13, 1819. A letter of Thomas O'Grady, General Secretary of the Linnean Society, to the author, London, Nov. 26, 1960, confirms Pavón's election as a member.

42. Petition of Gabriel de Sancha to the king, Madrid, Nov, 16, 1818. MCN. Marqués de Mataflorida to Pavón, Palacio, Dec. 25, 1819. Archives of the Jardín Botánico de Madrid, Reales ordenes pertenecientes a la Flora Peruana y Chilense, No. 5. Hipólito de Peiroso (of the Contaduría General) to Secretario de Estado y del Despacho de Hacienda de Yndias, Madrid, Oct. 2 I, 1829.

43. Museo to Pavón, Madrid, July 30, 1820 ; Pavón to Secretario de la Junta de Protección del Museo, Madrid, Sept. 19, 1820. MCN. 
Having been reassured, Pavón complied with a brief summation that could as easily have been written a dozen years before:

I. Volume IV was ready to print.

2. Volume V was "very far along" and work was still going on.

3. He was preparing a monograph on quinas, with data on over fifty new species. tabilium.

4. He was also working on Volume II of the Systema vege-

5. Gálvez was correcting drawings, making new ones, and coloring them.

6. Pavón knew nothing of the fiscal status of the enterprise, but thought that fewer than 40,000 reales remained in the publication fund. ${ }^{44}$

The junta, with the inborn suspicion of any regulatory body, next wanted to know where the profits (!) had gone. Pavón again pleaded ignorance. He knew that Gabriel de Sancha (or rather, his son Yndalecio, who had inherited the printing business), was still owed over 36,000 reales, and still held possession of the printed texts of all volumes except the Prodromus. The junta tried next to gain control of all the printed copies, ${ }^{45}$ but Sancha refused to let them go. The correspondence evoked a persistent theme: the Flora must avoid time-wasting interruptions. Let's bring unity to it; let's pay off its debts. Can we calculate when it will be done? ${ }^{46}$

At some point in the past four years, probably very recently, and for scarcely logical reasons, Pavón had received a raise of 3,000 reales a year, giving him a total of 17,000 reales. Now the draftsman Gálvez thought he deserved the same, because of the "sameness of their services." ${ }^{\text {47 }}$ Pavón, too, had a new resolve: having failed to get his son and namesake José Antonio a job in England, he now hoped to place him on the staff of the Flora Peruviana.

Gálvez failed to convince the ministry, ${ }^{48}$ but for a time it appeared that Pavón would succeed. The professor of botany at the

44. To Junta de Protección del Museo, Madrid, Sept. 27, 1820. MCN.

45. Junta's note of Oct. 2 and I6, I 820 ; Pavón to junta, Madrid, Oct. 6, 1820; junta to Ministerio de la Península, Oct. 28, 1820. MCN.

46. See esp. ibid.

47. Gobernación de la Península to Protector del Museo de Ciencias Naturales, Palacio, Sept. 20, 1820. MCN.

48. In a letter of Juan del Gayo to Secretario de Estado y del Despacho de Hacienda de Indias, Madrid, April 21, I829 (MCN), Gálvez's salary was still recorded at 14,000 reales and Pavón's at 17,000 . 
garden in Madrid, Mariano La Gasca, was charged to investigate Pavón's request. Pavón had said in 18 I 5 that he did not "cultivate" La Gasca, that he had no close ties with him. By 1820 , however, they seem to have become quite friendly. ${ }^{49} \mathrm{La}$ Gasca concluded that a man was needed to care for the collections and act as clerk, making copies of the plant descriptions worked up by the senior Pavón. The clerk must be chosen with care. He must write Spanish and Latin to perfection, and be informed in the humanities "at least pretty well." José Junior easily met this test, ${ }^{50}$ and besides was "a young man of good habits, with a very good intellectual aptitude." Importantly, he was very "addicted to the new institutions," a phrase that had special significance in the prevailing political climate. He had risen to the rank of sergeant second class of the first company of the second battalion of the national militia in Madrid. The professor was personally aware of the young man's knowledge of botany, and his reasonably good artistic ability, for he had been La Gasca's pupil.

All in all, he seemed to La Gasca no "mere pen pusher," but a good catch. With some training on the job and a few years added to his nineteen, he would become a likely successor to his father. He deserved a decent salary, say 6,000 reales, which could be increased as he learned more of plant science and the "indispensable" physics and chemistry.

It is an incontrovertible truth that Spain has spent more wealth than any other European nation in fostering progress in the natural sciences, and particularly botany. It is also true that she has never received the fruits to be expected from so many sacrifices. One of the principal causes is having abandoned or at least neglected the - enterprises after having made the principal expenditures.

If the Flora were not to become yet another failure on the scrap heap of Spanish penury and procrastination, the government ought to hire the new clerk, pay old Don José more money, and give the nearly done volumes the needed financial help. These would then be con-

49. "Letters to Lambert," Nos. 104 and 107, Madrid, July 31 and Aug. 9, 1815. Pavón refers to La Gasca frequently in later correspondence with Lambert.

50. Pavón presented certificates to verify his studies in Spanish and Latin grammar, rhetoric, arithmetic, algebra, geometry and trigonometry, geography, logic, drawing, and the French language. He was at the time studying English. (Statement by the elder Pavón, enclosed with his letter of Oct. 6, 1820, to Martín de los Heros, secretary of the museum junta. MCN.) La Gasca's reply was sent to the museum from Madrid, Nov. I1, 1820. MCN. 
cluded "with the speed that scientific progress, the welfare of the country, and the honor and luster of the nation demand."

The museum junta decided against a salary for the young man, but agreed to recommend a grant-in-aid from money once alloted to Ruiz's stipend. They would thus avoid tying funds up forever, in case young Pavón proved incompetent. The son could work on the Flora, all right, but let him do it without pay, "acquiring worthiness that will be noticed at the opportune time." that Pavón Junior ever accepted the challenge. Six years later he was working in the auditor's office of the Cádiz customs house. ${ }^{53}$

The stirring political events of 1820 set new fires aglow in the breast of Pavón. The Flora, he knew, could not be rebuilt in a day, but perhaps it was time to lay fresh foundations. We ought to see progress, he wrote to Lambert on May 25, I 820,

as soon as the great edifice of the temple of liberty of the Spanish Nation melts in the great crucible the chains that this Peninsula used to drag along at the bidding of the Despotism, and destines this insufferable iron weight to the shaping of arms to divide among the Citizens, to defend their liberty, independence, their common and individual rights, [and] their fundamental laws, molded and stamped out of the Sacred Constitutional Code, and to be always vigilant in opposing even unto death the despotic oppressors of liberty, whether interior or exterior.

This is a new picture-Pavón the Patriot. The Patriot, though not the Republican, for he enclosed with his letter to Lambert a copy of a "sublime and true eulogy" and engraved portrait of Isabela la Católica, "one of the queen-heroines we have had in Spain," a monarch "worthy of all praise." 54

The "new course of the Spanish political ship," as Pavón described it, is reflected in more activity at the botanical office than we have heard about for years, though no more, in truth, than took place in I8r9. At least the government again paid the rent. The account books begin to show some payments to advance the Flora:

51. Ibid.

52. Junta of the museum to Ministerio de la Gobernación, Madrid, Nov. 27, 1820 ; Gobernación (Sección de Instrucción Pública) to Protector del Museo, Palacio, Jan. $19,1821$. MCN.

53. Pavón to Philip Barker Webb, English plant collector, no date but apparently 1828 , sometime after Jan. 14. Also see Webb to Pavón, Seville, Feb. 3, 1826. Archives of the Istituto Botanico della Università di Firenze (hereinafter" "Webb Correspondence"). I am indebted to Professor Alberto Chiarugi, director of the Istituto, for a microfilm copy of the letters between Webb and Pavón.

54. "Letters to Lambert," No. I53, Madrid, May 25 , 1820. 
342 reales in 1819 and 288 in 1820 to engrave letters and numbers on the plates for Volume $V ; 70$ reales in 1819 and 39 reales in 1820 to correct previous plates "for the forthcoming reprinting" (!); 480 reales in 1819 to engrave the drawing of the Unanuea febrifuga for Volume $V$; 52 reales in 1820 to polish two copper plates for the engraving of Volumes V and VI. ${ }^{55}$ The accounts, of course, reflect only the expenditures made to outside helpers; we do not know of the salaried people. The record is not exciting, but one might call it encouraging.

Yet there were no signs of a let-up in Pavón's extramural affairs. He still filled special orders for Lambert and notified him on August $2 \mathrm{I}, \mathrm{I} 82 \mathrm{O}$, that he was sending the finished plates for Volume V. And when the Englishman heard that Pavón was about to let someone else have his "great Spanish and American Herbarium," and a collection of American fruits, Pavón had to placate him with this message:

My good friend Mr. Lambert. You have no motive for complaint in saying that I haven't preferred you in asking if you would like to buy my great Spanish and American Herbarium composed of duplicate and multiple specimens of many plants, and of American fruits, also duplicates and multiples-both well preserved and good specimens. Please know that up till now I have made no pact or agreement of any kind. Also, I inform you that the English consul who was here wanted to buy all my Herbarium, and you ordered me to suspend action; I complied, giving him an honest apology and never spoke again about the matter.

But the issue was still alive, for Pavón now specifically asked Lambert to put in his own bid, and quickly, with the implied hint that otherwise Pavón would go elsewhere. If Lambert should decide to buy, Pavón asked part payment in a gold watch of the best English make, worth perhaps 3,000 reales. ${ }^{56}$ The correspondence file breaks off before we learn of Lambert's decision. One would think he had already bought nearly every specimen in Pavón's collection. But in I 824 , when the known letters resume again, Pavón is still sending him plants.

55. Accounts for 1819 and 1820 , dated Dec. 31 of each year. MCN. The government paid the botanical offce a total of 5,019 reales in 1819 and 5,500 in I 820 to cover operating expenses.

56. "Letters to Lambert," Nos. I 53 and 154, Madrid, May 25 and Aug. 21, 1820. 


\section{TREADMILL TO NOWHERE}

By midsummer of I 82 I the spirit to save the Flora was still willing, but the flesh-and-blood funds were weak. The office rent was again six months overdue and earlier deficits remained unpaid. But enlightened ministers induced the king, subject to congressional approval, to provide funds from the "unforeseen expenses" account, and the Flora was reprieved again-only to have Pavón fall ill with "black bile" and take himself off for a rest cure to the village of Cienpozuelos. ${ }^{57}$

The stopgap measures brought no real relief. If anything, matters were worse. The landlady now chose to tear down her building in order to erect new rooms, and office space was as scarce as money. The ministry saved the day by moving Pavón's headquarters about mid-June, I822, into the former Jesuit Colegio Imperial ${ }^{58}$ where the Dirección de Estudios and Universidad Central held forth. Within a few months university officials were demanding his eviction in order to take over his quarters, but Pavón rode out the storm. In fact, he became quite attached to the place. It was big enough, he said, to house the collections of all the scientific expeditions of America. More important, the government still budgeted 500 ducats a year for expenses, even though Pavón no longer paid rent. At those fortunate times when the government actually paid him the sum (admittedly not very often), he could use it all to provide for "great progress toward publication of the Flora." ${ }^{29}$

57. Pavón to Ministro de Hacienda, Madrid, June 20, I82 I, and attached correspondence, including Antonio Barata to Secretario del Despacho de la Gobernación de la Península, Palacio, July 17, I 821 ; Pavón to Junta de Protección del Museo, Madrid, Aug. 31, 1821, and letter of concession, Sept. 2, I821. MCN.

58. Manuel Josef Quintana, Dirección General de Estudios del Reino, Sección de Escuelas Especiales, to Secretario de Estado y del Despacho de la Gobernación de la Península, Madrid, June 26, 1822, and attached papers. MCN. The matter was referred to the Cortes on March 1, 1823. See MCN, 1823. The date of moving is calculated from the fact that rent was paid only until June 18,1822 . See "Pliego de reparos a la cuenta presentada por $\mathrm{D}^{\mathrm{n}}$ José Pavón," June 22, 1824 , Archives of the Jardin Botánico de Madrid, Reales ordenes pertenecientes a la Flora Peruana y Chilense, No. 22.

59. "Nota" to letter of Jesuit provincial to Ministerio de Hacienda, Madrid, Feb. I 2, 1824. MCN. José Mariano Vallejo, Dirección General de Estudios, to Pavón, Madrid, Oct. 22, 1822. Archives of the Jardín Botánico de Madrid, Reales ordenes pertenecientes a la Flora Peruana y Chilense, No. I2. Pavón to Junta de Protección del Museo de Ciencias Naturales, Madrid, March 15, 1824; Pavón to Ministerio de Hacienda, April 20, 1824. MCN. 
But liberalism died in Spain in 1823 and Ferdinand VII became an absolute monarch once more. The Jesuits, who had been suppressed since August 17, 1820, would soon return to the colegio. Anticipating complications, Pavón sought in August, 1823, to nail down his right to stay at the school, on the grounds that, by means of the Flora, he was bringing honor to the state, as well as saving it money. (Presumably, he meant that all of his allowance could be spent directly on his work and not wasted on rent.) At the moment the Jesuit provincial, Pedro Cordón, had no complaint, for very few members of the order had yet begun to occupy the building.

By February, I 824, however, he saw things in a different light. Novices were pouring in to begin their training for service in the resuscitated order, only to find their intended quarters filled with army troops. They had to huddle together, two or three to a room, like patients in a hospital, "without the comfort and liberty appropriate to the religious life." The king had promised to return to the Jesuits all of their possessions and he could well start by vacating the botanical office. ${ }^{60}$

Pavón, receiving orders on April 8, I824, to move out of the colegio, tried to bargain. He had no money for rent in a new establishment, having spent his allowance, he said, on supplies and plates for the Flora. ${ }^{61}$ If the government would like to pay the arrears of September, I 821 , to May, I823, some 9,625 reales, plus current credits of I,375 reales for February-April, 1824, he would be glad to move. The Ministry of the Treasury, dragged into the affair with little knowledge of its antecedents, acted with the usual caution. Aware that Pavón had had to pay no rent since mid-1822, they wondered why he deserved the arrears. He had used his allowance to make "great progress" on the Flora? What progress? Had he published anything since $\mathrm{I} 802$ ?

The botanist meanwhile turned to the Minister of State, who had recently, by a fluke, inherited supervision of the Flora. Pavón induced him to try to change the Jesuits' mind, on the grounds that the crown would save 500 ducats a year if the Flora remained at the colegio. But Father Cordón refused to budge, protesting vigorously Pavón's "subterfuges" and "tergiversations." The Ministry of Grace

60. Pedro Cordón to Ministerio de Hacienda, Madrid, Feb. 12, March 16, and May 29, 1824, and "Notas" of the ministry regarding these letters. MCN.

61 . Unfortunately, the record of expenditures for 1823 is missing from presentday archives. 
and Justice, about to take over direction of the Flora again, now chimed in. Since when had Grace and Justice worried about saving a mere 500 ducats? The Flora might be of great import, but was it preferable to the spiritual nourishment and the teaching of youth that His Majesty sought in reconstituting the Society of Jesus? Treasury now became concerned over whether Pavón had illegally accepted government money, but seemed happiest at the thought of dumping the problem into the lap of Grace and Justice. ${ }^{62}$

Having ruined the digestions of three ministries and the Society of Jesus, Pavón moved out on June I, I 824, to Calle Toledo number 5, overlooking a gate of the Plaza Mayor. Five porters carried the office impedimenta on their backs. Pavón dipped into his purse again to pay the carpenter who built his shelves, the painter who made a new sign for his doorway, the cabinetmaker who fixed his mahogany furniture piece, and the workman who repaired his bell cord. At last the new portrait of His Majesty was hung on the office wall and Pavón could again get down to botanical business. Months later Grace and Justice was still trying to learn whether Pavón owed it money, or the other way around. ${ }^{63}$

Obviously, ministerial authority was even more changeable than the site of the botanical office. The Interior department had had to learn the ropes in I820. Even here liability oscillated between the "Overseas" and "Peninsula" branches. In 1822 , some of the papers came into the hands of the Dirección General de Estudios, but when the king was restored to power in 1823 the files, such as could be found, ended up in the Office of State. By then no one knew which way to go, and the monarch decided to return the Flora to its ancestral home in the Ministry of Grace and Justice for the Indies. ${ }^{64}$ Repetitious briefings, prolonged deliberations, uninformed decisions, division of responsibility, and lost documentation were inevitable results.

62. Pavón to Ministerio de Hacienda, April 20, 1824; Provincial to Hacienda, May 25, 1824; Conde de Ofalia, Minister of State, to Cordón, Aranjuez, May 18, 1824 , and "Notas" of the Treasury ministry with reference to these letters. MCN. 63. Pavón to Ministry of the Treasury, Madrid, June 13, 1824; cuenta for 1824 , dated Dec. 31; "Nota" following summary of a letter from Pavón of Jan. I2, 1825. MCN, I824.

64. Ministry of Grace and Justice to Ministry of State, Aranjuez, May 31, and San Ildefonso, Aug. 31, 1824. MCN. See also Josef Aznárez of the ministry for ultramar to Pavón, Palacio, Oct. 12, 1823, in Archives of the Jardín Botánico de Madrid, Reales ordenes pertenecientes a la Flora Peruana y Chilense, No. 21. 
The futility of expecting to finish the Flora Peruviana was apparent to anyone who would face the facts. Yet, ministerial innocence and a Spanish propensity for planning the impossible led the government to even wilder schemes. Pavón was appointed in February, I 824 , to a committee to prepare for publication the vast collections of José Celestino Mutis: 4,000 manuscript pages and some 7,000 drawings of 2,700 species, the result of thirty-three years of effort (1783-1816) in New Granada by close to fifty men! Many boxes had never been opened since their arrival in Spain. Signs of neglect were rife. Yet, here was a committee supposed to start work, at least to put the plants in order: Antonio Sandalio de Árias, professor of agriculture and president of the junta of the royal botanic garden; Vicente Soriano and José Pavón, "professors"; and Isidro Gálvez and Antonio Delgado Meneses, draftsmen.

Sandalio de Árias had already notified the Department of State of the absurdity of assigning to the task a man like Pavón, who had undeniably reached an "advanced age." Even if he still had the vigor of youth and "all the aptitude imaginable," he could not finish the Flora Peruviana in one long lifetime, let alone study the other collections.

Although the ministry now saw its error, it did not withdraw his appointment. Nor did Pavón demur. The enterprise could move in with him at the Jesuit colegio, where he still held forth when the plan was first proposed; one suspects he thought it a means of preserving his place at the school. The collections of Peru, New Granada, and New Spain, and that of Louis Née ought to be together, he said, for the sake of easier comparison.

Sandalio de Árias, however, feared to take action without the approval of Simón de Rojas Clemente, the former overseer of the Mutis collection, who had retired to his native village for reasons of health. No one could fill his shoes. The only other knowledgeable custodian had been Mariano La Gasca, former professor at the botanic garden, but he was in disgrace, having been a member of the liberal Cortes. With the restoration of the king to full power he had fled to London, where he would remain for a decade. ${ }^{65}$ Sandalio de Árias did not even examine the boxes until November, when he found them losing a battle with the rats and the rains. Meanwhile, Árias himself had been declared "impure"-loyal to the ousted revo- 
lutionists-and his right to serve on the Mutis committee was thrown into doubt. Pavón soon moved out of the Jesuit colegio. It need hardly be added that the Flora of New Granada advanced no closer toward completion. ${ }^{66}$ (Footnote to history: The Spanish and Colombian governments in 1954 began to publish a beautiful set of $5 \mathrm{I}$ volumes of the Mutis collection. By the following year three volumes had appeared, but there is still no sign of a fourth. $)^{67}$

In 1824 it is doubtful that Pavón did much to foster his own Flora Peruviana. He paid 300 reales to Pedro Nolasco Gascó to refinish the engraving of the rataña plant, which had originally appeared in Volume I; 480 reales to Isidro Gálvez to engrave the cascarilla fina de Uritusinga, for publication in the projected Nueva quinologia; and 50 reales to buy the polished plate. And even though he purchased 37 quires of fine writing paper and eleven of ordinary, ${ }^{68}$ we are left to wonder whether much was done, for Pavón was still selling specimens to Aylmer Bourke Lambert.

\section{A FEW QUESTIONS OF PROBITY}

Dealings with Lambert approached a shattering denouement. Pavón's disillusion began to take hold in October, I824. He was deeply in debt and asked Lambert to settle his account by a draft payable at once. Imagine Pavón's chagrin to learn that, after much

66. Conde de Ofalia to Junta de Protección del Museo, Palacio, Feb. I, 1824; Sandalio de Árias to Secretario del Despacho de Estado, Madrid, Dec. I7, 1823 ; letters of Sandalio de Árias, Pavón, and Soriano to junta, Madrid, March 14, 15 , and 2x, 1824; Sandalio de Árias to Antonio Gutiérrez of the junta, Madrid, Sept. 27, 1824; Pavón to Gutiérrez, Oct. 28, 1824; Sandalio de Árias to junta, Nov. 27 , 1824 ; junta to [Ofalia?], Madrid, Dec. 15, 1824. MCN, 1824 .

The painter Antonio Delgado Meneses in late 1824 , when no immediate action was apparently in prospect, petitioned to be added to the staff of the Flora Peruviana. $\mathrm{He}$ was temporarily refused by the crown until he could acquire more experience. He must, however, have been given some work, for in 1828 he petitioned for a regular salary. The king decided that when Isidro Gálvez should vacate his job, Delgado Meneses be kept in mind. Meanwhile, he could be paid for any work done at the request of $\mathbf{P}$ avón; financial circumstances permitted no further generosity. (Francisco de Zea Bermúdez to Pavón, Palacio, Dec. 20, 1824, and Jan. 19, 1825 ; Ramón Garces de Marcilla to Pavón, Madrid, March 27, 1828; Manuel González Salmón to Pavón, Palacio, May 11, 1828. Archives of the Jardín Botánico de Madrid, Reales ordenes pertenecientes a la Flora Peruana y Chilense, Nos. 25, 26, 29, and 30.)

67. Flora de la Real Expedición Botánica del Nuevo Reino de Granada.

Ediciones Cultura Hispánica.

68. Cuenta for I824, dated Dec. 3I. MCN. 
delay, the Englishman was sending a partial payment of 4,500 reales, not even collectible until the following January!

Lambert's choice of a 90-day letter is unclear, but the partial payment stems from discontent with the latest shipments of Pavón. The Englishman protested receiving sometimes only one specimen instead of two; Pavón said he had no more. These were now almost exclusively plants from New Spain, but it also irked Lambert to find I 50 Peruvian plants, long ago a part of his collection, among them.

Pavón, hating his beggar's role, was nonetheless reluctant to concede his mistake. "You well know," he wrote to Lambert, "that I am somewhat frank, though not as much as you." If Pavón had sent Peruvian plants, it was because Lambert had asked for them. They were good specimens, esteemed by botanists everywhere. But surely this was not cause for severing "the tie of our old friendship." Though suspending work on Lambert's behalf, Pavón in October, I 824, also canceled all accounts payable, and made a proposition for the future. He would resume shipments if Lambert would henceforth send a draft as soon as notified that the plants were ready. Pavón in return would not collect on the draft until Lambert had received the plants. He would calculate his waiting period from the average shipping time between Bilbao and the English port. ${ }^{69}$

By July, I 825 , however, Pavón's illusion of idyllic friendship with Lambert had vanished forever. We do not know all that happened in those nine months. We know little of Lambert's side of the story. But there is much in Pavón's eloquent letter of July I8, I 825 , now picayune, now plausible. He was shaken. He had restudied minutely the correspondence of this past decade. In a series of steps he re-examined the justice of his own position and found it firm:

I. Where was Lambert's decency in the matter of the rejected sea shells? Pavón had given him carte blanche the right to discard them, but had Lambert ever told him of their final disposition?

2. What right did Lambert have to confiscate the Peruvian plants he had refused to pay for? Certainly he must not have burned them or thrown them in the trash bin. There were plenty of botanists in Madrid who would have been glad to have them. Not even an Indian would act in Lambert's fashion. "There are as good men - among the Indians as any in England."

69. "Letters to Lambert," Nos. $155,156,157$, Sept. 23, and Oct. I I and 22, 1824. 
3. Why had Lambert refused to pay Pavón by a sight draft? He could not blame his agent Mr. Matthiessen for that error, for it had happened twice.

4. Why did Lambert agree to a stipulated price, and then when Pavón had remitted his plants, take the advice of friends that they were too expensive, and refuse to pay? This was the crux of the argument and Pavón poured forth his soul. Here are his words, in the translation prepared for the eyes of Lambert himself:

Have the goodness to answer this question categorically. Why did you not take the advice of your friends at the very beginning if the value of each exemplar of the American plants great and small was dear, excessive or exorbitant? And did you not agree with me that for every I,000 plants of a single exemplar each the value was to be set at 4,000 reals? as in fact you paid me till the last payment? Why did you not tell your friends that there had been a formal and infrangible agreement, and it is probable that they would have done justice even though the question had related to pieces of stick. You thought doubtless that I was to submit to an undervaluing of exotic plants of so much interest, as well as of so much cost and difficulty in procuring, examining, determining and describing them. This I call wandering from the question and lastly after obtaining the plants you have given me the law and done what has been dictated by your arbitrary pleasure, trampling on reason; passing over every thing and ordering me imperiously as a Lord orders his slave. My education which has not been common does not permit me to repay you with personalities and reproaches of the greatest audacity. You have made a most unjust comparison of my proceeding with that of the haggling and hawking Jews. I thank you. Foreign and native scientific bodies have not so honoured me. For the honour, and salutations you have given me in your two late letters particularly the last, do more detriment to you than to me.

If I had been disgraced as many Spaniards who reside in your capital of beneficence and had undergone the same fate and taken refuge at London I have no doubt I should have shown myself to you, we should have had an interview and I should have convinced you with powerful arguments that such is not the way of acting among men who think, but that it belongs to those who forget and debase themselves. It is however enough and I beg you to suffer this little but just effusion.

Pavón wedged in one final remark as he closed the curtains on a decade: "Your attentive servant and man of good will, who bears no resemblance whatsoever to the Jews, as you have thrown in my face in writing."

70. Ibid., No. 158, and translation, No. 159, July 18, 1825. 
The government had a chance in I 825 to look into Pavón's behavior, but seems to have virtually passed it by. The matter came into the open as the result of a dispute between Pavón and the botanical office porter, Domingo Robles, who had been hired in 1819. Pavón charged him with stealing copper plates. Robles responded in kind by telling the authorities that Pavón had, upon "various occasions," "removed and sold for practically nothing" objects belonging to the office. He especially mentioned them as having been remitted to France (!). Furthermore, Pavón had, in "coarse and dirty language," both written and oral, showed himself "not devoted to His Majesty." As a result of this interchange of words, Pavón had fired Robles.

Documentation is tantalizingly brief, and many questions remain unanswered. But despite the probable truth of both allegations against Pavón, he apparently escaped unscathed. Nor did Robles suffer a penalty, other than temporary loss of his job. Robles presented a detailed list, now unfortunately lost, of the items Pavón is alleged to have sold. He also claimed that the police commissar had found some of the missing objects. Yet when the Alcaldía de la Real Casa y Corte undertook to investigate the charges, it apparently could not find an office inventory in order to make a comparison. Nor could it gain police co-operation. Accusations of Pavón's disloyalty must likewise have been taken lightly.

Robles is made to appear the greater malefactor of the two. Pavón submitted proof of the porter's misdeeds with the copper plates, saying that "a man so openly declared to be his enemy, and, who by his bad conduct, is capable of attempting all manner of crimes, cannot inspire in him the slightest confidence." The report of the police commissar is said to have done "mighty little" for Robles. And it was Robles' loyalty to the crown that ultimately came into doubt, though he was at last "purified," after nearly a year of discussion, on November 27, I 825. Pavón, it turned out, could not fire the porter, for Robles had been appointed by order of the king. ${ }^{71}$

If Pavón escaped censure for selling government goods, he could not evade other questions in the minds of his bosses. They had begun

71 . See esp. the "extracto" in MCN, 1825, beginning with Jacobo María de Parga to Primer Secretario de Estado y Despacho, Palacio, Jan. 3 I, I 825 , and ending with ministerial action on Nov. 27,1825 . To complicate matters, the cuenta of 1825 (MCN) indicates that Robles was ill in 1825 and was in the process of paying a substitute, Rafael Pardal, at the rate of 6 reales a day. 
to wonder again, not what Pavón was doing to them, but was he doing anything for them? When Pavón protested by the end of 1825 that the office salaries and expense money were at least six months overdue, ${ }^{72}$ the king countered by demanding a report of all accomplishments of the staff since October $1,1823 .^{73}$ (This date had marked the official return of the king to full power after the liberal revolution.) Once more the foolish opéra bouffe had come full circle: Pavón could not get money because he was doing nothing; he was doing nothing because he could get no money. ${ }^{74}$ We thus must insist on the humor in a memorandum Pavón directed to the museum junta on July 27, I826: Please take note at your next meeting of thirtytwo seeds from Havana I am sending, to be planted in the Jardín Botánico. And please send me an acknowledgement. The junta dutifully recognized Pavón's constant zeal and love of the science, of which he had given "repeated proofs."

Pavón continued to seek solace from trying times through correspondence with the outside world. Unable to find nourishment in the Flora Peruviana, he sustained his self-pride, assuaged his loneliness, added to his library, and kept abreast of the times by means of letters to other lands. Two of his correspondents were the great Alexander von Humboldt and Augustin de Candolle. ${ }^{76}$ And in 1826 he found another English botanist to take the place in his affections (and income) of Aylmer Bourke Lambert. His new friend was Philip

72. Cuenta for 1825 , dated Dec. 31. MCN. The account for 1826 (MCN) is contradictory in stating that the men were still owed nine month's pay for 1825 . The cuenta for 1825 is more detailed and very likely more accurate. The crown frequently found errors in Pavón's accounts.

73. Duque del Infantado to Pavón, Palacio, Jan. 6, 1826. Archives of the Jardin Botánico de Madrid, Reales ordenes pertenecientes a la Flora Peruana y Chilense, No. 27.

74. The cuenta for $1825(\mathrm{MCN})$ shows 60 reales to buy a copper plate. Out of a total income of 5,492 reales, rent consumed 3,650 . Another 672 reales was paid to the substitute porter, Rafael Pardal. Normally the porter's pay came from another source. In 1826 the office was able to pay only seven months' rent. The drawing of one plant, Cinchona lucumaefolia, intended for the Nueva quinologia, was engraved at a cost of 480 reales. Another 70 reales went for the purchase and preparation of a copper plate, and for the engraving of various letters and numbers. Meanwhile, the men went on buying paper, 18 quires of it, and spent 20 reales to repair seven straw chairs, so they were apparently putting the office to use in some fashion. (Cuenta of 1826 , dated Dec. 31. MCN.)

75. Pavón to Secretario de la Real Junta de Protección del Museo, Madrid, July 27, 1826, and draft of reply to Pavón, Aug. II, 1826. MCN.

76. Pavón to Philip Barker Webb, Madrid, Sept. 19, 1826, in "Webb Correspondence," Archives of the Istituto Botanico della Università di Firenze. 
Barker Webb (1793-1854), who had inherited a sizable fortune which enabled him to travel extensively in search of plants.

Webb became Pavón's "companion in botanic arms," "brother in a career in the natural sciences," co-partner in a "great and dominant passion" for "enchanting, wonderful, divine botanical science," and customer for his dried plants. Pavón is not so deferential to Webb as he once was to Lambert. Webb, in an early letter to Pavón, refers to the Spaniard as "such a celebrated botanist." "7

They carried on dealings while Webb traveled through the Peninsula, studying the plants of Portugal and southern Spain. During a year and a half he bought from Pavón (without ever meeting him), over 4,500 different species of dried plants, for which he paid 8,000 reales and expenses. There were specimens of all classes of Linnaeus from Peru, Chile, Guayaquil, Quito, New Spain, the Philippines, Havana, and Puerto Rico, 24 species of Cinchona among them. But Pavón could not touch the plants from New Granada, or those collected by Louis Née, for they were securely in control of the Jardín Botánico. ${ }^{78}$

The Spaniard had learned his lesson with Lambert and now demonstrated more caution in advertising his wares. Some of the plants, he said, were in bad condition from their very resistance to drying; others had been victimized by insects. But better something, though only a vestige, than nothing at all. Pavón also disclaimed thorough knowledge of some of his plants, especially, of course, those from areas he had not seen. And to forestall another source of vexation, he stated clearly that any duplicates were to be considered a gift. These extras, by the way, ran into the hundreds. ${ }^{79}$ But some words of Pavón have a familiar ring. These plants, he wrote, will "fulfill your desires, as happened with Mr. A. B. Lambert, who was

77. Pavón comments frequently in their correspondence on his brotherly relationship with Webb. Nine letters from Pavón for the period 1826-1828 may be found in the "Webb Correspondence" in Florence. Drafts of two of Webb's letters are also in the collection. The quotation above is from Webb's letter of July 29,1826 , from Málaga.

78. Pavón to Webb, July 7-29, Sept. 19, Dec. 26, 1826, and undated to Lisbon [1828]; Webb to Pavón, Málaga, July 29, I 826 . "Webb Correspondence." Pavón had turned over to Antonio Sandalio de Árias in 1825 the keys to the room housing the Mutis collection and was unable to get them back. (Pavón to museum junta, Madrid, May 30, 1827 . MCN.) Webb bequeathed his herbarium to the Grand Duke Leopold II of Tuscany; it is preserved today in the Istituto Botanico della Università di Firenze.

79. "Webb Correspondence," July 7-29, Aug. 15, Oct. 20, Dec. 26, 1826, and undated to Lisbon [1 1828 ]. 
very delighted." Webb, he hoped, would be no less satisfied with Pavón's "punctilious scrupulosity," which the Spaniard preferred "to all mundane and fleeting interests." 80 Indeed their correspondencewritten in Spanish-preserved a tone of cordiality throughout. Pavón selected a choice plant for his new genus Webbia, but could offer no predictions on a publication date. Webb, pleased at the honor, offered to pay the cost of printing. ${ }^{81}$

\section{SWAN SONG LARGO E SOSTENUTO}

If Pavón kept his foreign correspondence alive during the succeeding years-and we do not know if he did-he was fortunate indeed, for at home there was naught but decadence and despair. The landlord at Toledo number 5 had only partial success in getting the government to pay Pavón's rent for $1827 .^{82}$ During two more years his only recompense was an occasional payment from Pavón's own pocket, and in 1829 the landlord started legal proceedings to attach the property of the botanical office. ${ }^{83}$

Although Pavón could muddle through, the porter Robles was desperate. He, like Pavón, had escaped intact from the affair of the "stolen" goods, and was still on the office rolls. But when the government neglected to pay his small wage of eight reales a day (about one-sixth the size of Pavón's) it turned out to be a catastrophe. For many months during 1828,1829 , and 1830 , there was no sign of income for any member of the staff. In fact, by 1829 the government had even omitted the botanical office from the newly established budget.

Robles is a piteous figure as he begs for loving-kindness from the state. His wife is ill. He has no belongings to sell. Four days they have gone without hot food. He walks house-to-house asking for broth. On June I3, I 828, the crown, upon Pavón's recommendation,

80. "Webb Correspondence," Aug. 4, I826.

81. Pavón to Webb, Dec. 26, 1826, April 6 and May 25, 1827; Webb to Pavón, Seville, Feb. 3, 1827. "Webb Correspondence." At least three botanists, in addition to Pavón, dedicated a genus to Webb, but all of these plants are now considered to be members of other genera.

82. Francisco Diaz Lavandero, landlord of Toledo number 5, to Secretario del Despacho de Estado, Madrid, May 22, I 827 . MCN. Although the king consented to pay the landlord (Manuel González Salmón to Secretario del Despacho de $\mathrm{Ha}$ cienda, Palacio, Aug. 14, 1827. MCN), soon thereafter the rent was again in default. (Pavón to Ministerio de Estado, Madrid, May 22, 1828 . MCN.)

83. Pavón to Ministerio de Estado, Madrid, Oct. 20, 1829. MCN. 
gives him 30 ducats (about 4 r days' pay) "for one time only" out of charity funds. All of Robles' means are exhausted. He must take his wife to the baths. On August 20, I829, the crown gives him another 30 ducats from charity funds. Robles' wife is apparently incurable. A doctor has attended her the past forty days without charge. The medicine alone costs 600 reales. On April 17, I830, the crown gives him 50 ducats. He has also apparently received some back pay up to the end of I 829. He now asks for a new job. $\mathrm{He}$ is in "utmost misery." His wife has received all the sacraments. His two children, nine months and three years, have no means of support, not even alms begged at night. Now his wife is dead. There is no money to bury her. He has not a shirt left on his body nor a bed to sleep in. He has sent petitions to the crown on July I3, August 2I, September I2, and September 23, I830. On October I4 word comes at last from the king that the Flora staff will be paid again, including even some back salary, plus 6,490 reales for expenses during the previous two years. ${ }^{84}$

In 1828 , deep in its pit of despair, the office, of all things, had added a botanist. The move in reality only confirmed the melancholy state of the project. The newcomer was Dr. José Demetrio Rodríguez, former vice-professor of botany at the garden in Madrid. After hot words with one of his bosses, Rodríguez had asked to be retired on a pension. The museum junta suggested instead that he be added to the staff of the Flora Peruviana. His 8,000-real salary would then be chargeable to the Flora accounts. This is precisely how matters worked out. He officially joined Pavón on May 23, I 828, with pay retroactive to September I 8, I 827 . Yet in that same month of May, Rodríguez had been declared "impure" for disloyalty to the royalist cause. ${ }^{85} \mathrm{~A}$ vindictive observer might justifiably think the

- Flora Peruviana a boneyard for rejects.

84. Ministerial summary [Grace and Justice], dated Palacio, Feb. 9, 1829; Robles to Ministerio de Estado, Madrid, May 22, 1828; junta of the museum to First Secretary of State, Madrid, May 29, 1828; Pavón to Ministro de Estado, Madrid, May 22, 1828, and notes of May 31 and June 13; Robles to Estado, July 15, 1829; royal order to Director General de Correos, Palacio, Aug. 20, 1829; Robles' petition, Madrid, Dec. 4, 1829 , and ministerial comments, Jan. 6, 1830; Robles to Estado, April 7, 1830; royal order to Correos, April 17, 1830, and ministerial summary; Robles to Estado, July 13, Aug. 21, and Sept. I2 and 23, 1830; royal order to Directores Generales de Correos, Palacio, Oct. 14, I830. MCN. Back pay offered in 1830 was to be one-half of the salary owing since the establishment of the budget.

85. González Salmón to museum junta, Palacio, Jan. 18, 1828; junta to Primer 
As a further incongruity, Pavón and Gálvez asked for a raise. The request has a logical explanation. Both men at the time were seventy-three. Widows' pensions would amount to one-third the salary of the deceased. The bigger the salary, the bigger the pension. But the supervisory junta was logical, too, and refused the requests. ${ }^{86}$

Gálvez's wife, in fact, died before her husband. He passed on sometime in I 829 , and his daughter María sought to claim the pension. Because of her substantially younger age, the museum junta could recommend only 3,000 reales a year, or a little more than onefifth of the artist's salary. ${ }^{87}$

Statements of account for I 828-1830 show the same round of petty expenditures eating away at a too-often hypothetical 500 ducats the government was supposed to pay the Flora office. In I 828 Pavón bought a band of vari-colored ribbons so he could decorate His Majesty's portrait and hang it from a balcony upon the monarch's return from Catalonia. For the same occasion he must buy eight wool damask curtains to adorn his three balconies. And there were all the other "days of entry, birthdays, and days of His Majesty" to celebrate, too. The special office-cleaning sessions were a job for three menials, not for Domingo Robles. And when Robles cleaned forty old plates from Volume II he was paid an extra 100 reales. The expenditures directly on behalf of the Flora? In 1828 , a healthy 965 reales to purchase 24 copper plates, and another 580 reales to polish 29 plates in preparation for engraving; in I 829 there was 225 reales to clean 90 plates already engraved for Volume IV; in I830, a mere 80 reales paid to the daughter of the late Isidro Gálvez for an engraving he had done of Cinchona lucumaefolia. That is all. ${ }^{88}$

Ministro de Estado, Madrid, Jan. 31, 1828; González Salmón to Secretaría del Despacho de Hacienda, Palacio, March 11, I828; ministry to king, Feb. 21, 1828; draft of royal order to Rodríguez, Palacio, March I1, 1828; Pavón to Estado, April 18, 1828; González Salmón to museum junta, Palacio, May I2, 1828 ; notification to Secretario del Despacho de Hacienda de España, May 23, 1828. MCN, 1827 and 1828. Ramón Garces de Marcilla, secretary of the museum of natural science, to Pavón, Madrid, May 31, 1828. Archives of the Jardín Botánico de Madrid, Reales ordenes pertenecientes a la Flora Peruana y Chilense, No. 31 .

86. González Salmón to museum junta, Palacio, Jan. 31, I828, and marginal note of junta, Feb. 10, 1828 . MCN.

87. González Salmón to museum junta, Palacio, Oct. 28, 1829; junta to Primer Secretario de Estado, Madrid, Nov. 9, 1829 . MCN. We do not know if the pension was paid, but inasmuch as the daughter was assuredly not a minor, the case offers a certain interest for its picture of the Spanish attitude toward state support of dependent persons.

88. Cuentas of 1828,1829 , and 1830 . MCN. That of 1830 is in MCN, 1831 . 
Pavón, however, in 1828 also managed to remit to the botanic garden thirty-seven more seeds from Havana, as a "zealous lover of the Spanish gardens, though they be few and these extremely poor in so many indigenous plants and still worse in exotics." ${ }^{\text {"8 }}$ Pavón could not even use the garden library when it suited his fancy. In 1828 he tried to borrow Jacquin's Hortus Schoenbrunnensis and all the dried plants, drawings, and descriptions of quinas in the garden collection, to make comparisons for his Nueva quinologia, which was "very far along" toward completion. The garden overseer could but reply that the teachers needed these things, and too many borrowers had in the past shown "little refinement" by failing to return valuable items to the library. The royal order requiring the garden to give Pavón "all aid" meant that he should be helped within the bounds of the establishment. If Pavón wanted to come to the library, fine! As soon, that is, as the librarian had put things in order and could be there at the customary hours. ${ }^{90}$

If Pavón felt neglected, he could scarcely compete with the House of Sancha for patience amidst trying times. Yndalecio Sancha in 1828 took up his vigil again in the hope of seeing his father's bill for printing the Flora, a quarter-century overdue, honored by the government. This necessitated another round of probing: what ministry was responsible? how many copies were printed? how many sold? who got the profits? who held the unsold copies?

There is no reason for the government to have failed to pay Sancha in full. Pavón many times had supported the claim, and the museum junta had agreed. A treasury spokesman pointed out that the debt could be liquidated with ease. But Sancha's petition had stirred up a forgotten issue: what had happened to moneys collected in America to sponsor publication of the Flora? ${ }^{91}$ As long as this question lay unresolved, Sancha's case was hopeless. In all justice, he should have been paid from emergency funds while the ministries argued about the ultimate source of the money. But bureaucracies are never happier than when toying with problems like these. $\mathrm{MCN}$.

89. To museum junta (Ramón Garces de Marcilla), Madrid, April 15, 1828.

9o. Pavón to Garces de Marcilla, undated; Conde de Argillo to museum junta, Madrid, May 5, 1828. MCN, 1828 .

9r. Junta de Protección del Museo de Ciencias to Primer Secretario de Estado y del Despacho, Madrid, July 17, 1830 ; Victor Soret to Miguel de Lardizábal, Madrid, Oct. $28,1814$. MCN. 
There was only one other solution: to sell the remaining copies, perhaps at a lower price. With little comprehension of past sales history, the Treasury naïvely suggested that the tomes find buyers in Cuba, Puerto Rico, and the Philippines, practically the only possessions remaining of the vast colonial empire. There was one indisputable conclusion: "Whether it's to pay Sancha, or recover the costs, or derive the benefit that reading these books is supposed to produce, they ought to try to sell them before the dust and moths destroy them any more than they perhaps are already." ${ }_{92}$

It was inevitable that someone should ask again that most awk ward and unanswerable of questions: What do they do in this mysterious office? What have they done these many years? Now, for the first time in these many years, someone began to ask the next, and most painful, and most obvious question: Ought the Flora to be finished at all? As a first step, the Council of Ministers decided to unite all of the papers from the many ministries that had handled Flora affairs (a familiar suggestion) in the hands of the Junta for the Protection of the Museum of Natural Sciences. The junta would in turn advise what to do next.

The ministers also wanted the junta to take direct possession of the Flora Peruviana. But where could its belongings be put? The herbaria of Cavanilles and Née were already fit food for the rats and the moths in a dusty garret at the museum of art. If the government would only assign the junta a new site! ${ }^{93}$ With Pavón's rent again eight months overdue in February, $1831,{ }^{94}$ the crown conceded the point. It instructed the junta to investigate costs of renting a site to house all of its many activities, or to offer any other solution within reach of "the present poverty of the Royal Treasury."

The junta jumped to the task with delight, and resurrected a plan to build two salons over some old tanks at the botanic garden. With

92. Pavón to Garces de Marcilla, Madrid, July 12, 1830; museum junta to Secretario de Estado y del Despacho, Madrid, July 17, 1830 ; Rafael Morante, contador general, to Secretario de Estado y del Despacho de Hacienda, Madrid, Feb. I8, 1830; Treasury ministry summary, March, 1830. MCN.

93. Treasury ministry notes, March, 1830; González Salmón to Diego Clemencín, Palacio, June 5, 1830; draft of junta letter to Primer Secretario de Estado y del Despacho, Madrid, June I6, 1830. MCN. González Salmón to Pavón, June 5, 1830. Archives of the Jardin Botánico de Madrid, Reales ordenes pertenecientes a la Flora Peruana y Chilense, No. 35.

94. The crown settled Pavón's rent to June 30, 1830 (González Salmón to Pavón, June 30,1830 , in ibid., No. 36), but immediately allowed it to lapse again. (Cuenta for 1830 , dated Dec. 31 . MCN, 1831.) 
a foundation and two walls already in place, the junta estimated the job could be finished in one and one-half years by increasing the public works allowance one thousand reales a week. ${ }^{95}$ His Majesty went along with the plan, and the junta set immediately to work drawing up specifications and a budget before the dream disappeared. Nor did the crown flinch when the architect estimated 90,000 reales as the cost for the job. On August 6, 1831, word came from the king to pay that sum in ninety weekly instalments. ${ }^{96}$ But should we be surprised to learn that the salons were not erected? ${ }^{97}$

New salons or no, the junta would not be denied its control over the Flora Peruviana. When no ready-made, convenient, cheap, and comfortable quarters could be found, Pavón's materials were crammed in with the flora of New Granada, leaving space enough only to walk and to close the doors to the shelving. ${ }^{98}$

Pavón was ordered to report to his office at II A.M. on April I 5, I 831, to make a formal transfer of effects to the Conde de Argillo. ${ }^{98}$ Eleven in the morning, April 15, 1831-the inglorious end of an era. For the first time in the fifty-five years since the expedition was conceived, Pavón would have no share in directing the enterprise to which he had devoted nearly all of his life.

Pavón's final accounting, dated April 30, is pathetically brief: 2,190 reales paid out in back rent; 16 reales to the water carrier; 32 reales to clean out the office; 24 reales to replace broken windows. ${ }^{100}$ How much does one pay for a broken heart? Or did Pavón celebrate the lifting of a burden? Or was he too weary to care? Let the novelist decide; we do not know. ${ }^{101}$

95. González Salmón to president of the museum junta, Palacio, Feb. 25, 1831 ; Conde de Argillo to museum junta, Madrid, March 7, I831. MCN.

96. González Salmón to museum junta, Aranjuez, April 10, 1831; Conde de Argillo to Antonio López Aguado, in charge of building plans, Madrid, April 13, 1831 ; Diego Bolón, building foreman, to Argillo, Madrid, April 15, 1831; Argillo to Garces de Marcilla, Madrid, April 24 and June 9, I831; González Salmón to president of museum junta, San Ildefonso, Aug. 6, I831. MCN.

97. Even a plan two years later to put the library and all herbaria into a room to be built beneath that occupied by the flora of Mutis turned out to be an illusion, for the location was too wet, the building problems too great, and the cost of alterations too high. (Bolón to Argillo, Madrid, May 6, 1833; Argillo to Garces de Marcilla, Madrid, May 12, I833. MCN.)

98. González Salmón to president of the museum junta, Palacio, Feb. 25, 1831 ; Argillo to museum junta, Madrid, March 7, 1831. MCN.

99. González Salmón to Pavón, Aranjuez, April 10, 1831 ; Garces de Marcilla to Pavón, Madrid, April 14, 1831. Archives of the Jardín Botánico de Madrid, Reales ordenes pertenecientes a la Flora Peruana y Chilense, Nos. 40 and $4 \mathrm{x}$.

100. Cuenta of 1831 . MCN.

101. The move from Toledo number 5 deprived the porter Robles of even a 


\section{THE OCTOGENARIAN'S ATONEMENT}

Pavón got little help to keep his pride alive. Two and one-half years after the transfer of effects he sounded out the junta to have his name inserted in the directory of public officials as an agregado of the botanic garden. The junta, however, disclaimed authority to do so, and apparently let the matter stand. ${ }^{102}$

But the most crushing blow to Pavón came in the following year, in the wake of a change in the political complexion of Spain. Ferdinand VII had died on September 29, I833, after designating his infant daughter Isabella as queen in order to keep his brother Don Carlos from the throne. Ferdinand's wife María Cristina assumed the task of regent, and was forced to grant moderate liberal reforms in order to stay in power against the threat of the Carlist War. This meant a return to the spotlight of men exiled for a decade, and the resurgence of a progressive spirit in Spanish governmental circles.

Now that the political climate had changed, the queen mother ordered Pavón to recite once more the status of the Flora. We could almost do it for him by heart, so often have we heard the tune. But Pavón was no longer in charge, and a statement of greater interest to the monarch was that of two members of the museum junta. They were Antonio Sandalio de Árias and Vicente Soriano, who had served with Pavón on the ephemeral committee to oversee the flora of Mutis. Pavón would not have been happy to read their report.

They began with some facts that were "quite well known and of no little notoriety" among the professors at the botanic garden. The Flora Peruviana had not advanced one whit toward completion since the death of the "industrious and learned" Ruiz. The scanty profits

place to live, for he had been residing at the botanical office. But inasmuch as the crown on April 8, 1831, granted 400 reales to tide him over an illness, and within a month had restored his wage of 8 reales a day, it turned down his request on June 12 for an additional 2 reales a day to pay his rent in new quarters. The following month Robles was at it again, relating how he had been ill for eight months. So that he might buy medicine, could he please have 1,060 reales of his pay for a year ago? (Robles to Ministro de Estado, Madrid, March 18, 1831, and attached summary; royal order to Directores Generales de Correos, Aranjuez, April 8, 1831 ; Robles to ministry, Madrid, April 26, 1831; Junta del Museo to Secretario de Estado, Madrid, April 29, I83I; González Salmón to Junta del Museo, Aranjuez, June I2, 1831; Robles to Secretario de Estado, Madrid, July 19, 1831. MCN.) MCN.

Io2. Pavón to Junta del Museo, Madrid, Nov. 29, 1833, and affixed notation. 
from the sale of the work, and the French Revolution and its aftereffects had indeed hindered publication of Volume IV. But most important was the death of Ruiz himself, "snatching away prematurely the precious life of the scholar who was with just reputation at the head of the enterprise." The tragic event had "paralyzed in an absolute fashion the scientific works of that Office, there not being in it a person who could continue them."

Not only had Dombey's collection given rise to competitive publication, but the Swiss botanist Augustin de Candolle was now examining "at his pleasure" the "magnificent" herbarium of Aylmer Bourke Lambert, with its collection identical to that of the Flora Peruviana. "Thus," the pair from the junta mourned, "we can almost affirm that, with De Candolle continuing the labors in which he so assiduously busies himself, there will not be a Peruvian plant left . . . that will not be published by the indefatigable and scholarly botanical reformer."

There was still hope, however, for Spain. Though many specimens were mangled beyond repair, enough good ones remained, and enough "important and curious" bits of knowledge lay unused, to open a fertile field for "whatever learned botanist" might wish to accept the challenge. But before making recommendations, the investigators preferred to await the return from exile of Professor Mariano La Gasca, for he had seen other European herbaria, and would know better how to proceed. ${ }^{103}$

Meanwhile, the campaign to revive the Flora went ahead on two other fronts. Sancha's son was asked once again to spell out the complexities of past publication before being paid his overdue bill. Though he had lots of data on current accounts and found he was now owed 28,406 reales, he had thrown away the earlier papers the junta wanted, never dreaming, he said, that he had been dealing with "an office and director" who did not keep their own records. But Sancha's problems were bigger than that, for his firm had gone into bankruptcy. It was the receivers' turn to push the government for action. ${ }^{104}$

103. Soriano and Sandalio de Árias to junta, Madrid, April 14, 1834. MCN. 104. Sancha to Garces de Marcilla, Madrid, April 29, 1834; museum to Sancha, Madrid, May 14 and June 28, 1834 ; Sancha to Garces de Marcilla, Madrid, June 30, I 834; Manuel de Bárbara and Julian Saes, receivers in the bankruptcy proceedings, to president of the Academia de Ciencias Naturales, Madrid, Sept. 15, 1834; museum to Sancha, Oct. 17, and to Bárbara and Saes, Oct. 23, 1834; Sancha to 
All the while, the junta peered into Pavón's role in the debacle of the Flora. Pedro Alcántara Arguil was set to the task of comparing the only known inventories of the botanical office, those of 1823 and $183 \mathrm{I}$. He came up with shortages in $183 \mathrm{I}$ in the following amounts: 14 sets of the prints for Volume II, and I2 for Volume III; 712 original illuminated drawings; 7 polished plates and 89 unpolished ones; 4 boxes containing roots, bark, and similar products; 24 empty boxes; and various books, including an expensive illuminated set of the Flora Peruviana.

The junta wrote twice to Pavón for elucidation without receiving a reply. After four months, they finally resorted to threats. Either Pavón would answer within two weeks or be reported to the government. On the tenth day of grace, October IO, I 824, he at last spoke up, only to protest, as before, that he had received no summons. Three weeks later he was ready with an answer. A dozen sets of the prints for Volumes II and III had gone to Sancha in I 827 to replace those eaten by rats, and Pavón had a receipt to prove it; the missing original drawings could not be identified from the data given, though three hundred of them, used for the first three volumes, had been bound in board covers; three or four of the polished plates had been used for illustrations of the genus Unamuea, the calaguala root, and the star reed, and the others sold to meet office expenses, as the ministry had already been apprised; most of the other plates had gone for Volume $V$, except some of poor quality that had been sold; the empty boxes had been taken apart for shelving; the boxes of herbs had been consolidated into fewer containers so the empties could also go for shelving; as for the books, all had been lost in moving except the illuminated tomes of the Flora, and Pavon knew nothing of them. ${ }^{105}$

The junta was far from satisfied, at least with regard to disposition of the original drawings. One has the feeling that the junta had hoped to uncover proof of greater dereliction. They must have known of the sales to Lambert, for they lamented De Candolle's access to the Englishman's herbarium, and the porter Robles had once portrayed Pavón as a despoiler of public property. On October

Garces de Marcilla, Nov. I2, I834; Copia de la Cuenta presentada . . por Sancha, Madrid, Nov. 12, 1834 . MCN.

105. Garces de Marcilla to Alcántara Arguil, Madrid, April I 8, I 834; Alcántara Arguil to museum, Madrid, April 20, 1834, and "Nota de las diferencias"; museum to Pavón, Madrid, June 28 and Sept. 29, 1834 ; Pavón to museum, Madrid, Oct. 10 and Nov. 2, 1834 , and accompanying documents. MCN. 
17, 1834, the junta notified the Minister of the Interior of Pavón's shortages without waiting for the latter's explanation, and this at last evoked a reply from the queen mother on July 21,1835 . The junta must, Her Majesty said, learn what had disappeared through negligence, and decide how much responsibility must be laid to Pavón.

The junta's reply of August 25, 1835, sounded as though the members wished they had never brought up the subject. With the "worthy and industrious" Ruiz dead, there was no one left to explain things but Pavón, who was "touching the threshold of decrepit age." And how could anyone arrive at a true value for the missing property? Any painter might assess the artistic worth of a drawing, but what about its scientific accuracy? Anyone could weigh a piece of copper, but how could he calculate the worth of an engraved plate?

Even assuming the possibility of setting a fair value on the missing goods, the queen must face the fact that neither Pavón's salary nor his property was large enough to cover the losses. While the junta strove to find a solution, the government's only recourse would be to demand that Pavón tell "clearly and simply" of "the person or persons in whose power the missing effects can be found . . . and the means used to acquire them." Until Pavón complied, his salary ought to be suspended "in its totality." The Ministry of the Interior did so on September 30, I 835.

Having denied even a crust of bread to Pavón in the decrepitude of his eighty-first year, the junta felt a tinge of compassion and asked the queen for clemency. Pavón, they said, was "surprised beyond measure"; the Flora property had been spirited away by subalterns. About all they could ask Pavón to do was contained in his own offer: to recover as many of the items as possible and forfeit a third or a quarter of his salary in payment for the rest. ${ }^{106}$ We can learn no more of what happened during the five years that remained of Pavón's life. He passed away in 1840 at the age of eighty-six.

Whether Sancha's creditors ever won their battle against the bureaucracy is as much in doubt. In August, 1835, a move was afoot in the Spanish Cortes to liquidate the internal debt of the government. The Caja de Amortización (Department of Public Debts)

1 o6. Junta de Protección del Museo de Ciencias Naturales to Secretario de Estado y del Despacho de lo Interior, Madrid, Oct. 17, 1834; Minister of the Interior to the senior member of the museum junta, Madrid, July 2I, 1835; minute of the junta's letter to the Minister of the Interior, Aug., 1835; Interior to museum, Madrid, Sept. 30, 1835; museum to Interior, Madrid, Oct. 17, 1835. MCN. 
advised the museum junta to solicit the return of the remaining Flora funds, in order that Sancha might be paid. The Junta, replying a year later, still clung to the long-outdated figure of 198,048 reales, which was accurate for $\mathrm{I} 802$, but much too high for $1836 .^{107}$ Whether they got any part of this, even enough to pay Sancha, cannot be determined. But one thing is certain-not another page of the Flora Peruviana or any other flora saw the light of day from the funds collected in America, or from any funds, until the small edition of Volume IV published in I957, and the elaborate tomes of the Mutisian flora now being issued in Spain. ${ }^{108}$

\section{A LAST WORD}

A marcescent Flora of Peru, withered by neglect of two score years, exuding a miasma growing ever stronger with each new decade of decadence, was an image far from that in the mind of Charles III as he set Spain upon a course of botanical resplendency in $\mathbf{I} 776$.

Would the story have been the same if Ruiz had lived until I 840 instead of Pavón? The former undoubtedly had more verve. His "irascible" nature might have been less willing to submit to the indignities of these later years than Pavón's "docile" disposition. $\mathrm{Pa}$ vón, early in the game, conceded defeat and turned to hawking his specimens. The Spanish government seems not to have questioned this aspect of his international dealings, though he had violated the spirit of his original instructions, and brought sadness to his fellow scientists. Witness this experience of Joseph August Schultes, a professor of botany in Bohemia, who visited England in 1824, and wrote of his travels to the celebrated naturalist Count Sternberg:

Whilst we were employed in viewing Count Lambert's treasures, a little man dressed in black entered the apartment, and he cast a glance full of sorrow and indignation upon some packages which belonged to the herbarium of Ruiz and Pavón. This look attracted my

107. Ygnacio Ordovás, of the Ministerio de la Gobernación del Reino, to the senior member of the museum junta, Madrid, Jan. 15, 1836; museum junta to Junta de Liquidación de la Deuda del Estado, Madrid, Aug. 16, 18 86 . MCN. The junta had at least rectified the error of 1,000 reales which had caused the figure to be stated as 199,048 reales over a period of many years.

108. It must be acknowledged, in addition, that the Mexican government published in $1893-1894$ an incomplete selection of materials, without the corresponding drawings, gathered by Sessé and Mociño during the life of the royal botanical expedition to New Spain. 
attention, as did the general elevated physiognomy of this person. I could not suppress my curiosity, and asked Mr. Don who this little man might be. When he replied, Señor Lagasca! I threw myself into the arms of my old friend, who was much puzzled to imagine who I could be, for we had only known each other by correspondence which had continued for some years; and here we meet, as in a dream, where we least expected to see one another. Poor Lagasca! he had not only lost all his domestic happiness, (his wife and five children being in Cadiz,) and his fortune; but also his great herbarium; the manuscript of his Flora of Spain, on which he had been employed for more than twenty years, and which was ready to be printed. ... All, all were destroyed! He saved nothing from the great shipwreck of that Cortes to which his talents and virtue had raised him, but his own life. Far from his beautiful country, and from his beloved relations, he now lives in the foggy and expensive London, where he participates in the afflictions of so many of his worthy and exiled countrymen! ${ }^{109}$

Pavón was not the only one to suffer in those times.

If Pavón's venture into foreign trade did not exhaust his collection of plants (though it obviously diminished the stock of drawings, and resulted in the loss of numerous manuscripts to England), it kept him from devoting needed time to his own publication. Ministries came and went. Governments shifted and re-shifted from conservative to liberal and back. Funds were in disarray. Yet the repeated cry rang out: "The Flora must be finished!" And though that was probably too much to hope for, we can still hear Antonio Sandalio de Árias and Vicente Soriano intoning a requiem for the lifeless Flora: Death, "snatching away ahead of time the precious life of the scholar who was with just reputation at the head of the enterprise," had killed not only Ruiz but had "paralyzed in an absolute fashion" the Flora Peruviana et Chilensis.

How do we vindicate the pages used and the hours spent in recording this chronicle of arrant despair? Is it, after all, but an AngloSaxon recital of Hispanic incompetence? A prolonged anecdote concerning an entrenched bureaucrat whose reason for being was long since lost sight of? On a loftier plane, is it a case study in the failure of a grand design? A portrayal of the Spanish tragic sense of lifethe philosophy that all things are destined to pass away? Or, remembering the wrangling of earlier years, is it a universal tale of troppo rog. "Schultes's Botanical Visit to England," Botanical Miscellany, I, 63. 
disputare la verità fa errare-argue too much and truth goes a-wand- ering?

Certainly there is more to recall than calamity. Who would deny the achievement of men who withstood for a decade the rigors of one of the harshest lands on the face of the globe? Let Antonio Raimondi, a latter-day explorer for plants in Peru, take the stand for the defense:

How many times the naturalist risks his life for an object of natural history that in the eyes of the common people has no value whatsoever!

An insignificant plant presents itself to his sight in a craggy ravine; because of the intervening distance he cannot clearly distinguish its form, and it seems to be completely unknown to science; uneasy doubt has entered into his spirit and there is established within him a struggle between the desire to examine it close-up, and the danger of dropping into the deep abyss. He comes near the edge, to test the strength of the earth; but, Oh misfortune! the earth gives way, and tumbles the soil and stones into the river that runs at the foot of the gorge. The instinct for preservation causes him to abandon his reckless escapade and continue on his way; but he has hardly gone a few steps when the doubt and the desire to reach the unknown plant return; he halts his advance, wavers a moment, the urge to discover the truth becomes more intense, and he goes back to the place he had just left. The sight of the object stirs his enthusiasm; now he doesn't see the danger, and grasping the little shrubs and the projecting rocks, he descends into the ravine at the risk of tumbling to the bottom of the precipice. Arriving finally at the coveted object, he looks at it up close, and if he has really discovered a new plant, the torments of doubt are transformed into joy, and nimbly he climbs back up to the top, carrying in triumph the precious jewel, the cause of so much anxiety. ${ }^{110}$

Laboring under such conditions, even the confident Joseph Dombey admitted his work to be "full of faults," an analysis the Spanish would readily agree with. ${ }^{111}$ It is not to be wondered, then, that Ruiz and Pavón made mistakes. Yet despite all obstacles to creation of a deathless work, a good hundred out of I4I new genera announced by the Spanish pair are still recognized today. Over five hundred species still bear the names given by Ruiz and Pavón. ${ }^{112}$

110. Raimondi, El Perí, I, 37-38.

111. To Thouin, Cádiz, April 24, 1785. Hamy, Dombey, p. 159.

I 12. Barreiro, "Epílogo," in Ruiz, Relación, I, 513. See Álvarez López, "Algunos aspectos," Anales del Instituto Botánico A. J. Cavanilles, XII, 80-82, for a list of the genera. 
Though the authors early learned the importance of recording their finds promptly in print, the Flora Peruviana remains incomplete. When Cavanilles allegedly "stole" some of their genera by publishing descriptions based on greenhouse specimens, he had an answer difficult to dispute: If Ruiz and Pavón had found these plants, of what use was it unless they published their analyses? "If I publish some plants first, and if I expose myself to the censure of scholars," said Cavanilles, "no one has the right to take away the place that the circumstances of my literary efforts afford me."113

The late Spanish botanist Enrique Álvarez López puts part of the blame for the slow pace of publication on the rigid Linnaean orientation of Ruiz and Pavón. While they puzzled over doubtful classifications until complete data could be assembled, they left unpublished other species for which they had thorough knowledge, because the turn for publication of the latter had not arrived, in accordance with their Linnaean classification number. ${ }^{114}$

But though three-fourths of the tomes did not reach print, the Ruiz-Pavón expedition was the only one of the great Spanish scientific ventures of the epoch to have any findings published during the lifetime of the participants. The three volumes of the Flora actually issued, together with Cavanilles' tomes, were certainly the best Spanish botanical productions up to that date. Perhaps the illustrations of the Flora of Peru lacked the glow and lifelike quality of Redouté's plates. Cavanilles, too, could do beautiful work. Nevertheless, Ruiz justly took pride in "the naturalness and exactitude in the representation of plants and their parts" in his Flora, "according to the opinion of the French, English, Italians, Swedes, Germans, and the other cultivated nations of Europe."115

When the French minister Turgot first proposed the expedition

I 13. "Respuesta á Cavanilles," Memorial literario, XVII, 62-63. Cavanilles, Colección de papeles, pp. I2, 39-40, 90-91, 199, 2 II.

114 . "Algunos aspectos," Anales del Instituto Botánico A. J. Cavanilles, XII, 77.

I 5 . To O'Higgins, [1799]. Schwab, "Carta inédita de Ruiz," Boletín bibliográfico, XVII, 130. The following note appeared in a Spanish periodical in 1805 : "Although one can be assured that this work [the Flora Peruviana] is better known in foreign countries than among us, one may suspect at least that hardly a single interesting work of this kind is published there in which the Flora of Peru is not spoken of with esteem. The same thing happens in their periodicals, and lately in the Bayonne Gazette of March II last, a letter of March 9 was inserted, sent to the editors by the naturalist Ladowiski, and in it he praised beyond measure the Flora of Peru, its authors, and Sr. Casimiro Ortega who brought about this interesting expedition." ("Progresos de las ciencias físicas en Europa," Variedades de ciencias, literatura $y$ artes, III [1805], 354.) 
to Peru, the Spanish government was hard-pressed to find botanists with even a modicum of training to accompany Joseph Dombey. But by 1802 the Semanario de agricultura y artes in Madrid could publish a series of articles, entitled "Principles of Botany in Letters to a Lady," in which it was stated that the study of botany was "so simple," so "adapted to the capacity of children," that one might "find in the field a pleasure that those who had never acquired this agreeable and useful knowledge could never enjoy." Botany was a study "appropriate for persons of whatever status or profession." True, women could not yet pursue the subject in halls of learning-even in the theater they were seated separately, "not without some disadvantages"- ${ }^{116}$ but popularization was on the way, and with it inducement for more serious students to become professional botanists.

That war intervened to slow the process is not the fault of Spanish scientists. Nor is there anything especially un-Spanish about the study of plants. After all, it was Philip II who sent out the first botanical expedition in the sixteenth century. More typically Spanish was the shortage of money. The English government did very little to support herborizing, but ample private resources made up the difference; the Spanish way was through public funds, too often notoriously short.

In the 1820's, Pavón had to sell his specimens abroad because he got little salary at home. Ministers could easily cry, "The Flora must be finished!" Talk is cheap. But could they as easily raise the funds to finish it? In the 1860 's Spain sent a new scientific expedition to the Pacific, "so ill prepared and so neglected," says its historian, that its findings were "suffocated in their very cradle" for lack of financial resources to bring them to public view. ${ }^{117}$ In the 1960's the director fondles his maroon and gold guestbook at the garden where scarcely anyone comes and the gardeners cannot work full-time for want of money to pay them.

Only in the brief moment of glory that marked the reign of Charles III, "restorer of the botanic art for the health and delight of his citizens," was Spain truly a leader in world botanical competition. Considering the hurdles in her way, perhaps we should ask no more.

I16. "Principios de botánica en cartas a una señora," Semanario de agricultura $y$ artes, XII (Madrid, 1802), $210,211,248$.

11 7. Barreiro, "Epílogo," in Ruiz, Relación, I, 478. 

A P P E N D IXES 



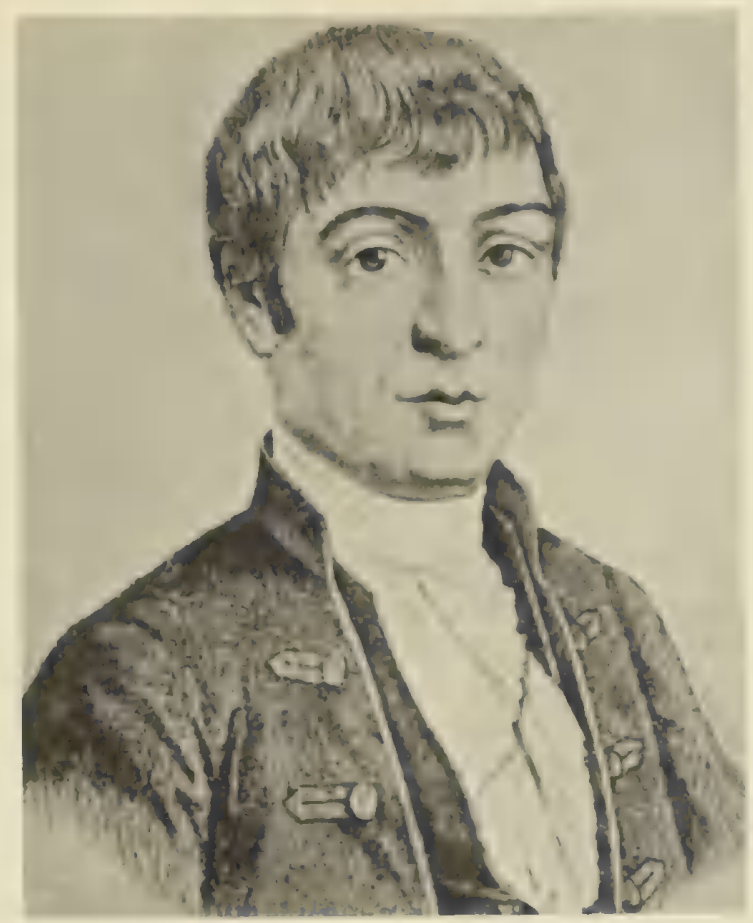

Don Hipólito Ruiz (Jardín Botánico de Madrid: photo A. Rodríguez)

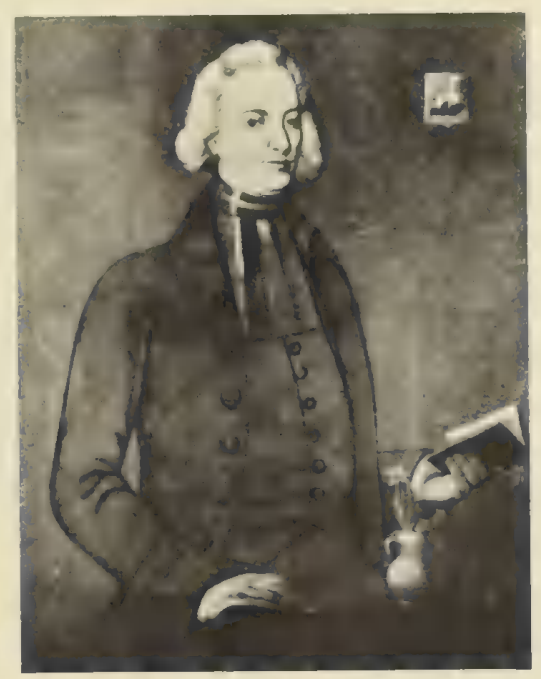

A. J. Cavanilles (Jardín Botánico de Madrid: photo A. Rodríguez) 


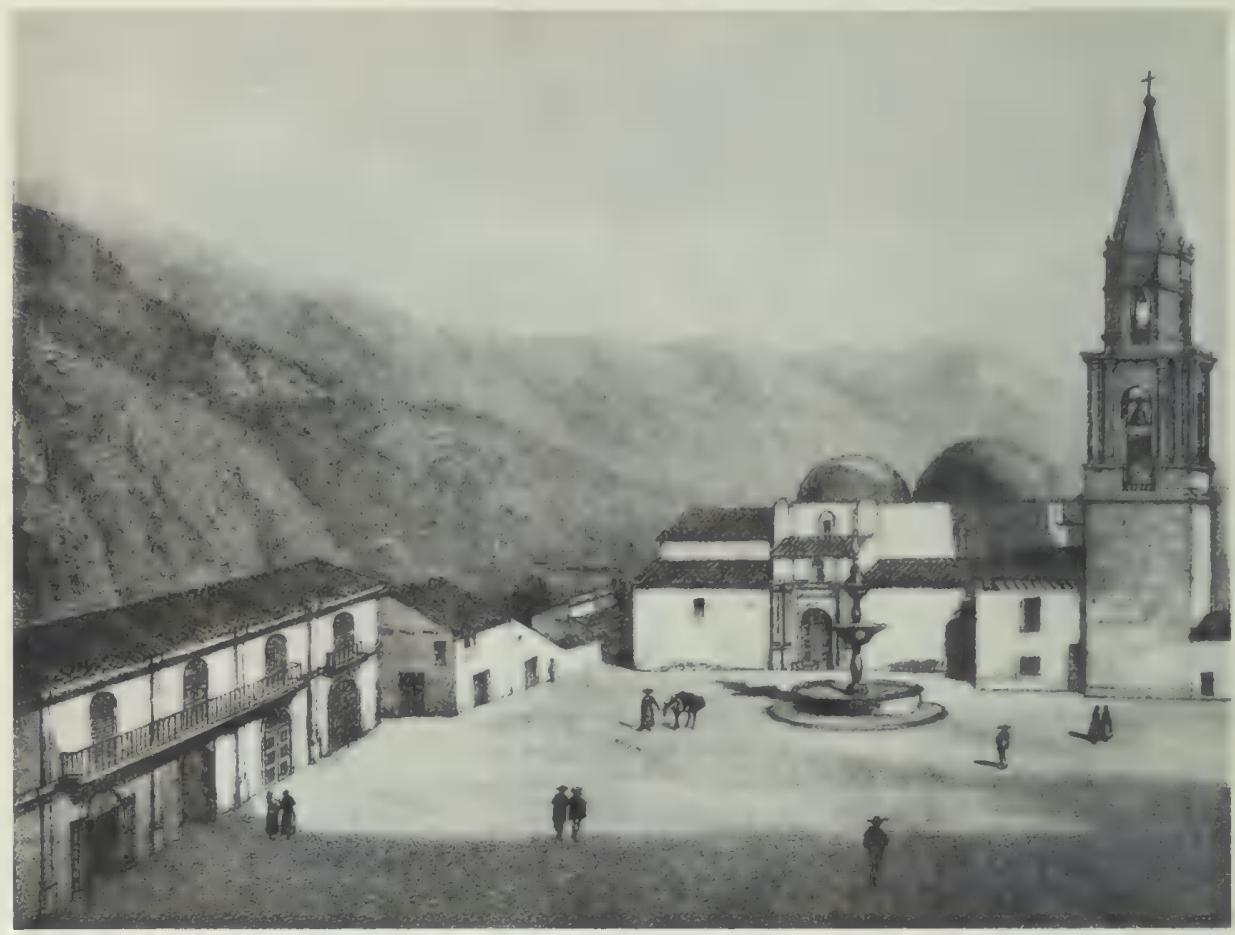

Plaza Mayor de Huánuco, from Mariano Felipe Paz Soldán, Atlas geográfico del Perú.

Facing page: Illustrations from Gómez Ortega's work on the shipment of living plants: "No. I. Box for bringing on board seeds already germinated in the same box; No. 2. Box for bringing on board little trees, which have taken hold well in it beforehand." (Archivo General de Indias, Seville: photo Macario Valpuesta Cortés) 


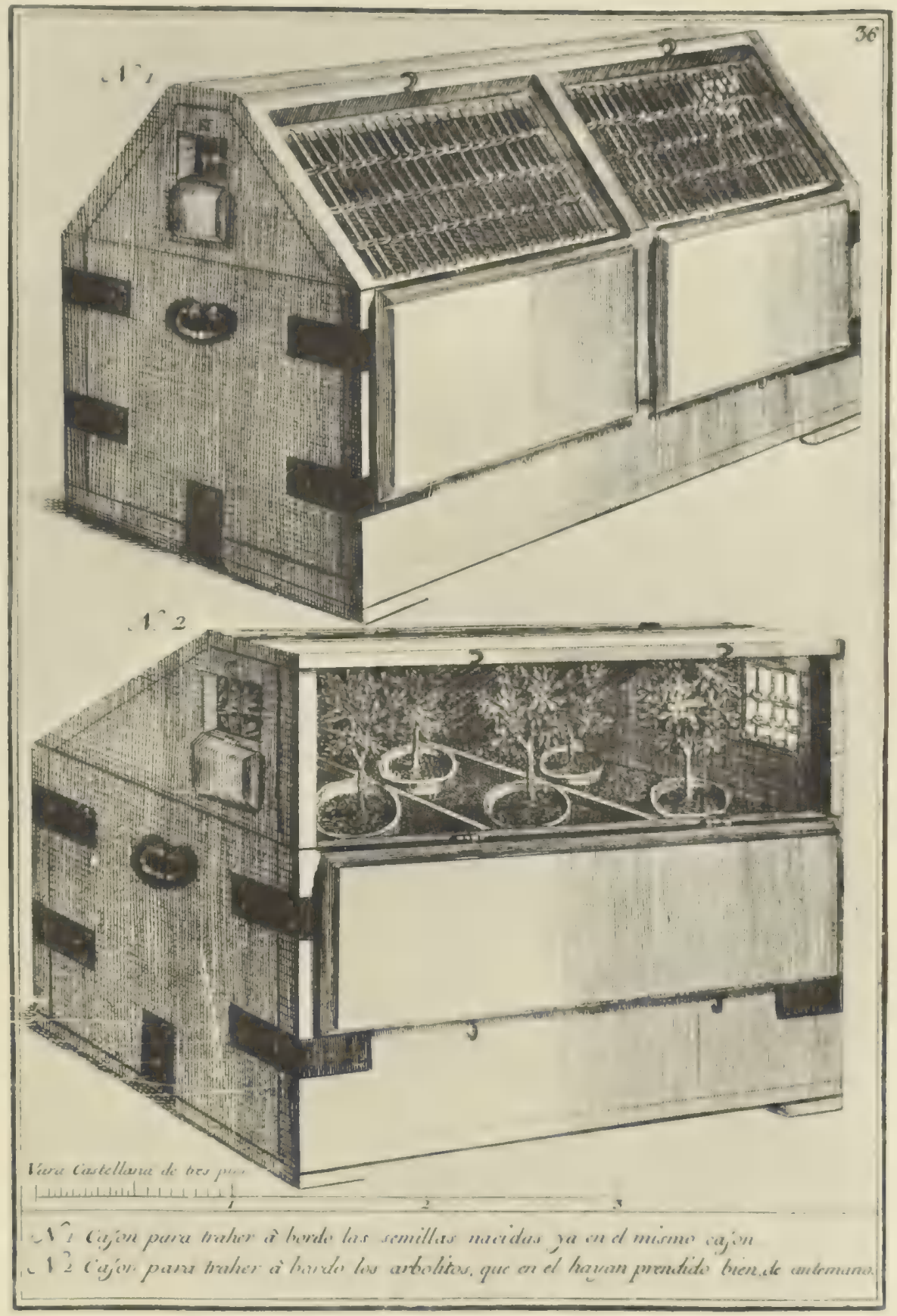




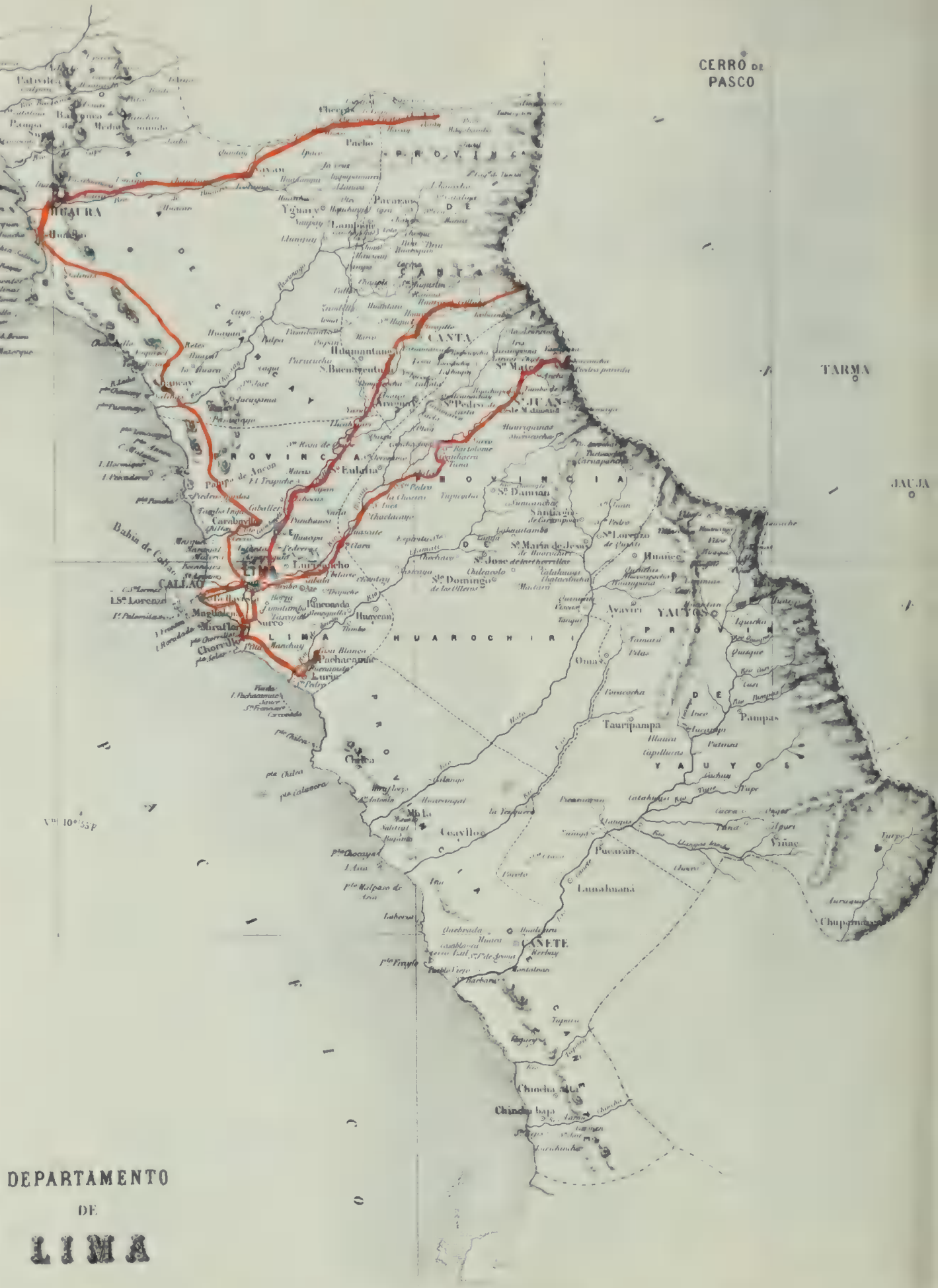

Routes of Ruiz, Pavón, and Dombey, shown here on portions of maps reproduce 


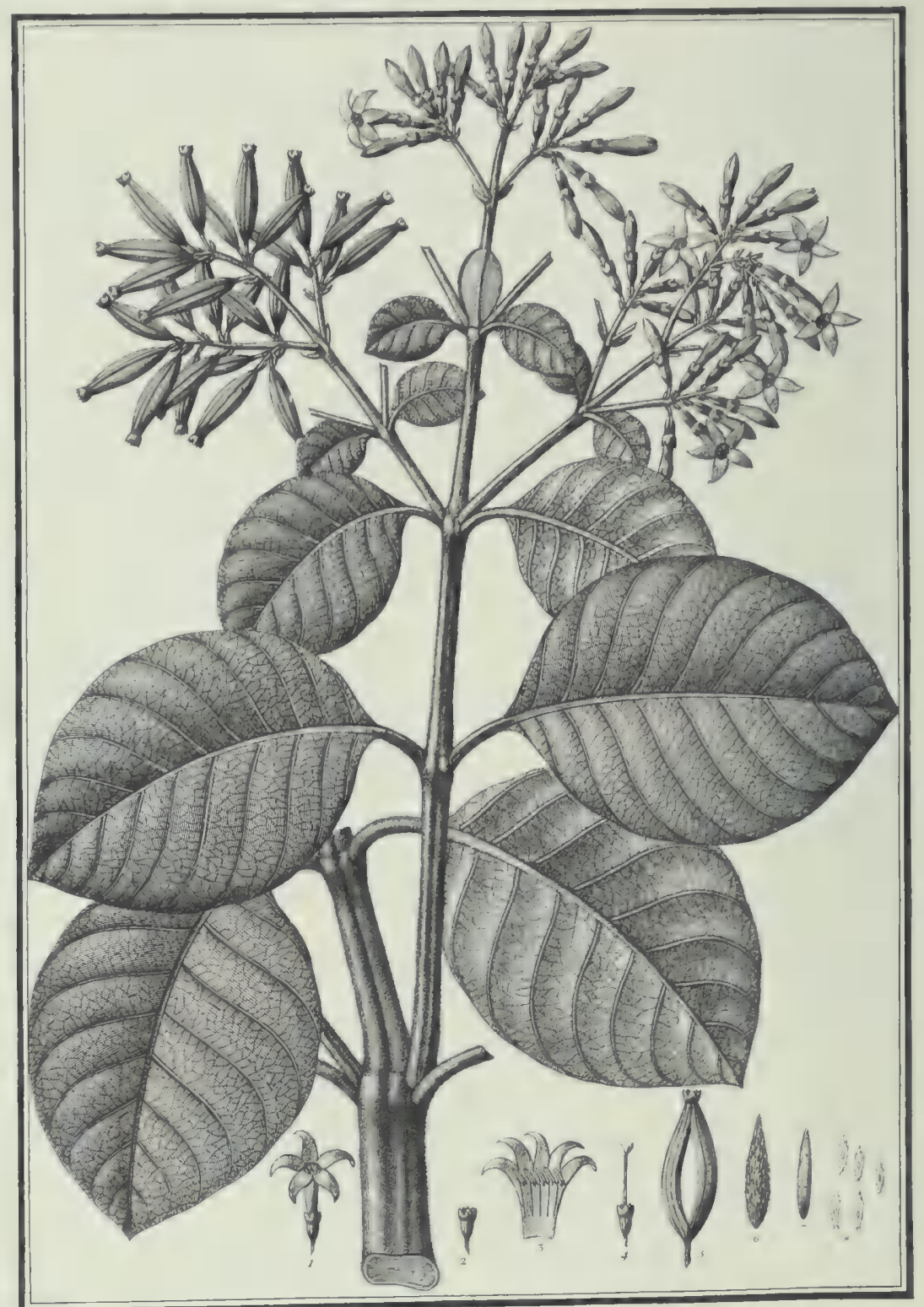

Cinchona ovata: Plate from the Flora Peruviana, vol. II, based on a drawing by Francisco Pulgar. (Courtesy Sterling Memorial Library) 


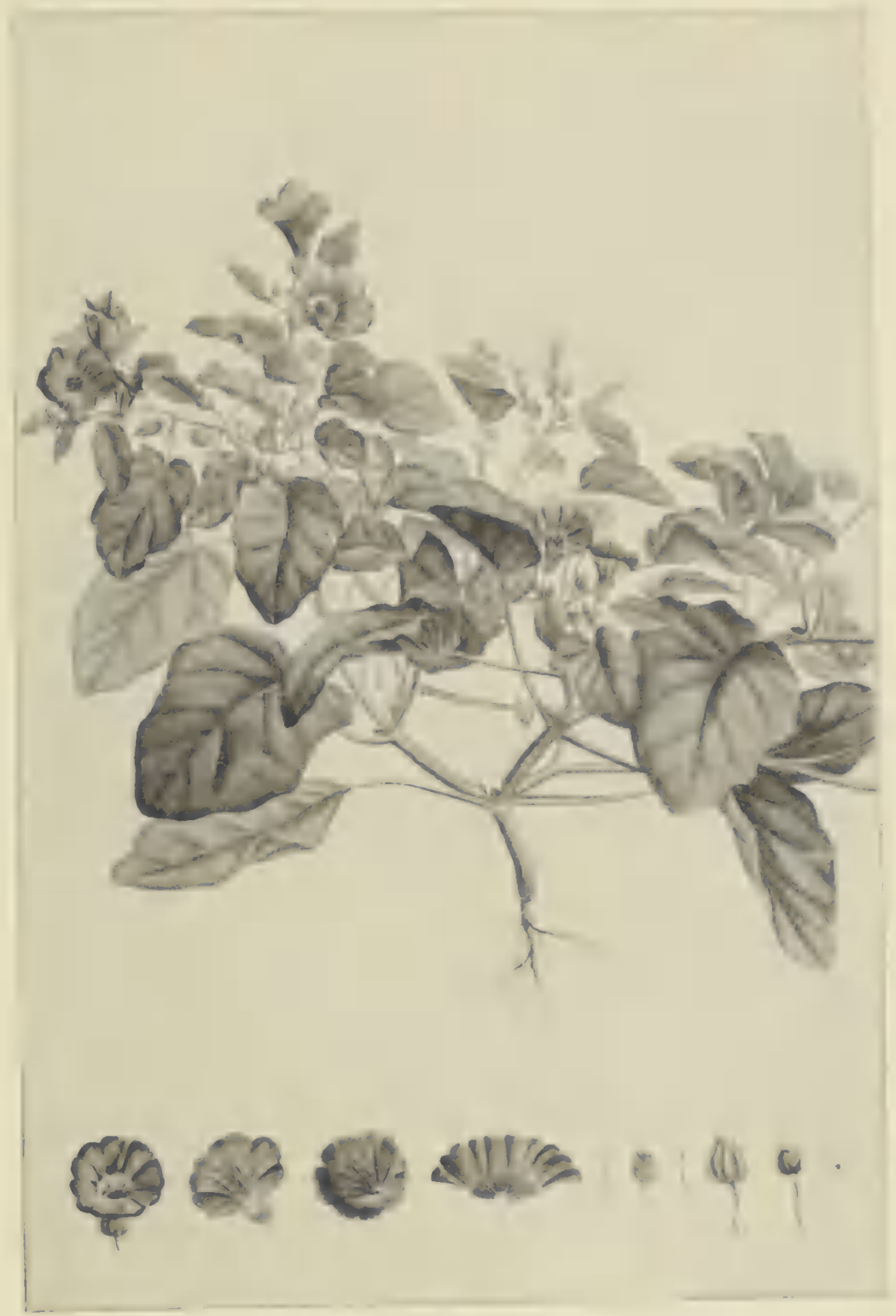

Physalis prostrata: Plate made from an illustration by the famous Redouté of a plant whose seed was collected near Chancay by Dombey and sent to France.

Published in L'Héritier's Stirpes novae, vol. I, fasc. 3. (Courtesy Hunt Botanical Library) 


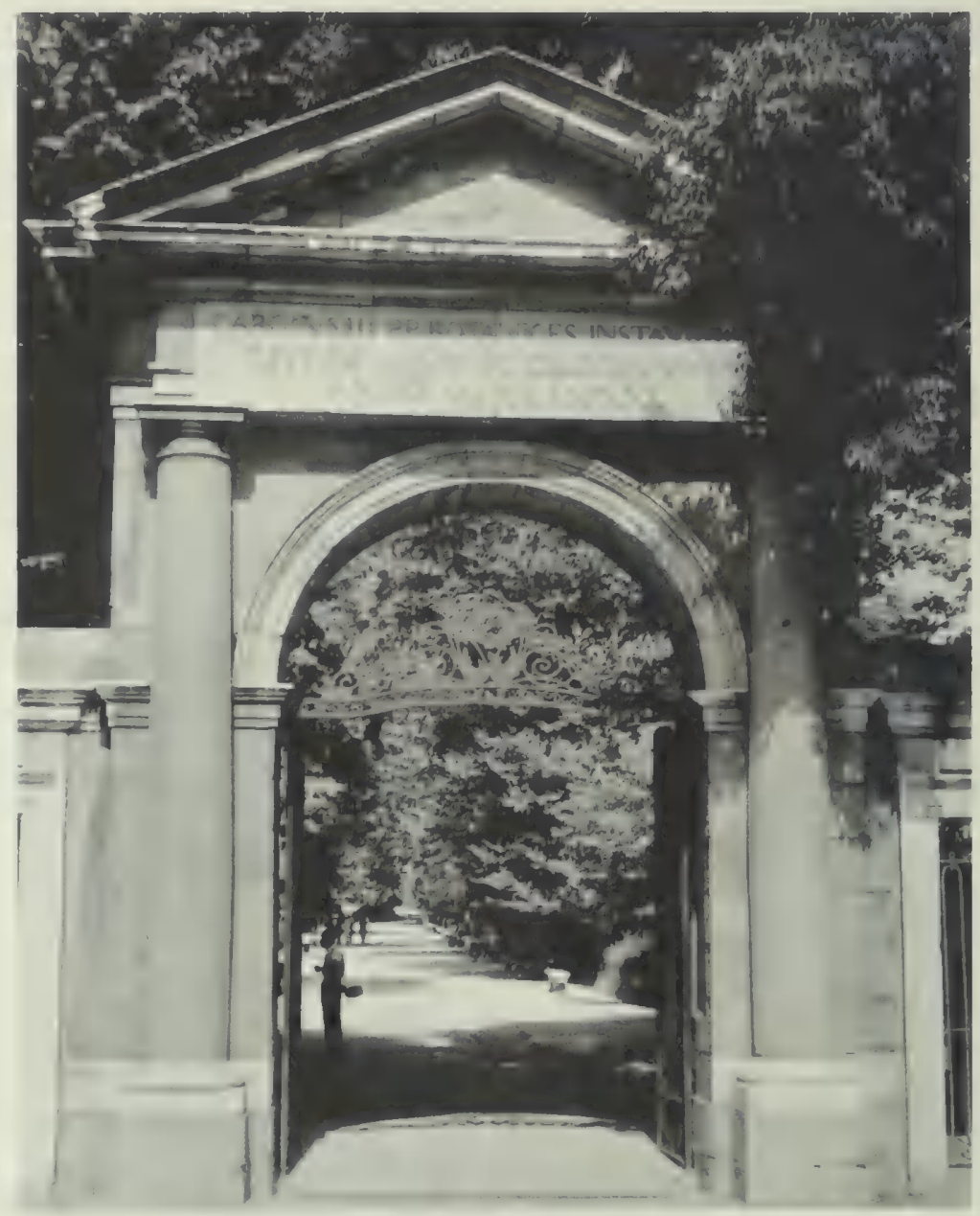

Gate of the Jardin Botánico de Madrid, constructed in 1781 . (Photo by the author) 


\title{
THE DECLINE OF SOUTH
}

\author{
AMERICA AS QUININE
}

SUPPLIER TO THE WORLD

The French government sent two scientists to Bolivia in I 843 to study cinchona. One of them, H. W. Weddell, besides publishing the Histoire naturelle des quinquinas in 1849 , and making known Cinchona Calisaya, brought some calisaya seeds to France and England. From these a young plant was given to the Dutch government, which successfully transplanted it to Java. Their enthusiasm whetted, Dutch authorities dispatched the superintendent of the botanic garden in Java, Justus Charles Hasskarl, to Bolivia in 1852 , under the alias of $\mathrm{J}$. D. Müller. The Dutchman managed by stealth to accumulate at least four hundred young calisaya plants from the no man's land of Carabaya, along the border between Peru and Bolivia. Packing them in small bales to resemble wool, he got them to the coast and on board a Dutch frigate placed at his disposal, from whence he embarked for Java. However, not only did most of the trees die en route, but Hasskarl knew little of cinchona. He selected the wrong site for a plantation and by 1856 had lost his job. Though his successor was able to transplant the trees, and raised a million more by 1860 from seeds brought by Hasskarl, very few turned out to be calisaya, and, in fact, there was scarcely a trace of quinine in them. The best specimens were offspring from Weddell's tree, but these were not robust and had only one-half the quinine content of the true Bolivian calisaya bark. Private planters had no interest in cinchona, and little wonder: coffee, tin, and sugar took their attention.

Next it was England's turn to experiment. The British tried an openhanded approach by asking their South American consuls in I 852 to procure plants and seeds, but only Ecuador complied and none of the plants survived. As a result, in 1859 Clements Markham, later to be knighted and known as a historian and man of letters, led an expedition bound for Bolivia. He was kept from entering that country and settled for specimens from Carabaya, as Hasskarl had done, and he too had to dodge local authorities in a strenuous and frigid trans-mountain journey to the coast. But the British government, unlike the Dutch, did not give Markham a 
vessel, and by the time he got the plants to India, all but two out of 237 calisayas had perished.

England, however, did not put all of its trust in calisaya bark. A certain Mr. Pritchett spent a busy time in old Ruiz-Pavón country in $\mathbf{1} 86 \mathbf{1}$, felling trees for seeds and collecting young plants of three Peruvian species. The seeds ultimately vegetated in the botanic gardens of Kew, Jamaica, and Ceylon, but were deficient in quinine content. The British became convinced that their biggest hope lay in the red cinchona ( $C$. succirubra) of Ecuador. Shortly before Markham's arrival, the government hired the free-lance botanist Richard Spruce, who had been collecting specimens of South American plants for a decade, to make the arduous trip to Ecuador in order to furnish Markham with trees and seeds. Though Spruce became paralyzed, he achieved success and within five years close to a million trees of the hardy red species were flourishing in southern India and Ceylon. England was even able to furnish trees for the floundering industry in Java. The rosy picture was blemished, however, by the undeniable fact that red cinchona, like the Peruvian species, produced less quinine than the delicate calisaya. It was nevertheless valuable if administered in larger quantities than calisaya, and was indeed easier to process. Its future as a "poor-man's quinine" thus encouraged the British government to set up a factory at Madras, to start plantations in widespread parts of the Empire, and to give seeds to other European colonial powers.

Meanwhile, the most dramatic part of the story began to unfold in South America. Charles Ledger had been a trader there in alpaca wool and cinchona bark since 1836 . From time to time he tried to find the true calisaya, aided by a loyal Indian servant, Manuel Incra Mamani, but without success. In fact, on two occasions an associate was murdered-the second one while trying to get seeds to sell to Markham. Then in 1865 Manuel showed up in Tacna after a dangerous and secret trip of eight hundred miles, carrying fourteen pounds of seeds from outstanding calisaya specimens. When the servant went back to Bolivia he was tortured and died, but Ledger sent the seeds to his brother George in London. When George could not entice the English government into buying them, he turned to the Dutch. They finally took one pound on trial and George peddled the rest to a skeptical vacationing cinchona planter from India, Mr. Money by name. He managed to unload it on the British Indian Cinchona Plantation, but somehow the seed in British hands failed to germinate.

Luckily, however, a small portion of the single pound bought by the Dutch germinated to produce 20,000 plants. In 1872 a Dutch chemist discovered the bark to be richer in quinine than any other yet found, yielding three to four times the content of the average American bark. In time it was proclaimed a new species, Cinchona Ledgeriana, related to C. Calisay'a. Lest the C. Ledgeriana be hybridized and ruined by proximity to other species, the Dutch government isolated it and gradually did away with other species. With success at last in the offing and a price for $C$. 
Ledgeriana nearly six times that for red, private planters began to take over the cultivation, though the government kept control of the seed. $C$. Ledgeriana proved to be a difficult tree to raise, and in India it was a failure. But conditions were excellent in Java; Amsterdam became the quinine capital; South American exports dropped from nine million kilograms in I 881 to two million in I884; British Indian planters replaced much of their cinchona with tea.

The rest of the story is a complex one of an international monopoly (ultimately called the Kina Bureau), rigged prices, and limited production. Even most South American supplies came under the Bureau's wing, except for tracts staked out in Peru by a low-priced rival Japanese company which finally lost its holdings in 1937. The United States at various times tried to promote cinchona production in Haiti, Guatemala, Puerto Rico, the Philippines, and Costa Rica. During World War II, until the substitute synthetic, atabrine, began to prove successful, United States missions scoured Ecuador, Colombia, Peru, and Bolivia for bark.

In 1944 two American chemists achieved the artificial synthesis of quinine, but the process was too costly to allow production of the drug on a commercial scale. Other synthetics besides atabrine, however, have been found to be as effective against malaria as quinine. The World Health Organization is at present in the midst of a program to eradicate malaria in the world by I968, through extensive spraying campaigns financed largely by the governments of the infected areas. Under such circumstances, quinine and the synthetics are considered as of most value in the closing stages of the program, to wipe out the last remaining foci of infection.

[Sources: Duran-Reynals, The Fever Bark Tree, pp. 142 et seq.; Norman Taylor, Cinchona in Java: The Story of Quinine (New York, 19+5); Howard, Illustrations of the Nueva Quinologia of Pavon, pp. viii-xiv, 36-41, 45-62; The American Peoples Encyclopedia, XVI, tog; Encyclopedia Americana, XXIII, 95; Gloria Bell, "World Fights Against Malaria," Science News Letter, LXXVII (April 9, 1960), 234-235.] 


\section{SUMS COLLECTED IN THE}

\section{SPA NISH EMPIRE TO PUBLISH}

\section{THE FLORAS OF A M ER I A}

Funds sent from the Spanish Empire to support publication of the floras of America were invariably collected in pesos, the unit of money in the Indies. These sums were converted into reales in Spain at the rate of twenty reales to the peso, and all accounts of the Flora of Peru were expressed in reales. The table on the following page is inserted in order that the interested reader may verify the author's calculations of this conversion. In the column "Converted to Spanish Reales" those figures marked "est" represent in almost all cases a straight multiplication by twenty of the pesos sent from the Indies. The other figures in this column were found in documents of the period. They do not represent an exact conversion on the basis of twenty reales to the peso in all instances, because some minor shipping expenses or commissions seem to have been deducted. No figures are given in this column for La Plata and Cuba, because exact information was available on the "Net received in Spain," as shown in the next column, and the intermediate conversion stage was not necessary. The principal chance for error in the "Net received" column lies in deciding how much should be deducted for shipping costs. In some cases exact figures were available. Estimates for the others are based on application of a similar percentage for expenses. In any case, the margin of error should not be significant if we assume that the original figures on shipments from the Indies are complete. 


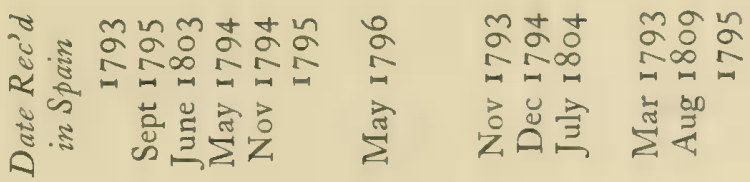

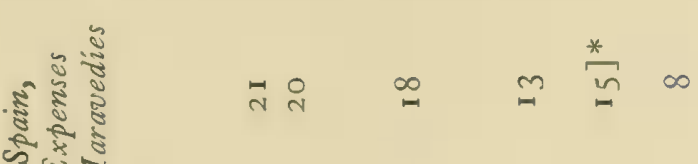

है सर

$\frac{\pi}{2}=\frac{\pi}{2}$

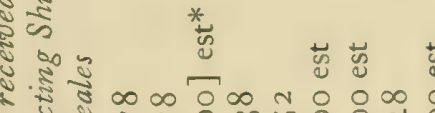

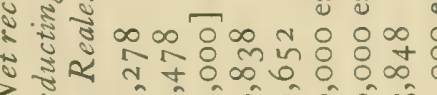

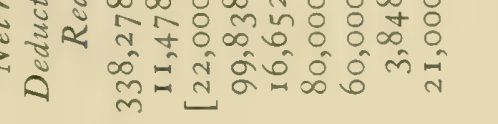

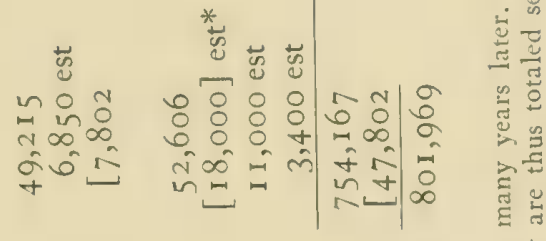

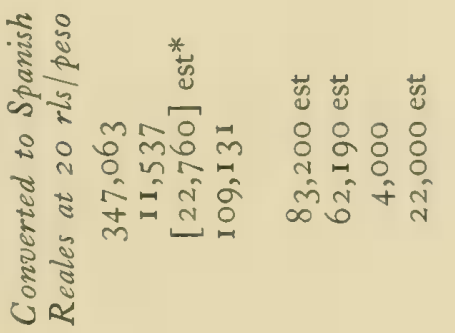

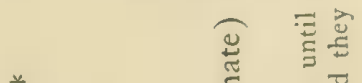
*

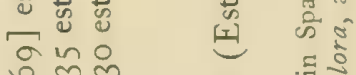
\% $m$ m 7

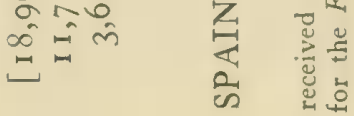
乙 造芯

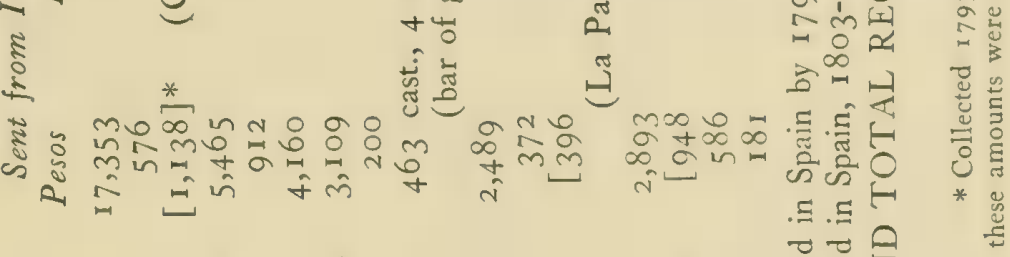




\title{
B I B L I O G R A P H Y
}

\author{
Abbreviations Used in Footnotes
}

AGI = Archivo General de Indias (Seville)

BNS = Biblioteca Nacional de Santiago (Chile)

MCN $=$ Museo Nacional de Ciencias Naturales (Madrid), Ruiz-Pavón Papers

\section{Note}

By all odds, the most important manuscripts consulted for this study are in the Museo Nacional de Ciencias Naturales in Madrid. They are most important not only because they comprise the files of the Ministry of the Indies and its successor agencies as overseers of the expedition, but because they have never before, to the author's knowledge, been the object of an exhaustive analysis. Their existence was not hitherto unknown (see José Tudela de la Orden, Los manuscritos de América en las bibliotecas de España [Madrid: Ediciones Cultura Hispánica, 1954], pp. 308309 , 3II-3 I4), but only a short time before the author arrived in Madrid had they been rescued from an amorphous pile which had hidden their true scope for many years.

The Archivo de Indias in Seville and the Jardín Botánico in Madrid are, as might be expected, two further founts of undeniable significance. Labors in the former were made easier by the fact that the Anales de la Real Academia de Farmacia of Madrid publishes in each issue the texts of numerous papers from that archive relating to natural history. As for the botanic garden, Dr. Enrique Álvarez López, director of the Instituto Botánico A. J. Cavanilles of Madrid, before his untimely death in December, 196I, had treated the contents of its files on Ruiz, Pavón, and their era in several excellent monographs.

In previous studies of the expedition, José Pavón has remained obscurely in the background. By making use of the letters Pavón wrote to Aylmer Bourke Lambert, now preserved at the Royal Botanic Gardens at Kew, near London, and, to a lesser extent, correspondence in the Istituto Botanico of the University of Florence and the Linnean Society of London, as well as the official papers in the Museo de Ciencias Naturales in Madrid, the author has been able for the first time to give some substance to this shadowy figure.

Two printed source works stand out for their extreme usefulness: a transcription of the Relación composed by Hipólito Ruiz to describe the 
progress of his expedition, and a collection of letters written by or pertaining to Joseph Dombey.

The Relacion, still in manuscript at the time of its author's death, was at last published in I93 I by Father Agustín J. Barreiro. The editor admittedly used a preliminary and incomplete draft and seems to have had difficulty in interpreting many passages, for the published version is dotted with small mistakes. Barreiro added an "Epilogue" which summarizes the post-expedition story, and reproduced numerous documents. This edition was translated into English in 1940 by B. E. Dahlgren for the Field Museum of Natural History, a version subject, of course, to the same deficiencies as its Spanish model.

In 1952 Jaime Jaramillo-Arango, then ambassador of Colombia to Great Britain, published a beautiful edition of the Relación, based in large part on what seems to have been the final, unfinished draft (dating from some time later than I 801 ), a manuscript that had long lain untouched in the British Museum. The concluding parts of the transcript are from an earlier draft, also in the British Museum, written by Ruiz some time after 1793. Besides closing the gaps left by Barreiro, the new editor was able to rectify a vast number of slips in orthography. This second edition is naturally of greater usefulness and is an outstanding contribution to the literature on the Ruiz-Pavón expedition. Jaramillo reproduces the documents and epilogue from the Barreiro edition, and also adds an amazingly complete and varied series of indexes to the Relación and a most thorough set of maps dating from colonial times. This second edition is used throughout the present study except in the few instances where the early draft contained information deleted from the subsequent versions.

Dombey's correspondence, largely written to his friends at the Jardin du Roi in Paris, and so full of pungent and informative comments about his part in the expedition, was published in 1905 by E. T. Hamy. The editor was also successful in locating numerous related letters, written by friends and officials, which help to clear up many uncertain references in the Dombey papers. He adds a preface of some one hundred pages, drawn almost entirely from the contents of the letters.

The following bibliography includes only those works cited in the footnotes, with the exception of a few additional studies deemed of sufficient importance to mention, and all have been seen by the present author. For a discussion of works written by Ruiz and Pavón and not listed in the bibliography, the reader is directed to pages $210,286-288,290$, and 291.

\section{MANUSCRIPTS}

Archivo del Ministerio de Relaciones Exteriores (Lima)

Libro I-I6, fols. I6v.-I8: Royal order, September 17, I79I, regarding Flora.

1-16, fol. 158: Contribution of consulado to Flora.

2-13, fols. 4-92: Opinions of consulado on quina de calisaya. 
Archivo General de Indias (Seville)

Audiencia de Chile

Legajo 192: President Benavides to Ministry of the Indies, 1781I 782 , Nos. 53, 86, 93, I 24, regarding pines.

387: Summary expediente beginning "Santiago de Chile, 4 de octubre de 1783 " and miscellaneous papers relating to Dombey's analysis of mercury mines in Chile.

391: Roxas to Álvarez Azevedo, April 28, 1785 , regarding mercury.

Audiencia del Cuzco

Legajo 66: Bishop of Cuzco to Eugenio de Llaguno, July 10, I 795, regarding collection for Flora.

Audiencia de Lima

Legajo 243: Petition of Rivera for new post, December 7, 181 I.

606: Correspondence of Magallón and Gálvez, 1776, regarding permission for expedition to Peru.

677: Causa Criminal seguida por los Profesores Botanicos de S.M. contra Don Matias Trauco, No. 36D; and viceroy to ministry, No. 33, June $16,1788$.

679: Viceroy Croix to ministry, March 31, 1788, regarding Ruiz's conduct; certificates of recommendation for Pavón.

686: Viceroy to ministry, August 30, 1789 , remitting drawings.

698: Viceroy Gil to ministry, April 5, I791, regarding agregados.

749: Viceroy Concordia to ministry, April I7, I815, remitting drawings and descriptions.

798: Viceroy Croix to ministry, February and March, I 789 , remitting boxes.

I018: Petition of Quintanilla to become agregado, August 23, I818, and opinion of Pavón, September 16, 1818.

Audiencia de Quito

Legajo 227: "Méritos y servicios" of López Ruiz.

Audiencia de Santa Fe

Legajo 757: Papers concerning the López Ruiz-Mutis controversy.

835: Papers concerning platinum-working in Spain, 17551789.

Indiferente General

Legajo 551: Lardizábal to ministry, June 16, I814, regarding move of Flora office to Franciscan quarters, and conduct of botanists; papers concerning boxes of quina in Archivo de Indias, and Flora funds. 
1544: Instruccion sobre el modo mas seguro y económico de transportar plantas vivas por mar y tierra á los paises mas distantes. Madrid, 1779.

1545: Tafalla to ministry, May I 5, August 30, November 20, 1790 , and June 20, 1791 , regarding remittances, salaries, and voyages; Gorbea y Vadillo to Casa de Contratación, September 2 I, I 790.

I 546: Tafalla to ministry, November 20, I 79 I, regarding voyage; information on items received in Spain from Tafalla.

1550: Viceroy Jáuregui to Gálvez, September I6, I 783 , regarding shipment of platinum by Dombey.

1555: Pavón and Isidro Gálvez to crown regarding job in Quito, I 790.

1556: Gazeta de Madrid, August 15, 1806, regarding quina.

1557: Olmedo as quina administrator in Quito.

1656: Viceroy Gil to Llaguno, September 8, 1795, remitting objects.

2760: Extract of expediente on shipwreck of San Pedro de Alcántara.

2762: Expediente on shipwreck; resolutions of Council of the Indies.

2763: Cargo list of San Pedro de Alcántara; resolutions of Council of the Indies.

Archivo General de Simancas (Spain)

Sección de Estado, legajo 7323 antiguo: Correspondence regarding capture of Buen Consejo by British, November 26, 1779 , through February 22, 1780 .

Archivo Histórico de Hacienda (Lima)

Libro 900, fols. 19, 24, 28, 41: Correspondence between Visitador Escobedo and crown (Gálvez), January 3 and September 10, 1783 ; November 18, 1784; January 31 and June 4, I 785 . Fols. 263-264: Royal order, April 25,1794 .

1060, fols. 58-58v., 80-80v., 432, 454: Index of cédulas and orders on botanists received by Viceroy Gil in 1790 et seq.

I I64, fols. 20v., 42, 74v., 76v., I I 3v., I 29, I 3 I v., 228, 267 v., $283 v ., 284,303,3$ I 2v., 313, 335: Correspondence on salaries and appointments of Tafalla, Rivera, Manzanilla, and Cortés, I 807-I 8 I I.

I I 70, fols. 72v., 73, 89-89v., 95-95v., I O I, I 20v., I 47v.-1 48: Salary matters concerning agregados; shipment to 
Spain of 20 boxes; license for Tafalla and Rivera to go to Chile. $1807-1810$.

Archivo Municipal de Lima

Libro 29, fols. 251-25IV., and Libro 30, fol. 338: Expressions of thanks to various bodies from the crown for Flora funds.

Archivo Nacional del Perú (Lima)

Sección Consulado

Nos. II 3 and I7I I: Details concerning funds for Flora.

Sección Real Hacienda

Legajo [34-number given by me]: Correspondence of Tafalla and Pulgar with viceroy and Treasury, July, 1793.

Archivo Nacional de Santiago (Chile), Capitanía General

Vol. 675, "Expediente Flora Americana," pp. 4-4v.: Order of the Marqués de Bajamar, September 17, I791; pp. 6-59: Details concerning receipt of moneys for Flora.

Vol. 726, doc. 56, pp. 125-137: Instrucción.

Biblioteca Real Palacio (Madrid)

Signatura 2512, Papeles Varios, Vol. V, doc. 24: Francisco Dionisio Fernández Molinillo to Class of Agriculture, January 25, I780; Casimiro Gómez Ortega to Joseph de Guevara Vasconcelos, March 21, 1778; Joseph Melchor de Urquijo to Guevara Vasconcelos, March 31, 1778.

Signatura 2860, Miscelánea de Ayala, XLVII: Memoria of Count Milly on platinum, 1779 .

Signatura 2873, Miscelánea de Ayala, LV: Informe of Gómez Ortega on the use of platinum.

Istituto Botanico della Università di Firenze

Correspondence between José Pavón and Philip Barker Webb, I 8261828. (Cited as "Webb Correspondence.")

Jardín Botánico de Madrid

Manuscritos Botanicos de Descripciones Originales hechas en el Peru desde el año de $177^{8}$ por $\mathrm{D}^{\mathrm{n}}$ Jose Pavon y $\mathrm{D}^{\mathrm{n}}$ Hipolito Ruiz.

Reales ordenes pertenecientes a la Flora Peruana y Chilense.

Linnean Society of London

Correspondence between Aylmer Bourke Lambert and Alexander MacLeay, I8I5-1817, and recommendation of Pavón for membership, January 20, 1818 .

Museo Nacional de Ciencias Naturales (Madrid)

Papers concerning Ruiz, Pavón, and the Flora Peruviana.

The Royal Botanic Gardens, Kew (England)

Letters from Pavón to Aylmer Bourke Lambert, 1814-1825, in a bound manuscript volume entitled "Letters. A. B. Lambert, Esq." (Cited as "Letters to Lambert.") 
Universidad Nacional Mayor de San Marcos (Lima)

Decree of Viceroy Amat, February 21, 1766, concerning establishment of training in mathematics.

Informe del cathedratico de Matematicas sobre el punto fixo, February 27, 1768 (manuscript No. 25).

\section{PRINTED PRIMARY SOURCES}

Anales de la Real Academia de Farmacia. Each issue beginning with Nos. 5-6 (1954) contains a section, "Estudios en el Archivo General de Indias de Sevilla," giving the text of documents relating to some aspects of natural history. See especially XX (1954); XXI (1955); XXIII (1957); also XVI (1950).

Asso, Ignacio de. "Discurso sobre los naturalistas españoles," Anales de ciencias naturales, III (I801), I 70-179.

Barnades, Miguel. Principios de botánica, sacados de los mejores escritores, y puestos en lengua castellana. Madrid, 1767.

Barreiro, Agustín J. El viaje científico de Conrado y Cristián Heuland a Chile y Perí, organizado por el gobierno español en I795. ("Publicaciones de la Real Sociedad Geográfica.") Madrid, I 929.

Benítez Miura, José Luis. "El Dr. Francisco Hernández: 1514-1578 (cartas inéditas)," Anuario de estudios americanos, VII (1950), 367409.

Bourgoing, J[ean] $\operatorname{Fr}$ [ançois]. Modern State of Spain: Exhibiting a Complete View of its Topography, Government, Laws, Religion, Finances, Naval and Military Establishments, and of Society, Manners, Arts, Sciences, Agriculture, and Commerce in that Country. Translated from the last Paris edition of 1807.4 vols. and atlas. London, 1808 .

Bueno, Cosme. "Disertacion sobre el arte de volar," El conocimiento de los tiempos (Lima, I 793).

- "Disertacion sobre los antojos de las mujeres preñadas." In Manuel de Odriozola (ed.), Documentos literarios del Perí (Lima, 1863-1877), III, 279-293.

1863-1877), Geografía del Perú virreinal (siglo XVIII). Daniel Valcárcel, ed. Lima, 1951.

- Parecer que dio el Doctor Don Cosme Bueno sobre la Representacion que hace el Padre Fray Domingo de Soria para poner en práctica la inoculacion de las Viruelas. Lima, 1778.

[Cabello, Manuel, et al.]. Pro publico totius philosophiae examine in hac regia Divi Marci Academia .... [Lima, 1778.] In Biblioteca Nacional de Santiago (Chile), Sala Americana, I 4 (259-8).

Cangas, Gregorio de. "Descripción de la ciudad de Lima," Revista histórica (Lima), XIV ( I 94 I), 325-342.

Cárdenas, Santiago de. Nuebo Sistema de Nabegar por los aires sacado de las obserbaciones de la naturaleza volátil .... [Lima, 1937.] 
"Carta de un vecino de Lima á los autores del Memorial Literario, acerca de las disertaciones Botanicas de D. Antonio Joseph Cabanilles," Memorial literario, instructivo y curioso de la corte de Madrid, XV (September, 1788 ), I67-169.

Cavanilles, Antonio José. Colección de papeles sobre controversias botánicas de $D$. Antonio Joseph Cavanilles, con algunas notas del mismo a los escritos de sus antagonistas. Madrid, 1796.

[-.] "Observations de M. L'Abbé Cavanilles de l'Académie des Sciences d'Upsal, sur le cinquième fascicule de M. L'Héritier," Observations sur la physique, sur l'histoire naturclle et sur les arts (Paris), XXXIV (March, I 789), I83-I93.

-. "Suplemento al género Buena," Anales de ciencias naturales, IV (1801), I O9-I 20.

Colección de documentos históricos, recopilados del Archivo del Arzobispado de Santiago. 4 vols. Santiago de Chile, I9I9-I92I.

Colección de documentos inéditos para la historia de España. Madrid, 1842-I 895. I, 362-379. [Letters from Francisco Hernández to Philip II.]

Concolorcorvo [Calixto Bustamante Carlos Inca.] El lazarillo de ciegos caminantes. Gijon, I 778 .

[Condorcet, Marquis de. Marie Jean Antoine Nicolas Caritat.] Oeuvres. A. Condorcet O'Connor, ed. I 2 vols. Paris, 1847-1849. "Eloge de M. de Linné, II, 332-357. "Éloge de M. de Jussieu," II, 357-369. Correo de Madrid (ó de los ciegos), II (October, I 787), 475-476, "Si existe el ayre en las plantas"; 485-486, 493-495, 500-501, "En que estado existe el ayre en las plantas, y qual es su efecto."

Crespo, Pedro Nolasco. "Carta apologética de la quina, o cascarilla, escrita a la Sociedad por el Dr. D. Pedro Nolasco Crespo," Mercurio peruano, VIII (July 4 and 7, I 793), I 48-I 52, I 56-I 66.

[Cruckshanks, Alexander.] "Account of an Excursion from Lima to Pasco, Edinburgh, Nov. 25th, I 830, to Dr. Hooker from Alexander Cruckshanks," Botanical Miscellany, II (London, I 83I ), I68-205.

Cuvier, Georges. "Éloge historique de l'Héritier lu le 5 avril i 80 r," Recucil des éloges historiques lus dans les séances publiques de l'Institut de France (nouvelle édition; Paris, I 86I), I, 57-73.

De Jussieu, Joseph. Description de l'arbre à quinquina: mémoire inédit de Joseph de Jussieu (I737). Paris: Société du Traitement des Quinquinas, 1936.

Deleuze, J. P. F. "Notice historique sur Joseph Dombey," Annales du Muséum National d'Histoire Naturelle, par les Professeurs de cet Etablissement (Paris), IV (1804), 136-169.

Dillon, John Talbot. Travels Through Spain, with a View to Illustrate the Natural History and Physical Geography of that Kingdom. 2nd ed. London, 1782.

Dombey, Joseph; see Hamy. 
[Dupont de Nemours, Pierre Samuel.] Mémoires sur la vie et les ouvrages de $M$. Turgot, ministre d'état. Philadelphia, 1782 .

Estatutos de la Real Sociedad Patriótica de la M. N. y M. L. Ciudad de Sevilla, y su reynado. Seville, 1778 .

"Extracto de una memoria del Dr. D. Joseph Celestino Mutis, célebre médico y botánico de Santa Fé de Bogotá," Semanario de agricultura y artes dirigido á los párrocos, IV (August I6 and 23, 1798), IOI-IIO, I $19-123$.

Feuillée, Louis. Journal des observations physiques, mathématiques et botaniques faites par l'ordre du roy sur les côtes orientales de l'A mérique Méridionale, et dans les Indes Occidentales, depuis l'année 1707, jusques en I7I2. 3 vols. in 2. Paris, I 7I4-I725.

Flora de la Real Expedición Botánica del Nuevo Reino de Granada. 3 vols. published to date. Madrid: Ediciones Cultura Hispánica, I954-.

[Frézier, Amédée François.] Relation du voyage de la Mer du Sud aux côtes du Chily et du Pérou, fait pendant les années I7I2, I7IJ et I7I4. Paris, 1716.

Gazeta de Madrid, No. 55 (July I I, 1786), pp. 453-454; No. 67 (August 15, 1806), pp. 700-701.

Gilibert, [Jean Emanuel]. "Notice sur la vie et les travaux d'Antoine [sic] Dombey, médecin naturaliste," Recueil des actes de la Société de Santé de Lyon, depuis l'an premier jusqu'à l'an cinq de la République; ou Mémoires et observations sur divers objets de chirurgie, de médecine et d'histoire naturelle. Lyon, I 798.

Gómez Ortega, Casimiro. Continuación de la flora española ó historia de las plantas de España, que escribió don Joseph Quer. 2 vols. Madrid, 1784 .

González Laguna, Francisco. "Memoria de las plantas extrañas que se cultivan en Lima introducidas en los últimos 30 años hasta él de I 794," Mercurio peruano, XI (July 10, 1794), 165-166.

"Necesidad de la historia natural científica," Mercurio peruano, X, (January 1 2, 16, 19, 23, 1794), 25-58.

Gordillo, José. Chemiae vegetabilium synopsis quam pro gradu baccalaureatus obtinendo. Lima, [18II]. In Biblioteca Nacional de Santiago (Chile), Sala Americana, I4 (259-10).

Hamy, E. T. (ed.). Joseph Dombey, médecin, naturaliste, archéologue, explorateur du Pérou, du Chili et du Brésil ( $I 778-I 785)$ : sa vie, son oeuvre, sa correspondance. Paris: E. Guilmoto, 1905.

Helms, Anton Z. Travels from Buenos Ayres, by Potosi, to Lima. London, 1807 .

Hernández, Francisco. Cuatro libros de la naturaleza y virtudes medicinales de las plantas y animales de la Nueva España. Morelia, Mexico, I 888 .

Historia de las plantas de Nueva España. 3 vols. Mexico City, I $942-1946$.

- Obras completas. 3 vols. Mexico City, 1959-1960.

Hernández de Alba, Guillermo (ed.). Archivo epistolar del sabio natura- 
lista José Celestino Mutis. Vol. I. Bogotá: Ministerio de Educación Nacional, 1947.

Humboldt, Alexander von. "Cinchona Forests of South America." See Lambert, An Illustration. ... .

- Essai politique sur le royaume de la Nouvelle-Espagne. 2 vols. Paris, 18 I 1 .

- Political Essay on the Kingdom of New Spain. Translated by John Black. 3 rd ed. 3 vols. London, 1822.

Journal général de France. No. 6 (January 14, 1786), pp. 22-23.

Jussieu; see De Jussieu.

La Condamine, Charles Marie de. Viaje a la América Meridional. 2nd ed. Buenos Aires, 1945 .

Lambert, Aylmer Bourke. An Illustration of the Genus Cinchona; comprising descriptions of all the officinal Peruvian barks, including several new species. Baron de Humboldt's account of the Cinchona forests of South America: and Laubert's Memoir on the different species of Quinquina. To which are added several dissertations of Don Hippolito Ruiz on various medicinal plants of South America. With Several Plates. And a Short account of the Spikenard of the Ancients, with a plate. London, I82I.

Latorre, Germán. "Instrucción general o parecer sobre el modo de hacer descubrimientos en las Indias," Congreso de Historia y Geografía Hispano-Americanas, Actas y memorias (Madrid, I9I4), pp. 297-303.

Laubert. "Memoir on the different Species of Quinquina." See Lambert, An lllustration. ...

L'Héritier de Brutelle, Charles Louis. Stirpes novae, aut minus cognitae, quas descriptionibus et iconibus. 2 vols. Paris, I784-I 785.

Linnaeus, Carl. Bibliotheca botanica. Amsterdam, 1751.

[- . " "Cartas de propia mano de C. Linneo que se conservan en el Jardín Botánico de Madrid," Memoria de la Real Sociedad Española de Historia Natural, V (1908), Memoria $3^{\mathrm{a}}$.

- Iter Hispanicum, eller Resa til spanska Länderna uti Europa och America, förrättad ifràn Ar $175^{1}$ til Ar 1756 , med Beskrifningar och Rön de Märkvärdigaste Växter, ut gifven Ester Dess Fräfälle. Stockholm, 1758.

Löfling, Pehr, "An Abstract of the Most Useful and Necessary Articles Mentioned by Peter Loefling, Botanist to His Catholic Majesty, in His Travels Through Spain, and that Part of South America Called Cumana, Consisting in His Life, and in Systematical Descriptions of the Plants of Both Countries, Referred to the Pages of the Original Swedish Edition." In Vol. II of [Jean Bernard] Bossu, Travels Through that Part of North America Formerly Called Louisiana (London, I 77 I), pp. 69-422.

- "Observaciones de historia natural hechas en España y en América por Pedro Loefling: traducidas del Sueco, segun la edicion de Carlos Linneo, por D. Ignacio de Asso," Anales de ciencias naturales, III 
(1801), 278-315; IV (1801), 155-19I; V (1802), 82-104, 296340.

López Ruiz, Sebastián Josef. Defensa y demostracion del verdadero descubridor de las quinas del Reyno de Santa Fé, con varias noticias utiles de este especifico, en contestacion á la memoria de don Francisco Antonio Zea, su autor el mismo descubridor D. Sebastian Josef Lopez Ruiz, honorario de la Real Academia Medica de Madrid. Madrid, I 802 .

"Manuscritos inéditos relativos a la Universidad de San Marcos," Boletín bibliográfico (Universidad Nacional Mayor de San Marcos de Lima), XII (I942), II6-I 34 .

[Martínez de la Ruda, Manuel, et al.] Certamen ò conclusiones Matematicas, defendidas en esta Real Universidad de $S$. Marcos, en presencia del Excmo Señor Virrey, Real Audiencia, y demas Tribunales .... [Lima, June I I, 1768.] In Biblioteca Nacional de Santiago (Chile), Sala Americana, I 4 (356-15).

Memorias de los vireyes que han gobernado el Peru, durante el tiempo del coloniaje español. 6 vols. Lima, 1859 .

Mémoires de mathématique et de physique, présentés à l'Académie Royale des Sciences, par divers savans, et lus dans ses assemblées. Vol. XI. Paris, I 786.

Memorial literario, instructivo y curioso de la corte de Madrid.

I (February, I784), I 8-2 I: "Real Gabinete de Historia Natural."

I (April, 1784), 28-30: "Real Jardín Botánico."

II (July, I 784), 48-85: "Descripción de las fiestas públicas con que la Imperial Villa de Madrid celebró la paz, y el feliz nacimiento de los dos Serenísimos Infantes D. Carlos y D. Felipe en los días I3, I 4 y 15 de este mes."

III (September, 1784), 8-9: "Real Jardín Botánico."

VI (December, I785), 482-494: "Noticia de los exercicios públicos de Botánica, que en los dias 28 y 3 I de este mes tuvieron los discipulos de la Escuela del Real Jardin de esta Corte, dirigidos por D. Antonio Palau y Verdera, segundo Catedrático de Botánica por S. M."

IX (October, I786), I49-I60: "Real Sociedad Aragonesa de los Amigos del País."

IX (December, I786), 494-502: "Botánica. Relación de los exercicios públicos que de esta facultad se han tenido en los dias 6 y 9 de este Mes, en el Real Jardin de esta Corte."

XI (July, I 787), 306: "Real Jardín Botánico."

XV (September, I 788), 69-76: "Exercicios publicos de Botanica que se tuvieron el dia I6 de Julio de este año en el Real Jardin Botanico de esta corte; dirigidos por el Dr. D. Casimiro Gomez Ortega ...." XV (September, I788), I67-169: "Carta de un vecino de Lima á los autores del Memorial Literario, acerca de las disertaciones Botanicas de D. Antonio Joseph Cabanilles." 
XV (December, 1788), 685-697: "Epitome historico de la Literatura Botánica Española, recorriendo y comparando las épocas de esta Ciencia con las de la Historia profana."

XVI (April, I 789), 580-596; XVII (May, 1789), 4I-64: "Respuesta á la carta que D. Antonio Cavanilles ha publicado en contextacion á la de un vecino de Lima, sobre la falta de fundamentos para haber establecido varios géneros de Plantas en sus disertaciones Botánicas."

XVII (August, 1789), 589-607: "Breve discurso que para dar principio á los primeros exercicios públicos de la Botanica, que se celebraron el dia 3 de noviembre del año de 1788 en la sala del Real Jardin Botánico del Departamento de Cartagena...."

Mitchill, Samuel L. "A Discourse Delivered Before the New York Historical Society, at their Anniversary Meeting, 6th December, 1813, Embracing a Concise and Comprehensive Account of the Writings which Illustrate the Botanical History of North and South America," New York Historical Society, Collections, II (I8I4), I 49-2 I 5.

Molina, Juan Ignacio. Saggio sulla storia naturale del Chili. Bologna, I 782 .

Monardes, Nicolás. Joyfull Newes out of the Newe Founde World. ("Tudor Translations" series.) 2 vols. London, 1925.

[Moreno, Gabriel.] "Elogio del doctor don Cosme Bueno," Almanaque peruano y guia de forasteros. Lima, 1799.

Mouton-Fontenille, M. J. Eloge de Joseph Dombey, médecin, botaniste du roi. Bourg, [ca. 1800$]$.

[Mutis, José Celestino.] Instrucción formada por un facultativo existente por muchos años en el Perú, relativa de las especies y virtudes de la quina. Cádiz, I 792.

[Noriega, José de, and Mariano Tristán. Theses.] (No title, or title page lost. Starts with "Ex logica.") [Lima, 1777.] In Biblioteca Nacional de Santiago (Chile), Sala Americana, 14(259-8).

Novo y Colson, Pedro de (ed.). La vuelta al mundo por las corbetas Descubierta y Atrevida al mando del Capitán de Navío D. Alejandro Malaspina desde 1789 á I794. Madrid, I885.

"Observaciones, y Conocimientos de la Quina, debidos al Doctor D. Celestino Mutis, Comisionado por S. M. para este y otros importantes asuntos," Mercurio peruano, XII (I 795), 2 I I-2 I 4.

Odriozola, Manuel de (ed.). Documentos literarios del Perú. Lima, I8631877. Materials relating to Cosme Bueno in Vols. III and IV.

Oviedo y Valdés, Gonzalo Fernández de. Historia general y natural de las Indias, islas y Tierra-Firme del mar océano. Ist complete edition. 4 vols. Madrid, 185 I-1 855 .

Paredes, José Gregorio. Theses quas pro gradu licentiatus in Medicina obtinendo apud regalem Sancti Marci Universitatem. Lima, 1815. In Biblioteca Nacional de Santiago (Chile), Sala Americana, I4(259-Io). 
[Pauw, Cornelius de.] Recherches philosophiques sur les Américains, ou Mémoires intéressants pour servir à l'histoire de l'espèce humaine. 2 vols. Berlin, I 770.

Ponz, Antonio. Viaje de España. One-volume edition. Madrid: M. Aguilar, 1947. (Ist edition. I 8 vols. 1772-1 794.)

"Principios de botánica en cartas a una señora," Semanario de agricultura $y$ artes, XII (Madrid, I 802), 209-224, 226-239, 242-256, 261-272, 279-287.

Quer, Joseph. Flora española, ó historia de las plantas que se crian en España. 4 vols. Madrid, 1762-1 764.

"Real Orden sobre el donativo para la impresion de las Floras Americanas," Mercurio peruano, XI (May 4, 1794), 12.

[Ribera, Lázaro de.] Certamen o teses Mathematicas, demostradas en la Real Universidad de San Marcos, en presencia de los Excelentisimos Señores Don Manuel Guirior... y de su Exma Esposa la Sra Doña Maria Ventura Guirior por Don Lazaro de Ribera, Alferez de CabaLleria de la Guardia de S. Exc. baxo la instruccion, y direccion del Doct. D. Cosme Bueno, Catedratico de Prima de Matematicas, y Cosmógrafo mayor del Reyno. [Lima, I778.] In Biblioteca Nacional de Santiago (Chile), Sala Americana, I 4(259-8).

[Rivero, Tomás, et al.] Carolinum pensum trienni primi, sive universae philosophiae theses una cum primis Matheseos Elementis .... [Lima, April 15, 1774.] In Biblioteca Nacional de Santiago (Chile), Sala Americana, I 4 (356-15).

Rodríguez Casado, Vicente, and Guillermo Lohmann Villena (eds.). Joaquín de la Pezuela, virrey del Perú, 18I6-I82I: memoria de gobierno. Seville: Escuela de Estudios Hispano-Americanos de Sevilla, 1947.

Romero, Carlos A. "Algunos documentos sobre la misión geodésica francesa de 1736," Revista histórica (Lima), X (1936), 107-1 17.

[Ruiz, Antonio.] An Historical Eulogium on Don Hippolito Ruiz Lopez, First Botanist, and Chief of the Expedition to Peru and Chile .... Translated by H. Hatcher. Aylmer Bourke Lambert, ed. Salisbury, I 83 I.

Ruiz López, Hipólito. "Memoir on the Virtues and Uses of the Plant Called in Peru the Star-Reed (Bejuco de la Estrella)." See Lambert, An Illustration . . . .

[-_.] "Memoria sobre las virtudes y usos de la planta llamada en América Bejuco de la Estrella." Summary in Variedades de ciencias, literatura $y$ artes (Madrid), III (1805), 59-62.

- Quinologia, o tratado del árbol de la quina ó cascarilla, con su descripcion y la de otras especies de quinos nuevamente descubiertas en el Perú. Madrid, 1792.

- Relación del viaje hecho a los reynos del Perú y. Chile por los botánicos y dibuxantes enviados para aquella expedición, extractado de los diarios por el orden que llevó en estos su autor. Agustín J. Ba- 
rreiro, ed. Madrid: Real Academia de Ciencias Exactas, Físicas y Na. turales, I $93 \mathbf{I}$.

- Relación histórica del viage, que hizo a los reynos del Perú y Chile el botánico D. Hiprilito Ruiz en el año de 1777 hasta él de 1788 , on cuya ipoca regresí a Madrid. 2nd ed. of previous item. Jaime Jaramillo-Arango, ed. 2 vols. Madrid: Real Academia de Ciencias Exactas, Físicas y Naturales, 1952. (Cited as Ruiz, Relación.)

- Respuesta para desengaño del público á la impugnacion que ha divulgado prematuramente el Presbitero don Josef Antonio Cavanilles, contra el Pródromo de la Flora dil Perí, é insinuacion de algunos de los reparos que ofrecen sus Obras Botánicas. Madrid, 1796.

- Travels of Ruiz, Pavin, and Dombey in Peru and Chile (I7771788). Trans. of Relación del viaje by B. E. Dahlgren. (Botanical Series, Field Museum.) Chicago, 1940.

Ruiz López, Hipólito, and José Pavón. Flora Peruvianae, et Chilensis prodromus, sive novorum generum plantarum Peruvianarum, et Chilensum descriptiones, et icones. Madrid, I 794. (Cited as Ruiz and Pavón, Prodromus.) Also, a second edition, ed. Gaspar Xuárez, published in Rome, 1797 .

- Flora Peruviana, et Chilensis, sive descriptiones, et icones plantarum Peruvianarum, it Chilensium, secundum systema Linnaeanum digestae, cum characteribus plurium generum evulgatorum reformatis. 3 vols. [Madrid], 1798-1802. (Vol. IV published Madrid, 1957; Vol. $\mathrm{V}$ now being published in instalments in Anales del Instituto Botínico A. J. Cavanilles de Madrid [XVI (1958), 353-462; XVII (1959), 377-495]).

Suplemento a la quinología, en el qual se aumentan las Especies de Quina nuevamente descubiertas en el Perú por Don Juan Tafalla, y la Quina naranjada de Santa Fé con su estampa. Añadese la Respuesta á la Memoria de las Quinas de Santa Fé que insertó Don Francisco Zea en los Anales de Historia natural, y la satisfacion á los reparos, ó dudas del Ciudadano Jussieu sobre los Géneros del Pródromo de la Flora del Perí y Chile. Madrid, 1801.

Schultes, Joseph August. "Schultes's Botanical Visit to England," Botanical Miscellany, I (1830), 48-78.

Schwab, Federico. "Una carta inédita del botánico español Hipólito Ruiz," Boletin bibliográfico (Universidad Nacional Mayor de San Marcos de Lima), XVII (June, I947), I27-I30.

Townsend, Joseph. A Journey through Spain in the Years 1786 and I787; with Particular Attention to the Agriculture, Manufactures, Commerce, Population, Taxes, and Revenue of that Country; and Remarks in Passing through a Part of France. 3rd ed. Dublin, 1792. Ulloa, Antonio de. Noticias americanas: entretenimientos físico-históricos sabre la América meridional, y la septentrional oriental. Madrid, I 792.

-. A Voyage to South America ..... 2nd ed. 2 vols. London, I 760.

Unanue, Hipólito. "Botánica. Introducción [y Conclusión] a la descrip- 
ción científica de las plantas del Perú," Mercurio peruano, II (May 29 and June 2, 1791), 68-76, 77-86.

Vargas Ugarte, Rubén. Manuscritos peruanos en las bibliotecas de América. ("Biblioteca peruana" series, Vol. IV.) Buenos Aires, 1945.

$V$ ariedades de ciencias, literatura y artes.

III (1805), I 89-192: "Memoria sobre la legítima calaguala, y otras raices que con el mismo nombre nos vienen de la América meridional."

III (I 805), 253-256: "Anuncio."

III (I 805), 315-320: "Memoria sobre las virtudes y usos de la raiz de la planta llamada Yallhoy en el Perú."

III (1805), 351-362: "Progresos de las ciencias físicas en Europa."

Ward, Bernardo. Proyecto económico, en que se proponen varias providencias, dirigidas a promover los intereses de España, con los medios y fondos necesarios para su plantificación, escrito en el año 1762 . Madrid, I 779 .

Zea, Francisco Antonio. "Memoria sobre la quina segun los principios del Sr. Mutis," Anales de historia natural, II (Madrid, I 800), I 96-235.

\section{SECONDARY WORKS}

Aiton, Arthur S. "The Impact of the Flora and Fauna of the New World upon the Old World during the Sixteenth Century," Biologia, II (Chronica Botanica, Vol. XII, Nos. 4-6 [1950-195I]), I 2 I-125.

Álvarez López, Enrique. "Algunos aspectos de la obra de Ruiz y Pavón," Anales del Instituto Botánico A. J. Cavanilles de Madrid, XII (1953), 5-III.

- "Cavanilles: ensayo biográfico-crítico," Anales del Jardin Botánico de Madrid, VI (I 945), I-64.

"Dombey y la expedición al Perú y Chile," Anales del Instituto Botánico A. J. Cavanilles de Madrid, XIV (1955), 3I-129.

Arber, Agnes. Herbals: Their Origin and Evolution. 2nd ed. Cambridge: The University Press, 1938.

Arévalo, Celso. "Bernardo de Cienfuegos y la botánica de su época." In Asociación Nacional de Historiadores de la Ciencia Española, Estudios sobre la ciencia española del siglo XVII (Madrid, 1935), pp. 323-335.

Barreda y Laos, Felipe. Vida intelectual del virreinato del Perú. 2nd ed.

Buenos Aires, 1937.

Barreiro, Agustín J. Don José Antonio Pavón y Jiménez, I754-1840 .... Extracted from the proceedings of the Asociación Española para el Progreso de las Ciencias, I932. [Madrid, 1933?]

La historia natural en España durante el último tercio del siglo

XVIII. Extracted from the proceedings of the Asociación Española para el Progreso de las Ciencias, conferencia pronunciada en la Sección de Ciencias Naturales, September I0, I9I9. [Madrid, 1920?]

- El Museo Nacional de Ciencias Naturale's. Madrid: Consejo Su- 
perior de Investigaciones Científicas, Instituto de Ciencias Naturales "José de Acosta," 1944.

Blunt, Wilfrid. The Art of Botanical Illustration. London: Collins, 1950.

Cameron, Hector Charles. Sir Joseph Banks, K.B., P.R.S.: The Autocrat of the Philosophers. London: Batchworth Press, 1952.

Cap, P[aul] A[ntoine]. Joseph Dombey, naturaliste. Paris, I 858.

Caullery, Maurice. "Histoire des sciences biologiques." In Histoire de la nation française. Gabricl Hanotaux, ed. XV (Paris, 1924), I-296.

Céspedes, Guillermo. "Lima y Buenos Aires: repercusiones económicas y políticas de la creación del virreinato del Plata," Anuario de estudios americanos, III (Seville, I 946), 667-874.

Chardín, Carlos E. Los naturalistas en la América Latina. Vol. I. Ciudad Trujillo, 1949.

Colmeiro, Miguel. "Bosquejo histórico y estadístico del Jardín Botánico de Madrid," Anales de la Sociedad Española de Historia Natural, IV ( I 875 ) 24 I-345. (Cited as Colmeiro, "Jardín Botánico.")

- La botánica y los botánicos de la peninsula hispano-lusitana. Madrid, 1858 .

Core, Earl L. Plant Taxonomy. Englewood Cliffs, N. J.: Prentice-Hall,

I955.
Coxe, William. L'Espagne sous les rois de la maison de Bourbon, ou Mémoires relatifs à l'histoire de cette nation, depuis l'avènement de Philippe V en I700 jusqu'à la mort de Charles III en I788. 6 vols. Paris, 1827.

Dakin, Douglas. Turgot and the Ancien Régime in France. London: Methuen \& Co., I939.

Dale, William Pratt. "The Cultural Revolution in Peru, 1750-1820." Unpublished Ph.D. dissertation, Duke University, 1941.

De Beer, G. R. Sir Hans Sloane and the British Museum. London: Oxford University Press, I953.

Desdevises du Dezert, G[eorges]. "La Richesse et la civilisation espagnole au XVIII e siècle," Revue hispanique, LXXIII ( I 928), I-488.

De Terra, Helmut. Humboldt. New York: Knopf, 1955.

Dictionary of National Biography, XII (London, 1921-1922), 649. Article on Alexander MacLeay.

Donoso, Ricardo. El Marqués de Osorno Don Ambrosio Higgins. Santiago de Chile: Universidad de Chile, I $94 \mathrm{I}$.

Duran-Reynals, M. L. The Fever Bark Tree: The Pageant of Quinine. New York: Doubleday, 1946.

Earnest, Ernest. John and IVilliam Bartram, Botanists and Explorers. Philadelphia: University of Pennsylvania Press, 1940.

Eguiguren, Luis Antonio (ed.). El Archivo Nacional del Perú, dependencia del Ministerio de Justicia: breve inventario de expedientes. Vol.

I. Lima, 1949.

dad de San Marcos y sus colegios. 3 vols. Lima, 1940-195 I. 
Enciclopedia universal ilustrada (Madrid: Espasa-Calpe, 1926), LII. Article on Hipólito Ruiz.

Encyclopedia Britannica (Chicago, 1949), XV, article on Antony Raphael Mengs; (Chicago, I960), V, article on Cinchona.

Ferrer, Pedro Lautaro. Historia general de la medicina en Chile. Talca, Chile, [1904].

Fries, Rob. E. A Short History of Botany in Sweden (Seventh International Botanical Congress, Stockholm, 1950). Uppsala, 1950.

Gager, C. Stuart. "Botanic Gardens of the World: Materials for a History." Brooklyn Botanic Garden Record, XXVI (No. 3, July, I 937), I 49-353.

Goodspeed, T. Harper. Plant Hunters in the Andes. New York: Farrar and Rinehart, I94 I.

Gredilla, A. Federico. Biografía de José Celestino Mutis con la relación de su viaje y estudios practicados en el Nuevo Reino de Granada. Madrid, I 9 II.

Gudger, E. W. "George Marcgrave, the First Student of American Natural History," The Popular Science Monthly, LXXXI (September, 1912), 250-274.

Gutiérrez, Juan María. "Escritores americanos anteriores al siglo XIX: Doctor Don Pedro de Peralta," Revista del Río de la Plata, VIII (I874), I94-2II, 33I-367; IX (I875), 6I-IOI, 44I-478, 553$626 ; X(1876), 329-381$.

Guyénot, Émile. Les Sciences de la vie aux XVII et $X V I I I^{e}$ siècles: l'idée d'évolution. ("L'évolution de l'humanité, synthèse collective," LXVIII.) Paris, I 941.

Hagberg, Knut. Carl Linnaeus. Translated from the Swedish by Alan Blair. London: Cape, 1952.

Haggis, A. W. "Fundamental Errors in the Early History of Cinchona," Bulletin of the History of Medicine, X (194I), 41 7-459, 568-592. Hanson, Earl Parker (ed.). The New W orld Guides to the Latin Ameri-

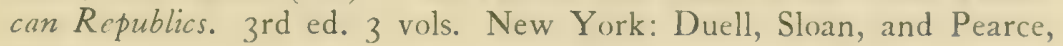
1950.

Harvey-Gibson, R. J. Outlines of the History of Botany. London: A. \& C. Black, I 9 I 9.

Hawks, Ellison. Pioneers of Plant Study. New York: Macmillan, I 923. Hernández C[ornejo], Roberto. El salitre (resumen histórico desde su descubrimiento y explotación). Valparaíso, Chile: Fisher Hnos., 1930. Herr, Richard. The Eighteenth Century Revolution in Spain. Princeton: Princeton University Press, 1958.

Herrera, Fortunato L. "Botanistas de fines del siglo XVIII: primeros escritos de vulgarización científica en el Perú," Revista del Museo Nacional, VI (Lima, I 937), 95-I 24.

- "La expedición botánica de Ruiz y Pavón (1777)," Revista del Museo Nacional, VI ( I 937), I 5 I-I 58.

. "Exploraciones botánicas en el Perú," Revista del Museo Nacional, VI (No. 2, I937), 291-358. 
-. "Juan 'Tafalla, ilustre botánico español: primer catedrático de fitografia en la Universidad de San Marcos," Revista de ciencias, XXXIX (Lima, December, 1937), 47-60.

- "Precursores de los estudios botánicos en el Departamento del Cusco (apuntes sueltos)," Revista del Museo Nacional, VII (1938), $53^{-1} 30$.

Howard, John Eliot. Illustrations of the Nueva Quinologia of Pavón. London, 1862.

Howe, James Lewis. Bibliography of Metals of the Platinum Group. ("Smithsonian Miscellaneous Collections," Vol. 38, No. 1084.) Washington, 1897 .

Index Kewensis plantarum phanerogamarum nomina et synonyma omnium generum et specierum a Linnaeo usque ad annum MDCCC$L X X X V$ complectens nomine recepto auctore patria unicuique plantae subjectes. 2 vols. and supplements. (Oxford: Clarendon Press, 1895-. Iriarte, Tomás de. Poesías. ("Clásicos Castellanos," No. I 36.) Madrid, I 953 .

Jaramillo-Arango, Jaime. The Conquest of Malaria. London: William Heinemann Medical Books, 1950.

- "Estudio crítico acerca de los hechos básicos de la historia de la quina," Anales de la Sociedad Peruana de Historia de la Medicina, X (1 949), 3I-88. Spanish version of The Conquest of Malaria.

Jiménez de la Espada, Marcos. "El cumpi-uncu hallado en Pachacamác," El Centenario. Revista ilustrada, organo oficial de la junta directiva encargada de disponer las solemnidades que han de conmemorar el descubrimiento de América, I (Madrid, 1892), 450-470.

Lacroix, Alfred. Notice historique sur les cinq de Jussicu, membres de l'Académic des Sciences (1712-1853): leur rôle d'animateurs des recherches d'histoire naturelle dans les colonies françaises .... Lecture fuite en la séance annuelle du 2 I décembre, 1936. Paris: Institut de France, Académie des Sciences, 1936.

Lanning, John Tate. Academic Culture in the Spanish Colonies. New York: Oxford University Press, 1940.

Lastres, Juan B. Historia de la medicina peruana. 3 vols. Lima: Universidad Nacional Mayor de San Marcos, I 95 I.

Laufer, Berthold. "The American Plant Migration," The Scientific Monthly, XXVIII (March, I929), 239-25I.

Lawrence, George H. M. Taxonomy of Vascular Plants. New York: Macmillan, 1951.

McDonald, Donald. A History of Platinum from the Earliest Times to the Eighteen-Eighties. London: Johnson Matthey \& Co., 1960.

McPheeters, D. W. "The Distinguished Peruvian Scholar Cosme Bueno, I 7 II-I798," The Hispanic American Historical Review, XXXV (November, 1955), 484-49I.

Mann, Bess Mae. "Pedro Peralta Barnuevo and the Culture of His Epoch." Unpublished M. A. thesis. Duke University, I 937. 
Medina, José Toribio. Biblioteca hispano-americana (1493-1810). 7 vols. Santiago de Chile, I898-1907.

-. Biblioteca hispano-chilena (1523-1817). 3 vols. Santiago de Chile, $1897-1899$.

- Historia del Tribunal del Santo O ficio de la Inquisición de Lirnu (1569-1820). 2 vols. Santiago de Chile, 1887.

- La imprenta en Lima (1584-1824). 4 vols. Santiago de Chile, I 904-1907.

Mendiburu, Manuel de. Diccionario histórico-biográfico del Perú. 2nd ed. II vols. Lima, I 931-1934.

Merrill, Elmer D. Botany of Cook's Voyages and Its Unexpected Significance in Relation to Anthropology, Biography, and History. Waltham, Mass. (Chronica Botanica, Vol. I4, Nos. 5-6), 1954. Pp. 164-384. Miller, Samuel. A Bricf Retrospect of the Eighteenth Cientury. Part First . . . Containing a Sketch of the Revolutions and Improvements in Science, Arts, and Literature During that Period. 2 vols. New York, 1803 .

Nouvelle biographie générale depuis les temps les plus reculés jusqu'à nos jours. J.C.F. Hoefer (ed.). Paris, 1872. Articles on Charles Plumier (XL, 499-50I) and Charles Marie de L'Héritier de Brutelle (XXXI, $70-72)$.

Olmedilla y Puig, Joaquín. "Episodios biográficos del sabio botánico español Hipólito Ruiz López," El porvenir farmacéutico (Madrid, No. I 5, I 885 ).

Paz Soldán, Carlos Enrique. "Don Cosme Bueno el Precursor," Mercurio peruano, XXI (September, I939), 353-373.

Paz Soldán, Mariano Felipe. Atlas geográfico del Perí. Paris, 1865.

Pezuela, Jacobo de la. Historia de la isla de Cuba. 4 vols. Madrid, I8681878 .

Priestley, Herbert Ingram. José de Gálvez, Visitor-General of New Spain $(1765-1771$ ). ("University of California Publications in History," Vol. V.) Berkeley, 1916.

Pulteney, Richard. Historical and Biographical Sketches of the Progress of Botany in England, from its Origin to the Introduction of the Linnean Systcm. 2 vols. London, 1790.

Quesada, Vicente G. La vida intelectual en la América española durante los siglos XVI, XVII y XVIII. Buenos Aires: La Cultura Argentina, 1917.

Quintana, Raúl. Breve reseña sobre botánica americana. Buenos Aires, I 945 .

Raimondi, Antonio. "Ligera revista histórica sobre los estudios hechos en el Perú en las ciencias naturales y de los escritores que se han ocupado en la historia natural del mismo," Anales universitarios, I (Lima, I 862), 196-224.

- El Perí. 6 vols. in 5. Lima, 1874-1913.

Ramos Pérez, Demetrio. El tratado de limites de 1750 y la expedición de 
Iturriaga al Orinoco. Madrid: Consejo Superior de Investigaciones Científicas, Instituto Juan Sebastián Elcano de Geografía, 1946. Reed, Howard S. A Short History of the Plant Sciences. Waltham, Mass.: Chronica Botanica, 1942.

Restrepo Tirado, Ernesto. "Apuntes sobre la quina," Boletin de historia $y$ antigüedades, XXX (Bogotá, September-October, 1943), 912-925. Reyes Prósper, Eduardo (ed.). Dos noticias históricas del inmortal botánico y sacerdote hispano-valentino don Antonio José Cavanilles por D. Antonio Cavanilles y Centi y $D$. Mariano La Gasca con anotaciones y los estudios bio-bibliográficos de Cavanilles y Centi y de La Gasca por el Dr. Eduardo Reyes Prósper. Madrid, 1917.

Rickett, Harold W. The Royal Botanical Expedition to New Spain.

Waltham, Mass. (Chronica Botanica, Vol. XI, No. 1), 1947.

Riva Agüero, José de la. "Don José Baquíjano y Carrillo," El Ateneo (Lima), VI (1905), 1945-1979; (1906), 5-47.

Rivas Godoy, Salvador. "Ruiz y Pavón, discípulos destacados de Gómez Ortega," Anales de la Real Academia de Farmacia, XXI (No. I, I955), 23-30.

Robbins, Wilfred W., and T. Elliot Weier. Botany: An Introduction to Plant Science. New York: Wiley, 1950.

Roldán Guerrero, Rafael. "Discurso del presidente," Anales de la Real Academia de Farmacia, XXI (No. I, I 955), 30-34.

Rose, T. Kirke. The Precious Metals, Comprising Gold, Silver, and Platinum. London, 1909.

Rydén, Stig. Pedro Loefling en Venezuela ( $1754^{-1756)}$ ). Madrid: Instituto Ibero-Americano Gotemburgo Suecia, 1957.

Sarrailh, Jean. L'Espagne éclairée de la seconde moitié du XVIII siècle. Paris: Impr. nationale, 1954.

Schwab, Federico. "Los almanaques peruanos y guías de forasteros ¿1680?-1874," Boletín bibliográfico (Universidad Nacional Mayor de San Marcos de Lima), XIX (1948), 1-48.

Sempere y Guarinos, Juan. Ensayo de una biblioteca española de los mejores escritores del reynado de Carlos III. 6 vols. Madrid, 1785I 789 .

Shafer, Robert J. The Economic Societies in the Spanish World ( $1763^{-}$ I 821 ). Syracuse, N.Y.: Syracuse University Press, 1958.

"Shape of the Earth," Sky and Telescope, XVIII (March, 1959), 249. Somolinos d’Ardois, Germán. "Bibliografía del Dr. Francisco Hernández, humanista del siglo XVI," Inter-American Review of Bibliography, VII (January-March, I 957), I-76.

Susto, Juan Antonio. Sebastián López Ruiz, médico y naturalista (1741I832). Panamá, 1950.

Taylor, Norman. Cinchona in Java: The Story of Quinine. New York: Greenberg, 1945.

"Vanguard Measurements Give Pear-Shaped Component of Earth's Figure," Science, CXXIX (February 27, I 959), 565-566. 
Verdoorn, Frans (ed.). Plants and Plant Science in Latin America. Waltham, Mass.: Chronica Botanica, I 945.

Visitor's Guide to Madrid and Places of Interest in Its Vicinity. Madrid: Afrodisio Aguado Guides, 1958.

Villareal, Federico. "Historia de las matemáticas en el Perú," Gaceta cientifica (Lima), III (May 31, I887), I69-178; (July 31, 1887), 228-236. This article began in the issue of April 30, 1887 , and ran in every monthly number for a period of several years.

Von Hagen, Victor Wolfgang. South America Called Them. New York: Knopf, I 945 .

Weberbauer, A. "Historia de la exploración botánica del Perú," Revista de la Universidad Católica del Perú, IV (July, August, October, I 936), 293-305, 368-377, 509-525.

Wolf, Howard, and Ralph Wolf. Rubber: A Story of Glory and Greed. New York: Covici, Friede, 1936. 


\section{N D E X}

Abaría, Francisco Antonio de, 214

Academia de Ciencias (Madrid), 292, 293n, 294-295

Academia de Medicina (Madrid), 3I, $67,81,240$

Academia de Nobles Artes de San Fernando (Madrid), 41, 54, 227, 230$23 \mathrm{I}, 254$

Académie des Sciences (Paris), 9, 17, 20, $22,93,184,234,237$; and Dombey, $50-51,61,96,134,164,168,173$, I 74

Accademia dei Lincei (Rome), 6

Acomayo (Peru), 196

Acuña, Pedro de, 229

Adanson, Michel, 13

Adler, Carl Fredrik, 13

Africa, I 3, 186

Afzelius, Adam, 13

Agonizantes, religious order, 66, 72

Agregados, I5 5 ; chosen, I42; salary, $142,143,153,268-271$; and chair of botany, $153,159,267,269,270,272-$ $273,278-281,283 ;$ and Cinchiona, $197,203,276-278,290 \mathrm{n}$; shipments of, $259,26 \mathrm{I}, 267-271$; travels, 268 $27 \mathrm{x}, 273-279,290 \mathrm{n}$; impact of, 272$273,283,284$; see also Cortés, Manzanilla, Pulgar, Rivera, Tafalla

Aguascalientes (New Spain), 222

Ague; see Malaria

Aguirre, Juan Joseph de, 270, 274

Albuerne, Manuel, 260 n

Alcalde, Josef Antonio, 2 I $5 \mathrm{n}$

Alcaldía de la Real Casa y Corte (Spain), $3 \mathbf{2} 2$

Alcántara Arguil, Pedro, 323

Alcarraz, Manuel, ros

Alcea (genus), $237 \mathrm{n}$

Alisbaguirre, Bernardo de, 2 I $5 \mathrm{n}$

Almadén, $126,127,128$

Almanac of Peru, 18, 68-69, $73 \mathrm{n}$

Alonso, Domingo, 255
Alonso, Zenon, 249, 251-254, 257, 273-

274

Alonsoa (genus), 254

Althaea (genus), $237^{\mathrm{n}}$

Álvarez Azevedo, Tomás, 124, $125-128$, I 74

Álvarez López, Enrique, xi, 237n, 243$244,328,338$

Amancaes, Paseo de, 80,82

Amantes del País, Real Sociedad de (Peru), 272

Amat, Manuel de, 67, 70, $72 \mathrm{n}$

Amazon River, 18, 20, 104

Amethyst, $85 \mathrm{n}$

Amsterdam, 12, 335

Anales de la Real Academia de Farmacia, 338

Anatomy, study of, 73

Andes Mountains, 98, 99, 102-104, 109I 10 , 1 I 5

Animals, 6, 29, 36, 41, 137, 189, 288

Anoda (genus), $235 \mathrm{n}$

Anonymous correspondence, 235-24I

Anthodon (genus), 254

Antilles; see West Indies

Antioguia (New Granada), 223

Antiquities, archeological, 4 $1,84-85,89$, I $2,137,171$, I $72 \mathrm{n}, 178 \mathrm{n}, 267-268$, 288

Aragón, 44, 48

Aranjuez (Spain), 6, 1 I

Araucanian Indians, 11 7-118, 120

Araucaria (genus); see Pines

Arbustrum Americanum, 14

Arbutus multiflora, 100

Arcano de la quina, 197-198, 207

Archeological relics; see Antiquities

Archimedes, $72 \mathrm{n}$

Architecture, nymph of, 187

Areche, José Antonio, 66n

Arequipa, 220

Arévalo, Celso, 49 
Argentina, 69; see also Buenos Aires, La Plata

Argillo, Conde de, 320

Aristolochia fragrantissima, $139-140$, 286,323

Aristotelia Macqui, $168 \mathrm{n}$

Aristotle, 3, 7

Armadillos, 85n

Arnedo; see Chancay

Art, Academy of; see Academia de Nobles Artes

Artifacts; see Antiquities

Artists; see Illustrators

Asesor, 149, I 5 I

Assonia (genus), 235n

Astrology, 69

Astronomy, 14, 17, 24, 45, 46, 68-69

Atacamite, 133

Atahualpa, 7 in

Aublet, Jean Baptiste Christophe, 23

Audiencia, 215, 217, 219,271

Austria, 12, 19, 22, 23

Avilés, Gabriel de, 219

Azores, 268

Baccharis (genus), $238 \mathrm{n}$

Bahamas, 15

Baldness, i i in, 134

Balearic Islands, 44,47

Balloons, $68 \mathrm{n}, 134$

Balsam, 19, 42, $106 \mathrm{n}$

Banks, Joseph, 12, I 3, 24, 86n, 133, I 79-180, 183

Baquíjano y Carrillo, José, 72

Barbados, 15

Barbarism, botanical, 27,37

Barbasco, 18

Barcelona, 28, 29n, 187

Barnades, Miguel, 26, 32, 37, 44, 46, 57

Barreiro, Agustín J., 339

Bartram, John, 14, 15

Basques, 47,48

Bayonne Gazette, $328 \mathrm{n}$

Bedoya, Bartolomé de, 149, 15I, 275 , 288

Begonia tuberosa, 8on, 82

Bejuco de la estrella, 139-140, 286, 323

Belorado (Spain), 53, 289

Benavente, Luis de, I 19 , I 20-12 I

Benavides, Ambrosio de, 119, 124

Berlin, I 2

Berlin, Andreas, 13

Bernouilli, Jean, 67

Biblioteca Real (Madrid), 26 in

Bibliothèque Nationale (Paris), I84, $249^{n}$
Bignonia alba, 140

Bío-Bio River, I 7

Birds, 41, 85n, 133, 137, 268, 288

Blagden, Charles, 179,180

Boerhave, Hermann, 68, 71

Bogotá, 23, 34, 91, 102, 223, 247, 283 284; and Cinchona, 45, 198-211; see also Colombia, New Granada

Boldo (shrub), I 2 I

Boldó, Baltasar Manuel, ix(n)

Bolivia, 21, 69, 108, 210-211, 224, 284, 333-335

Bologna, 10, 31, 37

Bonapartea (genus), 26 I

Bones, petrified, 133,267

Bonpland, Aimé, 209, 284, 294

Books: herbals, 4; published in Spain on botany, 37-39, 187 ; supplied to Ruiz and Pavon, 59; Dombey buys own, 60 ; lost in fire, $1+5-1+6$; L'Héritier buys, 183 ; Tafalla receives, $268 \mathrm{n}$; Pavón acquires, 292, 294; see also Publication

Bordenave, Jean de, 74,82 , I14-II5, 129,130

Botanic Garden of Madrid; see Jardin Botánico de Madrid

Botanic gardens, 14, 23, 333, 334; Spanish, vii, 6, 11, 12, 29, 31, 32, 36, 38, $39,187-189,266-267$; in Europe, 9$12,14-16,23$; in Peru, 66, 159, 266$267,271,281,283,284$; see also Jardín Botánico de Madrid, Jardin du Roi, Kew Botanic Gardens

Botanical exploration, 5, 12-16, 18, 2024,50 ; by Spanish, vii-ix, 5-7, 33-36, $46,221,266,308,329$; difficulties of, 327 ; see also Ruiz-Pavón expedition

Botanical instruction: in Europe, 11 , I 2; in Spain, 29, 36-39, 187-189, 244, 245; in Peru, 103n, 153, 159, $266,267,269,270,272-273,279-$ 283 ; in Mexico, 103n, 266-267, 269

Botanical Office of Peru, 205, 249, 253; inadequacy of quarters, $190,225-226$, $251,256,264$; location, $226,256-$ $257,263,305,307,309,319-320$; rent, $226,248,256-257,258 \mathrm{n}, 260$, $290,303,305,306,313 \mathrm{n}, 315,319$; activity in, $228-230,232,249-256$, 258-264, 290-291, 300-309, 312-313, 317-323; jurisdiction over, 243-245, 306-307, 319-320; inventory of, 312, 323 ; landlord seeks to attach property of, 315 ; omitted from budget, 315; 
adds Rodriguez, 316; see also Flora Peruviana

Botany: background knowledge of, ix, 326; handmaiden to medicine, $3-4$; in $17^{\text {th }}$ century, 7-8; study of, stimulated by Linnacus, 8-ro; history of, Priestley and after, 24-25; today, 25 26 ; 18 th century definition of, 26; Spanish interest in, 27-49, 46-49, 187$189,302,329$; joys of plant collecting, 327; see also Botanic gardens, Botanical exploration, Botanical instruction

Botany Bay, 24

Bougainville, Louis Antoine de, 23-24, 50

Bouguer, Pierre, 17

Bourbon, Island of, 13

Bourgoing, Jean François, 51-52, 172

Bowles, William, 39, 92

Bravo de Castilla, Toribio, 83-84

Brazil, 1 4, 22, 23,89, 1 34, 154, 1 70-1 7 1

Breath, bad, 140

British Indian Cinchona Plantation, 334

British Museum, 2 Ion, 339

Browne, Patrick, I 5

Bru, Juan Bautista, 4 I

Brunete, Joseph, 55, 60-6I, 156, I57, $189,228 \mathrm{n}$; see also Illustrators

Budapest, 12

Buddleja incana, 100

Buen Consejo (ship), 85, 93, I IIIII3, $137,163,179 n$

Buena Muerte, colegio and garden of (Lima), 193, 284

Bueno, Cosme, $18,66-71,139,153,193$, $269,284,286$

Buenos Aires, 22, 23, 24, 34, 64, 67, 76, 247

Buffon, Count, 10, 93n, 95, 176, 178 , I 79

Butterflies, 42, 293n

Byron, John, 38

Caballero y Góngora, Antonio, 34n, 45, I 99

Cabarrús, Count, 249

Cabildo, 217-219, $221-222$

Cabinet of Natural History (Madrid), $29,34,39-43,58,112,128 \mathrm{n}, 170$, $264 \mathrm{n}, 280,28 \mathrm{r}, 282$; Pavón's offer to, 289 ; shell collections of, 298 ; junta for protection of, 300, 301, 303, 317, 319-325; in France, $176,178 n, 184-$ 185 ; see also Natural History

Cacao, 105
Cádiz, 35, 64, 187, 200, 303; Dombey in, $134,161-173,175 \mathrm{n}$

Caja de Amortización, 258-260, 264, 324-325

Calaguala root; see Polypodium angustifolium

Calcra (Chile), 214

Calisaya, 197, 204, 210-21: 333, 334

Callao, 111, 115, 154, 159

Cambridge, 12

Campeche (New Spain), 222

Campillo y Cosío, José del, 48

Campomanes, Count, 47,48

Canada, I 3

Canary Islands, vii

Canchalagua, 286

Cañete (Peru), 127

Cangas, Gregorio de, 77

Cape Horn; see Horn

Carabaya (Peru), 333

Cárdenas, Santiago de, 67

Carlist War, $32 \mathrm{I}$

Carmen, presidio of Nuestra Señora del, $221-222$

Carmona, Bruno Salvador, 34,35 , I I 3

Carondelet, Barón de, 277

Carriel de Castro, Juan Joseph, 67

Carrión y Marfil, José, 220

Cartagena (New Granada), 201, 223

Cartagena (Spain), 187

Carvajal, Joseph de, 30, 33, 35

Casape (Peru), 107

Casapillo (Peru), 107

Casa Real, Marqués de, 214

Casatejada (Spain), 54, 289

Cascarilla: definition of, $106 \mathrm{n}, 194 \mathrm{n}$; varieties of, 196, 309; see also Cinchona

Casimiria (genus), 82

Castel, Juan de Dios, 34, 35

Castilla, Francisco de, i in

Catesby, Mark, 15

Catherine the Great, I 74

Cavanilles, Antonio José: rivalry with Gómez Ortega, 35n, 209, 235, 241245 ; conflict with Ruiz, $120,156-157$, 209, 233-245, 262, 286, 287, 29on, 328 ; and Chilean pine, 120, 240; names genera, 1 21, 122, $156-157,186$, $235,236,238,245$; works of, 156 , 234-239, 241, 281; criticizes L'Héritier, $182-183$; and Mutis, 209, 234, 239, 242n; at Jardín Botánico de Madrid, 209, 242, 244-245, 26.7; and Zea, 209, 264; beginnings in botany, 234-235, 24I; plates of, 234, 328; 
and anonymous letters, 235-241; and Linnaeus, 236,237 ; friendly to $\mathrm{Pa}$ vón, 236, 240-242, 287; and Académie des Sciences, 237; criticizes Prodromus, 238; death, 240, 245, 262, 2 gon; herbaria of, 319

Cavanillesia (genus), 238

Cayenne, 20

Cebu (Philippine Islands), 223

Celis, Isidoro, 72

Censorship, 72

Ceratostema grandiflorum, 100

Cerdá, Francisco, 179n, 227-230, 244, $250-251$; and "Botanical House," 226 , $228,248,256-257$

Certificates of services, $81,102 \mathrm{n}, 122$ I 23, I 6I, 254, 288-289

Cervantes, Vicente, $266,267,269$

Ceylon, 13, 90, 92 n, 94, 334

Chacahuassi (Peru), 158, 196

Chancay (Peru), 82-83, I1 1 , I15, I63, $288 n$

Charles II, of England, 19

Charles III, of Spain, vii, 38, 40-46, 50, $5 \mathrm{I}, 72 \mathrm{n}, 325,329$

Charles IV, of Spain, 21 2-214, 225, 226 , $227-228,248,256,259,262$

Charles V, Emperor, 5

Chauchín (Peru), 98

Chavaneau, François, 94

Cheisea Physic Garden, I 2

Chemistry, 88, 92-98, I 25-I29, 19I, 206, $21 \mathrm{I}, 280,283,302$

Chicoplaya (Peru), 269

Chile, x, 16, 38, 69; nitrate, 96-97; climate, I17, 119; Indians of, 117II $8,120,125$; pines, II9-I2I, 137, I $41,240,279,287,288$; trees, II 9 , 121-122; epidemics in, $122-123$; people of, and botanists, $124-125$, 129; mines, 125-129, 174; support for Flora, 213-218, 337

Chiloé (Chile), 218

China, 1 3, 29

China peruana, 273,286

Chinchao (Peru), 107, 109, 196

"Chit-chat parties," I25

Chocolate, 90

Chunchos, I01, r 06

Cicero, 297, 298

Cienfuegos, Bernardo de, 28

Cienfuegosia (genus), $235 \mathrm{n}, 236 \mathrm{n}$

Cinchona, 42 ; Plumier to study, 16,18 ; La Condamine discovers, $18,20,45$, 208; of Loja, 19, 20, 105, 194, 195, 197, 198, 199, 200, 204, 208, 276,
$277 \mathrm{n}$; reasons for lag in acceptance, 19-20; uses for, 19-20, 192-198, 200, $203 \mathrm{n}, 2 \mathrm{II}$; source of name, 20; and Linnaeus, 20, 45; and Joseph de Jussieu, 20-2 I, 108; Humboldt discusses, $20,201,202,203,207 \mathrm{n}, 208-$ 210 ; collection of, 21, 105, 158-159, 194-195; extract of, 21, 108-109, 137, 193, 196, 288; and Mutis, 45, 105, 106, 197-211; Ruiz and Pavón discover, $102,103,106,155^{-156,158,}$ 195-197; commercial rivalry over, 105, 197-211, 333-335; species, 106, $156,195-198,201,203 \mathrm{n}, 204,205$, $207,208,210-211,255,278,290 n$, $313 n, 317,333-335$; current nomenclature, 106n; in Peru, 105-106, 108109, 155-156, I 58-159, 193-197, 203-205, 207, 210-211; proposed monopoly in Quito, I91; Quinología, 192-197, 203, 207; standards for analysis, 195n; and Tafalla, 197, 203, 276-278, 29on; and England, 197, $201,333-335$; in Spain, 197; and Dombey, I99n; in Flora Peruviana, 20I, 255, 261, 29on; controversy of Ruiz, Pavón, and López with Mutis and Zea, 199, 201-210; and United States, 20I, 335; Suplemento a la quinologia, 203-207, 239; in Bolivia, 210-211, 333-335; studies by Pavón on, $210 n, 301,309,313 \mathrm{n}, 318$; manuscripts on, 210n; Dutch, 211, 333335; Lambert study on, 29+-295; Pavón sells, 295, 314; history of, since $1840,333-335$

Cinnamomum Zeylandicum, 9 I

Cinnamon, 21, 42, 45, 89-92, 102

Cisneros, Diego, 72

"Citrus blossom," ro6, 196

City of Kings; see Lima

Clarke, Dr., $202 \mathrm{n}$

Classification of plants, 3, 15 ; Linnaean, 8-10, 23; natural, 9-10, I3, 37; Linnaean and Spain, 32, 36-38, 44, $48,79,188,227,228,236-237,245$, $262,290 n, 328$

Clavijo Fajardo, José, 289

Clayton, John, it

Clergy: Ximénez, 6; Hughes, 15 ; Feuillée, 16; Caballero y Góngora, 3+n, 45, 199; Flórez, 40; López de Cárdenas, 43; Mutis, 46n, 199, 202; interest of, in economic societies, 47; González Laguna, 66; Rer, 69; Celis, 72 ; and introduction of new ideas in 
Peru, 72; Bordenave, 74, 82 ; in montaña, 101, 106, 109, 138, 155, 158-159; Molina, 120; in Concepcion, 122-123; and contributions to Flora, $213-214,216-223$; Cavanilles, 234 ; see also Inquisition, Jesuits, Religion

Climate: Lima, $65 \mathrm{n}, 77,80,84,103$; Tarma, ıоo; montaña, 103, 140, 156; Huánuco, 110,140 ; Chile, I 17, 119 ; Spain, I r gn; Rio de Janeiro, 134

Clothing: of women in Lima, 77-75, 77 ; lost in fire, 146

Clugny, Jean Étienne Bernard, 52

Coca, 21, 42, 109, I 94, 273

Cochabamba, 223

Cocoa, 105,153

Coffee, 105,333

Coimbra, 12

Colchagua (Chile), 124

Colden, Cadwalader, I 4

Colombia, 93, 309, 335, 339; see also Bogotá, New Granada

Commerce: stimulus to, by economic societies, 47-48; Turgot's concern for, 50-51; Ruiz-Pavón expedition not to engage in, 58; decline of, in Peru, 76; rivalry over Cinchona, I05, $197^{-}$ $211,333-335$; contributions to Flora from, 21 5-216, 219 ; Pulgar suspected of engaging in, $274-275$

Commerson, Philibert, 23-24, 55, 61

Compostela (New Spain), 222

Conanthera (genus), 26 I

Concepción, 1 1 7-1 19, $122-123,163,213$, 216,218

Concolorcorvo, $75 \mathrm{n}$

Condal, Antonio, 34, 35

Condorcet, Marquis de, 9, 50-5 I

Conocimiento de los tiempos, 68-69

Conquista, Conde de la, 214

Conservatoire de Botanique (Geneva), I 85

Consulado, 2 I 9

Convictorio of San Carlos (Lima), 72, 267

Cook, James, I 3, 23-24, 50

Copiapó, 2 16, 2 I 7

Copper, 89, 94, $133 \mathrm{n}, 137,153,17 \mathrm{I}$, $248,295,312$

Coquet, Josef, 127

Coquimbo (Chile), I $26,128,133 n, 174$

Coquitos (palm fruit), $85 \mathrm{n}$

Córdoba (Argentina), 223

Cordón, Pedro, 306

Corps Législatif (France), 184, 249n
Correo de Madria, 188

Cortés, Xavier, 276-277, 279-281

Cortes, Spanish, 324

Cosmibuena (genus), 66, 240-241, 26 I

Cosmography, 67-69, 7on

Cost: of Spanish botanical expeditions, vii-viii; of Dávila's curiosities, 4 In; see also Flora Peruviana

Costa Rica, 335

Council of Castile, 250

Council of Ministers (Spain), 319

Creoles, 75-76

Crespo, Pedro Nolasco, 2 I I

Croix, Teodoro de, 151, 152, 159,268 , $288 n$

Cruz, Juan Manuel, 2 16n

Crystal, 134

Cuba, vii, viii (n), ix (n), 15, 23, 223 , $283-284,313,314,318,319,337$

Cuchero (Peru), 105n, 106-108, 196

Cućllar, Juan de, 169-172

Cuenca, I I 3, $220,277 \mathrm{n}$

Cuerpo de comercio (Chile), 215-216, 2 I 8

Cunningham, James, 13

Curso elemental de botanica, 39

Customhouse, 161-162, 164, 1 71, 303

Cuzco, 108, 220

Dahlgren, B. E., 339

D'Angeviller, Count, 95, 131, 171

Darwin, Charles, Io

Datura (genus), I OO, I I O-II I

Dávalos, José Manuel, 272, 273

Dávila, Pedro Francisco, 40-42

De Candolle, Augustin, $185,264 \mathrm{n}, 294$, $313,322,323$

De Jussieu, Antoine (elder), 28

De Jussieu, Antoine Laurent, 9-10, 5 I, 55-56, 6I, $120,166,234,239,240$, $249 n, 298$

De Jussieu, Bernard, 9, 22, 28, 51, 90, 9 I

De Jussieu, Joseph, 20-22, 51, 65, 74, 88-89, 108,13 I

De Pauw, Abbé, I 7 n

Delgado, Antonio, 253, 260n, 308, $309 \mathrm{n}$

Delgard, Martin, 88

Descartes, René, I7, 67, 71, $72 \mathrm{n}$

Descriptions, plant: of various botanists, $3,5,6,15,16,23,37$; royal instructions on, 58; of Dombey, I I3, I 70 ; of Ruiz and Pavón, 137, 138 , $145, \quad 152,159-160, \quad 165,212,225$, $228,234,240,249,254,261$; of L'Héritier, 176-177, I79, I 82-183, 
184, 185; of Cinchona, 195-198, 201, 203-204; of New Spain and New Granada, 246; of agregados, 270, 272-273, 278n, 279

Desdevises du Dezert, Georges, 49

Desfontaines, René Louiche, 184

Diamonds, 89

Dioscorides, 3-4, i in

Dirección General de Estudios, 305, 307

Discurso sobre el fomento de la industria popular, 47

Disease: discussed in almanacs, 69; see also Epidemics, Fevers, Malaria, Mal del valle, Mal de Mayco, Malsito, Smallpox, Venereal

Disputes, legal: Ruiz and Pavón vs. Trabuco, 148 -1 52

Disputes, official: José de Gálvez and France, 51-52; Dombey and Spanish officials, III-I13, I 3I-132, I 75 ; L'Héritier and the French government, 179-180, 184-185; Ruiz and Pavón and the Jardín Botánico de Madrid, 190 ; Madrid edition of Prodromus and the Spanish court, $232-$ 233; Ruiz and Pavón and Caja de Amortización, 259-261; Pulgar and Spanish officials, 274-275; Pavon, the Jesuits, and the colegio, 306; see also France, Partition, Spain

Disputes, personal and professional: see Banks, Cavanilles, Cerdá, Cinchona, Cook, De Jussieu, Dombey, Gálvez, Godin, Gómez Ortega, Lambert, L'Héritier, López Ruiz, MacLeay, Mutis, Pavón, Quer, Rubio, Ruiz, Sancha, Uses of Plants, Zea

Dombey, Joseph, ix-x, 50, 60, 64, 86n, $88,89,101,189,228,295,322,327$, 329,339 ; and Joseph de Jussieu, 22, $65,88-89,131$; and Spanish, 39, 56$57,65-66,73-75,77,82,102,1$ I 2 114, I 33, I61, 166, 170, 172, 175, 178 ; accused of spying, 51,129 ; must leave duplicates in Spain, 52, 58-59, 162-164, 167; early career, 55-56; physician, 55, 73-74, 102, 122-123, $130,161,175 \mathrm{n}$; description of, 56; financial problems, $56,61-63,82,85$, I1 $0,126,129,130,164,170,172-$ 174 ; relationship to Ruiz and Pavón, 56-58, 80-82, 83, 98, I I 4-II 5, 124 , I 28 -130, 133, 162, 165, I 67, I 72 , $174,175,287$; servants of, 63,98 , 130 ; friends in Lima, 65-66, 73-75, 87 , II3-II5, I29, I30; names plants,
$80,81,82$; friction with Gómez Ortega, 81, 82, 96, I $12-113,132$, I 42n, 162-167, 170, 178; certificates of services, $81,122-123,161$; and thieves, $83 ;$ and antiquities, 84-85, I 12; shipments of, $84-85$, I II-II 3 , $133,172,177$; and mineral waters, 85,98 ; and shipping living plants, 86 ; and mines, 89, 125-128, 174; and cinnamon, 89-92; and platinum, 92$94,162,172$; and saltpeter, 94-97, 174 ; illness, 102, I1 $6,131,134,161$, $169,174,177,186$; and mock raid, 106-107; and rubber, I10, 134; offers food to Huánuco, I10; to measure tides, III-112, I 75n; and Chilean pine, 120; genus named for, 120,157 , $186,235 \mathrm{n}, 238$; offered wife, 123 ; quarrel with Escobedo, I $31-132$; Spanish fears he will publish, 132$133,147,162,167$; offers reward, 134 ; and Brazil, 134 , 170-171; partition, 161-172; nominated to Académie, 164,174 ; feels sense of doom, 164,165 ; promise not to publish, 165-168, 176; publication by L'Héritier, 168, 176-185; sends manuscripts to France, 169,179 ; and Cuéllar, 170 ; attempts on life of, 173 ; retirement, 174-175; loses interest in botany, 174-175; and Catherine the Great, 174; burns his papers, 175; Banks criticizes, 180 ; death, $185 \mathrm{n}$, I86; and quina, $199 \mathrm{n}$

Dombeya (genus), 1 $20,157,186,235 \mathrm{n}$, 238

Donations for Flora, 212-224, 247, $248 n, 255,284,318$

Don Quixote, 107

Draftsmen; see Illustrators

Dried plants: orders concerning, 43, 80; Ruiz and Pavón, 85, 99-1or, 113, I $38,156,225,228$; Dombey, 86, 98, $113,133,162-165,172,176-182$, $184-185,228$; eaten by insects, ro3; Pavón, $103,289,304,325$; in art museum, II 3 ; on San Pedro de Alcántara, 137; lost in fire, 145 ; lost in shipwreck, 154; Banks, 179, 183; in French museum, 185 ; of botany students, 188; Cinchona, 204, 205, 206, 208,318 ; controversy over use of, $232 \mathrm{n}, 233-235,237-238,242-243$; at Jardín Botánico de Madrid, 245, $320 n$; shipped by Tafalla, 267-268, 270; Medical College, Lima, 272; 
Ynciarte, 280; Lambert receives, 291, 292, 293, 295, 299, 310-311, 322; Webb, 314-315; Née, 319; Cavanilles, 319 ; La Gasca, 326

Drugs, 5-6, 19-20, 90, 100, $110-111$, $121-122,137,139-140,286,309$, 323 ; see also Cinchiona, Coca, Herbs, Medicine, Uses of plants

Drunkenness, 104, $110-111,158$

Dryander, Jonas, I 79-180

Du Gage de Pommercuil, Marquise, 73, 80

Dugagesia verticillata, 80

Duhamel, Henri Louis, 38

Dutch, 9, 13, 14, 22, 34, 90, 91, 211, $333-335$

Earth: measurement of, 16-17

Earthquakes, 74, 77, 189

East Indies, 13, 29

Echegaray, Juan Baptista de, 66

Echevers, Pedro, 65, 27x

Economic societies, 47-48, 90, 91, 249

Ecuador, 333-335; see also Guayaquil, Quito

Efemeridi letterarie di Roma, 232

Eguía, Manuel de, 154, 155

El Brillante (ship), 156

El Dragón (ship), 159, 189

El Jasón (ship), 159

El Peruano (ship), 64, 79n, 133, 134, I $6 \mathrm{I}, 162$

El Pilar (ship), 156

Elhuyar, Fausto and Juan José de, 127 , $177 \mathrm{n}$

Encomiendas, 105

Engineer: Frézier, 16; Joseph de Jussieu, 2 I

England: botany in, 8-9, 1 2 ; naturalists of, 13-15, 24; Dombey accused of spying for, 51, I29; war with Spain, $67,103,115$, II $8,131,247$; and Buen Consejo, I11-112; influences manners in Brazil, 134; snake root of, 139; L'Héritier in, I 79-181, 183; captures Dombey, 186; and quina, $197,201,333-335$; method of engraving in, 252; Pavón sends specimens to, 29I-300, 304, 309-3II; see also Kew Gardens, London

Engravers: needed in Mexico, 221 ; Ruiz and Pavón seek most competent, 225 ; Martí, 227; Rubio, 227-232; Ruiz and Pavón cannot keep up with, 229 ; Gálvez, 231, 251, 309; Gálvez and
Rubio each to keep four busy, 232 ;

Gascó, 260n, 309; see also Engravings

Engravings, 4, 168, 221, 249, 291; in Flora Peruviana, 225, 227-232, 251$255,260-264,309$; cost of, for Flora, $247-248,253,256 \mathrm{n}, 258 \mathrm{n}, 26 \mathrm{on}$, $262 \mathrm{n}, 304,3 \mathrm{In}, 317$; see also Illustrations, Plates

Epidemics, 21, 102, 122-123

Eraso, Manuel, 65

Erythraea Chilensis, 286

Escandón, Domingo, 282

Escobedo, Jorge, visitador general, 115 , $124,127,131-132,135-137,140$, $142,143,147,148,151,1600,267$

Estufas (heaters), 79, 86, 245

Euclid, $72 \mathrm{n}$

Expeditions, botanic; see Botanical exploration, Ruiz-Pavón expedition

Extract of quina, 21, 108-109, 137, 193, 196,288

Falkland Islands, 23, 67, 154

Feathered quilt, 267-268

Feijóo, Benito Jerónimo de, 7 on

Ferdinand VI, of Spain, 30, 36, 39

Ferdinand VII, of Spain, 306, 308, 313 , 321

Feria, Marqués de, 2 I 9

Fernández Balmaceda, Pedro, 2 15n

Ferns, $228 \mathrm{n}$

Feuillée, Louis, 16, 59, 7 on

Fevers, 19-20, 35, 152, 186, 193, 198; see also Malaria

Fire at Macora, 144-152

Fiscal, 149, 151-152

Fish, 36, 41, 137

Flor de azahar, 106, 196

Flora of New Spain, 264n, 325

Flora of Spain, 37, 187,326

Flora Peruviana et Chilensis, 190, 191, 207, 271, 272, 279, 293n, 295, 302, 303 ; stagnant, ix, $263-265,282,285$, 290, 300-301, 306, 313, 319, 321326,328 ; quality of, $180,225,246$, $248,249,263,292,328$; funds for, 192, 212-224, 225, 226, 255-260, $264,301,305,325,336-337$; Cinchona described in, 201, 204, 205, $255,261,290 n$; plans for publication, $225-226,248,26$ I, 282, 290n, 300$301,303,305,322$; plates in, 227 , $232,248,25 \mathrm{I}, 253-255,259-263$, $290 \mathrm{n}, 304,306,309,312,3 \mathrm{I} 3 \mathrm{n}, 317$, 323,328 ; expenses of, $227,247-248$, $252,253,255-256,258-260,290$, 
$301,303-304,306,307,309,317$, 320 ; price of, $232,246,255,256$; publication, $239,250,254,255,26 \mathrm{I}$, 262, 325; and Cavanilles, 239, 244, 262 ; jurisdiction over, $243,244,301$, 306-307, 319-320; delays in publication of, $244,249,250,259,328$; inventory, 246-247, 255, 26I; sales of, $246,247,255,260,261,318,319$; gifts of $246,247,249 \mathrm{n}, 255,26 \mathrm{on}$, $26 \mathrm{r}$; binding, $247 \mathrm{n}, 256 \mathrm{n}, 26 \mathrm{n}$, $262 \mathrm{n}$; importance of Jovellanos to, 249-250; trouble with Rubio, $250-$ 254; new genera in, 254, 255, 261, $290 \mathrm{n}$; copies presented to king, $255 \mathrm{n}$, 256,259 ; lends money to Caja de Amortización, 257-261; debts of, 260 , $262,300,301,305,306,318,322$, 325 ; supplement, $26 \mathrm{I}, 290 \mathrm{n}$; indexed, 287 ; “profits," 301, 318, 321-322; see also Botanical Office of Peru, Prodromus, Ruiz and Pavón

Flora Virginica, 14

Florence, $303 \mathrm{n}, 3$ I $4 \mathrm{n}$

Flórez, Enrique, 40

Florida, I 5

Floridablanca, Count, 39, 18 In, 188 , $192 \pi, 254$

Floripondio, red, 100

Flying, $18,67-68$, I 34

Food: of Dombey, 98 ; of Ruiz and Pavón, 106, 138, 143 ; contributed by Dombey, 110; lost in fire, $146 \mathrm{n}$; of natives at Chacahuassi, I58, I 59

Foreign Affairs, Ministry of (France), I 68, I 69

"Formulary for making scientific voyages," 286

Forsskal, Pehr, I 3

Forster, Johann R. and Johann G., 24

France, 247n, 249n; botany in, 8-12; expeditions of, 13,15-24; and Cinchona, 19, 278n, 333; and Dombey expedition, 50-52, 61-63, 88-89, I I2, 132 , $172-174$; attitude of, 56, 57, 102, 162 ; scientific experimentation in, 9293,95 ; and partition, $161-164,168-$ $169,171-172$; and L'Héritier, 176 , $178-180, \quad 184-185$; Revolution in, 183-186, 248, 322; occupation of Spain by, 262-264; Pavón sells goods to, 295, 312

Francis I, Emperor, 22

Franciscans, 101, 263, 264

Franco, Francisco ( 16 th century), in Frankfurt, 12
Freemasons, 66, 88, 130

Frézier, Amédée François, 16, 7on

Funds: for publication, $192,212-224$, $225,226,247-248,255^{-2} 56,258-260$, $264,301,305,325,336-337$

Galdeano, Joaquín, I I I

Galen, 67

Gálvez, Isidro, $246 \mathrm{n}, 269,285,301$; Dombey approves of, 55 ; baptismal certificate, $55 \mathrm{n}$; salary, 60-6r, 136, 190-191, 232, 248, 256, 259, 301, 317; travels of, 101, 109, 189; tries to return to America, 191 ; friction over, 191, 229-232, 253n; duties in Spain, 228n; related to Pavón, 230 ; as engraver, 231, 232, 251, 309; on Mutis' Flora committee, 308 ; see also Illustrators

Gálvez, José de: and origins of RuizPavón expedition, 51-52, 54; and Dombey, 61, 110, I1 2, I 31, 161, 162, $166,174,175$; plant dedicated to, 82 ; and scientific study, 91, 93, 96; and Ruiz and Pavón, 136, 165, 168-169; L'Héritier disregards, 176 ; death, 181 ; at botanic recital, I88; takes away López's job, 199; Pavón ingratiates self with, 287

Gálvez, Miguel María de, II 5

Galvezia limensis, 82

Gamero, Marcos Alonso, 2 I 4

Garden, Alexander, 14

Gardens; see Botanic gardens

Garia, 80

Gascó, Pedro Nolasco, 26on, 309

Gassendi, Pierre, $72 \mathrm{n}$

Gazeta de Lima, 97

Gazeta de Madrid, 177-178, 180, 255n, 29 on

Gazeta de México, 266n

Genera, new: Cinchona, 20; Gonzalagunia, 66; Cosmibuena, 66, 240; Unanuea, 73; Moreno, 73n; Dugagesia, 80; Guirriora, 82; Casimiria, 82 ; Galveria, 82; Araucaria, 119 120, 240; Ruizia, 121-122; Pavonia, 122 ; Gomortega, 122; Aristolochia, 139; of Cavanilles, I 56-r 57, 235-240, 328 ; question of, in Stirpes of L'Héritier, 182-183; Dombeya, 186; in Prodromus, 227 ; Jovellana, 249; in Flora Peruviana, 254, 255, 26I ; Krameria, 286; Monnina, 286; plans to publish, 290 ; total in Flora, 327 Geneva (Switzerland), 185 
Geography, 14, 17, 18, 33, 45

Georgia, 15

Germany, 9, $247^{n}$

Gifts: of Flora, 246, 247, 249n, 255 , $260 n, 261$

Gil de Taboada y Lemos, Francisco, $219,267 \mathrm{n}, 269$

Glowworms, 109

Godin, Louis, 1 7, 18, 21, 31, 7on

Godoy, Manuel, 232,26 in

Gold, 89, 92-94, $132 \mathrm{n}, 137,153-155$, I 7 I , 213, 223

Gómez Ortega, Casimiro: publications, $6,37,38,59-60,86 \mathrm{n}, 187 ;$ and Cavanilles, $35 \mathrm{n}, 209,235,241-245$; and Löfling's notes, $36 \mathrm{n}$; early career, 37-38; as teacher, $37-39,53,54,188$, 266 ; defender of Linnaeus, 38 ; as director of Ruiz-Pavón expedition, 52$55,58,102,112,113,140 \mathrm{n}, \mathrm{I}_{4} \mathrm{I}^{-1} 42$; and Dombey, 52, 57, 58, 81, 96, $112-$ I $3,132,142 \mathrm{n}, 162-167,178-179$, 199n; and Ruiz, 53, 166, 209, 230, 242-245, 249, 250; and Pavón, 54, $166,229-230,249,250,287,298$; praised, $81,298,328 \mathrm{n}$; genus named for, 82,122 ; and scientific research, 90-93, 96; and agregados, 142, I 53, $267,269,270$; and Flora Peruviana, $162,165,167,225-226,228,244$, $253 \mathrm{n}$; and Thouin, I66, I67n, I99n; and partition, 169,170 ; fat, 181 ; and L'Héritier, 182; and López Ruiz, 199, 209; and Mutis, 209, 242n; and Isidro Gálvez, 228-231; Sancha criticizes, 229; retires, 244 ; death, 245, 298; and Rubio, 250, $253 \mathrm{n}$; Linnean Society member, 298

Gomortega nitida, 122

Gonzalagunia (genus), 66

González Laguna, Francisco, 66, 139 I 40, 142, I 59, I $93,267,271,274$, 283,284

Good Advice (ship); see Buen Consejo

Gordillo, José, 280

Göttingen, 234

Grace and Justice, Ministry of, 226-229, $233 \mathrm{n}, 243,244,249,250,254,257$, $258,306-307$

Gravier del Valle, Rafael, 282

Greece, 13

Grew, Nehemiah, 7-8, 24

Gronovius, John Frederick, 14

Guadeloupe, I 86

Guanajuato (New Spain), 222

Guatemala, 223-224, 335, 337
Guayaquil, $85 \mathrm{n}, 102,197,273-278,314$

Guettard, Jean Etienne, 174

Guiana, 13, 20, 23, 33

Güines Canal (Cuba), vii, viii (n)

Guio, José, ix (n)

Guirior, Manuel de, 65, 71, 82

Guirriora (genus), 82

Gunpowder, 94, 97

Guzmania (genus), 261

Haenke, Thaddeus, 97, 284

Haiti, 15, 335

Hales, Stephen, 25

Haller, Albert de, $89 \mathrm{n}$

Halley, Edmund, 68

Hamy, E. T. 339

Hasselquist, Fredrik, I 3

Hasskarl, Justus Charles, 333

Havana, viii $(n), 223,283-284,3$, 314,318

Health: Supreme Council of (Madrid), 263 ; see also Illness

Heaters; see Estufas

Hedwig, Johann, 294

Heras, Bartolomé de, 220

Herbals, 3-4, i in

Herbaria; see Dried plants

Herbs, I1, 29n, 79, 214 ; see also Drugs

Hermosilla, Ignacio de, 54, 61

Hernández, Francisco, 5-7, 59, 233

Heuland, Christian and Conrad, $128 \mathrm{n}$

Hibiscus (genus), $235 \mathrm{n}, 236 \mathrm{n}$

Higgins, Ambrosio, I $17-118,120,123$, $211,213-218,247,273,274,288$

Hijar, Duke of, 188

Hiptage (genus), $238 \mathrm{n}$

Hirtella (genus), 240

Historia naturalis Brasiliae, I 4

Hoffmannia (genus), 254

Holland; see Dutch

Horace, 291-292

Horn, Cape, 22, 64, 86, I 34, 268

Hortus Schoenbrunnensis, 318

Hoste, Paul, 55

Houston, William, I 5

Howard, John Eliot, 2 I on

Huallanca (Peru), 149

Huamalíes (Peru), 108, 109, 195, 269

Huamanga (Peru), 2 I 9, 220

Huancavelica (Peru), 126, 127

Huánuco (Peru), 96n, 27I, 274; conditions in, 104-105, I10-III, 288; Ruiz and Pavón in, 104-105, I07, 109-11 I, I 15, I 37, I 40-142, 146, I 52, I 56, I57, 159, 287, 288; and Cinchona, 105-106, 193, 195, 200; 
Dombey offers food to, I1 o; daughter of Pavón in, 140-141; Trabuco jailed in, 149-150; agregados in, 268-2.70, 274 ; elects Pulgar alcalde, 275

\section{Huaqueros; see Antiquities}

Huarochiri (Peru), 127

Huasahuasi (Peru), roI

Huaura (Peru), 84, 96n, 98, I I I, II 5

Huaylas (Peru), 275

Hughes, Griffith, I 5

Humboldt, Alexander von, vii, 20, 24 , $45,20 \mathrm{I}-203,207 \mathrm{n}, 208-210,283-$ $284,293,294,313$

\section{Ica (Peru), 269}

Icho grass, 42, 99

Icones, of Cavanilles, 238,242

Île de France; see Mauritius

Ilex Paraguariensis, 42, 288

Illness: Löfling, 35 ; Ruiz, 53, 128, 137 , $140,143,152-153,259 \mathrm{n} ;$ Dombey, 102, I 16, 131, 134, 16 1, 169, I 74, 177, 186 ; on El Peruano, I 34 ; draftsmen, 143; Pavón, 144, 299, 305 ; Rubio, 252 ; Tafalla, 268, 276, 277; Pulgar, 274, 275; Manzanilla, 277, 28I ; Rivera, 279; Lambert, 299; Rojas Clemente, 308; Robles and wife, $312 \mathrm{n}$, 315-316, 321n; see also Epidemics, Fevers

Illuminated plates, $247 \mathrm{n}, 253,256$, $258 \mathrm{n}, 259,26 \mathrm{on}, 290 \mathrm{n}, 295,301,323$

Illustrations: in early botanical works, $4,6,7,15,16,28,35,37$; of Dombey's plants, $80-81,163,164,167$, I 68, 177, 178, 181, 182, I 85 ; of RuizPavón expedition, $85-86,113,137$, $138,156,159,165,166,212,225$, $228,246,293 \mathrm{n}, 300,323,328$; of Cavanilles, 157; of Cinchona, 192, 201, 203-206; duties of Gálvez concerning, $228 \mathrm{n}, 229$; of Rubio, $25 \mathrm{In}$, 253 ; of agregados, 267-270, 273, 275, 279; see also Engravings, Illuminated Plates, Plates

Illustrators: Castel and Carmona, 34, 35; of Mutis, 44, 46; of Ruiz-Pavón expedition, 54-55, 60-6 I, 249, 309; duties of, $54,228 \mathrm{n}$; refused to Dombey, 129; value of, to botany debated, 142 ; trouble with, I43-144, 146, 147, 150, 156, 228n; Redouté, 176, 181 ; Sowerby, 181 ; Cavanilles, 234235; Rubio, 250-254; see also Brunete, Cortés, Gálvez (Isidro), Pulgar
Incra Mamani, Manuel, 334

Index Kequensis, 295n

India, 13, 94, 334, 335

Indian Ocean, 50

Indians, 64, 98, 1 01, I1 9, 174, 276, $286,288,334$; drawings of, $36 \mathrm{n}$; attacks of, 64, 72, 106-108, 110,115 , I $17-118,131,175,189$; opinions on, $72,75,76 \mathrm{n}, 104,118,125,138,155$, $157^{-158}$; population of, in Lima, $76 \mathrm{n}$; uses of plants by, $79,86 \mathrm{n}, 100$, 109, 110-111, 139; artifacts of, 84$85,89,112,137,171,267-268,288$; and coca, 109; Araucanians, 11 7-118, 120 ; compared to English, 310

Indies, Archives of the, 278, 338

Indies, Council of the, 5 I

Indies, Ministry of the, 55, 82, 119 , I $26,153,162-163,165,177-178,181$, I 82, 190, 338; see also Gálvez (José de), Grace and Justice

Indigo, I 05

Infantado, Duque del, 234

Infatuation: plants to induce, 110

Ingenhousz, Jan, 25

Inoculation, 68

Inquisition, Holy Office of the, 66, 88$89,102,250$

Insects, 41, 103, 1 $71,176 \mathrm{n}, 288,29 \mathrm{I}$, 293, 314

Institut National (France), $184,249 \mathrm{n}$

Instruction: in mathematics, 45, 67, 7071,72 ; in anatomy, 73 ; in engraving, 221 ; in painting, 269,270 ; see also Botanical instruction

Instructions of 1776 to expedition, 57$59,79-80,86,90,167,230$

Intellectual life, $17-18,47,65-74,272-$ $273,283-284$

Intendant, $148,149,15 \mathrm{I}$

Interior, Ministry of the (France), 185 Interior, Ministry of the (Spain), 307, 324

Inventory, 246-247, 255, 261, 312, 323

Iriarte, Tomás de, 28

Iron, 89

Isabela la Católica, 303

Isabella II, $44 \mathrm{n}$

Isidrogalvia (genus), $26 \mathrm{I}$

Istituto Botanico della Università di Firenze, $303 \mathrm{n}, 314 \mathrm{n}, 338$

Italy, 6, 10, 1 2, 31, 37, 232-233, 234, $247 \mathrm{n}$

Iter Hispanicum, 36

Iturriaga, Joseph de, 33 
Jacobeli, José, 137

Jacquin, Nikolaus Joseph von, 22-23, $44,59,146,240,318$

Jaen de Bracamoros (Ecuador), $277 \mathrm{n}$

Jail: Dombey, 62; Trabuco, 149-150;

Pulgar, 274

Jamaica, 15, 334

Jansenism, 19

Japan, 13, 29, 335

Jaramillo-Arango, Jaime, 339

Jardin Botánico de Madrid, vii, 36n, 39, $132,206,264,282,308,314,316$, $319-320,329 ;$ and Ruiz and Pavón, $58,79,80,113,190,228 \mathrm{n}, 279,302$, $313,318,321,338$; and Cavanilles, $209,242,244,245$; see also Botanical instruction

Jardin du Roi (Jardin des Plantes) (Paris), Is, 12, 55, I68, I84n, 234, 249n

Jaros, Colonel, 65

Jauja (Peru), Ior, I 95

Jáuregui, Agustín de, 132

Java, 2 I1 333-335

Jesuits, 6, 19, 69, 120, 225, 305-308

Jews, 66, 3 I I

Jordán de Asso y del Río, Ignacio, 44 Journal de Paris, $183 \mathrm{n}$

Journal général de France, 176, 178, 179

Jovellana (genus), 249, 254

Jovellanos, Gaspar Melchor de, 249, 250, 257

Juan, Jorge, 17, 52, 59

Jung, Joachim, 7

Jungle; see Tropical forest

Junta: for Flora Peruviana, 226, 228232, 244, 249-251; for Protection of Museum of Natural Sciences, 300, $301,303,317,319-325$

Jussieu; see De Jussieu

Kalm, Pehr, I 3

Keule, tree, 122

Kew Botanic Gardens (England), I 2, 24, I 79, 180, 291n, 333, 338

Koenig, Juan Ramón, 16, 7 on

Krameria triandra (rataña), 286, 309

La Condamine, Charles Marie de la, I718, 20, 45, 700, 90, II 3,208

La Fe (ship), 156

La Gasca, Mariano, 302-303, 308, 322, $325-326$

La Jarilla (Chile), I 27-1 28

La Oroya (Peru), 99
La Paz, 108, 2II, 224

La Plata, viceroyalty of, $135,223,337$; see also Buenos Aires

La Serena (Chile), 217,218

La Tourette, Marc Antoine Louis, 89n

La Vauguyon, Duke of, 171

Ladowiski, Remigijusz, $328 \mathrm{n}$

Lagrange, Jacques, 88

Laguna (genus), $235 \mathrm{n}$

Laguna, Andrés, II

Lalande, Joseph Jérome le François de, 68-69, 89n, $111,175 \mathrm{n}$

Lamarck, Jean Baptiste, 120, 234, 235, 298

Lambert, Aylmer Bourke, 291-300, 304, 309-311, 313, 314-315, 322, 323, 325,338

Lambertia (genus), $295 \mathrm{n}$

Lapageria (genus), 261

Laurel, I $21,122,287$

Laurus indica, 91

Lead, 89

Ledger, Charles and George, 334

Legal proceedings, 148-1 52

Leibnitz, Gottfried Wilhelm von, 17,67, $72 n$

Leipzig, I I

León, Francisco, 255

Leonia (genus), 255

Leopold, Archduke, of Austria, 19

Leopold II, Grand Duke of Tuscany, $3 \mathrm{I} 4 \mathrm{n}$

Lerena, Counts of, 53

Leyden, I I, I4

L'Héritier de Brutelle, Charles Louis, I $68,176-185,190,231,298$

Lichen, $195^{\mathrm{n}}$

Lima: conditions in, $16,74-78,80,84$, $283-284$; scientist visitors to, $16-18$, $21-22,23,34,283,284$; intellectual climate in, $17-18,65-74,79,272-273$, 283-284; Ruiz-Pavón expedition in, $58,62,64-66,73-74,79-80,82,85$, 99, 101-103, 110, III, II 5, I31, 135$136,139-140,142,155,157,159$; climate, $65 \mathrm{n}, 77,80,84,103,175 \mathrm{n}$, 273; and nitrate, 95 ; and Cinchona, I05, I93; and mineral tests, 127; botanical instruction proposed for, $153,159,267,269,272,273,279-$ 283 ; and Flora, $219-220,247$; protomédico of, 270

Linnaeus, Carl, 14, 2 1-22, 82, 120, 179, 206, 266n, 268n, 3I4; sexual classification system, 8-10, 23, 36, 38, 44, $48,79,188,227,228,245,261,262$, 
298,328 ; and pupils, I $3,30-36,103$; and Cinchona, 20, 45; and Spain, 27, $30,32,33,35-39,48,49,187,188$; and Ruiz and Pavón, 38, 59, 79, 145 , $227,228,254,255,26 \mathrm{I}, 262,286$, 290, 296, 298, 328 ; and Mutis, 44, $45,65 n, 198 \mathrm{n}, 199$; and Cavanilles, $234,236,237$

Linnean Society of London, 291, 292, $293,295-296,298,299-300,338$

Lisbon, I I 2

Living plants, 20, I 20, 333; shipped by Ruiz and Pavón, 66,80, 86, I 13,137 , I 40, I4 I, 147, I 54, I 56, I 59, 268 ; controversy over studying living vs. dried plants, 205-206, 208, 233-237, $242-243$

Llaguno, Eugenio de, 243, 249 n

Llano Zapata, Eusebio, 18

Llanos, Nicolasa, 15 I

Löfling, Pehr, 23, 27, 31-36, 44, 59, I 03, I I 3, 146

Loja (Ecuador), I 9, 20, I 05, I 94, I 95 , $197,198,199,200,202,204,205$, $208,276,277$

Lomas, 84

London, 3 II, 326; see also Kew Botanic Gardens

London College of Physicians, 9

London Society of Apothecaries, 12

López, Manuel, 53

López de Cárdenas, Fernando José, 43 López Ruiz, Sebastián José, I99-203, 206,209

Lord chamberlain, 200, 20 I

Louis XIV, of France, I 5, I9

Louis XVI, of France, 50, 51, 52, 57, 85

Louvain, University of, I 9

Lurín (Peru), 84

Luz, Rafael de la, 22 I

Luzuriaga (genus), 26 I

Lyons, 12

Lysiloma latisiliqua, i i

Macfadyena bracteosa, 140

MacLeay, Alexander, 292-293, 295-296

Macora (Peru), I43-I46, I48-152, I89, $268 \mathrm{n}, 275$

Madagascar, 13

Madras, 334

Madrid, 6, 44, 53-54, 262; early botanic gardens in, I 1, I 2, 29, 3 I, 32, 36,39 ; botanical interest in, $31-32$, I 87-189; Löfling in, 31-33; museum established in, 39-43; Economic Society in, 47-48, 9I; Brunete and
Isidro Gálvez born in, 55 ; protomedicato in, 270 ; no conchologists in, 299; manuscript sources in, 338 ; see also Academia . . Botanical Office of Peru, Jardín Botánico de Madrid, Cabinet of Natural History

Magallón, Fernando de, 5i, 56, 6 I

Majas de Cabrito (Chile), I 27-128

"Make drunk-make drunk," plant, 100 Mal del walle (dysentery), I75n 193

Mal de Mayco, I 44

Malaria, 19, 20, 193 $\mathrm{n}, 198,274,275$, 335

Malaspina, Alessandro, 97, $175 \mathrm{n}-176 \mathrm{n}$, $250 n, 268,284,2900$

Maldonado, Pedro de, 90, 9 I

Malpighi, Marcello, 7-8, 24

Malsito, I 23

Malva (genus), $236 \mathrm{n}, 238$

Manila, vii

Manzanilla, Juan Agustín, 276-28I

Marañón River, 104

Marcgrave, Georg, I 4, 59

Maria Cristina, regent of Spain, $321-32+$

Markham, Clements, 333, 334

Marshall, Humphry, i $\$$

Marti, Francisco de, 227

Martínez de la Torre, Faustino, 260 n

Martinique, is

Masts, I I 9, I 20,12 I

Mata, Luis de, 2 I 5

Mata Linares, Francisco de la, 2 I 6

Materia medica; see Medicine

Mathematics: Feuillée and Frézier, I 6 ; Godin, I 7, 3I, 7on; Bueno, I8, 707 I ; Joseph de Jussieu, 22; Mutis, 45, 199; at University of San Marcos, 67, 70-71; Rer, 69; Moreno, 7on; taught at Convictorio, 72 ; nymph of, I 87 ; in America, 283

Matthiessen, William, 296-297, 3 I I

Maudit, I $76 n$

Mauritius (Île de France), 23-24

Medical college of San Fernando (Lima), 73, 272-273, 278-28I

Medicine: botany handmaiden to, 3-4, 188; Monardes, 5; Hernández, 5-7; Tovar, II; and botanic gardens, I I 12; Piso, 14; Surian, I 5 ; Feuillée, I6; Medical Society of Seville, 29; Academia de Medicina, Madrid, $3 \mathbf{I}$ $67,81,240 ;$ Joseph Ortega, 31 ; Löfling, 36n; Gómez Ortega, 37 ; Mutis, 45; Dombey, 55; Ruiz-Pavón expedition to promote, 58 ; doctorate of, at San Marcos, 67; value of plants 
to, 79, 90, 105, 122, 27 I, 284; Royal Society of (Paris), 108 ; nymph of, 187 ; chair of materia medica, 267 , 272-273, 278-282; see also Cinchona, Drugs, Pharmacists, Pharmacy, Physicians

Memorial literario, 237

Mengs, Antony Raphacl, 55

Mercurio peruano, 73, $211,271-273$

Mercury ; see Quicksilver

Merits and services: of Rubio, 254; of Pavón, 288-289

Mesía de la Cerda, Pedro, 44

Mestizos, $76 \mathrm{n}$

Metallurgy, 45, 49; see also Mines, Platinum

Mexico, $325 \mathrm{n}$; see also Mexico City, New Spain

Mexico City, 221-222, 247, 266-267, 283-284; see also New Spain

Migas Calientes, 29, 36, 39, 53

Milan, I 2

Military: and mathematics, 70 ; at Huasahuasi, 101; at Huánuco, I10; Tafalla and Pulgar in, 142, 272 ; contributions to Flora from, $216-219$, 222

Miller, Philip, I 5

Milly, Comte de, 93

Mimosa latisiliqua, i in

Minerals, 89, 288, 333; study of, by Hernández, 6; Philip V seeks unusual specimens of, 29; Bowles interested in, 40; in Madrid museum, 41; of Dombey, 86, 172-173; from Tafalla, 267-268, 269; study of, in America, 283 ; see also Copper, Gold, Platinum, Quicksilver, Silver

Mineral waters, 85,98

Minerva peruana, 97

Mines: in Peru, neglected, 76 ; odor of, 89; near Huánuco, 105 ; in Chile, I 25 - I 29, I 74, 217

Minuart, Juan, 31, 32, 36, 37

Missionaries, IOI, 138, I 55 , 158 - I 59

Mitchell, John, I 4

Mitchill, Samuel L., viii

Mociño, José, 264, 295n, 325n

Molina (genus), 238

Molina, Juan Ignacio, 120,184

Moluccas, I 3

Monadelphia, I 56, 234-236, 238,24 I

Monardes, Nicolás, 5

Moñino, José, 254; see also Floridablanca

"Monkey puzzle" tree, I 19
Monkeys, 270

Monnina (genus), 254, 286

Montaña; see Tropical forest

Monte Pio, Marqués de, 213, 223

Montevideo, 23

Montpellier, 1 1, 28, 32, 55, 272

Monzón (Peru), 197, 269

More, Robert, 30

Moreno, Feliciano, 274

Moreno, Gabriel, 70 , $73 \mathrm{n}$

Morrison, Robert, 12

Mosquitoes, I 89

Moxos, viceroyalty of La Plata, 223

Mulattoes, $75,76 \mathrm{n}, 272$

Muña (Peru), I 55, 196, 274

Muñoz, Juan Bautista, 6

Murder: attempts on Dombey, I73; of L'Héritier, 185

Museum: Flórez has own, 40; see also Cabinet of Natural History

Mutis, José Celestino, $38 \mathrm{n}, 2 \mathrm{I} \mathbf{1}$; early career, 44 ; memorials of, to Charles III, 44-45; and Linnaeus, $45,65 \mathrm{n}$, $198 \mathrm{n}, 199$; and cinnamon, 45 ; and Cinchona, 45, 105, 106, 197-211; and botanical expedition, $46,115,135$, 199,273 ; is cleric, $46 n, 202$; impressed by Guirior, 65; and L'Héritier, $177 \mathrm{n}$; and Ruiz and Pavón, I97, 203, 204, 206-210, 2 In; Arcano de la quina, 197-198, 207; and López Ruiz, 199, 201, 202, 203, 206; Zea defends, 201-202, 205; Humboldt defends, 202, 208, 209-210; called great botanist, 206; and Gómez Ortega, $209,242 \mathrm{n}$; and Cavanilles, 209,234 , $239,242 \mathrm{n}$; nephew of, 2 ion; Flora of, 308-309, 31 4n, 320n, 321

Myroxylon Peruiferum, 19

\section{Nancy, I 2}

Napaea (genus), $237 n$

Napoleon, Joseph, 263

Napoleon Bonaparte, 250, 260, 26I, 262,264

Narcissus odorus, 8 on

Natural history: study of, by Marcgrave, 14; of Jamaica, I5; on Cook expedition, 24; cédula on, 29; Gómez Ortega adds notes on, 38 ; interest in, in Spain, 40-43; and Mutis, 4.5; and Campomanes, 47 ; and Aragonese society, 48; interest in, awakening, 50; see Cabinet of Natural History, Museum

"Naturalist and the Newts," 28 
Navarre, 142

Near East, 13

Née, Louis, 250-251, 284, 308, 314, 319

Negroes, $75,76 \mathrm{n}, 83$

New Granada, viii, 34n, 93, 94, 223 , 245, 246, 273-27t, 278, 314n, 337; see also Bogotá, Cinchona, Colombia, Mutis

New Jersey, I 3

New Spain, 270, 271, 283; botanical expedition of, vii, viii, $266,325 n$; botanical instruction in, $103 \mathrm{n}, 266-$ 267 ; contributions of, for Flora, 221 222,337 ; Botanical Office of, 245; Flora of, 246, 264, 308, 325n; Pavón sells plants of, 295n, 3 10, 314

New York, viii, 13, 14

New Zealand, 24

Newton, Isaac, I 7, 45, 66, 67, 71, 72

Nitrate, 86, 94-97, 174

North America, 13

Nuestra Señora de Belén (ship), I I 5

Nueva quinologia, 2 I on, 287, 301, 309, 3 I $3 \mathrm{n}$

Nuevo León (New Spain), 222

Oaxaca (New Spain), 222

Ocopa (Peru), Ior, 155

O'Higgins, Ambrosio; see Higgins

O'Higgins, Bernardo, I I $7 \mathrm{n}$

Ohigginsia (genus), 254

Oidor, 219,271

Olaya (Peru), 222

Onís, José Antonio, 150, 151

Orchids, r о I

Orinoco River, 23, 33

Ormachea, Miguel de, 127-1 28

Ortega, Casimiro Gómez; see Gómez Ortega

Ortega, Joseph, 31-32, 36, 37

Osbeck, Pehr, I 3

Osorno, Marqués de; see Higgins, Ambrosio

Oviedo, 47

Oviedo, Gonzalo Fernández de, 4-5

Oxford, 12

Pachacamac (Peru), 84-85

Packing cases, 13 on

Padua, 10, 247n

Palau, Antonio, 38, 53, 57, 187, 226, 281,286

Palauk (genus), $235 \mathrm{n}$

Palma, 47

Palma, Ricardo, 68n

Palmer, Jaime, 267,271
Pamplona, 187

Panama, 223, 282

Panatahuas (Peru), 195, 196, 269

Papaya, 266n

Paper, for Flora, 227,229

Paraguay, 69, 223

Pardal, Rafael, 312n, 313n

Paredes, José Gregorio, 280

Paris, 20, 22, 24, 40, 55, 108, 169, 234, 235, 268n; see also Académie des Sciences, Jardin du Roi

Parma, Prince of, 233n, $247 n$

Partition of Dombey's shipment, I6 I-I 72

Pasamayo River (Peru), 83

Pasco, 104, 157

Pastor, Benito, 34, 35

Patagonia, 23, 38

Pavón, José Antonio (son), 299, 301303

Pavón y Jiménez, José Antonio, $53 \mathrm{n}$, $103,316$; spelling of name, viii( $n)$; as pharmacist, 53-54; early life, 54; and Gómez Ortega, 54, 166, 229$230,287,298$; no portrait, 54n, 289; salary, 60-61, I 36, 190-191, 248, $256,259,260,26 \mathrm{In}, 263-264,289$, $293,301,302,313,315,316,317$, 324,329 ; acquires testimonials, 8 In, 288 ; travels, 101, 156, 157, 187, 189; and Chilean pine, 119-120, 240, 287 ; genus named for, $122,157,235 \mathrm{n}$, $236 \mathrm{n}, 238$; and mock raid, 106-107; and Dombey, I1 $4,124,129,174$, 287; and Indians, $117,120,288$; daughter of, 140-14I; illness, 144, 299, 305; and Macora fire, 145, I49, I50; called "docile," 148,325 ; sought for professorship of botany, I 59; herbarium questioned, I 65 ; son of, 191, 299, 301-303; tries to return to Indies, 191-192; writings of, 2 Ion, 287, 29I, 3I8; and Cinchona, 2 I on, $287,288,294-295,301,309$, $313 n, 314,318$; called insubordinate, $229-230,287$; related to Isidro Gálvez, 230 ; clashes with Ruiz, $230,240-$ 241,287 ; and Cavanilles, $236,240-$ 242,287 ; during French occupation, $263 \mathrm{n}$; sells plants, 264, 291-300, 304, 313-315, 325, 329; and agregados, 279-280, 281, 282, 290; indexes Flora, 287 ; botanical knowledge of, 287,298 ; praise for, $287,288,292$, 295-296; ingratiating, 287-288; style, 287-288; and animals, 288 ; and minerals, 288; hopes to be curator, 
288, criticized by Clavijo, 289 ; anniversary celebration, 289 ; work on Flora, 290-291, 300-301, 303-304, 317; book collector, 291-292, 294; and Lambert, 291-300, 303, 304, 309311, 314-315; eager for friendship, 292, 294, 296, 297, 298, 299, 310; and Linnean Society, 292, 295-296, 299-300; criticized by MacLeay, 292293, 296; and Linnaeus, 296, 298; moral conduct questioned, 296 ; and shells, 296-298, 310; and L'Héritier, 298; guilty conscience, 300 ; and $\mathrm{La}$ Gasca, 302 ; supports Liberal government, 303, 312; and Webb, 303n, 313-315; fights eviction, 306; government criticizes, 306-307, 308; and Mutis collection, 308, 309, 314n, 321 ; advanced age, 308, 324; dispute with porter, 312 ; and missing goods, 312, 323-324; remits Havana seeds, 313,318 ; pays rent from own pocket, 315 ; and Jardín Botánico, 318, 321 ; removed from control of Flora, 320 ; queen mother investigates, $321-324$; museum junta threatens, 323 ; death, 324 ; see also Botanical Office of Peru, Flora Peruviana, Ruiz and Pavón, Ruiz-Pavón expedition

Pavonia (genus), 122, 157, 235n, 236n, 238

Pennsylvania, $x_{3}, 14$

Pension, $157 \mathrm{n}, 285,317$

"Pepper-pepper," 100

Peralta y Barnuevo, Pedro, 18, 7on

Pérez, Manuel, 285

Perignon, ambassador, 249n

Peru, I 26; botanical expeditions to, 6, 16, 327; intellectual life, 17-18, 65$74,272-273$; why selected for RuizPavón expedition, 50-52; De Jussieu's manuscripts in, 51, 88-89; "Description" of, 69; lack of maps of, 69; displays of servility in, 71-72; condition of Indians in, 75, 104, 138, 155, 157-158; economy, 76, 89, 95-97; grands of, 77; Ruiz and Pavón in, 80, 82-87, 99-112, I1 5, 135-160; freemasons in, 88; saltpeter in, 94-97; mineral waters in, 98 ; mountains, 98 , 99, 102-104, 109-110; climate, 103; Cinchona in, 103, 105-106, 108-109, 155-156, 158-159, 193-197, 203-205, 207, 210-211, 276, 334, 335; Indian warfare in, 108, I10; agregados in, $142-143,153,155,267-275,279-28 \mathrm{r}$,
283-284; contributions to Flora fund from, $218-220,247,337$; botany in, $266,271,278-279,280-281,284$; impact of agregados on, 283 ; independence of, 283, 290; see also Iluánuco, Lima, Ruiz-Pavón expedition, Tropical forest

Petrified wood, 89

Peumus fragrans, 12 I

Pharmacists: work published for, in Mexico, 6; Ruiz and Pavón, 26; Salvador, 28; gardens help to eradicate ignorance of, 29; Minuart, 31; Joseph Ortega, 31 ; Vélez, 32 ; Gómez Ortega, 38; Rodenas, $124-125$; in Chile, 129; Tafalla, 142; Cuéllar, 169

Pharmacy: Ruiz and Pavón have knowledge of, 53,54 ; practitioners of, study botany, 188; of Ruiz, 229, 259n; pharmacoepoeia, 263; Ruiz inspector of, $265 \mathrm{n}$; in Peru, 28I; see also Drugs

Philadelphia, I 4, 202n

Philip II, of Spain, 5, 6, 28, 329

Philip III, of Spain, I I

Philip V, of Spain, 28,29

Philippine Islands, vii, viii, 90, I69, $223,314,319,335,337$

Philosophy, Newtonian, 45, 72

Physicians: Hernández, 5; Aztec, 5-6; of Philip III, I I; Jardin du Roi created to aid, II; Cunningham, I3; Garden, 14; Sloane, I5; Browne, 15; Houston, 15; Bueno, 18, 66-67, 284 ; Vopiscus Plempius, 19; Talbor, 19; De Jussieu, 20-22; Barnades, 32 ; Condal and Pastor, 34; Suñol, 36; Mutis, 44, 45, 197, 199; Unanue, 73, 284; oppose Dombey, 73-74; census of, in Lima, 73n; Dombey, 102, 122-123, I30; recommend Smilax China, 140n; as teachers of botany, 153; and Cin chona, 194-195, 200-201; Dávalos, 272 ; study botany and chemistry, 280; Quintanilla, 282; see also Medicine

Physics, 72, 187, 282, 302

Physique des arbres, $L a, 38$

Pillao (Peru), 1 57, 196

Pineda, Antonio, 290 n

Pines, 42, 1 19-121, 137, I4 I, 240, 279, $287,288,294$

Pinus (genus), 120, 240, 294

Pisa, 10, 3I, 234

Piso, Willem, 14, 59 
Piura (Peru), 278n

Pizarro, Gonzalo, 90

Plant classification; see Classification of plants

Plates: in Feuillée and Frézier, 16; in Flora Peruviana, 227, 232, 248, 251, $253-255,259-263,290 n, 291,304$, $306,309,312,313 n, 317,323,328$; in Prodromus, 228, 230 ; of Cavanilles, 234

Platinum, 86, 92-94, 130, 132, I62, I 72, 295

Plempius, Vopiscus, 19

Pliny, 3

Plumier, Charles, 1 5, I 8, 59, 146, $268 \mathrm{n}$

Poirel, Jean Baptiste, I 69

Polypodium angustifolium (calaguala), I $37,286,323$

Poncho of the Inca, 85, 112

Ponz, Antonio, 4 1

Population: Lima, 76n; Tarma, Ioo; Huánuco, Io4; Concepción, 118 ; Santiago, 125

Porcel, Antonio, $233 \mathrm{n}, 250,253,258$, $282 n$

Porcelain Factory, Royal, $252-254$

Porlier, Antonio, 188

Porter: of Botanical Office of Peru, 248, $258 \mathrm{n}, 285,3 \mathrm{I} 2,3 \mathrm{I} 3 \mathrm{n}$

Portobelo, 282

Portugal, 12, $13,64,112,154,293 n$, 3 I 4

Potatoes, 86n

Potosí, 2 1, I 33 n

Poverty: in Lima, 77; in Santiago, 214 ; at Presidio del Carmen, 222

Powwow, 117-I I 8

Pozuzo (Peru), I38-140, 1 96, 274

Prado Museum of Art, vii, $44 n$

Premio Real, Marqués de, 105

Presa Carrilla y Albornoz, Pedro de la, 267,271

Priestley, Joseph, 24, 188

Principios de botánica, 37

"Principles of Botany in Letters to a Lady," 329

Printer, 225 ; see also Sancha

Prodromus, 293n, $30 \mathrm{I}$; in France, I84, 249; purpose, 227, 234; plates for, $227,228,230,246,247 \mathrm{n}, 25 \mathrm{I}$; paper, 227,229 ; delays in publication, 227 233; preface, 228-229, 242; second edition, 232-233; scores use of dried plants, 233-234; Cavanilles criticizes, 238 ; Chilean pine and, 240 ; Cosmibuena in, 240-241, 261; Pavón criti- cizes, 240; price, 246; sales, 246, 247; gifts, 246, 255; in America, 247 ; expenses, $247-248,258 n$; corrections on, $254,261,290 n$; "coordinated," 291 ; used to pay debt, 300

Promise of Dombey not to publish, I 65 I 68,176

Protestants, 33

Protomédico, 5, 32, 44, 45, 200, $265 \mathrm{n}$, $270,272,279$

Ptolemy, $72 n$

Public Debts, Department of; see Caja de Amortización

Publication: of Hernández's work, 6-7, $59-60$; and instruction of 1776 to Ruiz-Pavón expedition, 58, I 67 ; fear of, by Dombey, I 32-133, 162, 164 , 167, 189; Spanish plans for, 162 , $165,167,225,227,244,247-248$; by L'Héritier, 168, 176-185; of Quinologia, 192; of Arcano de la quina, 197-198, 207; of Suplemento a la quinologia, 203 ; colonies requested to support, 212-214; donations for, 213-224; of Flora Peruviana, 225 , $249,250,253,254,255,259,261,262$, 325; of Prodromus, 227-228, 232233, 246-247; by Cavanilles, 234 , 238, 243; against Cavanilles, 239 240; of flora of New Granada, 308309; of flora of New Spain, 325n; Ruiz and Pavón slow in, 328

Puerto Príncipe, 223

Puerto Rico, 282, 314, 319, 335

Pulgar, Francisco, I47n, I57, 270; chosen agregado, 142; salary, I42, $143,153,157 \pi, 268,270,274,275$; shipments, 268, 275; and chair of painting, 269,270 ; draws coca, 273; illness, 274, 275; and successor, 274; marries, 274; in trouble with authorities, 274-275; government official, 275,279

Punitaqui (Chile), 128

Puno (Peru), 223

Putrampui root, 286

Quechua, 286

Quer, Joseph, 31, 32, 36, 37

Querétaro (New Spain), 222

Quicksilver, 42, 86, 89, 125 -1 29, I 7 I

Quina: used as synonymous with quinine, 18-19; confusion in name, I9-20; see also Cinchona

Quinine: source of name, $18 n, 211$; see also Cinchona 
Quinoa, 86n

Quinologia, 192-197, 203, 207

Quinquina; see Cinchona

Quintanilla, José Alonso de, 282

Quito: La Condamine expedition to, 17 ; science in, 17, 284; Cinchona in, 19, $105,191,194,195,198,199,200$, $204,208,276,277 \mathrm{n}, 333-335$; smallpox in, 21 ; Löfling supposed to go to, 23, 34; cinnamon in, 42, 90-91; botanists' "promised land," 58; goal of Ruiz-Pavón expedition, 58, 87, 102, 115, 135; quina monopoly in, 191; Pavón and Gálvez seek to go to, I9I; Rodriguez Olmedo botanist in, $191 \mathrm{n}$; rivalry with New Granada, 200; contribution to Flora, 220 ; agregados in, 275-278, 29on; Pavón sells plants of, 3 I 4

Races, mixture of, $75-76$; population in Lima, 76n

Raid, mock, 106-107

Raimondi, Antonio, 327

Rancagua (Chile), 217,218

Rapuntium, 65

Rataña, 286, 309

Ray, John, 8, 9, $12 \mathrm{n}, 15$

Real Confianza, Marqués de la, 65

Real Sociedad Aragonesa, 48

Real Sociedad Económica de Madrid, 47-48, 90, 9I, 249

Reccho, Nardo Antonio, 6, 233

Receipts, for Dombey's plants, 162-163

Redouté, Pierre Joseph, 176, 179, 181, 328

Religion: Lölling, a Protestant, permitted in Orinoco, 33-34; Löfling turns Catholic, 34 ; relationship to plant study, 46 ; drunkenness in fiestas, I 58 ; see also Clergy

Renquifo, Francisco, 105n

Rent; see Botanical Office

Rer, Juan, 69

Revolution, in Spain, 282, 300, 303, 313

Rhus decandria, I 44

Ribera, Lázaro de, 7 I

Rico, José, 228

Riego revolt, $282,300,303$

Rieux, Louis, $20 \mathrm{I}$

Rio de Janeiro, 23, I 34, 154

Rivera, José, $274,276,279$

Robles, Domingo, 3 I 2, 3 I 5-317, 32 on32 In, 323

Rodenas, Fulgencio, I 24-125

Rodríguez, José Demetrio, 3 I 6
Rodríguez de Mendoza, Toribio, 72

Rodriguez Olmedo, Vicente, 19 in

Roemer, Johann Jakob, 294

Rojas Clemente, Simón de, 308

Rolander, Daniel, 3

Rome, 6, 232-233

Roots, 105, I 37, 286, 323

Rotenone, 18

Rousseau, Jean Jacques, 55

Roxas, Josef Antonio de, 127-128

Royal Society of London, 14, 24, 30, 179

Royal Society of Those Who Love the Country, 272

Rúa, Francisco, 65

Rubber, I 8, I 1 0, 1 33, I 34, I 7 I, 174

Rubio, José, $227,228,230-232,247 n$, $250-254,258 \mathrm{n}$

Ruiz, Agustín, 145, 150

Ruiz, Antonio, 54, I90, 243-244, 253n, $261 \mathrm{n}, 263,288$

Ruiz de Balmaceda, Juan, 214

Ruiz de Tagle, Francisco Antonio, 214

Ruiz López, Hipólito, 271, 273; early life, 53; pharmacist, 53, 229, 259n, 265 ; illness, $53,128,137,140,143$, 152-153, 259n; and Gómez Ortega, $53,166,209,230,242-245,250$; description and character of, 54,148 , $192,283,285-286,287,325$; chosen first botanist, 57 ; salary, 60-61, 136 , 190-19I, 226, 246n, 248, 256, 259 , 260,26 in, 263, 303 ; opinions on Peru, 74-77, 101, I 04-105, 138, 155, 158; on Indians, 75, I 04, I I 8, I38, $155,157^{-}$ 158 ; and nitrate, 95 ; and Dombey, 98, 107, I I 4-1 1 5, 124, I 28-1 30, I 33, $163,165,167,172,174-175$; travels, $101,109,124,137,187,189$; relationship to Pavón, 107, I17, 124 , $191-192,229-230,240-241$; on coca, 109 ; opinion on Chile, 117, 125; and Cavanilles, 1 20, I 56-157, 209, 233 243,286 ; and Chilean pine, $120-121$; genus named for, 121, I57, $235 \mathrm{n}$, $236 \mathrm{n}, 238$; on star reed, 139-140; and draftsmen, $142-144,146,156$, 191-192, 229-230, 250-254; and agregados, $142,143,153$; and $\mathrm{Ma}$ cora fire, 145, 148-150; sought for chair of botany, 159; manuscripts and publications of, $165,286-288,293$, 338-339; and L'Héritier, I $8 \mathrm{In}$; son, $190,243,285,288$; on Mutis and Cinchona, 192-197, 203-211; limited funds of, 192; Sancha criticizes, 229 ; 
marries, 230; and Xuárez, 233; defends own genera, 239; and anónimos, 241 ; praise for, $249,288 n, 328$; and Rubio, 250-254; and Née, $250-$ 251 ; during French occupation, 263 ; death, $265,285,298,321,322,324$, 326 ; bust of, 289; see also Botanical Office of Peru, Flora Peruviana, Ruiz and Pavón, Ruiz-Pavón expedition

Ruiz, Hipólito, and José Pavón: prefer Chile, $x$; were essentially plant hunters and classifiers, 26 ; and Linnaeus, $38,79,26 \mathrm{I}, 26 \mathrm{z}, 290 \mathrm{n}, 296,298$, 328 ; and Dombey, 56-58, 81-82, 83 , I 14 -I I 5, 162, $163,166,175$; grants to, 63,136 ; dedicate plants, $65-66$, 7 on, $73,82,12 \mathrm{I}-122,238,249,254$, $255,261,284,327,328$; opinions of, by Lima townspeople, 79; herbaria of, 85, 99-101, $113,138,156,225$, 228,325 ; and cinnamon, 90 ; at University of San Marcos, $103 \mathrm{n}$; on Cinchona, 108, 201, 203-204, 2 I on, 278; José de Gálvez satisfied with, 136 ; and agregados, $142-143,153$, $267,269,270,272,273,275,276-$ 278,283 ; criticized by Thouin, $166-$ I67; and L'Héritier, 177, 181, 182; and Mutis, 197, 204, 206-210,2 IIn; vs. Zea, 201-206; favor López Ruiz, 206, 209; clashes between, 230, $240-$ 24I, 287; argument over classifications by, 233-234; and Cavanilles, $234-239,262,328$; and Vecino de Lima, 235 ; acknowledge support of Jovellanos, 249; and Rubio, $250-254$; seek new artist, 252, 253; conflict with Cerdá, 256-257; loyal to Spain, $263 n, 264$; spur to botanical study in Peru, 284 ; study rataña, 286 ; make mistakes, 327 ; praised, 328 ; see also Botanical Office of Peru, Flora Peruviana, Pavón, Prodromus, Ruiz (Hipólito), Ruiz-Pavón expedition

Ruiz-Pavón expedition: reasons for, 50 $52,57-58$; personnel of, 52-57; instructions to, 57-59, 79-80; proposed trip of, to Quito and New Granada, I02, I $5,135 \mathrm{n}$; voyage of, to America, 64 ; reception of, in Lima, $65-66$; first botanizing of, $80-82$; repulses thieves, $82-83$; to Chancay and $\mathrm{Hu}-$ aura, $82-84$, 11 3 ; to Lurín, $84-85$; shipment of, on Buen Consejo, 85-86, I I I, 112-I 13; first trip into montaña, 99-111; mock raid, 106-107; studies
Cinchona, 106, 108-109, 156; in Chile, I I5-I31; at Indian powwow, 117-118; studies Chilean pine, 11912I; gets extension, 124, 135-136; returns to Peru, I31; Dombey leaves, 133 ; sends shipment on San Pedro de Alcantara, 136-137, 141, 147, 153155,163 ; at Pozuzo, 138,139 ; shipments of, 140, 156 ; trains agregados, $142-143$, 153; has trouble with draftsmen, 143-144, 147; undergoes f.re, 144-152; at Muña, I 55-156; Brunete dies, 157 ; at Pillao, I57; at Chacahuassi, I 58 ; returns to Lima, I 59; embarks for Spain, I59-160; arrives in Spain, 189

Ruizia (genus), 121, 157, $235 \mathrm{n}, 236 \mathrm{n}$, 238

Ruiz Tagle, Manuel Francisco, 214 Rumphius, Georg Eberhard, $12-13$

Russia, $93 n$

Savedra, Francisco de, $257^{-2} 5^{8}$

Sage, Balthasar Georges, 95

Saint-Emond, 50

Salamanca, Domingo, $215 \mathrm{n}$

Salary: Joseph Ortega, 31 ; Lölling and associates, 34 ; Dávila, 4 I ; Ruiz, $\mathrm{Pa}$ vón, and draftsmen, 60-6I, I 36, I $90-$ I9I, 248, 256, 259, 260, 26 In, 263-26+; Isidro Gálvez, 60-6I, 232 , $248,256,259,301,317$; Dombey, $61-63$, 126, I 30,173 ; agregados, $142,143,153,157 \mathrm{n}, 268,269,270$, $271,274,275,276,279,280$; López Ruiz, I99; Mutis, 206; Rubio, 232, 25 I, 252, 258n; Gómez Ortega, 244; Ruiz, $246 \mathrm{n}, 303$; not paid, $26 \mathrm{xn}, 263$, 264 ; to be restored, $262,264 \pi$; policy concerning, 277-278; Cervantes, 269; Pérez, 285; Pavón, 289, 293, 301, $302,313,315,316,3$ I $, 324,329$; Pavón's son, 302 ; Delgado, 309n; Pardal, 3 I $2 \mathrm{n}$; Botanical Office, 3 I3, 316; Robles, 315-3I6, 32 In; Rodriguez, 3 I 6

Sales, of Flora Peruviana, 246, 247, 255 , $260,261,318,319$

Saltpeter, 86, 94-97, I 74

Salvador family, 28, 29, 31

Salvarega, José, 200

San Andrés, Hospital of, $267 \mathrm{n}, 27 \mathrm{I}$

San Fernando, medical college of; see Medical college

San Francisco de la Selva (Chile), 217 San Juan's Day, 80 
San Luis Potosi (New Spain), 222

San Marcos, University of; see University

San Martín, José de, 283

San Pedro de Alcántara (ship), I19, 120-121, 136, 141, 147, 153-155, $162,163,165,166,189,228 \mathrm{n}, 232 \mathrm{n}$, $234 \mathrm{n}$

Sancha, Gabriel de, printer: selected, 227; wrangling over paper, 227, 229; markups, 255n-256n; debt owed to, $259-260,261,264,300,301,318$, 322,324 ; see also Publication

Sancha, Yndalecio, son of Gabriel, 260 n, $300,318,322,324$

Sandalio de Árias, Antonio, 308-309, $314 \mathrm{n}, 321-325,326$

Santa Fe de Bogotá; see Bogotí

Santa María, Pedro, $248,258 \mathrm{n}$

Santa Marta (New Granada), 223

Santiago (Chile), 1 22-126, 21 3-2 1 8

"Santiago the Flyer," 67

Sargasso alga, 286

Sayán (Peru), 96n, 11 I

Schönbrunn, gardens of, 23,318

Schultes, Joseph August, 325-326

Sculpture, nymph of, 187

Sea-urchins, 267

Seeds, $41,80,85,86,137,268,269$, $271,279,280,289,313,318$

Segovia, 47

Séguier, Jean François, 89

Semanario de agricultura $y$ artes, 329

Seniergues, Jean, I 13

Señora de las Mercedes (ship), I 3 I

Senra (genus), $235 \mathrm{n}$

Sepúlveda, José, 217

Serra, Buenaventura, 44

Servility, $7 x-72$

Sessé, Martín, 221, 247n, 295n, 325n

Seville, I1, 29, 47, 278,338

Sheepskin shoes, 74

Shells, 85n, 89, I 33, 137, 171, 267; and Lambert, 295, 296-299, 310

Shipments: of early botanists, 6, 1 3-1 6, $18,21-23$; of Ruiz and Pavón to Spain, 85-86, I 1 1-1 12, I 36-137, 140, 14in, 153-155, 156, 159-160; by Dombey, 85, III-I I3, I33; of Tafalla and Pulgar, 259, 267-270, 275; of Ruiz to Lima, 271; of Unanue, 273; of Manzanilla, 279; of Pavón to Gálvez, 287; of Pavón to Lambert, 293, 294, 295, 299, 300, 304, 3103II; of Pavón to Webb, 314-315

Shipwreck; see San Pedro de Alcántara
Sibthorp, Humphry, 12

Sida (genus), $236 \mathrm{n}, 237 \mathrm{n}$

Siegesbeckia flosculosa, $168 \mathrm{n}$

Sierra, Benancio, 217

Silk stockings, 74

Silver, $86,89,92,125,132 \mathrm{n}, 137,153$, I 54-155, 17 I

Sloane, Hans, $15,18 \mathrm{n}$

Smallpox, 21, 68

Smilax (genus), 140 n, 286

Smuggling, 94

Snake root, 139

Snakes, formed from women's hair, 43

Snuff boxes, 93

Sobrino y Minayo, Blas, 2 I 3

Societies; see Economic societies

Society of Jesus; see Jesuits

Solander, Daniel Karl, : 3,24

Soliva, Salvador, 44

Sonnerat, Pierre, 13

Soriano, Vicente, 308, 32I-325, 326

South Carolina, 14, 15

Sowerby, James, 18 I

Spain: war with England, 67, 103, 115 , I 18, 131, 247; expenditures for war, 212,220 ; political situation in, 232, $282,306,321,326$; independence of Peru from, 280, 290; poorer than England, 294

-relations with the sciences: attitude toward botany, vii; support for botanical exploration, vii-ix, 4-7, 23, 29 , $42-43,46,57,63$; overestimates ability to publish botanical works, 7, 308; builds botanic gardens, I1, 12, 29, 39 ; state of scientific and botanical knowledge in, 27-28, 30, 31-32, 40, $41,46-49, \quad 51,52,56-57,187-189$, $235,266,282,302,318,325$; efforts to replenish forests of, 38 ; establishes museum of natural history, 39-43; economic societies in, 46-48; "monstrous paradoxes" of Spanish argument, 47; and studies on platinum, 92-94; nitrate in, 94; quicksilver in, I 26 ; indecision of, on publication, $162,165,167$; Cinchona production proposed for, 197; suspends quina shipments from New Granada, 2002 or ; libraries of, get Prodromus, $247 \mathrm{n}$ -relations with France: and France, ix, 50-52, 56, 57, I02, I 62, 262-264; acknowledges Dombey's superiority, 56; Dombey's opinions on, 56-57, 77, I02, I12, I 13, 16I, I70, I75; pays botanists better than French, 60, 63; 
and partition of Dombey's boxes, 163 I 64, I 65-166, I 68, I 69-1 72, I 75, 180 ; and L'Héritier, 177-182; see also France

-relations with the scholars: Tournefort, 8, 1 3, 38; La Condamine, 17 ; Löfling, 23, 33-36; Linnaeus, 27, 30, 32, 33, 35-39, 49, 187, 188; L'Héritier, $177-182$; Ruiz and Pavón return to, 187, 189; López Ruiz, 199, 201, 206; publishes Mutis' work, 309, 325; see also Disputes, official; France; Partition

Sparrman, Andreas, 13

Species: four thousand new, vii; Ruiz and Pavón responsible for discovery of five hundred, 327

Spilanthes albus, $168 \mathrm{n}$

Spruce, Richard, 334

Star reed, 139-140, 286, 323

Starfish, 267

State, Ministry of (Spain), I 88, I90, $243,244,306-307$

Stemodia (genus), 73

Sternberg, Count, 325

Stirpes novae, of L'Héritier, I 68n, 177 , $181,182-183,294$

Straits of Magellan, 23, 24

Subdelegado, 149, 151, 152, 275

Subercaseaux, Francisco, 216, 217

Sugar, 333

Suñol, Joseph, 36

Suplemento a la quinologia, 203-207, 239

Surco (Peru), 65, 85

Surian, Joseph Donat, I 5

Surinam; see Guiana

Sweden, 13, 33, 95; see also Linnaeus

Swieten, Gerard van, 68

Systema vegetabilium, 254-256, 262, 301 Systems of plant classification; see Classification of plants

Tacna, 334

Tafalla, Juan: chosen for expedition, 142; soldier, 142, 272; salary of, I $42,143,153,157 \mathrm{n}, 268,269,270$, $27 \mathrm{I}, 276$; birth date, $142 \mathrm{n}$; experience as botanist, I43; and Macora fire, I 44, I49, 150; and chair of botany, 153, $159,267,269,270,272-273,278-$ 279,283 ; and Cinchona, 197, 203, 276-278, 29on; gets copy of Prodromus, 246n, 247; shipments of, 259 , $261,267-270$; is recommended, 267 , $269,270,273$; in Huánuco, 268, 270-
271 ; escorts Malaspina, 268 ; illness, $268,276,277$; in montaña, 269, 270; in obscurity, 272,283 ; relationship to Lima intellectual life, $272-273$, 283,284 ; called mediocre, 273; studies coca, 273; in Guayaquil, 273$278,290 n$; and fellow agregados, 274-278, 279; to Chile, 279; death, 279, 281, 284; long experience, 283

Tagle y Bracho, José de, 219

Tagle Ysoaga, José Manuel de, 2 I9

Tahiti, 24, I 33

Talbor, Robert, 19

Talca, 124, 129

Talcahuano (Chile), II 5, I20, 154

Tapa anca, 267-268

Tarapacá (Chile), 96-97

Tarma (Peru), 99-101, I03, I04, I15, $133 \mathrm{n}, 15 \mathrm{I}, 163,269,27 \mathrm{I}, 275,288$

Tärnstrom, Christopher, 13

Tea, 335

Telescopes, $93 \mathrm{n}$

Termites, 103

Tertulias, 125

Theft, 22, 82-83, 99, 189, 3 I 2

Theophrastus, 3,8

Thermal baths, 98

Thorn apple, 1 ro

Thouin, André, 56, 8I, 91, 93n, 164, $166-167,172 \mathrm{n}, 175,179,18 \mathrm{I}, 199 \mathrm{n}$, 234

Thunberg, Carl Peter, I 3, 167, 234

Tides: Dombey to measure, I I I-I I 2

Tillandsia (genus), 100, $26 \mathrm{I}$

Tin, 89, 333

Tobacco, 109, 273n

Tofieldia (genus), $26 \mathrm{r}$

Toledo, 142

Toothaches, I00, I 39

Torén, Olof, 13

Torti, Francesco, r 9, 193n

Tournefort, Joseph Pitton de, 8, I0, I3, $27,28,33,36,37,38,59, \mathrm{I}+5,268 \mathrm{n}$

Tovar, Simón, I I

Townsend, Joseph, 4 in

Trabuco (Trauco), 144-I45, I 48 -1 52

Treasury, Ministry of the (Spain), 2 I5n, 257-258, 270, 306-307, 318, 319

Tropical forest, IOI-III, I $38-I_{4} 0, I_{4}$ $146,148-152,155-159$, I 91,270 , $273,274,283$

Tucumán, 232

Tudela (Spain), 47

Tupac Amaru, 72, 108, 110, 175 
Turgot, Anne Robert Jacques, 50-52, 328

Ulloa, Antonio de, 17, 22, 39, 52, 59, $75 \mathrm{n}, 92$

Unanue, Hipólito, $72-73,273,279,284$

Unanuea (genus), 73, 284, 304, 323

United States, 14, 186, 201, 335

Universidad Central (Madrid), 305

University: of San Marcos (Lima), 17 , $65,66-67,70-71,103 \mathrm{n}, 153,199$, 219; of Louvain, 19; of San Felipe (Santiago), 217, 218; of Mexico, 266-267; see also Convictorio of San Carlos, Medical college of San Fernando

Uracan, 83

Urena (genus), 238

Urrutia, Esteban de, 66, 130

Urrutia y Mendiburu, Joseph de, 2 I3, $216 n$

Uruguay, 23, 69

"Useful knowledge," 33, 47

Uses of plants: Cinchona, 19-20, 192193, 195-196, 198, 200, 203n, 2 II; economic, $34,44,46-48$, 139 ; discussed in cédula, 42-43; González Laguna discusses, 66, $27 \mathrm{I}$; in medicine, 79, 121-122; by Indians, 79, 86n; Ruiz discusses, 100; of coca, rog; Datura Stramonium, I Io-III; marine, II9; boldo, I2I-I22; laurel, 122; keule, 122; star reed, 139-140; Smilax China, 140 ; rataña, 286

Valdecazana, Marquis of, 200

Valdés, Antonio, 182

Valencia (Spain), 44, 47

Valparaíso, 13 I, 2 I 5, 2 I 8

Van Helmont, J. B., 7

Vanilla, I 05
"Vecino of Lima," 235-237, 241-244

Vélez, Cristóbal, 32

Venereal disease, $75 \mathrm{n}$

Venezuela, 23, 33-36, 223,337

Vergara, Royal Seminary of, 94, 127

Vergennes, Comte de, 168, 169, 171, $172,175 \mathrm{n}, 178,181$

Versailles, 9, 12

Vestidura del Inca, 85,112

Vienna, 12, 22, 23

Villahermosa, Duke of, 188

Villanova, Tomás Manuel, 44

Villapalma, Marqués de, 214

Virginia, 14

Visitador general, $66 \mathrm{n}$; see also Escobedo

Ward, Bernardo, 48

"Wars of Chile," 286

Webb, Philip Barker, 303n, 313-315

Weddell, H. W., 333

West Indies, 15, 22-23, 186, 334, 335

White Knight, 124-125

Willdenow, Karl Ludwig, 234, 294

Witch doctors, 79

Women, 68, 74-75, 125, 188, 329

Wood, 38, 4r, 42-43, 89, 137 ; see also Pines

World Health Organization, 335

Ximénez, Francisco, 6

Xuárez, Gaspar, 232-233

Yallhoy root, 286

Yerba maté, 42, 288

Ynciarte, Juan de Dios, 280-281

Yrigaray, Ignacio, 217

Zaragoza, 47, I 87

Zea, Francisco Antonio, 201-206, 209, 264,286

Zúñiga y Ontiveros, Felipe de, 221, 222

Zurich, 234 






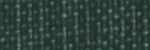

(2)

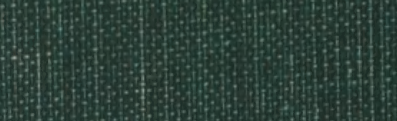
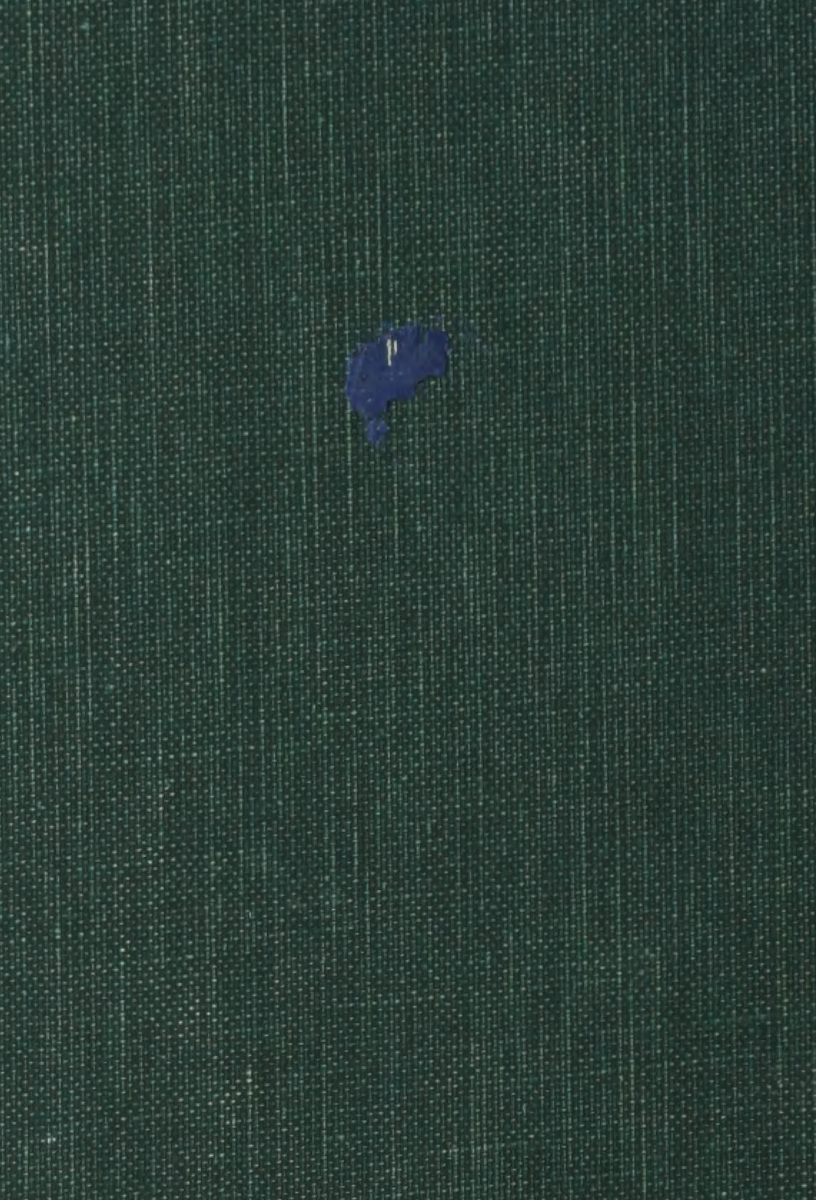

\begin{tabular}{l} 
W \\
\hline
\end{tabular}

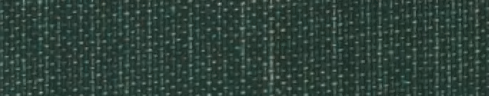

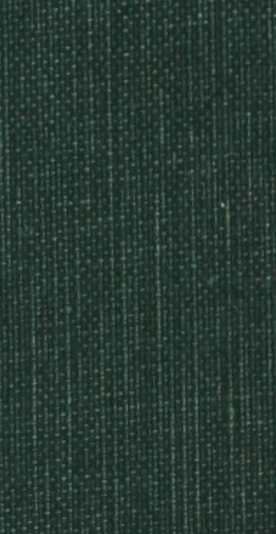

$$
\begin{array}{|l|l}
\hline & \\
&
\end{array}
$$

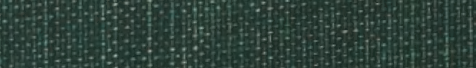

